
THE UNIVERSITY

OF ILLINOIS

$$
\begin{gathered}
\text { LIBRARY } \\
595.79 \\
\text { M82i } \\
\text { V.1 }
\end{gathered}
$$

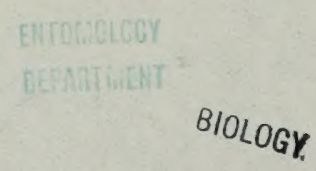




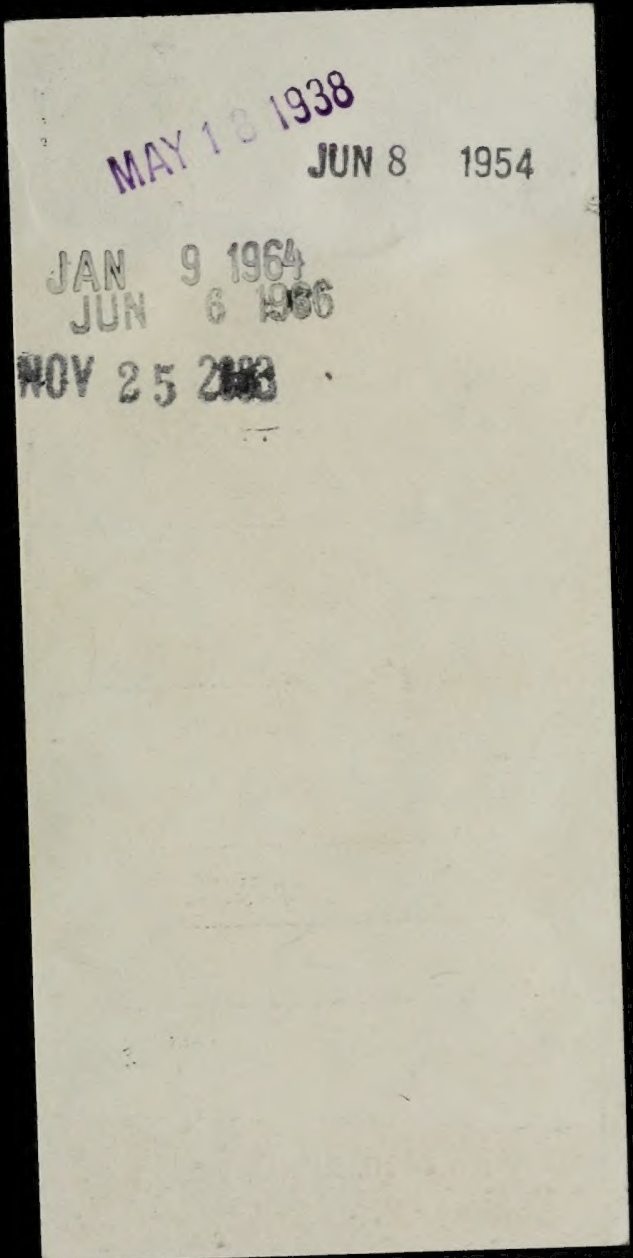





\section{BRITISH ICHNEUMONS}

ICHNEUMONINAE 




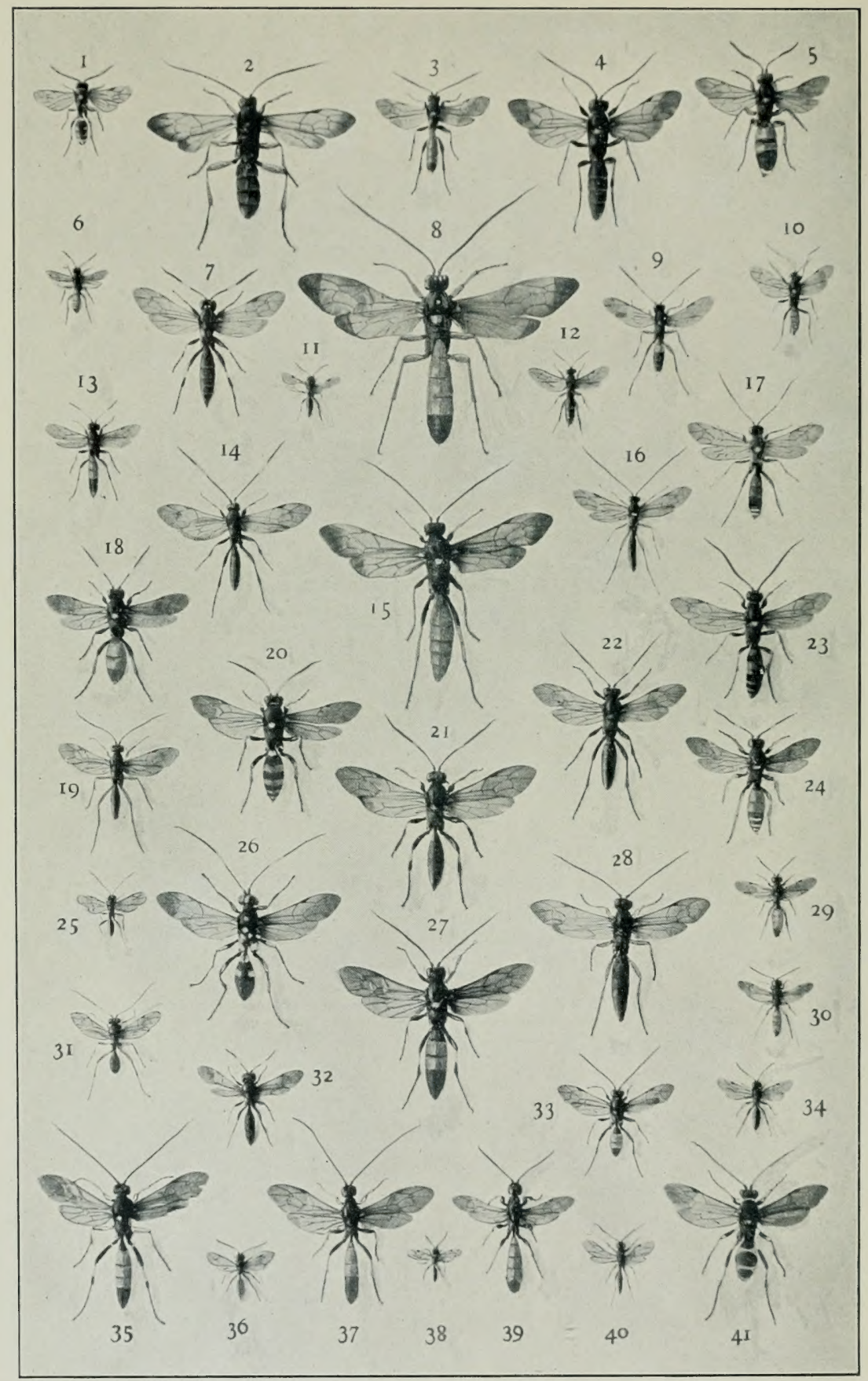


I. Listrodromus nyctemerus, Grav., $q$.

2. Dinotomus lapidator, $F a b$.

3. Barichneumon lepidus, Grav., ô.

4. Melanichneumon leucomelas, Gmel., ơ .

5. Ichneumon sarcitorius, Linn., $q$.

6. Ichneumon latrator, Fab., ㅇ.

7. Coelichneumon fuscipes, Gmel.

8. Trogus lutorius, $F a b$.

9. Stenichneumon ochropus, Grav., ㅇ․

I0. Hoplismenus perniciosus, Grav., 오.

I I. Dicaelotus pumilus, Grav.

12. Herpestomus brunnicornis, Grav.

13. Chasmias motatorius, Fab., + .

14. Cratichneumon nigritarius, Grav., है.

15. Protichneumon fuscipennis, Wesm.

16. Hypomecus quadriannulatus, Grav.

17. Tricholabus strigatorius, Grav.

18. Ichneumon extensorius, Linn., $q$.

19. Eurylabus rufipes, Steph.

20. Ichneumon xanthorius, Forst., f

21. Eupalamus Wesmaeli, Thoms.

22. Probolus alticola, Grav., ㅇ․

23. Spilichneumon occisorius, $F a b$., of.

24. Spilichneumon occisorius, Fab., $q$.

25. Platylabus pedatorius, Fab., var.

26. Hepiopelmus variegatorius, Panz.

27. Ctenichneumon divisorius, Grav.

28. Ctenichneumon castigator, $F a b$.

29. Colpognathus divisus, Thoms.

30. Centeterus confector, Grav.

31. Platylabus dimidiatus, Grav., $q$.

32. Phaeogenes cephalotes, Wesm.

33. Anisobas hostilis, Grav., var.

34. Phaeogenes fulvitarsis, Wesm., q.

35. Amblyteles palliatorius, Grav., ठิ.

36. Diadromus troglodytes, Grav.

37. Alomyia debellator, Fab., ơ.

38. Epitomus parvus, Thoms.

39. Alomyia debellator, Fab., $q$.

40. Stenodontus marginellus, Grav.

41. Amblyteles armatorius, Forst., q. 
P. , 3.

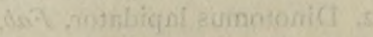

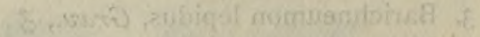

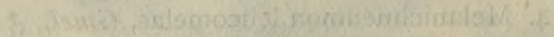

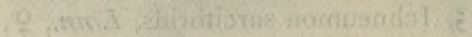

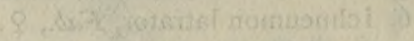

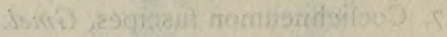

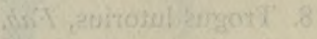

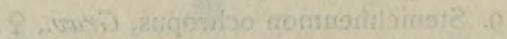

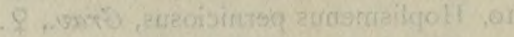

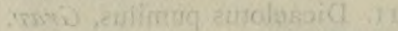

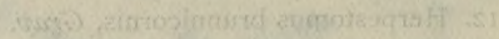

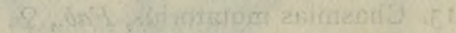

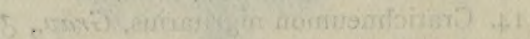

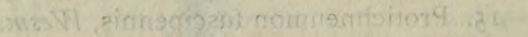

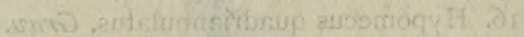

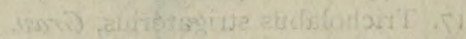

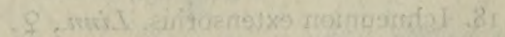

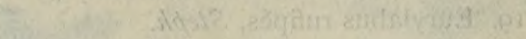

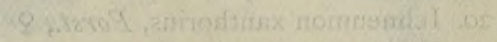

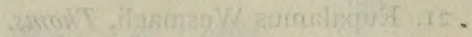

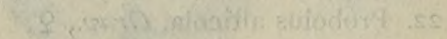

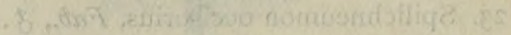

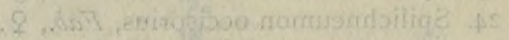

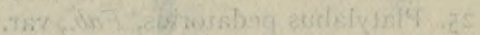

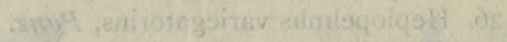

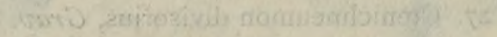

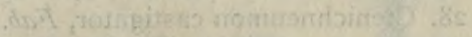

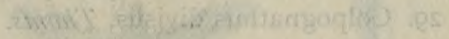

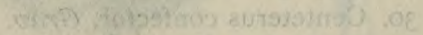

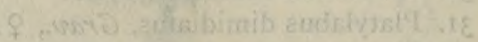

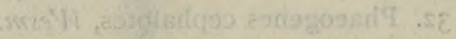

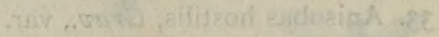

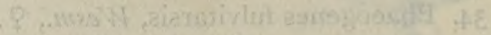
bु ...

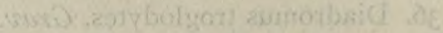

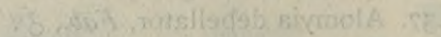

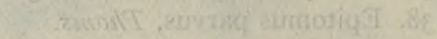

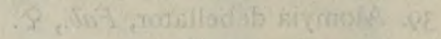

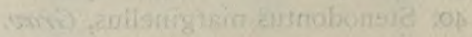

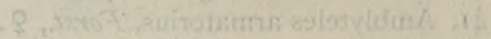




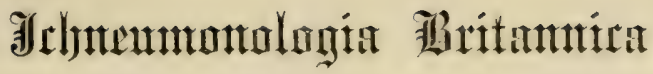

THE

\section{ICHNEUMONS OF GREAT BRITAIN}

A DESCRIPTIVE ACCOUNT OF THE FAMILIES, GENERA AND SPECIES

INDIGENOUS TO THE BRITISH ISLANDS, TOGETHER WITH NOTES AS TO Classification, Iocalities, habiTATS, hosts, ETC.

B1

CLAUDE MORLEY, F.E.S.

Author of "Hymenoptera of Suffolk"

etc.

\section{ICHNEUMONINAE}

Finis creationis telluris est gloria Dei ex opere naturae per hominem solum.-LiNN.

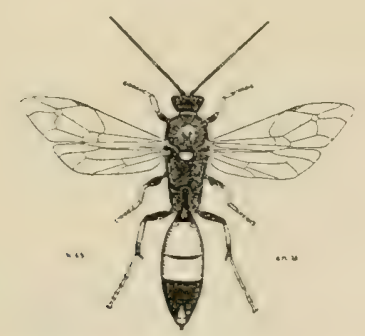

Ichnemon terminatorius, Grav., $q$.

PLYMOUTH

JAMES H. KEYS, WHMPLE STREET

MCMII. 



\section{PREFACE.}

THE absence of any work treating exclusively of British species has been felt more keenly during recent years in the case of the Ichneumonidae than in that of any other branch of our native fauna ; firstly, because all those Orders of insects which entomologists most generally study have been already adequately monographed, some of them over and over again, and secondly, because all the remaining groups which have not yet formed \& the subject of indigenous comprehensive works, such as the smaller $\checkmark$ hymenopterous, dipterous and neuropterous families, are so minute in $d$ size and obscure of definition that few students have experienced inconvenience from the deficiency. In the Ichneumonidae, however, the large size and handsome coloration of the majority of its species, together fwith their ubiquity and interesting economy, have led many collectors to 1 accumulate large numbers of specimens, and their disgust at discovering the almost entire impossibility of satisfactorily determining their captures has usually led them to at once cease collecting these insects; hence the scarcity of material upon which to work and the extreme rarity of any 3 note or reference to them in serials which teem with those upon other Orders of insects. What Curtis said so long ago (B.E. I 20), "the vast number of species, together with the difficulty of seizing distinctive characters, has either caused this family to be totally neglected or but imperfectly understood in most countries, but in none more so than in our own," is still substantially true to-day.

From the earliest times, I have experienced much affection for these elegant and sagacious insects, and one night in August, i 898, I determined to devote myself to their study. The short time which has since elapsed -will, it is hoped, be sufficient excuse for those inaccuracies and imperfections which the present volume doubtless contains, but it has been thought expedient to present what is already known of our species rather than to delay its publication for an indefinite period, and, by so doing, to at once engage the interest and co-operation of those who, failing some text book however imperfect, would never have thought of commencing the study. 
In all instances I have done my best to verify the records whenever such a course has been practicable; but the great number of species still relying solely upon Stephens' British records must be regarded with suspicion, since the nomenclature has, more recently, undergone such radical emendations and his species have so often been sub-divided.

The great stumbling block in the study of Ichneumons is the difficulty with which their identification is fraught. In the Coleoptera, \&c., the distinctions are often extremely minute, though nearly invariably easily perceptible when seen in a favourable light; in the present insects, however, the distinguishing features are often, like those of many members of the genera Homalota and Longitarsus, extremely hard to define, though the several kinds are different enough to the trained eye. One of the dangers of determining Ichneumons from mere descriptions, more even than other iusects, on account of their great similarity to one another, is that of forcing specimens into descriptions with which they agree in most points though not entirely; and this is augmented by the wide range of variation both in structure and colour which some species exhibit. Imagination, tempered with caution, is a most useful factor in determination. and will transmit from the description a figure of the insect and its parts to one's mind, with which the specimen before one must agree in every detail, or at least in all essential characteristics. Negative descriptions, in which are mentioned only those points not shared by allied species, such as Professor Thomson's, are of the utmost service, but hardly suffice the average student, who therein often feels the want of a general idea of the insect's facies. I have endeavoured to give a positive description, sketching the insect under consideration in such a way as to convey its word-picture, and have in most instances afterwards drawn attention to the points peculiar to it. In treating of a subject so little known, at least in Britain, as the present, it is better to present as full an account as possible of each species, provided discriminating features be also indicated, the omission of which so greatly stultified the utility of the older authors; moreover, it is most puzzling to find but a few features mentioned, and appended a note to the effect that the remainder are analogous with those of the preceding, which, in turn, carries one yet further back, and so ad nanseam.

The disparity of the sexes is more marked in the insects here dealt with than, perhaps, in any other branch of Entomology. To so great an extent is this usually the case that nearly all the modern authors continue to describe the sexes individually, and the old writers con- 
sidered them to be distinct species, which has added vastly to their cumbrous synonymy. Besides being unnatural, however, this method adds nothing to the convenience of determination; and $I$ have described them collectively, taking care to clearly indicate what peculiarities appertain to one sex only.

In the tables prefixed to each genus, too, this method has been adopted, and points of sexual agreement have been chosen whenever possible, rather than more obvious ones existing in one sex alone. Consequently, these tables, though of sounder foundation than sexual ones, are slightly more difficult to follow, and they are intended to be taken, not as the alpha and omega of identification, but as mere guides to the fuller descriptions.

My object throughout has been rather to put what was already known, though in so scattered a form, of our indigenous species into concise and easily assimilated fashion, than to bring forward additional or new species and original observations upon them, but these have been inserted wherever it has happened to be my good fortune to meet with them. Beyond this, it was very necessary that British students should become familiarised with modern Continental and American methods of classification and nomenclature, regarding which nothing whatever was to be ascertained from our own literature, since it has been an unbroken tenet to take the now obsolete Marshallian list as a basis for all work. Sound and fundamental as this list undoubtedly was thirty years ago, more recent investigation and the inevitable evolution of the study since 1872 have brought to light new facts, which camnot, on the plea of their many subtilities, be ignored.

Concerning the distribution of these insects with us, the study is too young for any definite statement to be reliable; and I will only say that, in spite of what Berthoumieu has written to the contrary, I am of opinion that their greater or less prevalence is not due to the frequency of Lepidoptera and their larvae in general, but to that of those kinds of them which are peculiarly subject to parasitic attacks. Many hundreds of hosts are now known in the Ichneumoninae alone, yet a very large proportion of the commoner lepidopterous insects which one would expect to find freely preyed upon are, as far as is at present known, entirely immune from attacks. McLachlan and J. J. Weir have referred to the larvae of Cucullia and Diloba, both of which are conspicuous, but for long supposed to be free from attack; and Bates has pointed out that information is also required as to what larvae are most subject to ichneumonidous onslaughts, and has asked 
whether, amongst the British kinds, there are many, or any, whose larvae are entirely immune from such attacks; and, if any, were they conspicuous larvae? ${ }^{1}$ We now know many species of the former genus to be freely preyed upon, though I once bred over a score of C. verbasci, taken at large in the full-fed larval state, without a trace of parasitism; and I have also found that of Diloba caeruleocephala bearing agglutinised Apanteles cocoons. Tugwell states ${ }^{2}$ that he at one time had two hundred larvae of Deilephila galii, not one example of which showed the least sign of a parasite. Nevertheless, the appended list of hosts will indicate that, at least at present, we cannot pronounce with anything approaching positiveness upon the question, the solution of which requires so much especial investigation.

The central European zone-that lying between the 42 nd and $54^{\text {th }}$ degrees of latitude ${ }^{3}$-is said to be the most prolific of these insects which appear to affect a temperate climate, since in the tropics, where they attain large proportions and brilliant coloration, their numbers appear to be proportionately vastly inferior. This, however, may to a great extent be due to the fact that Sweden, Germany, Belgium and France are the most thoroughly worked countries; very little is known in this respect regarding Russia, or the eastern and southern parts of Europe; and Berthoumieu is of opinion that when these districts are adequately explored the number of European species of Ichneumoninae will be doubled. As regards our present knowledge of the number of the above sub-family alone, about 800 have been described, of which some 3 10 are herein brought forward as pertaining to Britain. Rev. T. A. Marshall informs me ${ }^{4}$ that he considers the species of the world's Ichneumonidae to reach the vast total of some 7 I 0,000 .

Considering our ignorance of these insects, a quite surprisingly large number of local catalogues of British species have been published, comprising lists from Alderney, Barnby Broad in Suffolk, Dorsetshire, Devonshire, South Devon, Glanvilles Wootton, Great Yarmouth, Hastings District, Isle of Man, Land's End, New Forest, Norfolk, South-west Ireland and Yorkshire, which will be found under the "Works Consulted." Many of these records, however, from a variety of more or less obvious reasons, must be accepted cum grano salis, and, where verification has been impracticable, they are here recapitulated for whatever they may be worth. Such as they are, these lists go to show that the distribution,

1 Proc. Ent. Soc., 1867, p. 8 s.

2 Young Naturalist, 1890, p. 94 .

3 Land's End is 50 degrees, Newcastle 54 degrees.

1 Marsh., ith lit, and May, 1902. 
in many instances, is very wide-spread, though the observations in most cases are extremely meagre and superficial.

My task has been lightened by the kindness and generosity I have everywhere experienced in regard to material. Large collections of specimens have been presented to me by Miss Ethel Chawner, F.E.S., Rev. E. N. Bloomfield, M.A., Albert Piffard, Esq., F.E.S., Dr. P. B. Mason, F.L.S., and A. Adie Dalglish, Esq., F.E.S.; much information has been most kindly given me by the late Rev. T.A. Marshall, M.A., F.L.S., and G.C. Bignell, Esq., F.ES.; and I am greatly indebted to the following for numbers of bred or captured specimens :-F. C. Adams, Miss E. M. Alderson, Rev. C. D. Ash, Dr. J. H. Bailey, E. R. Bankes, A. Beaumont, E. C. Bedwell, WV. H. Bennett, Lieut.-Col. C. T. Bingham, R. C. Bradley, E. Brunetti, E. A. Butler, Prof. J. IV. Carr, Dr. R. 'T. Cassal, Dr. T. A. Chapman, H. J. Charbonnier, W. M. Christy, IV. G. Clutten, J. IV. Cross, C. W. Dale, H. St. J. Donisthorpe, W. W. Esam, W. Evans, Rev. H. S. Gorham, J. C. Haggart, A. H. Hamm, S. Image, W. J. Kaye, S. W. Kemp, J. H. Keys, W. A. Luff, J. R. Mallock, A. M. Montgomery, Rev. F. D. Morice, K. Morton, J. F. Musham, E. A. Newbery, F. H. Peachell, G. T. Porritt, R. M. Prideaux, C. B. Routledge, E. Saunders, H. W. Shepheard-Walwyn, A. Sich, F. W. Sladen, E. G. J. Sparke, Rev. A. Thornley, B. Tomlin, C. J. Wainwright, C. J. Watkins, F. G. Whittle, J. Wigin and Col. J. W. Yerbury.

R. McLachlan, Esq., F.R.S., and C. G. Barrett, Esq., F.E.S., have rendered valuable assistance in the technique and the classification of the hosts. To Ernest A. Elliott, Esq., F.E.S., I owe the inception and completion of the work.

Where no authority is given, the record is in most cases my own.

\section{CLAUDE MORLEY.}

Ipswich, May Jst, I903. 



\section{GLOSSARY.}

Abdomen . . The third and hind section of the body, bearing the organs of generation and reproduction.

Acetabula . . The sternal cup-like cavities in which the coxae revolve.

Acioulation . A series of fine, close, longitudinal lines, as though scratched with a needle.

Aculeate . . Furnished with a sting.

Acuminate. Terminating in a sharp point.

Alutaceous. . Covered with minute cracks, like the human skin.

Anal . . . Pertaining to the anus.

Annellus . . The minute third joint of the antennae and first of the flagellum.

Anmulated . Ringed or banded (of colour).

Ante- . . (In composition) Before.

Antennae. . The horns; two elongate, porrect organs of appreciation rising from the front of the head.

Anus . . The apical segments of the abdomen.

Apex . . . The end of anything furthest from the base.

Apical . . Pertaining to the apex.

Apodous . . Without legs.

Apophyses . . (Gr. Apophuo, an offshoot). The dorso-lateral metathoracic spines. It has been incorrectly employed to denote the apical joint of the trochanter (trochanterellus, Schm.) by Ratzeburg and Desvignes.

Apterous . . Wingless.

Arcuate . Arched; curved in a bow.

Areola . . . The central or superomedial area of the metathorax; not used in reference to the wing.

Areolet . . The second cubital cell of the front wing; areola, auct.

Armature . . Corneous parts of the genital organs, usually of the male. Articulated . Jointed.

Attenuate . . Gradually tapering to a more or less distinct point.

Auriculate. In the form of an ear.

Bradious . Blackish-red, often infuscate; between castaneous and black.

Base . . The nearest part of any member to the central point of juncture of the mesothorax with the scutellum.

Ji- . . . (In composition) Two-fold.

Buccate . Inflated; bulged out; cheeks are so termed when they form almost a right angle with the clypeus, viewed from in front.

Calcaria . . The spines at the apex of the tibiae.

Callosity . A slight elevation or hump. 
Callus

A small callosity immediately hefore radix of fore wing.

Canaliculate . Furrowed; elongately impressed.

Carina . A keel, ridge or elevated line.

Carinate. . Keel-like; with a raised line.

Castaneous . Chestnut-red.

Candale . In the form of a tail.

Cheeks . . . That part of the head between the base of the mandibles and the lower margin of the eyes.

Chitinous . Pertaining to chitin, of which the exoskeleton of insects is composed; presenting a hard surface.

Ciliate . Fringed with hairs or cilia, like an eye-lid.

Clavate . Clubbed.

Clazes . . The little hooks at the apices of the tarsi.

Clypeus . . That part of the head between the face and the mouth.

Coalesced . Intermingled; run together ; having become common.

Compressed. Squeezed laterally; higher than broad.

Confluent . Intermingling; becoming common.

Conicul . . Cone-shaped.

Connate . Inflexibly soldered together.

Contiguous . Touching; in close proximity.

Contour . . General outline or shape.

Cordiform . Heart-shaped.

Coriaceous . Presenting a surface like that of leather.

Comeons . Horny.

Costa . . A small elevated ridge; rarely used of the front edge of the wing.

Costula . Exclusively used to denote the little costa separating the externo-medial metathoracic areae into two parts $(c f$. details post).

Coxa . . . The first or basal joint of the leg, that nearest the thorax.

Cribrary . Pertaining to the mouth.

Cristula . A little and usually elongate crest.

Deflexed . . Bent downwards.

Dentate . . Toothed.

Deplanate. . Depressed or flattened dorsally.

Disc . . . The central region.

Discreted . . Separated, usually by an impressed line ; in the case of the petiolar area it indicates that there are present two longitudinal carinae dividing it into three parts.

Divergent . . Spreading apart; not parallel.

Emarginate. With the margin not continuous, generally centrally notched.

Entire . . Without excision, emargination or projection.

Epicnemia . The elevated anterior margin of the mesosternum.

Epistoma . The central, and often longitudinally elevated, portion of the face. Gravenhorst calls the whole front of the head, from the frons to the mandibles, the facies or hypostoma. Berthoumieu writes "L'épistome ou clypeus."

Efomice . The elevated margin of an oblique furrow in the propleurae for the reception of the front femora.

Explanate . Widened out; expanded. 
Face

The area between the antennae and clypeus, laterally bounded by the eyes.

Facies . . General aspect; superficial appearance.

Fascia . . A dark or coloured band.

Femur . . The third section and fourth joint of the leg; the thigh.

Fenestra . . A pellucid or interstitial point or space in a wing-nervure.

Ferrugineous . Rust-red; between red and castaneous.

Filiform . . Thread-like ; of equal thickness throughout.

Flagellum . That part of the antennae beyond the scape, i.e., joints 3 to apex; the funiculus.

Flavidous . Rather lighter or darker than flavous.

Flavous . . Somewhat pale yellow ; between white and fulvous.

Fovea . . A circular depression, usually of some size.

Foveola . . A small fovea, often distributed in series.

Frons . . . Forehead; the region of the head between the vertex and the face.

Fulvous . . Tawny-yellow, darker than flavous.

Fusiform . . Spindle-shaped; thickest centrally, narrowed towards both extremities.

Fiscous . Dark-brown; between fulvous and piceous.

Gastrocaeli . The usually transverse foveae on either side, near the base of the second segment.

Genal . . Pertaining to the cheeks.

Geniculate. . Elbowed.

Gibbous - . Humped, strongly convexed.

Glabrous . . Smooth and shining, with usually neither sculpture nor hairs.

Glaucous . Greenish-white colouring.

Granulate . Covered with small, round elevations.

Head . . . The first and front section of the body, bearing the eyes, cribrary organs and antennae (for details cf. post).

Hirsute . . Covered with long hairs.

Humeral . Pertaining to the shoulder, near the base of the wing.

Hypopysium . The apical ventral segment of the abdomen.

Impunctate . Without punctures.

Incisure . . The depressed line of junction between the abdominal segments.

Incrassate. . Thickened.

Infuscate . Clouded with fuscous colouring.

Insertion . . Point of attachment of a movable part.

Joints . . The articulations of the antennae and legs; not used of abdomen.

Juxta- . . (In composition) Near.

Labrum . . A chitinous plate lying between the bases of the mandibles, immediately before the clypeus.

Lanceolate . Narrowly elliptical.

Lateral . Pertaining to the sides.

Linear. . . Narrow and equilateral.

Lumate. . . Crescent-shaped.

Lumula . . The crescent-shaped pale spot often present at the vertical orbits; the small circular glabrous area on the sides of the abdominal segments. 
Maculate . Spotted.

Mandible . . A tooth on either side before the clypeus, usually bidentate and folded across the front of the head.

Membraneous. Composed of thin semi-transparent tissue.

Mesosulaus . Central longitudinal furrow of mesosternum.

Mesothorax. The second and central section of the thorax.

Metathorax . The third and hind section of the thorax (for details $c f$. post).

Moniliform . Bead-shaped.

Mucronale . Prolonged into a sharp point.

Mutic . . Immune, simple; strictly, without a tooth or spine.

Nierescent Blackish.

Nitidulous . Strongly shining.

Normal . According to the usual form; bearing nothing noteworthy.

Notıuli . The usually short or obsolete furrows on either side of the mesonotum in front, which are incorrectly termed parapsides by Holmgren.

Notum . . The upper surface of the thorax; that of the prothorax is the pronotum, or collar; and so on.

Obsolele . . Traceable, though almost effaced.

Obluse . . Blunt; not sharply pointed.

Occiput. . The back of the head, between the vertex and the collar.

Ocelli . . The three simple eyes, always present upon the vertex of head.

Ochraceous . Brownish-yellow.

Onychium . The apical tarsal joint, bearing the onyches or claws.

Orbits . . Margins of the head round the eyes.

Oval . . . Longer than broad, laterally rounded, with the extremities of equal breadth.

Ovate . . Similar to oval, but with the extremities unequal; eggshaped.

Palpi . . Sensitive organs of appreciation, articulated and attached to the maxillae and labium.

Parapsides . Strongly declived parts between the scutellum and tegulae.

Pectinate . Furnished with teeth, like a comb.

Pectoral . Pertaining to the breast or sternum.

Pedicellus . The minute second joint of the antennae and apical of the scape.

Penultimate . Last but one.

Petiole. . The narrow basal half of the first abdominal segment; pedicle ; peduncle.

Phytophagous Plant-feeding.

Piceous . Pitchy, dark-brown; between fuscous and black.

Pilose. . Hairy; hairs longer than in pubescence, shorter than hirsute.

Pleurae . . The lateral surfaces of the thorax; those of prothorax are the propleurae, and so on.

Plicate. . Furnished with a fold.

Post-annellus. The fourth joint of the antennae and second of the flagellum.

Post-scutellum The small sub-rotund prominence between the scutellum and the metanotum. 
Prothorax . The first and front section of the thorax; the collar.

Pubescence. . Very short, fine hairs, lending a downy appearance.

Pubescent . Bearing pubescence.

Punctate . . Covered with small circular pits or punctures.

Punctulate. . Covered with fine, often sub-obsolete, punctures.

Pygidium . . The apical dorsal segment of the abdomen.

Quadrate. . Square.

Kadius . . The radial nervure of the front and hind wings.

Radix . . . Base of the wings, and their point of insertion.

Reflexed . . Bent backwards; upturned.

Reniform . . Kidney-shaped.

Reticulate . Covered with a network, like the human skin.

Rugose . . Irregularly and roughly wrinkled.

Rugulose . . Irregularly but not roughly wrinkled.

Scubriculous. Regularly and finely wrinkled.

Scabrous . . Regularly and somewhat roughly wrinkled.

Scape. . The basal antennal joint; used collectively for the two basal joints, of which the pedicellus is very small.

Scopula . A small, dense tuft of hair.

Scrohes. . The usually circular impressions upon the frons in which the scapes revolve.

Scutellum . The usually triangular, raised area at the dorsal base (between the meso- and metanotum).

Scutum . . The mesonotum.

Segments . . The articulations of the abdomen; not of antennae and legs.

Serrate. . Furnished with strong teeth, like a saw.

Sessile. . (Of the abdomen). Broadly connected with the thorax; in contradistinction to petiolate.

Seta . . A long, isolated bristle.

Setaceous . . Gradually tapering from base to apex, like a bristle.

Setigerous. . Bearing setae.

Shagreened . Unevenly glabrous; not smooth, but with sculpture obsolete.

Simple. . Bearing no peculiar modifications.

Simuate . Presenting a waved, undulating outline.

Spatuliform. Flattened out; deplanate; like a spatula.

Spicula . The oviduct, or central organ of the terebra. (Of the female only).

Spinate . . Produced into an acuminate spine.

Spinose . . Bearing spines or bristles.

Spinulose . . Bearing small, often indistinct, spines.

Spiracle . A respiratory orifice in the surface of the exoskeleton.

Sternauli. . The short, and often obsolete, furrows on either side of the mesosternum.

Stermum . . The lower surface of the thorax; that of the prothorax is the prosternum, and so on.

Stigma . . The corneous mass in front margin of the fore wing.

Stramineous . Straw-colour; primrose-yellow; between white and flavous.

Striate . Furnished with distinct impressed lines.

Striolate . Bearing large and deep aciculations. 
Sub- . . (In composition) diminishes the density of the qualification.

Sulciform . . Resembling a sulcus.

Sulcus . . An impressed longitudinal furrow.

Tarsus. . . The apical section of the leg, next after the tibia; the foot; consisting of five distinct joints, of which the onychium bears two claws.

Tectiform . . Tent-shaped.

Tegula . . The cover of the base of the wing; squamula, auctt.

Terebra . Ovipositor; borer; aculeus; the oviduct and sheaths collectively. (Of the female only).

Testaceous. . Darkish yellow; between flavous and fulvous.

Thorax . . The trunk or middle section of the body, bearing the legs and wings; always divided into three parts, termed the pro-, meso- and metathorax; the upper surface is the notum, the lower the sternum, and the lateral surfaces are the pleurae (for details $c f$. post).

Thyridii . The apical margin of the gastrocaeli, often alone visible.

Tibia . . . The fourth section of the leg, between the femur and the tarsus; the shin.

Tomentose . Covered with short interwoven hairs or pile.

Tri- . . . (In composition) Thrice.

Trochanter . The second section of the leg, between the coxa and the femur ; divided, in Ichneumonidae, into two joints.

Truncate . . Cut off in a straight line, neither sinuate nor curved.

Tubercle . . A small, raised, abrupt, circular prominence.

Tuberculiform In the form of a tubercle.

Uni- . . (In composition) One.

Valvulae . Branches of genital forceps of male; usually visible externally and liable to be mistaken for the terebra, if sub-exserted.

Ventral . Pertaining to the lower surface of the abdomen.

Villose . . Clothed with long, raised, closely-set hairs.

Vitture . . Streaks or bands of colour, usually on mesonotum.

Wanting . . Entirely absent.

Wings . . Lateral organs of flight, one pair on either side (for details cf. post).

Xylophagous . Wood-feeding. 


\section{WORKS CONSULTED.}

\section{SERIALS.}

Ann. Nat. Hist.-The Annals and Magazine of Natural History. London. I 84 I, et seqq.

An. Soc. Esp. Hist. Nit.--Anales Sociedad Española di Historia Natural. Madrid. 1872, et seqq.

Ann. Soc. Fr. - Annales de la Société Entomologique de France. Paris. I 832 , et seqq.

Ann. Scot. Nat. Hist.-Annals of Scottish Natural History. Edinburgh. 1892 , et seqq.

Beit. Ent. Schl.-Beiträge zur Entomologie besonders in Bezug auf Schlesien. Breslau. I 829, \&c.

Bul. Ac. Brux.-Bulletin de l'Académie Royale des Sciences de Bruxelles. Brussels. I 832 , et seqq.

Bul. Ac. Pet.-Bulletin de l'Académie Impériale des Sciences de St. Pétersbourg. St. Petersburg. I 836, et seqq.

Bul. Soc. Fr.-Bulletin de la Société Entomologique de France. Paris. 1832 , et seqq.

Deut. ent. Zeits.-Deutsche entomologische Zeitschrift herausgegeben von der Deutschen entomologischen Gesellschaft. Berlin. I875, et seqq. E.MI.M. - The Entomologists' Monthly Magazine. London. I 66.4 , et seqq. Enc. Brit.-Encyclopaedia Britannica. Ed. viii. Edinburgh. 1855 .

Ent. Ann.-The Entomologists' Annual. London. 1856-74.

Ent. Mag.--The Entomological Magazine. London. I833-38.

Ent. Nachr.-Entomologische Nachrichten. Putbus and Berlin. 1875, et seqq.

Ent. Rec.-The Entomologists' Record. London. I890, et seqq.

Ent. Tidskr.-Entomologisk 'Tidskrift utgifven af entomologiska Föreningen i Stockholm. Stockholm. I880, et segq.

Entom.-The Entomologist. London. I 840-42, I864, et seqq.

1sis.-Isis, encyclopädische Zeitschrift für Naturgeschichte, vergleichende Anatomie und Physiologie. Jena and Leipsic. 1817-48.

Jihresb. - Jahresberichte über die Fortschritte der Forstwissenschaft und forstlichen Naturkunde nebst original-Abhandlungen aus dem Gebiete dieser Wissenschaften. Berlin. I837, et seqq.

Kroy. Tids.-Naturhistorisk 'Tidskrift. Copenhagen. I $\$ 37-49$, I 86 I, et seqq.

Mem. Ac. Sc. Torin.-Memorie della Reale Accademia delle Scienze di Torino. 'Turin. 1784 , et seqq.

Mém. couron. Ac. Bels. - Mémoires couronnés par l'Académic Royale des Sciences et Belles-lettres de Bruxelles. Brussels. i 852 , etseqg.

Nat. Jour. - The Naturalists' Journal. London. I 892-1902.

Nat. Sicil.-Naturalista Siciliano. Palermo. 1882 , et seqq. 
Nov. Act. Ups.-Nova Acta Regia Societas Scientiarum Upsaliensis. Upsala. I 780 , et setgq.

Nouv. Mém. Ac. Brux.-Nouveaux Mémoires de l'Académic Royale des Sciences et Belles-lettres de Bruxelles. Brussels. I 827 , et seqq

Proc. Berwick Club.-Proceedings of the Berwickshire Naturalists' Club. Alnwick. $\quad 1832-97$.

Proc. Lancs. Soc.-Proceedings of the Lancashire and Cheshire Entomological Society.

Proc. S. Lond. Soc:-Proceedings of the South London Lntomological and Natural History Society. London. I 885, et segq.

Proc.U.S. Mus.-Proceedings of the United States National Museum. Washington. I 879, et seqq.

Rev. Sc. Bourb.-Revue scientifique du Bourbonnais et du centre de la France. Moulins. I 888, et seqq.

Schr. Nut. Ges. Dans.-Schriften der naturforschenden Gesellschaft in Danzig. Dantzig. I 863 , et seqq.

Stett. Zeit.-Entomologische Zeitung herausgegeben von dem entomologische Vereine zu Stettin. Stettin. I840, et seqq.

Sv. Ak. Handl.-Kongliga Svenska Vetenskaps Akademiens Handlingar. Stockholm. I 780 , et seqq.

Trans. Devon. Assoc.-.The Transactions of the Devonshire Association for the advancement of Science and Art. Plymouth. I 868, et seqq.

Trans. Ent. Soc.-The Transactions of the Entomological Society of London. London. I 834 , et segq.

Trans. Norf. Soc.-Transactions of the Norfolk and Norwich Naturalists' Society. Norwich. I 869 , et seqq.

Trans. York. Un.--The Transactions of the Yorkshire Naturalists' Union. Leeds. I 878 , et seqq.

Trans. Linn. Soc.-The Transactions of the Linnean Society of London. London. I 79I, et seqq.

Trans. Guernsey Soc.-The 'Transactions of the Guernsey Society of Natural Science. Guernsey. I882, et seqq.

Trans. Penzance Soc.- The Transactions of the Penzance Natural History and Antiquarian Society. Plymouth. I 848 , et seqq.

Verh. pr. Rheinl. - Terhandlungen des naturhistorischen Vereins der preussischen Rheinlande und Westfalens. Bonn. I 84.4 , et segq.

Verh. z.-h. Ges. - Verhandlungen der kaiserlich-königliche zoologischbotanischen Gessellschaft. Vienna. I 852 , et seqq.

Wiegm. Archiv.-Archiv der Naturgeschichte. Berlin. 1835 , et seq9.

Zeits. Ges. Nat.-Zeitschrift für die gesammten Naturwissenschaften. Herausgegeben von dem naturw. Vereine für Sachsen und Thüringen. Halle. $\mathrm{x} 843$, et seqq.

Zeits. Syst. Hym.-Zeitschrift für systematische Hymenopterologie und Dipterologie. Teschendorf, Mecklenberg. rgor, et seqq.

Zool.--The Zoologist. London. i 843 , et seqq. 


\section{AUTHORS AND SEPARATE WORKS.}

Albin, Nut. Hist. Eng. Ins.-Albin, E. A Natural History of English Insects. Illustrated with a hundred copperplates, \&c. London. May 4 th, 1720.

Ashm.-Ashmead, IV. H. See Serials.

Berth.-Berthoumieu, V. See Serials.

Bignell.-Bignell, G. C. Lists of Parasites in Buckler's Larvae of British Butterflies and Moths. London. 1886-I 90 I.

Billups.-Billups, T. R. See Serials.

Boie.-Boie, F. See Serials.

Bridg.-Bridgman, J. B. See Serials.

Bridg.-Fitch.-Bridgman, J. B., and Fitch, E. A. See Serials.

Brisch.-Brischke, C. J. A. See Serials.

Capron.-Capron, E. See Serials.

Christ Hym.--Christ, J. L. Naturgeschichte, Klassification und Nomenclatur der Insekten vom Bienen, Wespen, und Ameisengeschlecht. Frankfort-on-Maine. I 79 I.

Curt. B. E.-Curtis, J. British Entomology. London. I823-40.

Curt. Farm Ins.-Curtis, J. Farm Insects. London. 1860.

Dale.-Dale, C. W. The Lepidoptera of Dorsetshire. Dorchester. 1886. Desv. Cat.-Desvignes, T. Catalogue of the British Ichneumonidae in the British Museum. London. 1856.

Don. B. 1.-Donovan, E. The Natural History of British Insects. London. I 792-I 8 I 3 .

Drezes, and Boie.-Drewsen, C., and Boie, F. See Serials.

Evans.-Evans, W. See Serials.

Fab. E. S.-Fabricius, J. C. Entomologia Systematica. Copenhagen. I $792-1798$.

Fab. M. I.-Fabricius, J. C. Mantissa Insectorum. Copenhagen. I 787. Fab. Piez.-Fabricius, J. C. Systema Piezatorum. Brunswick. ISo4.

Fab. S. E.-Fabricius, J. C. Systema Entomologiae. Flensburg and Leipsic. I 775 .

Fab. S. I.-Fabricius, J. C. Species Insectorum. Hamburg and Kiel. I $78 \mathrm{I}$.

Först.-Förster, A. See Serials.

Fonsc.-Fonscolombe, E. L. J. H. B. de. See Serials.

Forst. Nov. Spp. Ins.-Forster, J. R. Novae Species Insectorum. London. I $77 \mathrm{I}$.

Fourc. E. P.-Fourcroy, A. F. Entomologia Parisiensis. Paris. I 785.

Geer Mém.-Geer, C. de. Mémoires pour servir à l'Histoire des Insectes. Stockholm. I $75^{2-78}$.

Gmel. S. N.-Gmelin, J. F. Caroli a Linné Systema Naturae. Ed. xiii. Leipsic. I $788-93$.

Gr. I. E.-Gravenhorst, J. L. C. Ichneumonologia Luropaea. Breslau. 1829.

Hal.-Haliday, A. H. See Serials.

Hardy.-Hardy. J. See Serials.

Hart.-Hartig, T.-See Serials. 
Holmgr. Ichn. Suec-Holmgren, A. E. Ichneumonologia Suecica. Stockholm. I 864-89.

Illig. Rossi F. E.-Illiger, J. C. WV. Fauna Etrusca, sistens Insecta quae in provinciis Florentina et Pisana praesertim collegit P. Rossius. Iterum edita, et annotatis perpetuis aucta. Helmstedt. 1807.

Kirby Int.-Kirby, William, and Spence, W. An Introduction to Lntomology. London. 1822-26.

Kirby Mon. Apum Angl.-Kirby, William. Monographia Apum Angliae. Ipswich. 1802 .

Kriech.-Kriechbaumer, J. See Serials.

Lab. und Imh. I. S.-Labram, J. D., and Imhoff, L. Insecten der Schweiz. Basle. $1836-45$.

Latr. Cuv. R. A.-Latreille, P. A. In Cuvier's Règne Animal. Paris. I 849 .

Linn. F. S.-Linné, C. von. Fauna Suecica. Ed. ii. Stockholm. i 76r. Linn. S. $N$.-Linné, C. von. Systema Naturae. Ed. xii. Stockholm. I $766-68$.

Luff.-Luff, W. A. See Serials.

Marquand.-Marquand, E. D. See Serials.

Marsh.-Marshall, T. A. Ichneumonidum Britannicorum Catalogus. London. 1870.

Marsh. Cat.-Marshall, T. A. A Catalogue of British Hymenoptera. London. 1872.

Morl.--Morley, Claude. See Serials.

Moufet Ins. Theatr. - Moufet, T. Insectorun sive minimorum Animalium Theatrum. I.ondon. I 634 .

Müll. Prodr.-Müller, O. F. Zoologiae Danicae Prodromus. Copenhagen. $\quad 1776$.

Nat. Hist. Hastings.--The Natural History of Hastings. Hastings. $1878-98$.

Nezeman.--Newman, E. An Illustrated Natural History of British Moths. London. I869.

Nezuport.-Newport, G. See Serials.

Paget.-Paget, C. and J. A Sketch of the Natural History of Great Yarmouth and its neighbourhood. Norwich. 1834.

Panz. F. G.-Panzer, G. IV. F. Faunae Insectorum Germanicae initia. Nuremberg. I 792 I 8 IO.

Panz. Krit. Revis,-Panzer, G. IV. F. Kritische Revision der Insektenfaune Deutschlands. Nuremberg. 1805-6.

Panz. Schaef. Ic.-Panzer, G. IV. F. J. C. Schaeffers Iconum Insectorum circa Ratisbonan indigenorum enumeratio systematica. Erlangen. 1804 .

Parfitt.-Parfitt, E. See Serials.

Pic.-Pic, M. See Serials.

Poda Ins. Graec.-Poda, N. Insecta Musaei Graecensis, quae in ordines, genera et species juxta Systema Naturae Caroli Linnaei digessit. Graecii. I $76 \mathrm{r}$.

Ratz. Ichn. d. Forst--Ratzeburg, J. T. C. Die Ichneumon der Forstinsecten in forstlicher und entomologischer Beziehung. Berlin. I 844-52.

Retz. Spp. Ins. - Retzius, A. J. See Geer. Genera et Species Insectorum. Leipsic. 1783 . 
Rossi Mant.-Rossi, P. Mantissa Insectorum, exhibens species nuper in Etruria collectas, adjectis Faunae Etruscae illustrationibus et emendationibus. Pisa. I 792-94.

Rud.-Rudow, F. See Serials.

Ruthe.-Ruthe, J. F. See Serials.

Schm. Opusc. Ichn.-Schmiedeknecht, O. Opuscula Ichneumonologica. Blankenburg. 1902.

Schr. En.-Schrank, F. von P. Enumeratio Insectorum Austriae indigenorum. Augsburg. I 781 .

Schr. F. B.-Schrank, F. von P. Fauna Boica. Nuremberg. I 798-I804. Scof. Ent. Cur.-Scopoli, J. A. Entomologia Carniolica. Vienna. I 763 .

Shuck.-Shuckard, W. E. See Serials.

Sieb.-Siebold, C. T. E. von. See Serials.

Sle. Illus. M. - Stephens, J. F. Illustrations of British Entomology; Mandibulata. Vol. vii. London. I835.

Stephani.-Stephani-Perez, T. de. See Serials.

Sulz. Gesch.-Sulzer, J. H. Abgekürzte Geschichte der Insekten nach dem Linneischen System. Winterthur. 1776.

S. v. Voll. Pinac.--Snellen van Vollenhoven, S. C. Pinacographia. The Hague. $1875^{-80}$.

S. v. Voll. Schets. - Snellen van Vollenhoven. Schetsen ten gebruike bij de studie der Hymenoptera. The Hague. I 868.

Tasch.-Taschenberg, E. L. See Serials.

Thoms. O. E.-Thomson, Prof. C. G. Opuscula Entomologica. Lund. I $869-97$.

Thunb.-Thunberg, C. P. See Serials.

Tisch.-Tischbein, P. See Serials.

Trentep.-Trentepohl, J. J. See Serials.

Vill. Linn. Ent.-Tillers, C. J. de. Caroli Linnaei Entomologia. Leyden. I 789 .

IValker, C.-Walker, C. H. H. See Serials.

Walker.-Walker, Francis. See Serials.

WVesm.-Wesmael, C. See Serials.

Westze. Introd.-Westwood, J. O. An Introduction to the Modern Classification of Insects. London. 1839-40.

Wilson. - WVilson, J. See Serials.

IVilson, T.-Wilson, T. See Serials.

Woldstedt. - Woldstedt, F. IV. See Serials.

Wood Ins. at Home.--Wood, J. G. Insects at Home. London. 1883.

Zett. I. L.-Zetterstedt, J. W. Insecta Lapponica descripta. Leipsic. I 840 . 



\section{INTRODUCTION.}

IT has been aptly said that, while birds are the Sauls who slay their thousands, Ichneumons are the Davids who slay their tens of thousands. Were it not for the check the latter so effectually exercise over the ever increasing multiplicity of other insects, it is probable we should be able to procure no surface vegetables for our tables, no corn for our bread, no flowers for our vases, and, above all, that the landscape would become devoid of the lovely herbage, leaves, grasses, plants and even trees, presenting a brown and barren waste of sterility. All moths and butterflies lay some hundreds of eggs apiece, and if each of these attained maturity to go and lay another hundred, their numbers would so quickly increase that the plants upon which they subsist would speedily be extirpated. What has at various times been noted in this respect ${ }^{1}$ has caused utter ruin. A single instance may be cited of the prodigies possible to insects which have been imported into strange lands without the Ichneumons essential to the preservation of their normal numbers. MIr. Bignell has concisely set forth the damage committed by the Gipsy Moth in North America. This scourge was imported by a French naturalist, who allowed a few specimens to escape, in 1869 ; twenty years later the heel of the invader was felt throughout two hundred and twenty square miles of country; the larvae completely defoliated the trees; hundreds of men are regularly employed in their destruction and have, since $\mathrm{I} 890$, inspected and re-inspected over forty-two million trees, and have killed about two-and-a-half billion larvae. Twenty thousand pounds per anmum has been necessary for the work. This expenditure has lately increased and the pest is only reduced to seventy-five miles of forest. Now, if that French naturalist had only turned loose an antidote in the form of a few Ichneumons after the escaped moths, we should have heard no more about them, for they would have been restricted to respectable propagation.

So vast a mass of literature has been compiled respecting the parasitism of the Ichneumonidae that it is totally impossible to do more here than give some meagre outline of it, and to take, as relating to the present volume, the lines pursued in common by the majority of the Ichneumoninae. The eggs of this family are invariably deposited in or upon the larvae of insects and among the eggs of, or upon mature, spiders. ${ }^{2}$ Lepidoptera exclusively constitute the victims of the Ichneumoninae, and

1 Cf. Curtis, Farm Insects, p. 78 ; Miss Ormerod's Reports, Se.

2 I know of no authentic instance of their deposition in the pupa; and IVestwood has shown (Introd. ii., 144) observations upon the presence of phytophagous larvae in this family to be fallacious, as also we are led to consider those set forth in Ent. Rec., 1900, p. 293. 
generally also of the Ophioninae. The majority of the Tryphoninae are parasitic upon saw-fly larvae, though the Schizodontes have a predilection for Diptera; the Prosopi for Micro-lepidoptera, and Orthocentrus for small Coleoptera. Pimplinae prey largely upon xylophagous and other Coleoptera, Aculeate Hymenoptera and, in a few cases, Arachnidae. Many of the Cryptinae are hyper-parasitic, through Braconidac and other Ichneumonidae, including their own sub-family, upon Ixpidoptera, but they appear extremely omnivorous, and also attack certain 'T'enthredinidac, Cynipidac, Colcoptera, I)iptera, Neuroptera and spiders. Hyper-parasitism is largely practised in this family. 'The parent insect lays her egg in the body of a parasitic larva already ensconced within a lepidopterous caterpillar, this, hatching, assimilates to itself the juices drawn by the parasite from its host, which, eventually, is destroyed by the parasite, just as the latter is demolished by the hyper-parasite, which alone attains perfection through the dead bodies of both.

The Ichneumoninae leave but a single egg with each victim; if two be deposited, one of the ensuing larvae will invariably destroy the other, since the juices of the host are incapable of sustaining both, and were both to live the host would perish before either had attained maturity. It has been ascertained by anatomy that each female possesses from eight to sixteen egg-sacs, each of which is capable of producing at least six eggs. The terebra is conformed, from the very short ones of the Ichneumoninae, which Berthoumieu tells us oviposit upon the skin, to the tremendous weapons of some of the Pimplinae, which bore with them through at least an inch of solid wood, ${ }^{1}$ entirely in accordance with the kind of host upon which the insect preys. The position assumed while in the act of egglaying very considerably varies in different, but is usually identical in the same, species.

The number of hosts often enumerated in the following pages, under a single parasite, will entirely disprove the ancient theory that each species was confined to one in particular. The only restriction would appear to be the very natural one that the host must be of suitable size to sustain the parasite till the latter be full-fed. Much has been written upon the wonderful instinct of the female in choosing a suitable pabulum for her eggs, and, indeed, there do appear to be a few species which are restricted to a single kind of host, but their number is ever decreasing as more and more species are bred from a larger diversity of victims. A small, and very common Cryptid, Hemiteles areator, has been bred from as many as eighteen different kinds of Lepidoptera (Bombyces, Tortrices and T'ineae), ten kinds of Hymenoptera (Tenthredinidae, Ichneumonidae, Braconidae and Cynipidae), several kinds of Coleoptera, one of Diptera and one of Neuroptera.

The extent of the perfect existence is extremely variable. Many kinds of Ichneumoninae and Cryptinae hibernate in this state, which then lasts from the end of August to, probably, the following May; others so quickly effect the cycles that as many as two, or even three, generations are com-

1 E.g., Rhyssa persuasoria. Cf. Proc. Ent. Soc, Meeting, Ist April, 1867; lib. cit., Meeting, 3rd Oct.,

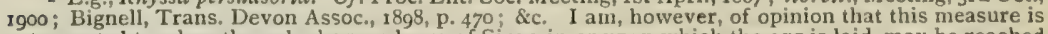
not resorted to when the xylophagous larva of Sirex, in or upon which the egg is laid, may be reached by intruding the ovipositor along the already excavated galleries. Miss Chawner says (in lit., th $^{\text {th }}$ January, I90I) that the species is very common in her garden, and she has watched it poking its long ovipositor into the borings of the larvae; Mr. F. C. Adams writes (in lit., 7 th December, 190o) also from Lyndhurst, that he has seen the female inserting her terebra as far as possible into holes, in fir posts, but that he does not think it can itself pierce the wood unless it be in a very rotten condition. 
pleted in the year. I am sure that the females of certain kinds hibernate after copulation, and that certain kinds do not, i.e., when we come to know them more thoroughly we shall find that at least the majority of species have certain times of appearance, though doubtless a few are nearly always abroad during the summer months. No male has ever yet been known to hibernate. In confinement, however, their life is of short duration. Listrodromus nycthemerus left its host's pupa at 5-40 p.m., on 23 rd May, and died during the night of the 27 th, or a little over five days; Ichnenmon delivatorius, forced to an unnaturally early emergence in February, lived three days in a warm room; a male Mesostemus obnoxius emerged on 27 th May and died late on 3 oth; a female of the same species emerged from pupa at midnight of 28 th, appeared to be in incessant motion till the 2 nd June, late on which day it died, or five days ; another male lived six days, from $15^{\text {th }}$ to 2 ist May. The Anomalons appear to have a somewhat longer span, since I have noted that captured specimens lived six days or seven days in a very confined space.

'The collecting of these interesting, and often handsome, insects is one of the easiest points in their study. Like the Coleoptera, they may be found always, and in the summer everywhere. In the spring, the hibernated females may often be beaten from fir trees, as well as seen upon the blackthorn bushes. When the buds of the oak are but beginning to burst many rare species have been taken by Mr. Bignell, who also boxed, upon the fully-expanded leaves of a solitary beech, about six feet high, some eighty specimens during a dull day. In bright weather, however, large numbers may be obtained by simply swinging a net to and fro through the air. The majority of captures at this time of year will be found to belong to the 'Tryphoninae, which are especially abundant in the vicinity of hazel bushes. A very effective trap is constructed in a favourable locality by glass affixed to and sloping slightly downwards from an ordiuary wall. The insects, on rising to surmount the wall, are caught in the angle formed by the glass and the wall, where, since it is contrary to their instinct to fly downwards, they are held prisoners. In this way, Mr. Adams takes large numbers at Lyndhurst. 'These insects are marvellously agile, and when caught in a net the majority will at once take to flight upon the least opportunity, often darting straight from its bottom upwards; many have an aggravating habit of settling just for long enough to give one a fleeting glance and then flashing away at full speed. Cryptinae, however, more generally seck to hide themselves at the bottom, among the débris. With the exception of the genus Anomalon and its immediate allies, these insects never attack one another and, consequently, any number may be brought home alive in a single box; it is, moreover, extremely rarely that one discovers a mutilated specimen, and I have only once captured such a one, though those with the wings externally tattered are not uncommon in worn examples. 'They are hardly ever to be met with after the sun sinks low and begins to lose its power, and must then be sought at the roots of the herbage; there are fewer abroad in the morning than in the afternoon, though, perhaps, the percentage of females is then greater, at all events upon flowers. Trampled and bruised grass has been stated to have peculiar attractions for them; and many kinds of Ophioninae, including the big red Oplion lutens, so familiar to all, are freely attracted by artificial light and by "sugar." Berthoumieu tells us they hide away among low herbage during very hot weather, whence they are forced by the dampness 
to proceed after a heavy shower, which, he claims, is the psychological moment to capture them. I have not personally noted this fact.

The above methods of capture fall into insignificance, however, when compared with flowers. No insect is more fond of sweets, and none more indifferent to bright-coloured, flavourless objects, than the Ichneumon. Many kinds, especially Meniscus murinus, will be discovered hovering about the blackthorn blossom, in April ; numbers of Cryptinate frequent whitethorn flowers, in May, and are also to be beaten from those of mountain ash ; in June, many captures of smaller species may be effected upon chervil and hemlock, in fact, it is the Umbelliferae in general which are most attractive, on account of the greater amount of saccharine matter secreted by the stylopods. ${ }^{1}$ Elliott has found these insects to frequent meadow-sweet, and Berthoumieu tells us they are attracted by Euphorlicae. I have never found them at bramble, ragwort, nor, like the Aculeates, to be fond of bryony. One of the three flowers which most profitably repay close working, is the cow's parsley, whose great white tables are often quick with parasites in July, while in August the more slender, yellow fennel is hardly less populous. The best plant of all is the angelica, and if you should meet with a clump of these flowers in some marshy spot you need go no further that day ; angelica is in bloom from early August till the fall of the frosts, and is always prolific, which cannot be said of other autumnal flowers, such as scabious, ragwort and yarrow, though carrot, both in its wild and cultivated states, produces species up to the end of October. As regards collecting upon angelica in August, I have noticed that sunshine is almost absolutely necessary to the insects' presence ; isolated heads are those most affected, but when growing in large beds, the highest heads, and those on the outskirts, but especially those in fullest bloom, are chiefly frequented. The insects are often difficult to capture, since they see the net descending, and instantly dart off. When alighting, the Ichneumoninae make a quick plunge at the flower and at once begin to feed, but the 'Tryphons, when approaching Heracleum, appear to dart swiftly to the flower, hover before it like Syritta pipiens for a moment, then gently alight beneath the table, and afterwards crawl up on to its surface. Cryptinae alight very gently and circumspectly upon the upper surface, after hovering for a moment or two.

Ichneumonidae are not so easily frightened away as are Syrphidae. Pimplae, which have an affection for thistles, though not, I think, for the flowers, will sometimes return and again hover at the plant whence they have been frightened. Ophion and Ichneumons will never return in this manner to flowers. The former is not especially nervous, but when once alarmed it flies off hurriedly, careering wildly (like a Tipula) for some twenty or thirty yards ; the latter, if only slightly disturbed, gently flit away and a quick stroke of the net will secure them, but, if thoroughly alarmed,

1 I have, at various times, found the following species of Umbelliferae, in their order of merit, to be attractive to Ichneumonidae:-Angelica sylvestris, IIeracleum Sphondylium, Foeniculum vulgare, Daucus Carota, Pastinacen sativa, Chaerophyllum temulum, Anthriscus sylvestris, Conium maculatum, Cicuta virosa, Smyrnium Olusatrum and Pimpinella Saxifraga. I have also found these insects at Nasturtium officinale, Malva sylvestris, Vicia sativa, Prumus spinosa, Crataegus Oxyacanthus, Matricaria inodora, Tanacetum vulgare, Ly'simachia vulgaris, Mentha, Scutellaria galericulata, Myrica Gale and Allium ursinum, though it is not always the flowers which are affected. On 25 th July, 1899 , Bassus laetatorius, Fab., was exceedingly abundant upon Polygonum, near the beach, at Slaughton by Aldeburgh. They were running up and down the stems and leaves, poking both antennae at once into the cups surrounding the former's bases, and evidently in search of something which was not visible to the naked eye during fifteen minutes of observation. It is generally believed to be parasitic upon Syrphid larvae ( $c f$. Brischke; Bignell, in Entom., 188, p. 167, \&c.), none of which were apparent. 
they flash off on the instant; even the falling of a shadow disturbs them, though its removal appears more startling. Banchi slightly disturbed will stand motionless for one-and-half minutes with antennae straightened and, even after the resumption of feeding, still keenly on the alert; they alight on Heracleum without hesitation, feed like Exetastes, with head deflexed and abdomen elevated above the long hind legs, in which position they may usually be secured between the fingers. 'They nearly always choose the highest flower-heads, and are capable of emitting a defensive odour resembling that of pomade. Exetastes cinctipes, Retz. (= osculatorius, Fab.) and Perilissus praerogatur alight gently, after hovering with pendent legs and backward flowing antennae. Sometimes these insects (e.g., Amblyteles palliatorius) are found, apparently gorged, beneath the flowers. 'They never crawl backwards, but are capable of turning in a wonderfully small space; thus I have seen a female Ephialtes, which measured, all parts included, fifty-eight millimetres, turn completely round in an eight-and-a-half millimetre tube, and the much stouter Ichneumon lautatorius of twenty-five millimetres is capable of the same feat.

The caution employed before feeding upon the nectar is most rigorous in the protection of the mouth. First, each stylopod is investigated with the tips of the perpendicularly curved antennae, which are then usually, though not always, held forward, and not far apart, to ward off frontal attacks, and the inspection is continued more closely with the maxillary palpi. Satisfaction being attained, the stylopod is at length licked with the ligula, much as a cat laps milk, the while the maxillary protect the flanks and the labial palpi are trailed backwards to intercept all attempts from the rear. Should the antennae meet with a Braconid, or other object already in possession, the insect remains motionless for a moment with antennae keenly alert, then moves gently off to another part of the flower. These precautions would seem unnecessarily elaborate were it not that upon the disc of the tables there sometimes lurks a rather large spider, Misumena vatia, Clk., so exactly resembling in colour and in its widespread legs the flower on which it rests as to be practically invisible, at least to human eyes. In its meshes I have found Ichneumon lautatorius entangled and destroyed, having been attacked from beneath. The vulnerable point in the Ichneumon's chitinous tegument is said to be at the junction of the head and collar, and it is here that the Wolf Flies (Dioctria) are enabled to pierce the membrane and suck the vital juices.

It is now generally acknowledged that the sting of the Aculeates is a modified terebra, but for long the faculty of Ichneumons for stinging was a moot point. I cannot here enter into all that has been written upon the subject, but I may say that beyond all doubt some kinds do and some do not possess this faculty, though whether it be at certain periods in, or throughout, their perfect existence does not appear plain. Anatomy shows the females to be, at least sometimes, furnished with a linear and branched poison gland ( $c f$. Bordas, in Zool. Anz., I894, p. I3 I), whose liquid is stored in a vesicle adjoining the terebra. Westwood truly says that Ichneumons held in the fingers always try to sting, but usually unsuccessfully. William Kirby states he has been stung by a species of Ephialtes and by another Ichneumon with a concealed terebra. I have often allowed them to do their worst, with no result, though once a Paniscus, with which I was not experimenting, succeded in puncturing the skin and the pain in this case was but momentary. Butler tells me that the large Ophioninae 
can give a sharp prick, though the pain is very evanescent. 'Tuck has also been stung by an Ophion, and Charbonnier quite sharply by Melanichneumon leucomelus and Cryplus tarsoleucus.

Lastly, during the long winter months certain kinds of Ichneumonidae are to be met with beneath the moss on and at the base of trees and stumps, beneath fallen logs, under the bark of living and dead trees, and many Pezomachi, \&c., dwell among ground mosses in the early spring. All these are, of course, females belonging almost, or quite, exclusively to the Ichneumoninae and Cryptinae. But the hibernaculum, which is most favoured, is the clumps of the tuft grass (Aira [Deschampsia] caespitosa), which does not appear to have been before particularised for its fertility; the tuft should be cut off as near its roots as possible and conveyed home in a bag. In an hour I have taken from a single tuft of this grass, about a foot in diameter, which I had cut to the roots nineteen months before in my favourite locality, the Bentley Woods, on $7^{\text {th }}$ December, no less than eighteen species represented by fifty-one specimens of Ichneumonidae.

As to the mode and details of setting, I am inclined to say "chacun à son goût," though I do not recommend the British method of cardgumming, unless you are prepared to float the insects off before they come to be identified, since the coxae, \&c., are so often of primary importance in determination, and I would stipulate that the mandibles be always distended, especially among the Phaeogenides. I need hardly say how valuable are full data of capture, or emergence, when attached.

These insects are very liable to grease which, Dr. Knaggs has kindly informed me, may most easily be removed by placing the affected subjects in an air-tight bottle containing methylated ether, where they should remain a week or so. A yellow deposit is sometimes left upon them, which may usually be removed with a paint brush ( $c f$. also Entom., 1878 , p. 23 ; E.M.M., I895, p. I6.). ${ }^{1}$

\section{METAMORPHOSES.}

It is by no means an easy matter to draw up a succinct account of the metamorphoses of the Parasitica, since so little, comparatively speaking, is known of the extremely interesting modifications through which they pass from an adipose and apodous larva to a chitinous and active imago. The following account, however superficial, will lend some idea of the circumstances under which at least a part of the Ichneumonidae arrive at maturity.

The eggs of these insects are laid either upon, or inserted by the spicula beneath, the skin of lepidopterous and other larvae, to which, in the former case, they adhere by the viscous matter covering them. They are clliptic or pyriform in shape and usually ashy-grey in colour at the moment of oviposition, assuming a darker tint on contact with the air. Those of certain genera of the Ophioninac, however, are somewhat bean-shaped and are attached near one end by a long, slender and curved peduncle to the

1 Referring to a remark of mine (cf. Ficld Naturalists' Quarterly, 1902, p. 40), Mr. Carleton Rea, B.C.L., M.A., has been good enough to inform me that the "mould "which so often destroys lepidopterous pupae is Isaria farinosa, which is the anidial condition of Cordyceps milntaris; he adds that those which attack insects in cabinets are very varied, but, being of universal distribution, they are almost impossible to exclude. 
skin of their victim. The duration of this state has not been observed, but doubtless varies greatly under diverse atmospheric and other conditions. When the egg-shell splits, the enclosed larva does not at once emerge, but commences to imbibe the juices of its host through the fissure. The larva does not evacuate its shell till after the first moult, its cast skin having been found by Brischke and the older authors attached to the egg. The internal feeder now penetrates the caterpillar's skin and takes up a position between the muscles contained in the splanchnic tissues and the alimentary canal, on the dorsal surface, above the stomach on which it often rests, near the centre of the body and nearly always with its head in the same direction as that of its host. Certain species of 'Tryphoninae, however, appear to be larviparous, since they may often be seen carrying masses of what Gravenhorst thought to be eggs, but which were proved by Haliday to at least sometimes be living and often cannibalistic larvae, at their anal extremity. In the Pimplinae, \&c., the larvae are often external, lying like a muffler round the prothorax of their hosts (usually spiders), while those of certain Cryptinae feed exposedly upon the eggs of spiders, protected by nothing but the thread-sacs which enclose the latter.

In general, the entomophagous larvae of Ichneumonidae are apodous, soft, whitish or yellowish, nearly cylindrical or ovate, somewhat pointed at each end, and always with a broad lateral border of fleshy tubercles, bearing spiracles. In the earlier stages of growth, and sometimes (as in Orthopelma) throughout it, they are curved. They consist of fourteen segments. The first, or cephalic, segment bears traces of antennae on the frons, below which is a sometimes discreted clypeal area, anteriorly bordered and occasionally reflexed. On either side, below this border, are attached the very short, slender, deflexed and corneous mandibles, of variable shape. Beneath these are concealed the labium and maxillae, with the latter's minute palpi. These organs are usually of dark coloration, as also are the spiracles, but the whole remainder of the body is pale, exhibiting few distinctive features, excepting the explanate lateral border, which is distinctly discreted from the main body.

Within the egg, the larva is gradually evolved from the ventral surface upwards. Dorsally, the cephalic segments first coalesce, then the anal, and, lastly, the intervening space gradually becomes entire from behind forwards, the prothorax being finally completed. The alimentary canal is also formed from behind forwards. Its anal extremity is the commencement of the colon and small intestine, which retain their cellaeform conformation to a late period of the larval life, and constitute, in structure, one of the chief points of distinction between the larvae of parasitic Hymenoptera in general. The digestive apparatus is a hollow cavity, or pear-shaped and elongated sac, with a very short intestine, connecting anteriorly with the short and narrow oesophagus and with the oral organs, though at first closed behind. It is very similar in all hymenopterous parasites, whether internal or external. Its cellaeform, becomes transformed into a glandular, structure of two kinds, of which one elaborates the digestive juices, while the other diffuses the results in the form of nutriment throughout the body. In every case the intestinal portions continue small and rudimentary, passing no faeces, till the larva has attained maturity and ceased to feed. The colon and ilium are gradually evolved from without inwards into muscular tissue, from a column of cells connecting the digestive cavity with the anus; their function being to 
transmit the faeces, they are not perfected till a late period of the larva's existence.

The head and mandibles of the larva of Trogus, so ably described by George Newport, are corneous and yellow, with the margins and apices of the latter black. The mandibles are curved, apically acute, fitted for penetration and suction, but not for manducation. The maxillae are three-jointed, with the terminal joint broad, triangular, soft and membraneous, the second very short, and the basal joint strong and elongate. The labium is triangular, with a slight median ridge. The antennae are entirely rudimentary, but represented by small, corneous callosities on the frons. The lateral margins of all the segments are explanate, and project in the form of tubercles, which are prominent in the three thoracic segments, as well as in the pre-abdominal. Their tubercular form is, however, most marked in the fifth and eleventh segments, which also bear distinct mammaeform tubercles laterally upon the venter, acting as locomotive organs. In the later stages of growth, these organs gradually more closely approximate, and illustrate the greater development of the dorsal than of the ventral surface. True legs are indicated only by six points upon the lower surface of the thoracic segments, in the same position as the abdominal tubercles. The pedal process of the apical segment is pointed and projecting, and is said by Berthoumieu to be reduced to a normal form after the second or third moult. It is opposable to another, beneath the thirteenth segment, and with it forms a prehensile organ, by means of which the larva is enabled to affix itself and alter its position. The spiracles are oval, corneous and situated on either side of the anterior part of each segment. The whole of the tracheal vessels are distinct and distended with air. This fact abundantly disproves Boisduval's theory that internal larvae do not directly breathe, but obtain sufficient oxygen from their food, which, he says, is not taken through the mouth, but assimilated by a kind of general absorption, in which case cribrary and respiratory organs would be superfluous. Professor Owen was of opinion that internal parasites undoubtedly destroy many of the minute branchial tracheae which ramify in the adipose tissue, and these would probably permit the escape of sufficient air for the respiration of the parasitic larvae.

When full-fed, the larva emits rejectamenta to the extent of half its former size, and the abdominal segments become much shrivelled, though the thoracic are inflated and distended. About a month after evacuation, the larva begins to assume the pupal state. The head is then swollen and retracted into the thoracic segments, rudiments of the eyes become infumate and convex. The larval skin first splits along the cephalic dorsum and in half-an-hour the pupa has entirely cast it off. Many larvae of Ichneumonidae, when full-fed, leave their hosts' bodies and construct for themselves silken cocoons, numbers of which are very beautiful, being composed of iridescent strands or threads of mingled black and white. Others, like the Ichneumoninae, remain in the chrysalis of the demolished host, generally spinning for themselves an internal silken lining upon it.

The pupa of Ichneumonidae exhibits, like that of the Coleoptera, all the members of the perfect insect inclosed in individual sheaths. In Ichneumon bellipes, a typical example of the first sub-family, the head is deflexed upon the prosternum; the antennae lie along the outer edge of the sternum and extend to the centre of the fourth ventral segment; the mandibles are closed and the palpi extended straight downwards until their 
apices nearly approximate. The abdomen is fully developed, though the lateral tubercles are still very conspicuous, and the conformation of the basal segment undergoes considerable modification during the pupal state. The genital organs are very prominent, at first rudimentary and surrounded by thick liquid, but gradually becoming perfect as emergence approaches. ${ }^{1}$ The legs are pressed closely to the sides of the body; the femora are drawn forward and the tibiae folded back upon them; the tarsi lie along the outer side of the antennae in a continuous line, the hind ones extending to the base of the seventh ventral segment.

As is the case in most Hymenoptera, the final quiescent condition of the larva is protracted to the proportionate brevity of its pupal existence, which often is no longer than of ten days' duration. As far as my observation extends, the mandibles of these insects serve but one purpose, that of effecting an exit from their hosts', or their own, cocoons. May we not, therefore, forecast in some measure from the greater or less development of these organs upon what kind of host they prey, or is it not rather the amount and potency of the potassium hydroxide secreted to aid the mandibles in this function by which we should judge the solidity through which they are capable of forcing their way? Thus, the mandibles of Paniscus cephalotes, a parasite upon Dicranura vimula, are certainly stouter than those of Stenichneumon trilineatus, which preys upon Abraxas grossulariata. After the imago has thrown off the pupal sheath, it remains, unlike the Lepidoptera, in the cocoon for a day or two, during which period it attains such complete perfection that, having effected an exit by means of its mandibles, its wings are already available for flight and nothing retards its instant volition.

\section{INTERNAL STRUCTURE.}

The alimentary canal of the imago, as in the larva, is formed, says Newport in describing Trogus, of distinct layers or tissues :- a muscular, a glandular and a mucous ; and is invested externally by a distinct transparent peritoneal membrane, processes or reflexions of which clothe every internal organ, the salivary and hepatic glands, the organs of circulation. and reproduction, the adipose tissue and tracheae. The short and narrow oesophagus becomes considerably elongated, and, instead of terminating as in the larva in the mesothoracic segment, is extended in the imago through the metathoracic into the abdominal segments. It is there dilated into a conical crop, which, by a constriction at its apex and a reflexion inwards of its tissues to form the cardiac valve, is separated from the true digestive cavity or stomach. This portion of the canal, the chylific ventricle, which occupies nearly the whole interior of the larva, is now restricted to the fifth, sixth and seventh abdominal segments. It is a powerful muscular structure, somewhat elongate-oval in shape and is followed by the hepatic or Malpighian organs, from twenty to thirty in number, where, internally by reflexion of the tissues, is formed a second valve, the pylorus. The canal then becomes narrowed into what may be regarded as the duodenum and ilium, or small intestine. Beyond this it is again dilated into a more

1 In Paniscus I lave noticed these organs not to become perfect until after the pupa is so far advanced as to be able to move its legs. 
muscular structure, the colon or rectum, which is usually filled with ejecta and terminates at the anal valve.

\section{EX'TERNAT, STRUCTURE.}

There are always present a distinctly separated Head, bearing a pair of elongate antemnae, Thorax and Ibdomen, three pairs of I,egs and usually two pairs of membraneous Wings.

The Head, viewed from above, is transverse or quadrate ; from in front, it becomes more or less strongly narrowed towards the mouth and is always sculptured with punctures or reticulations. The eyes are very large and occupy nearly the whole anterior side of the head. The vertex bears three ocelli, situated triangularly, and behind them is the occiput sloping to the collar. Between the ocelli and the insertion of the antennae is the frons, usually bearing glabrous scrobes upon its anterior portion; below these is the face, known centrally as the epistoma, its apical margin being discreted from the clypeus, which extends across the whole front of the head, by a usually present transverse impression terminating on either side in a fovea. The apical margin of the clypeus is usually truncate, or sub-bisinuate, though occasionally dentately reflexed or rotund. 'The cheeks, which lie between the apical extremity of the eyes and the base of the mandibles, and the temples, behind the eyes, are more or less broadly buccate, and the former vary in their length according as the eyes approach or recede from the mandibles, which are broader basally than apically, and sometimes as broad as the cheeks are long. The apex of the mandibles, which lie folded the one upon the other across the front of the clypeus, is usually bidentate, the upper in most cases being much longer than the lower tooth, but in some instances the teeth are of equal length or the lower is wanting. Between the apex of the clypeus and the mandibles, the labrum is more.or less visible, rotund and ciliated. The two pairs of palpi, the maxillary and the labial, are elongate ; the former consists of five usually cylindrical, the latter of two triangular and two cylindrical, joints. The mentum, ligula, hypo-pharynx, \&c., are not alluded to in descriptions.

The Antennae are inserted between the eyes in the front of the head. They are multiarticulate, as many as seventy joints being found in certain genera, while in others the number diminishes to fourteen. The scape consists of the two basal joints (the radicula or basal joint not being mentioned in descriptions). The first of these is oval or shortly cylindrical, with an incision on its under side, in which is inserted the second joint or pedicellus, having its apex always free, but shorter than the scape proper. Next follows a minute joint, termed the annellus, which, with the remainder of the antennae, constitutes the flagellum. The joint immediately following the annellus is known as the post-annellus. During life the antennae are porrect and held while in repose straight forward, not recurved beside the body as in most Orders. After death they very often become convoluted and spirally coiled, as described by the older authors.

The Thorax consists of three distinct sections:- that nearest the head is the prothorax, bearing the front pair of legs; the middle section is the mesothorax bearing the intermediate pair of legs and anterior pair of wings; the last section is the metathorax bearing the hind pair of legs and posterior pair of wings. The disc of these sections is known as the 
notum, their sides as the pleurae, and the lower surface as the sternum. The prothorax is very short, usually transverse, extending laterally to the radix. Its pleurae bear grooves, in which the front femora rest during repose, and their margins are known as the epomiae. The mesothorax is usually as broad as, or a little broader than, the head, and is divided into two distinct sections, called the scutum or disc, which is produced into the prominent Scutellum. This is much smaller than the disc, and is situated at the base of the mesothorax, between the hind pair of wings. It is generally somewhat convex, triangular, with erect pilosity. At its apex is a small prominence designated the post-scutellum. It will be noticed that the post-scutellum forms the centre of a transverse, almost linear, band which, laterally, bears the hind wings. This is the true metanotum, which is not referred to in descriptions. The convex portion between it and the petiole has been proved by micro-anatomy to be the true first abdominal segment, and is superincumbent upon the true metanotum, which will be found to laterally extend back to, and bear, the hind coxae. This portion is termed the propodeum by Saunders, but its old collective name, metathorax, embracing both the true metathorax and the superincumbent abdominal segment, is here, for the sake of convenience, retained. 'The region of the scutellum is the centre of the insect, consequently the prothorax is at the apex of the mesothorax and the abdomen at the apex of the metathorax.

The Abdomen is connected with the thorax by a more or less distinctly constricted stem, called the petiole. This is the base of the first abdominal segment, which towards its apex becomes more or less explanate, and is thence known as the post-petiole, usually bearing distinctive sculpture. The second segment before its base is often deeply impressed sulciformly at the sides, and these impressions are the gastrocaeli, their apical margins being the thyridii. There are eight dorsal segments, of which the pygidium is rarely visible, being retracted beneath the seventh segment. There are also eight ventral segments in the male, but only six in the female. These are often longitudinally plicate, in the centre, after death, owing to the contraction of the soft tissues upon desiccation. 'The apical ventral segment is the hypopygium, and is of variable form and extent, often covering the base of the terebra, which is composed of the central, true ovipositor or spicula and its two lateral, protecting valvulae or sheaths. The length of the terebra varies from twice that of the insect to barely visible beyond the apex of the hypopygium.

'The Legs, so distinctive in many groups of insects, are here dis appointingly uniform in structure, being nearly invariably long and slender with few modifications. The basal joint or coxa, however, often bears a little tuft of dense pilosity known as the scopula, is sometimes dentately mucronate or obliquely cristate, and is always more or less closely puncate. The next two joints compose the trochanter, which is followed by the elongate and rarely dentate femur. The sometimes spinulose or intumescent tibia is articulated to the apex of the femur, and is followed by the five-jointed tarsus. The onyches are occasionally internally pectinate or furnished with comb-like bristles, and the basal joint of the front tarsi is excised beneath, forming with the calcaria, or apical tibial spurs, a beautiful apparatus for cleansing the antennae, \&c. The anterior legs are the two front pairs collectively; the posterior the two hind pairs collectively. The front and hind legs each comprise but a single pair. 
The Wings vary greatly in extent though little in outline, and they do not extend beyond the anus; sometimes they are rudimentary and in one genus usually entirely wanting. The number of the nervures is not great, and these vary but slightly in extent and position. 'T'here are usually three cubital cells, but the central one, known as the areolet, is extremely variable in shape, and often has its external nervure pellucid or entirely wanting. 'l'he wings are nearly, or quite, transparent or hyaline, covered with extremely minute bristles, and none of our species exhibit the violet or black infumescence of the tropical representatives. The point of junction with the thorax is known as the radix, which is partly covered by the squamulae or tegulae.

The above very brief sketch will serve to connect the more detailed descriptions of individual parts contained in the Glossary, and also a few essential characters, which it is necessary to detail at greater length below.

\section{DETAILS OF TIIE IIEAD.}

A clear knowledge of the various capital characters is of primary importance in following the descriptions, which, it is hoped, the accompanying figure will sufficiently illustrate. In it, I is the vertex bearing (2) the ocelli, with the occiput out of sight behind it; 3 is the frons, the lower part of which is excavate, glabrous, and forms the antennal scrobes

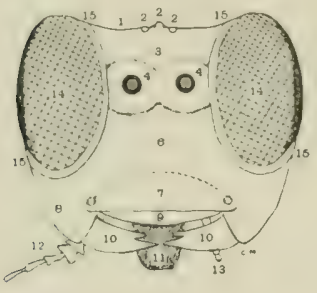

DeTaILS OF THE HEAD.-I, vertex ; 2 , ocelli ; 3 , frons ; 4 , antennal scrobes ; 5 , insertion of anten. nae; 6 , face; 7 , clypeus; 8 , cheeks; 9 , labrum; IO, mandibles; II, ligula ; I2, maxillary palpus; 13 , labial palpus; 14 . eyes; I5, orbits.

and extends on either side (4), and the insertion of the antennae (5); 6 is the face, the central portion of which is often convex and termed the epistoma; 7 is the clypeus, with the lateral foveae circularly indicated before ( 8 ) the cheeks; 9 is the labrum, in front of which are (10) the bifid mandibles; II is the ligula or tongue; I 2 one of the two maxillary palpi, and I 3 a proportionate labial palpus ; 14 are the compound, reniform eyes, with (I5 to I5) their orbits, which also extend throughout their posterior circumference. The basal side of the head, i.e., that nearest the prothorax, is attached to the latter by a very slender peduncle. Some distance above this peduncle is a raised margin, which forms the lower edge of the occiput of the head to the lower extremity of the cheeks, known in its lower part as the genal costa. This costa is sometimes nearly or quite straight, from level with the peduncle downwards, but at others is inflexed or obtusely angulated some distance from its apex. Viewed from above, the head varies greatly in length and breadth behind the eyes, being of en very short and narrow, occasionally as long as the eyes themselves appear from that position; and, when inflated in such a way as to be laterally broader than the eyes, it is said to be buccate. The cheeks in the figure are normal. IVhen so broad and vertically straight as to form a right angle with the clypeus they are termed buccate; occasionally they are so narrow that the head is triangular, viewed from in front. A genal sulcus is sometimes present upon the disc of either cheek, extending from the lower extremity of the eyes to the base of the mandibles. 


\section{DETAILS OF THE METATHORAX.}

This figure represents a postero-dorsal view of the metathorax, the various areae of which, outlined by elevated costae, though not always stable, form valuable characters for discrimination, especially in the two first sub-families, in which they are more fully developed. In this figure, I is the basal area, always very distinct in the Joppides and usually obsolete

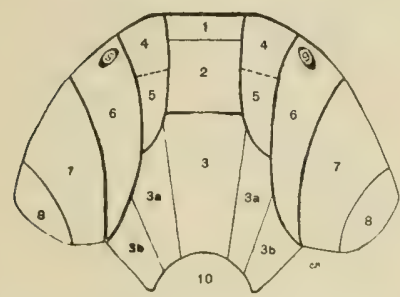

Metathorax.-I, basal area; 2 , areola ; 3 , posterior or petiolar area; $3 a$, postero intermedial areae; $3 b$, postero-external areae; 4, external areae; 5 , dentiparal areae; 6 , spiracular areae ; 7 , lateral or pleural areae ; 8 , juxta-coxal areae; 9 , spiracles ; 10, apex. or wanting in the Ichneumonides ; 2 is the areola (area superomedia), behind which, sloping downwards, is (3) the posterior orpetiolar area. From this, the postero-intermedial $(3 a)$ and the postero-external $\left(3^{b}\right)$ areae are sometimes discreted, and to its apex (at io) the petiole is attached. The upper lateral areae are very often also centrally discreted, in which case the anterior (4) is the external, and the posterior (5) the dentiparal areae. From the apex of the latter rise the thoracic spines or apophyses. These two areae are centrally divided by the costula, a term confined to this particular ridge.

The spiracular areae (6) bear the metathoracic spiracles (9), which are of variable shape (the anterior portions of the thorax also bear obscure spiracles, not referred to in descriptions). The lateral or pleural areae (7) are sometimes distinct from the juxta-coxal (8). Of these areae, the areola is the most important and constant, at least some part of it being present when all other areae, through the razing of the costae, have become obsolete or wanting. Its apical ridge has been especially employed by Förster in grouping the Pezomachi, \&c., and it is also a conspicuous feature of the Cryptids and Pimplinae. Ashmead has founded genera upon the confluency of the juxta-coxal and pleural areae, and in most cases the apical central costae are wanting.

\section{DETAILS OF THE WINGS.}

'The wings of the Ichneumonidae at first sight appear so uniform that, with the exception of the points already referred to, the older authors 1 gleaned but few distinctive points therefrom. When these were indicated, original names were almost invariably applied to them, whether others had been already known or not, and in this manner the nomenclature of the nervures and cells has become considerably involved, and in some cases chaotic. Modern authors ${ }^{2}$ have been hardly more uniform, and it seems advisable to here attempt some sort of synonymy of these bewildering and often misleading terms. Gravenhorst named all the cells, but few of the

1 Cf. Gr. I. E. i., t. x ; Wesm. Nouv. Mém. Ac. Brux., 184., f. I; Bul. Ac. 13rux., $1849,17.117$ Holmgr. Sv. Ak. Handl., 1855, t. ix.; Ichn. Suec. i., ff. I et 2 ; Först. Verh. z.-b. Ges., i865, 1p. 874-6, Taf, x. ; Sic.

2 Cf. Bridg.-Fitch, Entom., 1880 , pl. i., f. 2 ; lib. cit., 1882, p. 279 ; Bignell, Trans. Devon. $\Lambda$ ssoc., 1898 , p. 46 ; Thoms. O. E., 531, ff. I-10; Berth. Ann. Soc. Fr., I895, pl. iii., ff. I-6; Sc. Also compare Marsh. (Braconidae). Trans. Ent. Soc., 1885 ; Saunders, Acul. Brit. Isles, I8g6, Struct. pl., f. I; Cameron, Phytoph. Hym., 1882-93; Sc., \&c. 
nervures, and these sufficed, when mentioned at all, to subsequent authors till Förster elaborated names for all the nervures and all the cells. Since these convey little or nothing, however, beyond their sound to the uninitiated, I prefer a more direct method than that of Marshall, transposed to the Ichneumonidae by Bridg.-Fitch, and propose the adoption of the following intelligible orismology, which claims nothing but simplicity, facility of retention and more or less uniformity with those terms applied to analogous organs in the other groups of Hymenoptera.

In the forewing, the nervures set forth in the figure are best explained by the names attached to them. The costal and sub-costal are united in the costa, which extends from the radix $(B)$ to the base of the stigma ${ }^{1}$;
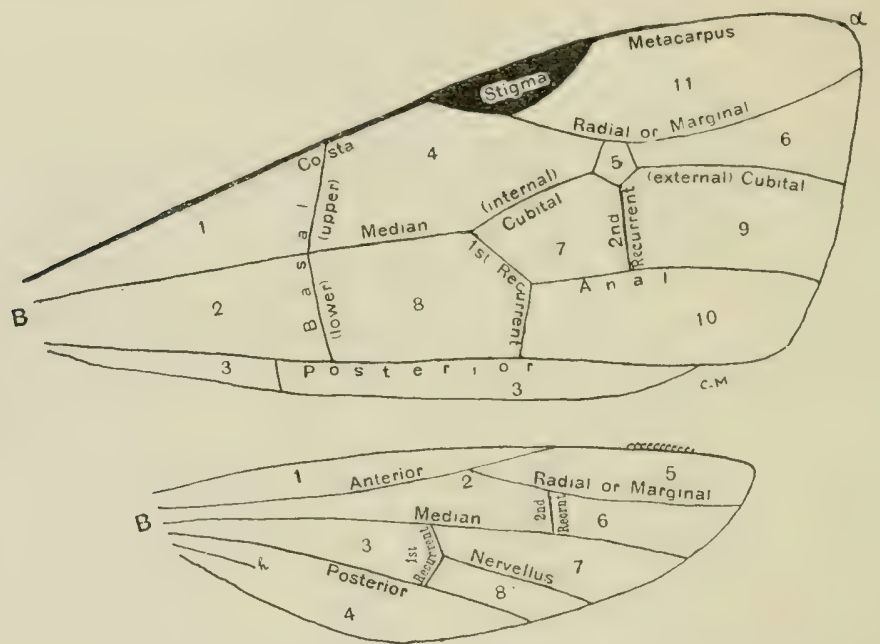

Certs of the Fork Wing.-1, 2, 3, basal; 4, 5, 6, cubital; 7,8, 9, discoidal; Io, anal; r1, apical, or radial : $a$, apex

CEllS OF THE HIND WING,-I, costal ; 2,3 , basal ; 4 , anal ; 5 , radial ; 6 , cubital ; 7,8 , first and second discoidal; $h$, humeral nervure.

from the apex of the stigma to that of the wing (at $a$ ) is the metacarpus ${ }^{2}$; from the radix emanate two other nervures, the median ${ }^{3}$ and the posterior. ${ }^{4}$ The median is continued, from its junction with the first recurrent ${ }^{5}$ to the apical margin of the wing, under the name of cubital nervure, that part before the second recurrent ${ }^{6}$ being the internal cubital, ${ }^{7}$ sometimes emitting a central nervelet, and beyond it the external cubital, ${ }^{8}$ which is

1 Vorderrand, Först.

2 Holmgren termed the costal nervure the first, the stigma (Randmal, Först.) the second, and the metacarpus the third abscissa of the costa.

3 This is the prebrachial of Bridg.-Fitch, the cubitus of Thoms., the median of Berth. and Saund, and the first part of Förster's Mittalader, vena media.

1 The pobrachial of Bridg.-Fitch, brachium of Thoms, anal of Berth., Hinterader or vena postica of Först., and posterior of Saund.

5 The posterior discoidal recurrent, Bridg.-Fitch; recurrens primus, Grav, ; recurrens ordinarius, Holmgr.; the middle part of Forster's Mittalader, its apical part being his second II umeralquerader.

6 Die 2 Discoidalquerader, Forst. ; exterior discoidal recurrent, Bridg. Fitcl,; recurrens discoidalis, Holmgr. It is often in part interstitial, the pellucid portions being termed fenestrae.

7 The internal discoidal recurrent, Bridg.-Fitch; disco-cubitalader or vena disco-cubitalis, Först. (Holmgren, 1855, fig. 26, refers to the upper basal as the internal cubital in errore).

$\checkmark$ Die Fortsatz der Ellenader (cubitalader), vena cubitalis, of Forst. 
apically often pellucid or spurious. From the base of the stigma to near the apex of the wing extends the marginal or radial nervure, ${ }^{1}$ the two short nervures connecting the radial and cubital being termed the submarginal. ${ }^{2}$ Below the cubital, and nearly parallel with it, is the anal nervure, ${ }^{3}$ rising from the first recurrent; both the anal and the radial nervures are sometimes apically pellucid. Nearer the radix, and traversing nearly the whole breadth of the wing, is the basal nervure, ${ }^{4}$ its upper portion ${ }^{5}$ being above, and its lower ${ }^{i}$ beneath, the median nervure, through which it is often not directly continuous as in the figure. Below the posterior nervure is a small line known as the axillary, though rarely referred to.

The above nervures, it will be seen, sub-divide the fore wing into eleven areae or cells, 1,2 and 3 of which are the basal ${ }^{7} ; 4,^{8} 5$ and $6^{9}$ are the cubital, of which the central varies very greatly in shape and constancy, as has already been pointed out, and is termed individually the areolet "1"; $7^{11}$ and $8^{12}$ and $9^{13}$ are the discoidal, of which 7 in many instances is nearly super-incumbent upon 8 ; ro is the anal cell ${ }^{11}$; I I the apical or radial cell, ${ }^{15}$ and this also varies greatly in shape in different genera.

The neuration of the hind wing is much less complex, and but little attention, except in such genera as Anomalon, \&rc, had been paid to it till 'Thomson exhibited the varying position of the nervellus in relation to the first recurrent nervure. 'The other nervures, all more or less pellucid towards their apices, are of but little importance ; $h$ is the humeral nervure, ${ }^{16}$ and is usually sub-obsolete. From the radix (at $B$ ) rise three nervures, the anterior, ${ }^{17}$ the median, ${ }^{18}$ and the posterior. ${ }^{19}$ The first of these emits the radial nervure from near its apex, and this is attached to the median by the little second recurrent. ${ }^{20}$ Between the median and posterior nervures, in the middle of the wing, is the first recurrent, ${ }^{21}$ which is said to be antefurcal, if its upper extremity be nearer the radix than its lower, continuous or opposite, if both extremities be equidistant therefrom, and post-furcal, if

1 The radius of Bridg.-Fitch, radialader of Först., marginal of Saund. ; often divided into three parts by Holmgr, and Thoms., of which that immediately above the areolet is the central.

2 These, in descriptions, are usually termed the sides of the areolet; they are the intercubital recurrent nervures of Bridg.-Fitch.

3 Nec Berth.; the apical portion of the Mittalader, Först

4 Brachial recurrent, Bridg.-Fitch.

5 Grundader or vena basalis, Först. ; cubitalis internus, Holmgr.; nervus basalis, Thoms. upper basal, Saund.

6 Nervus transversus ordinarius, Thoms. ; lower basal, Saund. ; die I Humeralquerader, Först.

7 The three liumeral cells, Grav.; costal, median and anal, Berth.; das vordere Schulterfeld, vordere und hintere Sclutterfeld, Först.; basal, Saund.

$y$ The first cubital, Bridg.-Fitch, Holmgr., Berth. ; cubitalis interna, Grav. ; disco-cubital, Wesm., Först., Berth. ; first discoidal and sub-marginal, Saund.

9 Third cubital, auctt.; cubitalis externa, Grav.; third sub-marginal, Saund.

10 Areola, anctt.; intermedia, Grav.; cubitalis secunda, Wesm., Holmgr., Först. ; second sub. marginal, Thoms. and Saund.; areolet, Bridg.-Fitch ; cellule, Ste. Ill. M. vii., p. 127, pl, xxxix., ff.

11 First discoidal, mihi; prediscoidal, Bridg.-1 itch; discoidalis intermedia, Grav.; discoidalis,

Thoms., lerth. ; second discoidal, Saund. leurst.

12 Second discoidal, mihi; podiscoidal, Bridy.-Fitch; postica interna, Grav.; das hintere mittlere Schulterfeld, lïrst.; brachialis secunda, Thoms, ; discoidalis interna, Wesm. ; third discoidal, Saund. 13 'Third discoidal, Först.; externomedial, Bridg.-Fi.ch.; discoidalis externa, Grav.; posterior, Berth.; first apical, Saund.

14 Anal, 13ridg.-Fitch; postica externa, Grav. ; afterzelle, Först. ; posterior, 13erth. ; second apical, Saund.

15. Radialis, auctt. ; radialfeld, Fürst. ; marginal, Saund.

16 This is the humerus of 'Thoms.

17 Die Unterrandader, Först. This is really the sub-costal nervure which is not, "as in the front wing, connate with the costal, though the intervening space (the costal cell) is usually of a deeper colour than the remainder of the wing.

1n Mittclabar, Iö̈rst.; cubitus, Thoms.

19 Hinteralder, fürst, brachium, Thons.

20 Ramus superior cubiti, Thoms.

il Humeralquerader, Först. ; nervus transversus ordinarius, Thoms. 
the lower extremity be the nearer thereto. In the first of these cases the nervellus ${ }^{1}$ is emitted from below the centre of the nervure, as in the Ichneumoninae, in the second from its centre, and in the last from above its centre, always at the point of angulation.

Between these nervures are an inner and an outer series of four cells, of which $I$ is the costal, ${ }^{2} 2^{3}$ and $3^{4}$ the basal, 4 the anal, ${ }^{5} 5$ the radial, 6 the cubital, 7 and 8 the first and second discoidal. ${ }^{6}$ The discoidal are often no more divided than is the anal cell by the humeral nervure.

In common with Hymenoptera in general, the hind wings are anteriorly provided with a series of hooks (disproportionately conspicuous in the figure), which clasps and steadies the fore wing in flight, and rises from the hakenkamm, which extends from the anterior nervure to the apex of the wing.

Nervellus or nervus spurius, Thoms. ; nervule additionnel, Berth.

2 Brachial, Berth.

3 Pre-brachial, Bridg.-Fitch; costal, Berth.

Pobrachial, Bridg.-Fitch ; median, Berth.

5 Axillary, nec anai, Bridg.Fitch; anale, Berth.

6 These two are collectively the posterior of Berth., and individually the discoidal and anal of Bridg.-Fitch. 


\title{
A HISTORY OF THE STUDY OF THE
}

\author{
ICHNEUMONIDAE.
}

\section{GEOLOGICAL TIMES.}

THE first appearance of the Insecta is in the carboniferous measures of the Palaeozoic epoch, and they are further represented in the Mesozoic Lias and Oölitic groups. ${ }^{1}$ Insects of the present family cannot, however, be traced back further than the formations in which they are associated with the gnats and flies of most of the recent families, as well as the ants and bees and a few Lepidoptera. Considering their economy, they were probably not introduced much before the last Order, $^{2}$ though it is, I conceive, very far from impossible that they were originally fossorial, becoming entomophagous in the course of evolution. The discovery of the earliest forms of Ichneumonidae appears to have been at Aix, in 1829, when Sir Roderick Murchison ${ }^{3}$ and Sir Charles Lyell formed a collection of fossil insects from the Upper Eocene system, which also comprised genera of the Tenthredinidae, Formicidae, Vespidae and Chalcididae. In the middle Miocene beds of the marls, of Radoboj, in Croatia, ${ }^{4}$ were discovered eighty-five species of Hymenoptera, of which twenty-two appertained to the Ichneumonidae, and the remainder to the Formicidae, Vespidae, Apidae and Sphegidae. Upwards of 5,000 specimens of insects have been obtained from the celebrated Upper Miocene lacustrine formation, of Eningen, in the Rhine Valley; the great majority of the Hymenoptera being distributed among the Ichneumonidae, Formicidae and Apidae. From the Tertiary strata of the United States, also, Ichneumonidae, Formicidae and Chalcididae have been described. ${ }^{5}$ During Pliocene and post-Tertiary times, no remains of Hymenoptera have been discovered; not, probably, because they did not exist, but because the conditions under which these formations were compiled were unfavourable to their preservation, reducing them to comminuted fragments to such an extent that the most chitinous parts of Coleoptera, Hemiptera and Orthoptera alone survived. ${ }^{6}$

\section{PRE-LINNEAN TIMES.}

Aristotle, the tutor of Alexander the Great, is said, by Strack, ${ }^{7}$ to have applied the name Ichneumon not at all to the insects which now-a-days bear it, but to the Fossorial Hymenoptera ${ }^{8}$; and Berthoumieu tells us he

1 Cf. Lyell. Elements of Geology, pp. 387, 396, 586, \&c.

2 I'arfitt. Trans. Devon. Assoc. I88i, p. 2.

3 Cf. Edinburgh New Plil. Journ. October, 1829, pp. $287-297$.

1 Cf. Prof. Heer. Die Insectenfauna der Tertiargebilde, \&c.

$\therefore$ Cf. Scudder. Geological and Geographical Survey of United States. 1880

(i) Goss. The Geological Antiquity of Insects. 1880.

7 Aristoteles Naturgesclichte der Thierc, 186.

8 Quoted by Caius Plinius Secundus. Historia Mundi. 
referred to "un Hyménoptère parasite et fouisseur." Indeed, the prototype of our insects, which was the Ichneumon or Mongoose (Herpestes ichneumon) of Barbary, Egypt and the Cape of Good Hope, appears to have represented both these conditions, though I never heard of an insect which did so! This mammal was reverenced by the natives for its utility in depositing its young in the intestines of, and for living internally upon, the crocodile, as do our parasites upon other insects. It is also represented as digging up, like the fossors, and devouring, its host's eggs, as well as attacking its young; and Dallas ${ }^{1}$ goes so far as to state that it destroyed the crocodile itself.

It will be interesting to here lightly touch upon the quaint olden works, treating in part of the Ichneumonidae, which appeared during the earliest stages of their study. In 1623 , Ulysses Androvandus noticed, in his De Animalibus Insectis, that small fly-like animals were sometimes substituted for butterflies, on emerging from their pupae, and that caterpillars laid eggs, like a grain of wheat, each of which contained a worm; and, in I634, MInufet, who seems to know nothing of their economy, describes several "MIusca tripilia" - so named from the three-pieced terebra-which may, from his figures, be referred to the Ichneumonidae. Goedart's four works, which appeared fron I. 662 to 1700 , show that the author, a careful observer of metamorphoses, bred several parasites, which he describes and figures. from Lepidoptera. It was Swammerdam, in 1669, who first excluded the spiders from the middle of the Insecta, and gave rise to the title Vespae-Ichneumones, which, however, embraced the Fossores and not the Ichneumons of to-day. A study of Ray's History of Insects ${ }^{2}$ shows very plainly what an intelligent man can do in the way of original work, and illustrates how little our views really have advanced in the last two hundred years. In it we find that (roughly speaking) his Gregaria = Aculeata, of which Mellifica $=$ the Anthophila, Apis-Mansueta constituting the Andrenidae, \&c., and Bombylius the Apidae; Non-Mellifica = the Fossores and Diploptera, divided into Crabrones and Vespae. His Solitaria or Non-gregaria = Terebrantia, of which Apiformia and Vespiformia are part ; the latter he divides into Muscae-Vespiformes = Sessiliventres, and VespaeIchneumones $=$ Pupivora, Majores and Minores. Consequently these latter, which he noticed bury their eggs in the bodies of caterpillars, are the true Parasitica as we know them to-day. Ray's error of grouping certain neuropterous genera under the Hymenoptera (Tetraptera or Quadripennia, as he calls them), when one considers the heterogeneous forms still included under the former broad Order, is not so heinous as it at first sight appears.

Albin and Frisch were the first to describe new Ichneumons in the eighteenth century, and the latter appears to have first set forth and named, in his Beschreibung von allerley Insecten in Teutschland, the exoskeleton, more especially the cribrary organs and neuration. Gravenhorst's comment on his computation of the number of species is amusing; the latter adds, exultingly, "Bone Frischi, quid hodie diceres!"; and we might, now-adays, venture a tu quoque. ${ }^{3}$ The seven volumes of Réaumur's Mémoires, which appeared $1734^{-42}$ and laid a very firm foundation to the study of the economy of the Ichneumonidae, are even to-day often quoted as

1 Elements of Entomology, p. 239.

2 Histori: Insectorum. Johannes Raius. Londini. I710. (Posthumous).

3 Gravenhorst described about $1,6,0$ species; Marshall's present computation is 710,000 species ! 
models of minute observation and judicious deduction of facts therefrom. These were supplemented, by Roesel, in $x 749$. Three years later, De Geer's MIémoires began to appear, and, not being completed until I 778 , form a connecting link between pre- and post-Linnean time, which is reckoned from the publication of the tenth edition of Linnés Systema Naturae, in $175^{8}$; consequently it was not always easy, until the recent publication of Mr. Sherburn's work, to tell to which the descriptions of the former belong.

\section{POST-LINNEAN TIMES.}

In 1735 , Linné brought out the first editon of his epoch-marking Systema Naturae, followed by Fauna Suecica, in 1746 . But it is from his $175^{8}$ work that priority, that bone of contention, is usually accepted to date. In it he removes all the fossorial Hymenoptera from among the parasites into a new genus, called Sphex. The Parasitica he divides into seven families, the first of which has the abdomen sessile and mucronate. The next five are distinguished nearly entirely by the colour of the scutellum and abdomen, and the last has the body small and sessile. After him wrote Poda, several of whose Ichneumoninae have recently taken precedence to the for-long-accepted names of later authors. The remainder of the eighteenth century authors of note will be found in the "Works Consulted" and need no especial notice here. The first work entirely devoted to the Hymenoptera, as we now understand that Order, is Fabricius' Systema Piezatorum, of I804. Eighty-three genera are here delineated, distinguished primarily by the structure of the mouth and, secondly, by the antennal conformation. Here the Ichneumonidae are again intermingled with Fossors, Sawflies, Evaniidae, \&c.; and, taken as a whole, this work of one of the most celebrated entomologists is in strong contrast to the Ichneumonologia Europaea, of Professor J. L. C. Gravenhorst, which appeared in I829, and embodied the observations of Latreille, Schrank, Panzer and Jurine. This monumental work constituted for the Ichneumonidae what Rev. William Kirby's Monographia Apum had been for the Anthophila-a sound and, at the time of its publication, exhaustive basis for all subsequent research. In it is summed up and concreted such knowledge as then existed respecting these insects, and it is only within comparatively recent years that we have dared to depart in any essential detail from the classification there adopted, which had previously, in $18 \mathrm{r} 8$, been mapped out in the same author's Conspectus Ichneumonidum.

Since the time of Gravenhorst, the subject has attained such proportions that no one has treated of it in its entirety. The first subsequent author of note is Wesmael, who, in the Nouv. NIém. Ac. Brux., of $\mathrm{r} 844$, published his 'I'entamen Dispositionis Ichneumonum, which treated of those groups contained in the present volume 'This was supplemented by its author in his Mantissa, which appeared in $\mathrm{IS}_{4} 8$; in his Adnotationes, of $\mathrm{IS}_{49}$; his Ichneumones Platyuri Europaei, of 1853 , and Amblypygi, of 1854 ; in his Miscellanea, of 1855 , and Otia, of 1857 , all of which were published in the Bul. Ac. Brux. His final Remarques Critiques sur la Collection de Gravenhorst appeared in the Mém. Couron. Ac. Belg., in 1859 , and is of the greatest utility in studying the latter's great work. Where Wesmael left the Ichneumoninae, they were taken up by Holmgren, who not only collected the former's treatises into systematic form, but considerably 
augmented them in the three volumes of his Ichneumonologia Suecica (by which Bridgman mainly worked). Gravenhorst divided the whole group into five sub families:- the Ichneumoninae, Cryptinae, Ophioninae, Tryphoninae and Pimplinae. Of the last three, Holmgren, very greatly assisted in the comprehensive classification in his Swedish Monographiae, published in the Sv. Ak. Handl., in 1858,1859 and 1860 , respectively; as well as more detailed Dispositiones of the genera Exochus, in Ofv. V.-K. Förh., in 1873 , Campoplex, in 1872 , and Mesoleius, in 1876 , both in the Sv. Ak. Handl. Of the Cryptinae, however, both Wesmael and Holmgren wrote little or nothing; and the task of revising the Gravenhorstian types devolved upon Taschenberg, who, in 1865, published an account of them, in the Zeits. Ges. Nat.; which was initiated by Professor Förster's Monographie der Gattung Pezomachus, in the Wiegm. Archiv., of $\mathrm{I} S_{50-5} \mathrm{I}$, and elaborated, by Thomson, in his classical Opusc. Ent. The more recent works upon the four other sub-families will be treated of in their proper positions, since they have now been sufficiently defined; and we may momentarily glance at what has of late been achieved with regard to the Ichneumoninae.

As Gravenhorst laid firm the foundation of the Ichneumonidae as a whole, so Wesmael's Tentamen formed the basis of work upon the subfamily Ichneumoninae, followed, as I have just said, by Holmgren. From 1852 to 1882 , Tischbein described a large number of new forms, from Hungary, Germany and Austria, many of which were at most mere varieties of extant species; and the voluminous Kriechbaumer scattered notes and descriptions broadcast through a diversity of periodicals, from 1 S 54 to I 90 I. In 1878 , Brischke published an annotated catalogue of the Prussian species, and in it described a few which were new; but his best work is in the economic department of the study. M. l'Abbé Berthoumieu has summed up all that is known of the Continental species, in his capital compilation, Monographie des Ichneumonides d'Europe, which appeared in the Ann. Soc. Fr., I 894 to I 896 , supplemented with notes by M. Pic and himself in the Bul. Soc. Fr. It is unfortunate, however, that he was not a close student of Professor 'Thomson, the keenest observer and most talented systematist of modern times, who published upon this sub-family three invaluable papers in his great Opuscula Entomologia :- "Bidrag till Kannedom af Ichneumones Pneustici," "Anmärkningar of ven Ichneumoner särskilt med hänsyn till nâgra af A. E. Holmgren's typer," i. and ii., which are developed in a most original manner; and, if the system employed be more subtle than that of other authors, the nomenclature arrived at is the most natural possible of attainment under existing conditions.

\section{BRITISH AUTHORS.}

My notes on the new species described by the older British authors appeared in the E.M.M. of I902, pp. I I $8-123$, and in them I attempted to synonymize their names with those now in use upon the Continent. Many of the descriptions of these Ichneumoninae, however, appeared identical with none I could find. These were tentatively considered to be good species and have been herein described at some length, from the type specimens in the British Museum and elsewhere. Of the oldest of our authors, Moufet, Ray, Albin, I) novan, William Kirby, \&c., mention has already been made. With the exception of Forster's Novae Species, 
in $177 \mathrm{I}$, no Ichneumonidae of note were brought forward till the publication of Curtis' beautiful work, begun in 1823 , which contained, among the Ichneumoninae, descriptions of Lilineumon Alropos and Alumla vititor only.

The appearance of Gravenhorst's book, in I 829, stimulated the study here as elsewhere, and was closely followed by the Illustrations, of Stephens, in 1835 . This author, refuting the error that "for some untenable reason" all the species described by Gravenhorst were to be found in Britain, recorded hence just over four hundred and fifty species, many of which had already been noted in his Systematical Catalogue of British Insects, of I $\$ 29$, and were included in Curtis' Guide to an Arrangement of British Insects, of $\mathbf{I}_{37}$. Stephens, pretending to no particular knowledge of the subject, tells us the indigenous species of Ichneumonidae amount to several hundreds, of which he describes thirty-three Ichneumoninae as new, and sets forth, in tabular form, fifty-four native genera. ${ }^{1}$ Of his species, about half were included in the Gravenhorstian genus Ichneumon; but of the remainder only the genera Trogus, Phygadeuon, Cryptus, Stilpnus, Mesoleptus, Tryphon, Exorhus, and their immediate allies, were dealt with. Here the sexes are usually described as distinct species, and those affiliated under a common name often appertain to different kinds. The descriptions are short, structural features are rarely referred to, and no especial distinguishing points are indicated, as was the custom of the period, beyond the mere descriptions. He would indeed be no conscientious systematist who now-a-days relied upon the almost exclusively colour differences therein set forth, for the identification of such variable insects as those under consideration. Such is the only detailed attempt ever made to describe our native Ichneumonidae.

The middle age of the study, as may be termed the interval between Stephens and Marshall, was not more brilliant than the first. Although Haliday's writings are contemporaneous with those of Stephens, his method of description certainly places him in this period. He was, indeed, as Verrall has said," "the most perfect describer of a new species or genus in my experience," as his diagnoses of New British Insects indicated in Mr. Curtis' Guide, which appeared in the Ann. Nat. Hist., of I 839 , amply demonstrate. Six new genera are here brought forward, ${ }^{3}$ and about fifty new species shortly but very concisely described. He also first reviewed a few Ichneumonidae, from the Straits of Magellan, in the Trans. Linn. Soc., of 1837 ; and it is to be regretted that his labours extended no further in our particular branch of Entomology. In $s_{5} 6$, there appeared I)esvignes' Catalogue, a synonymic list of those species contained in the British Museum and other collections, with descriptions of fifteen species of Ichneumoninae believed by the author to be new. Herein are brought forward sixty British genera." Rather more than seven hundred species of

1 Of these the great majority are copied directly from Gravenhorst, to which Agriotypus, Curt. (Walker published no description of it), Lampronota, Hal., and (H) Enicospilus, Steph., are added; Paclymerus = Collyria, Schiöd., Eucerus = Eumesius, Westw., Alomya = Alomyia, Panz., Peltastes = Metopius, Panz. Of Trachyderma, Grav, and Stibonota which appears to have never been diagnosed, I know nothing.

2 Presidential Address before the Entomological Society, rgoo.

3 Cteniscus = Exenterus, Hart. ; Helictes = Megastylus, Schiöd., 1839; Periope, Clepticus, Acro. dactyla and Lampronota.

4 The author omits Trachyderma, Odontomerus, Stilbonota, and treats (H)Enicospilus as a Sub-genus of Ophion; he adds to our list Pristiceros and Sphinctus, Grav., Trachynotus = Nototrachy's, Marsh. Cat. Chyronomon, Desv, = Sphecophaga, Westw, Macrocoleus, Desv, = Coleocentrus, Grav., A pacticus (sic) and Platylabus, Wesm., and Pristomerus, Curt.; Desvignes reinstates such recent genera as Listrodromus ( $c f$. IVesm. Tentamen, 184t, \&c.), Agrothereules (cf. Fürst. Gattung Pezomachus, 1850), Trichomma (cf. Wesm. Des Anomalons, \&c., Sc.), as sub-genera of, respectively", Ichneumon, Pezomachus, Anomalon, Sic., of Gravenhorst. 
Ichneumonidae are recorded as being at that time known to inhabit these Islands. His descriptions are a decided improvement on those of the first period, though his terminology is often a little obscure. He might have advantageously quoted more fuily from the Continental authors, and it is to be especially regretted that he was not cognizant with Holmgren's excellent Monographia Tryphonidum. Lesvignes also contributed descriptions of several supposedly new species to the Trans. Ent. Soc., 1850--64, and to the E.M.M., in I868. Rev. T. A. Marshall's i 870 Catalogus bears the print of the master systematist and sounds the knell of the superficial work of the middle period. It very greatly augments the number of British species and enumerates one hundred and thirty-five indigenous genera, accepting and tabulating all the most recent Continental researches.

The same author, to a very great extent, removed, in 1872 , one of the primary difficulties of our study, that of its cumbrous synonymy, in his Catalogue of Hymenoptera, published by the Entomological Society. This has remained till the present day, though now sadly obsolete, the standard list of the British Ichneumonidae, comprising I, I86 species, distributed through 136 genera. It lent so strong a stimulus to hymenopterists as to give rise, not only to a multiplicity of notes, records and descriptions, by Marshall, Parfitt, Capron, Bignell, Hellins, Bairstow, Wilson and others, in our serials, but was the corner stone to the beginnings of a capital annotated synopsis of the British species, by Bridgman and Fitch, in the Entomologist, of I880-85, which, unfortunately, like its predecessor of 1835 , was never completed, terminating abruptly in the middle of the Ophioninae, with only the Ichneumoninae and Cryptinae tabulated. Since that time nothing of importance has appeared, with the exception of Bridgman's annual Additions, in I88I, and Further Additions to Mr. Marshall's Catalogue of British Ichneumonidae, in I882-89. These and all other additions I could find were incorporated in a paper read before the Entomological Society of London, on 6th March, I90I, in which were enumerated I,7I9 species, comprised in I54 genera, of British Ichneumonidae, which is the total of those recorded from, though by no means of those which occur in, these Islands.

\section{CLASSIFICATION.}

\section{Order. HYMENOPTERA.}

Since 1669 , when Swammerdam attempted to erect a system of the Insecta, based solely upon their metamorphoses, to the appearance of Ashmead's Classification of the Ichneumon Flies, in $1900,{ }^{1}$ men of science have striven after a natural and convenient grouping of the mass of families, genera and species into which the Hymenoptera have gradually become divided; and it indeed seems strange that no perfectly natural order has yet been enunciated, when we find that, as early as the end of the seventeenth century, Ray had already grouped this mass much as we to-day recognise it." Saunders, in his recent work on the British Aculeata, makes no reference to the relative position of this Order in the scale of Nature, which was doubtless unnecessary in so compact and highly 
specialised a group, constituting exactly one of the two great divisions of Linné. But it is quite necessary to here set forth what does and what does not belong to the family Ichneumonidae, since this appears to be often imperfectly understood, among even distinguished general cntomologists of the present day. The other division of Linné was the Terebrantia of Latreille, embracing all those insects whose females were possessed of a terebra in place of a sting; and it was not till $175^{S}$ that the former grouped the social species under Sphex, and separated the remainder by the sessility of the abdomen, dividing the Ichneumons into four purely artificial families. Consequently by this method a male specimen was, from the very outset, undeterminable.

Forster ${ }^{1}$ proposed the division of Hymenoptera by the joints of the trochanters; those with two joints were designated Ditrocha, those with but one were Monotrocha. Here difficulties also arose upon application, since no hard line could be drawn, instances occurring in which a second joint was distinctly present, though connate with, and apparently forming part of, the femur; and the ensuing divisions disseminated obviously natural affinities, giving rise to the most incongruous grouping. De Geer had, in I 752, employed the comparative extent of the connection between thorax and abdomen for his minor groups of the Terebrantia, and this feature is now acknowledged to be as essential and natural for main divisions as is to be obtained in so heterogeneous and vast an Order, of which more than four thousand seven hundred species are said to inhabit Britain alone.

Ashmead primarily divides the Hymenoptera into Phytophaga, in which the abdomen is sessile, with the trochanters two-jointed and the larva legged, and Heterophaga, in which the abdomen is more or less petiolate, with the trochanters either one- or two-jointed, but the larva apodous. This latter is sub-divided roughly into the Aculeata, with the Oxyura, emitting the terebra from the apex of the abdomen, and the Ichneumonidea, with the Cynipoidea and Chalcidoidea, emitting the terebra from the ventral surface of the abdomen. Further evidence is, however, I think, needed before mingling the Proctotrypidae with the Aculeata, and, in fine, it appears most desirable to follow the classification set forth by Konow."

This, in effect, differs little from that of Westwood, ${ }^{3}$ though it raises the Phytophaga to equal dignity with the Entomophaga and Aculcata. We thus have not a dichotomous but a three-fold classification, in which each section possesses some feature common to both the remainder. The new element introduced is centred in the number of cubital wing-cells supposed to have been originally present. The first of these sections is the Vespoidea, bearing one-jointed trochanters, petiolated abdomen and, at least in the ancestral type, four cubital cells. The second is the Ichneumonidea, bearing twojointed trochanters, petiolated abdomen, and but three, often suppositious, cells. The third, the Tenthredonidea, bearing two-jointed trochanters, sessile abdomen, and four, often suppositious, cells. Thus we have the first and second sections constituting the Clistogaster; the third the Chalastogaster. The second and third the Ditrocha; the first the Monotrocha. The first and third the Tetrastega, and the second alone the 'Tristega.

1 Dr. Arnold Förster, Synopsis der Familien und Gattungen der Braconen, 1862, and der Ichneu. monen, 1868 .

2 Ent. Nachr. 1897, p. I48; cf. E.M.MI., I899, p. 12t; et Deut. Ent. Zeit. I89o, p. 228.

3 Modern Classification of Insects, $18+0$. 


\section{Sub.Order. ICHNEUMONIDEA. ${ }^{1}$}

All the members of this cxtensive group are believed to be parasitic upon other insects, spiders, \&c., excepting a part of the Cynipidae. It consists of $\operatorname{six}^{2}$ sufficiently distinct families, which are thus recognised :(1) Evaniidae alone have the abdomen rising from the dorsum of the metathorax; (2) Cynipidae alone have the terebra partially coiled and rising from near the base of the abdomen; (3) Proctotrypidae alone have the terebra tubular; (4) Chalcididae alone usually possess geniculate antenuae, and the body of brilliantly metallic colours; and, lastly, (5 and 6) Braconidae and Ichneumonidae, of which the antennae are not geniculate, and the terebra is divided into three pieces. These last two families undoubtedly take precedence in the scale of Nature, on account of the complexity of their specialised conformation and probably also of their instinct, though little is known of the economy of the smaller Ichneumonidea. To the first four families the last bears no very close resemblance, and from them it will at once be distinguished with a little experience ; but, with the Braconidae, many genera exhibit a very intinate affinity, and it becomes essential to remember that,-

Ichneumonidae have two transverse nervures in the fore wing.

Braconidae have but one transverse nervure in the fore wing.

In a few genera of the former, however, e.g., Hemiteles and Orthocentrus, the second transverse nervure, though always traceable, is often pellucid, being usually stronger at its anal extremity; and, in those genera whose wings are rudimentary or wanting, no reliance must be placed upon such neuration as may exist. In such cases, it is necessary to fall back upon the tegument of the abdomen, which is flexible in Ichneumonids, e.g., Pezomachus, but hard and chitinous, with the central segments connate and inflexible, in Braconids, e.g., Chasmodon.

Hence we find that an Ichneumonid always has the abdomen rising from the apex of the metathorax ; the terebra straight, not tubular, exserted from the ventral surface near the apex of the abdomen; the antennae not geniculate; the coloration not metallic, though often strongly nitidulous; and the second transverse nervure present, or, in apterous and brachypterous forms, the venter not connate.

\section{A TABLE OF FAMILIES OF ICHNEUMONIDEA.}

(2). I. Abdomen emitted from dorsum of meta-

(I). 2. Abdomen emitted from apex of metathorax.

(8). 3. Front wing with discoidal nervures.

(7). 4. Terebra rising from near apex of the usually depressed abdomen.

(6). 5. Front wing with two recurrent nervures......

(5). 6. Front wing with one recurrent nervure ......

(4). 7. Terebra rising from near base of the usually compressed abdomen ....................

EVANIIDAE.

ICHNEUMIONIDAE. BRACONIDAE.

Cynipidae.

1 I have striven throughout the work to follow the suffices proposed by the German Zoological Society for sub-orders, families, tribes, \&c.

2 The Chrysididae are considered to have possessed four cubital cells in the ancestral type, and must, consequently, be grouped among the Vespoidea. 
(3). 8. Front wing with no discoidal nervures.

(10). 9. Antennae of $\delta^{*}$ with some ring-like joints ; venter emitting terebra $\ldots . . . . . . . . . . . . . .$. .

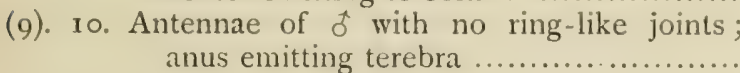

Chalcididae.

ProctotRYPIDAR:

\section{Family. ICHNEUMONIDAE.}

- It is of this important family,-so well known superficially from long pre-Linnean times, on account of its species' wonderful economy and instinct, and even yet one of the least critically elucidated, because of the extreme specific similarity, individual variation and the consequent difficulty of discrimination, - that I propose to treat in the following pages. Typical examples of the sub-families are most distinct and unmistakable, but the outlying genera, such as Megastylus, Atractodes, Exetastes, \&c., are difficult to correctly place in natural sequence; and, although superficially abundantly distinct, the most widely separated of the Ichneumonidae will be found to differ comparatively little from one another structurally: Hence has arisen a great impediment to their study, even now among the most neglected of the whole Insecta, which fact is the more surprising, until investigated, on account of the large size and striking appearance of its more conspicuous members, especially of those herein described.

It was, as I have already remarked, De Geer who first proposed dividing the Terebrantia into sections, corresponding with the sessility of the basal abdominal segment upon the metathorax. This method was elaborated by Schrank, in I 802, and the diversity of the neural structure supplemented thereto, by Jurine, in his Nouvelle Méthode de Classer les Hyménoptères, in 1807 . In 1818 , Gravenhorst and Nees von Esenbeck drew up the first at all satisfactory system of natural sequence; and this was followed by the former's Ichneumonologia, so full of thought, industry and unavoidable errors as to have required nearly a century's elucidation. It deals exhaustively with the Ichneumonidae as understood to-day, to the exclusion of all other terebrant Hymenoptera, and divides them into species with compressed or depressed, secondly petiolate or sub-sessile, abdomens; the shape of the head; presence or absence of the areolet; extent of exsertion of the terebra; shape and convexity of the scutellum, and many other pertinent points, evolving therefrom twelve genera and sixty sub-genera. The principal of the former were Ophion and Banchus alone having the abdomen compressed; Pimpla and Xorides, with the abdomen sub-sessile and the terebra exserted; Tryphon and Bassus, with abdomen sessile, but terebra concealed ; Cryptus, with petiolated abdomen and terebra exserted; and, lastly, Ichneumon, with petiolated abdomen, but terebra concealed. These genera constitute the basis of modern classification; and, although the sexes were at that time to a large extent considered distinct species - a common error, first indicated by Schrank, in $178 \mathrm{I}$, - it would be quite impossible to here refer to the subtle and gradual modifications which have since been found from time to time to be needful, or to revert to the many hundreds of genera into which the above sixty have more recently been sub-divided, upon the discovery of new forms, or of points of divergence in the old ones, overlooked by their erectors. It will be seen that the following sub-families, into which the 
Ichneumonidae are now primarily divided, differ only in elaboration and detail from the genera above quoted :-

\section{A TABLE OF SUB-FAMILIES OF THE} ICHNEUMONIDAE.

(4). I. Areolet pentagonal, never entirely wanting; abdomen depressed.

(3). 2. Post-petiole distinctly sculptured; terebra not, or hardly, exserted .......................

(2). 3. Post-petiole not or indistinctly sculptured; terebra far exserted $\ldots . . \ldots \ldots \ldots \ldots \ldots \ldots \ldots$.

(I). 4. Areolet not pentagonal, often wanting; abdomen sometimes compressed.

(6). 5. Abdomen laterally compressed, basally petiolate .......................................

(5). 6. Abdomen dorsally depressed, basally subsessile or rarely sub-petiolate.

(8). 7. Metanotum usually longitudinally costate; terebra not exserted ......................

(7). 8. Metanotum not longitudinally costate; terebra far exserted

ICHNEUMONINAE*

Cruptina ${ }^{1}$

\section{OPHIONINAE.}

TRYPHONINAE.

Pimplinae.

Nowhere probably throughout the Animal Kingdom is the instability of Nature more strikingly illustrated than in the Ichneumonidae, which have been termed the teeth and claws of Nature; nor is this surprising. How marvellous a thing is it indeed that there should be constancy of any kind in a group of insects, whose larvae are almost shapeless maggots, feeding wholly immersed within the bodies of other insects; one kind of parasite very often attacking several different sorts of host, entirely devoted to the varying fortunes and propensities of their living pabulum, which in certain cases appertains to even different Orders. As though this were not sufficient cause for instability, we are told by Kriechbaumer ${ }^{2}$ that even to surprise a pair of the imagines in coitû is no criterion to their being specifically identical, since cross-breeding is common among allied species of Ichneumons. Consequently, at the very outset, caution is necessary, in that each of the sub-families enumerated above contains so great a variety of forms as to be difficult of concise tabulation. Thus, in the Ichneumoninae, instances occur in which the exterior nervure of the areolet is, as in Hemichneumon and Epitomus, at least pellucid; in which the wings, as in a brachypterous form of Ichneumon latrator, have no areolet; the abdomen, as in Limerodes, compressed, or, as in Ichneumon spurius, with no distinct petiolar sculpture; or the terebra, as in some examples of Cratichneumon, distinctly exserted. In nearly all these vicissitudes, however, it will be found that the mesosternum is entire, and not, as is invariably the case in the Cryptinae, \&c., laterally sulcate. Among the Cryptinae the terebra is rarely, as in Stilpnus, not exserted; the areolet, as in Mesostenus, not pentagonal, or its exterior nervure, as in Hemiteles, almost entirely

1 The Agriotypidae differ from the Cryptinae primarily in having the second and third segments connate and the venter chitinous. Modern authors follow Haliday in considering it to constitute a family of equality with the Ichneumonidae, its single genus, Agriotypus, Curt. (Cratopus, Holmgr.), connecting it with the Braconidae.

2 Ent. Nachr. 1889, p. 290. 
wanting. Here we have a whole genus, Pezomachus, with the females and often also the males apterous, which is, nevertheless, rendered distinct by this very character (which obtains nowhere else) and by the distinctly petiolate abdomen. The Ophioninae may become accidentally deplanate, by artificial or other contingencies; and the abdomen of the Banchini, the conformation of whose areolet is peculiar to it, is naturally as much depressed and sessile as is the case in many Tryphoninae. ${ }^{1}$ No reliable character has yet been enunciated by which the males of the last two subfamilies may be discriminated, though the bodies of the former usually bear more red coloration, are more fusiform and not tuberculate, with the legs, excepting in the Prosopini, longer and more slender. 'The following diagnoses are necessary to elaborate the above table:-

\section{Sul-family. ICHNEUMONINAE.}

Head generally transverse or tumidulous, more rarely sub-globose; eyes oblong, entire; clypeus imperfectly discreted; mandibles apically narrowed, bi- or very rarely uni-dentate, the teeth nearly always of strongly unequal length. Antennae filiform or setaceous, very rarely sub-serrated ; of $q$ more robust and convoluted. Thorax stout, longer than high, finely punctate ; metathorax profusely areated, sometimes armed with apophyses; coxal areae usually entire; spiracles linear, more rarely sub-ovate or circular; mesosternum usually without trace of lateral sulci. Abdomen depressed, petiolate, oblong-fusiform or sub-linear; first segment obtusely geniculate towards its apical third, its spiracles almost always placed considerably behind the centre and further from each other than from apex of segment; post-petiole generally transverse with distinct sculpture; gastrocaeli nearly always distinct ; terebrả stout, concealed or only slightly exserted. Legs normal or a little incrassate ; front coxae transverse, hind ones not conical nor cylindrical, sometimes scopulate; onyches very rarely pectinate. Wings normal, hardly ever incomplete; areolet nearly always pentagonal, very rarely sub-deltoid or rhomboidal.

\section{Sub-family. CRYPTINAE.}

Head as in preceding; eyes oblong or sub-rotund, entire or nearly so; clypeus often discreted by a distinct impressed line; mandibles more rarely narrowed apically, bi-dentate, teeth generally of equal length. Antennae setaceous, often very slender or incrassate throughout. Thorax stout, finely punctate; mesonotal notauli distinct ; metathorax often imperfectly areated, sometimes with large apophyses; spiracles sub-circular, more rarely ovate; mesosternum always with distinct lateral sulci. $\mathrm{Ab}$ domen usually distinctly petiolate, rarely sub-sessile and sub-compressed; first segment arcuate, longer than width of the generally smooth and glabrous post-petiole, its spiracles in or behind the centre and nearer to each other than to apex of segment ; gastrocaeli wanting or sub-obsolete; terebra exserted, often longer than half the abdomen, very rarely subconcealed. Legs slender, sometimes with femora incrassate, or tibiae intumescent. IVings rather ample, not rarely rudimentary or wanting; areolet pentagonal, sometimes imperfect, rarely wanting, often very large and equilateral.

1 To such an extent is this the case that Professor Thomson considers them to form a natural group in the latter sub-family; see my notes on this group, E.M.M., 1903. 


\section{Sub-family. OPHIONINAE.}

Head transverse or buccate; eyes oblong, often emarginate next the antennae; face nearly always with sericeous pilosity, often prominent ; clypeus usually indistinctly discreted; mandibles narrowed apically, teeth sub-equal. Antennae filiform or setaceous, elongate. Thorax stout, more rarely sub-compressed or rugose, very finely punctate; metathorax often longitudinally impressed, the areae wanting or inconspicuous, areola often semi-circular; spiracles oblong or circular. Abdomen compressed throughout, or at the apex only; petiolate, very rarely sub-sessile or sub-cylindrical, usually elongate; terebra short, often half, very rarely as long as, the body ; first segment narrow, sub-linear, rarely abruptly dilated apically, its spiracles usually in or behind, rarely before, the centre. Legs normal, hind femora rarely incrassate and dentate, their tarsi sometimes spatuliform, and onyches rarely pectinate. Wings normal, often narrow; areolet triangular, rhomboidal, often petiolate or wanting; stigma sometimes very large and semi-circular; the radial cell sometimes broadly trapeziform.

\section{Sub-family. TRYPHONINAE.}

Head transverse, tumidulous or sub-globose; eyes entire, very rarely emarginate next antennae; face sometimes strongly protuberant; clypeus generally discreted; mandibles a little narrowed apically, the teeth not always equal. Antennae filiform or setaceous, very rarely incrassate at centre or apex. Thorax stout; metathorax distinctly or obsoletely areated, longitudinal costae usually present; its spiracles circular, more rarely ovate. Abdomen of variable outline, depressed or, in $q$, apically sub-compressed; petiole sessile or sub-sessile; first segment nearly straight, rarely subarcuate; its spiracles placed before, more rarely in or slightly behind, the middle; terebra very short, usually concealed, at most sub-exserted. Legs normal or incrassate; tibial calcaria more rarely wanting; onyches sometimes pectinate. IVings normal; areolet wanting, triangular or rhomboidal, very rarely pentagonal.

\section{Sub-fanily. PIMPLINAE.}

Head transverse, more rarely tumidulous, buccate or sub-globose; eyes often emarginate; clypeus usually convex and excavate before its apex; mandibles a little narrowed apically, teeth sub-equal. Antennae filiform or setaceous, very rarely centrally erosed. Thorax stout, often depressed dorsally; pronotum sometimes elongate; mesonotum rarely trans-striate, notauli deep and elongate; metathorax rarely areated, transverse costae alone usually distinct ; its spiracles oblong or circular. Abdomen elongate ; depressed or slightly convex, often rugulose, tuberculate or with impressed lines ; sessile; first segment either convex, short and tumidulous or long and sub-petiolate basally, its spiracles before the centre; terebra always exserted, sometimes more than twice length of the body. Legs normal; onyches often pectinate. Wings with areolet wanting or broadly triangular, more rarely somewhat pentagonal. 


\section{SUb-Fanilly. ICHNEUMONINAE.}

A Table of Tribes.

(4). I. Basal sulcus of metanotum broad and deep; scutellum usually convex.

(3). 2. Metanotal spiracles transverse oval; tarsal claws small and often pectinate ...........

(2). 3. Metanotal spiracles obliquely linear; tarsal

(г). 4. Basal sulcus of metanotum inconspicuous;

LISTRODROMIDES. scutellum very rarely convex.

(8). 5. Petiolar spiracles situated beyond centre of basal segment ; head not cubical.

(7). 6. Metanotal spiracles linear or, at most, ovate

(6). 7. Metanotal spiracles circular ..................

(5). 8. Petiolar spiracles situated in centre of basal

segment; head cubical ...................... Alomyides.

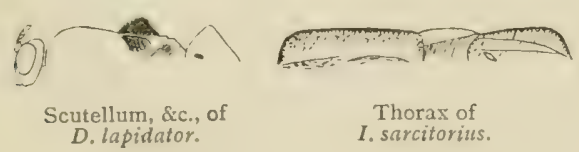

JOPPIDES.

ICHNEUMIONIDES.

Phaeogenides.

TRIBE.

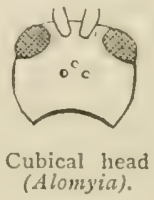

LISTRODROMIDES.

This tribe constituted Förster's thirty-second family, the Listrodromoidae, distinguished from the remainder of our Iclnenmoninae by the pectinate onyches ; it is, however, an extremely artificial division, since those of the $\delta$ are simple and differ only in their relatively small size from the onyches of the Joppides, which tribe members of the present resemble in their strongly convex scutellum, short metanotum, and deeply impressed incisures, but they may be at once distinguished therefrom in both sexes by the entire absence of lunulae on the second and third segments and, at least in the European exponents, by the small, indistinct, more or less circular metathoracic spiracles.

Thomson, on the other hand, considered the two following genera formed, with Anisobas, a small, compact group among the Amtlypgini sharing the following characters in common:-Clypeus not discreted, 
its lateral foveae obsolete or inconspicuous; genal costa continuous. Antennae curved, inserted high on frons; the scapes not further from each other than from the ejes. Metanotal costulace entire; dentiparal areae extemally arcuate. Anus with white fasciac. 'Tibiac nearly mutic, the hind ones hardly longer than their femora. Wings with the nervulus oblique, antefurcal, or not or hardly inflexed.

Only the following genera are known in Europe, though Ashmead, who places this tribe between the Platyrini and the Placegenides, has included others from North America, \&c., which bear yet less seizable characters.

\title{
Table of Genera.
}

(2). I. Clypeus centrally mucronate ; scutellum pyramidal ; coxal areae entire ..............

(I). 2. Clypeus centrally mutic; scutellum simply convex; coxal areae wanting ............. Neotypus, Först.

\section{LISTRODROMUS, Wesmael.}

\author{
Wesm. Nouv. Mém. Ac. Brux., i 844 , p. Ir I.
}

Head semi-circular anteriorly, narrowed behind the eyes; clypeus strongly rounded apically, with a small acuminate tooth in the centre; internal orbits not parallel, divergent. Antennae slender, somewhat short; of $q$ filiform, of $f$ sub-moniliform towards the apex. Pronotum not centrally tuberculate; metathorax strongly areated; coxal areae entire; sternauli distinct, crenulate; spiracles sub-rotund, appendicular. Scutellum pyramidal, laterally carinate throughout. Abdomen broad ovate, apically obtuse, black with flavous markings; post-petiole sub-explanate, pilose, with the carine obsolete; gastrocaeli normal; incisures sub-aciculate. Legs somewhat short and stout; onyches of $q$ distinctly pectinate. Wings with the second discoidal cell a little nearer the radix than the first cubital; nervulus often pellucid; nervellus nearly vertical.

\section{I. nycthemerus, Grav.}

Ichnenmon nycthemerus, Gr. I. E. i. 399, + ; Desv. Cat., I8, d. Listrodromus nycthemerzes, Wesm. Nouv. Mém. Ac. Brux. 1844, p. I46; Bul. Ac. Brux. I854, p. I39, Annexe pl. f. 13 ; Thoms. Ann. Soc. Fr. 1888, p. 123; Berth. lib. cit. I896, p. 303 ; Thoms. O. E. xix. 2100 , o क. 1. quinqueguttatus, Gr. I. E. i. 626, o. L. quinquestuttalus, Bridg.-Fitch, Entom. IS8I, p. I3I, of \&; cf. Morl. Ent. Rec. 1900, p. IS6.

Head stout, black; palpi pale ; internal broadly, and external orbits flavous or testaceous; of with stramineous lateral clypeal dots. Antennae, at least beneath, rufescent, apically piceous; scape usually flavous beneath. Thorax strongly convex and somewhat shining, black with lines before and beneath the radix flavous; areola sub-quadrate; costulae entire. Scutellum flavous. Abdomen subovate, centrally scabriculous, black; the first two or three segments broadly bimaculated, the remainder margined, with flavous; of has the third, fourth and, usually, seventh immaculate; postpetiole glabrous, basally sub-aciculate and often with a central fovea ; gastrocaeli somewhat large, striate, deeply impressed, with the intervening space sub-striate; of valvulae testaceous. Legs black; tibiae and tarsi more or less red. IVings sub-hyaline; stigma and tegulae black; radix piceous ; areolet broad, sub-quadrate. Length, $8 \mathrm{~mm}$. 
The markings are somewhat variable in extent and citrinous, but fade very considerably after death; two examples in my collection have the scutellum entirely black, and it is hard to believe it has ever been flavous.

The only species with which the present can be confused is the Spanish $L$. cabrerae, Berth., which has the areola strongly transverse and the spiracles more elongate; its head and thorax are broadly red, the antennae entirely ferrugineous and the hind tibiae black throughout; it is, too, rather larger.

The economy of L. mycthemenus, which would appear to be a rarity, though probably only overlooked on the Continent, where it occurs in Germany, France and Italy, has recently been somewhat fully investigated in Britain. Until $\mathrm{x} 897$ it was supposed to be of extremely rare occurrence, and was known only from the examples described by Desvignes. Marshall (cf. E.M.M. I897, p. 235) took a larva of Lycnenut argiolus in his garden, at Botusfleming, in Cornwall, in July, from whose pupa an example of the present species emerged about a month later. Bignell subsequently bred it from the same host, in South Devon, on I 4 th July. Mrs. Redmayne sent me specimens to name, bred from L. argiolus, at Chalford, in Gloucester. The larvae pupated early in September, and females of the parasite emerged therefrom at the end of the ensuing April (Ent. Rec., I900, p. 164). Prideaux has bred this species during two or three consecutive years from the above host at Reigate, and tells me that there one occurs in about every dozen chrysalids of its host, considering whose frequency the parasite should be by no means uncommon (lib. cit. p. 269), but it appears never to have been taken on the wing, and one is almost led to conjecture that its habits are nocturnal or at least reclusive.

The similarity of this parasite's pupa to its imago is to be seen in the tumidulous scutellum and the neuration of the wings, which though concolorous with the cells is much elevated and inflated. The pupa is stramineous with the meso-notum and -sterna black; the eyes are nigrocastaneous with the ocelli and mandibular teeth castaneous and widely distended; all the members are detached and visible, the antennae and legs being enclosed in separate sheaths and neatly folded upon the ventral surface; the thorax is of a somewhat more sordid colour than the head, wings and abdomen; there is no trace of lateral abdominal spiracles, and those of the host's pupa, within which the whole of the parasite's ecdysis takes place, are, like the remainder of the shell, interiorly thickly conted with a silken lining, which would indicate in ichneumonidous pupae an incomplete respiratory system. Its length is $7 \mathrm{~mm}$. ( $c$. Ent. Rec. I900, p. 187 , ff. I et 2).

Shortly before emergence the imago can be easily traced, since most of the markings and especially the outer orbital are already conspicuous; the pale apices of the three basal segments are, however, not represented at this stage of its evolution. The convex post petiole is very distinct, though the antennae, palpi, face and wings are still enveloped; the first are now flavous throughout, the scape only showing piceous; the abdomen has undergone considerable modification and its contour is quite changed.

As far as I am aware this species commences to gnaw its way through the host's pupa at about $2-0$ p.m. and succeeds in piercing an orifice in a couple of hours; actual emergence being accomplished about 5-30 p.m. by means of a more or less regular circular incision which entirely removes the capital extremity of the host's pupa, of which only the catergillar's 
shrivelled skin and corneous head remain at its anal extremity. The duration of the life of the imagn in captivity is a little over five days in May; and it will eagerly feed upon the stylopods of Chaerophyllum sylvestre, which are first carefully investigated with the apices of the antennae. Beaumont has given me many examples of both sexes, bred from Hadena prolea and Lycaena argiolus, by Col. Partridge, but in these cases emergence took place at the end of October; possibly the pupae were "forced" (cf. Ichnemmon deliratorius, \&c., post).

\section{NEOTYPUS, Förster.}

Först. Ver. pr. Rheinl., I868, p. I94.

Head hardly dilated; clypeus and face convex, not discreted, former broadly rounded apically, with no central dentation; internal orbits not parallel, divergent. Antennae short, of $q$ filiform. Mesothorax of $q$ rufescent; pronotum not centrally tuberculate; metathorax distinctly areated; coxal areae wanting; sternauli hardly indicated; pleural costae sub-angularly inflexed; spiracles oval, appendicular. Scutellum convex, laterally carinate to near its apex. Abdomen fusiform, apically conical. Legs somewhat stout; onyches of $q$ pectinate. IVings with the second discoidal cell a little nearer the radix than the first cubital; nervulus often pellucid; nervellus nearly vertical.

\section{I. lapidator, Fab.}

Ichneumon lapidator, Fab. E. S. ii. I60; Piez., 84; Trentep. Isis, IS26, p. 77 (nec Fal. M. I. i. 266), ㅇ. Listradromus lapidator, Wesm. Bul. Ac. Brux. 1854, p. I40, excl. synon.; Mém. couron. Ac. lielg. I 859 , p. 78 ; Voll. Pinac. pl. xxvii. f. 8, 9 . Neotypus lapidator, Holmgr. Ichn. Suec. ii. 292; Berth. Ann. Soc. Fr. I896, p. 304 , ơ +. I. nohilitator, Gr. I. E. i. 627, \&. L. nobilitator, IVesm. Bul. Ac. Brux. I857, p. 404, ․ N. Nobilitator, Thoms. Ann. Soc. Fr. 1888, p. I23; O. E. xix. 2100 , o क

Head black, smoothly and evenly punctate throughout; frontal and post-ocular orbits narrowly stramineous; 0 with clypeus laterally white. Antennae somewhat slender; of $q$ inconspicuously white-banded, with flagellar joints cylindrical, ferrugineous towards the base beneath, the tenth quadrate; of of black. Thorax, at least of $q$, broadly sanguineous ; areola sub-quadrate or semilunar, apically truncate; costulae entire. Scutellum of $\delta$ usually black; of $q$, with post-scutellum, red. Abdomen villose, finely punctate; black, with the first two segments apically bimaculated, and the last four margined, with white; post-petiole convex, centrally foveolate or glabrous, its carinae obsolete; gastrocaeli large and deep, intervening space narrow and evenly punctate. Legs black, with front femora at apex and anterior tibiae red, the latter internally testaceous. Wings sub-hyaline, stigma piceous; areolet pentagonal, broad above. Length, 5-7 $\mathrm{mm}$.

This species closely resembles the Continental $N$. melanocephalus, Gmel. (lapidator, Grav. et Thoms), but it is much smaller and the antennae are more slender; the petiolar area is narrower and strongly impressed; the scutellum more convex; the gastrocaeli are broader; anterior femora and tibiae darker, with the hind ones entirely black; moreover, the of antennae are always white, and the of mesonotum is often rufescent. 
Confirmation of the right of this beautiful species in our native list is certainly most requisite. Desvignes, whose accuracy is not always beyond necessitating investigation, included it in his 1856 Catalogue on the strength of an example in his own collection; subsequently Fitch apparently examined this specimen in the British Museum, and says it is "certainly not lapidator." There the matter rests; I know of no indigenous records. On the Continent, it occurs in Sweden, Russia, Germany, Prussia, France and Spain.

Since writing the above, I have found a $q$ in Mr. F. IV. Sladen's collection, which removes all doubt, since it was captured at St. Margaret's Bay, on 2 Ist July, 1898 , on a flower-head of Centaurea scabiosa, on the top of the cliff, and about a yard from its edge, in company with many aculeate Hymenoptera.

TRIBE.

\section{JOPPIDES.}

A part of the Joppides constituted Förster's twenty-seventh family, that of the Trogoidae, which was distinguished by its pyramidal scutellum; and the latter section is culled from the genus Ichneumon of Linnaeus, by Thomson, on account of the deep sulcus which divides the metanotum from the scutellum and is due to the greater development of the wingmuscles, but which nevertheless appears a constant character, the presence of a basal metathoracic area being strong evidence of a sulcus in the ancestral type. Thomson's divisions are now coming into general adoption, and it is well to seize with avidity any good feature which goes to assist in simplifying the great father's, or rather Gravenhorst's, most unwieldy genus, so natural and asymmetrical in its contour and facies, so incongruous in its sexes and colour.

\section{Table of Genera.}

(10). I. Scutellum strongly convex; metanotum short ; areolet ustially rhomboidal.

(9). 2. Central segments not deeply incised, and not laterally margined.

(8). 3. Labrum not concealed; areola normal ; areolet sub-pentagonal.

(7). 4. Scutellum immarginate; mandibles slender; apophyses acute.

(6). 5. Clypeus apically truncate; hypo-

(5). 6. Clypeus apically emarginate; hypopygium covering terebra ............

(4). 7. Scutellum laterally margined; mandibles stout ; apophyses obtuse ...

(3). 8. Labrum concealed ; areola tuberculate ; areolet rhomboidal .........

(2). 9. Central segments deeply incised, and laterally margined ....................

(I). Io. Scutellum not strongly convex; me-

I. Hoplismenus, Grav.

2. HyBOPHORUS, Tisch.

4. Automalus, IVesm.

5. 'Trogus, Pañ.

3. Dinotomes, Först. tanotum normal ; areolet pentagonal.

(12). I1. Metathoracic juxta-coxal and pleural areae confluent .......................

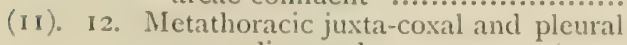
areae discreted

6. PROTICHNEUMON, Thoms.

7. Coelichneumon, Thoms. 


\section{HOPLISMENUS, Gravenhorst.}

Gr. I. E. ii. 409 (IS29); IVesm. Nouv. Múm. Ac. Brux, IS44, p. I3.

Head not tumidulous, somewhat narrowed behind the eyes and towards the mouth; clypeus large, apex truncate; labrum usually very shortly exserted. Antennae slender setaceous; of $q$ often stouter towards apex. Thorax gibbulous; mesonotum somewhat convex with distinct notauli; metathorax with basal sulcus profound, and usually two acute apophyses; spiracles linear or oval. Scutellum strongly elevated, abruptly declived. Abdomen sub-fusiform; terebra distinctly exserted; hypopygium not covering base of terebra. Legs somewhat slender. Wings normal; areolet pentagonal.

The bidentate metathorax, exserted terebra, \&c., lend members of this genus decided Cryptid facies, and in colour $H$. perniciosus closely resembles Mesostenus obnoxius; but the males bear only the faintest traces, and the females none at all, of sternauli. To Platylabus it also bears a superficial resemblance, but may be distinguished, besides the major points before indicated, by the straight, slender, hind tibiae and by the large and pentagonal areolet.

This genus has been placed by all former authors among the Oxypigini, but the conformation of the metathorax and scutellum clearly ally it with the Trogoidae of Förster ; among the Oxypigini it is certainly aberrant.

\section{Table of Species.}

(4). I. Gastrocaeli small; thorax with strong spines; anus immaculate.

(3). 2. Anus infuscate ; length $9 \mathrm{~mm}$. or more ..... r. PERniciosus, Grar.

(2). 3. Anus rufous ; length $8 \mathrm{mmi}$ or less.......... 2. ALBIFrons, Grav.

(I). 4. Gastrocaeli broad; thorax with small spines; anus white marked

3. Uniguttatus, Grav.

\section{I. perniciosus, Grav.}

Ichneumon armatorius, Panz. F. G.. ㅇ (?). Hoplismenus perniciosus, Gr. I. E. ii. 4I 3 ; Ste. III. M. vii. 275 ; Wesm. Nouv. Mém. Ac. Brux. I844, p. IOS; Bul. Ac. Brux. I848, p. I86; Holmgr. Ichn. Suec. i. 208; Thoms. O. E. xix. 2082 ; Berth. Ann. Soc. Fr. I894, p. 513, of o. I. bellicosus, Stephani, Nat. Sicil. 1886, f. Var. J. bidentatus, (imel. S. N. p. 2685, ठ; H. bidentalus, Gr. I. E. ii. 4I2, ठ; Thoms. O. E. xix 20 SI.

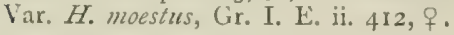

Head confluently punctate, black; internal or frontal orbits often whitish, of also with cribrary organs sometimes white, the $q$ palpi and mandibles ferrugineous; vertex narrow; clypeus and cheeks produced, former separated and the lateral fovea deep. Antennae long and slender, basal flagellar joint thrice longer than broad; of $q$ compresso-dilated beyond centre, white banded; of $t$ with scape beneath and, rarely, central joints white. Thorax dull, black; of with linear callosities at radix and pronotum usually white; notauli distinct; metathorax rugose, laterally coarsely punctuate, bisal sulcus profound; upper areae usually complete, juxta-coxal costa obsolete;

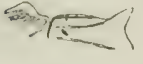

Metathoracic sulcus dentiparal with strong, acute apophyses; areola slightly of $H$. perniciosus. elevated, of $q$ semi-oval, of of semi-circular or semi-lunar, often emarginate at base and apex, its costae strong. Scutellum more or less white, strongly convex, shining and finely punctate; perpendicular 
behind, especially in the $\delta$. Abdomen dull, very finely and closely punctate, red; the first and apical segments nigrescent, and anus always immaculate; post-petiole more or less strongly punctate, or glabrous with isolated punctures ; gastrocaeli shallow, rarely sub-obsolete, the intervening space rather broader than the centre of post-petiole, rarely rugose ; terebra distinctly exserted, black, spicula fulvous; hypopygium of of elongately acuminate. Legs most commonly black, usually with anterior femora and tibiae more or less reddish; hind coxae simple; of with third and fourth joints of hind tarsi, and often the anterior coxae, white. Wings hyaline ; stigma piceous or ferrugineous; tegulae infuscate; areolet pentagonal, broad above. Length, 9-- $2 \mathrm{~mm}$.

Gravenhorst described three varieties as distinct species, and Holmgren has tabulated ten forms, of which that with black hind femora is the type ; that with the abdomen black, segments two and three only being red, is H. bidentutus; that of of with abdomen black, segment two only red, the hind femora and tibiae black is $H$. moestus. The coloration of the antennae, scutellum, abdomen and legs is very variable.

I do not expect this species is uncommon in Britain, though Bridgman and Fitch considered it so. Stephens, however, also says it appears to be rare with us and records it from Darenth Wood in June, and, doubtfully, as taken near Kimpton, by Rev. G. T. Rudd; neither Bridgman nor Bignell met with it; I possess specimens taken in the New Forest by Miss Chawner, and it is recorded from Essex. It has been bred on the Continent, where it is a common species, from the pupa of Satyrus Moera and from Aspilates strigillaria. The female may probably be found throughout the autumn, and is said to hibernate in moss.

\section{2. albifrons, Grav.}

Hoplismenus albifrons, Gr. I. E. ii. 417 ; Ste. Ill. M. vii. $275, \delta$; Thoms. O. E. xix. $208 \mathrm{I}$, of $\%$.

So closely allied to the preceding species as to need no detailed description, but differing therefrom in its smaller size, more finely punctate and, except at base, entirely red abdomen, invariably white scutellum, and in the white face of the 0 , which, in the last species, is only laterally pale. Nevertheless the distinction of primary importance is probably to be found in the metathoracic spiracles, which in the present species are sub-oval and in the former linear. The costulae, too, are obsolete or wanting. Length, 7-8 $\mathrm{mm}$.

I am certainly inclined to consider $H$. allifrons a good species, though most authors have followed Wesmael in merging it in $H$. perniciosus. Thomson says (loc. cit.), "species parva, scutello alba, abdomine basi excepta rufo, facie maris albida discedens," and of $H$. bidentatus, which he also considers good (on the strength of its colour only), that it is nearly twice larger than $H$. albifrons, with its hind legs and the segments beyond $3^{\text {rd- }} 4$ th black, with the post-petiole punctate centrally.

Stephens took this species in the vicinity of London, in June; and Piffard has found it at Felden, in Herts. I have captured it upon flowers, at Walberswick, in Suffolk, in the middle of July, and the female at Brandon, in the same county, in September. 


\section{3. uniguttatus, Grav.}

Hoplismenus unigullatus, Gr. I. E ii. 423, ; Wesm. Nouv. Mém. Ac. Brux. I844, p. 109 ; Bul. Ac. Brux 1848, p. 292 ; Berth. Ann. Soc. Fr. 1894, p. 516, ðे q.

Head black; clypeus large, smooth and apically rotund, slightly reflexed. Antennae slender, setaceous, white-banded in both sexes. A callosity at the tegulae and the pronotum white; metathorax feebly bidentate; areola sub-hexagonal, posteriorly sharply arcuate. Scutellum very convex, perpendicular behind; white. Abdomen of $f$ black, of $q$ red, with apical segments, and sometimes the first, black; both sexes with anus whitemarked; post-petiole nearly glabrous ; gastrocaeli sulciform, deep, occupying nearly the whole base of second segment, intervening space very narrow; terebra distinctly exserted; of with hypopygium and the genital valvulae white. Legs slender, red; coxae, as well as hind tarsi and base of tibiae laterally, black; tarsi white-banded in ${ }^{\star}$. Wings slightly clouded; stigma ferrugineous, radix white, tegulae black; areolet narrowed above. Length, 7-8 $\mathrm{mm}$.

A variety of the of with the internal orbits, post-scutellum, margin of fifth and sixth segments, \&c., pale, is found in Germany.

It is recorded as British by Marshall, and Bridg.-Fitch considered it uncommon with us. I know of no records and it has not been bred. It is by no means common on the Continent, where it extends from France to Russia.

\section{HYBOPHORUS, Tischbein.}

Tisch. Stett. Zeit. 1875, p. $28 \mathrm{I}$.

Head sub-triangular, strongly narrowed behind the eyes; mandibles slender; clypeus strongly convex and broadly emarginate at apex; face protuberant. Antennae setaceous, centrally incrassate. Metathorax somewhat short and abruptly declived posteriorly, distinctly bidentate, with basal sulcus not very deep, spiracles elongate; costulae wanting. Scutellum gibbous or tectiform; declived from apex. Abdomen oblongovate; of $q$ with eight visible dorsal segments, the hypopygium reaching to its apex and covering base of terebra; of $\delta$ with ventral segments $2-4$ plicate. Legs long and slender; tarsi setose beneath; onychii simple. Areolet pentagonal.

I do not know this genus, which is said by Berthoumieu to be in his Amblypygi what Hoplismenus - with which it was identified in the absence of the female by Marshall, following Wesmael-was among the Oxypygi. There can, however, be no doubt that Ashmead is in error in leaving it among the Ichneumonini, since Tischbein distinctly says (Inc, cit.) that the mesonotum is short, abruptly declived and similar to that of Trogus; indeed, since the erection of the tribe Joppides, $I$. aulicus appears to scarcely merit generic rank, as it differs from Hoplismemus only in the extended hypopygium.

\section{I. aulicus, Grav.}

Ichneumon auticus, Grav. I. E. i. 562, o. Hoplismenus aulicus, Wesm. Bul. Ac. Brux. 1857, p. 396 ; Tisch. Stett. Zeit. 1874, p. 139, 3. Hybophorus aulicus, Tisch. lib. cit. 1875, p. 281 ; Berth. Ann. Soc. Fr. 1896, p. 291, of.+ . flavipetiolalus, Tisch. Stett. Zeit. I873, of. Var. I. auxilifer, Tisch. lib. cit. I876; Berth. Ann. Soc. Fr. I 894, p. 591, ठ. 
Head strongly and closely punctate, dull black. Antennae stramineousbanded in both sexes; flagellum pale, scape red-marked beneath. Thorax strongly and closely punctate, dull black; metanotum rugosely punctate; areola semi-oval, broadly emarginate apically, of ot transverse; apophyses short and distinct, stronger in ô. Scutellum very strongly convex, black. Abdomen ovate-lanceolate, dorsally depressed, finely and closely punctate; black, with the two basal and more or less of the third segments rufotestaceous, of sometimes with apices of the remainder narrowly fulvous; post-petiole coriaceous, with distinct carinae; gastrocaeli superficial, the intervening space broader than centre of post-petiole. Legs somewhat slender; black, with all tibiae and tarsi, and half the front and apices of posterior femora, testaceo-flavous; onychii black. IVings somewhat strongly flavescent, stigma and nervures piceous; radix and tegulae nigrescent. Length, I $2-14 \mathrm{~mm}$.

The variety auvilifer has the abdomen black, with the second, or second and third segments more or less ferrugineous dorsally, and the hind tibiae piceous.

This species was introduced as British by Marshall, in his I870 catalogue; Kriechbaumer says it "preys on a caterpillar which lives on willows, as I have always taken it, in the end of August or early September, flying round willows or on the flowers near them." I know of no indigenous records, and on the Continent it is only found in Germany, France and Western Russia.

\section{DINOTOMUS, Förster.}

Först. Ver. pr. Rheinl. I868, p. I88 ; Psilomastix, Tisch. Stett. Zeit. I868, p. 255 ; Trogzes, Gr. I. E. ii. 37 I (part).

Head much narrower than thorax, constricted behind eyes; labrum strongly exserted; clypeus apically truncate or emarginate. Antennae in both sexes filiform, and not perceptibly centrally dilated. Thorax stout. Scutellum more or less pyramidal or conical, apically immarginate. Abdomen aciculate or striate, with more than three visible dorsal segments very deeply incised and laterally bordered ; lunulac on segments $2-4$ wanting or very indistinct. Legs slender, hind femora reaching at most to apex of fourth dorsal segment. IVings clouded; areolet sub pentagonal or subrhomboidal.

\section{Table of Species.}

(2). I. Clypeus apically emarginate ; scutellum black...... (1). 2. Clypeus apically truncate ; scutellum partly pale.

(4). 3. Metathorax not spined; areolet narrow above......

(3). 4. Metathorax spined; areolet not narrow.

I. LAPIDATOR, Fab.

2. PICTUS, Kriech.

3. SPINOSUS, Morl.

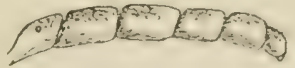

Abdomen of D. lapidator.

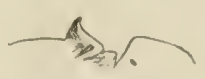

Scutellum of D. pictus.

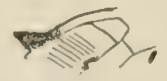

Apophysis of D. spinosus.

\section{I. lapidator, Finb.}

Tchneumon lapidator, Fab. M. I. i, 266, 8; Piez. 67 (nei E. S. ii. 160). I. coerulator, Fal, l'iez, 68. I. caeruleator, Panz. Schaef. Ic. cxxxv. fig. 3 (?). Trochus cocmlcutor, 
Trentep. Isis, I826, p. 297. Banchus venator, Illig. Rossi F. E, No. 767. Trogus cacruleator, Panz. F. G., pl. c., t. 13; Revis. 80. T. lapidator, Gr. I. 1.. ii. 39I ; Wesm. Bul. Ac. I3rux. 1854, p. 135, ठ. Psilomastix lapidator, Tisch. Stett. Zeit. 1868, o ㅇ ; of. Krisch. Ent. Nachr. 1882, p. 173. Dinotomus lapidator, Berth. Ann. Soc. Fr. 1996 , p. 296 ; Morl. E. M.M. 1901, p. 249, ठै \&. Var. Trogus fuscipennis, Gr. I. E. ii. $3^{S 9},+$.

Head black, transverse ; eyes prominent ; face entirely black, somewhat protuberant longitudinally in the centre, strongly and evenly punctate; clypeus black, apically emarginate, slightly raised laterally, strongly punctate, with scanty white hairs; mandibles black, rufescent apically, punctate and margined, very obsoletely bifid and much depressed apically ; labrum, ligula, maxillary and labial palpi fulvous; second joint of maxillary palpi strongly lobed, apical long and cylindrical ; labial palpi with joints sonewhat moniliform. Antennae rather short, entirely black above, flagellum ferrugineous below towards the base; darker, with joints more cylindrical in $q$. Thorax black; mesonotum finely, evenly and distinctly punctured, with an anterior central depression in $q$; mesopleurae finely scabrous, inter-sternal sulcus smooth and narrow; metathorax strongly punctate, with black pilosity; areola very short, triangular, the posterior area only well defined. Scutellum black, strongly punctate, with dark pilosity, tumidulous, apically acuminate. Abdomen violaceous- or caeruleous-black, longitudinally rugose, the sculpture much coarser in $q$, incisures deeply impressed, dorsum of central segments depressed; petiole bicarinate, much explanate apically with the central area narrow, aciculate in $\delta$, rugose in $q$; gastrocaeli normal, deeply impressed; two apical segments small and inconspicuous; fo with ventral fold on segments $2-5$, $q$ on $2-3$; terebra scarcely visible, and barely exserted beyond apex of the hypopygium. Legs fulvous, coxae and trochanters, except apex of hind pair, black; hind tarsi more or less nigrescent, onychii red. IVings somewhat infuscate; costa and tegulae piceous, radix ferrugineous; basal nervures piceous, the apical and the stigma ferrugineous; areolet distinctly sub-petiolate, its sides converging above. Length, I3-1 $8 \mathrm{~mm}$.

The var. fuscipennis has the wings very dark, with a violet reflection.

This species is a well known parasite of Papilio Machaon. It is solitary in its parasitism, and the imago emerges from the host's pupa through a large irregularly circular hole, often in the right wing-case. All the British examples have been bred from the above host.

There is a $q$ in Rev. T. A. Marshall's collection (Mus. Mason) labelled "British, I893," and others in those of Messrs. A. Beaumont and W. IV. Esam. The latter received twelve larvae, of which only three pupated, two of these producing the sexes of $D$. lapidator (above described). "There is little doubt these also are British, since they were obtained from a collector in the Cambridge Fens, in June, through Edmonds, who had no foreign Machaon till the autumn. Mr. Janson has also bred it from $P$. Machaon, but is by no means sure that the host was British.

On the Continent it is very rare in Sweden, where Holmgren never met with it, and uncommon in central and southern Europe, extending to Algeria. It has been bred from Argynnis Pandora, by Mocsary. Gravenhorst says, "Habitat in floribus, in dumetis, in regionibus sylvaticis," and M. Pic has recently taken it at Digoin, on umbelliferous flowers, in August. 


\section{2. pictus, Kreich.}

Psilomastix pyramidalis, Tisch. Stett. Zeit. 1868, +, (sic o). P. lapidator, var. 19, lib. cit. $1874, \delta$ o. P. pictus, Kreich. Ent. Nachr. I882. Dinotomus pictus, Berth. Ann. Soc. Fr. I896, p. 297 ; Morl. E.M. M. I891, p. 250, $q$.

Very like the preceding, from which it may be known by its truncate clypeus and flavous markings, as well as by the following points. Head concave behind the eyes; facial, genal, and vertical orbits broadly fulvous, often entirely black in $\delta$; clypeus apically truncate; mandibles rufescent throughout in $q$, at base in $\delta$, distinctly bidentate; joints of maxillary palpi sub-cylindrical. Antennae of $q$ with joints I I-I 5 stramineous; usually red beneath in $\delta$. Thorax black in $q$; 0 with pronotum, lines before and beneath radix, and two distiuct dots before scutellum, flavous; areola represented by a tubercle, posterior area with strong lateral costae. Scutellum finely punctate, black, its posterior face stramineous; acuminately arcuate. Abdomen black; of with metallic violet reflection; the petiole not usually explanate apically; its central area aciculate in both sexes; gastrocaeli broad and deeply impressed; terebra slightly exserted beyond pygidium. Legs bright fulvous, coxae and trochanters almost entirely black; anterior femora and tibiae infuscate above; the $q$ has all the tarsi entirely fulvous. WVings sub-hyaline, with a slightly darker apical fascia; all the nervures piceous; areolet sub-deltoid, not petiolate. Length, IO-I $4 \mathrm{~mm}$.

The $q$ above described differs from the type form in the immaculate scape, mesopleurae, coxae and trochanters, and in having the hind femora, tibiae and tarsi unicolorous.

A single female was bred from a pupa of Apatura Iris on July I 2 th, I 90 I, by Mr. J. F. Musham; the larva was taken in the New Forest. The parasite emerged through a "circular hole one-eighth inch diameter in the upper left half of the thorax, not quite in the centre; the pupa was only slightly discoloured, much less so than when the host emerges. The larva before pupation was very small and sluggish, and its right process was only half as long as the left; oviposition of the parasite took place in the autumn, before hibernation, when the larva was in its earliest stages." (cf. E.M.M. loc. cit.)

It is very rare on the continent; M. l'Abbé Berthoumieu records it only from Hungary; Tischbein bred it from the above host.

\section{3. spinosus, $s p . n$.}

Simaller and more finely sculptured than the preceding. Head somewhat coarsely but not deeply punctate, black, strongly narrowed behind the eyes ; frons deplanate, with large glabrous scrobes; cheeks longer than base of mandibles; face not protuberant, pilose; clypeus elongate, slightly convex, apically truncate and indistinctly discreted from the face; labrum strongly exserted; mandibles small and inconspicuous; palpi testaceous; facial orbits broadly, and frontal narrowly, flavous. Antemnae long, setaceous, sub-nodulose towards the attenuate apices; black, ferrugineous beneath; seventh flagellar joint quadrate. Thorax finely punctate; black, with whitish pubescence; pronotum laterally, and a small callosity beneath the radix, indistinctly flavidous; notauli and sternauli distinct, though small ; metanotum rugose, sub-regularly transcostate below the large and acute apophyses ; 
costae strong, areae complete; areola transverse, narrowed basally and truncate apically; posterior area tri-divided and transversely wrinkled; spiracles linear. Scutellum conical, finely punctate and pilose, shining, concavely declived behind vertically, bright flavous; basal carinae strong, coalescing truncately in a fine costa across the vertex. Abdomen sub-ovate, apically obtuse, distinctly margined, not very coarsely and alutaceously punctate, black; incisures and thyridii ferrugineous; post-petiole stout, its carinae strong, central area shagreened, with a transverse row of five distinct (and perhaps accidental) punctures before the apex, its spiracles somewhat large and oval; gastrocaeli normal, deep and striate; thyridii oblique; ventral segments $2-5$ with a ferrugineous fold. Legs normal, piceous; coxae and trochanters black; anterior femora and tibiae testaceous internally. Wings milky-hyaline; stigma, radix and tegulae piceous ; areolet broadly pentagonal. Length, io $\mathrm{mm}$. of.

The male above described was recently taken in the New Forest by Miss Ethel Chawner, who has kindly presented me with the type, together with a large number of other parasitic Hymenoptera. I have seen no female of this very distinct species.

\section{AUTOMALUS, Wesmael.}

Wesm. Nouv. Mém. Ac. Brux. IS44, pp. I I I, I44; Trogzus, Gr. I.E. ii. p. 37 I (part).

Head sub-tumidous; cheeks and temples a little buccate ; mandibles with two stout apical teeth; clypeus with the apex mutic and the lateral angles rotund; labrum nearly invisible. Antennae setaceous, of $\delta$ attenuate beyond centre. Thorax robust, strongly punctate; mesothorax evenly rounded in front; metathorax rugose, short; dentiparal area transverse, coxal wanting; spiracles linear. Scutellum centrally elevated, sub-pyramidal ; sides and apex distinctly bordered. Abdomen elongate, obtuse, subequilateral, segments not laterally bordered; second segment only ventrally plicate; post-petiole rugose; gastrocaeli large; hypopygium covering base of terebra. Legs slender; scopulae wanting. Wings normal; areolet deltoid ; radial nervure incurved at base and apex.

M. Duprez mentions an hermaphrodite of $A$. alboguttatus in Ann. Soc. Entom. Belgique, I896, p. 507.

\section{I. alboguttatus, Grav.}

Trogus alboguttatus, Gr. I. F. ii. 373 ; cf. Suppl. i. 695 ; Ste. Ill. M. vii. 269; Boie, Kroy. Tids. I840, p. 317 ; Ratz. Ichn. d. Forst. i. I3I. Automalus alboguttatus, Wesm. Nouv. Mém. Ac. Brux. I844, p. I44; Bul. Ac. Brux. I854, p. 136 ; Holmgr. Ichn. Suec. i. 286 ; Berth. Ann. Soc. Fr. 1896 ; p. 294, $\delta$; of. Thoms, lib. cit. I888, p. I2I. Antblyteles dinidiativentris, Rud. Ent. Nachr. 1888. Ichneumon balticus, Ratz. Ichn. d. Forst. i. 135, of

A rather large, shining, black species, boldly marked with white. Head black, finely punctate, with long white pubescence; the scrobes large and shining; of alone has the palpi, a mandibular and genal mark, two on the clypeus, the facial and frontal orbits, white. Antennae inserted high on forehead; of $f$ black, sub-dentate, of $q$ with a flavous band. Thorax somewhat strongly punctate, dull; gencrally with the callosities at radix white; metanotum strongly rugose, the upper areae complete, of which the areola is elevated, sub-circular, and anteriorly rounded. Scutellum 
white, with white hairs; apically sub-striate. Abdomen bluish-black, depressed; $\delta^{t}$, at least, with third and following segments transverse and finely alutaceous; post-petiole explanate and margined or bimaculated apically with white, somewhat rugose with rounded angles and bisinuate apically ; second and third segments narrowly red-margined; the segments with a dorsal depression; seventh centrally white, in $q$ with a longitudinal basal carina; ventral fold flavous. Legs slender, pubescent, black; apex of anterior femora and part of coxae, all the trochanters, tibiae and tarsi, except apex of hind ones, stramineous, darker in $q$. Wings somewhat clouded ; tegulae black; radix and base of costa, white ; stigma reddish or fuscous. Length, I 2-I $6 \mathrm{~mm}$.

The capital markings are somewhat variable, but the genal patch and apical band of first segment are very distinctive.

This species is said to be common in Britain, though Stephens tells us it used to be not very abundant, though found occasionally, in June, at Darenth and elsewhere about London, as well as in Devonshire, the New Forest, Norfolk, Salop, \&c. Bignell has bred it from Orgyiu pudibunda, to which it appears to be nearly confined in Britain, in the middle of June, in South Devon ; and Mr. Waterton has given me an example from the above host in southern England about the same date. Beaumont has specimens from Bury St. Edmunds, and it has been taken at Bishop's Wood, Yorkshire, early in August. On the Continent, where it is common, it has also been bred from Thyatira batis, Liparis auriflua, and Bombyx monacha. The host's cocoon sent me by Mr. Waterton is expanded to its fullest capacity, and the parasite emerged through a very jagged semicircular incision towards the capital extremity, but the operculum is not removed as is usually the case in the emergence of Ichneumons; within the parasite had spun no vestige of a cocoon for itself. Bignell, in Buckler's "Larvae," says Mr. R. Adkin once bred this species in Britain from Sphinx ligustri.

\section{TROGUS, Panzer.}

Panz. Krit. Revis. ii. 80 (I806) ; Först. Ver. pr. Rheinl. I868, p. I88.

Head slightly tumidous; cheeks and temples sub-buccate; mandibles obtusely bidentate, the lower tooth somewhat the shorter; clypeus apically a little dilated; labrum shortly exserted. Antennae of $q$ more or less dilated beyond centre. Thorax robust, longer than high, punctate; notauli very distinct; metathorax short, basal sulcus profound; spiracles elongate. Scutellum elevated, sub-pyramidal. Abdomen oblong or oblongovate, apically obtuse; segments truncate, with no distinct aciculations or foveolate impressions; terebra short, scarcely exserted. Legs normal. IVings large and stout ; areolet rhomboidal ; radial nervure apically incurved.

As Stephens remarks, these insects are extremely variable in colour, upon which no reliance can be placed: in some examples the thorax is nearly black with various rufescent markings, in others it is red with various black markings; the abdomen may be entirely testaceous or the four apical segments deep black throughout; the legs also are very inconstant in colour. Stephens included Ichneumon flavatorius, I. luteiventris and his own $T$. dissimulator in this genus on account of their large size and sub-convex scutellum. 


\section{Table of Species.}

(2). I. Metanotum with dentiparal areae regularly transversely costate; second and third ventral segments centrally plicate .........

(1). 2. Metanotum with dentiparal areae intricately confusedly costate ; second ventral segment only bearing a fold ...................

I. LUTORIUS, Fab.

2. exaltatorius, Panz:

\section{I. lutorius, Fab.}

Ichneztmon lutorizs, Fab. M. I. i. 262 ; Piez. 64 ; $c$. Albin. Nat. Hist. Engl. Ins. 1720 , pl. vii. Trogus hutorius, Gr. I. E. ii. 374 , excl. var. 5 ; Ste. Ill. M. vii. 270 ; Ratz. Ichn. d. Forst. i. I30; Wesm. Nouv. Mém. Ac. Brux 1844, p. I43 ; Bul. Ac. Brux. 1854. p. I34; Holmgr. Ichn. Suec. ii. 285 ; Berth. Ann. Soc. Fr. I896, p 295. to. Ichneumon imperatorius, l'anz. Schaef. Ic. t. ccxlv. ff. 5, 6, $q$. I. pisorius, Panz. lib. cit. t. xx. f. 6. I. cirrogaster, Schr. En. 348 ; F. B. 28I. I. crocatus, Fourc. E. P. 399. Trogzes excellens, Tisch. Stett. Zeit. 1882, ठ。.

A large and robust species, variegated with black and red. Head not narrowed behind the eyes, for the most part fulvous; marked with black, especially upon the occiput. Antennae black; basal half beneath, or entirely, reddish. Thorax more or less black, with the pronotum, callosities before and beneath the radix, and the scutellum flavous; often also with two lateral marks on prothorax, and on the disc of mesonotum, and the posit-scutellum, fulvous; areola very small, triangular; upper areae complete; dentiparal areae with parallel or sub-parallel distinct transverse costae. Abdomen large, apically obtuse ; fulvous, with more or less piceous marking; post-petiole black, often apically fulvous in $\delta$, punctate or

sub-aciculate; gastrocaeli normal ; second and third ven-
with central fold. Legs rufescent-fulvous, coxae and apical

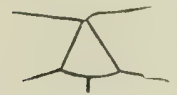

Areolet of

T. lutorius. tral segments with central fold. Legs rufescent-fulvous, coxae and apical
half of hind femora usually black. Wings, especially towards their apices, fulvescent; stigma fulvous. Length, 20-25 mm.

Rev. T. A. Marshall mentions (E.M.M. I 896, p. 265) a most peculiar circumstance, which we may, although the species of the parasite is not determined, attribute with some certainty to $T$. lutorius. He says a pupa of Acherontia Atropos was forced by artificial heat to an unnaturally early emergence, when within the body of the imago was discovered a large Ichneumon, still in the larval condition, the forcing of the host having not led to a similar effect upon its parasite; this would, however, appear to be the exception rather than the rule-cf. Melanichneumon leucomelas, Ichneumon deliratorius, \&c., post.

The species of this genus are not very commonly found, in June and July, around London, in gardens and woods (Stephens) ; they are frequently captured during the summer months heavily flitting - "something between a fly, a jump, and a buzz" - in the neighbourhood of privet, throughout the day (Entom. I88I, p. I 29) ; flying about sallows at Whittlesea Mere, in July (Curtis); Lynn, in Norfolk (Bridgman); rare about Yarmouth (Paget); Carah Lake, in Co. Kerry, in middle of August (Yerbury); Aldeburgh, in Suffolk, bred from Deilephila galii (misnamed in E.M.M. I889, p. 455). It is a common parasite upon Acherontia Atropos and Splinx ligustri, and has also been bred from Smerinthus ocellatus and S. populi, in Britain. Bignell, who has bred this species from S.ligustri, in Devon, 
says (Entom. I 878, p. 274) that immediately after its emergence the host's pupa is "about half-filled with thick creamy-looking matter," but that there is no indication of a distinct pupa-case. Rev. A. Thornley has given me this species from the New Forest; it is recorded from Naldon, in Essex; I have seen it from Derbyshire and Wicken Fen; Beaumont has taken it at York; and it has been bred from $A$. Atropos in Yorkshire.

\section{2. exaltatorius, Panz.}

Ichnezumon, De Geer, Mém. ii. 848 , n. 3, t. 29, f. 9. I. cxaltatorius, Panz. Schaef. Ic. t. ccxlii. f. 3. Trogus exaltatoriues, IVesm. Nouv. Mém. Ac. Brux. 1844, p. 143, of $q$; Ilolmgr. Ichn. Suec. ii. 285, $q$; Berth. Ann. Soc. Fr. 1896, p. 296, of $q$; if. Thoms. lib. cit. 1888, p. 121, I. Alropos. Cur. B. E. pl. ccxxxiv. ; Farm. Ins. 443 ; cf. Gr. I. E. i. Suppl. 697 ; Newport, Tr. Linn. Soc. xxi. 85, pl. ix. ; Proc. Linn. Soc. 1849 , p. 54, et 1853, p. 213 (oecon.). T. Alropos, Ste. Ill. MI. vii. 27 I ; Wood, Ins. at Home, 32, pl. x. f. 3. T. atrocaudatus, Ste. Ill. M. vii. 271.

Very like the preceding, but easily separated by the characters given above, and also by the longer antennae, slightly more slender and darker legs, and by the wings, which are less fulvescent with the apical cloud more clearly determinate.

Much confusion has always existed in Britain concerning the species of this genus, and it is quite impossible to tell, from Stephens' mere colour descriptions, to which his $T$. lutorius, atrocaudatus, and Curtis' $T$. Atropos belong. In the case of atrocaudatus, of which no type is indicated in the author's collection, I have followed Desvignes' reference to the second species as more correct; it differs slightly from the type form, itself extremely variable in colour, in having the inner orbits, the four basal segments alone, instead of nearly the whole abdomen, fulvous, the posterior coxae paler, and the fulvescence of the wings somewhat more pronounced. T. Atropos may be known by a large fulvous patch on either side of the metanotum, the four apical segments are deep, shining black, and the wings are bright testaceous with their apices infuscate; this form is certainly referable to the present species, the type being extant in the British Museum.

There can be no doubt that this species occurs frequently with us, and is probably not rare. Bridgman and Fitch, from their remarks (Entom. I88I, p. I29), appear to know it well; yet it was never recorded in their lists of parasites, and a specimen in my possession, positively thus named by the former, is undoubtedly referable, as the dentiparal costae instantly show, to $T$. lutorius. Curtis records his Alropos from Rochester (Prof. Henslow); Darenth Wood, in July (Davis); and bred from Acherontia Atropos, at Faversham, in Kent (Miss Giraud). Newport, whose account of this species' economy has already been dealt with at some length, took many about Canterbury, in $1 \$ 29$, \&c., in young ash plantations, and says it is " a truly Kentish species, commoner on ligustri than Atropos." Besides Sphinx ligustri, it preys upon Smerinthus ocellatus, from which it has been bred at Askern Spa, in Yorks.; Bignell has found it in South Devon, Routledge in Cumberland; it is recorded from Maldon, in Essex, and Beaumont has examples taken at Bury St. Edmunds, by, probably, the late Dr. Wratislaw. It appears much more restricted in its Continental distribution than the last species, having only been recorded from (iermany, Belgium and Sweden. 
I have already, in the Introduction, fully entered into the economy of this species, and it is necessary to here only add that the host is attacked usually immediately after its assumption of the final larval skin; that the full-fed parasite only occurs in its host's pupa, attaining this state between the end of October and that of April ; in the latter month the parasite assumes the pupal condition, extending over a month or six weeks; the imago usually emerges in June, through a dorsal orifice cut in the host's chrysalis.

\section{PROTICHNEUMON, Thomson.}

Thoms. O. E. xviii. I893, I899.

Size large. Head not triangular, vertex broad with pale lunulae; clypeus apically sub-truncate, mutic ; mandibles stout, their apices bifid. Antennae of $q$, and rarely of $\delta$, white-banded ; flagellum of former attenuate apically. Metathorax with deep basal sulcus; basal area large; areola elongate; petiolar area narrow, equilateral ; dentiparal elongate ; juxta-coxal distinct. Scutellum somewhat flat, pale. Abdomen not convex; post-petiole centrally striolate-punctate, sometimes punctate throughout; gastrocaeli and thyridii large, strongly impressed; abdomen red or black, anus not pale-marked. Wings normal, areolet pentagonal.

This and the following genus are closely allied to the Ichneumonides, and some forms are scarcely separable; it requires considerable care and the closest scrutiny, as Ashmead says, to detect the metathoracic distinctions given in the table of Tribes before one can determine their correct position. The Introductory P'apers (Entom. I S80), embracing all those species of the Wesmaelian genus Ichneumon, considered indigenous by $\mathrm{N}$ Iarshall, in $\mathrm{I} S 72$, may with advantage be referred to in this connection, though they cannot be considered to lead to final determination.

The species of this genus are larger and stouter than any of the Ichneumonides, and prey exclusively upon our largest Lepidoptera-the Sphingidae. There are two Continental species not yet recorded from these islands-1. rubens, Fonsc. and $I$. Jesperi, Holmgr.-but it is by no means improbable they may be found, for the former occurs in France and Germany, and the latter, much resembling $P$. erythrogaster, in Sweden.

\section{Table of Species.}

(10). I. Abdomen for the most part red.

(9). 2. Head and thorax not ferrugineous.

(4). 3. Mesosternal tubercles large; head and thorax flavous-marked .................

(3). 4. Mesosternal tubercles small ; head and thorax white-marked.

(8). 5. Hind tibiae partly black; i coxae scopuliferous.

(7). 6. Post-petiole striate hind tibiae apically black.

(6). 7. Post-petiole rugose; hind tibiae mainly black ....

(5). 8. Hind tibiae entirely fulvous; \& coxac nude

(2). 9. Head and thorax mainly ferrugineous

(I). Io. Abdomen black

I. FUSORIUS, Limn.

2. PISORIUS, Linn.

3. ERYTHROGASTER, Steph.

4. FUSCIPENNIS, Wesm.

5. Disparis, Poda.

6. LAMinatorius, Fab. 


\section{r. fusorius, Linn.}

Ichnezmon fusorius, Linn. F. S. ed. i. no. 966 ; ed. ii. no. 1598 ; Berth. Ann. Soc. Fr. I 894 , p. 525, of $q$; $c$. Thoms. lib. cit. 1886, p. I4. I. pisorizts, Gr. I. L. i. 462 ; Ste. Ill. M. vii. IS8; Zett. I. L. 363 ; Wesm. Nouv. Mém. Ac. Brux. I844, p. 24 ; Ratz. Ichn. d. Forst. i. I37 ; ii. I34; iii I7 I ; Fonsc. Ann. Soc. Fr. I847, p. 400 ; Wesm. Bul. Ac. Brux. I857, p. 363 ; Holmgr. Ichn. Suec. IO, \& 9 . Protichneumon fusorius, Thoms. O. E. xviii. 1900, of \&.

A very large and stout species, somewhat resembling Trogus superficially. Head black, with cheeks and temples somewhat inflated; frontal broadly, and a dot at the vertical orbits flavidous; of with mouth, clypeus, face and nearly the whole orbits flavous. Antennae stout, black; $q$ white-banded, attenuate and compresso-dilated before apex; scape flavous beneath in 0 . Thorax with the pronotum, callosities before and beneath radix and the scutellum, flavous; metathorax rugulose, upper areae complete; areola elongate, apically emarginate and elliptic towards the base. Abdomen brick-red; first segment, except sometimes its apex, and very rarely the anus, black; post-petiole finely aciculate, strongly punctate at its apex; gastrocaeli broad and deep. Legs black; anterior with coxae often whitemarked, and the femora in part, the tibiae and tarsi, somewhat flavidous; intermediate tibiae sometimes apically black; hind femora, tibiae and tarsi basally flavous; coxae of $q$ not scopuliferous. Wings infumato-hyaline; stigma fulvous or fuscous; tegulae piceous, of to with a flavous mark. Length, 22-25 $\mathrm{mm}$.

Examples occur with flavous vittae on the mesonotum and pleurae.

At once distinguished from the following, which it much resembles, though constantly of a larger size, by the flavous markings, the antennal band alone being white, and by the more acute tubercles of the mesosternum, as well as by the nude hind coxae of the $q$, which last character it shares only with $P$. fuscipennis, WVesm.

This species has been bred on the Continent, where it is widely distributed, from a large variety of hosts:-Smerinthus ocellatus, S. populi, Sphinx ligustri, S. pinastri, Ptilodontis palpina, Tryphaena pronuba, and Hadena pisi. It would appear to be rare in Britain, since Stephens says it is so around London, and neither Bridgman nor Bignell met with it in Norfolk and Devon; but these notes must be regarded with caution, since the true synonymy was not discovered till I893. There is no doubt, however, that this species occurs with us, since I have seen an example in Bignell's collection, taken in Ireland.

\section{2. pisorius, Limn.}

Ichneumon pisorius, Linn. F. S. ed. i. no. 968 ; ed. ii. no, 1589 ; Berth. Ann. Soc. Fr. I894, p. 524, of $q^{1}$; cf. Thoms, lib. cit. I886, p. I4. T. expectatorius, Fab. L. S. Suppl. 219; Piez. 59, ‥ I. similatorizes, Holmgr. Ichn. Suec i. II, of o (nec Fab.). $I$ fusorius, Gr. I. E. i. 457 , excl var. 4 ; Ste. Ill. II. vii. 187 ; Wesm. Nouv. Mém. Ac. Brux. I844, p. 24, excl. var. I ; Bul. Ac. Brux. 1848, pp. I43, 335. I. lentorius, Panz. F. G., o. I. fugatorius, Panz. Schaef. Ic., + . Protichneumon pisorius, Thoms. O. E. xviii. 1900.

Smaller than the preceding, but the sculpture is the same. Very like $P$. erythrogaster, but somewhat stouter. Head black; cheeks somewhat in-

1 Berthoumicu (loc. cit.) gives as a synonym " $l$, crassicornis o Desv. Trans." I find no foundation for this reference, and am not aware that Desvignes described an insect under this name. 
flated ; $q$ with internal orbits broadly white, of with palpi, mandibles in part, clypeus and face laterally, frontal, post-ocular, and a dot at vertical orbits white. Antennae stout, black, scape of t more or less pale beneath ; white centrally above in 9 . Thorax with pronotum, callosities before and beneath radix in $\delta^{t}$, and beneath only in $q$, and the scutellum entirely or apically, white; metathorax obtusely bidentate. Abdomen brick-red, first segment almost entirely black. Legs black; anterior with marks on coxae, femora and tibiae in front, and the tarsi, stramineous, the last being darker in $\%$; hind tibiae and tarsi, except apices, fulvous. Wings infumatohyaline, darker towards apex; stigma reddish; tegulae black, sometimes externally paler. Length, $18-23 \mathrm{~mm}$.

This is the species hitherto referred to in Britain as $I$. similatorius, but since Thomson has pointed out the true synonymy (loc. cit.) no further confusion need exist.

It is possible, though improbable, that Stephens discriminated correctly between the species of this group ; in any case, he says, the present is rare about London, and I know of but few records in Britain. It occurs all over Europe, and has been bred from Sphinx pinastri and Hadena pisi.

\section{3. erythrogaster, Sleph.}

Ichneztnon fusorius, Coq. Ic. 12, pl. xi. fig. 5 (?). I. erythrogaster, Ste. Ill. M. vii. I88, o ; cf. Morl. E. M.M. 1902, p. I20. I. fusorius, var. I, Wesm. Nouv. Mém. Ac. Brux. 1844, p. 24, o $\$$; Bul. Ac Brux. 1857. p. 363. I. Coqueberti, Wesm. Bul. Ac. Brux I848, pp. I44, 355 ; lib. cit. I849, p. 36 ; Holmgr. Ichn. Suec. i. 13, excl. q ; cf. Ent. Tidskr. 1880, p. 23, et Thoms. Ann. Soc. Fr. 1886, p. I4; Berth. lib. cit. 1894, p. 523, of ?. Protichnezmon Jesperi, Thoms. O. E. xviii. 1900 (part).

Nuch resembling the preceding species, but slightly smaller and more slender. Head black, hardly narrowed behind the eyes; cheeks very little inflated; clypeus apically truncate, bi-foveolate; $q$ with palpi and labrum piceous, frontal orbits narrowly and a vertical dot, white; fo with face and clypeus white, the former sometimes centrally black. Antennae stout, black, strongly attenuate, and somewhat compresso-dilated before the apex; second flagellar joint more than twice the length of the first ; white centrally above in o only. Thorax rather narrower than head, punctate; rarely entirely black, usually with callosities before and beneath radix and the scutellum white; metathorax rugulose, upper areae complete; areola semi-elliptic, apically emarginate. Abdomen brick-red, first segment black ; post-petiole rugose, somewhat aciculate in $q$; gastrocaeli rather large and deep, triangular; intervening space sub-aciculate. Legs black; anterior coxae often white-marked in $\delta$, their femora in front, tibiae and tarsi pale; hind tibiae entirely piceous or slightly castaneous centrally. Wings clouded, somewhat fulvo-hyaline ; stigma reddish ; tegulae black. Length, I $8-20 \mathrm{~mm}$.

Very like $P$. pisorius, but differs from it in having the posterior tibiae nearly black, the antennae not spiral, and the areola broader. This is distinct from $I$. Jesperi, Holmgr., in which the of has white-banded antennae, and the o a posteriorly truncate areola.

Stephens says the hind tibiae of his I. erythrogaster are "fuscescent, with a slightly paler tint towards the base on the outside," and since no doubt can remain both from his description and from the type in the National Collection that $I$. Coqueberti is the species he refers to, the earlier name is 
here adopted. What his ô was, if it existed, I cannot conjecture ; that of $P$. fuscipennis, Wesm., with which Berthoumieu associated both sexes, sometimes has the face black, but its hind tibiae are fulvous.

It has been bred from Callimorpha dominula, and by Bridgman from Melanippe fluctuata, which seems a wondrous strange host for so large a parasite ; Stephens' type was taken by the Rev. J. Burrell, in Norfolk, and is still extant in the British Museum. In France it occurs rarely in woods, in autumn.

\section{4. fuscipennis, Wesm.}

Ichneumon fusorius, var. 4, Gr. I. E. i. 460. Amblyteles fusorius, Holmgr. Ichn. Suec. ii. 256, o q. A. fuscipennis, IVesm. Nouv. Mém. Ac. Brux. 1844, p. 138, q; Bul. Ac. Brux. I 84 \&, p. 394 ; lib cit. I854, p. I33; Berth. Ann. Soc. Fr. I895, p. 582, 3 9; cf. Thoms. lib. cit. 1888, p. 120. Protichneumon fuscipennis, Thoms. O. E. xviii. I9OI.

Closely allied to the preceding species, but the $q$, generally, though not always, has the terebra basally corered by the hypopygium, which in the of is broadly rounded. Head slightly buccate and narrowed behind the eyes; black ; o with frontal orbits broadly white at vertex ; f with palpi fuscous, a constant vertical dot, and sometimes more or less of the orbits white; cheeks of $\delta^{*}$ with long fine pubescence, of $q$ with sparse, shorter setae. Antennae setaceous, strongly attenuate, with a six-jointed white band above in $q$. Thorax stout, punctate, callosities before and beneath radix, and usually the pronotum, white; a deep sulcus before the metanotum, which is rugulose; areola smoother, semi-elliptic, with the apex emarginate, and base often sharply pointed ; costulae

Metathoracic sulcus of P. fuscipennis. wanting ; posterior area narrow, sub-equilateral ; coxal areae distinct, dentiparal elongate; mesosternum with an indistinct tubercle before the trisinuate basal margin. Scutellum white, finely and sparsely punctate, with darker hairs. Abdomen brick-red, the basal segment black and apical ones rarely infuscate ; post-petiole aciculate-punctate, its apical angles obtuse and sides trans-striate beneath; gastrocaeli large and deep, the intervening space sub-aciculate, narrower than the centre of post-petiole; hypopygium of $q$ opposite the fifth dorsal segment, of $\$$ broadly rounded at apex, the fourth ventral segment with no central fold. Legs black, front femora apically or within, intermediate at apex, and all the tibiae and tarsi entirely, fulvous; claws apically fuscous; hind coxae without scopulae. Wings lighter or darker infumato-hyaline, the apex infuscate; tegulae black; stigma fuivous; sides of the areolet nearly coalescing in of above, wider in $q$; radius somewhat curved. Length, $16-20 \mathrm{~mm}$.

This species has been much confused with $P$. pisorius, in Britain, and there were a fine pair under that name in Mr. W. W. Esam's collection, which he tells me were bred from larvae of Chaerocampa porcellus, found early in August, at Beachy Head. He found only two larvae, both very small, about half-an-inch in length, and both were already "stung," producing the sexes of $P$. fuscipennis during the following June or July. It is, I expect, a not uncommon insect with us. Mr. Bignell has bred it from the above host, on June I Sth. The Ichnenmon pisorius of "Nat. Hist. Hastings," second suppl. p. 9, is a ${ }^{+}$of the present species and was bred at Camber, near Rye, from the above host. Mr. A. H. Hamm has taken it near Torquay, on I 2th August. It is recorded from Essex, and Beaumont 
possesses an example from Bury St. Edmunds. On the Continent, where it is widely distributed, it has been bred from Acherontia Atropos, Sphinx ligustri and convolvuli, Chatrocampa elpenor, Macroglossa stellatarum and fusiformis, Callimorpha dominula and Myselia oxyacanthae. It is there found not uncommonly on umbelliferous flowers, on the margin of woods.

\section{5. disparis, Poda.}

Sphex disparis, Poda, Ins. Mus. Graec. 176r. \%. S. crassicornis, Scop. Ent. Car. n. 769. Ichneumon flavatorius, Fab. E. S., Suppl. 220, 1775, ठ; Panz. F. G. Ixxviii. 12, ơ; c. 12, q; Wesm. Nouv. Mém. Ac. Brux. 1844, p. 88, ó q. 1. fermgineus, Schr. En. I781, q. I. flaviceps, Gimel. S. N. 1788, o. I. ictericus, Christ, Hym. I791, o. I. culpatorizs, Schr. E. B. I798, q. I. sociatorius, Panz. Schaef. Ic. 1804,. I. Schaefferi, Panz. lib. cit. o. I. disparis, Berth. Ann. Soc. Fr. 1895, p. 287, $\delta$ \&. Trogus flavatorizı, Gr. I. E. ii. 382 ; Ste. Ill. M. vii. $27 \mathrm{I}$; Ratz. Ichn. d Forst. i. 130, ठ 9 .

A handsome, rufescent species. Head testaceous; orbits entirely whitish in $\sigma^{*}$, black in $q$. Antennae setaceous, piceous ; scape of 0 apically flavous beneath; of $q$ white-banded with first six joints ferrugineous and the apical ones piceous, paler below. Thorax stout, gibbous, ferrugineous; paler, with white humeral lines in of; more or less numerously black-marked; areola semi-oval Scutellum flavous, sub-quadrate, slightly convex. Abdomen sub-fusiform, rarely entirely testaceous, usually with the Ist and

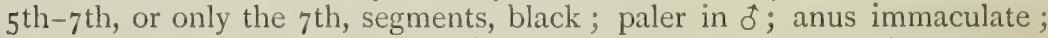
post-petiole coarsely and often aciculately punctate; gastrocaeli somewhat large and deeply impressed. Legs normal, fulvous with hind femora apically black; scopulae flavous. Wings broad and flavescent; stigma orange ; areolet deltoid. Length, I 5-20 $\mathrm{mm}$.

So distinct is this species that it, at first sight, appeared to me to fall into none of the sub-genera of Thomson, who makes no mention of it, accurately, and I am indebted to Dr. O. Schmiedeknecht for pointing out to me its true position, which is, undoubtedly, that here assigned to it. Stephens, following Gravenhorst, included it in Trogus on account of its large size, flavescent wings and convex scutellum.

This grand insect is, undoubtedly, rare in Britain, whence I have seen no examples. Stephens records it from Whittlesea Mere and the neighbourhood of London, in June and July, rarely; and Gravenhorst says it is parasitic upon Smerinthus tiliae and Hyogymna dispar. It has several times been bred on the Continent, where it is widely distributed but apparently uncommon, from Ocneria dispar, as well as from Lifaris salicis and L. monacha. The $q$ is said to hibernate among moss, \&c.

\section{6. laminatorius, Fiab.}

Ichneumon laninatorius, Fab. E. S. Suppl. 220; Piez. 60; Gr. I. E. i. 2IS; Ste. III. vii. I 50, ơ. Amblyteles laminatorius, Wesm. Bul. Ac. Brux. 1854, p. I32; Holmgr. Ichn. Suec, ii. 276; Berth. Ann. Soc. Fr. I895, p. 583, o 9 . Protichnezmon laminatorize, Thoms. O. E. xviii. I90I, of + . I. Protezs, Christ, Hym. 347, pl, xxxv. fig. 2 ; Gr. I. E. i. 217 ; Ste. Ill. M. vii. I50 ; Ratz. Ichn. d. Forst. i. 136, \&. A. Protaeus, Wesm. Nouv. Mém. Ac. Brux. I844, p. 137, 9.

A large, robust species, closely punctate, somewhat dull black, variegated with white. Head black, stouter in $q$, frontal orbits and mark at vertex white; of also has part of the palpi, the mandibles, clypeus, sometimes a 
genal patch and more or less of the face white. Antennae black, setaceous ; compresso-dilated and white-banded in $q$; the scape white

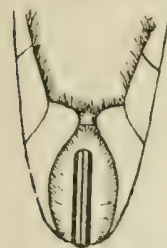

Anus of

P. laminatorius, $q$, from beneath. beneath in $\delta$. Pronotum and scutellum white, of with callosities at radix and sometimes two dots on post-scutellum also white; areola small, semi-elliptic, not internally excavated, forming a glabrous and shining plateau in the centre of the villose metathorax. Abdomen broad, dull black, the apex shining and obtuse; post-petiole rugosely punctate; gastrocaeli large and deep. Legs black; $q$ front tibiae white internally; of with coxae usually, trochanters, basal half of femora, of tibiae and of tarsi white. IVings clouded, more especially at the apex; stigma croceous or ferrugineous; areolet narrowed above. Length, 22-26 $\mathrm{mm}$.

At once distinguished from the remainder of the genus by its black abdomen, the black silky clothing of the mesonotum, broad post-petiole, and by being closely punctate throughout, as well as by the white-marked legs of the male. This species is more usually placed in the genus Amblyteles, but the hypopygium of the $q$ never quite covers the base of the terebra, and the post-scutellar sulcus is very deep; the $\delta$, moreover, bears a fold on the second ventral segment.

The larva is of the normal type; large, fleshy, sordid white, occupying the whole of its host's pupa. It is full fed, and the host entirely demolished soon after the latter has effected its change to the chrysalis state.

This species is well known as the parasite par excellence of Chaerocampa elpenor. Not uncommon, in June, in marshy places about London, where elpenor occurs; also found in Devonshire (Stephens); bred at Bodmin, Cornwall (Nat. Journ. 1899, p. 85) ; captured at Cann'Wood, 7 th July, and bred from above host (Bignell); bred from Deilephila galii, taken at Aldeburgh, Suffolk (E.M.M. I889, p. 455, which appears to be the only record from this host). Reading, Bury St. Edmunds, Maldon in Essex, Glanvilles Wooton; not uncommonly bred at Sproughton, Bramford, Sudbury, etc., in Suffolk, at the end of May. Bridgman does not record it from Norfolk, though it is, doubtless, common in the Broads. It is figured by Christ, by Donovan, at plate 478 , and poorly by Wood, "Insects at Home," 320. On the Continent it has been also bred from Smerinthus populi and Sphinx pinastri.

\section{COELICHNEUMON, Thomson. ${ }^{1}$}

Thoms. O. E. xviii. I893, I90r.

Size somewhat large. Head with cheeks short and generally buccate, as long as the base of the mandibles; the latter stout and a little narrowed towards their apices; face with an inter-antennal tubercle; vertical and exterior orbits usually pale-marked. Antennae setaceous towards their apices. Metathorax convex, with the basal sulcus somewhat deep; basal area distinct ; petiolar long, equilateral ; dentiparal much produced posteriorly ; areola not elongate, usually sub-cuadrate or transverse, narrowed in front.

1 The type of Stephens' Ichneumon eximius (Ill. M. vii. 186) appears to be lost, and Berthoumieu has synonymized it with Amblyteles glaucatorius, Fab.; but, as I have stated (F.M.M. 1902, p. 120), it would appear more nearly related with Coelichnewmon cretatus, Grav., a species not unlikely to occur with us, as it does in Belgium, Sc. So little, however, is at present known that it is liere omited, pending re-discovery. 
Scutellum somewhat flat, rarely entirely pale. Abdomen often blue-black, more rarely castaneous towards the apex; with post-petiole centrally striolate and generally also punctate at the apex; second segment with gastrocaeli and thyridii large and very deep; incisures of central segments usually profound ; terebra slightly exserted, anus sub-truncate, immaculate. Legs stout, the tibiae normal. Wings often clouded.

The species of this genus are somewhat large and stout insects, superficially resembling the larger ones of Melanichneumon, \&c., but at once distinguished by their more robust contour, often metallic reflection and the conformation of the metathorax. Usually they are black with small white markings and never bear the clear red of Ichneumon and Barichneumon, though some have the abdomen more or less castaneous. They appear to prey mainly upon Noctuid moths, but the records of the older collectors must always be to a great extent doubtful regarding these closely allied parasites.

\section{Table of Species.}

(6). I. Abdomen caerulescent, centrally distinctly white-marked.

(3). 2. Abdomen elongate-oval; ventrally not plicate

(2). 3. Abdomen sub-equilateral ; ventrally distinctly plicate.

(5). 4. Post-petiole apically always whitemarked ................................

(4). 5. Post-petiole nearly invariably immaculate ............................

(1). 6. Abdomen not or scarcely cyaneous ; centrally immaculate.

(I0). 7. Tibiae broadly white-marked.

(9). 8. Scutellum apically white; scopulae distinct ..............................

(8). 9. Scutellum black; scopulae wanting..
(7). Io. Tibiae not white-marked (excl. $\delta$ of 8 ).

(36). I I. Central segments basally deplanate.

(15). 12. Scutellum entirely or half white, its basal carinae immaculate.

(I4). I3. Capital vertex broad; stigma fulvous

(13). 14. Capital vertex narrow; stigma fuscous ................................

(12). 15. Scutellum rarely white at apex, its basal carinae very often pale.

(23). 16. Petiole thrice longer than apically broad; scutellar carinae immaculate.

(18). 17. Clypeus truncate; incisures red; scopulae distinct .....................

(17). I8. Clypeus bisinuate ; incisures not red ; scopulae wanting.

(22). 19. Antennae compresso-dilated ; areola sub-quadrate ; legs mainly black.

(21). 20. Areolet broad above; $\delta$ with flagellum black.

(20). 2I. Areolet deltoid; \& flagellum red beneath..............................

(19). 22. Antennae sub-filiform; areola hexa-
gonal ; legs mainly red...............

I. Bohemani, Holmgr.

2. SUGILLATORIUS, Linn.

3. CYANIVENTRIS, Wesm.

4. FUSCIPES, Gmel.

5. PERISCELIS, Wesm.

6. SINISTER, WeSm.

7. LEUCOCERUS, Grav.

8. COMITATOR, Linn.

9. DERASUS, Wesm.

Io. Bilineatus, Grav.

I I. Consimilis, Wesm. 
(I6). 23. Petiole twice longer than apically broad ; scutellar carinae pale.

(35). 24. Antennae of $\&$ white-banded; of clypeus apically sub-sinuate.

(32). 25. Areolet pentagonal ; $\delta$ face not entirely white ; $q$ coxae scopuliferous.

(27). 26. Abdomen blue-black throughout, not red-marked

I2. LINEATOR, $F a b$.

(26). 27. Abdomen in part red.

(29). 28. Areola sub-quadrate; anus alone red

(28). 29. Areolasub-elongate; abdomen mainly red.

(3I). 3o. Gastrocaeli sub-oblique

13. RUFICAUDA, IVesm.

14. MICROSTICTUS, Grav.

I5. LIOCNEMIS, Thoms.

(30). 3r. Gastrocaeli transverse .................

(25). 32. Areolet sub-deltoid ; t face entirely white ; $\&$ coxae not scopuliferous.

(34). 33. Abdomen blue-black, base of second segment striate

(33). 34. Abdomen black; base of second segment finely punctate..............

(24). 35. Antennae of $q$ black; $\delta$ clypeus apically rounded

(II). 36. Central segments not or hardly basally deplanate

\section{I6. ALBICILLUS, Grav.}

I7. MoEstUS, Grav.

I8. IMPRESSOR, Zett.

I9. Castaneiventris, Grav.

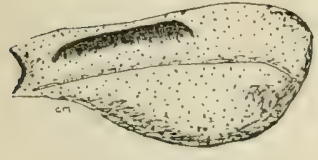

Scopuliferous coxa of C. lineator.

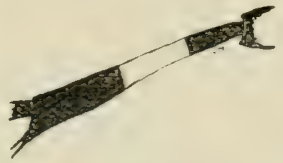

Hind tibia of C. fuscipes.

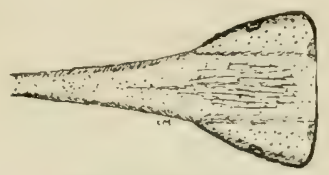

Petiola twice longer than broad.

\section{Bohemani, Holmgr.}

Ichneumon designatorius, Gr. I. E. i. 440 (nec Linn.); Ste. Ill. M. vii, I86; Wesm. Nouv. Mém. Ac. Brux. I844, p. 29 ; Bul. Ac. Brux. 1848, p. 147, excl. $\delta$; Mém. couron. Ac. Belg. I859, p. 54. T. Bohemani, Holmgr. Ichn. Suec. i. I4, $\%$; Thoms. Ann. Soc. Fr. I886, p. I3 ; Berth. lib. cit. I 894, p. 529, of o ; ? Kriech. Ent. Ges. vii. pt. 8, of. Coelichneumon Bohemani, Thoms. O. E. xviii. I902, $\delta$ o .

A bluish species with white-marked abdomen; the of with comparatively long pubescence. Head black; checks slightly buccate and strongly punctate; clypeus inconspicuously bisinuate on either side; frontal and a point at the vertical orbits of $q$, the palpi, clypeus, face, internal and external orbits of $\delta$, pale flavous. Antennae compresso-dilated and attenuate; central band in $q$, and a mark below the scape of $\delta$, white. Lines at tegulae and apex of scutellum in $q$, also the pronotum and whole of scutellum in 5 , white; areola semi-lunar. Abdomen in both sexes elongate-oval, caerulescent especially towards the apex; segments I-4 or 5 bimaculated laterally with pale flavous, the apex immaculate; fourth ventral segment with no fold; post-petiole aciculate, sometimes rugosely so, its apical angles almost quadrate; gastrocacli large and deep. Legs black; $q$ with anterior tibiac apically fusco-testaceous, hind covae not scopuliferous; of with anterior tibiac and tarsi yellowish-white, their coxac 
sometimes white-marked, hind ones coarsely punctate. Wings only slightly clouded, darker in of stigma fulvous; sides of areolet somewhat converging above. Length, $16-24 \mathrm{~mm}$.

Kriechbaumer says this species is probably as variable in colour as C. sugillatorius, from which the of is distinguished by its larger size, coarser but more diffuse puncturation, especially as regards the mesonotum and posterior coxae, which latter are more shining, and by the colour of the pubescence, which is not pure white, but ashy grey.

Very rare. Taken in the New Forest and in Scotland, in July (Stephens). It is said to be parasitic on Noctuae, and is only found in N.W. Europe, extending as far east as Hungary.

\section{2. sugillatorius, Linn.}

Ichneamon designatorius, Linn. F. S. 40 I ; Gr. I. E. i. 440, excl. ․ I. sugillatorius, Linn. I. S. 397 , $\$$; Gr. I. E. i. 437 ; Ste. Ill. M. vii. I85, excl. 8 ; Zett. I. I. 360 ; Ratz. Ichn. d. Forst. i. I 37 ; ii. I35; iii. 140 ; Wesm. Bul. Ac. Brux. 1857, p. 364 ; Mém. couron. Ac. Belg. I859, p. 57 ; Holmgr. Ichn. Suec. i. I5; Thoms. Ann. Soc. Fr. 1886, p. 13; Berth. lib. cit. 1894, p. 527, ơ \&. I. guttiger, Wesm. Nouv. Mém. Ac. Brux. 1844 , p. 29 ; Bul. Ac. Brux. 1848, p. 146, o + . I. moratorizes, Fab. Piez. 54, . Coelichneumon sugillatorius, Thoms. O. E. xviii. 1903.

Very like the preceding, though generally narrower and smaller. Head black; cheeks and temples deeply and coarsely punctate throughout; frontal and vertical orbits, of also with maxillary palpi, angles of clypeus, and sometimes marks on cheeks, white. Antennae dilato-compressed and attenuate; white-banded in $q$. Scutellum white; areola sub-hexagonal, deeply emarginate apically in $\delta$, which sex has also the pronotum bimaculate, generally callosities at tegulae and sometimes the post-scutellum, white. Abdomen almost linear, broader in $q$, bluish towards the apex, with distinct ventral fold; segments one always to three, sometimes to four or five, with white sub-rotund marks ; post-petiole gradually explanate apically, aciculate-punctate, its apical angles generally quadrate, sometimes obtuse ; gastrocaeli large and deep. Legs black ; anterior tibiae internally flavous, hind coxae rarely white-marked and in $q$ always distinctly scopuliferous. WVings somewhat clouded; stigma piceous ; sides of areolet nearly contiguous above in 0. Length, I $2-16 \mathrm{~mm}$.

The shape of the abdominal pale marks is different from that of those of $C$. cyaniventris.

The of antennae are rarely white-banded (var. muptus, Berth.), or with an apical white mark beneath the scape; the metathorax is also said to be occasionally white-marked.

Stephens, who confused the following species with it, says the present is very rare in the south of England, but, he believes, more frequent towards the north. It appears to be rare in France, and has been bred in Germany from Liparis monacha. Bignell has taken it at Ivybridge, near Plymouth, in the middle of May; Marquand in the Land's End District, and Dale records it from Middemarsh, in Dorset. The female is known to hibernate beneath moss.

\section{3. cyaniventris, Wesm.}

Ichneumon sugillatorius, Gr. I. E. i. 437, excl. $\$$ (nec Linn.) ; Ste. III. M. vii. I85 ; Wesm. Nouv. Mém. Ac. Brux. 1844, p. 28, o \&, excll. varr. I. cyaniventris, Wesm. 
Mém. couron. Ac. Belg. I859, p. 58 ; Holmgr. Ichn. Suec. i. 17 ; Berth. Ann. Soc. Fr. I894, p. 527, of $\&$. Coelichnenmon cyaniventris, Thoms. O. E. xviii. 1903, of.

Very like the two species already described, and often confounded with them. Head black; cheeks and temples somewhat deeply punctate, but the former are smooth apically; frontal orbits only of $q$, $f$ with palpi, angles of clypeus, facial and marks at vertical orbits, white. Antennae compresso-dilated, attenuate and white-banded in both sexes. Thorax of $q$ entirely black, scutellum white; of of with pronotum, and rarely callosities at radix, white; areola broadly semilunar. Scutellum punctate, with erect pale pubescence, that of torely black. Abdomen sub-parallel-sided; with distinct ventral fold ; cyanescent or purpurascent ; first segment nearly always immaculate; second to third or fourth always with lateral transverse white marks; post-petiole finely aciculate, apical angles rounded; gastrocaeli large and deep, with the intervening space closely striate. Legs black; anterior tibiae in part pale flavous; hind coxae finely punctate, of o with scopulae smaller than in the last described species. Wings somewhat clouded; tegulae often white; stigma piceous; areolet sub-deltoid. Length, I2-16 $\mathrm{mm}$.

If the first segment be immaculate, the insect may with confidence be referred to the present species, which is usually smaller than sugillatorius, with which it was for long intermingled. The abdomen, especially towards the apex, is more brightly cyaneous, its first segment nearly always immaculate, which, with the smooth apex of the cheeks and smaller coxal tufts of the $q$, render it sufficiently distinct.

Bignell once bred it in South Devon, on June $\mathrm{I}$ th, from pupae of Odontopera bidentata; and I have seen a of taken by Mr. R. C. Bradley, at Llanbedr, in Carnarvon, on August 22nd, 1895; and others by Col. Verbury and him at Barmouth, in August and June. It is not uncommon on the Continent, but does not appear to have been there bred.

\section{4. fuscipes, Gmel.}

Ichneumon fuscipes, Gmel. S. N. i. 2684, ơ ; Gr. I. E. i. 224, ơ q, excl. var. 2 ; Ste. Ill. M. vii. I5I ; Wesm. Nouv. Mém. Ac. Brux. 1844, p. 23, excl. ó; Bul. Ac. Brux. 1848, p. 142, ơ \& ; Mém. couron. Ac. Belg 1859, p. 59, excl. var. 2 bis, f ; Holmgr. Ichn. Suec. i. 40 ; Berth. Ann. Soc. Fr. I894, p. 537, of $q$. Coelichneumon fuscipes, Thoms. O. E. xviii. I905 of q. Var. I. subguttatus, Gr. I. E. i. 449 ; Ste. Ill. M. vii. I 87, i o 0 .

The present and following species are distinguished from their congeners at once by the broad, clear white band on the hind tibiae in both sexes. Head black; cheeks and temples somewhat inflated and sparingly punctate ; orbits more or less white ; $\delta$ with palpi, a mark in centre of each mandible, clypeus laterally and often the whole face, white. Antennae setaceous, conspicuously dilated, first joint of flagellum twice longer than broad, the seventh quadrate; white-banded in $q$ only, scape white beneath in of. Markings at radix, and the apex of the somewhat flat scutellum, white; upper metathoracic areae complete, areola sub-quadrate, not longer than broad, posteriorly emarginate. Abdomen bluish, especially in $q$, towards the apex; post-petiole aciculate in $q$, aciculate-punctate with strong carinae in of; second segment rather longer than broad ; gastrocacli large and deep, the intervening space rugose. Legs black; anterior femora 
apically flavous, their tibiae in part white; hind tibiae with a broad conspicuous white band before the base ; tarsi not pale-narked ; anterior coxae entirely black; + scopulae short and distinct. Wings a little clouded; stigma piceous; sides of areolet almost contiguous above. Length, I 4 -I $8 \mathrm{~mm}$.

The variety $I$. subguttatus has a minute white dot on either side of the first, and sometimes also of the second segment, which affiliates it with the preceding species of this genus, from which, however, the distinct tibial band at once distinguishes it ; the post-petiole is said to be also narrower than in the type form.

This species may be distinguished by the lateral glabrosity of the antennal scrobes; by the distinct tufts on the $q$ hind coxae; and the white apex of the scutellum, which last appears to be, as is not often the case, a pretty constant marking, although I possess a $q$ in which it is absent.

From Eupalamus oscillator, Wesm., to which it bears some resemblance, it may be at once distinguished by the aciculate post-petiole of the $q$, and by the quadrate areola of the $\delta$.

Taken near London and in Salop, in June (Stephens); not very common in Devon (Parfitt); captured at Slade, Cornwood, 2oth August (Bignell); Swansea, in August (Beaumont); Maldon, in Essex (Harwood); Miss Chawner has taken both sexes in the New Forest, where I also met with it, at Lyndhurst, in Mr. F. C. Adams' garden. A series was bred in Britain, from larvae of Acronycta myricae (cf. Ent. Rec. v. p. I9; and E.M.M. I896, p. 93). It has also been bred on the Continent, where it is common, from an unidentified Noctua. The variety subguttatus has been bred from an unknown host and captured at Alphington, in Devon (Parfitt).

\section{5. periscelis, Wesm.}

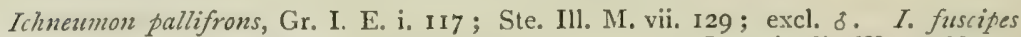
var. 2 bis, IVesm. Mém. couron. Ac. Belg. I859, p. 59, $\$$. I. periscelis, Wesm. Nouv. Mém. Ac. Brux. I844, p. 32, ơ; Holmgr. Ichn. Suec. i. 42 ; Berth. Ann. Soc. Fr. IS94, p. $550, \delta$ o. I. dubius, Tisch. Stett. Zeit. I876, + . I. falcatus, Tisch. lib. cit. I873, o. Coelichneumon periscelis, Thoms. O. E. xviii. I905, $\delta$ \%.

Much resembles the last-described species, but is at once known by the characters given. Dull, finely punctate. Head black, somewhat buccate; cheeks and temples finely and isolatedly punctate; mandibles and angles of clypeus rufescent ; frontal and a point at the vertical orbits of $q$, palpi, mandibles, clypeus, and face of $\delta$ also, white. Antennae a little dilated, attenuate; $q$ white-banded ; of scape pale flavous, and flagellum reddish, beneath. Scutellum entirely black in both sexes. Thorax entirely black in $q$, lines at radix white in $\delta$; metathorax alutaceously punctate; upper areae complete; areola emarginate posteriorly. Abdomen bluish-black, second segment sometimes apically rufescent in $q$; gastrocaeli large; post-petiole aciculate, sometimes bi-maculated with white in 8 . Legs black; anterior tibiae internally whitish, hind ones with a broad, conspicuous white band; anterior coxae white-marked in of; hind ones with no trace of scopulae. Wings sub-hyaline; stigma piceous; sides of areolet narrowed, though not contiguous, above. Length, $12-18 \mathrm{~mm}$.

The $q$ is very similar in general facies to that of $C$. leucocerus, from which, however, it may with ease be distinguished by the simple posterior coxae, 
the much finer punctation of the whole insect, the entirely black scutcllum, and the white tibial band.

From $C$. fuscipes it is easily recognised by its duller reflection, finer punctuation, by the upper antennal scrobes which rise much higher towards the vertex, the longer joints of the flagellum, the entirely black scutellum, and obviously narrower tarsi and the pale anterior coxae.

Stephens says his $I$. pallifrons, the $q$ of which only is referable to the present species, was not very common about London and in Shropshire; Bignell has taken it at Bickleigh, in Devon, towards the end of August; Essex. On the Continent, where it appears rarer than the preceding, and occurs in August, it has been bred from an unknown Noctua; and by Billups, in London, from Spilosoma fuliginosa, L.

\section{6. sinister, Wesm.}

Ichnezmon leucocems, Gir. I. E. i. 208 (?), excl. क; Holmgr. Sv. Ak. Handl. I $\$ 54$,

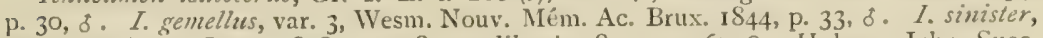
Wesm. Bul. Ac. Brux. I 848 , p. 148 , ó ; lib. cit. 1855 , p. 367, o; Holmgr. Ichn. Suec. i. 20 ; Berth. Ann. Soc. Fr. 1894, p. 540, of 9. Coelichnewmon sinister, Thoms. O. E. xviii. 1904 , o ? .

This and the following species may be at once known from the former groups by their black bodies and hind tibiae. Rather shining, coarsely punctate, black. Head buccate, cheeks and temples strongly inflated; clypeus truncate, with broad lateral foveae; internal, and a small dot at vertical orbits white, of also with margin of clypeus white. Antennae apically setaceous; white-banded in both sexes, scape white beneath in 0 . Thorax somewhat short; pronotum and a line before and beneath radix of $o$, beneath only in $q$, and the whole scutellum in both sexes white; metathorax somewhat rugosely punctate, more finely at the base; areola semi-oval, broadly emarginate apically. Abdomen black, shining and very faintly bluish towards the apex; its sides sub-parallel; segments three to five distinctly depressed basally ; two and three narrowly red-margined in of; post-petiole aciculate-punctate; gastrocaeli deep, the intervening space somewhat narrow and, of $\delta$, rugose. Legs, including all the coxae, black; anterior legs, especially of $\delta$, more or less flavidous laterally ; $q$ scopulae small but distinct. IVings flavescent; stigma fulvous, tegulae black; areolet broad above. Length, I5-I $8 \mathrm{~mm}$.

This species may be readily distinguished by its entirely white scutellum, buccate cheeks, and by the broad vertex of the head; in the $q$ by the antennae, which are not spiral, and by the posterior coxae being furnished at their apices with tubercles bearing tufts; the of by its antennae, which are semi-annulated with white and have elevated carinae on joints eight to twenty ; moreover, the stigma in both sexes is pale.

Mr. F. H. Day has, I believe, taken the $q$ at Carlisle; it is also recorded from Essex. On the Continent it is uncommon, being recorded only from France and Sweden, where it occurs in August.

\section{7. leucocerus, Grav.}

Ichnenmon semi-orbitalis, Gr. I. E. i. 212 , o (part). I. lencocems, Gr. Mem. Ac. Sc. Turin, 1820 , p. 289 ; I. E. i. 208 , excl. 8 ; Ste. Ill. M. vii. 148, ; Wesm. Nouv. MIém. Ac. Brux. 1844 , p. 30, excl. var.; Holmgr. Ichn. Suec. i. 22 ; Berth. Ann. Soc. 
Fr. I 894, p. 539, o \&. Coelichneumon leucocerns, Thoms. O. E. xviii. 1904, o \&. (?) I. binotatus, Ste. Ill. M. vii. 147, d; of. Morl. E.M.M. I902, p. I20.

Shining, punctate, black, Head not buccate, narrowed behind the eyes; cheeks and temples moderately inflated; frontal and a part of the vertical orbits white, of also with palpi, mandibles, external orbits in part, sides of clypeus and of face, white. Antennae slightly compresso-dilated towards the apex and attenuate; a mark beneath the scape in both sexes, and the central band in $q$, white. 'Thorax stout, notauli distinct, lines at the radix, the of pronotum, and the whole $q$ and a large part of $\delta$ scutellum, white; metathorax rugosely punctate, the upper areae complete; areola sub-hexagonal, posteriorly emarginate. Abdomen lanceolate, black, somewhat coerulescent towards apex in of; segments three to five distinctly depressed basally; post-petiole aciculate-rugose; gastrocaeli rather deep, the intervening space rugosely striate. Legs, including all the coxae except rarely the front ones in 5 , black; anterior femora and tibiae internally pale; scopulae large. Wings slightly clouded; stigma fuscous; areolet somewhat narrowed above. Length, I 5--18 mm.

It differs from $C$. sinister, which Gravenhorst confused with it, in the narrow vertex of the head, the metathorax shining basally, and the darker stigma. The $q$ has a white line before as well as beneath the radix, and the tufts on the posterior coxae are large; the black flagellum and less prominently elevated carinae on joints seven to eighteen of the antennae will distinguish the $\delta$.

Not common; found near London and in the north of England in July (Stephens). Taken at Bickleigh, South Devon, September and (Bignell) ; and recorded from Essex. Bred on the Continent, where it is widely distributed and much commoner than the two preceding, from Acrony'cta megacephala, and the female may be found beneath moss during the winter.

\section{8. comitator, Linn. ${ }^{1}$}

Ichneumnon comitator, Linn. F. S. 402, ; Gr. I. E. i. I08, excl. var. stigmate rufo ; Ste. Ill. M. vii. I27; Zett. I. L. 359, excl. ơ ; Ratz. Ichn. d. Forst. i. 304 ; ii. I33; iii. I64; Wesm. Nouv. Mém. Ac. Brux, I844, p. 30 ; Holmgr. Ichn. Suec. i. 30, o \&; Ent. Tidskr. 1880, p. 24, ơ; Fonsc. Ann. Soc. Fr. I847, p. 52 ; Berth. lib. cit. I894,

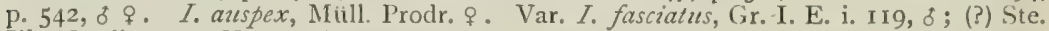
Ill. M. vii. 129. Var, I. bianmulatus, Gr. I. E. i. 230, ठ; Ste. Ill. M. vii. 152. Var. 1. nothus, Holmgr. Ent. Tidskr. I880, p. 26 ; Berth. Ann. Soc. Fr. 1894, p. 549, ơ. Var. I. specularis, Tisch. Stett. Zeit. I873, \&; cf. Kreich. Ent. Nachr. I894. Coelichneumon comitator, Thoms. O. E. xviii. 1906, of o.

Shining, punctate, black. Head black, clypeus glabrous and truncate; cheeks and temples strongly inflated; mouth parts reddish; frontal and a point at vertical orbits usually pale flavous, ơ also with palpi, mandibular mark, sides of clypeus and of face, white. Antennae conspicuosly dilatocompressed and attenuate, the fifth joint quadrate; white-banded in $q$,

I The Rev. William Kirby, M.A., F.R.S., \&c., described (Monographia Apum Angliae, ii. 253) an Ichneumon under the name femorator, which was taken out of the foramina of $A$ pis maxillosa (Chelostoma florisome), and which may easily be confounded with $I$. comitator. He says it is entirely black with piceous hind femora and white central flagellar band, differing from $I$, comitator in the antennae being hardly longer than the thorax, the femora piceous, shorter and more incrassate, the wing-nervures nigrescent or ferrugineous and in its thrice smaller size. His types, however, are not in his collection in the British Museum, and it is now quite impossible to guess from what insect his description was drawn, perhaps even from one of the Tryphoninae, as the pabulum would suggest; it is certainly referable to neither of Stephens' species of that name. 
entirely black in $\delta$. Thorax entirely black in $q$, callosities at radix white in 0 ; notauli distinct; metanotum strongly punctate; areola smoother, short, arcuately emarginate at apex. Scutellum entirely black. Abdonch black, often with a decidedly bluish reflection; segments two to five with the incisures usually red; post-petiole somewhat broad, centrally aciculate ; gastrocaeli deep, somewhat triangular, the intervening space coarsely aciculate; terebra slightly exserted. Legs black; $q$ anterior more or less rufescent, with tibiae internally flavidous; hind coxae closely punctate, their scopulae piceous and distinct; of tibiae and tarsi white with only the apices of the posterior infuscate or black. Wings clouded; stigma and tegulae piceous ; areolet wide above, narrower in to. Length, $12-17 \mathrm{~mm}$.

This species may be distinguished from its allies by the clouded wings, the distinct tufts of the female's closely punctate coxae, quadrate second joint of the flagellum, and usually blackish stigma; the f, moreover, has second joint of the flagellum incrassate, and joints four to seventeen with raised carinae, its mesopleurae are shining and sparsely punctate, and its tibiae and tarsi basally white.

The variety bianmulatus (I. funelris, $q$ et var. I, Holmgr. Ichn. Suec, i. 39 = comitator, var. I, Wesm. Tent.) is considered distinct by Thomson, and it certainly differs widely from the type in the following particulars: antennae of $q$ a little dilated towards the apex, the coxal tuft absent, the stigma generally ferrugineous; the of has the mesopleurae more closely punctate, the flagellum less thickened, the joints being longer, with raised carinae on five to sixteen. This variety, Stephens says, is found very rarely around London, in June.

I. fasciatus appears to differ only in possessing a white dot at the radix of the wings, which is generally absent in the type form. Stephens says it is very rare in Britain, but has been taken, in July, in the New Forest (cf. Ctenichneumon caeruleator, post).

I. nothus is a variety of the of with the first two joints of the flagellum white-marked.

The type form is said by Stephens to be not uncommon about London, in gardens, woods, \&c., in June and July, and to have been met with in Scotland. It is also not uncommon on the Continent. It preys upon Bombycidae, Trachea piniperda, Abraxas srossulariata, Cleora ziduaria, Fidonia piniaria and Plusiu gamma. It has been taken upon umbelliferous flowers near woods, frequently in S. Devon, and in the district of Land's End; Davies has found it at St. Issey, in Cornwall.

\section{9. derasus, Wesm.}

Ichneumon comitator, var, stigmate rufo, Gr. I. E. Io8,. I. derasus, WVesm. Nouv. Mém. Ac. Brux. I844, p. 31 ; Holmgr. Ichn. Suec. i. 33 ; Berth. Ann. Soc. Fr. I894, p. 555, of ․ I. carbonator, Tisch. Stett. Zeit. 1874, o. Coelichneumon derasus, Thoms. O. E. xviii. 1906, \& \&. Var 1. percussor, Tisch. lib. cit. 1876, $\$$.

Rather shining, duller in ô; punctate, black; body stout. Head black ; clypeus hardly bisinuate; facial, frontal, and a point at the vertical, orbits sometimes white, of also with maxillary palpi and angles of clypeus white. Antennae compresso-dilated, and attenuate; white-banded in $q$, entirely black in $0^{\star}$. Thorax entirely black, or with white dot at radix, in $q$; lines 
at radix white in of; metanotum strongly punctate; areola smoother, subquadrate or semi-elliptic, apically slightly emarginate. Scutellum entirely black. Abdomen narrow, black with a slight bluish reflection; post-petiole finely aciculate; second segment longer than broad; gastrocaeli normal, somewhat deep, intervening space sub-aciculate. Legs b'ack; anterior tibiae internally paler; hind coxat closely punctate, with the scopulae practically absent; ot legs marked with red. Wings slightly clouded; tegulae piceous; stigma ferrugineous; areolet wide above. Length, I 2-I $6 \mathrm{~mm}$.

Similar to $C$. bilineatus but easily distinguished-besides the points given - by the areolet, which is very much broader above. From $C$. comitator it may be known by the longer terebra and second joint of the flagellum, the hardly indicated $q$ coxal tufts, and the ferrugineous stigma; the of differs in having joints $5^{--1} 7$ of the flagellum with raised carinae and in the legs being red and black. The $q$ variety, $I$. percussor, has the hind femora and tibiae for the most part red.

In Norfolk it has once occurred, at Eaton, in July. Col. Yerbury has taken it at Loo Bridge, Co. Kerry; Luff, in Alderney; Piffard, at Felden, in Herts; Bignell, in the New Forest; Essex; and Bairstow records it from the neighbourhood of Leeds, bred from Taeniocampa gothica.

\section{Io. bilineatus, Gmel.}

Ichneumon bilineatus, Gmel. S. N. i.-2698, o; Gr. I. E. i. I27 (part); Ste. Ill. M.vii. 132 ; Wesm. Nouv. Mém. Ac. Brux. 1844, p. 26 ; Bul. Ac. Brux. 1848, pp. 145, 336 ; Mém. couron. Ac. Belg. 1859, p. 12 ; Holmgr. Ichn. Suec. i. 35 ; Berth. Ann. Soc. Fr. 1894, p. 554, of ․ I. comitator, Sulz. Gesch. 1776, + . Coelichneumon bilineatus, Thoms. O. E. xviii. 1908. $\delta$ \&.

A rather large black species, with bluish reflection. Head evenly and strongly punctate in front, finely behind; cheeks and temples inflated; clypeus sub-sinuate apically ; frontal, and a dot at vertical, orbits white, $\hat{\sigma}$ also with palpi, mandibles above or throughout, a line at the external orbits, sides of clypeus and of face, white. Antennae setaceous, of $q$ strongly dilato-compressed and white-banded, of of with scape usually white, and flagellum rufescent, beneath. Thorax stout, entirely black in $q$, pronotum and lines at radix white in $\delta$; mesonotum finely and distinctly punctate, with no notauli ; metathorax finely scabrous, the upper areae complete and smoother; areola transverse, nearly glabrous and apically emarginate. Scutellum usually entirely black, rarely laterally, not basally, white-marked; flat, with individual punctures distinct. Abdomen immaculate, slightly bluish-black, apically shining; post-petiole aciculate-punctate; second segment sub-quadrate; gastrocaeli large and deep, the intervening space sub-striolate. Legs black; anterior femora and tibiae sometimes rufescent; hind coxae sparingly punctate, with no scopulae. Wings slightly clouded; stigma and tegulae nigro-piceous; areolet sub-deltoid, the sides nearly coalesced above. Length, I 2-- $7 \mathrm{~mm}$.

The clypeus on either side is sub-sinuate; with a distinct vertical dot; scutellum, except apically, coarsely and strongly punctate. The $q$ has a small elevated ridge on the inner margin of the posterior coxae beneath ; the cheeks are buccate; the of flagellum has joints two to fifteen with raised carinae: which points are distinctive.

It is similar to $C$. lineator, but the head is more tumidous, and not 
narrowed behind the eyes; the areolet is strongly narrowed above, the sides there nearly coalescing; the coxae of the $q$ bear no scopulae; the scutellum is entirely black.

Found near London and in Shropshire, in June (Stephens). It has been bred, on $14^{\text {th }}$ June, from Byroplila glandifera, in S. Devon; and from Notodonta dodonea. It is a common parasite upon Abraxas grossularia' $a$, and has been found in Norfolk; Essex; South Leverton, in Notts., in June; Hastings; Lastingham, in Yorks., and Bickleigh, in Devon.

\section{II. consimilis, Wesm.}

Ichncumon consinilis, Wesm. Nouv. Mém Ac. Brux. 1844, p. 22, ㅇ ; Bul. Ac. Brux, 1857, p. 359, ơ $q$; Mém. Couron. Ac. Belg. 1859, p. 13; Berth. Ann. Soc. Fr. IS94, p. 55I, o $\$$; $c f$. Thoms. O. E. xii. I22I, et xviii. I9II. I. explorator, Tisch. Stett. Zeit. I881. Var. I caelareator, Tisch. lib. cit. $\delta$.

Head black; face covered with long white pilosity in $\delta$; mandibles red in 9 ; frontal, a dot at the vertical, and sometimes the external orbits, white ; o also has angles of clypeus and lines at the facial orbits white, or the head entirely black; clypeus slightly but distinctly bisinuate apically; cheeks not buccate. Antennae sub-filiform, a little attenuated; white-banded in $q$, entirely black in $\delta$. Thorax nitidulous, entirely black or with a pale dot before the radix in both sexes; areola transversely sub-hexagonal, apically concave; costulae entire. Scutellum black, shining, with distinct sparse punctures; rarely with two white apical dots. Abdomen convex, shining, black, sometimes slightly cyanescent; post-petiole aciculate, laterally punctate ; gastrocaeli large, deep and rufescent with the intervening space, and base of the second segment, irregularly striate. Legs stout, for the most part red; the coxae and apices of hind tibiae and their tarsi black ; hind coxae closely punctate, not scopuliferous; Wings hyaline, stigma and tegulae piceous; areolet somewhat broad above. Length, I0-- $2 \mathrm{~mm}$.

The male may at once be known from the preceding by its white facial pilosity, and the much less blue reflection of the abdomen; the red femora are also distinctive.

In a specimen of the pupa of this species, which I recently examined, the antennae were not laid at full length along the abdomen, as is usually the case, but were carried outwards to the tegulae and thence abruptly curved inward in such a manner that their apices approximated above the mesosternum; the mesonotum was deeply sulcate longitudinally in the centre; and the head was ferrugineous.

Bridgman took both sexes in Norfolk, the male at Cromer, in June. Piffard has several times taken it at Felden, in Herts. ; Luff has kindly given me both sexes from Guernsey; and I have seen a specimen in Bignell's collection. Mr. Stanley Kemp has bred several of both sexes together from chrysalids of Bryophila muralis, Forst. (= glandifera, Hb.) at Hythe, in Kent, during September, rgor ; one of these is a remarkably small female of only $6.1 \mathrm{~mm}$. in length; the parasite in emerging entirely removes the capital extremity of the pupa in a somewhat jagged manner, having constructed no cocoon whatever of its own and leaving that of its host transparent, with only some whitish debris in the anal extremity; the larvae-skins and silicious cocoons were intact. This is a widely distributed species throughout western Europe, and occurs, probably, not uncommonly with us. 


\section{2. lineator, Fab.1}

Ichneumon lineator, Fab. E. S. ii. 168, o; Gr. I. E. i. 120, excl. var. 3, (part) ; Ste. Ill. M. vii. 130 ; Zett. I. L. 358 ; Wesm. Nouv. Mém. Ac. Brux. 1844, p. 21 ; Holmgr. Ichn. Suec. i. 23; Berth. Ann. Soc. Fr. I894, p. 543, o \&. I. nigerrimuls, Ste. III. M. vii. I30, o; of. Morl. E.M.M. 1902, p. I19. Coelichneumon lineator, Thoms. O. E. xviii. 1908, ơ o. Var. I. ferreus, Gr. I. E. i. I7 I, ơ ; Wesm. Nouv. Mém. Ac. Brux. I844, p. 22 ; Bul. Ac. Brux. 1848, p. 334 ; Berth. Ann. Soc. Fr. 1894, p. 544, 8 \&. I. biguttatus, Thunb. Nov. Act. Ups. 1784, \&. Var. I. restaurator, Gr. 1. E. i. 197, ơ W Wesm. Nouv. Mém. Ac. Brux. 1844, p. 22, \& o. Var. I. caenulescens, Tisch. Stett. Zeit. 1879, \&.

$\Lambda$ stout, shining, blue-black species. Head black; clypeus sub-sinuate; cheeks moderately inflated; temples rather narrow; frontal, external, and a dot at the vertical orbits usually white-marked, of also with facial orbits and sides of clypeus generally white. Antennae somewhat dilato-compresed and attenuate, seventh joint sub-quadrate ; $q$ with a six-jointed white band; of scape nearly always white beneath. Thorax black, stout ; lines on pronotum and before radix sometimes white in of only; metathorax rugulose, with upper areae complete; areola sub-hexagonal, occasionally sub-quadrate, shorter in $\delta$, somewhat rounded in front and concave apically. Scutellum flattish, black, strongly punctate, and sometimes apically foveate; basal carinae and very rarely an apical dot white, rarely entirely black. Abdomen blue-black throughout, never red-marked; post-petiole strongly aciculate, the lateral area and sometimes the apex punctate; gastrocaeli large, deep, triangular and strongly striate, with the intervening space strongly and subrugosely aciculate; segments two and three dorsally sub-aciculate, remainder becoming more nitidulous towards the apex. Legs black; front tibiae internally pale; hind femora often reddish; $q$ with hind coxae not very closely punctate, scopulae rufescent. IVings a little clouded; stigma and tegulae piceous; areolet wide above ; radix often posteriorly white beneath. Length, I0--1 $8 \mathrm{~mm}$.

Superficially this insect resembles Melanichneumon trilineatus, Gmel., from which the posteriorly broader head, and the centrally strongly striolate second segment will serve to distinguish it. From $C$. comitator the female may be known by its somewhat sparsely punctate coxae and less dilated flagellum, the joints of which become quadrate at the seventh.

This is a most variable species, and has several times been described under distinct names :- I. restaurator has the abdomen black without blue reflection; the $\delta$ has pale lateral dots at apex of the first abdominal segment (var. $q$ caerulescens), and the scutellum of the $q$ has an apical pale spot. This is a common form. 1. ferreus, also has the abdomen black and the extreme apical margins of segments two to seven, as well as the femora and tibiae, red. The $q$ has the upper margin of the pronotum marked with white, and the areola rougher. Berthoumieu ranks this variety as a good species on the strength of the paucity of the abdominal blue refiection and the more rugose areola. This form has been bred by Mocsary from Hydraecia leucographa.

Of this last variety IVesmael has noticed two very distinct male forms ;

1 Considerable confusion has existed concerning the specific rank of the three following species. Marshall followed Holmgren in considering $I$. microstictus a mere colour variety of $I$. lineator, since which time Thomson has indicated, in the "Annales," good structural distinctions. I. Muficauda, Wesmael originally thought was hardly more than a form of $I$. vufuns, Grav, (nec Holmgr.) or $I$. microstictus ; from the latter, however, he found it quite distinct upon comparing it with the Gravenhorstian types, in 1859 . 
the first having four white spots at the apex of the basal abdominal segment, and the second, in addition to these, two parallel white lines on the disc of the mesonotum (var. mumeratus, Berth.). Of the type form he noted six varieties, which go to show that the scutellar markings and the colour of the legs are extremely variable; in fact, Bridgman and Fitch, in their tab!es, including with it $C$. microstictus, Grav., had to present it in no less than seven different positions.

No doubt remains that $I$. nigerrimus, Ste., is a dark form of the of this species, having the head and thorax immaculate, and the anterior tibiae unusually pale internally. I have examined the type in the British Museum; it has the metanotum somewhat rugulose, and the areola quadrate, slightly longer than broad, its costae feeble. Berthoumieu, misled by Stephens' remark, "cellule nearly triangular," incorrectly considered it synonymous with $C$. bilineatus, from which its lack of markings at once distinguishes it.

It has been bred, in Britain, from Nonagria geminipuncla, Gortyna farvago, a Bombyx and a Noctua; and, on the Continent, from Ipsipetes elutata, Eurranthis plumistraria, Bjrophila glandifera and Tortrix crataggana. It

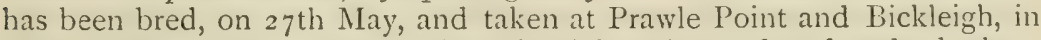
South Devon; two males have been bred from larvae found under bark, at Brundall, in Norfolk; and it is also recorded from Askham Bog, in Yorks., early in June; Land's End; Shropshire; Essex, and the Hastings district. Francis Walker includes it in his Isle of MIan list (Entom. I 873, p. 432), on Marshall's authority. I have seen a fine typical male, captured by Sladen, at St. Margaret's Bay, in the middle of June, and a female, in July, at Dover; Beaumont has taken it at Byfleet, early in August; Miss Chawner has sent it to me from the New Forest; Piffard, from Feldon, in Herts. ; Wainwright, from Land's End; Hamm, from Boars Hill and Bagley at Oxford, in August; and I have once or twice found it in the Bentley Woods, in the middle of June.

\section{3. ruficauda, Wesm.}

Ichneumon rufinus, var. 3, Gr. I. E. i. 481, $\$$; var. 2, Holmgr. Ichn. Suec. i. 29, b 9. I. ruficauda, Wesm. Nouv. Mém. Ac. Brux. I844, p. 23 ; cf. Bul. Ac. Brux. I 849 , p. 36 ; Holmgr. Ichn. Suec. i. 31, of o. I. muficaudus, Berth. Ann. Soc. Fr. I894, p. 546, of o. Coelichneumon ruficanda, Thoms. O. E. xviii. 1909.

Similar to preceding, excepting in colour and genal inflation. Head black; cheeks normal; palpi, angles of clypeus and orbits of the eyes, yellowish-white, of also with mandibles pale. Antennae strongly dilated and attenuate; $q$ with a six-jointed white band; of scape pale flavous beneath. Thorax black; lines on pronotum occasionally and at radix stramineous; mesonotum not white-marked; areola sub-quadrate, apically emarginate. Scutellum entirely black, or with basal carinae and its lateral margins basally stramineous. Abdomen black; segments five to seven entirely brick-red; post-petiole aciculate; second segment sub-quadrate; gastrocaeli large and deep; segments four and five basally aciculate. I eurs black; femora and tibiae usually dark-red; puncturation of the black hind coxae sparse, their scopulae flat. Wings with stigma nigrescent : terulue red brown, with paler margin in $\delta^{*}$; areolet slightly narrowed aloure, not deltoid. Length, I $4 \mathrm{~mm}$. 
Flagellum of antennae strongly incrassate before apex; areola and segment two of abdomen sub-(quadrate; sides of scutellum apically not white; abdomen reddish at the apex only, are the principal distinctions to be noted.

The female differs from $C$. microstictus in the narrower cheeks, and the male in its colour.

Widely distributed on the Continent, and parasitic upon Cosmia abluta and $C$. trapezina. In Britain, it is mixed with $C$. lineator, but appears to have certainly been taken at Prawle Point, in Devon, by Mr. Parfitt, in August.

\section{I4. microstictus, Grav.}

Ichneumon microstictus, Gr. I. E. i. 480, + ; Wesm. Bul. Ac. Brux. I848, p. 334 ; Mém. couron Ac. Belg. 1859, p. 60; Thoms. Ann. Soc. Fr. 1886, p. 15; Berth. lib. cit. I894, p. 546, of q. I. lineator, var. 5, Holmgr. Ichn. Suec, i. 24, of $q$ (et Marsh. Cat.). Coelichnenmon microstictus, Thoms. O. E. xviii. I909, of o. Var. I. serenus, Gr. I. E. i. 484 ; Ste. Ill. M. vii. 190: Wesm. Nouv. Mém. Ac. Brux, I844, p. 23 ; ff. Bul. Ac. Brux. 1848 , p. 334 ; lib. cit. 1857 , p. 360 , of $q$. I. lachirymator, Fonsc. Ann. Soc. Fr. 1847 , p. 403 , $\delta$.

Similar to, though more stout and redder than, the preceding species, Head black; clypeus bisinuate; cheeks very strongly inflated; mandibles and margin of clypeus red; internal, and usually external, orbits and vertical dots, white, ot also with sides of clypeus white. Antennae somewhat stout, compresso-dilated and strongly attenuate; sixth joint quadrate; $q$ with an

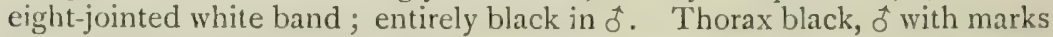
on pronotum and at radix white; areola elongate-quadrate, apically angulated; mesosternum shining, very sparingly punctate. Scutellum very flat, puncturation isolated; sometimes entirely black, but usually with the basal carinae and the lateral margins white. Abdomen basally black; segments two to four, and rarely post-petiole, more or less red and dorsally deplanate, apical ones entirely darkish red; post-petiole regularly aciculate; gastrocaeli very broad and deep ; intervening space rugosely and closely striolate ; segments two to five basally aciculate in $\delta$. Legs short and stout, black; femora and tibiae often red, hind femora rarely black in ${ }^{*}$; hind coxae very sparingly punctate, the scopulae rather small and not very dense. IVings with stigma red-brown; tegulae piceous; areolet wide above. Length, I $2-17 \mathrm{~mm}$.

'This species differs from $C$. lineator in being always larger, with the abdomen for the most part castaneous, the head behind the eyes narrower, the forehead above the antennae deeply excavated, and the areola longer; the of has the pale antennal band eight jointed, and its posterior coxal tufts are shorter, occupying only the inner part of the apex; the sides of the post-petiole too, are more closely punctate.

The variety of this species, $Y$. serenus, Grav., differs from the type in having two apical pale spots upon the scutellum, and in its constantly larger size ; I. lachrymator, Fonsc., is its male.

It is widely distributed, but rarer than $C$. lineator on the Continent. Stephens took the var. serenus in the vicinity of London, in June; and I have seen an example taken by Bignell, at Bickleigh, in Devon, in the middle of the same month, as well as a fine female, in Guernsey, by Luff. 


\section{I5. liocnemis, Thoms.}

Ichneumon rufinus, Holmgr. Ichn. Suec, i. 28 , ơ $q$, excl var. (nec Grav.). Coelich. neumon liocnemis, Thoms. O. E. xviii. 1909, of o. I. liocnemis, Berth. Ann. Soc. Fr. I 894, p. 543, oै के

A very stout, sub-depressed, black species, with abdomen and legs red. Head somewhat buccate, black; cheeks and temples rather broad and sparsely punctate; clypeus slightly bisinuate apically; $q$ with palpi and mandibles red; frontal and vertical orbits flavidous; of also with palpi, mandibles, sides of clypeus and of face, flavidous. Antennae sub-filiform and very little dilated centrally; first flagellar joint hardly twice longer than broad, the following quadrate; of $q$ joints eight to twelve white. Thorax dorsally deplanate, black ; callosity below radix, in of another before it and the pronotum, flavidous; metathorax indistinctly punctate, the areola apically incomplete or emarginate; the petiolar area distinctly concave. Scutellum flat, with its basal carinae and lateral margins flavidous; of $q$ sometimes entirely black. Abdomen dorsally deplanate, of ô sub equilateral, of $q$ elongate-ovate ; all the segments distinctly transverse, castaneous-red; first segment, and, in $\delta$, part of second and third, fuscous ; post-petiole very broad, aciculate, its apex sparsely but somewhat coarsely punctate, rectangular; gastrocaeli broad and deep, the intervening space striolate-rugose. Legs stout, red; of $f$ partly black; coxae, hind tarsi and apices of their tibiae black; hind coxae nearly smooth, with large, fuscous scopulae. Wings sub-hyaline; stigma and tegulae piceous, latter partly pale in $\sigma^{\star}$. Length, Io $\mathrm{mm}$.

In the females below referred to, the antennae are strikingly short, being only $6 \mathrm{~mm}$. in length; the metanotal areae are complete; the spiracles oblique; areola sub-quadrate; the basal area distinct; the mesopleurae strongly shining and obsoletely punctate ; the gastrocaeli are distinctly transverse, the intervening space being as broad as the centre of post-petiole; segments two to four are finely aciculate on the disc, with the incisures deep; the hind femora are impunctate below and the areolet wide above. They differ from the above description only in having the radical callosities and base of scutellum imnaculate; this last bears two indistinct apical dots, resembling those of $C$. microstictus, var. serenus. Length, $12 \mathrm{~mm}$.

Holmgren says this species differs from $C$. lineator in its shorter antennae, the often incomplete areola, shorter basal segment, broader post-petiole, and second segment, and in having the femora and tibiae evidently stouter.

It differs from $C$. microstictus in the more finely punctured frons, red femora and tibiae, much larger and denser scopulae, the sub-filiform antcmmae having only a five-jointed band; in the female's stouter legs and quadrate second flagellar joint, and in the male's more finely punctite and broader post-petiole.

Marshall considers $I$. mfinus of Holmgren to be synonymous with that of Grav., which is not the case, since the latter belongs to the genus Stenichneumon, with which, indeed, the present species is very closely allied, on account of its indistinct thoracic sulcus and transverse gastrocaeli, which latter, however, are very deeply impressed, and the distinct basal area and general contour relate it nore closely with the present grouj) in which Thomson has placed it. It is probably to the present species that Marshall refers, and as I have met with no indigenous example of S. mifuns, Grav., that species is but tentatively retained in our list. 
The only specimens of this species I have seen were bred from Orthosia upsilon, at Blackheath; by Mr. Musham, at Lincoln, from Deilephila euphorbiae, in June; and by myself, at the end of April, from a Noctua pupa found under aspen bark, at Brantham, in Suffolk. It would appear to be known on the Continent only from Sweden.

\section{I6. albicillus, Grav.}

Ichneumon albicillus, Gr. Mém. Ac. Turin, 1820, p. 287 ; I. E. i. 177 ; Ste. Ill. M. vii. I4I; IVesm. Mém. couron. Ac. Belg. 1859 , p. 21 ; Berth. Ann. Soc. Fr. 1894, p. $550, \delta$; $c f$. Thoms. O. E. xviii. 1911 .

Body somewhat slender. Head black; palpi, mandibles, cheeks, orbits of eyes and most of face, white. Antennal scape white beneath. Thorax with lines before and beneath radix white. Scutellum with basal carinae and lateral margins, as well as post-scutellum, white. Abdomen blue-black, strongly punctate, segments two to six a little deplanate dorsally and narrowly red-margined; post-petiole aciculate; gastrocaeli large and deep. Legs black; front coxae white, anterior femora and tibiae flavous, with whitish tarsi; hind femora castaneous internally, piceous without, their tibiae and tarsi fuscous. Wings sub-hyaline ; areolet deltoid ; stigma flavofuscous ; tegulae white. Length, II-I $4 \mathrm{~mm}$. ; $q$ unknown.

This species is very like some forms of $C$. lineator, from which, however, the more parallel-sided body, more strongly punctate abdomen, and entirely white cheeks appear to render it distinct.

Stephens says, "Rare ; taken near London, in July." It is also rare on the Continent, having been found only in Piedmont, and has never been bred.

\section{I7. moestus, Grav.}

Ischnus moestus, Grav. I. E. i. 653, ㅇ․ Ichneumon moestus, Wesm. Bul. Ac. Brux. I 857 , p. 357 ; Berth. Ann. Soc. Fr. 1894, p. 553, ơ 우

Head large, black; clypeus bisinuate; cheeks inflated; mandibles and apex of clypeus red; palpi, internal and external orbits flavous ; tolso with the whole of the clypeus, of the face and of the cheeks, white. Antennae setaceous, hardly dilated, white-banded in t, scape white beneath in 0 . Thorax black, pronotum and lines at radix white; of with a mesopleural line, also white. Scutellum with lateral margins and sometimes its apex white, of always with its apex and that of the post-scutellum white. Abdomen entirely black, twice the length of the thorax; post-petiole aciculate ; gastrocaeli very large, the intervening space always finely punctate; incisures conspicuously shallow. Legs red; hind coxae and tarsi black; anterior coxae and trochanters more or less white in $\delta^{t}$; hind coxae closely punctate, with no scopulae. Wings sub-hyaline; stigma and tegulae piceous in $q$, latter white in $\$$; areolet deltoid. Length, 8-10 $\mathrm{mm}$.

No doubt remains, from the linear spiracles, depressed scutellum, and the conformation of the clypeus and petiole, that this species is not referable to Ischnus, as Gravenhorst thought. It differs, nevertheless, from all the species of the present genus in having the central abdominal incisions not deeply impressed, and the finely punctate base of the second segment is also most distinctive. I do not find the areola described.

It is apparently a rare species on the Continent, being known only in 
Italy, Savoy and Holstein. I do not know whence came Marshall's British record. It has not been bred.

\section{8. impressor, Zett.}

Ichneumon castigator, var. I, Gr. I. E. i. 125, (?) б. I. impressor, Zett. I. L. $36 \mathrm{I}$, ㅇ ; Holmgr. Ichn. Suec. i. 30, $\delta$; ; $c$. Ent. Tidskr. 1880, p. 24, + ; Berth. Ann. Soc. Fr. I894, p. 541, ठ ․ I. inquilinus, Holmgr. Ichn. Suec. i. 35, đ. I. nigricomis, Wesm. Nouv. Mém. Ac. Brux. IS44, p. 28 , ơ q. Coelichneumon impressor, Thoms. O. E. xviii. I910, ๙ $q$.

A broad-headed, black species, with immaculate antennae and red legs. Head not narrowed posteriorly, of t with fine brown pubescence ; clypeus of $q$ slightly bisinuate, of $\delta$ rounded; cheeks and temples inflated; palpi fuscous, mandibles and apices of cheeks red; frontal orbits in $q$, a line at the internal and external and a dot at vertical orbits of 0 , whitish. An-

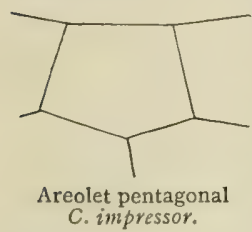
tennae very slightly attenuate towards apex, sub-filiform, entirely black in both sexes; seventh flagellar joint quadrate. Thorax, with scutellum, entirely black, stout ; or, in 0 , sometimes with pronotum and dots at radix and two at base of scutellum whitish, mesonotum somewhat shining; areola of of short, transverse and smooth, of $q$ somewhat elongate, with costae weak and emarginate apically ; costulae entire. Abdomen dull black, with a slight violet reflection and incisures rarely rufescent; post-petiole aciculate-punctate, with lateral areae simply punctate; second segment quadrate, not or hardly longer than broad; gastrocaeli large and deep, intervening space rugosely striate. Legs stout, black; all the femora and tibiae, as well as anterior and the base of hind tarsi, red ; hind coxae nearly glabrous, scopulae castaneous, large and elevated. Wings hyaline; stigma and tegulae piceous ; areolet broad above. Length, I2-I $5 \mathrm{~mm}$.

This species is distinguished by the fulvous tibiae and femora, and the black o antennae; while the tibiac and femora of the $\delta$ are red, the abdomen less strongly sculptured and the clypeus truncately rotund.

I. nigricornis, Wesm., differs in nothing but its larger size, being I5-1 8 mm. long ( $f$. Kriech. Ent. Nachr. I 896, p. 354).

In the British Museum is a specimen said to be of this species with no areolet in the right primary. Irregular neuration is very rare in the Ichneumoninae, and had both wings of this example been thus curiously abnormal, it would probably have long remained an unique species or even genus.

It has been bred at Lynn, in Norfolk, on June I Ith ; in Devon; and, upon other occasions, from Gortyna flavago ; and has been found at Guestling, in Sussex, Essex and Hartlebury, in August; near Birmingham, and at Ogley Bog, Oxford, in July. It is probably common, but its distribution appears nearly confined to our own latitude in Europe.

\section{9. castaneiventris, Grav. ${ }^{\text {? }}$}

Ichneumon castaniventris, Gr. I. F. i. 586, \&; Ste. Ill. M. vii. 198, o \&; Wesm. Nouv. Mém. Ac. Brux. I 844, p. 32 ; Bul. Ac. Brux. 1848, pp. 147, 336 ; IIolmgr. Ichn. Suec. i. 37 ; Berth. Ann. Soc. Fx. 1894, p. 557, o o. I. castanicaudus, Tiscl. Stett. Zeit. 1881, 8. Var. I. haemorrhoidalis, Gr. I. E. i. 539 ; Ste. Ill. M. vii. 195, 8. Coelichnesemon castaneiventris, Thoms. O. E. xviii. I9II, o क. Var. I. melanopyrrhus, Ste. Ill. M. vii. 195, ठ ; cf. Morl. E. M.M. 1902, p. I2I. (?) Var. I. anospilus, Thoms. Ann. Soc. Fr. I886, p. 15; O. E. xviii. 191 I. 
A dull, black and dark red species. Head of $\delta$ hardly, of $q$ moderately buccate; temples and cheeks somewhat broad, punctate, the latter short; clypeus apically quite truncate; black, of with palpi, sometimes mandibles, lateral clypeal mark, internal or facial orbits and a vertical dot, whitish; o with palpi fuscous, mandibles centrally piccous, sometimes the frontal and a dot at the vertical orbits testaceous. Antennae somewhat stout, attentuate, of ơ setaceous, of $q$ compresso-dilated before apex; basal flagellar

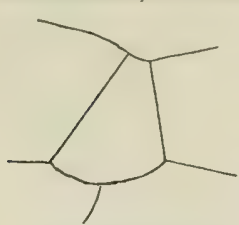

Areolct sub-deltoid.

C. castaneiventris. joint not twice longer than broad; nigrescent, scape of f sometimes with one or two pale dots beneath, f with joints six to twelve white above. Thorax stout, punctate, black; of usually with a minute mark before, and more often a line beneath, the radix, pale; metathorax finely rugose; upper areae often incomplete; areola smoother than remainder, emarginate and always incomplete apically, that of semi-lunar. Scutellum black, of of not bordered to the centre, with two very often distinct pale dots. Abdomen elongate, apically acute, narrower in o ; black, more or less marked centrally and apically with dull ferrugineous; post-petiole centrally aciculate, laterally rugose with the angles sub-obtuse, in of apically punctate; second segment a little longer than broad; gastrocaeli deeply impressed, rugose, the thyridii being large and deep, and the intervening space strongly striolate or longitudinally rugose; terebra exserted, the length of the seventh segment. Legs black, usually the tibiae in part rufescent, the front or anterior ones being laterally stramineous in o*; tarsi fuscous with base paler; coxae not scopuliferous. Wings slightly fuscescent, moderately broad; sides of areolet quite or nearly coalescing above ; stigma fusco-piceous; radix and tegulae blackish, latter often with a pale exterior margin. Length, I I-I $7 \mathrm{~mm}$.

Metathoracic areola always open behind; segments two to seven entirely or partly red; areolet strongly narrowed above ; second and third incisures alone narrowly impressed; to joints seven to fifteen of the flagellum with abbreviated carinae, and scutellum usually dotted with white ; o antennae strongly dilated centrally, and terebra length of seventh segment.

Examples in my collection bear distinct central nervelets to the internal cubital and second transverse nervures.

The colour of the legs and abdomen is extremely variable; the latter may have segments one to two, three or four red; two to six red with a narrow black margin (var. I. bicuspis, Kriech. Ichn. Wien. Mus.); the apical

\section{Ichneztmon ancipterus, Desv. Cat. 19, ठ.}

I am quite at a loss to know where to place this insect. The following description, however, taken direct from the single example in Desvignes' collection in the British Museum would appear to relate more nearly with $C$. castaneiventris than with the genus Amblyteles to which I have previously referred it (cf. E.M.M. I902, p. I22).

Head black; frontal orbits narrowly, facial orbits broadly flavous, the colour of the latter ceasing truncately some distance above the clypeus; palpi flavous. Antennae setaceous, gradually attenuated, entirely black. Thorax black; metathorax rugose, with the basal sulcus somewhat deeply impressed; costulae wanting; areola exactly horseshoe-shaped; basal area distinct; the pleural and juxta-coxal areae incompletely discreted. Scutellum black. Abdomen narrow, black above, with segments two and three more or less rufescent and the anus rufo-fulvous; ventral segments two and three flavous and two to four plicate; post-petiole aciculate; gastrocaeli shallow and inconspicuous, the intervening space being somewhat broad. Legs ochreous; coxae and trochanters. anterior femora externally, hind ones entirely, and the apical half of the hind tibiae, black; hind tarsi, except extreme base fuscous. Wings infumate-hyaline; stigma fulvous; costa ferrugincous, becoming fusco-flavous basally; radix and tegulae piceous; arcolet sub-pentagonal, somewhat narrowed above. Length, $12 \frac{1}{2} \mathrm{~mm}$. 
segments only red (var. 1. melanopyrrhus, Ste. = sub-niger, Berth.); the seventh segment only red (var. haemorrhoidalis, Grav.); or, indeed, the whole abdomen, excepting only the petiole, may be red or ferrugineous (var. anospilus, 'Thoms.). In the varieties bicuspis, Kriech., secretus, Berth. and anospilus, 'Thoms., the areolet is more or less widely open above.

Stephens says it is not very rare, and that it has been taken in Darenth Wood, in the middle of June; and also in Devonshire, where, more recently, Parfitt bred it from pupae dug up at the base of trees, though I am not aware any specified British host has ever been cited. It is recorded from Essex; Wellington College, in Berks., in August ; Guestling, Sussex, \&c. ; and I have taken it flying to the burrows of Crabrones, in a gate-post, at Ipswich, in the middle of June, and beaten it from hazel, in Assington Thicks, Suffolk, at the end of May. Common throughout Europe and Algeria. Bred in Austria, from Ophiusa craccae.

TRIBE.

\section{ICHNEUMONIDES.}

Table of Sub-tribes.

(4). I. Petiole not depressed, or so little as not to be wider than thick dorsoventrally

(3). 2. Abdomen of $q$ apically acute, hypopygium not covering base of terebra; to with second to fourth ventral segments plicate ............................

(2). 3. Abdomen of $q$ apically obtuse, hypopygium covering base of terebra; fo with second to fourth ventral

segments usually not or not alone plicate ........... AMBLYPYGINI.

(I). 4. Petiole depressed, wider than thick dorso-ventrally...

OXYPYGINI.

Platyurini.

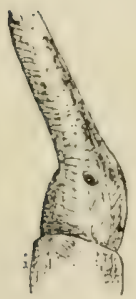

Petiole of Oxypygini.

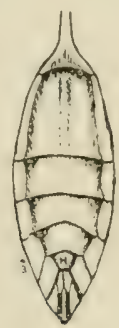

Abdomen of Oxypygini, i ventral view.

Hypopygium (H) not covering base of terebra.

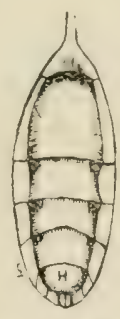

Abdomen of Amblypygini, o; ventral view.

Hypopygium (H) covering base of terebra.

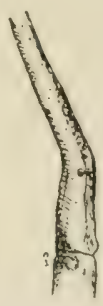

Petiole of Platyurini.

\section{SUB-TRIBE.}

\section{OXYPYGINI.}

The females of this sub-tribe, with which Protichneumon and Coelichneumon have until quite the nther day been commingled, are at once distinguished by the characters already indicated; but in the case of the males the matter is less simple, as is pointed out in my notes under the 
genus Ctenichneumon. Thomson, who sub-divided the genus Ichneumon as it remained after Wesmael's various capital parturitions, erected genera which are most undoubtedly quite natural groups, and it is by no means difficult to tell at a glance to which of them a specimen, seen for the first time, should be ascribed. It is, however, a very different matter to specify points of distinction in a table such as the following, and the characters there enumerated must be accepted in their broadest sense. Thomson indicates a variety of structural features for his genera, some for one and some for another, but there is no hard and fast line drawn between then, and the points indicated in one genus are very often omitted in some or all of the others, e.g., the genal costa of his genus Ichneumon is said to be inflexed, but one is left to pre-suppose that that of all the other genera is entire since no reference is made to it. Ashmead helps one not at all, since he relies mainly upon the shape of the areola which, so far from being constant, usually differs more or less widely in the sexes of the same species; and I am not prepared to vouch for the stability of the juxtapleural carina. Dr. Schmiedeknecht in I902, presents a table of these genera in which Stenichneumon differs from the remainder in its posteriorly narrowed head; Barichneumon from Ichneumon in its pentagonal areola whose costulae are emitted from behind the centre ; the remaining characters, excepting the stronger costulae in Melanichneumon than in Cratichneumon, are not original and the aciculation of the post-petiole cannot be of the least use in characterising the genus Ichneumon. Nevertheless, no doubt remains that these genera are good ones, and it is now only necessary to discover their peculiarities.

\section{Table of Genera.}

(I6). I. Clypeus truncate or slightly and evenly rounded, not apically emarginate.

(15). 2. Basal segment not dorsally intumescent in the centre.

(14). 3. Gastrocaeli often large; terebra and eighth dorsal segment rarely exserted.

(5). 4. Base of second segment narrowly margined; post-petiole broad and sub-glabrous $\ldots . . . \ldots \ldots \ldots . . . .$.

(4). 5. Base of second segment immarginate ; post-petiole centrally normal and sculptured.

(7). 6. Juxta-coxal and pleural areae confluent ; areola usually quadrate

(6). 7. Juxta-coxal and pleural areae usually discreted by a distinct carina.

(II). 8. Face usually convex; body small or slender ; areola semi-circular or transverse.

(10). 9. Post-petiole centrally aciculate or shagreened; antennae of $q$ filiform ...............................

(9). I0. Post-petiole centrally punctate ;
antennae usually attenuate ......

3. Eupalamus, Wesm.

I. Stenichneumon, Thoms.

2. CRATichneunion, Thoms.

5. Barichneunion, Thoms. 
(8). II. Face not distinctly convex; body normal ; areola basally rectangular.

(13). I2. Abdomen and stigma usually pale ; areola often elongate, always rectangular, its costae weak......

(12). I3. Abdomen and stigma usually black; areola hexagonal or sub-quadrate, its costae strong .............

(3). I4. Gastrocaeli sub-obsolete; terebra and eighth dorsal segment distinctly exserted

(2). I5. Basal segment dorsally intumescent in the centre ......................

(1). I6. Clypeus apically emarginate; body sub-cylindrical

6. ICHNEUMON, Lim.

4. Melanichneumon, Thoms.

7. Exephanes, IVesm.

8. PRoBoloides, Morl.

9. Chasmias, Ashm.

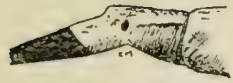

Proboloides. Intumescent post-petiole

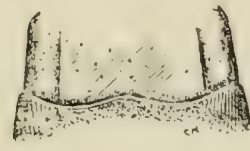

Eupalamus. 2nd segment margined.

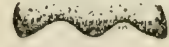

Chasmias. Emarginate clypeus.

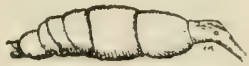

Exephanes. 8th segment exserted.

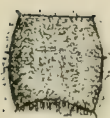

Stenichneumon. Quadrate areola.

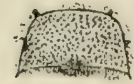

Barichneumon. Areola transverse.

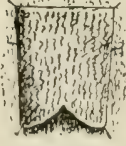

Ichneumon. Areola rectangular.

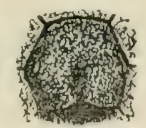

Melanichneumon. Hexagonal areola.

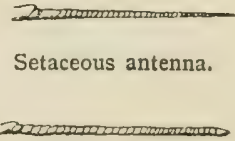

Filiform antenna.

\section{STENICHNEUMON, Thomson.}

Thoms. O. E. xviii. 1893, 1964.

Head triangular, face distinctly arched, narrowed behind the eyes and towards the mouth; cheeks not short; mandibles not stout, narrowed apically; antennae of female slender, flagellar joints not short beneath. Thorax with the mesonotum often dull, very closely punctate; metathoracic areola not triangular, petiolar area rarely impressed, dentiparal areae not spined. Abdomen with central area of post-petiole striolate or very finely scabrous; second segment with the thyridii not deep but strongly transverse, or more rarely oblique, nearly extending to the lateral margin; third with a distinct basal depression. Legs somewhat slender. Head sometimes with white vertical dots or lunulae; the abdomen apically immaculate, rarely dingy flavous- or white-marked. 
This genus appears to form a more or less natural link between Melanichnenmon and Cratichneumon, yet the conformation of the thorax reverts somewhat to that of the Joppides. Some of the species, e.g., S. apricus, \&c., resemble those of Amlilyteles, and Holmgren points out that the male of $S$. culpator is likely to be confounded with that of Ctenichneumon sputator, Fab.

Table of Species.

(12). I. Post-petiole and base of second segment centrally striolate.

(5). 2. Size large, I5-2I mm.; scutellum entirely white or black.

(4). 3. Scutellum black .........................

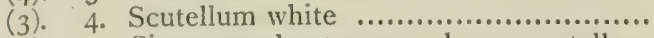

(2). 5. Size normal, $15 \mathrm{~mm}$. or less ; scutellum with sides narrowly white.

(I I). 6. Anterior femora with no white at apex.

(I0). 7. Sides of scutellum only white ; abdomen mostly black; length, at least $12 \mathrm{~mm}$.

(9). 8. Head narrower behind eyes; temples less prominent

(8). 9. Head broader behind eyes; temples more prominent ........................

(7). Io. Basal carinae and sides of scutellum white; abdomen rufescent; length,

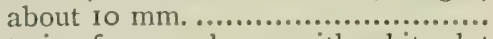

(6). II. Anterior femora always with white dot at apex...............................

(I). 12. Post-petiole and base of second segment not striolate.

(14). 13. Antennae of oै pale-banded; anus of $q$ pale-marked

(13). 14. Antennae of $\delta$ not pale-banded; anus of $q$ not pale-marked.

(18). I 5. Mesonotum dull.

(17). I6. Scutellum apically white .................

(16). 17. Scutellum apically rosy in $q$, flavous in $\sigma^{t}$

(15). 18. Mesonotum shining.

(20). 19. Scutellum apically flavous................

(19). 20. Scutellum entirely black ................

I. CULPATOR, Schr.

2. PISTORIUS, Grav.

3. TRILINEATUS, Gmel.

4. SCUTELlator, Grav.

5. RUFINUS, Grav.

6. multicinctus, Grav.

7. OCHROPIS, Gmel.

8. PICTUS, Grav.

9. CAstaneus, Grav.

IO. DEFRAUDATOR, Grav.

II. APRICUS, Grav.

\section{I. culpator, Schr.}

Ichneumon culpator, Schr. F. B. II. ii. n. 2077 ; Gr. I. E. i. 548 ; Ste. Ill. M. vii. 196, o ; Wesm. Nouv. Mém. Ac. Brux. 1844, p. 82; Bul. Ac. Brux, 1848, p. 173; Desv. Cat. 26, $\delta$; Holm. Ichn. Suec. i. 44 ; Berth. Ann. Soc. Fr. 1S94, p. 566, $\delta$ o. Stenichnezumon culpator, Thoms. O. E. xviii. 1965, \& \&. Var. I. fumigator, Gr. I. E. i. 537 , excl. + .

A large, dull, black species. Head entirely black, dull, coarsely punctate; cheeks narrow; clypeus apically truncate, its angles broadly rounded. Antennae black, slender, setaceous; central band in both sexes usually white. 'Thorax entirely black, dull, coarsely punctate; metathorax subbidentate; areola somewhat transversely quadrate, its base rounded and apex almost truncate. Scutellum strongly convex, entirely black. Abdomen elongate, black, with second, and usually third, segment castaneous, 
anus immaculate; post-petiole centrally flat, of $q$ coarscly, of of oblipucly, striate or rugose; lateral areae rugose and apical angles obtuse ; gastrocacli broad, deep and transverse, becoming oblique apically; intervening space little more than half width of centre of post-petiole. Legs black; intermediate femora of sinuate apically beneath ; tibiae more or less red, the anterior laterally fulvous, especially apically in of ; hind ones darker, sometimes black towards apex; anterior tarsi pale; hind coxae of $q$ very closely punctate, with an obtuse, shortly haired, stout tubercle or tooth, of of coarsely punctate, sub-carinate before apex. IVings somewhat clouded; stigma fulvous, tegulae piceous. Length, I 5-20 $\mathrm{mm}$.

The male occasionally has the antennae entirely black, which form is that of $I$. fumigator, Grav. The abdomen of both sexes is sometimes black instead of castaneous, and examples are known with both abdomen and legs quite black ( $c f$. Trans. Ent. Soc. I889, p. 410). Desvignes describes a male with the abdomen black, the incisures only being ferrugineous.

Stephens took the female in Coombe and Darenth Woods, in June; Bridgman records it from Ely. It is said to be scarce in Devon and not found in Norfolk, though common enough in woods and fields in Sweden. It has been bred from Melitaea Athalia, Setina aurita, and Trichiura crataegi on the Continent, where it is common. The female hibernates. In the British Museum is an example bred from Plusia festucae.

\section{2. pistorius, Grav.}

Ichnenmon pistorines, Gr. I. E. i. 23I ; Ste. Ill. M. vii. 153 ; Zett. I. L. 359, ó ; Wesm Nouv. Mém. Ac. Brux. I844, p. 8I ; Holmgr. Ichn. Suec. i. 43; Berth. Ann. Soc. Fr. 1894, p. 566, o \&. Stenichneumon pistorizs, Thoms. O. E. xviii. 1965, of \&. 1. molitorius, var. a, Schr. F. B., n. 2072. Var. I. delivatorius, Gr. I. E. i. 219, excl. of; of. WVesm. Mém. couron. Ac. Belg. I859, p. 26. Var. I. atroceruleus, Tisch. Stett. Zeit. I 868 , ․

Like S. culpator in size, conformation and sculpture. Head of $q$ entirely black, of of with the facial orbits usually broadly white. Antennae flavidouswhite-banded in both sexes. Thorax black, with usually a whitish line before the radix; of also has pronotum and generally a callosity below the radix white; metathorax roughly punctate, with complete upper areae, of which the areola is sub-quadrate or transverse. Scutellum flavidouswhite, strongly elevated in both sexes, and apically obtuse. Abdomen dull, of of sub-linear; black, with the central incisures, and sometimes the second segment of $\delta$, usually castaneous; apex immaculate; postpetiole centrally striate or coarsely aciculate, its apical angles obtuse; gastrocaeli transverse, intervening space narrower than centre of postpetiole, longitudinally rugose. Legs black, with intermediate femora broadly sinuate beneath apex in $\sigma^{*}$, slightly in $q$; front femora whitish below at the apex; tibiae white, black at apex and before base, the anterior entirely white laterally; front tarsi generally with the first joint basally white; hind coxae very closely punctulate, with narrow, indistinct scopulae. Wings a little clouded; stigma and tegulae red, latter sometimes whitish in $\delta$, fuscous in $q$; areola slightly narrowed above. Length, I 5-2 I mm.

The second segment in both sexes is not infrequently castancous or even red; the female has sometimes no white line before the radix, which form 
was I. deliratorius, Grav. ; the male rarely has the face entirely black. The var. I. atrocaeruleus, Tisch., has the abdomen bluish and the stigma fuscous.

The female differs from $S$. culpator in the thoracic markings and scutellum, the yellowish band of the antennae, which are a little more compressed centrally, and in the scopulae, which are not tuberculate. Both sexes are at once known by the white coloration of the legs, which superficially allies this species with $I$. deliratorius.

Rare; taken at Darenth, in June (Stephens).-Captured at Bickleigh, in Devon, 2oth August (Bignell). Probably rarer than the preceding species. Col. Yerbury has sent me the male from Golspie, in Sutherland, where he found it early in August; and it is also recorded from Essex. It has been bred, from Orgyia pudibunda, on the Continent, where it is widely distributed.

\section{3. trilineatus, Gmel.}

Ichneumon trilineatus, Gmel. S. N. i. 2679, ; Gr. I. E. i. I73; Ste. Ill. M. vii. 142 ; Wesm. Nouv. Mém. Ac. Brux. 1844, p. 35 ; Bul. Ac. Brux. 1848, p. I49; lib. cit. 1857, p. 368 ; Holmgr. Ichn. Suec. i. 46 ; Berth. Ann. Soc. Fr. 1894, p. 569, ơ 9 . Stenichneumon trilineatus, Thoms. O. E. xviii. I966. 1. Brisihkii, Ratz. Ichn. d. Forst. iii. I70. I. adulator, Tisch. Stett. Zeit. 1881, o. Var. I. umbraculosus, Gr. I. E. i. 199 ; Ste. IIl. M. vii. 146, o $q$.

A rather dull, black species, with the sides of the scutellum always pale. Head narrowed behind the eyes; cheeks elongate; mandibles not stout; angles of clypeus rounded, and face triangular; frontal orbits narrowly, and a vertical dot sometimes absent in $q$, flavidous-white; mouth piceous ; t also with palpi, mandibles, sides of clypeus and of face, and part of cxternal orbits, whitish. Antennae slender, setaceous, basally reddish ; of o more or less white-banded; of with scape flavidous beneath. Thorax dull ; black, with pronotum and callosities in ot, and the latter sometimes in $q$, flavidous; mesonotum closely punctate; metathorax with no basal sulcus, somewhat smooth, and finely scabrous; the upper areae complete, of which the areola is the most smooth, slightly longer than broad (at least in $q$ ), rounded at base, apically rectangular with the margin generally incomplete. Scutellum coarsely punctate, obtuse, apically depressed; black with the lateral, but not the basal, margin pale. Abdomen somewhat slender, of $\delta$ lanceolate, of $q$ elongate-oval ; closely punctate, more shining towards apex; usually entirely black ; post-petiole closely aciculate, apical angles slightly obtuse; second segment rarely castaneous in $q$, often centrally striolate throughout, its apical incisure and that of third deeply impressed; gastrocaeli transverse and deep, often castaneous, extending nearly to margin, the intervening space narrower than the centre of postpetiole ; terebra slightly exserted. Legs rather slender; black, with femora and tibiae for the most part piceous or ferrugineous, hind ones often black; hind coxae closely punctate. Wings hyaline, with stigma and tegulae blackish; sides of areolet nearly or quite coalescing above. Length, I 2-I $5 \mathrm{~mm}$.

The legs are sometimes blackish throughout (I. umbraculosus, Grav.), or the hind tibiae apically black; the female may have the apex of first and whole of second and third segments castaneous; males have been known with white-banded antennae.

Very closely allied to the next species, but the head is narrower behind 
the eyes, the temples less produced and the pale scutellar line is shorter; the stigma is also said to be darker.

I see no reason to doubt that Stephens, who perhaps was unaware of the variability in the colour of the legs, rightly named the specimens he took rarely near London, more especially since it is one of the commonest of our species of the genus Ichneumon (sensu Grav.). It is a common parasite upon Abraxas grossulariala, from which Bignell bred it, on August 7 th, in South Devon, and also from Bryophila glandifera, on June 3 oth. He says (Entom. r88o, p. 246) it emerges, as I believe do all Ichneumoninae, direct from the host's cocoon.

Stephens tells us the larva of the var. umbraculosus feeds on that of Eyprepia caja and Abraxas grossulariata, and the perfect insect is very common around London, in June and July. He also records it from Salop and the New Forest. Brischke bred it from Trachea piniperda. The female is often found hibernating beneath the bark of trees, and I have met with it beneath that of oak, aspen and Pinus sylvestris in damp situations, and also in the centre of woods, from October 5 th to April 6th ; on one occasion I found a cluster of five beneath the loose bark of a dead standing fir. All the males I have seen have been taken in July, when they may be seen investigating the hedgegrows. Bagley, Oxford (Hamm); New Forest (Chawner); Bonhill, Dumbarton; Pollockshields and Johnstone, Renfrew (Dalglish); Watford (Sladen); Appledore, Sussex (Beaumont); Carlisle, ex A. grossulariata (Day); Lewisham (Beaumont); Settle, Yorks., ex A. grossulariata (Clutten); South Leverton and Ashby, Lincs., several males, in July (Thornley) ; Felden, Herts., (Piffard) ; Essex. I have taken it at Claydon, Bentley Woods, Dodnash Wood, Martlesham and Clopton, all near Ipswich.

\section{4. scutellator, Grav.}

Ichneumon sculellator, Gr. I. E. i. I75 ; IVesm. Nouv. Mém. Ac. Brux. 1844, p. 35 ; Berth. Ann. Soc. Fr. I894, p. 568, \& \& ; Ratz. Ichn. d. Forst. i. 136 ; ii. 134; iii. 170, o; of. Thoms. Ann. Soc. Fr. 1886, p. 17. 1. digrammus, Gr. I. E. i. 179, o. Stenichneumon sculellator, Thoms. O. E. xviii. 1966.

So like the preceding species as to need no distinct description.

It differs from S. trilineatus in the head being much broader behind the eyes; the temples more produced; the antenuae shorter and more red beneath; the lateral pale line of the scutellum longer; the hind legs always red or yellowish; the stigma of the wing red; and the male has the face flavous-white with a central black spot; also the sides of the areolet are wider above; but the conformation of the head is probably the only stable distinction. Gravenhorst himself doubted its rights to specific rank.

As in the preceding, the incisures of the central abdominal segments are often more or less reddish.

Desvignes possessed indigenous specimens and records it in his Museum catalogue; it is probably confused with $S$. trilineatus and I know of no other British records. On the Continent it has been bred from Liparis chry'sorrhoea, Abraxas grossulariata and Trachea piniperda.

\section{5. rufinus, Grav.}

Ichneumon nufinus, Gr. Mem. Ac. Sc. Torin, 1820 , p. 336 ; I. E. i. 4 S1, \&, excl. varr.; Wesm. Nouv. Mrém. Ac. Brux. 1844, p. 36 ; Bul. Ac. Brux. 1848, p. 151; 
Berth. Ann. Soc. Fr. 1894, p. 569 of $\$$; of. Thoms. lib. cit. 1886, p. 16, et Holmgr. F.nt. Tidskr. ISSo, p. 24 (nec Ichn. Suec.). Stenichneumon rufinus, Thoms. O. E. xviii. 1966, o \&. Var. I. Helleri, Holmgr. Verh. z.-b. Ges. 1878, p. 167, ठ \&.

Head somewhat narrowed behind the eyes, black; temples and cheeks punctate; clypeus indistinctly separated, apically truncate; palpi ferrugineous; internal and external orbits usually narrowly flavidous ; of also with palpi, sides of clypeus and of face broadly flavidous. Antennae slender, setaceous ; of $q$ sub-filiform, slightly compressed and white-banded centrally, with the scape castaneous beneath ; of to attenuated towards apex with scape whitish beneath. Thorax black with usual callosities at radix, and in the pronotum as well as sometimes two vittae on disc of mesonotum and marks or lines on mesopleurae, whitish; metathoracic areae distinct, areola semi-oval and apically emarginate. Scutellum black with basal carinae, and sometimes its lateral margins, whitish. Abdomen castaneous-red, basal segment, and in the following centrally, black; post-petiole centrally aciculate; gastrocaeli transverse, posteriorly oblique ; second segment dorsally aciculate with its apical incisure deeply impressed; apex immaculate. Legs red ; coxae, trochanters, hind tarsi and apices of hind femora and tibiae, usually black; all the coxae closely punctate, somewhat shining, ot with front ones pale-marked, $q$ with hind ones bearing only small scopulae. Wings a little clouded; stigma and tegulae piceous; areolet narrowed above. Length, 10-1 $2 \mathrm{~mm}$.

The apical segments in both sexes, and the legs in the female, are sometimes entirely black; and in the variety Helleri, from the Tyrol, the legs are black, with the anterior femora and tibiae laterally flavous or fulvous.

Superficially it much resembles Coelichneumon lincnemis, Thoms., with which Holmgren confused it, but a glance at the coxae will suffice to distinguish them. These, in the present species, are closely punctate throughout, in the latter they are glabrous, with a few isolated punctures, and in the female the scopulae are much larger than in the present species. The gastrocaeli, too, are shallower and oblique posteriorly, the head is narrower, the areola not incomplete apically, the markings of the male are more profuse, and its body more slender.

In the present genus this species is at once known by the pale scutellar carinae and red abdomen.

I know of no British records of this species, and it is, perhaps, incorrectly included in our list, since Marshall followed Holmgren in considering the latter's I. rufinus as synonymous with that of Gravenhorst. On the Continent, it is found in France, Germany and Sweden, and has been bred from Hemithea thy'miaria, some Geometer which Brischke calls Cidaria aestivaria and from Ophiodes illunaris. The female hibemates among moss.

\section{6. multicinctus, Grav. ${ }^{1}$}

Ichneumon malticinchus, Gr. I. E. i. 453, o; Wesm. Bul. Ac. Brux. I857, p. 368 ; Berth. Ann. Soc. Fr. I894, p. 563, $\delta$ o. I. allostriatus, Tisch. Stett. Zeit. ISSI, o. Var. I. allogruttatus, Gr. I. E. i. II2; Ste. Ill. M. vii. I2S; IVesm. Nouv. Mém. Ac. Brux. 1844, p. 34 ; Bul. Ac. Brux. I848, p. 149, of.

Head rarely entirely black, in $\%$; clypeus apically truncate, laterally

1 As I have seen no specimens of this insect and it is not mentioned by Thomson, its position in the present genus is but tentative.-October, 1902. 
rounded; generally with the frontal and external orbits white-lined; of of also with mouth and face entirely white. Antennae slender, setaceous, black; of $q$ rather more than half length of body, centrally white above; of $\delta$ not reaching anus, scape white beneath. Thorax sometimes entirely black; usually with humeral callosities and post-scutellum white; of $\delta$ gibbulous, usually with pronotum, propleurae, and sometimes two marks on metathorax also white; areola sub-lunate. Scutellum sometimes with a sub-apical white fascia, or in of with the apex and the basal carinae white. Abdomen of $q$ nitidulous, blue-black, apical margin of petiole centrally white, of third and fourth segments with a glaucous-white dot; incisures of second and third ferrugineous; of 0 with less blue reflection, very finely and closely punctate, oblong-ovate; five basal segments with their apical margins entirely or in part white; post-petiole aciculate; base of second segment with centre aciculate and narrower than the large and deeply impressed gastrocaeli, which are not transverse; apex immaculate. Legs black : of of somewhat slender, with apices of all the femora white ; anterior legs mostly white in front and a white dot at apex of hind tibiae: of $q$ the anterior femora always, and the hind sometimes, with an apical white dot; front tibiae apically white; hind tibiae not white-banded; coxae not scopuliferous. Wings sub-hyaline; areolet sub-deltoid ; stigma and tegulae piceous. Length, I $2-15 \mathrm{~mm}$.

I have prefered to attach more importance to the peculiarly white knees ( $f f$. Wesm. "Otia"), than to the abdominal cinctures, which in some specimens are entirely wanting, as are also the thoracic markings. The colour of the scutellum is also most variable, the white markings being sometimes entirely absent; Gravenhorst's $I$. alboguttatus ( $q$ ) is referable to the latter form.

This species is probably commoner in southern than in northern counties, since it is not found in Scandinavia, though recorded from France, Germany, Italy, \&c. Stephens records it from the New Forest, very rarely, in June. I know of no recent records, and it has not been bred.

\section{7. ochropis, Gmel.}

Ichneumon ochropis, Gmel. S. N. i. 2679 ; Gr. I. E. i. I82 ; Ste. Ill. M. vii. I43; Wesm. Nouv. Mém. Ac. Brux. 1844, p. 104; Holmgr. Ichn. Suec. i. 193; Berth. Ann. Soc. Fr. 1895, p. 554, o \&; if. Thoms. lib. cit. I887, p. 15. Stenichneumon ochropis, Thoms. O. E. xviii, $1967, \delta$ o

Head triangular from in front; cheeks and temples narrowed; genal costa inflexed; mandibles slender, lower tooth very small ; black, of $q$ with palpi apically pale and the orbits more or less obscurely rosy; of with labial palpi ferrugineous, maxillary palpi, mandibles, labrum, clypeus and face usually, and more rarely the genal orbits, flavous. Antennae not filiform, scape sub-globose; blackish with the scape and basal flagellar joints mainly ferrugineous; white-banded in both sexes, of with scape flavous beneath. Thorax black with a line below the scutellum and generally the pronotum and usual callosities at radix, red or, in $\hat{\sigma}$, flavidous; mesonotum dull, notauli distinct; metanotum scabriculous with but three areae of which the areola of ${ }^{t}$ is quadrate, of $q$ slightly longer than broald, rectangular, apically truncate or sub-obsolete. Scutellum punctate with short, ferrugineous setae, finer in of; red, or in of whitish. Abdomen of of nearly linear, of $q$ elongate-oval; black with segments one and two, more 
rarely one to four, badious or castaneous, darker with only incisures castaneous in $\delta$; $q$ with sixth at apex and seventh flavidous-white; post-petiole scabriculous throughout, carinae often obsolete, apical angles obtusely rounded; second segment slightly longer than broad, very closely and alutaceously punctate, space between the large, broad but superficial gastrocaeli narrower than centre of post-petiole; terebra slender, distinctly exserted. Legs slender, pale red, anterior coxae sometimes stramineous; hind legs often blackish, their coxae very finely punctate with, in $q$, distinct red scopulae. IVings hyaline, stigma fulvous; areolet narrowed above; radix and tegulae rosy in $q$, somewhat flavidous in $\delta$. Length, 8-I I mm.

This species varies only in the directions above noted. It is at once distinguished by the pale $q$ anus and the banded antennae of the $\delta$; the mesonotum is dull, scabrously punctate. Ichneumon rubedinis, Desv., is not a variety of this species as was conjectured by M. l'Abbé Berthoumieu.

Undoubtedly a common species in Britain, though I have never personally met with it, and it appears to be very scarce in Devon, where Parfitt found only one female. Hope found both sexes near Netley; and Stephens tells us the larvae feed on those of Abraxas grossulariata, and that it is not uncommon about London and in Salop, in June; Bignell and Bridgman record it respectively at Bickleigh, in Devon, at the end of August, and at Norwich; Beaumont has found it at Courten, in Ireland, and Taynuilt, in Perthshire; and Bennett, at Guestling. I am indebted to Mr. Piffard for many examples from Felden, in Herts., to Mr. Adams, who took it at Lyndhurst towards the end of May, and to Mr. Peachell, who bred the female from the pupa of an Ennomid moth, the larva of which was beaten at Totteridge, near High Wycombe, on September Ioth. This last, in emerging from its host's chrysalis, had entirely removed the capital extremity by a somewhat regular circular incision, the inner margin of which was much discolured. On the Continent, it is very common in grassy places and among the undergrowth in woods.

\section{8. pictus, Grav.}

Hoplismenus pictus, Gr. I. E. ii. 418, excl. of. Ichneumon pichus, Wesm. Nouv. Mém. Ac. Brux. 1844, p. 220, $q$; Bul. Ac. Brux. 1848, p. I72 ; lib. cit. 1849, p. 38, ơ ; Holmgr. Ichn. Suec. i. 199; Berth. Ann. Soc. Fr. 1895, p. 567, \& \&; of. Thoms. lib. cit. 1887, p. 16. 1. rufescens, Ste. Ill. M. vii. 207, + . I. exornahus, Wesm. Nouv. Mém. Ac. Brux. 1844, p. 8o, q; Bul. Ac. Brux. 1855, p. 394, ơ \&; cf. Mém. couron. Ac. Belg. 1859, p. 86. Cryptus Ralzeburgii, Hart. Jahresb. 1838, p. 263 ; Ratz. Ichn. d. Forst. i. 139, $q$. Stenichneumon pictus, Thoms. O. E. xviii. 1967, + .

A small, slender, reddish species of Cryptoid aspect. Head short, narrowed behind the eyes, triangular in front; black with palpi, labrum and orbits whitish; of also has vertical lunulae and genal orbits pale; clypeus and face red, laterally in of flavous. Antennae slender, attenuate ; white-banded with scape red beneath in $q$; reddish, with scape black, beneath in $\delta$. Thorax of $q$ mostly red; pronotum and usual callosities at radix flavous; mesonotum somewhat dull with lateral black vittae; metathorax black, pleural areae often red-or sometimes even white-marked; areola sub-quadrate, costulae wanting, spiracular costae strongly curved, dentiparal mutic. Scutellum and post-scutellum red, apically white and somewhat truncate. Abdomen sub-linear, very finely and superficially punctate; red with the base and apex more or less infuscate, darker in $\sigma^{*}$; 
post-petiole broad, shagreened, with lateral foveae and apical depression, the angles obtusely rounded; second segment slightly elongate, space between the transversely linear gastrocaeli very narrow; terebra slender, length of the sixth and seventh segments. Legs red, coxae white-marked; trochanters, hind tarsi and apices of hind femora and tibiae darker; hind coxae finely and closely punctate, more or less scopuliferous. Wings hyaline, radix and tegulae ferrugineous in $q$, darker in $\delta$; stigma piceous ; areolet narrowed above. Length, 7-I I $\mathrm{mm}$.

The base and apex of the abdomen vary slightly in colour; the apical margin of the second segment of $\delta$ is often alone red. It may be at once recognised by the red thorax and far-exserted terebra of the $q$, and in both sexes by its broad post-petiole and almost shining mesonotum; the $q$ anus and the $\delta$ antennae are not pale-marked.

Stephens found his I. mfescens, near London, in June; and I have seen a $S$. pictus in Mr. Chitty's collection, taken in September, at Ilfracombe. This species has several times been bred from Cidaria fulvata, as well as from Macaria liturata, Ocneria dispar and Thera juniferata. On the Continent, it has a wide range from France to Sweden and Russia. Dr. Chapman has sent me the $q$, from Switzerland, bred in August, from some species of Thera which fed on larch trees.

\section{9. castaneus, Grav.}

Ichneumon castaneus, var. 2, Gr. I. E. i. 559, \&; Wesm. Nouv. Mém. Ac. Brux. 1844 , p. 77 ; Bul. Ac. Brux. 1848, p. I71, excl. var. 5 ; lib. cit. 1855, p. 394 ; Holmgx. Ichn. Suec. i. 197 ; Berth. Ann. Soc. Fr. 1895, p. 565, of of of. Thoms. lib. cit. 1887, p. I6. Slenichneumon castaneus, Thoms. O. E. xviii. 1967. Exephanes nufoniger, Tisch. Stett. Zeit. 1879, $\$$; cf. Kriech. Ent. Nachr. 1894. Var. I. castaneus, var. 4, Gr. I. E. i. 559, 9 . Var. I. pulchricornis, Gr. lib. cit. $564, q$.

The thorax is not red-marked. Head narrowed towards the mouth, black; mouth partly red, frontal orbits usually narrowly testaceous ; f also with palpi, mandibles, clypeus, face and genal orbits usually flavous. Antennae slender, filiform-setaceous, blackish with the central band white only in the $q$ and the basal flagellar joints often entirely or partly red; of of subnodulose with scape white, and flagellum more or less red, beneath. Thorax dull; of $q$ entirely black, of $\delta$ with usual humeral callosities flavous; metanotum with three, or in fo five, areae of which the areola is subquadrate and apically emarginate. Scutellum towards its apex or entirely rosy, of $\delta$ flavous; post-scutellum often concolorous. Abdomen ovatelanceolate, of of sub-linear; dull, entirely rufescent or with petiole and anus infuscate; anus immaculate; post-petiole finely scabrous, not longitudinally sculptured; second segment longer than broad, very closely punctate; gastrocaeli strongly transverse, the intervening space being closely punctate and a little more than half width of centre of the postpetiole; terebra distinctly exserted. Legs red; coxae, trochanters and sometimes hind femora black; anterior trochanters of $0^{*}$ usually strimineous; hind coxae of $q$ with elongate scopulae. Wings a little cluuded, stigma piceous or flavescent; tegulae ferrugineous, in of flavous; areolet narrowed above. Length, 9-12 $\mathrm{mm}$.

The structure is nearly identical with that of S. ochropis. The extent of black and red in the o varies considerably in the legs, abdomen and basal third of the flagellum. 'The var. pulchricornis has the antenuae tricoloured 
and two fulvous dots at the apex of the scutellum. The var. castaneus has the scutellum entirely rufescent.

The of may be known from that of the following species by its entirely black thorax and immaculate anus; the terebra is only slightly exserted; and the of by having no pale antennal band, the basal abdominal segments red and the post-petiole not explanate. The mesonotum in both sexes is dull.

It is widely distributed on the Continent, and has figured in the 13ritish catalogues since 1835 , when Stephens says it had been taken rarely at Darenth, in June, and also, probably, in Wilts. I know, however, of no more recent captures and the species does not appear to have been bred.

\section{ro. defraudator, Wesn.}

Ichneumon sedulus, Gr. I. E. i. 492, excl. ot et varr. I. defraudator, Wesm. Nouv. Mém. Ac. Brux. I844, p. 78 ; Berth Ann. Soc. Fr. I895, p. 566, ơ . ${ }^{1}$

The male is a very slender insect. Head much narrowed behind the eyes, black; palpi and mandibles ferrugineous; internal orbits white ; t also with palpi, mandibles, and cheeks white. Antennae sub-filiform, attenuate, piceous; of $q$ white-banded, of $\delta$ with scape white beneath. Thorax black; pronotum, humeral lines and post-scutellum flavidous ; metathorax with three upper areae of which the areola of $q$ is sub-quadrate, rounded in front and finely shagreened, of of semi-elliptic, glabrous and nitidulous. Scutellum strongly convex, flavous, basally red or black. Abdomen of of linear, of $q$ sub-cylindrical black, segments one to five red, apex immaculate; post-petiole finely shagreened, of of glabrous with a small fovea near the apex; gastrocaeli transverse and deep, intervening space narrow; terebra exserted. Legs black : of $q$ with anterior coxae partly red, hind ones scopuliferous; anterior, and sometimes hind, femora and all the tibiae red: of $f$ with coxae and trochanters white, anterior tibiae and femora flavous, hind ones red, apically black; calcaria white. IVings hyaline, stigma piceous or fulvous; tegulae flavous or white; areolet narrowed above. Length, ro $\mathrm{mm}$.

This species much resembles the preceding, but the head is narrower, the size smaller, and the colour a little different; the scutellum of the $q$ is flavous, red only at the base, and the post-petiole of the of has the central fovea peculiar to it.

I know of no British records, though it is included in our catalogues. It has a wide continental range through Hungary, Germany and France. The female hibernates among moss.

\section{II. apricus, Grav.}

Ichneumon apricus, Gr. Mem. Ac. Sc. Torin, 1820 , p. 350 ; I. E. i. 553 ; Ste. Ill. M. vii. 197, of; cf. Wesm. Mém. couron. Ac. Belg. 1859, p. 66 ; Berth. Ann. Soc. Fr. 1895, p. 288, ơ ㅇ. Amblyteles speciosus, Wesm. Nouv. Mém. Ac. Brux. IS44, p. I16, excl. ó. A. inlersertor, IVesm. Bul. Ac. Brux, 1854, p. 118, $q$.

1 I cannot find that a description of this species was ever published by A. W. Knoch, nor by C. L., nor G., nor Ludwig Koch; certainly none wrote in 1829 . Gravenhorst says, ... vidi etiam hanc feminam in museo Comitis de Hoffmannsegg, sub nomine Ichn. defraudatoris Knochii," quite probably a manuscript one; Wesmael simply misquotes Gravenhorst ; and Berthoumieu writes, "I. defraudator \& Koch. Mus. Hoff, I829." I can, however, find no reference to a description earlier than that of Gravenhorst ; no such author appears in Mocsary's "Literatura Hymenopterorum," 1882 . 
Head gently rounded behind the eyes, black, palpi red; of with mandibles, labrum, transverse line on clypeus, facial orbits and vertical dots, white. Antennae slender, setaceous, black; of $q$ white-banded, of $t$ with white dot beneath scape. Thorax black with humeral callosities white; areola semi-oval; metathoracic spiracles short; dentiparal costae mutic. Scutellum strongly convex, black. Abdomen elongate, subobtuse, black; segments two to three and apex of first for the most part red; anus immaculate; post-petiole very finely scabrous or shagreened, slightly convex, with no carinae and the spiracles inconspicuous; gastrocaeli superficial and sub-obsolete. Legs slender, coxae and trochanters black; femora and tibiae obscurely red, front ones internally whitish; hind tibiae apically black. Stigma red, of of piceous; tegulae and radix fuscous in + ; areolet narrowed above. Length, ro $\mathrm{mm}$.

Gravenhorst placed this species in the fabricator group (Cratichneumon), and I am not sure that he was not correct, for it is closely allied thereto by its abbreviated metathoracic spiracles, \&c., but diverges in the semi-oval areola, convex scutellum and slender legs; the pale vertex, shagreened post-petiole, black anus and slender legs and antennae, however, render its present position at least temporarily tenable. ITesmael did not know to which of his own divisions it most nearly approached.

The black scutellum and non-aciculate petiole will distinguish it from all the other species of the present genus. The abdomen is so obtuse apically as to resemble that of Amblyteles oratorius, Fab.

Stephens says it was found uncommonly, at Coombe Wood, in June; but further proof is certainly needed before it should finally be included in our list, since it is not found in northern France or Sweden, and seems to range only from Belgium, through Germany to Piedmont. It would appear to be but little known, even on the Continent.

\section{CRATICHNEUMON, Thomson. ${ }^{1}$}

Thoms. O. E. xviii. (I893) I945.

Head not triangular, vertex broad, cheeks buccate and very short; epistoma separated from the face by parallel impressed lines, facial arch distinct and interrupted by an inter-antennal tubercle; clypeus subdiscreted, the apex often sub-dentate centrally; mandibles stout, a little narrowed towards their apices, compresso-dentate, the lower tooth somewhat remote from the apex; vertical orbits with a pale dot and the exterior in the of not uncommonly stramineous or red. Antennae stout, of $q$ more rarely attenuate apically, of of nearly the length of the body and internally sub-crenulate. Thorax not convex; metathoracic areola generally subquadrate, spiracles usually small, apophyses obsolete or wanting. Scutellum sub-deplanate. Abdomen somewhat depressed; post-petiole centrally smooth, sub-rugose, or more rarely' sub-aciculate, twice broader than its lateral areae; second segment with thyridii always transverse, neither oblique nor deeply impressed, occasionally circular; gastrocaeli generally

1 Ichneumon tibiator, Grav. (Mem. Ac. Sc. Torin, 1820, p. 284; I. E. i. I5I; Stc. Ill. MI. vii. I37, 8) should probably be referred to this genus-if, indeed, it be an Ichneumon, sensu Wesm., at all-but, although included in all the British catalogues since Stephens recorded it rarely from near London, in June, no author here nor abroad has adequately described it, and, since the Gravenliorstian description is quite useless and it is not included in modern European works, it were certainly better to consign this "species" to the limbo of forgottenness. 
obsolete with the intervening space not striolate, though occasionally rugose ; third segment with a depression, at least in $q$; anus of $\$$ immaculate, of $q$ more rarely with a pale-marked membrane. Legs robust, claws usually stout and curved; the of calcaria elongate; tibiae of $q$ often externally white-marked in the centre. Wings with apex of radial nervure very often arcuate, though scarcely sinuate.

Certain species of this genus, Thomson remarks, closely approach those of Eupalamus, but differ in the areolation of the metathorax and in the conformation of the post-petiole.

\section{Table of Species.}

(4). I. Frontal orbits and nearly the whole scutellum stramineous.

(3). 2. Coxae of $q$ with scopulae; abdomen of ${ }^{t}$ testaceous .........................

(2). 3. Coxae of $q$ with no scopulae ; abdomen of ot black

(I). 4. Frontal orbits and scutellum castaneous or black, latter rarely apically flavous.

(ro). 5. Mesonotum dull ; orbits and scutellum of $q$ red, its anus usually flavous.

(9). 6. Post-petiole scabriculous; anus of $q$ pale ; flagellum of to white-banded.

(8). 7. Gastrocaeli deep ; abdomen mainly black ; o scopulae wanting ............

(7). 8. Gastrocaeli superficial; abdomen rufescent ; + scopulae distinct .........

(6). 9. Post-petiole punctate; anus of $q$, and flagellum of $\hat{\delta}$, immaculate

(5). Io. Mesonotum shining; orbits and scutellum of $q$ not red, its anus not distinctly flavous.

(32). II. Size $8 \mathrm{~mm}$. or more ; coxae of $q$ with no cristulae.

(23). 12. Abdomen black, or at most badious.

(18). 13. Tibiae of o not broadly white externally ; flagellum of ot pale-banded.

(17). I4. Vertical orbits immaculate; coxae of $q$ scopuliferous.

(16). I 5. Post-petiole not centrally glabrous......

(15). 16. Post-petiole centrally glabrous .........

(14). 17. Vertical orbits pale-marked; coxae of of with no scopulae ...................

(13). 18. Tibiae of $q$ broadly white externally ; flagellum of $t$ not banded.

(20). 19. Coxae of $q$ with scopulae; of thyridii linear, its tibiae not white ............

(19). 20. Coxae of $q$ with no scopulae.

(22). 21. Radial nervure incurved; of thyridii circular, its tibiae not white .........

(2I). 22. Radial nervure straight; posterior tibiae of $t$ externally white............

(12). 23. Abdomen of $q$, and usually of $\delta$, castaneous or red.

(29). 24. Terebra less than one-third shorter than abdomen; of with neither flagellar band nor coxae white.

(26). 25. Coxae of $q$ with no scopulae ; t abdomen castaneous.........................

I. LUTEIVENTRIS, Gr.

2. SICARIUS, Grav.

3. RUBRICOSUS, Holm.

4. RUFICEPS, Grav.

5. RUFIFRONS, Grav.
6. NIGRITARIUS, $G r$.

7. LIOSTYLUS, Thoms.

8. Dissimilis, Grav.

9. FABRICATOR, Fab.

IO. ANNULATOR, Fab.

II. PALLIDIfRONS, $G r$.

12. Fugitivus, Grav. 
(25). 26. Coxae of $q$ with scopulae ; t abdomen flavous or black.

(28). 27. Tibial white band small and indistinct

(27). 28. Tibial white band large and conspicuous

13. CORUSCATOR, Limn.

(24). 29. Terebra at least one-third as long as

14. GRAVEnhorsti, Fonsc. the abdomen.

(31). 30. Frontal orbits of $q$ immaculate; flagellum of $\delta$ white-banded .............

(30). 31. Frontal orbits of $q$ red ; flagellum of $\delta$ immaculate, its coxae white .........

(11). 32. Size $7 \mathrm{~mm}$. or less; hind coxae of $q$ with oblique cristulae.

(34). 33. Anterior legs white; coxae multicristulate

(33). 34. Anterior legs red; coxae tricristulate

I 5. albilarvatus, $G r$.

16. LANIUS, Grav.

I7. VARIPES, Grav.

I8. MAGUS, Wesm.

\section{I. luteiventris, Grav.}

Ichneumon huteiventris, Gr. Mem. Ac. Sc. Torin, I820, p. 330, of; Wesm. Nouv. Mém. Ac. Brux. I844, p. 73 ; Thoms. Ann. Soc. Fr. 1887, p. 13; Berth. lib cit. I895, p. 265, of \&. Trogus luteiventris, Gr. I. E. ii. 386 ; Ste. Ill. M. vii. 272, o . Cratichneumon luteiventris, Thoms. O. E. xviii. 1946, o + . I. indictus, Tisch. Stett. Zeit. $1874, \delta$.

§. Head black; face, mouth and all the orbits pale; mandibles apically fuscous. Antennae nearly the length of the body ; black, fulvous beneath; first two joints black above and flavous beneath. Thorax gibbous, pronotum, usual lines near radix, flavous and somewhat elongate, sometimes with two reddish marks on the disc of the metanotum; areola transverse. Scutellum and post-scutellum flavous. Abdomen generally narrower than thorax, somewhat parallel-sided, testaceous, with first and base of second segments black ; apical segments also black; post-petiole smooth; gastrocaeli very shallow. Legs pale red; anterior coxae and trochanters flavous or stramineous; posterior coxae pale stramineous beneath, black with a ferrugineous mark above; the femora vary from mostly fulvous to mostly black. Stigma and tegulae testaceo-flavous.

q. Body stout, nigropiceous and cinereo-pubescent throughout. Head black; cheeks and temples slightly inflated; mandibles rufescent; clypeus with a lateral dot and central mark red, rarely entirely black; frontal, vertical and occipital orbits pale. Antennae stout, somewhat attenuate apically, with a white central band and red scape. Thorax with margin of pronotum, a callosity beneath the radix and a line below the scutellum, pale; areola sub-quadrate. Scutellum pale flavous, not convex. Abdomen with the post-petiole smooth bearing a few isolated punctures; gastrocatli obsolete; segments one to three or one to four sometimes reddish towards the apex ; the sixth sometimes pale-margined; seventh apically testaceous. Legs somewhat robust, anterior pairs flavescent, the femora generally apically, and tibiae partly, red; scopulae large and conspicuous. W'ings a little clouded; stigma pale fulvous; tegulae red-brown. Length, I $2-17 \mathrm{~mm}$.

The castaneous abdomen and flavous scutellum of the $q$, and the testaccous (except base) abdomen and for the most part rufo-testaccous legs of the $\hat{\delta}$, will at once distinguish this species.

It is widely distributed throughout central Europe. Gravenhorst took 
the male, among undergrowth, on September $\mathrm{r} 2$ th, and Wesmael saw it frequently throughout the summer around Brussels. Stephens says it used to be very rarely found around I,ondon and in Norfolk, in June and July, which latter record, however, Bridgman overlooks; Bignell has not found it in Devon though he has seen an example recently taken at Hollington, near Hastings ; and I do not know that it has ever been bred.

\section{2. sicarius, Grav.}

Ichneumon nigratorizes, Panz. F. G. Ixxiii. I2 ; I. ingratorius (sic), Gr. I. E. iii. 872, १. I. jugalus, Gr. I. E. i. 452, 8. I. sicarizs, Gr. lib. cit. 214, \&; Drews, et Boie, IVeigm. Arch. I836, p. 38 ; Wesm. Nouv. Mém. Ac. Brux. 1844, p. 74 ; Holmgr. Ichn. Suec. i. 155; Thoms. Ann. Soc. Fr. 1887, p. 15; Berth. lib. cit. 1895, p. 268, $\delta$ o. Cratichnemmon sicarius, Thoms. O. E. xviii. 1947, of 9.

q. Head black, all the orbits more or less whitish or ferrugineous, the vertical being broadly so ; face, mandibles and palpi reddish. Antennae filiform, white-banded. Thorax black, somewhat dull; pronotum and usual elongated marks near tegulae flavous ; metathorax scabriculous, with complete upper areae, of which the areola is sub-quadrate, slightly rounded basally and apically truncate. Scutellum and post-scutellum flavous, obsoletely punctate and only slightly convex. Abdomen fusiform, black; post-petiole sub-parallel-sided, entirely scabriculous with weak carinae; second segment also scabriculous, with the gastrocaeli sub-obsolete, punctiform; anus sometimes whitish; terebra very distinctly exserted. Legs black; anterior femora and tibiae more or less fulvous ; base of hind tibiae sometimes ferrugineous; hind coxae evenly and not very closely punctate, with no scopulae. Wings a little clouded; stigma and tegulae lighter or darker testaceous ; areolet narrowed above.

o. Head black, all the mouth parts and orbits, face and clypeus, whitish. Scape pale beneath. Thorax marked and sculptured as in $q$, with the addition of some white on the breast. Abdomen black, often with a whitish lateral dot on the first segment; the second and third with apical margin stramineous. Anterior legs whitish; hind ones black, with apices of coxae, mark on trochanters, tibiae towards base, apex of second and whole of third to fifth joints of the tarsi, white. Stigma piceous ; tegulae and radix white; areolet deltoid. Length, ro- $22 \mathrm{~mm}$.

Bignell has bred this species in S. Devon, from Teplirosia extersaria, and Marshall knew it as British. It is sometimes abundant in woods and fields, in Sweden, where Holmgren found it in cop., a rare occurrence to come under observation in the genus Ichneumon. On the Continent, where it is also found in France and Belgium, it has been bred from Fidonia piniaria and Lithosia rubricollis.

\section{3. rubricosus, Holmgr.}

Ichneumon personatus, var. I, Gr. I. E. i. 207, to (?). I. tenebrosus, Wesm. Nouv. Mém. Ac. Brux. I844, p. I03; cf. Brisch. Schr. Nat. Ges. Danz. 1878, n. 6, p. 46, \& (part). J. rubricosus, Holmgr. Ichn. Suec. i. 190; Thoms. Ann. Soc. Fr. 1887, p. I5; Berth. lib. cit. 1895, p. 556 , of $q$. Cratichneumon mbricosus, Thoms. O. E. xviii. 1948, of $q$.

Head scarcely narrowed posteriorly; of $q$ sub-quadrate when viewed from in front; red, with temples in part, occiput, a frontal and a facial 
mark, black; palpi pale ; of of sub-circular from in front, black, with palpi, mandibles, labrum, clypeus, face, frontal and genal orbits, stramineous. Antennae filiform, not attenuate, rufescent throughout or beneath ; first flagellar joint twice longer than broad, fifth quadrate; white-banded in both sexes; $\delta^{t}$ also has the scape flavous below. Thorax black, pronotum and humeral lines red in $q$, white in $\delta$; mesothorax dorsally red in $q$; metanotum scabriculous with three upper areae, of which the areola is usually semi-circular. Scutellum red, somewhat strongly punctate, or (in of) tricoloured. Abdomen black, with the anterior incisures often red; of with sixth segment usually margined, and seventh dorsally marked, with white; post-petiole scabriculous; gastrocaeli transverse and rather deep, the interrening space narrow and scabriculo-alutaceous; terebra shortly exserted. Legs normal; the anterior fulvous with coxae and trochanters piceous; hind ones black, with base of tibiae, which are externally finely canaliculate in $q$, and apex of tarsi, fulvous ; anterior coxae of $\delta$ white-marked, hind ones of $q$ with no scopulae. Stigma stramineous; tegulae rufous, or in $f$ white; areolet coalescent above ; radius externally straight, only slightly inflexed at apex. Length, 10-1 $2 \mathrm{~mm}$.

This species may be distinguished from $C$. tenebrosus, Wesm., with which it was for long confused, by the $q$ being smaller, having the head and mesonotum entirely rosy, the smaller metathoracic spiracles, larger thyridii and by the absence of scopulae on the hind coxae. In the $\delta$, the more strongly nitidulous abdomen, which is never rendered dull by silky pubescence, the thyridii being larger than the intervening space, will render it distinct.

Females taken at Kingussie, in coll. Cameron, named by Bridgman ( $c$. Trans. Ent. Soc. ISSI, p. I 44) ; one by Col. Yerbury, in August, at the Nound, Sutherland, in my collection (posterior legs unicolorous red). Holmgren says it occurs among undergrowth throughout Sweden, not infrequently, and that the male is of much rarer occurrence than the female. It is also found in France, Germany and Russia, but has never been bred.

\section{4. ruficeps, Grav.}

Ichneumon ruficeps, Gr. I. E. i. 633 ; Ste. Ill. M. vii. 206 ; Holmgr. Ichn. Suec. i. 192 ; Thoms. Ann. Soc. Fr. 1887, p. 15; Berth. lib. cit. I895, p. 555, \&. I. fucatus, Wesm. Bul. Ac. Brux. 1855, p. 45, ․ Cratichneumon ruficeps, Thoms. O. E. xviii. 1948, of ․

q. Head croceous, not narrowed behind, nearly as broad as the thorax ; face occasionally in part, and palpi, fuscous. Antennae filiform, stout, not attenuate ; with the first joint generally croceous, and a white central band. Mesothorax with the disc rosy; the pronotum, an elongated humeral line, and another below the tegulae, red; the metathoracic areae are finely delineated, the areola being sub-quadrate, hardly longer than broad, laterally slightly curved. Scutellum and post-scutellum red. Abdomen croceous or red, sometimes infuscate apically, with white marks on the sixth and seventh segments; terebra black; the post-petiole is finely coriaceous, without distinct carinae ; the gastrocaeli sub-obsolete, transverse-linear, with the intervening space narrow. The legs are entirely croceous, with the coxae somewhat fuscous and the hind tibiac subobsoletely canaliculate externally; hind coxae with distinct scopulae. 
Wings flavescent; stigma and tegulae fulvous; areolet narrowed above. Length, $8-10 \mathrm{~mm}$.

to is very similar to that of $C$. muffrons in coloration, from which it may at once be distinguished by the pale band on the upper side of the antemnae and by the thyridii being nearly twice as broad as the intervening space.

Stephens says, "Very rare ; found near London, in July." Bignell has bred it in S. Devon, on 1)ecember I 9 th, from Selcnia Munaria; Bridgnan did not find it in Norfolk; though recorded from Essex, it would appear to be of uncommon occurrence with us. Holmgren, however, tells us it is common in grassy places among undergrowth, in Sweden; it also occurs in Germany, Hungary and Russia, but has not there been bred.

\section{5. rufifrons, Grav.}

Ichneumon rufifrons, Gr. I. E. i. I39; Ste. Ill. M. vii. I34, ; Wesm. Nouv. Mém. Ac. Brux. 1844, p. 104; Holmgr. Ichn. Suec. i. I 57 ; Thoms. Ann. Soc. Fr. 1887, p. 15; Berth. lib. cit. 1895, p. 269, of o. I. pallidatorius, Gr. I. E. i. 196; Ste. Ill. M. vii. I45, 8. Cratichneumon ruffifrons, Thoms. O. E. xviii. I948, of $q$.

o. Head with the clypeus, face, mouth and generally all the orbits ivory-white. Antennae with scape generally whitish, and flagellum rufescent, beneath. Thorax with small marks below the scutellum, below and before the radix, sometimes also on the pronotum and the breast, white; metanotum with three upper areae of which the areola is semi-oval. Scutellum rarely entirely, usually at the apex only, white. Abdomen blackish, with the apex of the segments more or less castaneous; apex of segment two rarely whitish ; petiole very sparsely and obsoletely punctate, smooth; gastrocaeli and thyridii very small, linear and reddish. Legs slender; the anterior stramineous, with the coxae and trochanters white, upper side of the femora, and occasionally of the tibiae also, more or less fuscous; hind legs black, generally with the base of the femora, the coxae and apex of trochanters, whitish, as well as the base of the tibiae, the calcaria and more or less of the tarsi.

․ Head sometimes entirely, but usually with the orbits, face, labrum and mandibles, rufescent; palpi fuscous; face protuberant below antennae. Antennae filiform, with scape castaneous beneath; sixth joint quadrate, flagellum white-banded. Thorax badious or black; a small line below scutellum, a dot before the radix and the pronotum obscurely red; metathorax finely and evenly punctate; spiracles short; carinae subobsolete, costulae wanting; areola semi-oval, usually incomplete apically. Scutellum black or castaneous. Abdomen dull, ovate, fuscous or badious, with the incisures paler; petiole closely, finely and distinctly punctate; second segment alutaceo-punctate throughout; gastrocaeli obsolete; thyridii distinct, though small; terebra somewhat exserted. Anterior legs ochraceous, rufescent above, the coxae, which bear no scopulae, and trochanters black or badious; hind legs somewhat short and stout, blackish, with trochanters and femora before the apex, tibiae at the base, the calcaria, and base of tarsal joints, ferrugineous. Wings sub-hyaline; stigma and tegulae red; areolet sub-deltoid in both sexes. Length, 5-10 mm.

The absence of the scopulae, more shining mesonotum, which is 
generally black, and the slightly exserted terebra of the $q$, the paler colour of the anterior legs and the small red circular thyridii of the $\sigma^{*}$, will serve to distinguish this species from its allies. The of closely resembles those of $C$. sicarius and varipes.

Stephens, who thought the female should be referred to the genus Plugadeuon, on account of the slightly exserted terebra, found both sexes rarely at Darenth IVood, \&c., around London, in June and July. Bignell took it at Plym Bridge, in May, and at Bickleigh, in S. Devon, early in July. Mr. E. A. Butler has taken it at Highgate; Mr. Piffard, at Pateley Bridge, and Felden, in Herts.; Mr. Dalglish, at Cambuslang, in Lanark., at the end of June; Mr. Adams, at the end of June, in the New Forest. I have frequently found it in Bentley Woods, near Ipswich, at Brandon and Staverton, where it is not uncommon upon the undergrowth. It has been bred on the Continent, where it is found, not uncommonly, in woods and fields, from Lithosia rubricollis and Cidaria corylata, Thunb. (= ruptata, Hb.).

\section{6. nigritarius, Grav.}

Ichneumon migritarizs, Gr. Mem. Ac. Sc. Torin, I820, p. $28 \mathrm{I}$; I. E. i. I13, form. typ.; Ste. Ill. M. vii. I28, ठ̋; Wesm. Nouv. Mém. Ac. Brux. I844, pp. 68, 219 ; Bul. Ac. Brux. 1848 , p. 167 ; lib. cit. 1857 , p. 382 ; Ratz. Ichn. d. Forst. iii. I63 ; Holmgr. Ichn. Suec. i. 138, excl. \& ; cf. Ent. Tidskr. I880, p. 85; Thoms. Ann. Soc. Fr. 1887, p. II ; Berth. lib. cit. I895, p. 258, \& o . I. comitator, Ratz, Ichn. d. Forst. i. I34, cf. iii. I64, \&. Cratichnenmon nigritarius, Thoms. O. E. xviii. 1949, o o. Var. Ichnenmon aethiops, Gr. I. E. i. I30 ; Ste. IIl. M. vii. I32 ; Ratz. Ichn. d. Forst. iii. I66, ot. 1. annulator, var. 3 , Gr. I. E. i. 147 , excl. $q$ orbitis frontalibus testaceis, $\$$; var. $I$. annulator, var. I., Wesm. Nouv. Mém. Ac. Brux. I844, p. 67, ơ.

q. Head black; cribrary organs red; cheeks and temples somewhat inflated, angles of clypeus broadly rounded. Antennae incrassate, filiform, white-banded; the post-annellus longer than broad; fifth joint quadrate. Thorax stout, slightly nitidulous; mesothorax strongly punctate; areola sub-quadrate or slightly longer than broad, a little emarginate apically, its costae complete and well defined. Scutellum black, strongly punctate (var. Brisclikei, Berth., has scutellum and post-scutellum red). Post-petiole scabriculous, not smooth centrally, and somewhat broad; second segment very coarsely punctate, almost rugose at the base, not shining; thyridii and gastrocaeli not large though distinct; segments two to seven somewhat dull, gradually becoming more finely punctate towards the apex; basal segments black, or badious with the incisures paler; Wesmael says the seventh segment is often pale above. Legs black; femora stout, often red; hind tibiae with a narrow white half-band in the centre externally; tarsi black; hind coxae carinate, with small but distinct grey-haired scopulae; terebra hardly exserted. Wings a little clouded; stigma fulvous ; areolet narrowed above; radius externally a little inflexed.

o. Head black; palpi and mandibles rufescent; face black or with orbits white; vertex immaculate. Antennae black, rufescent beneath ; broadly banded with pure white. Thorax black, rarely white-marked at radix; areola sub-quadrate. Abdomen black, with anterior incisures or several segments rufescent; post-petiole finely aciculate, sometimes subrugose ; gastrocaeli sub-obsolete; segments two to six parallel-sided. Legrs for the most part black, hind tibiae rarely centrally red; Gravenhorst says anterior femora pale beneath, tibiae rufescent above, paler below; hind 
femora black, the tibiae sometimes rufescent towards the base. Length, Io- $14 \mathrm{~mm}$.

It may be distinguished by the rugosity of the second segment, black scutellum and distinct gastrocaeli from its allies; and from Thomson's C. pallitarsis by the fact that the tarsi are always black or fuscous.

The coloration of this species is very variable, and a large number of forms have been indicated. The of may have the facial orbits white, with which is sometimes, though not always, combined ( $\mathrm{I}$ ) entirely red femora, of which the hind ones may, or may not, be apically black; (2) a whitish mark on the front coxae; (3) a white line before the radix. In other specimens the tibiae are all mostly red, the anterior having an external pale dot before the base. There are two distinct forms of the $q$, that having the frontal orbits red or testaceous, which Gravenhorst confounded with $C$. anmulator; and that having the face in part obscurely red, with a pale mark on either side beneath the antennae, and the scape red beneath. Both sexes vary in having (I) the posterior femora partly red; (2) all the femora entirely red, which was Gravenhorst's I. aethiops, of, or (3) in having the scape of the antennae red or stramineous beneath.

It is a common species on the Continent and probably also in Britain. Curtis records it from near Covehithe, in Suffolk, and Stephens says it is not uncommon in woods and hedges, upon umbelliferous flowers, within the Metropolitan district, in June and July, and that the var. aethiops is also found, in July, in Norfolk, in which county Mr. F. Norgate has since found it at Sparham (Bridgman). Bignell bred it, in S. Devon, from Abraxas grossulariata; Desvignes from Taeniocampa miniosa; Stephens from Plusia gamma and P. festucae; while on the Continent, where the female is known to hibernate, many hosts are recorded, such as Eriogaster lanestris, Angerona prunaria, Macaria liturata, M. signaria, Fidonia finiaria, Clostera reclusa, several times from Trachea piniperda, and various unknown Noctuids. Guestling, near Hastings (Bloomfield); Scotland, I oth June, I900 (Dalglish); Felden, Herts. (Piffard); Parfitt, beat it from hedges, in Devon, in June ; and I have beaten it from young birch bushes, not rarely in Bentley Woods and Assington Thicks, Suffolk, early in June; it is also recorded from Essex.

\section{7. liostylus, Thoms.}

Ichnenmon liostylus, Thoms. Ann. Soc. Fr. I887, p. 12, o o. I. infidus, Berth. lib. cit. I895, p. 262 (? totus). Cratichneumlon liostylus, Thoms. O. E. xviii. 1950; xxi. 2402.

Black, antennae white-banded; $q$ with hind coxae distinctly scopuliferous, tibiae semi-annulated with white and the post-petiole centrally smooth and shining; of with the palpi, the sides of the face and of the clypeus, white.

This species is very like, and is closely allied to, C. fabricator, from which the $q$ differs in having the antennae less stout and the hind coxal scopulae a little smaller; the areola is a little longer but less definitely delmeated above. The sculpture of the abdomen and of the thyridii is similar to that of $C$. anmulator, but the central area of the post-petiole is twice broader than the lateral ones and, in both sexes, glabrous; the of differs from that of $C$. ammlator in having a three- or sometimes even 
five-jointed pale flagellar band, the face not entirely pale and the temples and scutellum black.

I do not venture to synonymize this species with Ichneumon infidus, WVesm., as Berthoumieu has seen fit to do, mainly because Thomson himself points out that the latter is a form of $I$. annulator, Fab. Holmgren included it under $I$. nigritarius, however, indicating $I$. anmulator, var. I, Wesm. Tent., ơ, as synonymous; and Thomson tells us his species is probably also referable to Wesmael's male, which differed from that of I. nigritarius in its much paler pubescence and laterally white clypeus.

Mr. IV. Evans sent me for examination two males on one pin which appear to be referable to this species, taken at Forest Mill, in Clackmannanshire, on 2 Ist May, Igor ( $c f$. Ann. Scot. Nat. Hist. I 902, p. 57).

\section{8. dissimilis, Grav.}

Ichneunon dissimilis, Gr. I. E. i. I90; Ste. Ill. M. vii. I44, excl. ơ ; Wesm. MIém. couron. Ac. Belg. 1859, p. 21 , \& ; Holmgr. Ent. Tidskr, 1880, p. 86; Berth. Ann. Soc. Fr. I895, p. 273, o o. I. zephy'rzts, Wesm. Bul. Ac. Brux. 1857, p. 389 , o. I. jocularis, Wesm. lib. cit. I 848 , p. 164 ; Holmgr. Ichn. Suec. i. 206, + . I. punctifrons. Holmgr. lib. cit. I4I, o. Cratichneumon dissimilis, Thoms. O. E. xviii. I950, of o.

१. Head with face centrally protuberant; angles of clypeus rufescent ; a line at the frontal and a dot at the vertical orbits, and sometimes on the cheeks, whitish testaceous. Antennae stout, white-ringed, not attenuate apically ; fourth joint quadrate ; scape rufescent beneath. Pronotum and callosity at radix red; metathoracic spiracles minute; areola semi-elliptic and nitidulous, basally rounded. Apex of scutellum castaneous or whitish. Abdomen sometimes with all the segments red-margined, the apical narrowly pale; post-petiole extremely finely aciculate, almost glabrous; gastrocaeli wanting; thyridii somewhat impressed, transverse-linear ; terebra as long as segments five to seven. Femora and tibiae red, the hind ones with no white markings, apically black; hind coxae without scopulae; hind tibiae finely ridged internally. Wings a little clouded; stigma flavous; tegulae red.

§. Finely punctate, rather nitidulous. Head black; vertex deeply emarginate ; mouth, clypeus, face, genal, and always a mark at the vertical, orbits, stramineous. Antennae elongate, black with whitish band on joints 14 and 15 only; scape sometimes with a testaceous mark beneath. 'Thorax narrower than the head; the pronotum, a dot before the radix and often the apex of the scutellum, flavidous; areola somewhat semi-circular, not longer than broad. Abdomen linear-cylindrical, black with second segment apically red ; petiole very elongate ; post-petiole conxex, quadrate, glabrous and shining; gastrocaeli very small. Legs long and very slender; femora and tibiae red, the hind ones darker towards the apex; anterior tibiae fulvous laterally in front, their coxae whitish; hind tarsi with the joints basally testaceous. Wings somewhat ample, hyaline; stigma piceous ; tegrulae and radix white; areolet sub-deltoid; radius a little inflexed at the apex. Length, 6-10 $\mathrm{mm}$.

The $o$ is smaller and more slender than that of $C$. fabriator. Thomson says the $\&$ may be known by its convex frons, dark red orbits, unicolorous tibiae, entirely pale flavous face and whitish scutellum; the of by the dense and very fine punctuation of its abdomen, and by the transverse thyridii, which are hardly narrower than the intervening space. 
Berthoumieu considers the typical of, which would appear to be $I$. zephyrus, Wesm., has no white antennal band, and that the banded form always has the face red, not stramineous-marked, and the post-petiole aciculate.

Colonel Yerbury has given me a female, which he took at The Mound, in Sutherland, on 8th August, 1900. This has the frontal orbits (as described by (Grav.) and vertical dots testaceo-rufous ; clypeus and mouth badious; upper lateral metathoracic areae glabrous with large, individual punctures and distinctly discreted by the costulae; scutellum black; abdomen, except anus, black with apical margins of the two basal segments, and the thyridii, castaneous; agreeing in other respects well with the above description; its contour is that of a small $C$. annulator.

Stephens says it has been taken rarely near London, and, he thinks, in Wiltshire, but it is doubtful whether much reliance may be placed upon his record. since Gravenhorst's male may have belonged to a distinct species. Neither Bridgman nor Bignell took it, and it does not appear to have been bred. On the Continent it ranges from France to Sweden, where it is not infrequent, in August.

\section{9. fabricator, Fab.}

Ichnemmon fabricator, Fab. E. S. ii. I66; Piez. 68, o; Gr. I. E. i. 185; Ste. Ill. M. vii. I43; Zett. I. L. 360 , o क (part.); Lab. und Imh. I. S. ii. 22, $\delta$; Wesm. Nouv. Mém. Ac. Brux I844, p. 69 ; Bul Ac. Brux. I848, p. I68, excl. varr. II et 12; Ratz. Ichn. d. Forst. iii. I69; Holngr. Ichn. Suec. i. I42; Thoms. Ann. Soc. Fr, IS87, p. 12; Berth. lit. cit. I\$95, p. 259, 3 o . Cratichneumon fabricator, Thoms. O. E. xviii. 195I. I. a'irsicolor, Gmel. S N. i. 2700. I. lencostoma, Gmel, lib. cit. $2702 . \quad I$. quadricolor, Gmel. lib. cit. 2702. I. maculifrons, Ste. Ill. M. vii. 133, o. I. fulvipes, Ste. lib. cit. I44, ó. I. Hartigii, Ratz. Ichn. d. Forst. i. I33; ii. I32, o. I. extinctus, Ratz. lib. cit. i. 133, of. iii. I64, \&. Var. 1. albifrons, Ste. Ill. M. vii. 144. I. im. pugnator, Wesm. Nouv. Mém. Ac. Brux. I844, p. 72, ठ. Var. I. spiracularis, Tisch. Stett. Zeit. I881, o. Var. (?) 1. dissimilis, Gr. I. E. i. 190, excl. ?.

o. Much more nitidulous, especially on the mesonotum, than the mbricosus group. Head black, palpi fuscous, labrum and mandibles generally red; temples and cheeks broad. Antennae short and very stout, central band white, the remainder black, piceous or dark ferrugineous beneath. Thorax immaculate, somewhat dorsally deplanate; metathorax finely scabriculous, with three well-defined upper areae; areola quadrate or slightly longer than broad. Scutellum black. Abdomen ovate, usually more or less castaneous; post-petiole broad, aciculate-alutaceous, carinae not elevated; second segment transverse, evenly punctate, shining; thyridii transverse, distinct; gastrocaeli nearly wanting, rugose; abdomen becoming smoother posteriorly; terebra somewhat incrassate, hardly extending beyond apex of seventh segment. Legs red, piceous or black; coxae and base of trochanters black; all the tibiae somewhat thickened and externally broadly white in the centre; hind tarsi and tibiae at the apex, or base and apex, blackish, sometimes red; the hind coxae are punctate beneath, and elevated longitudinally on the inner side, the elevation bearing a large, fuscous scopula. Radix, tegulae and stigma piceous; radial nervure very little inflexed at the apex.

§. Head black; palpi, mandibles and clypeus stramineous; cheeks very short; face either entirely flavous, flavous with black markings, or black with the orbits flavous; the frons black, its orbits being sometimes flavous; the exterior orbits, too, are very narrowly flavidous, but are always dis- 
creted at the vertex from those of the frons. Antennae not white-banded, fuscous, sometimes paler with the scape often flavidous below. Thorax somewhat elevated in front, black, and generally with the apex of the scutellum and sometimes also the usual lines near the radix flavidous; upper metathoracic areae sub-complete; areola sub-transverse and semilunar, its apex slightly emarginate. Abdomen black or blackish, thyridii and incisures of the anterior segments always rufescent; post-petiole broader than long, aciculate-alutaceous; second segment punctate, somewhat scabrous towards the base, longer than broad; gastrocaeli nearly wanting, but the thyridii distinct, sub-transverse, not rotund; abdomen becoming smoother posteriorly. Legs red, coxae and base of trochanters black, generally with the hind tarsi and apex of tibiae infuscate. Stigma usually pale testaceous; areolet narrowed above; radial nervure a little inflexed at the extreme apex. Length, ro-I $4 \mathrm{~mm}$.

This is an exceedingly variable insect, and for years $C$. annulator was supposed to be the genuine $q$, till Holmgren pointed out good and constant differences in $I$. curvinervis. The of may have the coxae with white marks, the antennae entirely black, the abdomen castaneous or even red with the base only black, or the hind femora may be apically or entirely black, which last is the form I. impugnator, Wesm. The $q$ varies less, though the apex of the scutellum is sometimes entirely pale, which, with a white face, constituted $I$. fulvipes, Ste., or, at others it has two pale spots; the second and third segments may be partly red, or the whole abdomen castaneous, with the base only black; and examples have been known with a pale mark on the seventh segment; lastly, both sexes may have the antennae entirely red towards the base.

The type of Stephens' $I$. maculifrons in the British Museum differs from the $f$ of of the above species only in having the face purple and its facial orbits, pale above ; the clypeus has pale lateral spots; the labrum is entirely white, and the mandibles and hind coxae are piceous. In his description, however, he says "face pale yellowish . . . . coxae black."

Some of its forms are extremely like other species, and great care is necessary to satisfactorily differentiate it, especially from the next-described species. The of may be known by the flavescent line at the external orbits, which is nearly always present; the absence of an antennal band and the generally white apex of the scutellum, as well as by its very short cheeks, the breadth of the post-petiole and the linear thyridii. The $q$ may be known by its posterior coxae, which bear on their inner side large scopulae, extending from the middle to beyond the apex; the more strongly arched thorax and sub-quadrate areola ; the breadth of the postpetiole, which is centrally aciculate, and the shining transverse thyridii. The apex of the radial nervure is in both sexes moreover only slightly incurved.

It is a common species throughout Britain, occurring in woods and meadows, from May to August; Bignell has reared it from Taeniocampat populeti; it has been bred, among a large number of other hosts, from Orgyia pudibunda, Macaria liturata, Notodonta dromedarius, Arylia putris, Trachea pimiperda, and Cymatophora or. The $q$ is said to hibermate among moss. Parfitt says $I$. maculifrons is very rare in Devon, but that an example with the antennae basally immaculate was taken near Eieter, in April ; the var. albifrons is recorded, together with the type form, from Essex. 


\section{Io. annulator, Fab.}

Ichneumon anmulator, Fab. L. S. ii. I5I ; Piez. 65, $\$$; Gr. I. E. i. 147, excl. varr. 2 et 3 ; Ste. III. M. vii. 137, \& (part.); Wesm. Nouv. Mém. Ac. Brux. 1844, p. 67 , ? excl. o; Thoms. Ann. Soc. Fr. I887, p. 12; Berth. lib. cit. 1895, p. 262, of \&. Cratichncumon anmulator, Thoms. O. E. xviii. 1957. I. culex, Miill. Prodr. n. 1797. I. clavipes, Gmel. S. N. i. 2688. I. tibialis, Fourcr. E. P. 407. I. viator, Schr. En., n. 715. I. nigritarius, Holmgr. Ichn. Suec. i. I38, \&. I. curvinervis, Holmgr. Sv. Ak. Ilandl. I 54 , p. 33 ; Ichn. Suec. i. 144, o $\%$.

ๆ. Slightly more shining than the last-described species. Head black, palpi testaceous, labrum red, and Holmgren says the clypeus also; marcin of the face between the antennae sometimes red-marked, frontal orbits always black; temples and cheeks broad. Antennae short and very stout, third joint quadrate; central band white, the remainder black; paler, with the scape red, beneath. Thorax immaculate, distinctly dorsally deplanate; metathorax somewhat coarsely scabriculous; areola sub-quadrate or broader than long, its costae being less distinct than in fabricator. Apex of the scutellum sometimes red. Abdomen ovate, black or badious, the anterior incisures rufescent ; post-petiole sub-glabrous, carinae not elevated ; second segment punctate; gastrocaeli nearly wanting; thyridii distinct; seventh segment often apically pale; terebra somewhat incrassate, very shortly exserted. Legs red, coxae and base of trochanters black or fuscous, all the tibiae somewhat thickened and externally broadly white in the centre; hind tibiae, except centrally, and tarsi fuscous or red; hind coxae punctate throughout and not scopuliferous. Wings in both sexes sub-hyaline; areolet sub-deltoid; stigma fulvous; radial nervure externally decidedly inflexed at the apex.

§. Head black; palpi, mandibles, labrum, clypeus and face entirely stramineous; cheeks so short as to be almost wanting; exterior orbits usually pale-marked. Antennae with no white band, fuscous; paler, with the scape pale flavous, beneath. Thorax black, moderately elevated in front, a dot before the radix rufescent; apex of the scutellum usually flavous, sometimes entirely black; upper metathoracic areae incomplete; areola a little broader than long, sub-lunar, apically truncate. Abdomen badious or blackish, anterior incisures and thyridii ferrugineous; postpetiole sub-quadrate, centrally very nearly smooth; second segment punctate; gastrocaeli nearly wanting; thyridii distinct, sub-rotund, much less linear than in fabricator. Legs pale red, the coxae and base of trochanters black, generally with the hind tarsi, and sometimes the apex of the tibiae infuscate. Length, 5-8 $\mathrm{mm}$.

This species appears to vary much less than the preceding, to the typical forms of which it bears a most confusing similarity, especially in the sculpture and brilliancy of the abdomen ; both sexes are, however, always smaller and the extremity of the radial nervure is more incurved. The $q$ may instantly be known by the absence of the scopulae on the hind coxae, as well as by the thicker flagellum, the post-annellus which is hardly longer than broad, and by the apex of the clypeus and scape of the antennae beneath being dark red. In the of the post-petiole is sub-quadrate, and nearly smooth centrally, the face entirely pale, and the cheeks hardly visible, the tegulae are not pale and, above all, the thyridii are ovate-rotund and not linear.

I am of opinion that this species is commoner in Britain even than 
C. fabricator; it occurs everywhere, from May to August. Abroad it has been bred from Macaria liturata and (? Fidonia) piniaria and from Noctua piniperda. The $q$ is said to hibernate.

\section{II. pallidifrons, Grav.}

Ichnenmon pallifrons, Gr. I. E. i. I17 ; Ste. Ill. M. vii. I29, excl. §; Wesm. Nouv. Mém. Ac. Brux. 1844, p. 70 ; Holmgr. Ichn. Suec. i. I46; $c f$. Thoms. Ann. Soc. Fr. I887, p. 13 ; Berth. lib. cit. I895, p. 263, of o. I. anmulator, var. 3. Gr. I. E. i. I49, \& (excl. $q$ orbitis nigris). Cratichnezmon pallifrons, Thoms. O. E. xviii. 1952, o $\&$.

q. Head black, with the apex of the palpi and the labrum whitish; mandibles occasionally partly red; the margin of the clypeus and the frontal orbits always red; temples and cheeks broad. Antennae filiform, blackish with a pale band; the first joint of the flagellum twice longer than broad, seventh quadrate. Thorax black throughout; metathorax rugulose, with the areola rectangular, slightly longer than broad. Scutellum black. Abdomen black or badious, with the incisures of the segments rufescent, and the seventh generally whitish at the apex ; central area of the post-petiole usually distinctly aciculate; second segment somewhat rugosely aciculate at the base; the thyridii distinct, superficial, the intervening space broader than the central area of the post-petiole; terebra stoutish, very slightly exserted beyond the apex of the abdomen. Legs mostly rufescent, femora often darker and sometimes black; the tibiae externally white in the middle, the hind ones fuscous at base and apex; the posterior coxae remotely punctate, without scopulae. IVings a little clouded; stigma rufous.

t. Head black, with the palpi, clypeus, face and a line at the external, and sometimes the frontal, orbits pale. Antennae blackish, paler with the scape white beneath; pale central band wanting. Thorax sub-convex in front; the usual markings near the radix whitish; metathorax rugulose, with the areola short, transverse and the costulae traceable. Scutellum black, very rarely with two apical dots or the whole apex white. Abdomen black, or piceous, with the thyridii and anterior incisures rufescent ; central area of the post-petiole more or less rugosely aciculate; second segment rugosely aciculate or striate basally; gastrocaeli superficial and striate; thyridii transverse and narrow. Legs red, femora darker; coxae and trochanters black, anterior coxae sometimes white-marked; all the tibiae externally whitish-flavous in the centre; hind calcaria ferrugineous or dirty white. Stigma ferrugineous. Length, 8-I $4 \mathrm{~mm}$.

This species is readily distinguished by the characters given in the table: the tibiae in both sexes are externally broadly white, which character, in the $\sigma^{*}$, is peculiar to this species, and the radial nervure is not abruptly incurved as in $C$. annulator; the of has the frontal orbits dark red, no coxal scopulae and the post-petiole more or less distinctly aciculate ; the 0 has the face, clypeus, and generally the frontal and vertical orbits, pale; thyridii distinct and linear; the gastrocaeli and intervening space rugose.

Stephens, whose female, however, is not referable to this species, found C. pallidifrons not very common about London and in Shropshire. Neither Bridgman nor Bignell appear to have met with it personally; though it is recorded from Essex. It has been bred in Germany from the much parasited Trachea piniperda. It occurs in grassy places, undergrowth in woods, gardens and meadows, not uncommonly, on the Continent. 


\section{2. fugitivus, Gruv.}

Ichnenmon fugitivus, Gr. I. E. i. 552 ; Ste. Ill. M. vii. I96, of ; $c f$. Wesm. Bul. Ac. Brux. I857, p. 383 et Thoms. Ann. Soc. Fr. I887, p. 12 ; Berth. lib. cit. 1895, p. 266, of. Cratichneumon fusitivus, Thoms. O. E. xviii. 1952, o \&. I. pyrrhopus, Ste,

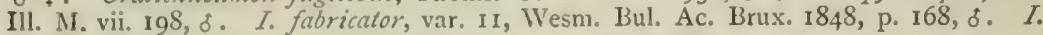
rutilus, Holmgr. Ichn. Suec. i. 152, $\delta$ \&.

ๆ. Head black, buccate, and very finely punctate; palpi testaceous; mandibles and clypeus red; frontal orbits castaneous. Antennae stout, moderately attenuate apically; blackish, often paler beneath, with the central joints white at least abore; first and second joints quadrate. Thorax entirely black, shining; metathorax scabriculo-punctate; areola somewhat semi-circular, its apex truncate; the upper lateral areae subconfluent. Abdomen red, the first segment except its apex black, punctate, post-petiole centrally smooth; second segment broader than long, punctate, gradually narrowed towards the base; gastrocaeli minute, oblique; intervening space broader than central area of post-petiole; terebra black, very shortly exserted beyond the apex of the seventh segment. Legs stout, red; coxae and trochanters black; anterior femora sometimes laterally fuscous, tibiae spinulose apically; hind legs blackish, base of tibiae broadly red, coxae very smooth beneath, sparsely punctate, with no scopulae. Wings a little clouded; stigma fulvous.

t. Head with variable pale markings, generally with the internal and external orbits, two dots beneath the antennae and the mouth flavous, a mark in the centre of the clypeus and the base and apex of the mandibles black. ${ }^{1}$ Antennae elongate, black, not white-banded; the scape flavous beneath. Thorax and scutellum entirely black, or with rufescent markings at radix; areola semi-lunar. Abdomen nitidulous, red or castaneous, paler apically; petiole black, more than half the width of the post-petiole, which is smooth; second segment black, apically castaneous; gastrocaeli small, oblique. Anterior legs pale red, femora laterally convex within, and tarsi partly fuscous; hind legs black, femora somewhat stout, tibiae ferrugineous towards the base. Length, 8-I I mm.

The points to be especially noted are, in the $o$, the dark red frontal orbits, the attenuate apex of the antennae, castaneous abdomen with black base, the stout legs with no white markings and with the hind coxae sparsely punctate and not scopuliferous; in the $\delta$, the castaneous abdomen with black base, the sub-quadrate post-petiole, the distinct but not broad thyridii, the flagellum dark fuscous below, scutellum and tegulae black, and the pale line at the posterior orbits which is dilated towards the mouth.

This species, originally considered distinct, was for long confused with C. fabricator by Wesmael, with whom Bridgman agreed in considering it a mere variety, in $\mathbf{1} 8.4$. He, however, 17 years afterwards, thought it sufficiently constant to claim specific rank, to which it has since been raised by Thomson. As Mr. Bignell has pointed out to me, fatricator has indistinctly three upper areae and fugitivus distinctly five, in the $\delta$, which may be a constant character.

Hope found it at Netley; Stephens took it near London, in the middle of June, and in Shropshire; Bignell has taken it at the end of August and

1 Berthoumieu (Mon. Ich. d'Europe, 249) says the $\delta$ differs from that of C. fabricator, var. ferrugineus - presumably a mythical though comprehensive form-mainly in the flavous external orbits of the eyes, "tandis que, chez $I$. fabricator, il n'y a qu'une linéole aux orbites des temples." But under fabricator $\delta$, he says, "orbites externes des yeux avec un petit trait jaune." Holragren says of I. rutilus $\delta$, "lineola vel puncto ad orbitas externas pallide stramineis." 
beginning of September at Mount Edgcumbe, and in Cann Wood, in Devon; Beaumont at Lewisham, Boxhill and Oxshott ; Hamm at Reading; Sladen bred it from an unknown host at Watford, in May; Bridgman found the of at Norwich, and Mr. F. H. Peachell has sent it to me, bred on 2oth April, from Taeniocampa gothica pupa, found at a poplar, near High Wycombe, Bucks.; Mr. Adkin has bred it from Retinea pinicolina and Rannoch Eupithecia helveticata; I have examined a male of this species in the British Nuseum, labelled "From Orthosia instabilis," and have captured examples at Lyndhurst and Ipswich.

\section{3. coruscator, Linn.}

Ichnenmon corruscator, Linn. F. S. 402 ; Gr. I. E. i. 133 ; Ste. Ill. M. vii. 133, ơ ; IVesm Nouv. Mém. Ac. Brux. IS44, p. 7 I ; Bul. Ac. Brux. I848, p. 170 ; Berth. Ann. Soc Fr. I895, p. 265, of \&. I. gasterator, Ste. Ill. M. vii. I99; of. Morl. E. M. M. I902,

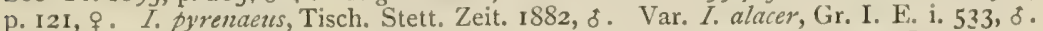
Var. I. huridus, Gr. I. E. i. 406 ; Ste. III. M. vii. I80; I. binotatus, Desv. Cat. 23, $\delta$.

†. Head strongly punctate, a little narrowed behind the eyes, black; mandibles frontal orbits, and rarely the margin of clypeus, red, the last with a few scattered punctures. Antennae filiform, stout, fourth joint quadrate; white-banded. Thorax black, strongly punctate; areola longer than broad, sub-hexagonal. Scutellum apically red. Abdomen red throughout, with petiole more or less black basally; post-petiole glabrous and shining, sometimes obsoletely aciculate; gastrocaeli sub-obsolete; terebra exserted. Legs stout, black; anterior coxae and femora sometimes piceous, their tibiae laterally red; hind tibiae not or hardly whitemarked, and hind coxae with normal scopulae. IVings a little clouded, stigma and tegulae red or piceous.

๙. Body slender and shining. Head black; palpi and mandibles partly red ; clypeus, face laterally only, frontal and external orbits, flavous ; clypeus slightly rounded in front. Antennae elongate, black, paler with scape usually flavous below ; not centrally white-banded. Thorax entirely black; areola semi-hexagonal. Scutellum convex, black, or apically flavous. Abdomen shining, black, with short silky pubescence ; segments two and three sometimes red-margined; ventral surface flavous; postpetiole narrow, glabrous, shining; gastrocaeli nearly wanting. Legs black; anterior tibiae beneath, and hind ones at the base, flavidous or red. Length, 8-14 $\mathrm{mm}$.

There are two well-marked of varieties of this species, which so materially differ from the type as to have been described as distinct.

Var. alacer differs in having the mouth, face, scape beneath and apex of scutellum testaceous; segments two and three testaceo-rufous, often with more or less infuscate dorsum; the anterior femora fulvous, black above ; tibiae testaceous, hind ones apically black. This is the commonest form in Britain.

Var. luridus has the face, pronotum, callosities at radix, marks on, or often the whole of, metanotum flavous; scutellum and post-scutellum pale; abdomen flavous, with petiole and segments five or six to seven black; anterior legs fulvous, hind ones black, with basal half of tibiae flavous.

[I. gasterator, Ste., $q$. Black, shining, punctate. Head smoothly and thickly punctate, shining, buccate, black, dilated behind the eyes; mouth 
parts reddish, palpi fuscous, mandibles red, with a long upper and an almost obsolete lower tooth; face strongly punctate, frontal orbits indistinctly reddish, clypeus anteriorly slightly rounded. Antennae stout, very slightly attenuate apically, joints transverse; black, white-ringed. Thorax entirely black, punctate; metanotum finely rugulose, with five faintly defined areae, of which the areola is elongate and apically sinuate; spiracles elongate; mesosternum not divided from the mesopleurae by a sulcus. Abdomen elongate-ovate, red, glabrous and shining; petiole black; gastroraeli nearly obsolete; paler below, with fold on segments two to four ; terebra only slightly exserted. Legs thick, stout, similar to those of Stylocryptus; coxae and femora piceous or black, tibiae and tarsi more or less reddish ; anterior femora at apex within, and anterior tibiae apically, rufescent; colour of hind tibiae variable; hind coxae finely punctate, distinctly scopuliferous. IVings with the areolet pentagonal, stigma and nervures fulvous. Length, 8-10 $\mathrm{mm}$.

I do not personally know the $q$ of Holmgren's I. rutilus, but the above description of $I$. gasterator agrees so exactly therewith, bearing moreover so strong a resemblance to a large $q$ Phygadeuon, as to justify the former's remark, "forsan ad familiam Cryptorum referri posset," that I should have considered them synonymous were it not that the latter bears distinct scopulae, thus leaving little doubt that it is referable to the present species. There are two females in the British MIuseum, from which I independently took the above description. Stephens says, "taken, not uncommonly, near London," and Marshall adds that it has been bred from Depressaria heracliella, in Devonshire.]

[I. binotatus, Desv. (nec Ste.), is a form of var. Iuridus. Head black; clypeus, face and external orbits flavous; frontal orbits not pale. Antennae porrect, length of the body; scape with a basal flavous mark beneath. Thorax black, with margin of mesonotum narrowly flavous; metanotum scabrous, with complete upper areae, of which the areola is transverse; spiracles large. Apical half of scutellum flavous; abdomen glabrous and polished (as in Colpotrochia) ; post-petiole smooth, apex of first to base of third segments flavous, second with two black dots on the disc; apex of third to seventh segments black. Anterior legs with femora and tibiae externally piceous, apex of former and latter within stramineous ; tarsi flavous; hind legs piceous-black, tibiae with basal third flavous beneath; tarsi fuscous. Wings with stigma and costa fuscous; tegulae testaceous. Length, $8 \mathrm{~mm}$.

There is one specimen of Desvignes' species and one of his variety, which has the second segment infuscate basally, the gastrocaeli striated and the abdomen narrower than that of his type, in the British Nuseum.]

This is probably a southern species; I know of no records north of Suffolk, and, since it is not recorded from Sweden, it probably does not occur in Scotland. It is said to be abundant near London, in June and July, the var. luridus being scarcer; it has been taken early in August, at Bickleigh, in I)evon, Taunton and Bentley Woods; in May, in the New Forest, as well as at Guestling; Parfitt says it occurs on flowers, near woods, in Devon, in June. In the British Museum is a typical male bred "from Orthosia miniosa." It has been bred on the Continent, where it has a wide distribution, from Agriopis aprilina and Noctur rustica (=Agrotis nigricans). The $q$ appears to be much rarer than the $\delta$. 


\section{I4. Gravenhorsti, Fonsc.}

Ichnezmon Gravenhorsti, Fonsc. Ann. Soc. Fr. 1846, + ; Berth. lil. cit. 1895, p. 26 I, १ (? ठ). I. fabricator, varr. 12 et ? II, Wesm. Bul. Ac. Brux. 1848, + . I. granticeps, Thoms. Ann. Soc. Fr. 1887, p. I3, + . Cratichneumon grandiceps, Thoms. O. E. xviii. I953, + .

This o very closely resembles $C$. fabricator, especially in the puncturation of the posterior coxae, but differs therefrom in the head, which is distinctly longer behind the eyes, the slightly stouter antennae, of which the second joint of the flagellum is quadrate, and in the red abdomen, the base of which alone is black. In structure, size and colour it is very similar to $C$. fugitivus, from which the hardly attenuate antennal apex, short post-annellus, which is scarcely longer than broad, all the tibiae semiannulated with white, and the large and conspicuous coxal scopulae, will distinguish it.

Berthoumieu describes a of as doubtfully appertaining to the present species. It has the mandibles red, the palpi white; clypeus, face, frontal and dots at external orbits, lines before and beneath the radix and sometimes two large oval dots on the scutellum, flavidous-white. The scutellum is, perhaps accidentally, canaliculate throughout longitudinally. Clypeus apically truncate with a little tooth in the centre. Antennae piceous, ferrugineous beneath. Areola transverse, hexagonal, and apically emarginate. Stigma and tegulae fulvous. Legs black; anterior femora, tibiae and tarsi red. Abdomen elongate-elliptic, broader than that of $C$. fabricator, with the post-petiole finely rugose-aciculate centrally; segments two to seven, and the first apically, red more or less infuscate dorsally. Length, 9-I $2 \mathrm{~mm}$.

That the present insect is more than a variety of $C$. fabricator is certainly improbable, the only good character appearing to be the posterior conformation of the head.

It is doubtless common but mixed with its allies in Britain, whence it has not previously been recorded. Miss Chawner has taken examples in the New Forest with both red and black hind legs; Doctor Wratislaw captured it near Bury St. Edmunds; and I have found it on flowers of Heracleum spondylium and in gardens at Lyndhurst from 7 th to $23^{\text {rd }}$ August. It was extremely likely to occur with us, since it has been recorded from southern Sweden and France.

\section{I5. albilarvatus, Grav.}

Ichneumon albilarvatus, Gr. Mem. Ac. Sc. Torin, I820, p. 352 ; I. E. i. 563 , ơ ; Ste. Ill. M. vii. 198; Wesm. Nouv. Mém. Ac. Brux. I844, p. I06; Thoms. Ann. Soc. Fr. 1887, p. 16 ; Berth. lib. cit. 1895, p. 280, o \&. Cratichneumon albilarvatus, Thoms. O. E. xviii, 1953, o 오.

q. Head black with the frontal orbits black and a dot at the facial orbits near the antennae pale red, flavescent, or sometimes wanting. Antennae stout, filiform, hardly attenuate towards the apex, with a white band. Thorax stout, black; Wesmael describes the metathoracic spiracles as somewhat short and elliptic, but Thomson (in Ann.) says they are large and oval; upper lateral areac sub-discreted; areola semi-oval, apically strongly bordered. Scutellum red, black with the disc reddish, or entirely black, sometimes with a red line behind it. Abdomen oblong-ovate, entirely red with the first segment only black; the post-petiole is centrally 
punctate-scabriculous, and the gastrocaeli almost wanting; the terebra is one third the length of the abdomen. Legs black; front femora and tibiae dirty red somewhat infuscate externally, the intermediate rufescent or fuscous, and the hind ones black. Wings a little clouded; stigma red.

d. Head with the clypeus, face and mouth-parts white; apex of the mandibles black. Antennae sub-nodulose, black above, with an entire white central band; remainder of flagellum sometimes ferrugineous beneath; scape beneath white. Thorax black; areola transverse, semihexagonal ; metathorax short, apically sub-bidentate; spiracles similar to those of $q$. Abdomen narrower than the thorax; petiole black, with distinct carinae ; post-petiole centrally rugulose ; from the apex of second segment, whose gastrocaeli are almost absent, to the fifth or sixth is more or less red, the remainder becoming darker to the apex; or, rarely (var. oliscurior, Berth.), the abdomen black, with the margins of the segments castaneous. Legs black; the anterior pairs being more or less red. Length, $10-12 \mathrm{~mm}$.

The $q$ may be known by the coarsely punctate post-petiole and immaculate frontal orbits; the $\delta$ by its black thorax and head, the latter having the face and clypeus white, and by its broadly white-banded flagellum.

This would appear to be an uncommon, though widely distributed, species on the Continent, and Bridgman did not meet with it in Norfolk; Stephens, however, records the of from Scotland, Shropshire and Darenth Wood, in June, "apparently scarce"; it is probably commoner in the south of Britain. Bignell has taken this species at Ivybridge, in Devon, on 2 oth May; it has not been bred.

\section{I6. lanius, Grav.}

Ichneumon lanius, Gr. I. E. i. 499 ; Ste. Ill. M. vii. I92, ơ; Wesm. Nouv. Mém. Ac. Brux. 1844, p. I05; Holmgr. Ichn. Suec. i. I58 ; cf. Bridg. Tr. Ent. Soc. I881, p. I52; Thoms. Ann. Soc. Fr. 1887, p. 16 ; Berth. lib. cit. 1895, p. 279. Cratichneumon lanizus, Thoms. O. E. xviii. 1953, o o. Phygadenon terminatorizes, Gr. I. E. ii. 663, $q$.

q. Head black ; palpi, mandibles, two marks on or whole of clypeus, the frontal and sometimes the vertical orbits, red. Antennae somewhat stout, filiform throughout, and centrally white-banded, generally with the scape red below. Thorax with a callosity before the radix, and generally a line below the scutellum, red; metathorax somewhat scabriculous, with only three upper areae, of which the areola is semi-circular and apically incomplete; spiracles short, elliptic. Scutellum apically red. Abdomen red, with the first segment except its apex black; central areae of postpetiole finely and very closely punctate; second segment closely punctate with obsolete gastrocaeli; terebra one-third to two-fifths the length of the abdomen. Anterior legs red, the femora somewhat darker and the coxae sometimes black; hind ones fuscous, tibiae becoming ferrugineous towards their base; tarsi sometimes with their onychii red. Stigma and tegulae red.

o. Head black; palpi, labrum, clypeus, cheeks, face and frontal orbits, white. Antennae not pale-banded; scape white, and funiculus fulvous, beneath. Thorax black, with usual marks at the radix, generally the sides of the pronotum and two large pectoral marks, white; the metathorax 
is somewhat scabriculous, the areola semi-circular and incomplete apically; the spiracles short, elliptic. The apex, or more rarely the whole apical margin, of the scutellum, white. Abdomen red with the first, the basal two-thirds of the second, and often an obscure discal spot on the remaining segments, more usually on the apical ones, black; the postpetiole is remotely punctate or nearly entirely glabrous; gastrocaeli obsolete, red, closely punctate. The anterior legs are fulvous; the hind ones black, with the base of the tibiae and femora and the apex of trochanters more or less red; all the coxae usually white-marked beneath. WVings a little iridescent; stigma piceous; tegulae and radix white. Length, 8-io $\mathrm{mm}$.

This species may at once be distinguished from the preceding by the $f$ having the frontal orbits always red, and the of no pale antennal band; the metathoracic spiracles also are smaller, the apex of the scutellum is white in the $\delta$, red in the $o$, which latter has the post-petiole more finely punctate and shining, and the $\delta^{*}$ has much more white marking on its head, thorax and legs.

The of appears to be of much more frequent occurrence than the $q$, which Gravenhorst placed under a distinct name in the genus Phy gadenon, on account of its exserted terebra. The former I have beaten from oak trees, in Bentley Woods near Ipswich, and from young birches, in Assington Thicks, in May, and Tuck took it on Chaerophyllum flowers, at Bury St. Edmunds, on 5th June; Stephens says it is common about London, and that it has been found in Salop, \&c. ; Hope took it at Netley. Bignell captured this species at Plym Bridge, and it is also said to have occurred at Alphington in Devon, on May 20 th ; Beaumont has found it at Lewisham, early in June; Bridgman says it is not uncommon around Norwich, and it is recorded from Essex. I do not find that it has ever been bred.

\section{I7. varipes, Grav.}

Ichnezumon varipes, Gr. I. E. i. 444, ठ ; Wesm. Nouv. Mém. Ac. Brux. 1844. p. 72 ; Holmgr. Ichn. Suec, i. I49; Berth. Ann. Soc. Fr. I895, p. 229, of . Cratichneumon varipes, Thoms. O. E. xviii. I954, $\delta$ \&. I. laevis, Ratz. Ichn. d. Forst. i. 132, ii. I31, iii. 162, 8. Var. I. decimator, Gr. I. E. i. 503, ‥

ๆ. Head black, palpi white; mandibles, labrum, clypeus, apex of the cheeks, centre of the face and its margin below the antennae, fulvous; orbits pale near antennae. Antennae stout, filiform, attenuate towards base, blackish ; the basal joints rufescent, at least below, and the central band white. Thorax black, with callosities at the radix fulvous; metathorax with complete upper areae, the areola being semi-circular, the petiolar area concave. Apex of scutellum yellowish-white. Abdomen very smooth, blackish ; second segment with mark before base and apical margin red; the remainder badious, apically red, the seventh is said to be entirely dirty yellow above; post-petiole smooth and shining; second segment strongly punctate at the base, with distinct transverse thyridii and obsolete gastrocacli ; terebra only just exserted beyond the seventh segment. Anterior legs stramineous; the hind ones have the coxae black with their apices and the trochanters stramineous, femora stout and red, becoming darker apically, tibiae pale flavous or whitish, rufescent apically; tarsi red-yellow; hind coxae with many elevated oblipue lines (cristulac) beneath. Wings sub hyaline, stigma fulvous, tegulae red. 
đ. Head black; palpi, mandibles, labrum, clypeus, cheeks, face, frontal and external orbits flavous or white. Antennae beneath vary from fuscous to red, always with the scape white; central band absent. Thorax black, a little elevated in front; normal marks near radix, two pectoral vittae, sometimes the margin of the pronotum and a line or two dots below the scutellum, whitish. Scutellum entirely or only at the apex white. Aldomen black, with the incisures often more or less stramineous; sculpture of the first and second segments as in $q$. Legs whitish stramineous; anterior coxac and trochanters always white; posterior femora somewhat stout, fulvous, apically black, tibiae white with black apex, tarsi black with the base of the joints generally white. Length, 4-7 $\mathrm{mm}$.

Both sexes may be known by their nitidulous surface and the extent of the white markings, the $q$ by the peculiar structure of the hind coxae and the punctured base of the second segment, and the of by its transverse thyridii, which are broader than the intervening space.

This species occasionally varies slightly in colour: the of sometimes has the hind coxae and femora nearly entirely black, and the $q$ has the apex of the scutellum red, instead of yellowish or white, and this variety constituted Gravenhorst's $I$. decimator; or the markings paler, with the apical margins of the segments stramineous.

Mr. Bignell has taken this species, which Stephens did not know as British, at Plym Bridge, on September $24^{\text {th }}$; it is recorded from Essex; and I have once found it in the Bentley Woods, in the middle of June. It ranges throughout the whole of Europe, where it has been found at the beginning of July, among undergrowth. It does not appear to have been bred.

\section{I8. magus, Wesm.}

Ichneumon magzis, Wesm. Bul. Ac. Brux. 1855, p. 389 ; Holmgr. Ichn. Suec. i. I48; cf. Bridg. Trans. Ent. Soc. 1886, p. 336 ; Berth. Ann. Soc. Fr. 1895, p. 270, $\delta$ \% Craticlneumon magus, Thoms. O. E. xviii. 1954, o o.

†. Head black; mandibles and apex of clypeus red; cheeks and temples inflated, sparsely punctate. Antennae stout, filiform; ferrugineous beneath throughout, excepting the central white band; fifth joint quadrate. Thorax black; metathorax punctate-scabriculous, with complete upper areae ; areola sub-transverse and apically emarginate. Apex of scutellum and post-scutellum red. Abdomen piceous ; post-petiole at the apex red and smooth, very finely punctate centrally before the apex; second and third segments with the incisures rufescent, the former with obsolete gastrocaeli; terebra only just exserted beyond the apex of the seventh segment. Anterior legs stout, red, with base of coxae piceous; the hind ones stout, dark piceous, tarsi and tibiae red, the latter darker apically; hind coxae with three elevated oblique lines (cristulae) benenth. Wings a little clouded; stigma and tegulae ferrugineous; areolet narrowed above.

đ. Head black; palpi, mandibles, clypeus, inner orbits and various central markings of the face, flavous. Antennae apically ferrugineous, with flavous mark on the scape beneath. Thorax black, somewhat convex in front ; the sculpture of the metathorax as in the $q$. Abdomen black, the thyridii and apical margin of second and third segments being rufescent; the sculpture of the post-petiole is like that of the $q$, the second with obsolete gastrocaeli, and the thyridii distinct. Anterior legs red with 
coxae and trochanters black; hind ones black, with apex of trochanters, base of femora, tibiae and tarsi reddish. Length, 5-7 $\mathrm{mm}$.

The formation of the hind coxae at once distinguishes the $q$, which is in other respects like that of $C$. anmulator, excepting in the colour of the tibiae ; the $\delta$ is also like that of $C$. annulator, but may be known by the colour of the legs, the longer cheeks, larger thyridii, and the entirely black occipital orbits and hind femora. The of differs from that of $C$. fabricator in the immaculate external orbits, the darker stigma, black posterior femora and obsolete gastrocaeli.

This species, which is one of the smallest of Wesmael's genus Iinnenmon, was introduced as British by Bridgman on the strength of three females bred by Mr. IV. H. B. Fletcher, from Paedisca solandriana, at Rannoch. These specimens, curiously enough, differed from the continental ones in having the hind femora dark red instead of blackish, though in one they were centrally fuscous; the abdomen, too, was rather paler than those described by Wesmael and Holmgren. It is only found on the Continent in Holstein, Russia and Scandinavia, extending to Lapland.

\section{EUPALAMUS, Wesmael.}

Wesm. Nouv. Mém. Ac. Irux. I844, p. I3; Thoms. Ann. Soc. Fr. IS86, p. II.

This so closely resembles the type genus that Holmgren and Marshall forebore to recognize its individuality, but Thomson has given to it the following characters, of which a careful study is necessary :-

The cheeks in $q$ short, sub-buccate, with a broad impressed sulcus, in of very short, the genal costa nearly continuous, very slightly inflexed; mandibles stout, sub-attenuate towards apex, lower tooth the shorter; clypeus apically truncate; labrum nearly semi-circular, face short, epistoma separated but not cornute below the antennae; antennal scrobes large, polished, confluent; vertex of head not broad. Flagellum $q$ strongly dilated in the centre, post-annellus excised below the middle, obviously shorter than the scape; of with joints seven to fifteen with elevated carinae. Metathoracic spiracles long and Iinear; areola longer than broad; coxal area distinct. Scutellum not transverse. Petiole gently and equally curved throughout, not higher than dorsally broad before the spiracles, post-petiole not aciculate, but smoothish or a little roughened, central area twice broader than the lateral; segment two with gastrocaeli small, sub-rugose; thyridii not large, placed far from the base; terebra slightly exserted. Posterior tibiae and femora stout. The thorax and abdomen are dorsally somewhat deplanate.

Thomson considered it better distinguished by the form of the head, antennae and petiole, than by the structure of the anterior tarsi upon which Wesmael mainly based it; I am of opinion, however, that if the costa which bounds the base of the second segment prove constant it is a more lucid feature.

On the Continent there are at least three known species of this genus, Wesmael's variety having been more recently recognised as distinct. Brischke and Thomson considered E. Trentefohlii a grood species on account of its elongate areola, but Berthoumieu has sunk it to a variety of oscillator; if such be the case, it should occur with the type form in Iiritain. 


\section{Table of Species.}

(2). I. Second flagellar joint elongate; scutellum entirely white ....................................

(1). 2. Second flagellar joint sub-quadrate; scutellum
partly white

OSCILLATOR, WeSm.

Wesmaeli, Thoms.

\section{I. oscillator, Wesm.}

Ichneumon pallipes, Gr. I. E. i. 233, excl. 8. Eupalamus oscillator, Wesm. Nouv. Mém. Ac. Brux. 1844, p. I4, ơ \&, excl. var. I ; of. Thoms. Ann. Soc. Fr. 1886, p. 12 ; O. E. xviii. I898. I. oscillator, Holmgr. Ichn. Suec. i. I72, excl. varr. ; Berth. Ann. Soc. Fr. 1895, p. 282, of \&, excl. var.

Head black; cheeks and temples somewhat inflated; $q$ palpi apically pale, frontal orbits whitish, external partly red; of also with palpi, mandibles, labrum, clypeus, face and rarely a mark at the genal orbits white. Antennae compressed centrally and strongly attenuate; second flagellar joint much longer than broad; white-banded in $q$, scape whitish or ferrugineous in of beneath. Thorax black, shining; pleurae partly aciculate; callosity at radix sometimes whitish; metathorax slightly bidentate, with three upper areae only, of which the areola is longer than broad, subhexagonal. Scutellum almost glabrous, entirely white. Abdomen shining black, sometimes bluish towards the apex ; post-petiole sub-arcuate, central area very broad, glabrous or with isolated deep punctures, in of sometimes aciculate-rugose, the lateral distinctly punctate ; gastrocaeli normal, rugose, but shallow, intervening space evenly punctate; terebra stout. Legs normal, black ; front tarsi dilated, reddish, in ot white, their femora laterally white; all the tibiae broadly white-banded ; $\delta$ coxae and trochanters often white-marked. Wings somewhat infuscate, stigma ferrugineous; tegulae often anteriorly white-marked. Length, I 5-1 $8 \mathrm{~mm}$.

The dorsal structure of the post-petiole of of appears variable; the reddish external orbits are noteworthy, and the simply punctate second segment will distinguish it from the species of Coelichnemmon with white tibiae.

This species may be easily distinguished from the others of the genus occurring on the Continent by its entirely white scutellum ; E. Trentepolalii, Wesm., is considered to be distinct.

Bignell has taken it at Bickleigh and Ivybridge, near Plymouth, in August; and it has been bred from Trichiura crataegi. It is said to be found among young trees and shrubs; its range extends throughout Europe.

\section{Wesmaeli, Thoms.}

Eupalamus oscillator, var. I, Wesm. Nouv. Mém. Ac. Brux. I844, p. I4. Ichneumon oscillator, var. 2, Holmgr. Ichn. Suec. i. I72. Eupalamus IVesmaeli, Thoms. Ann. Soc. Fr. I886, p. 12 ; Berth. lib. cit. 1895, p. 283; Thoms. O. E. xviii. 1898, \&.

A large black species with clouded wings; the apical half only of the scutellum, the whole of or lateral dots upon the post-scutellum, with broad tibial and flagellar bands, white. Length, $16 \mathrm{~mm}$.

In size and structure this $q$ is very similar to $E$. oscillator, of which it was for so long considered a constant variety; but the colour of the scutellum and post-scutellum, the much more strongly dilated intermediate 
tarsi, as well as the shorter first and sub-quadrate second flagellar joints, render it sufficiently distinct.

I swept an example from Erica, in the middle of a beech wood, at Denny, in the New Forest, on August I3th, I90 I ; and Miss Chawner has also taken it near Lyndhurst during recent years. It has not before been recorded from Britain, but is found in Central and Northern Europe.

\section{MELANICHNEUMON, Thomison.}

Thoms. O. E. xviii. I893, I954.

Head not triangular; cheeks more strongly punctate and not very short; mandibles stout and somewhat narrowed towards their apices; face not arched. Antennae filiform or a little attenuated apically. Thorax with complete costae and areae; areola sub-quadrate or hexagonal, posteriorly inflexed ; costulae stout, usually emitted from centre of areola. Abdomen black, or if red the thorax is also mainly red; the anterior segments rarely with pale lateral markings; the anus very often with one or two white marks; post-petiole centrally punctate or smooth, rarely punctatesubstriolate a little broader than the lateral areae; second segment strongly punctate, thyridii often small but deeply impressed; third segment with distinct depression. Hind femora sometimes slender. IVings usually with stigma nigrescent.

There is, I think, no doubt that Ichneumon erythraeus, Grav., and $I$. sanguinator, Rossi, which are not mentioned by Thomson, who might otherwise have modified its name, must be included in this genus, with the characters of which (excepting, perhaps, the deplanate face) they exactly coincide.

Into this group Holmgren restores Wesmael's genus Eupalamus, which has much in common with it, but may be differentiated by its generic characters.

\section{Table of Species.}

(2). I. Length over $13 \mathrm{~mm}$. ; frontal orbits broadly white in both sexes .........

(1). 2. Length under $13 \mathrm{~mm}$. ; frontal orbits immaculate or narrowly white.

(I6). 3. Abdomen with central segments black.

(7). 4. Post-petiole punctate or scabriculous.

(6). 5. Legs nigrescent with white markings

(5). 6. Legs mainly red, not white-marked ...

(4). 7. Post-petiole aciculate.

(9). 8. Gastrocaeli wanting; post-petiole centrally very broad .......................

(8). 9. Gastrocaeli small but deep; postpetiole normal.

(II). IO. Coxae of $q$ scopuliferous ; antennae of $\$$ pale-banded

(10). I I. Coxae with no scopulae; antennae of

1. LEUCOMELAS, Gmel.

2. DUMETICOLA, Grav.

3. NUDICOXA, Thoms.

4. Bimaculatorius, Pans. ơ with no pale band.

(15). 12. Scutellum apically or entirely white.

(14). 13. Second segment basally aciculate in o ; anus of $\delta$ immaculate............

(13). 14. Second segment evenly punctate; anus of $\hat{\delta}$ white-marked ............

6. MONOSTAGON, Grar\%

7. PERSCRUTATOR, IV'SM. 
(12). 15. Scutellum not or only laterally white

(3). I6. Abdomen with central segments red.

(18). 17. Thorax of $q$ white-marked, of $\delta$ dorsally rufescent

(17). 18. Thorax of $q$ not white-marked, of $\delta$ not rufescent

8. FAUnus, Grav.

9. ERYTHRAEUS, Grav.

IO. SANGUINATOR, Rossi.

\section{I. leucomelas, Gmel.}

Ichnenmon leucomelas, Gmel. S. N. i. 2679 ; Gr. I. E. i. 255 ; Ste. Ill. M. vii 158, excl. $\delta$; IVesm. Nouv. Mém. Ac. Brux. 1844, p. 87; Holmgr. Ichn. Suec. i. I7o; Thoms. Ann. Soc. Fr, 1888, p. I06; Berth. lib. cit., I895, p. 239, o $q$. Melanichncumon lencomelas, Thoms. O. E. xviii. 1956. I. bitineator, Don. B. I. xiv. 478, \&. I. albolineatus, Gr. I. F. i. 450 ; Ste. Ill. M. vii. I87. I. bipunctorius, Ste. Ill. M.

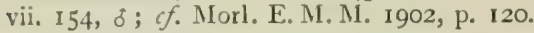

q. Body stout ; head black, with a large white vertical mark on each side near the ocelli. Antennae strongly attenuate towards the apex, somewhat slender, eighth joint quadrate; black, with at least a partial white band. Thorax entirely black, closely punctate; metathorax roughly punctate, with complete upper areae, of which the areola is sub-hexagonal, and apically emarginate. Scutellum white. Abdomen nitidulous, black, segments six and seven dorsally white-marked; petiole a little elevated between the spiracles; lateral areae of post-petiole closely punctate, the central generally in part punctate; second segment strongly and very closely alutaceo-punctate, with the gastrocaeli rather small and deeply impressed, the intervening space alutaceo-punctate, broader than the centre of post-petiole ; terebra only slightly exserted. Legs black, front tibiae internally reddish; tarsi fuscous beneath; hind coxae coarsely punctate and simple. Wings a little clouded, stigma and tegulae piceous or black; areolet only slightly narrowed above.

§. Head black; palpi piceous or whitish, a mark on each side of clypeus and the internal orbits broadly whitish. Antennae entirely black, hardly paler beneath. Thorax also black, with pronotum, usual marks at radix, and sometimes below the scutellum, white; mesothorax and scutellum distinctly higher than the metathorax, which is roughly punctate with complete upper areae of which the areola is sub-hexagonal and apically emarginate. Scutellum entirely, or in the centre, white. Abdomen black, always with the apical margin of the first segment, except generally in the centre, white; petiole a little elevated between the spiracles; post-petiole not closely punctate, the central area generally more finely than in the $q$; second segment as in $q$; anus immaculate. Legs black; front femora ferrugineous apically within; all the tibiae externally white, hind ones apically black ; tarsi mostly white, onychii always blackish. Stigma and tegulae piceous, latter sometimes white-marked. Length, I 3 -I $5 \mathrm{~mm}$.

Both sexes may be distinguished by their entirely downy thorax, the very broad white frontal mark, and the broad, smooth or only partly punc. tate central area of the post-petiole.

This is a very constant species, yet slight varieties are known, such as the $q$ being more or less piceous or fuscous on the abdomen, or having only one anal white mark (var. punctus, Berth.); and the of may have the first segment very rarely entirely black, the base and apex of the scutellum black, or even a white dorsal dot on the seventh segment. One of the last 
papers of the late 10r. Kriechbaumer (Zeit. für Syst. Hym. i. 5, p. 248) deals with a of variety of this species having the pale frontal orbits, pronotum, callosities before and beneath the radix entirely wanting, the texulae and basal segment immaculate and the legs almost entirely black or piceous, with mere remnants of whitish marking on the tibiae.

No doubt can remain that Stephens' I. bipunctorius is a of of this species, the only discrepancy in his description being that of the tarsi : "posterior fuscous," but one can with equal correctness read it "tips of the joints fuscous" ; moreover he says he expects it to be a variety of $I$. albolineatus, Gr., the true of $M$. leucomelas. Capron, who evidently thought it distinct, records it (Entom. I 879, p. I 5) from Shere, in 1878 .

$M$. leucnmelas is by no means an infrequent species in Britain, though Stephens seemed to think it not very abundant. He records it from Devonshire, Darenth Wood and around London, in June; Bridgman, however, says it is not uncommon, in Norfolk, at Mousehold, Earlham, \&c., and Bignell bred it, at the end of June, from Noctua brunnea, in South Devon. Peachell has also bred it, in the middle of April, from a pupa of Amphydasis betularia, dug at willows, at High Wycombe, in Bucks. ; this pupa had been strongly forced in a greenhouse. Charbonnier finds it not rarely in his garden, at Redland near Bristol, in July and August; one female, taken in October, stung his hand quite sharply. Bedwell has taken it at Oulton Broad, in Suffolk, at the end of August; Routledge near Carlisle; Sladen near Dover; Fitch at Malden, in Essex; Bradley at Birmingham ; Beaumont at Bury St. Edmunds; Wainwright once or twice at St. Ives, in July; Hamm near Oxford; it is recorded from Jersey in Ansted's "Channel Islands," and has also occurred at Ipswich, in October; I have found both sexes in the New Forest, and the male, in a greenhouse, at Ryde, I. W., in the middle of August. It is widely distributed throughout Europe, but does not appear to have been bred on the Continent.

\section{2. dumeticola, Grav.}

Ichnezumon dumeticola, Gr. I. L. i. 203 ; Ste. Ill. M. vii. I47, ơ ; Wesm. Nouv. Mém. Ac. Brux. I 844 , p. 86 ; Ratz. Ichn. d. Forst. iii. 172; Holmgr. Ichn. Suec. i. 169; Thoms. Ann. Soc. Fr. 1888, p. 107 ; Berth. lib. cil. 1895, p. 235, of o. Melanichnezmon dumeticola, Thoms. O. E. xviii. 1957. Phygadenon pinifferdae, Ratz. Ichn. d. Forst. i. 145 ; ii. 125 ; of. iii. $173, \delta$ \&.

q. Head very little narrowed posteriorly; black, with apex of palpi, a lateral mark on clypeus, and sometimes a small dot or line at the frontal orbits, pale. Antennae blackish, white centrally above; filiform, hardly attenuate towards apex, somewhat slender, eighth joint quadrate. Thorax entirely black; areola sub-hexagonal, apically emarginate. Scutellum white. Abdomen with greyish pubescence; black, with the apical margin of the second segment generally red, sixth and seventh white-marked; post-petiole a little elevated, its central area either somewhat punctate throughout, or, more usually, sub-glabrous with the apical margin quite smooth, the lateral areae closely punctate and the apical angles obtuse; the second segment is coarsely alutaceo-punctate, the gastrocacli foreiform, the intervening space being broader than the centre of post-petiole; terehra shortly exserted. Legs blackish; front tibiae, rarely also the posterior, more or less white; hind coxae closely punctate and simple below. IIings sub-hyaline; stigma and tegulae black; areolet sub-deltoid. 
o. Head black; palpi, mark on mandibles, sides of clypeus and internal orbits narrowly, quite white. Antennae black, the flagellum ferrugineous beneath. Thorax black, with normal marks at radix punctiform, white; areola transverse. Apex of scutellum white. Abdomen with grey pubescence; black with apical margin of second and third segments paler; sculpture as in 9 . Legs black; the anterior with tarsi and tibiae externally white, and whole base of latter also white, their femora internally stramineous; posterior tibiae also sometimes basally, and all the calcaria, quite white. Wings somewhat clouded, stigma black, tegulae either piceous with a white dot, or entirely white; sides of the areolet almost coalescent above. Length, Io-12 $\mathrm{mm}$.

The female much resembles that of $M$. bimaculatorius in the filiform flagellum, which is a little attenuate towards the apex, as well as in shape and size; but it is distinct in the generally punctate central area of the post-petiole being only a little broader than the lateral ones, the gastrocaeli and thyridii small and more deeply impressed; the male is at once distinguished by its black anus and antennae above.

Uncommon; taken at Coombe Wood, in July (Stephens). Captured at Plymouth Hoe, 28th September (Bignell). Rev. A. Thornley has given me a male, taken in the New Forest, in August, 1898 . Gravenhorst says that, as its name implies, it lives among undergrowth, in June; it has been bred on the Continent, where it is widely distributed and extends to Spain, from Lithosia quadra and Trachea piniperda.

\section{3. nudicoxa, Thoms.}

Jchnemnon saturalorius, var. 6 , Gr. I. E. i. 240 , ․ . I. albosignatus, Ste. 11l. M. vii. I40, $\delta$; Wesm. Nouv. Mém. Ac. Brux. I844, p. 83 ; Bul. Ac. Brux. 1848, p. I74; Holmgr. Ichn. Suec. i. I82, o \&: I. mudicoxa, Thoms. Ann. Soc. Fr. I888, p. 107; Berth. lib. cit. 1895, p. 237 , o $q$. Melanichneumon mudicoxa, Thoms. O. E. xviii. 1958 , \& ${ }^{1}{ }^{1}$

Head closely punctate and pubescent, hardly narrowed behind the eyes; temples broad and convex; clypeus apically truncate, of ot laterally whitedotted; palpi pale; the frontal orbits, and in of the facial also broadly, white. Antennae apically attenuate, rufescent at least towards the apex beneath; of $q$ centrally white above, with sixth flagellar joint sub-quadrate. Thorax a little narrower than the head, black; sometimes with pronotum, lines before and beneath the radix, white; metathorax finely rugose, areae complete; areola sub-cordiform, apically deeply emarginate. Scutellum stramineous. Abdomen black with the central incisures rufescent ; $q$ with seventh segment dorsally white; post-petiole sub-punctate or scabriculous, laterally coarsely punctate; second and third segments somewhat strongly punctate especially between the small, foveiform, triangular gastrocaeli; terebra slightly exserted. Legs normal, red, hind coxae simply punctate beneath ; coxae, trochanters, hind tarsi, apices of their tibiae and often of their femora, black. Wings a little clouded; stigma and tegulae piceous, latter sometimes pale-dotted. Length, 7-10 $\mathrm{mm}$.

This species is similar in size and conformation to I. albosignatus, Grav., with which it was so long confused; the head, however, is shorter and

1 Ichneumon balearicus, Kriech., which is considered a good species by Schmiedeknecht, was first regarded by Berthoumieu as a variety of Apacliticus bcllisosus and subsequently (Ann. Soc. Fr. 1896 , p. 396) to constitute, with Ichneumon mudicoxa, a variety of Barichnenmon bilumulatus. 
more rounded behind the eyes, the gastrocaeli flatter and less distinct, the hind femora are often apically black, and the $f$ coxae are simple, not scopuliferous. From $M$ dumeticola, it differs in the hind tibiae not being basally white, the body more nitidulous, more coarsely punctate, and less densely pilose.

It is undoubtedly the present species and not the true $I$. albosignatus which was recorded in Marshall's 1870 catalogue and probably also by Stephens from the North of England and Scotland; more recently it has been regarded as a variety of Barichneumon gemellus, from which it is abundantly distinct. Mr. Luff has found it in Alderney, and Mr. Bignell has confirmed its claim to inclusion in our list by the capture of 1. albosignatus, Holmgr. (nec Grav.) at Bickleigh, in Devon, upon 5th August, I 884. On the Continent it is recorded from Germany, France, Spain and Italy, but has not yet been bred.

\section{4. bimaculatorius, Pant.}

Ichneumon bimaculatorius, Panz. F. G. lxxx. 8, o; Wesm. Nouv, Mém. Ac. Brux. IS44, p. 65 ; Holmgr. Ichn. Stuec. i. 137 ; Thoms. Ann. Soc. Fr. I888, p. I06; Berth. lib. cit. I895, p. 227 , o क. Melanichneunon bimaculatorius, Thoms. O. E. xriii. 1956. I. saluratorius, varr. I et 4 , Gr. I. E. i. 238 , excl. maribus segmento $6^{\text {to }}$ toto nigro.

Head not narrowed behind the eyes, black; that of of with palpi and mandibles mostly red. Antennae of $q$ stout and filiform throughout; white-banded in both sexes; of with flagellar joints well discreted, setaceous, rufescent beneath. Thorax entirely black ; epicnemiae not extending to callosity at radix ; the metathorax distinctly lower than the mesonotum, with complete upper areae of which the areola is sub-hexagonal in o , and semi-oval, apically emarginate, in to. Scutellum white. Abdomen black, with segments six and seven white-marked in both sexes; $q$ lanceolateoval, of sub-linear; petiole long and narrow, its sides not transversely costate; post-petiole not broad, quite smooth, strongly nitidulous, its lateral areae, which are only half the width of the central, punctate; gastrocacli wanting, indicated by a slight sulcus; thyridii punctiform, rery remote from the base of the second segment, which is alutaceo-punctate; terebra a little exserted. Legs black; trochanters mainly white, anterior tibiae (paler in of) entirely, and hind ones basally, reddish ; calcaria white; tarsi fuscous, front ones reddish; hind coxae not scopuliferous. Stigma testaceous; tegulae piceous ; f with areolet strongly narrowed above, and the radial cell trapeziform. Length, 8-10 $\mathrm{mm}$.

Both sexes may be known by the white antennal band, scutellum and anus, by the sculpture of the second segment and by the punctiform thyridii. It is of the same size as $M$. dumeticola, which, howerer, has the post-petiole centrally punctate.

It differs from 11 . saturatorius: the of in having black genital valvulae; q antennae thicker, terebra rather longer, \&c.

Bridgman took a female of this handsome litt?e Ichneumon at Brundall, near Norwich, on September I 7 th, I884; and I have taken it in Covehithe Broad, in Suffolk, by sweeping reeds, on October Ist; and others upon Angelica flowers and Scutellaria, at Matley Bog, in the New Forest, in August. I should expect that it is a fen species. It is distributed throughout Europe, and the female hibernates in moss. 


\section{Saturatorius, Linn.1}

Icluneumon saturatorius, Linn. F. S. 399 ; Gr. I. E. i. 237 , excl. varr. 1, 4 ; Ste. Ill. M. vii. I54; Zett. I. L. $36 \mathrm{I}$; Wesm. Nouv. Mém. Ac. Jirux. 1844 p. 66; IJolmgr. Ichn. Suec. i. I33; Thoms. Ann. Soc. Fr. 1888, p. 106; Berth. lil. cit. 1895, p. 227 , \&. . Melanichnesemon saturatorius, Thoms. O. L. xviii. 1957. Var. I. camifex, Miill. Prodr. n. 1799.

․ Head entirely dull black, a little narrowed posteriorly. Antennae somewhat stout, filiform throughout; sixth joint quadrate, the central ones white above. Thorax silky, entirely black; metathorax rugulosely punctured, with complete upper areae, of which the areola is semi-oval and apically emarginate. Scutellum, at least apically, white. Abdomen oblong-oval, black; second and third segments apically and often laterally rufescent; apical margin of sixth and whole of seventh white; central area of post-petiole aciculate, the lateral ones coarsely punctate, its apical angles obtusely rounded; second segment a little broader than long, scabrously punctured at the base, the space between the normal gastrocaeli broader than centre of post petiole; terebra sub-obtuse, shortly exserted. Legs as in of hind coxae with distinct scopulae. Stigma yellowish-brown; areolet narrowed above.

§. Head black; mandibles very often rufescent before the apex. Antennae black; flagellum more or less ferrugineous beneath, its central joints white above; slender towards apex. Thorax black; metathorax rugosely punctured, with complete upper areae, of which the areola is semi-oval or hexagonal and apically emarginate. Scutellum entirely or apically whitish; convex, with close puncturation. Abdomen sub-linear, black; segments two and three with apical margins rufescent; seventh entirely white; genital valvulae white, sometimes black-margined. Legs often entirely black, generally red; coxae, trochanters for the most part, apex of hind tibiae and hind tarsi, black; hind coxae strongly punctured. Length, IO-I $2 \mathrm{~mm}$.

The colour of the legs is extremely variable, ranging from mostly red to nearly entirely black; sometimes the hind trochanters of the $q$ are entirely white, or white with the apex rufescent; those of the of sometimes also bear a white mark. In other respects it appears to be uncommonly constant.

The variety with black scutellum is I. carnifex, Müll.

1 Ichneumon fuscocastaneus, Grav.

Mr. Edward Parfitt has recorded (Trans. Devon. Assoc. 188r, p. 12) with no query nor hesitation this species, saying simply:- "Of this I have only seen one; it was presented to me by the late Mr. Style, who purchased the Raddon Collection. I presume, therefore, that this was taken in North Devon."

Gravenhorst (I. E. i. 486) thus describes his single o :-Antennae black above, with joints sixteen to twenty white; ferrugineous beneath, with joints sixteen to twenty paler and the two basal ones black. Scutellum white. Abdomen with segments two to seven badious with the margins paler. Anterior legs with the femora beneath, and the tibiae, except externally in the centre, red; their tarsi fuscous. Wings infumate-hyaline; stigma, costa and tegulae fuscous; radix ferrugineous; areolet sub-irregularly triangular. Length, $5 \frac{1}{2}$ lines. He adds that its size and shape are similar to those of I. sexlineatus (Barichneumon bilumulatus), but that the legs are a little more slender.

Wesmael examined this type, which was fonnd at Freiberg, in Germany, and states (Mém. couron. Ac. Belg. 1859, p. 6r) that it was too mutilated to pronounce upon with certainty, though the face, clypeus, \&c. were intact. He says it is a very closely punctate insect; that the metathoracic areae are strongly delineated, the areola quadrate and apically emarginate in the centre; petiole elongate; post-petiole only slightly explanate, finely and somewhat irregularly aciculate centrally, punctate laterally; gastrocaeli inconspicuous and longitudinal ; legs normal and areolet sub-deltoid. He adds that, if the seventh segment, which was wanting, luad been white, it would have been a of Mclanichneumon saturatorius similar to his var. 2 (Tentamen, 66, var. femoribus supra nigris).

Berthoumieu (Ann. Soc. Fr. 1895, p. 289) places this as an insufficiently described species, querying its synonymy with $I$. sternocarus, Thoms., the of of which, lowever, has the face, clypeus and thoracic callosities white and belongs, moreover, to the genus Cratichneumon.

One wonders how Mr. Parfitt named his rarity! 
This species differs from $\boldsymbol{M}$. bimaculatorins in the of having only the seventh segment white, in its larger size, breadth and sculpture of the post-petio!e centrally, as well as in its opaque mesonotum, and in the epicnemiae, which extend very nearly to the callosity at radix.

Hope took the female at Netley; but Stephens did not consider the species common, though he had found it in June and July, about London, in Salop and in Devonshire; I expect it is, nevertheless, of wide distribution with us, since it is by no means rare on the Continent, and Bridgman records it for Norfolk, at Earlham, Brundall and Lynn ; Mansbridge has bred both sexes from Mania tppica: Bignell bred it in Devon, where it is by no means common, though widely distributed, from Nonasria cannne, early in September; Fitch from Nonagria typhae, at Maldon (Entom.), and it also preys upon Dicramura vinula, Meliana flammea, Lencania ploragmitidis and Plusia gamma. There is a female (which is sometimes found hibernating in moss) with no data, in the Hastings Museum; and Beaumont has taken it at Boxhill, in July and September. Chitty tells me it is a common parasite of Euchelia jacobaene, from which he has bred both sexes, at Oxford; and I have found its pupa, which is of the usual Ichneumonid type, in that of the same host, at Brandon, in Suffolk.

\section{6. monostagon, Grav.}

Ichnermon monostagon, Gr. Mem. Ac. Sc. Torin, 1820, p. 287; I. E. i. I72; Ste. III. M. vii. I4I, ơ : Wesm. Mém. couron. Ac. Belg. I859, p. 23; Holmerr. Ichn. Suec. i. I67; Thoms. Ann. Soc. Fr. I888, p. 107 ; Berth. lit. cit I895, p. 237, o q. Melan. iclnezumon monostagon, Thoms. O. K. xviii. 1956. I. indagator, Wesm. Nouv. Mém. Ac. Brux. 1844, p. 84, ơ o ; Bul. Ac. Brux. 1849 , p. 6 ; lib. cit. 1855, p. 397 . I. percussor, Tisch. Stett. Zeit. 1879, of. I. rexinitus, Tisch. lib. cit. I871, o. Var. I. luctuosus, Gr. I. E. i. 200, o; Ste. Ill. M. vii. 146 (part).

ๆ. Head with cheeks and temples moderately inflated; black, with often a mark on the almost smooth clypeus, and the apex of the palpi, reddish ; vertical orbits usually with a narrow pale yellow line. Antennae and thorax black, the former white above in the centre, rather strongly attenuate, seventh joint quadrate; metanotum with complete upper areae, of which the areola is sub-hexagonal and apically emarginate. Scutellum white. Abdomen black, with the sixth and seventh, or rarely only the seventh segment marked with whitish-flavous; the central area of the post-petiole is rugosely- or punctato-aciculate, the lateral areae being more or less strongly punctate; the second segment is very closely punctate, with the gastrocaeli of normal size, rather deeply impressed, the intervening space being rugosely aciculate and broader than the centre of post-petiole ; the puncturation becomes gradually finer towards the anus; terebra shortly exserted. Legs similar to those of the $\delta$. Wings a little clouded; stigma and tegulae ferrugineous.

o. Head black; palpi apically, lateral dots on the clypeus and the internal orbits, narrowly white; a mark on the mandibles red. Antennae entirely black. Thorax black, sometimes with a small dot below the radix white; meso- distinctly higher than the metathorax, which has complete upper areae, the areola broader than long, semi-hexagonal and apically emarginate. Apex of scutellum white. Abdomen black, with anterior incisures deeply impressed and rufescent, without pale-markings on its anus or first segment; the sculpture as in the of. Legs either black, with the 
anterior femora and tibiae broadly rufescent laterally in front, or black with all the femora and tibiae rufescent; the femora are stout and the hind coxae coarsely and strongly punctate, with no scopulae. Length, 10-1 $3 \mathrm{~mm}$.

The wings are somewhat smoky; the post-petiole between the dorsal carinae distinctly striolate; the prothorax striolate beneath; the frontal orbits only narrowly pale in both sexes; the sides of the breast are deeply sub-rugose in $q$, sparingly punctate and shining in $\delta$.

This species is hardly smaller than the preceding; the antennae subdilated before the apex, the colour of the frons and the distinct dorsal carinae of the post-petiole, as well as its sub-strigose central area render it at once distinct.

'The form with the legs mostly black was Gravenhorst's I. Iuctuosus, in part; the $q$ sometimes has the orbits of the eyes, and the the whole of the scutellum entirely black.

Stephens considered it an uncommon species about London, Evans found it at Longniddry, in May, and Col. Yerbury has taken it at Kenmare, in July. It has been bred from Nonagria geminipuncta and $N$. sparganii, and has a very wide continental range.

\section{7. perscrutator, Wesm.}

Ichneumon perscrutator, Wesm. Nouv. Mém. Ac. Brux. 1844, p. 85 ; Berth. Ann. Soc. Fr. 1895, p. 238, ơ 9 .

Head black, not much narrowed behind the eyes; clypeus slightly depressed in the centre of the sub-truncate apical margin; of with a lateral dot on clypeus and the internal orbits entirely white, labrum fulvous, mandibles and palpi piceous; $q$ with a white lunula at vertical orbits. Antennae somewhat attenuate toward apex, black; $q$ somewhat slender, white-banded; of with joints six to eighteen of flagellum bearing very distinct raised lines, apical joints somewhat nodulose. Thorax dull, black; of with line before, rarely also beneath, radix and margin of pronotum white; of $q$ entirely black; metanotum scabrosely punctate, upper areae complete, the petiolar discreted; areola sub-quadrate, in $q$ entirely glabrous and apically emarginate, its costae strong. Scutellum flat, primrose-white with the apex black; of post-scutellum sometimes also white. Abdomen sub-cylindrical and flattened in $\delta$, dull black, very finely and closely punctate; somewhat nitidulous towards apex in $q$; second and third segments with incisures red and not deeply impressed; fifth, sixth, and usually fourth, apically in the centre, seventh entirely, white in both sexes; post-petiole closely punctate-aciculate, apical angles obtuse; gastrocaeli small and deeply impressed, the intervening space being evenly punctate in $q$, sub-aciculate in $\delta$, and broader than centre of post-petiole. Legs stout, red; hind tibiae towards the apex and the posterior tarsi infuscate; coxae and trochanters black, the former coarsely punctate in of, very shining, punctures only evident on the sides, with no scopulae in $q$. Wings hyaline; stigma and tegulac black or piceous, latter often with a white dot; radix dark ferrugineous; areolet of $\delta$ somewhat narrowed above, emitting recurrent nervure from beyond its centre. Length, io to I $2 \mathrm{~mm}$.

The $q$ differs from that of $M$. monostagon in the more slender antennae, 
punctate post-petiole, smaller gastrocaeli, more nitidulous hind coxae and in the white-marked fifth segnent; the antennal carinae of the of are very distinct.

Mr. W. Evans took one male, at Luffness Links, in Midlothian, on June roth, ISgS, in circumstances similar to those under which Wesmael found it on the sandhills, at Ostend, which, with one by I)avies, in Cornwall, are the only British examples. On the Continent it is only recorded from France and Belgium, and has not been bred.

\section{Faunus, Grav.}

Ichneumon Faunus, Gr. I. E. i. 249, 8; Wesm. Nouv. Mém. Ac. Brux, I844, p. 66 ; Bul. Ac. Brux, 1848 , p. 165 ; lib. cit. 1855 , p. 387 ; Holmgr. Ichn. Suec. i. 135 ; Thoms. Ann. Soc. 1888, p. I06; Berth. lit. cit. I895, p. 228, o o. Melanichneumon Faunus, Thoms. O. E. xviii. 1958. Var. of + , I. leucopygus, Gr. I. E. i. I57, \&.

9. Head black, rarely two narrow vertical dots white; the mouth parts red. Antennae filiform throughout, blackish ; the first five flagellar joints apically red and the central ones white above. Thorax entirely black; metanotum with complete upper areae, of which the areola is semi-oval and apically emarginate. Scutellum a little convex, castaneous. Abdomen black; segments two and three with apical, and often lateral, margins rufescent; sixth and seventh entirely white; petiole distinctly bicarinate between the spiracles, post-petiole centrally aciculate; second segment rugulosely aciculate between the gastrocaeli ; terebra stout, only slightly exserted. Legs as in o; hind coxae shining, punctate, with no scopulae.

§. Head black; palpi, mandibles and labrum stramineous; clypeus, face, frontal and external orbits whitish. Antennae black; scape stramineous, and flagellum ferrugineous, beneath; not pale-banded. Thorax black, pronotum and usual marks at radix white; sculpture of metanotum as in $q$. Scutellum a little convex, laterally whitish-flavous. Abdomen black, with a mark at the apical angles of first segment usually pale; the second and third with incisures red, the sixth broadly, and seventh entirely, white ; sculpture as in $q$. Legs blackish ; anterior with femora internally, and tibiae entirely, red; hind femora narrowly red before the base. Length, 8-10 $\mathrm{mm}$.

This varies less than the preceding species in the coloration of the legs, which, nevertheless, is far from constant; in the $q$ all the tibiae are sometimes very dark red, or the femora and tibiae may be red with the hind ones apically black, which form is $I$. leucopsgus, Grav.; or all the femora and tibiae entirely red ; the anterior tarsi are usually ferrugineous, the hind ones black; the of sometimes has the scutellum black, or only its apex castaneous, the frontal orbits, pronotum and post-scutellum are occasionally' castaneous also (var. rufatus, Berth.).

From $M$. saturatorius and bimaculatorius, it may be known by the pale stigma and frontal orbits. The second segment has a little lateral fold before the spiracles; the epicnemiae are entire; the nervulus post-furcal.

It may at once be distinguished from the species described by Thomson in the Annales by the central area of the post-petiole and base of second segment being striolate, by the of bimaculate and the $f$ castancous scutellum, in which last respect it resembles Barichneumon anator, but that species, among other divergences, has the post-petiole centrally punctate. 
Stephens did not find this species, which is widely distributed though rare on the Continent, in Britain. Mr. Bradley has taker both sexes at Sutton, near Birmingham, in July and September; it is recorded from Essex; and I have found it on flowers of Angelica sylvestris, at Matley Bog, in the New Forest, towards the end of August. It does not appear to have been bred; the female hibernates in moss, \&c.

\section{9. erythraeus, Grav.}

Ichneumon erythraens, Gr. Mem. Ac. Sc. Torin, I820, p. 357 ; I. F.. i. 632 ; Ste. III. M. vii. 206. + ; IVesm. Mém. couron. Ac. Belg. I859, p. So ; Berth. Ann. Soc. Fr. 1895, p. 229, o \& .

१. Head narrowed behind eyes, anteriorly red ; internal and external orbits whitish. Antennae very slender, filiform; white-banded. Thorax cylindrical, red or reddish, with its sides and the vicinity of the scutellum black; humeral marks and post-scutellum white; areola sub-hexagonal, apically emarginate. Scutellum red, apically white. Abdomen elliptic, black; segments one to four red; seventh entirely, fifth and sixth apically white; post-petiole finely aciculate; gastrocaeli small ; terebra exserted. Legs piceous; coxae white-marked, the anterior sometimes red; femora slender, anterior internally flavous; front tibiae pale beneath; hind coxae not scopuliferous. Wings a little clouded; stigma piceous; tegulae reddish with a flavous dot; areolet in both sexes sub-deltoid.

o. Palpi, mandibles, face, and nearly all the orbits, white. Antennae centrally white-banded; ferrugineous, with the scape white, beneath. Thorax red; a line on the meso-, two dots on the metanotum, and the vicinity of the scutellum black; pronotum, mesosternum and humeral lines, white; areola semi-elliptic. Scutellum white, basally reddish. Abdomen black; segments two to four and the finely aciculate post-petiole red; sixth apically, seventh entirely, last ventral segment and valvulae, white; gastrocaeli normal, though shallow. Legs reddish; coxae in part, tibiae beneath, and apical tarsal joints basally, white; the remainder of tarsi and coxae black. Length, 8-io mm.

The of very rarely has the clypeus discreted by a black mark, the scutellum entirely red, and the legs black, the front ones laterally flavous and the anterior coxae mostly white.

The small gastrocaeli and sub-hexagonal areola approximate this species to Melanichneumon, from which its colour cannot be considered sufficient basis for separation.

Very scarce; taken in June, near London (Stephens) ; captured at Plym Bridge, Devon, $27^{\text {th }}$ May (Bignell). Widely distributed in Central Europe; the female hibernates in moss. It appears to have been much mixed in British collections with the following species.

\section{ro. sanguinator, Rossi.}

Ichnenmon sanguinator, Rossi, Mant. ii. App. n. 85 ; Gr. I. E. iii. 918, ; Berth. Ann. Soc. Fr. 1895, p. 230, o o. I. refficollis, Ste. Ill. MI. vii. 206, o ; of. Morl. E.M.M. 1902, p. I21. I. discrepator, Wesm. Nouv. Mém. Ac. Brux. IS44, p. I02, ơ o. Cryptuts sanguinator, Desv. Cat. 58, o ; of. Bridg. Trans. Ent. Soc. IS82, p. I42.

․ Head much less narrowed posteriorly than in the preceding; anteriorly, vertically and at the external orbits, red; frontal and vertical 
orbits flavous. Antennae black, filiform; white-banded; reddish beneath. Thorax and scutellum red; vicinity of the latter and the sterna black; upper areae complete, costulae strong; areola sub-hexagonal, slightly elongate. Abdomen black; segments one to three, and base of four, red; six and seven, sometimes also five at apex, white; post-petiole finely aciculate; gastrocaeli shallow, striolate; thyridii linear; terebra exserted. Legs black, tibiae basally red. Areolet sub-deltoid; stigma piceous, tegulae red.

o. Head anteriorly, excepting frons, mostly, and external orbits, white. Antennae reddish beneath; central band, and scape beneath, white. Thorax black; pronotum, humeral lines and post-scutellum white; areola sub-quadrate, basally rounded. Scutellum white. Abdomen coloured as in preceding species; post-petiole finely aciculate; gastrocaeli sub-obsolete; seventh and eighth segments and the genital valvulae white. Legs black; front coxae whitish; front tibiae and tarsi flavous; all the femora black. Stigma and tegulae black. Length, 8-10 $\mathrm{mm}$.

Besides the points noticed in the table, the temples are much less retracted and the antennae stouter than in $\boldsymbol{\Lambda} \boldsymbol{L}$. erythraeus.

This and the last described species bear close analogy with those of Barichneumon in their strongly punctate thorax and scutellum, anteriorly rounded and narrowed areola and distinct sternauli, in colour strongly resembling $B$. ridioundus, but the aciculate post-petiole at once excludes them from that genus.

Bridgman considered Cryptus sanguinator, Desv., distinct from the present species, but I can see nothing in the respective descriptions from which to adduce such a conclusion; the terebra (always to a certain extent retractile) appears to be a little longer in the former, which also has the apical flagellar joints ferrugineous.

Stephens says his $I$. muficollis is rare, taken at Hertford, in June; Billups took several females hibernating in tufts of grass infested by Lasius flavus, at Mickleham, in February, also on the wing and by sweeping in the same locality in the summer (Entom. 1882, p. 92). Dr. Capron took a male at Shere (l. c., p. I39). There are specimens in Heysham's, Desvignes' and Power's collections. Berth. says Bridgman bred it from Depressariı umbellana. I took one female on umbelliferous flowers in the Bentley Woods near Ipswich, on 26 th July, 1897 . It has a restricted continental range, from Hungary to France.

\title{
BARICHNEUMON, Thomson.
}

\author{
Thoms. O. E. xviii. 1893, 1959.
}

Head with the face not distinctly arched, not or only slightly narrowed behind the eyes; mandibles sometimes stout, more rarely inconsiderable. Antennae generally attenuate towards the apex, those of the male shorter than the body. 'Thorax with the mesonotum not dull; notauli often distinct; metathorax with the petiolar area always separated, impressed; the areola pentagonal or subtriangular, usually broader than long, its costulae very often strong, emitted behind the middle, posterior margin generally rounded. Abdomen strongly convex transiersely; post-petiole centrally punctulate or smooth, not aciculate; second segment with thyridii 
sometimes transverse, not oblique, and the gastrocaeli small but deeply impressed; third segment with a distinct basal impression. Legs often with the femora stout and the calcaria long. 'The external nervure of the areolet is often pellucid and rudimentary, but always traceable.

The insects are small and often have a whitish dot or lunula at the vertical orbits; segments two to four or five very often red, and the anus of the female is nearly always white, that of the male sometimes with two or three white marks.

Some species are closely allied to Stenichnemmon, but the head is much less narrowed behind the eyes and towards the mouth; the female antennae are distinctly stouter and less attenuate; the mesonotum is shining and its notauli usually distinct; the areola is usually broader and less rectangular; post-petiole never striolate and the gastrocaeli gencrally deeper, never oblique; the legs are stouter and the anus more often and fully maculate.

Care must be taken to see that the metathoracic spiracles are not circular since the superficial resemblance with many species of the Plucogrenides is very strong; and in one or two instances these small ichneumons appear at first sight to be related to Phygadeuonids.

\section{Table of Species.}

(2). I. Antennae not reaching second segment ; abdomen black

(1). 2. Antennae reaching second segment.

(4). 3. Scutellum with raised margin; abdomen mainly black

(3). 4. Scutellum not margined; abdomen centrally red.

(6). 5. Pronotum with central tubercle; anus white.....................................

(5). 6. Pronotum without tubercle.

(I6). 7. Thyridii large and obvious.

(9). 8. Coxae of $t$ white-marked, of $q$ scopuliferous

(8). 9. Coxae of $\delta$ not white-marked, of $q$ not scopuliferous.

(II). I0. Carinae of post-petiole strong; areola transverse ............................

(IO). I I. Carinae of post-petiole indistinct; areola elongate.

(15). 12. Mesonotum black.

(14). 13. External orbits of of not white; $q$ mouth red

(13). 14. External orbits of of white; $q$ mouth white...................................

(12). I 5. Mesonotum red

(7). I6. Thyridii small and transversely linear.

(26). 17. Sternauli half length of mesosternum; anus not or hardly white.

(21). 18. Areola not rectangular.

(20). 19. Areola cordiform

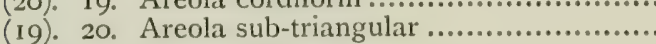

(18). 21. Areola rectangular.

(23). 22. Areola sub-quadrate

(22). 23. Areola transverse and narrow.

(25). 24. Metathoracic spiracles oval

I. ANATOR, Fab.

2. GeMellus, Grav.

3. RIDIBUNDUS, Grav.

4. Sexalbatus, Wesm.

5. TERGENUS, Grav.

\section{INCUBITOR, Limn.}

7. BASIGLYPTUS, Kriech.

8. RUFIDORSATUS, Bridg.

9. VACILlatorius, Grav. IO. HERACLEANAE, Bridg.

II. SEMIRUFUS, Grav.

12. PUlchellatus, Bridg. 
(24). 25. Metathoracic spiracles sub-circular......

(17). 26. Sternauli short or wanting ; anus often white.

(28). 27. Hind tibiae black with broad basal white band

(27). 28. Hind tibiae red or black, not broadly white-banded.

(30). 29. Areola transverse linear ; mesosternum thrice broader than long ..............

(29). 3o. Areola not transverse linear; mesosternum less than thrice broader than long.

(34). 3I. Hind coxae diffusely punctate; $q$ scutellum usually, and ơ anus, black.

(33). 32. Areola longer than broad; gastrocaeli sub-obsolete ; of coxae white .........

(32). 33. Areola not longer than broad ; gastrocaeli small ; of coxae black ............

(3I). 34. Hind coxae closely punctate ; scutellum and anus usually white.

(38). 35. Central segments strongly punctate.

(37). 36. Frons rugosely punctate; gastrocaeli normal.

(36). 37. Frons more finely punctate ; gastrocaeli longitudinal .............................

(35). 38. Central segments finely punctate.

(40). 39. Metathorax finely bidentate; $q$ anus compressed

(39). 40. Metathorax not bidentate; $q$ anus not compressed.

(42). 4I. Anus with two segments white-marked

(4I). 42. Anus with three segments white-marked
13. EupitheCiae, Brisch.

14. ALBICINCtUS, Grav.

I5. PLAGIARIUS, Wesm.

I6. DEROGATOR, WeSm.

I7. BILUnUlatus, Grav.

18. VESTIGATOR, Wesm.

I9. LEPIDUS, Grav.

20. ANGUSTatus, Wesm.

21. CHIONOMUS, Wesm.

22. CALLICERUS, Grav.

\section{I. anator, Fab.}

Ichneumon anator, Fab. E. S. ii. I69 ; Gr. I. E. i. 250 ; Ste. Ill. M. vii. 156; Zett. I. L. 361 ; Wesm. Nouv. Mém. Ac. Brux. 1844, p. 220 ; Bul. Ac. Brux. I848, p. 176, et I849, p. 39 ; Holmgr. Ichn. Suec. i. I8I ; Thoms. Ann. Soc. Fr. I888, p. IOS; Berth. lih. cit. 1895, p. 235, o \%. Coyptus anator, Fab. Piez. 87, o. Barichneumon anator, Thoms. O. E. xviii. I960, of \&. Var. I. microcerus, Gr. I. E, i. 249; Ste. Ill. M. vii. I56, ‥

A small, black and white species with red legs. Head black, somewhat broad behind the eyes ; cheeks short; palpi and the stout mandibles for the most part fulvous; frontal and, in $\delta$, facial orbits usually distinctly white; epistoma discreted. Antennae reaching about to or a little beyond the metathoracic spiracles; inserted low on frons, blackish, usually with the basal joints ferrugineous and, in $q$, the central ones clearly white. Thorax black, with the pronotum above and marks near the tegulae whitish; notauli shallow, sternauli wanting; pleurae nitidulous, finely punctate; metathorax with the spiracles elongate oval, not linear; subrugosely punctate, with complete upper areae, of which the areola is transverse semi-lunar. Scutellum flat and shining, with the apical half flavous. Abdomen oval, longer in ot, black, grey-haired and shining; incisures of the first three segments castaneous; apical margin of fifth, especially in $\delta$, and most or whole of sixth and seventh, albidous; postpetiole punctate, central twice broader than lateral areae, carinae distinct ; second segment not longer than broad, punctulate; gastrocaeli and 
thyridii triangular, small and deeply impressed; intervening space hardly broader than centre of post-petiole; terebra obtuse, very shortly exserted. Legrs red, coxae and trochanters, as well as apex of hind femora, tibiae and the tarsi blackish; hind coxac closcly punctate, with no scopulae beneath; front calcaria stout. Wings hyaline; tegulae in front and radix flavous; areolet somewhat narrowed above; radius straight. Length, 8-10 mm.

IVesmael mentions a form of the male with the thorax entirely black, and Gravenhorst's $I$. microcerus is a form of the female with the pale antennal band hardly visible.

The characteristic points of this species are the abbreviated antennae, barely reaching to the apex of the thorax, the form of the head, and the structure of the cheeks and mandibles.

I do not expect this is an uncommon species in Britain; it is found in grassy places, and among undergrowth, in June and July. Stephens found it in gardens and houses about London, at Harrietsham, in Kent, in June, 1840 (Entom. p. 200), and the form microcerus in Wiltshire; Bridgman took it at Norwich, and Parfitt says it is not common but generally distributed in Devon; Tuck captured males at Tostock, near Bury St. Edmunds, in June, and Dr. Bailey a female at Pendleton, in 1899. Aldemey (Luff) ; Essex (Harwood) ; Darenth, in May (Chitty); Copdock, Suffolk, in July (Hocking) ; near Gilasgow (Bignell) ; Ripple, near Dover, in August (Sladen). Although it has never been bred, Gravenhorst saw it flying around a colony of Apluides and Syrphid larvae, and it has been several times found on windows indoors.

\section{2. gemellus, Grav.}

Ichnermon gemellus, Gr. I. E. i. 201 ; Ste. Ill. M. vii. 147, ơ ; Wesm. Nouv. Mém. Ac. Brux. 1844, p. 33, excl. var. 3; Bul. Ac. Brux. 1848, p. 148; lib. cit. 1849, p. 36; Holmgr. Ichn. Suec. i. I3I ; Thoms, Ann. Soc. Fr. 1888, p. I08; Berth. lit. cit. 1895. p. 226, of $\uparrow$. Barichneumon gemellus, Thoms. O. E. xviii. 1960. Var. I. opticus, Gr. I. E. i. 13I ; Ste. Ill. M. vii. 132, ơ.

A dark species at once known by its laterally-raised scutellum. Head very little narrowed behind the eyes, cheeks somewhat buccate and apically smooth; black, mandibles and sides of the apically-emarginate clypeus rufescent ; frontal and vertical orbits pale ; 0 also has palpi, labrum, mandibles, sides of clypeus and of face pale flavous. Antennae black, reddish beneath ; of $q$ sub-filiform with the central joints white above, of twhitemarked beneath scape. 'Thorax pubescent, narrower than head, of $q$ entirely black; that of so with pronotum and callosities at radix generally pale flavous; metathorax scabriculously punctate, with complete upper areae, of which the areola is semi-elliptic or semi-lunar, and apically emarginate; spiracles linear. Scutellum black, short, obtuse, sometimes apically pale-marked; with raised lateral margins, which extend in $q$ to its centre, in o nearly to its apex. Abdomen sub-lanceolate, black, with second and third segments, especially in $q$, castaneous and their incisures deeply impressed; $q$ has sixth and seventh dorsally white, the seventh alone of $\delta$ is very rarely pale-marked; post-petiole centrally scabriculous or in of sub-aciculate, laterally indistinctly punctate, carinae distinct and the apical angles obtuse; second segment with a longitudinal carina on the disc, stronger in o ; gastrocaeli much broader, deeper and striate in ${ }^{*}$, intervening space roughly punctate, as broad as centre of post-petiole. 
Legs stout, black; anterior partly fulvous, front tibiae of of laterally stramineous; hind ones generally with rufo-piceous tibiae; hind coxae of \& closely punctate beneath with large scopulae; of with intermediate femora broadly and deeply emarginate apically, its anterior coxae sometimes white-marked. Irings a little clouded; stigma ferrugineous, areolet narrow above. Length, I0-14 $\mathrm{mm}$.

This is rendered a very distinct species by the structure of the scutellum, femora and abdomen. The male varies only in occasionally having the scutellum entircly black (I. opticus), the seventh segment with a minute central white dot, the femora and tibiae red, and the anterior coxae rarely white.

I expect this is one of the commonest of the restricted genus with us, since it is very frequent in Sweden, and Bridgman says that in Norfolk it appears to be generally distributed and, although perhaps not common, it has occurred at Heigham, Earlham, Brundall and Lynn; Stephens records it uncommonly from the London district, in June, and the form opticus, in July; it is not found in Devon. On the Continent, where Gravenhorst took it in August, it is of general distribution.

\section{3. ridibundus, Grav.}

Ichneumon ridibundus, Gr. I. E. i. 329, ó; Wesm. Nouv. MIém. Ac. Brux. I844, p. 99; Mém. couron. Ac. Belg. I859, p. 38 ; Holmgr. Ichn. Suec. i. 201 ; Thoms. Ann. Soc. Fr. 1888, p. 109 ; Berth. lib. cit. 1895, p. 554, of q. I. hassicus, Ratz. Ichn. d. Forst. ii. $135,+$. Barichnezumon ritibundus, Thoms. O. E. xviii. 1960, $\delta$ q

A pretty little red species, with black head and metathorax, white scutellum and anus. Head black, narrowed behind the cheeks and eyes; face often entirely reddish, usually with frontal and external orbits white, ot also has palpi, clypeus, facial orbits, the weak mandibles and whole or part of face, whitish; face distinctly punctate, clypeus not separated. Antennae hardly attenuate apically and only slightly thickened centrally; of $q$ white-banded, of $\delta$ black with the scape white, and flagellum ferrugineous, beneath. Thorax rarely entirely black, not broader than head; prothorax striolate beneath, and with callosities at radix in $\delta$, white; mesonotum somewhat dull, very finely and closely punctate, usually entirely reddish with a more or less distinct, nitidulous, translucent tubercle behind the margin of the pronotum in the centre; mesopleurae and apex of metanotum laterally often reddish in $q$ or even paler in $\delta$; metanotum finely scabrous, the upper areae complete, areola slightly longer than broad, sub-hexagonal, its apex evenly rounded; areola of of semicircular. Scutellum somewhat flat and shining; white, occasionally red or black at the base; post-scutellum sometimes red or white. Abdomen finely punctate, somewhat shining; red, with base of first and most of fifth and sixth segments black; disc of sixth and whole of serenth white; post-petiole sub-depressed, smooth, its carinae wanting and apical angles obtuse; second segment punctate, the gastrocaeli transverse, broader than the intervening space but withal not deeply impressed; third segment, at least in $q$, with a strong transverse sulcus throughout before the apex; terebra distinctly exserted, stout, black; of genitalia white. Ieegs reddish, with at least the hind coxac and trochanters, femora apically and tibiae broadly, black; hind coxae of $q$ may or may not bear minute scopulae; c with coxae and trochanters whitish, black-markicu 
above. Wings hyaline; stigma and tegulae of $q$ piceous; areolet somewhat narrowed above. Length, $6-8 \mathrm{~mm}$.

The extent of the red on the thorax and face of the $q$ varies; the $f$ may have all the coxae black and two black lines on the face; or the fifth segment entirely, and a mark on the fourth, black; both sexes sometimes have the face and hind femora nearly entirely black.

The thoracic tubercle and the transverse thyridii, which are not smaller than the intervening space, the head narrowed behind the eyes, the undiscreted clypeus, besides the arrangement of the white markings will render it distinct. 'The superficial gastrocaeli, dullish mesonotum, suttquadrate areola and posteriorly narrowed head, ally it with Stenichneumon pictus, Grav. Superficially it somewhat resembles Hoplismenus uniguttatus, which, however, has the scutellum strongly convex and no prothoracic tubercle.

Bridgman took the male, at Eaton, in July; and Bignell found the species at Langstone, Horrabridge, on 23 rd August, and at Laira ; I possess an example taken at Felden, in Herts., on Sth August, by Mr. Albert Piffard. It is probably not very common in Britain, and does not appear to have been here noticed by the older authors.

\section{4. sexalbatus, Wesm.}

Ichmentmon sexalbatus, Gr. I. E. i. 346 , ๆ (?) ; Wesm. Nouv. Mém. Ac. Brux. I $\$ 44$, p. 95 ; Bul. Ac. Brux. 1848, p. 46 ; Mém. couron. Ac. Belg. I859, p. 4 I ; Berth. Ann. Soc. Fr. I895, p. 252, o \&; cf. Thoms. lib. cit. 1888, p. IIO. I. sedulus, var. 5, Gr. I. E. i. 496, o. I. lepidus, Gr. lib. cit. 349, excl. $\delta$.

Very like B. incubitor; the puncturation is close, and the pubescence of the male white. Head finely punctate, black; palpi, frontal and vertical orbits, white; of also with mandibles entirely, clypeus and face laterally, and external orbits in part, white. Antennae black, of $q$ sub-filiform, setaceous and white-banded, of of fulvous, with the scape usually whitemarked beneath. Thorax somewhat shining, black; pronotum and callosities before and beneath radix, white, or in $q$ fulvous ; toften has two white dots on the metathorax, and the spiracles linear; areola sub-cordiform, in $q$ apically emarginate. Scutellum white, of $q$ basally black; post-scutellum sometimes red or white. Abdomen red; first and seventh segments, and sometimes sixth, black; first with the apical angles rarely white, and seventh rarely with a white dot in $\delta$; sixth and seventh whitemarked in 9 ; gastrocaeli small; post-petiole distinctly punctate. Legs black, with anterior femora mostly, and tibiae, except apices of hind ones, red; anterior tibiae of $\delta$ flavous in front, its hind tarsi piceous; coxae black, not red, closely punctate, hind ones of $q$ with small white scopulae, anterior of $\delta$ in part white; femora stout. Wings of $t$ with tegulae and radix white, and stigma black; stigma of $q$ piceo-rufous. Length, 8-10 $\mathrm{mm}$.

The British example of the male differs slightly from the above description of authors in having:-The mandibles entirely ferrugineous, the capital and thoracic markings flavidous, the scape immaculate, the tegulae piceous with white lunulae in front and radix fulvous, and, though the gastrocacli are small, the thyridii are as deep and nearly as broad as in $B$. incubitor, nevertheless "intervallo inter gastrocoelos paulo latiore," as 
Wesmael says. The areola is semicircular, not longer than broad, rounded in front with the apical margin slightly concave and angles slightly obtuse; the lateral areae are distinctly punctate and complete; the mesosternum has a common transverse fovea in the centre before its base; the sternauli are indicated; the scutellum is more convex and the post-petiole a little broader than in B. incubitor; the abdomen is closely punctate and dull throughout, not more nitidulous, though with longer pubescence towards the anus; the anterior coxae are distinctly white at their apices, the posterior calcaria white, and the anterior femora, except apices, and tibiae, except front ones, anteriorly black ; areolet somewhat narrow.

It is said to further differ from B. incubitor, L. (similatorius, Wesm.) in the slightly shorter clypeus, little longer and less curved lower mandibular tooth, shorter areola, and in the pubescence of the male which is white and not cinereous; all the authors agree, however, that the gastrocaeli, with which are included the thyridii, are smaller. The legs and sixth segment would appear to vary greatly in the extent of red and black coloration.

The only British specimen I have seen is that described above, which I took flying by the roadside at Lyndhurst, Hants., I 2 th August, I90 I. It appears to be somewhat rare upon the Continent, occurring in France, Germany, Belgium, and extending to Italy, but has not before been recorded for Britain.

\section{5. tergenus, Grav.}

Ichneumon octogutlatus, ${ }^{1}$ Gr. I. F.. i. 325 , के . I. tergenus, Gr. I. E. i. 6 I 5 ; Ste. Ill. M. vii. 205, excl. of; Wesm. Nouv, Mém. Ac. Brux. 1844, p. 89; Bul. Ac. Brux. I849, p. 39 ; Holmgr. Ichn. Suec. i. I79; Thoms. Ann. Soc. Fr. 1888, p. I09; Berth. lib. cit.

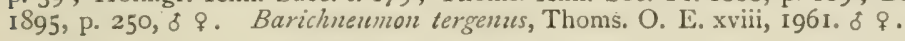

The $q$ is a squat, thick-set insect. Head black, almost always with pale vertical lunulae; of with palpi at apex and a mandibular mark pale, sides of clypeus, internal and part of external orbits white. Antennae of $q$ filiform, hardly attenuate apically, with white central band ; of of with scape white, and generally flagellum ferrugineous, beneath. Thorax black; of $q$ immaculate, of $\delta$ with pronotum and the usual callosities at radix white; prosternum not striolate; metanotum punctato-rugulose, with upper areae complete and very distinct ; the areola sub-hexagonal, transverse and apically emarginate. Scutellum of $q$ strongly deplanate and black; of ot obtuse, elevated, with piceous hairs and Lwo, often confluent, apical white dots. Abdomen darkish red, of $q$ ovate-acuminate ; first more or less and most of fourth to seventh segments black, the last two, or of of sometimes three, white-marked; post-petiole closely punctate, with distinct dorsal carinae; gastrocaeli normal, the intervening space about as broad as centre of postpetiole; third segment with basal incisure deep. Legs black, femora stout; anterior tibiae and front femora of of reddish, former laterally flavous; ô with anterior femora more or less piceo-stramineous apically, their tibiae and tarsi laterally whitish ; hind tibiae of $q$ generally obscurely ferrugineous basally; hind coxae closely punctate without scopulae; o

1 Why the continental authors persist in preserving priority to Gravenhorst's later name I cannot tell, but must suppose there is some good, though occult, reason for so doing, since what would appear to be the true synonymy has been presented by Mlarshall, and is here repeated. 
with valvulae white. Stigma piceous; tegulae black, often white-dotted; areolet narrowly open above. Length, I0-1 $2 \mathrm{~mm}$.

This species is rendered distinct by the post-petiole being evidently carinated, its central, which is hardly broader than the lateral areae, coarsely punctate, and by its obvious thyridii and gastrocaeli; the colour is also characteristic; scutellum black in 9 , apically white in the male; the femora and tibiae black, the front, or in the male, the anterior ones being laterally stramineous; the abdomen has the sixth and seventh segments, in both sexes, and the male valvulae white.

Westmael, in his "Tentamen," mentions a variety of the male, which appears to be unique, certainly Holmgren did not meet with it ; this has the second and third segments black, and the apical angle of the first white. Gravenhorst records a male with an entirely white scutellum.

Hope took one of the original specimens near Netley, and Stephens probably found it occasionally, in July and August, about London and in Salop. I know of no British records since his day, excepting the following. It should, however, be not uncommon at least in the North in grassy places and among undergrowth, since in such situations it is not infrequent in Sweden. An example in Mr. Beaumont's collection was captured at Lewisham, in Kent, in August ; and Mr. Adkin has bred three females of this, which is said to be "one of our handsomest species of Ichneumonidae" from larvae of Eupithecia helveticata ( $c f$. Proc. S. Lond. Soc. 1896, p. 82). It is recorded from Essex.

\section{6. incubitor, Linn.}

Ichnenmon incubitor, Linn. S. N. 933 ; Gr. I. E. i. 6I7, excl. varr. I et 2 : Ste. Ill. M. vii. 205 ; Ratz. Ichn. d. Forst i. I35, $q$; Thoms. Ann. Soc. Fr. I888, p. I10; Berth. lib. cit. I895, p. 253, o o. I. sedulus, Gr. I. E. i. 492, o. I. similatorius, Wesm. Nouv. MIém. Ac. Brux. 1844, p. 94, of $\$$. Barichneumon incubitor, Thoms. O. E. xviii, 1963, o ․

Very like the next species, but smaller; the puncturation close and fine throughout. Head black; $q$ with palpi and mandibles red, and a lunate vertical dot white; fo with the palpi, sides of clypeus, of face to vertex, and part of external orbits, white. Antennae black, feebly but elongately attenuate, somewhat pointed, compressed and rufescent towards apex ; of o white-banded, of flagellum fulvous or ferrugineous beneath, with scape immaculate and joints of apical half sub-nodulose. Thorax black, callosity beneath radix usually white in $q$; $\delta$ with callosity beneath and a longer or shorter line before the radix, and pronotum, white; upper metathoracic areae complete, the costulae not strong; areola sub-glabrous, semi-elliptic or sub-hexagonal. Scutellum flat, of $q$ entirely black or apically rufous, of of with apical half white. Abdomen black, somewhat dull, closely punctate and haired, the four basal segments red; $f$ with sixth transversely marked at apex, with seventh entirely, white ; of of sub-equilateral, petiole or first segment except apex, and fourth or fifth, with whole anus, black; post-petiole punctate, carinae not strong; gastrocaeli large, deep and strongly oblique, the intervening space being narrower than centre of post-petiole and punctate, those of $q$ less deeply impressed. Legs with anterior femora distinctly inflated; black, femora and tibiae red, the posterior apically black at least above; front femora sometimes broadly black; coxae occasionally a little fulvidous beneath. Wings slightly 
clouded; areolet narrowed above in $f$; tegulae fuscous, radix flavous, stigma piceous and not paler basally. Length, 7-10 $\mathrm{mm}$.

It may be known by its transverse thyridii, which are much broader than the intervening space; the basal flagellar joints are longer than those of $B$. derivator. The legs, especially the anterior, are rarely entirely black; the male sometimes has the seventh segment white-marked.

I found a male of this species, which appears to have been hitherto mixed in Britain with $B$. derogator, in Tuddenham Fen, Suffolk, on 24th August, I900; and another in Mr. Bignell's collection, taken at Bickleigh Vale, which is surrounded by oak woods some miles in extent, in Devon, by sweeping the herbage, on Ist August; Mr. Beaumont also has taken it at Blackheath, in June. Another male, which I took at Lyndhurst, in August, appears to differ in nothing but its apically white anterior coxae from the present species. It has not before been authentically recorded from Britain, though Stephens mentions it from near London, in June, and I am not aware that it has hitherto been bred. On the Continent it is widely distributed, occurring in woods, from June to September, but becoming rarer in the more northern districts.

\section{7. basiglyptus, Kriech.}

Ichneumon basiglyptus, Kriech. Ent. Nachr. 1890, $\$$; Berth. Ann. Soc. Fr. I895, p. $557, \delta$.

Head narrowed behind the eyes; mouth parts and vertical lunulae white, of also with sides of clypeus and of face, white. Antennae entirely black in $\delta$; of $q$ sub-filiform, a little dilato-compressed and white-banded centrally, with the apex obtuse. Thorax black throughout; areola large, semi-oval, apically emarginate and more glabrous than lateral areae, which are indistinctly complete. Scutellum black, of of rarely with two white apical dots. Abdomen red, of $q$ elongate-oval ; segments one basally, five apically, and six in part, or whole anus in $\hat{\sigma}$, black; $q$ with six and seven white-marked; post-petiole and following segments strongly punctate throughout, of has the former convex with no carinae; gastrocaeli transverse and somewhat deep, of with intervening space narrow. Legs stout, red, darker in $\delta$; coxae, trochanters and apices of posterior femora and tibiae, black; coxae not scopuliferous. Stigma piceous, centrally pale; areolet narrowed above. Length, 6-8 $\mathrm{mm}$.

There appear to be few structural features by which to distinguish this species from its allies, nevertheless the white mouth of the female is remarkable; the male bears a very close resemblance to that of $B$. inculitor, but it is a little smaller, with the frontal and external orbits, and usually scutellum, immaculate, the radical callosities also are immaculate and the stigma is centrally pale, as in $B$. chionomus.

I took two males, which agree well with the above description, at Lyndhurst, Hants., early in August, on flowers of Heracleum sphondylium, and have no doubt it is widely distributed, but overlooked, in Britain, since it is found in Savoy, about Paris, \&c., but has not been bred.

\section{8. rufidorsatus, Bridg.}

Ichnezunon nufulorsatus, Bridg. Trans. Ent. Soc. 1887, p. 36r; Berth. Ann. Soc. Fr. 1895, p. 562 \&. 
Head not narrowed behind eyes, black; mouth parts piceous. Antennae stoutish, scarcely longer than half body, black, slightly dilated and redbanded centrally, apically attenuate. Thorax black; pronotum and the shining mesonotum red; metathorax finely rugulose, with three upper areae, of which the areola is quadrate; their costae fine. Scutellum splarsely punctate, shining, red. Abdomen elongate ovate, black ; segments one to three red, six and seven dorsally fulvous; central segments transverse; post-petiole smooth, obsoletely reticulate, nitidulous, slightly punctate apically; gastrocaeli transverse, broad, shallow, the intervening space narrower than centre of post-petiole; terebra distinctly exserted. Legs red; tarsi apically piceous; hind coxae entirely black and not scopuliferous. Tegulae reddish; stigma testaceous; areolet wide above. Length, $7 \mathrm{~mm}$. Male unknown.

The stout antemnae, broad head and shagreened post-petiole appear to ally this species with Barichneumon in spite of the immaculate vertex. It much resembles Ichnemmon picticollis, Holmgr., from which the colour of the legs and the incrassate antennae distinguish it.

Mr. G. C. Champion took one specimen, at Aviemore, in I887. It is unknown on the Continent.

\section{9. vacillatorius, Grav.}

Ichneumon vacillatorius, Gr. I. E. i. 500 ; Ste. Ill. M. vii. I92; Wesm. Nouv. Mém Ac. Brux. I844, p. IOI; Bul. Ac. Brux. IS 48 , p. I83; Holmgr. Ichn. Suec i. 160 ; Thums. Ann. Soc. Fr. I888, p. III ; Berth. lib. cit. 1895, p. 277, o \&. Barichnenmon vacillatorius, Thoms. O. F. xviii, I96r, o ㅇ.

A small black species, with the scutellum more or less white and the abdomen mainly red. Head black; clypeus discreted from the prominent epistoma; mandibles red-marked; $q$ with frontal orbits distinctly white, the colour being a little incurved along the epistomal costa which extends to the eyes; of with mandibles, except their apices, the internal orbits and centre of face, flavous. Antennae sub-filiform, black; those of $q$ whitebanded, of $\delta$ ferrugineous, with the scape flavous below. Thorax black, shining, a callosity beneath, and in of before the radix, flavous; metanotum sparingly rugose, with complete areae, areola cordiform, the apical angles rounded and the apical margin gently curved, not emarginate; petiolar area discreted; notauli punctiform; sternauli distinct, reaching from apex to centre of mesosternum; spiracles rather small, linear or elongate-oval. Scutellum flat, sparsely punctate, with erect setae; apically truncate and white, rarely black throughout. Abdomen red; first segment, except its apex, and most of the last three black; the sixth and seventh narrowly white- or red-margined; post-petiole more or less strongly punctate, the carinae indistinct and apex glabrous ; second segment punctate, sub-quadrate, with the gastrocaeli sub-obsolete and sub-striolate, the intervening space being very broad and evenly punctate. Legs black; hind tibiae, which are internally canaliculate in of, and more or less of the anterior legs, red; hind coxae without scopulae, their femora vary from red to piceous or black. Wings slightly infuscate; $q$ tegulae and stigma piceous, radix flavous, areolet somewhat narrowed above. Length, 7-8 $\mathrm{mm}$.

The variation is confined to the colour of the female legs and scutellum.

This small species forms, as Thomson has pointed out (loc. cit.), somewhat of a connecting link with the Phaeosenides, much resembling super- 
ficially some of the larger Phacogenes, and this is accentuated by the fact that the metathoracic spiracles are not quite constant in conformation, becoming at times almost elongate-oval, but from every Phaeogenes it is instantly distinguished by the absence of a transverse linear impression on the second segment. From its allies it may be known by its small size, generally bright red abdomen, the anus of which is not dorsally white, the small thyridii and thoracic spiracles, by the absence of vertical dots on the head, and by the transversely costulate sides of the metathorax.

The female, which hibernates in moss, \&c., appears to be of much more frequent occurrence than the male, which I have not seen. Probably a common species with us. Stephens found it uncommonly about London, in June. I have several examples, taken in the New Forest, by Miss Chawner, and at Guestling, near Hastings, by the Rev. E. N. Bloomfield. It is probably mixed with Phaeogenes in collections; and is widely distributed on the Continent.

\section{Io. heracleanae, Bridg.}

Ichnemmon heracliana, Bridg. Trans. Ent. Soc. 1884, p. 42r, + . I. heraclianae, Berth. Ann. Soc. Fr, 1895. p. 277, ㅇ․

A rather small red and black species, with dark legs. Head black, narrowed behind the eyes; face centrally prominent; clypeus distinctly discreted, broadly rounded in front and sparsely punctate. Antennae filiform, not or scarcely attenuate at apex, half as long as the body, white-banded, apically reddish beneath. Thorax black; sternauli and notauli distinct; metanotum rugulose, with complete upper areae; areolia broad triangular, basally pointed and apically emarginate in the centre, broadly rounded at the angles; spiracles short oval, equilateral and oblique. Scutellum indistinctly punctate, black. Abdomen elongateovate, black; segments two to four and apex of one red; post-petiole distinctly punctate throughout, with weak carinae; gastrocaeli small, shallow and indistinct, the intervening space broad and closely punctate; terebra very slightly exserted. Legs piceous ; coxae, and more or less of the hind femora apically, black; hind femora more or less broadly red at the base; hind coxae finely punctate, not scopuliferous, but indistinctly trans-sulcate centrally beneath. Wings hyaline; stigma fuscous; areolet sub-pentagonal, narrowed above. Length, $8 \mathrm{~mm}$. Male unknown.

The sub-oval metathoracic spiracles are so short as to somewhat approach those of the Phaeogenides, but there can, nevertheless, be no doubt that this species is here correctly placed, in spite of the immaculate vertex; by the same characters, as well as by the five black segments, it may be at once distinguished from its allies.

Mrr. Bignell has kindly presented me with one of the original specimens, which was bred by himself from Depressaria heracleana, on $\mathrm{r}$ ath August, 1878 ; the late Mr. Fred. Smith named it I. vacillatorius, at the British Nuseum; and it is recorded under that name in Entom. I878, p. 254 , where the former remarks that he bred thirty-seven parasites out of fiftyeight of the host's pupae in Heracleum sphondylium, and that it makes no pupa-case of its own, but undergoes its metamorphoses in that of its host. Five years later it was bred from the same host by Mr. WV. H. B. Fletcher, and Bridgman then described it as new. Bridgman took one specimen at Lymn, Norfolk, and others are thought to have been bred from the 
above host, in Devonshire. It would appear to be unknown on the Continent.

\section{II. semirufus, Grav.}

Ichneumon seminufus, Gr. Mem. Ac. Sc. Torin. I820, p. 338; I. E. i. 488, excl. var.; Ste. Ill. M. vii. I9I; Wesm. Nouv. Mém. Ac. Brux 1844, p. 100; Berth. Ann. Soc. Fr. I895, p. 278, ช์ \&.

q. Head black; clypeus sub-rotund in front; frontal orbits sometimes reddish. Antennae sub-filiform, white-banded. 'Thorax entirely black; areola sub-quadrate, laterally cmarginate. Scutellum at least partly white. Abdomen oblong-ovate, black, segments one to four red; post-petiole punctate ; gastrocaeli nearly wanting ; terebra exserted. Legss black ; tibiae and tarsi red, hind ones apically fuscous ; femora stout; hind coxae nude. Areolet sub-deltoid.

o. Head black; labrum, angles of clypeus, sides of face, external narrowly and occipital orbits, flavous. Antennae black ; reddish, including scape, beneath. 'Thorax black, sometimes with humeral dots and postscutellum white; areola transverse, sub-quadrate. Scutellum almost always apically white. Abdomen sub-cylindrical, black, segments two to four and apex of post-petiole red; the latter shining, punctate ; gastrocaeli distinct, longitudinal. Legs as in female. Length, 9-1 $2 \mathrm{~mm}$.

Stephens says it was not very common, near London, in June and July. There are two males under this name in Marshall's collection (Mus. Mason), one of which is from Botusfleming, Cornwall. It would appear to be somewhat local on the Continent, and has not been bred.

\section{I2. pulchellatus, Bridg.}

Ichneumon pulchellatus, Bridg. Trans. Ent. Soc. I889, p. 4 II ; Berth. Ann. Soc. Fr. :895, p. 276, ơ क ; $f f$. Bul. Soc. Fr. I 899, p. 136.

Head transverse, scarcely narrowed behind eyes; black, mandibles, frontal orbits, and vertical lunulae, flavous; of has the whole clypeus, palpi, with centre and sides of face also flavous; clypeus apically truncate. Antennae shorter than body, sub-filiform; piceous, red-banded in $q$, scape flavous beneath in of. Thorax shining, strongly punctulate; black, lines at radix, and in $\sigma^{*}$ marks on the propleurae, flavous; metanotum somewhat coarsely rugose, upper areae complete; areola strongly transverse and very narrow; spiracles ovate, longer in ơ; petiolar area discreted. Scutellum somewhat rotund, flavous; post-scutellum of to flavidous. Abdomen cylindrical, black; segments two to four entirely, apex of first and part or whole of fifth, red; anus immaculate; post-petiole centrally obscurely rugulose, apically glabrous with the lateral areae roughly punctate; gastrocaeli moderately shallow, deeper in of, the intervening space as broad as centre of post-petiole; terebra exserted. Legs red; coxae and trochanters black, the anterior flavous-marked in of; femora and tibiae partly piceous, the anterior flavous in front in $\delta$; hind coxae simple, their tarsi apically fuscous. Wings hyaline; stigma piceous, tegulae black; areolet pentagonal. Length, 7-8 $\mathrm{mm}$.

Berthoumieu (Bul. Soc. Fr.) describes a $q$ variety from Switzerland with the antennae entirely black, the base of the mandibles and the postscutellum white, and the second segment only red. He remarks (loc. cit.) 
that he strongly suspects this species to be synonymous with the following, but the points indicated below will at once serve to distinguish between them.

Mr. J. E. Fletcher, and Mr. Bignell, in Devon, bred this species from Eupithecia pulchellata, Ste. The above would appear to be the only continental record.

\section{I3. eupitheciae, Brisch.}

Ichnermon eupitheciae, Brisch. Schr. Nat. Ges. Danz. 1878, no. 6, n. 45, \& \&. Phacogenes eupitheciae, Berth. Ann. Soc. Fr. I896, p 380; ff. Bul. Soc. Fr. I899, p. 136 .

Very closely allied to the last-described species. Head transverse, black; mandibles, frontal orbits and vertical lunulae white; to has the mouth, clypeus and facial orbits also white; clypeus apically broadly rounded, and the face protuberant. Antennae black, scape of of white beneath. Thorax black, lines at radix white; spiracles nearly circular; areola transverse. Scutellum and post-scutellum white. Abdomen black; segments two to four or five and apical margin of the following, red; postpetiole longitudinally sculptured; gastrocaeli transverse, nearly convergent centrally, not deep. Legs red; coxae black, the front ones white-marked in $\delta$. Wings hyaline; stigma piceous; areolet pentagonal. Length, $6 \frac{1}{2}-7 \mathrm{~mm}$.

This species may at once be known from $B$. pulchellatus by the structure of the metathoracic spiracles, which are only just longer than broad; they are, however, much larger and face upwards, not backwards as in the genus Pharosenes; its contour and conformation, moreover, proclaim it a true Oxypygini, to which Berthoumieu (Bul. Soc. Fr.) subsequently wished to reclaim it. In other particulars it differs from the last species in the broadly rounded clypeus, slightly transverse scutellum, in the space between the gastrocaeli being narrower than centre of post-petiole, the immaculate prothorax and intermediate cosae, and in the anterior legs not being marked with flavous.

I have only seen one British specimen, which differed slightly from the above $o$ in having the face entirely flavous, and the first segment, except its base, red. The sternauli are distinct; the post-petiole has two or three central longitudinal striae, which can hardly be termed aciculation, and it is certainly not centrally rugulose. Berthoumieu is in error in recording it hence, since it has hitherto been here unknown. This male was bred from the pupa of Eufithecia helveticata, Boisd., in the Pentland Hills, in September, 1897 , by Mr. W. Evans; the parasite in emerging had entirely removed the capital extremity of the chrysalis, which itself measures but $7 \mathrm{~mm}$., in a jagged, irregular manner. Brischke bred it from pupae of what he calls $E$. digitaliata (=? pulchellata), in Prussia.

\section{I4. albicinctus, Grav.}

Ichneunon albicinctus, Gr. I. E. i. 509; Ste. Ill. MI. vii. 193; Wesm. Nouv. Mém. Ac. Brux. 1844 , p. IOI ; Ratz. Ichn. d. Forst. iii. 171 ; Ruthe, Stett. Zeit. I859, p. 362 ; Holmgr. Ichn. Suec. i. 203; Thoms. Ann. Soc. Fr. 1888, p. III ; Berth. lib. cit. 1895, p. $562, \delta$ \&. I. lautus, Tisch. Stett. Zeit. 1863, ó. Barichnenmon albicinclus, Thoms. O. E. xviii. 1961, $\delta$ \&.

A small red and black species, with white tibial band. Ifad black, 
epistoma prominent; frontal and lunulae at vertical orbits white; $q$ with the mandibles and more or less of the distinctly separated clypeus red; of with the palpi, mandibles, clypeus, face and cheeks entirely white. Antennae ferrugineous beneath; in $q$ stout, filiform and white-banded; in of much longer, sub-attenuate, more slender, with scape white beneath. Thorax black and shining; of with pronotum, a long line before and often another beneath the radix, and occasionally two marks on the metathorax, white; metanotum roughly punctate, with complete areae; the areola sub-semicircular, broader than long, especially in of, apically rectangular, with the margin truncate; spiracles small, more rounded laterally in $q$. Scutellum, and often in the $\delta$, the post-scutellum, entirely or apically white; rarely black throughout in $q$. Abdomen nearly smooth, shining, red to its apex, which, however, is sometimes infuscate in $\delta$; first segment nearly entirely black; post-petiole finely and distinctly punctate, or nearly glabrous; second segment basally impressed throughout, with broad, transversely linear thyridii, and simple, small but distinct gastrocaeli; terebra piceous, exserted the length of half the first segment. Legs black, anterior femora and tibiae, and hind femora more or less towards the base, red; hind tibiae black, with a broad white basal band; $\delta$ with anterior coxae sometimes flavidous; $q$ hind coxae shining, sparsely punctate, with no scopulae. Wings hyaline, radix flavous, stigma piceous ; areolet somewhat narrowed above; radial nervure externally incurved; tegulae of 0 t flavous, of $q$ piceous. Length, $6-8 \mathrm{~mm}$.

A small and very distinct species, at once known by the black, basally white-ringed, hind tibiae, by the white vertical dot on the head, the absence of white on the anus, and by the far-exserted terebra, which gives it a somewhat Cryptid appearance.

Var. Piffardi. I have a very distinct variety of the male, probably meriting specific rank, to which, in the absence of the female, it were foolish to raise it. From the type form it differs in having all the markings, including the anterior coxae, pure white; the flagellum is fulvous beneath, with its apical joints somewhat more nodulose; the areola is apically emarginate; the post-petiole much more strongly arcuate, and its central area much broader; the gastrocaeli are distinctly trans-striolate, and the thyridii more deeply impressed and internally bounded by a distinct tuberculiform prominence, between which the space is very narrow, a little less impressed and evenly punctate; the wings are a little more elongate and very slightly flavescent, with the radial nervure externally quite straight. Length, $6 \frac{1}{2} \mathrm{~mm}$.

This variety was taken at Felden, in Herts., by Mr. Albert Piffard, F.E.S., to whom I owe much for most valuable assistance and the gift of his collection of British Ichneumons.

$B$. albicinctus is not uncommon on the Continent, upon Umbelliferae, \&c., from May to September. Stephens found it in Darenth Woods, in June, and Bridgman says it is very common in Norfolk. It is a well known parasite of Fidonia piniaria, and has also been bred, in Germany, from Macaria liturata. Bignell has bred it, on May 5 th, from Hypsipetes muberata, and on September 9th, from Eupithecia rectangulata, in South Devon. It is undoubtedly a common and widely distributed species in Britain. I have received examples, bred from Melanippe fuctuata, at Edinburgh, by Mr. J. Waterton, in June, and from Epunda viminalis, at 
Doncaster, by Mr. W. G. Clutten. Tostock, Suffolk, in June and September, and Finborough Park, Suffolk, in October ('Tuck); Fairlight and Guestling, Hastings; Greenings, near Reigate, in June (IVilson Saunders); Isle of Man, in 1869 (Walker, Entom. I 873, p. 432); Bristol, Box Hill, Lewisham, Colwyn, Pitlochry (Beaumont). I have found the hibernating females in tufts of Aira caespilosa, at Brede, near Hastings, in March, and taken the males, at Eaton, near Norwich, and at Barton Mills, in June, as well as females, by sweeping reeds, at Ipswich, in October; it would appear to be attached to marshy situations, which cannot be said of Fidonia piniaria.

\section{5. plagiarius, Wesm.}

Ichnemmon plagiarius, Wesm. Bul. Ac. Brux. 1848, p. 47, o ; Bridg. Trans. Lnt. Soc. I889, p. 411, of; Berth. Ann. Soc. Fr. I895, p. 243, of $q$.

Head black; mandibles, clypeus, and a mark in centre of face, red; palpi and vertical lunulae white; of also has clypeus and internal orbits white. Antennae of $q$ sub-filiform, piceous, white-banded; scape red beneath; of 0 entirely black. Thorax black; pronotum and callosity beneath, and in of before, the radix, white; areola transverse, sub-linear, glabrous; mesosternum thrice broader than long. Scutellum white; post-scutellum of $q$ red, of $\delta$ sometimes white. Abdomen somewhat short, black; segments one to three, and four laterally, red; six to seven of $q$ only, dorsally white; post-petiole punctate throughout; gastrocaeli small; terebra exserted. Legs red; coxae trochanters and apices of hind femora and tibiae blackish; hind coxae simply punctate. Stigma and tegulae piceous. Length, 6-7 mm.

Bridgman took both sexes in the neighbourhood of Norwich, in August; on the Continent it has a restricted range from Hungary to Belgium, and is certainly uncommon.

\section{6. derogator, Wesm.}

Ichneumon albinotatus, Gr. I. E. i, 507, ó, excl. var. (probabiliter). I. incubitor, var. 2, Gr. lib cit. 6I8, \&. I. derogator, Wesm. Nouv. Mém. Ac. Brux. I844, p. 93 ; Bul. Ac. Brux. I848, p. 178; Thoms. Ann. Soc. Fr. 1888, p. I10 ; Berth. lib. cit. 1895, p. 247, of $\$$; Holm. Ichn. Suec. i. 186, o. Barichnenmon derogator, Thoms. O. E. xviii. 1963 , o $\$$.

Head black, shining, finely and sparsely punctate, somewhat broad behind the eyes ; occiput elevated between posterior ocelli ; face prominent, epistoma produced into a small obtuse tooth beneath scape; + clypeus sub-distinctly separated, convex, glabrous, with a line of fine punctures before the red truncate apex; cheeks not longer than the basal breadth of mandibles, which are stout, in $q$ red and glabrous; $q$ palpi piceous, with the two apical joints of the maxillary fulvous; vertical lunulae white; $\delta$ also has palpi, mandibles, clypeus, face, the frontal and a line at external orbits, white. Antennae black, of o filiform, apically obtuse, whitebanded, the scape sub-globose; of of gradually attenuate, ferrugineous towards apex, and scape sometimes white, beneath. 'Thorax shining, black, with rather coarse and not very close puncturation; mesonotum deplanate in $q$, sternauli wanting ; notauli distinct, and metanotum finely rugose in of; upper areae complete, areola sub-cordiform, longer than broad, apically emarginate; spiracles linear; to bas pronotum, lines at 
radix, and often two marks on metanotum, white. Scutellum flat, shining, sparsely punctate; of $q$ with erect setae at base only, black, rarely white; of $\delta$ white at apex, sometimes with two dots on post-scutellum pale. Abdomen sub-cylindrical, sanguincous-red, closely and finely punctate and strongly nitidulous; base of petiole and last three segments black; $q$ with basal angles of fifth red, sixth with an apical fascia, and the whole disc of seventh, white; in the apex of first segment is usually white, the next two or three entirely castaneous, and the remainder black; post petiole closely and finely punctate, apically smooth in of, carinae obsolete in $q$, apical angles obtuse, and just beyond them are the sub-obsolete, minute gastrocaeli, which are more distinct, though still small, in of. Legs stout, black, femora sometimes piceous; calcaria in $q$, apices of anterior femora, and whole of tibiae, except apices of posterior, red; anterior tibiae of $\delta$ partly flavous; coxae shining, finely and diffusely punctate, with no scopulae, of of the anterior at least marked with white ; tarsal claws small ; calcaria of white and base of its hind tibiae pale. Wings slightly clouded; nervures, stigma and tegulae piceous, this last white in $\delta$; radix whitish; areolet narrowed above, sides coalescing in $\delta$. Length, 7--8 $\mathrm{mm}$.

The male much resembles that of $B$. albicinctus, but the legs are stouter, the tibial band obscure, the cheeks and anus black, no basal impression on second segment and small gastrocaeli; from its allies, the prominent face, obsolete gastrocaeli, and black scutellum will at once separate the female, which further differs from that of $B$. chionomus in its stouter legs, more denticulate epistoma, and unicolorous stigma.

Bignell took this species at Bickleigh, in Devon, in August; Piffard a male at.Felden as late as I 5 th September; and I possess a female taken by Mr. W. H. Tuck, on flowers of Chaerophyllum, at Tostock, Suffolk, in June, and a male which I found on Heracleum sphondylizm, at Lyndhurst, in August. It occurs throughout N. IV. Europe, and has there been bred from Macaria liturata and Trachea piniferda.

\section{I7. bilunulatus, Grav.}

Ichneumon bilunulatus, Gr. I E. i. 33I, \&; Wesm. Nouv. Mém. Ac. Brux, 1844, p. 98 ; Bul. Ac. Brux. 1848, p I82 ; Holmgr. Ichn. Suec. i. I87; Thoms. Ann. Soc. Fr. 1888, p. I10; Berth. lit. cit. 1895, p. 249, o ?. I. sexlineatus, Gr. I. E. i. 487; Ste. Ill. M. vii, I90; Ratz. Ichn. d. Forst. iii. I7 I, J. I. Troscheli, Ratz. lib. cit. i. 138 ; ii. $135, \delta$. Var. I. derivalor, Wesm. Nouv. Mém. Ac. Brux. 1844, p. 92 ; Thoms. Ann. Soc. Fr. 1888, p. 1 10, q. Barichnenmon derivator, Thoms. O. E. xviii. 1963, of 9. Var. I. procerzıs, Gr. I. E. i. 550 ; Ste. Ill. M. vii. 196 ; Wesm. Mém. couron. Ac. Belg. ז859, p. $65, \delta$.

Front tibiae pale; hind coxae sparsely punctate. Head somewhat buccate, hardly narrowed behind the eyes; cheeks short, face centrally prominent, clypeus discreted; black, palpi and part of mouth pale; vertical lunulae broadly white; of also with centre of mandibles, internal and genal orbits, and generally sides of clypeus, white. Antennae black ; of $q$ stout, dilato-compressed and feebly attenuate, white-banded; of $\delta$ not longer than half body, ferrugineous beneath. Thorax black, with pronotum and callosity beneath radix, and another before it in $\delta$, white ; sternauli distinct; metanotum with complete upper areae; areola subcordiform, transverse in $\delta$, apically emarginate. Scutellum partly white. Abdomen black, not finely and closely punctate; basal three segments 
lighter or darker red; $q$ with sixth and seventh dorsally white, of rarely with latter pale; post-petiole broad, closely punctate; second segment with basal incisure deep; gastrocaeli small, especially in $q$, but distinct. I.egs black, femora stout, those of t more or less red ; tibiae and tarsi in part red; front tibiae laterally flavous or whitish and shortly spinulose; hind coxae shining, sparingly punctate and not scopuliferous. Wings a little clouded; stigma and tegulae piceous or ferrugineous, latter in to whitedotted; areolet narrowed above; external radial nervure apically curved. Length, 8-ro $\mathrm{mm}$.

I follow most authors in considering $I$. derivator, Wesm., a mere blackscutellum variety of the female; but Thomson not only points out in the "Annales" that it is smaller, at most $8 \mathrm{~mm}$., with the frons more thickly punctate, legs more slender, tarsal claws longer and the oral costa dentately elevated, but in his "Opusc. Ent." he includes it definitely in Barichneumon, while placing I. bilunulatus tentatively next to it, as doubtfully referable to this sub-genus, on account of the tibial formation. If there be two species, they are not understood in Britain, and since the true I. bilunulatus of Gravenhorst has never been found in Sweden, where Holmgren says $I$. derivator is only "minus frequens . . . in graminosis et fruticetis," both probably do not occur here.

Like the preceding species, $B$. derivator may be known by the short antennae being inserted low on the forehead, and the second flagellar joint being sub-transverse, but is distinguished from it by the clearly inflexed genal costa, which is more dentately elevated, as well as by its shorter areola, much larger gastrocaeli, and by the colour of the front tibiae.

The colour of the male is somewhat inconstant in curious directions; thus the antennae will at times bear vestiges of a white band, the postpetiole have an apical white dot on either side, or even the seventh segment with a white dorsal dot; the hind femora are sometimes red.

Var. triplax, Berth., is a male with white-banded antennae, the scutellum black, and the seventh segment white-marked. The variety procerus, Grav, though normal in other respects, has the front tibiae ferrugineouc, thus agreeing with $B$. derogator.

Stephens records this species, "scutellum white at the apex," as uncommon, about July, near London, and the var. procerus, thence very rarely in June. Bridgman says 1. bilumulatus is common in Norfolk, and Bignell took it at Bickleigh, in Devon, on August 2oth. It has been frequently bred on the Continent from Tracheit piniferda, and also from Orgyia fudibunda, Hadenu adusta and H. balticar; the var. derivutor has emerged from Fidonia piniaria.

\section{I8. vestigator, Wesm.}

Ichneumon deceptor, Gr. Mem. Ac. Sc. Torin, 1820 , p. $30 S$ (part); I. E. i. 332 ; Ste. IIl M. vii. I7o, excl. $f$ et indivv. : antennae subtus albo et stigmate fusco aut piceo; cf. WVesm. Ném. couron. Ac. Belg. 1859, p. 39; Berth. Ann. Soc Fr IS95, $\mathrm{p} 244$, o 9. I. suavis, var. I, Gir. I. F., i. 348 , o. I. vestigalor, ${ }^{1}$ IVesm. Nouv. Mím. Ac. Brux. I844, p. 90 ; Holm. Ichn. Suec. i. 175; Thoms Ann. Soc. Fr. 1S8S, p. 109 \& \&. Barichnetmon vestigator, Thoms. O. E xviii. 1962, ठै \&.

A dull red and black species, with white scutellum and anus. Head

1 Since Gravenhorst obviously gathered the females of more than one species under his $I$. deceptor, and his description is not intelligible, it is certainly preferable to retain the very lucid one of Wesmael, which embraces both sexes. 
strongly punctate, black ; frons very coarsely punctate and deplanate; clypeus separated, sparsely punctate in $q$ and truncate, apically reddish with the lateral fovere small; $q$ with mandibles, extreme apices of cheeks, dots at vertex and sometimes the internal orbits, red; with vertical lunulae and usually facial orbits distinctly white. Antennae of $q$ sub-filiform, strongly dilato-compressed beyond the middle, which is white-banded, basal joints and scape beneath often red; of $f$ attenuate, usually reddish beneath. Thorax very dull, black, and strongly punctate; $q$ with pronotum sometimes reddish; of with pronotum, and, rarely, a dot beneath radix white; sternauli distinct; metanotum more finely punctate, with the areae complete; areola scarcely longer than broad, rounded at base and apex, with angles of latter acute, broader with apex emarginate in $t$. Scutellum sparsely punctate, shining white; post-scutellum often pale. Abdomen elongate-oval; of st sub-cylindrical; dull, and somewhat strongly punctate; red, the fourth and fifth segments, and sometimes the first of $\delta$, black, sixth and seventh, and sometimes fifth of $\tilde{o}$, dorsally white; post-petiole strongly and closely punctate throughout, not very shining, the carinae not strong and the apex rectangular; second segment faintly transversely impressed in the centre; gastrocaeli small and oblique; terebra somewhat exserted, piceous. Legs black ; femora rather stout and in part red, front ones a little dilated beneath, especially in $q$; tibiae and tarsi red, hind or posterior apically infuscate; basal joint of front tarsi strongly excised beneath, less so in $\delta$; coxae somewhat closely punctate, with no scopulae. Wings sub-hyaline, stigma and often nervures fulvous; tegulae and radix piceous, the former with white dot in front in $\delta$; areolet narrowed above; in $f$ extreme apex of radial nervure distinctly curved. Length, $8-10 \mathrm{~mm}$.

Head sub-triangular, with a small pale vertical dot; frons not convex, sub-rugosely punctate; antennae of $q$ dilated before the apex; sternauli indicated; mesonotum and segments two and three coarsely punctate, nearly opaque; legs slender; tibae sub-mutic; male has the external orbits, mouth and clypeus entirely black; the antennal scape not white beneath; thorax sometimes entirely black; the fourth abdominal segment is black, with the basal angles or whole base red, and it is not white-marked. The female differs from $B$. callicerus, \&c., in having the metanotal areae complete, and the fifth segment immaculate, and by its rufous markings.

This species is very like $B$. lepidus, but has a distinct white vertical dot, the frons is flattish, and the mesonotum more strongly punctate.

The colour of the legs appears to vary much in the extent of the black markings.

Stephens, whose "deceptor" is in part referable to this species, says it is not uncommon in the vicinity of London, and is also found in Norfolk, Salop, Scotland, Sc. ; Bridgman quotes this, and also records B. vestigator from Norwich; Essex; Bignell captured it at Bickleigh, in Devon, on September 6th; I have found it about Ipswich; at Eye, in Suffolk, on Angelica ; and at Lyndhurst, in Hants., on Scutellaria, in August. Felden, Herts. (Piffard) ; Tostock, in July and September (Tuck); Cornwall, in September (Davies); both sexes in the New Forest (Miss Chawner); Kilmore, Woking, Oxshott, Catford, Weybridge and Blackheath (Beaumont); Oxford (Hamm). It does not appear to have been bred, though it is undoubtedly not uncommon in Britain, and on the Continent. The female is said to hibernate. 


\section{I9. lepidus, Grav.}

Ichneumon lepidus, Gr. I. E. i. 349; Wesm. Nouv. Mém. Ac. Brux. r844, p. 98, excl. \& ; Mém. couron. Ac. Belg. I859, p. 45 ; Holmgr. Ichn. Suec. i 177 ; Thoms. Ann. Soc. Fr. IS88, p. 109; Berth. lib. cit. I895. p. 246, o \&. I. suavis, excl. var. I, Gr. I. E. i. 348, o. Barichneumon lepidus, Thoms. O. E. xviii. 1962, o \&. Var. Ichneumon fallax, Gr. I. E. i 35 I, o.

Extremely like $B$. vestigator. Head somewhat strongly punctate, black ; frons slightly convex; clypeus sparsely punctate, apically sub-sinuate; $f$ with mandibles, and sometimes apex of clypeus, reddish; $\delta$ with frontal orbits very rarely white. Antennae of $q$ sub-filiform, dilated beyond the middle, which is white-banded, basal joints often reddish; of $\delta$ attenuate, more or less reddish beneath. Thorax dull, strongly punctate, black; the pronotum of $\delta$ white, of $q$ sometimes rufescent; of rarely has a white callosity beneath the radix; sternauli distinct; metanotum more finely punctate, with the areae complete, the costulae sometimes indistinct; areola sub-hexagonal, apically emarginate. Scutellum sparsely punctate, shining, white; post-scutellum sometimes rufescent in $q$. Abdomen of of sub-cylindrical, broader posteriorly, somewhat dull and a little strongly punctate ; red, fourth and fifth segments, sometimes also first of $\delta$, black; six and seven, sometimes five of $t$, dorsally white; post-petiole never closely, usually strongly and sparsely punctate, sometimes sub-glabrous with the punctures obsolete, often strongly nitidulous, the carinae not strong and the apex rectangular; gastrocaeli of to very distinct, longitudinal, twice longer than broad, shining, of of small. Legs as in $B$. vestigator. Wings slightly clouded; stigma and nervures piceo-fuscous; tegulae and radix piceous, the former often with a white dot in front in 0 ; areolet narrowed above; $t$ with apex of radial nervure straight. Length, 8- $12 \mathrm{~mm}$.

It differs from the preceding species in many inconspicuous points, which are more or less constant, and of which the conformation of the gastrocaeli is probably the most reliable. 'The frons is less rugosely and more evenly punctured, and in the female slightly convex, with the flagellum nearly always tricoloured, the first flagellar joint being shorter than the scape; the post-petiole is much more sparsely punctate, often shining, and the puncturation of the second and third segments is also finer, and they are more shining; the gastrocaeli are larger and extend much further from the base in the male, whose head is very rarely whitemarked at all, and tarsal claws stouter, its mesonotum is more convex anteriorly, and the abdomen broader in its apical third. I am not, however, convinced that the species are distinct.

The female appears to be comparatively constant in its markings, but the colour of the male is very variable, especially that of the legs; that of the head is sometimes white in the facial, frontal, and rarely even the vertical, orbits; the antennae are occasionally sub-annulated with white (var. fallax); and the peticle is red or black.

It occurs as frequently as the preceding, and I have always taken it in marshy places; Tuddenham Fen, Suffolk, in June; Filby Broad, and the var. fallax, at Eaton, near Norwich, in June; Lyndhurst, Hants, in August. Brundall and Norwich (Bridgman); Giffnock, carly in June (Dalglish); Bignell did not meet with it in I)evon, but he tells me 
Harwood has bred it from Lycaena Iolas, probably at Colchester. ${ }^{1}$ It has been bred from Defressaria heracleana (Entom. I884, p. 70); and the var. fallax from Mania typica. The female would appear to be of much rarer occurrence than the male, and I have not seen an example of it.

\section{0. angustatus, Wesm.}

Ichnezmon militaris, Gr. Mem. Ac. Soc. Torin. I820, p. 3 10; I. E. i. 342, excl. \&; Ste. Ill. M. vii. I72 ; Wesm. Mém. couron. Ac. Belg. 1859, p. 40, §. I. raptorius, var. a, Trentep. Isis, I826, p. 228, \& (nec Fab.). I. albicaudatus, Fonsc. Ann. Soc. Fr. I 847 , p. 62, 万. I. angustalus, Trentep. Is $\mathrm{s}, 1826$, p. 228, of (?) ; Wesm. Bul. Ac. Brux. 1848, p. 180, ; lit. cit. 1855, p. 400 ; Berth. Ann. Soc. Fr. I895, p. 241. of $\$$.

Head strongly punctate, black ; mandibles and margin of clypeus red; vertical, and in of facial, orbits white. Antennae black, of $q$ slightly attenuate, white-banded, scape red, rarely black beneath; of of with the basal six joints usually reddish beneath. Thorax strongly punctate, black; pronotum and callosity beneath tegulae white; metathorax obtusely bidentate, its areola semi-lunar and apically strongly arcuate, shorter in $\delta$. Scutellum, and in of often post-scutellum, white. Abdomen of to sublinear; black, strongly compressed and attenuate apically in $q$, eighth segment often exserted; the very finely and closely punctate second and third segments, as well as the apex of $q$ post-petiole, red; fourth to seventh more or less shining and white-marked; post-petiole strongly and rugosely punctate; gastrocaeli small and striolate. Legs black; anterior femora, tibiae and tarsi, and in $q$ base of hind tibiae, red; all the tibiae spinulose. Wings infuscate-hyaline; stigma ferrugineous; tegulae piceous, with white dots; areolet narrowed above. Length, 8-I I mm.

The female is at once known by its spinose tibiae and compressed anus; and the male differs from $B$. vestigator in the narrower areola, the black post-petiole and hind tibiae.

Stephens records this species, under the name of militaris, from London and Salop, not very common in the spring. I have seen a male, which had the orbits immaculate, and was taken at Copdock, Suffolk, in May. The female hibernates. It occurs in France, Germany and Hungary.

\section{I. chionomus, Wesm.}

Ichnemmon callicerus, var. I, Gr. I. E. i. 343, o. I. inculitor, var, I, Gr. I. E. i. 617 q. I. chionomus, Wesm. Nouv. Mém. Ac. Brux. 1844, p. 9r ; Bul. Ac. Brux.

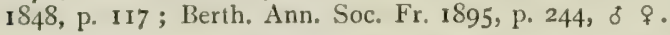

A rather small, shining, red and black species. Head black, face somewhat protuberant; frons punctate and shining; mandibles and angles of clypeus, which latter is glabrous with a few scattered punctures, not separated, and apically truncate, sometimes red; lunulae at vertex generally distinctly white; to has also the palpi, sides of clypeus and of face, somewhat broadly white. Antennae black, of $q$ stoutish, filiform, not dilated, white-banded: of $t$ slender, joints somewhat nodulose, fulvous, with scape more or less white, beneath, Thorax black, punctate and shining; of with pronotum, and sometimes callosities at radix, white; sternauli indicated; areae of metanotum complete; areola semi-oval, slightly longer than broad, glabrous, with the base and apex evenly

1 The record of this species from Guestling (Nat. Hist. Hastings, 3rd suppl., p. 14) is an error. 
rounded. Scutellum sparsely punctate, black or white; usually with the apical half white in $\delta^{t}$. Abdomen of $q$ elongate-oval, of ot sub-cylindrical ; finely punctate and shining, red; segment four, except its basal angles, fifth entirely, and sometimes first of $\hat{\sigma}$, black; sixth and seventh dorsally, and sometimes five to six apically in $\delta$, white; post-petiole somewhat closely punctate and shining; gastrocaeli distinct and small, especially in $q$. Legs fulvous, darker in $\delta$; coxae, trochanters, apices of hind tibiae and tarsi, and sometimes the femora in part, black; hind coxae simply and closely punctate, not scopuliferous. Wings hyaline; stigma and nervures piceo-fuscous, base of former distinctly paler; tegulae black, radix flavous; areolet somewhat narrowed above. Length, 7-9 $\mathrm{mm}$.

The male may be known by its laterally white clypeus, immaculate fourth segment and small gastrocaeli; and the female by the entirely fulvous front tibiae, which, in $B$. bilumulatus, are internally flavous or stramineous. The vertical dot is sometimes nearly wanting in the female and the scutellum often black, which lend it much the appearance of the I. latrator group of species.

Bignell has taken it, at Bickleigh, in August and September, and Davies, in Cornwall; it has been bred from Geometrae, and (Berthoumieu say's) from Hadena adusta, by Bridgman. Mr. C. J. Wainwright took a female in May, I899, at IVest Hide, near Hereford; and I also have females found at Felden, Herts., by Mr. Piffard, and at Lyndburst and Matley Bog in the New Forest by Mr. Adams and myself. It frequents the flowers of Angelian sylvestris, in August, and the female is said to hibernate among moss. It ranges through N. IV. Europe, but does not extend further north than Britain, being unknown in Sweden.

\section{2. callicerus, Grav.}

Ichnezunon calliceruis, Grav. Mem. Ac. Sc. Torin, I820, p. 3 II ; I. E. i. 343 , excl. of et var. I; Wesm. Nouv. Mém. Ac. Brux. 1844, p. 96; Bul. Ac. Brux. 1849, p: 39, $q$; Holngr. Ichn. Suec. i. 184; Thoms. Ann. Soc. Fr. 1888, p. 109; Berth. lib. cit. 1895, p. 25I, ơ . I. gracilicornis, Gr. I. E. i. 29I, excl. q; WVesm. Mém. couron. Ac. Belg. I859, p. 35. I. phurialbatus, Wesm. Bul. Ac. Brux. I855, p. 40, ô, excl. var. I; of. lib. cit. p. 398. Barichneumon callicerus, Thoms. O. E. xviii. 1962, $\delta$ o .

A pretty little shining black and red species, adorned with white. Head very finely punctate and pubescent, not broad behind the eyes, black; face prominent, epistoma of $q$ sub-dentiform above, with a distinct forea between the scapes; palpi apically pale; margins of the separated and convex clypeus truncate, and in the of sometimes rufescent; vertical lunulae white; of also with the mouth, sides of clypeus and of face, and part of external orbits, white. Antennae somewhat slender, slightly attenuate; of $q$ white-banded, of $\delta$ with scape white beneath, and of both sexes more or less ferrugineous beneath. Thorax black, finely punctate and shortly pubescent; a mark on the pronotum and a small callosity beneath the radix white, of with callosity before the radix also white; sternauli wanting; metanotum with only three upper areae, of which the areola is semi-oval, not longer than broad, sub-glabrous and apically broadly emarginate. Scutellum, and sometimes post-scutellum of of, nitidulous, obsoletely punctured and clear white. Abdomen finely punctate and strongly shining throughout, red; base of first segment, fourth except basal angles, base of fifth and of sixth, black; remainder of 
last three segments and generally apex of fourth in $\delta$, clear white; postpetiole very closely and finely punctate throughout, carinae distinct, apical angles depressed and obtusely rounded; second segment with basal and apical incisures deep; gastrocaeli small, striate, circular and deeply impressed. Legs stout, black; front femora, tibiae and tarsi, and base of posterior tibiae reddish; tibiae distinctly spinulose; hind coxae very finely and closely punctate, grey haired and without scopulae. Wings sub-hyaline; tegulae, which bear white dots in of, radix, nervures and stigma, piceous, this last basally ferrugineous; areolet somewhat large; radial nervure externally curved. Length, $7-8 \mathrm{~mm}$.

Very like $B$. vestigator and B. lepidus in the colour of the scutellum and anus, but the abdomen is broader, the three basal segments much more finely punctate, with the gastrocaeli and thyridii larger; the thoracic costulae in the female are obsolete or wanting, and the head is clothed with short, dense, greyish white pubescence, and is closely and very finely punctate; sternauli wanting; legs stout, all the tibiae distinctly spinose; the male differs from $B$. vestigator in the shorter silky pubescence of the mesosternum, and in the facial orbits being more broadly, with the sides of the clypeus, white.

It is probably a not uncommon species with us, though I know of no records, beyond my own capture of a female on Angelica sylvestris flower, at Matley Bog, in the New Forest, in August; on the Continent it is very widely distributed, and has been bred from Hadena adusta, by Brischke.

\section{ICHNEUMON, Linnaeus.}

Linn. S. N. ed. I (1735), partim; Wesm. Nouv. Mém. Ac. Brux. I844, p. I8, partim; Thoms. O. E. I893, 191 I.

Head with genal costa inflexed, clypeus not dentate centrally at the apex, facial arch below the antennae not separated, but with a distinct inter-antennal tubercle. Areola sub-quadrate, rarely transverse, sometimes twice longer than broad, the sides always nearly straight, the posterior margin not arcuate but truncate, or somewhat deficient centrally, always rectangular. Abdomen with the central area of the post-petiole nearly always striolate, not twice broader than the lateral ones; thyridii and gastrocaeli of second segment always distinct, large or small ; terebra slightly or hardly extending beyond the apex of abdomen. Legs with the tibial calcaria rather long, the posterior tarsi sometimes sub-dilated. The head in both sexes with no vertical pale mark, and the external orbits not white. Wings generally with the stigma and nervures pale red. Apex of abdomen in o usually, in of sometimes, marked with white. Ventral segments two to four with a central fold, on the fourth very rarely distinct at the base only; dorsal segments two and three not uncommonly red or in the of flavous, the ventral valvulae not sinuate laterally.

Of the eighty-two species enumerated by Thomson (op. cit.) we have about thirty-five in Britain, and doubtless many of those recently described only need looking for in collections and in the country to be recorded. 


\section{Table of Species.}

(58). I. Second flagellar joint not or hardly longer than broad; cheeks shorter than base of mandibles; areola not transverse; radical marks usually pale ; antennae of $q$ filiform.

(3). 2. Clypeus apically sub-bisinuate; abdomen entirely black .................

(2). 3. Clypeus apically truncate; abdomen not entirely black.

(5). 4. Abdomen caerulescent ................

(4). 5. Abdomen not caerulescent.

(7). 6. Each segment of $q$ banded with, and post-petiole of $\delta$, flavous ............

(6). 7. Apical segments only of $q$ flavous; o post-petiole immaculate.

(I I) S. Segment six, but not seven, of $q$ pale ; of with several segments flavousbanderl.

(10). 9. Segment three of $q$ not flavousbanded; second of of not fulvous

(9). I0. Segment three of $q$ flavous-banded; second of $\delta$ entirely fulvous ......

(8). I I. Segments six and seven, or neither, pale; of without several segments pale-banded.

(25). I2. Length less than II mm.

(I6). I3. Scutellum pale.

(I 5). I 4 . Segment five of $q$ pale-margined......

(I4). 15. Segment five not pale-margined ......

(I3). I6. Scutellum black.

(20). 17. Coxae of $q$ red; orbits of $\delta$ not, or not alone, flavous.

(19). 18. Metathoracic costae weak; of with face black

(18). I9. Metathoracic costae strong; of with face flavous .........................

(17). 20. Coxae of $q$ black; orbits of $\delta$ alone flavous.

(22). 21. Post-petiole glabrous

(21). 22. Post-petiole aciculate.

(24). 23. Anus of $q$ and clypeus of $\delta$ palemarked....

(23). 24. Anus of + and clypeus of $\delta$ immaculate ..................................

(12). 25. Length more than i i $\mathrm{mm}$.

(31). 26. Segment two mainly black ; tibiae of $q$ centrally stramineous.

(30). 27. Scopulae distinct; second segment of ot partly flavous.

(29). 28. Scutellum sub-transverse

I. LUGENS, Grav.

2. DELiRATORIUS, Lim.

3. XANTHORIUS, Forst.

4. SARCITORIUS, Lim.

5. Lautatorius, Desv.

6. CAEDATOR, Grav.

7. MULTipictus, Grav.

8. LATRATOR, Fab.

9. SUBQUADratus, Thoms.

IO. SPURIUS, Wesm.

I I. ANALIS, Grav.

I2. WALKERI, Wesm.

I3. MOLITORIUS, Grav.

14. CRASSIFEMUR, Thoms.

(28). 29. Scutellum not transierse ................

(27). 30. Scopulae wanting; second segment of of entirely black

(26). 31. Segment two red or flavous; tibiae 15. MELANOTIS, Holmgr. of $q$ not stramineous, sometimes flavous.

(35). 32. Anus of $q$ with three pale marks, the first the largest; base of $\delta$ hind femora narrowly pale internally. 
(34). 33. Mandibles of $q$ sinuate beneath, of $\delta$ apically sub-glabrous

(33). 34. Mandibles of $q$ not sinuate below, of t not apically glabrous ...........

(32). 35. Anus of $q$ with two pale marks, or three with the first the smallest; base of $t$ hind femora somewhat broadly pale.

(4I). 36. Anus of $q$ with three pale marks; scutellum of strongly punctate and strongly convex.

(38). 37. Abdomen centrally black or badious

(37). 38. Abdomen centrally flavous or fulvous.

(40). 39. Abdomen of $q$ centrally fulvous; hind tarsi of $f$ piceous ...................

(39). 40. Abdomen of $q$ centrally flavous ; hind tarsi of $\delta$ fulvous ....................

(36). 41. Anus of $q$ with two pale marks; scutellum of finely punctate and hardly convex.

(45). 42. Abdomen black or badious ; or third segment of $f$ transverse.

(44). 43. Scutellum of $q$ indistinctly punctate; third segment of of quadrate. ......

(43). 44. Scutellum of $q$ distinctly punctate; third segment of $f$ transverse......

(42). 45. Abdomen centrally red or flavous; third segment of quadrate.

(47). 46. Hind tibiae entirely black

(46). 47. Hind tibiae not entirely black.

(53). 48. Hind tibiae of $q$ not flavous; segments two and three of flavous.

(52). 49. Coxae scopuliferous ; central flagellar joints of of internally carinate.

(5I). 50. Pronotum of $q$ white ; flagellum of $\delta$ fulvous beneath ......................

(50). 5 I. Pronotum of $q$ not white ; flagellum of $\delta$ black beneath .................

(49). 52. Coxae simple ; central flagellar joints not in carinate .....................

(48). 53. Hind tibiae of $q$ centrally flavous; segments two and three of $\delta$ flavous.

(55). 54. Coxae scopuliferous; flagellum of $\delta$ not carinate..........................

(54). 55. Coxae simple ; central flagellar joints of ${ }^{t}$ internally carinate.

(57). 56. Antennae of $q$ filiform ; intermediate tibiae of opically black............

(56). 57. Antennae of $q$ sub-attenuate ; intermediate tibiae of 0 immaculate ...

16. BUCCULENTUS, Wesm.

17. SUSPICIOSUS, Wesm.

18. LANGUIDUS, Wesm.

19. TERMINATORIUS, Grav.

20. STRaMentarius, Grav.

21. COMPUtATORiUs, Mïll.

22. INQUINATUS, Wesm.

23. MILITARIS, Grav.

24. ALBICOLLLIS, Wesm.

25. EXTENSORIUS, Limn.

26. GRACILENTUS, Wesm.

27. CONFUSORIUS, Grav.

28. TeMPestives, Holmgr.

29. MACROCERUS, Thoms.

(1). 58. Second flagellar joint elongate; cheeks not shorter than base of mandibles; areola not elongate : radical marks rarely pale; antennae of $o$ apically attenuate.

(98). 59. Anus of $q$ pale-marked; scutellum of of not white at apex only. 
(93). 6o. Scutellum pale.

(66). 6r. Size $17 \mathrm{~mm}$. or more.

(63). 62. Apophyses distinct

(62). 63. Apophyses sub-obsolete.

(65). 64. Femora black

(6.4). 65. Femora red

(61). 66. Size $16 \mathrm{~mm}$. or less.

(8o). 67. Anus with three pale marks, rarely obsolete in $\delta$; hind tarsi infuscate.

(75). 68. Abdomen centrally clear red or flavous.

(72). 69. Anterior femora immaculate.

(71). 70. Antennae of dark red or black, $q$ central band five-jointed .............

(70). 71. Antennae of $\delta$ clear red beneath, $q$ central band two-jointed .............

(69). 72. Anterior femora black-marked.

(74). 73. Segments two and three of $q$ immaculate; clypeus of ô flavousmarked................................

(73). 74. Segments two and three of $q$ partly black ; clypeus of of not flavous...

(68). 75. Abdomen centrally black or badious.

(77). 76. Callosity beneath radix alone white...

(76). 77. Callosities beneath and before radix white.

(79). 78. Flagellum pale-banded

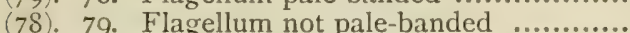

(67). 80. Anus with two pale marks, wanting in $\delta$; hind tarsi mainly pale.

(90). 8I. Abdomen centrally clear red or flavous.

$\left(8_{3}\right) .82$. Mandibles slender, edentate.

(82). 83. Mandibles normal, bidentate.

(85). 84. Hind tarsi immaculate; hind tibiae of $q$ mainly flavous

(84). 85. Hind tarsi apically infuscate; hind tibiae of o not flavous.

(87). 86. Antennae of $q$ centrally incrassate; scutellum of 0 convex ..............

(86). 87. Antennae of $q$ not incrassate; scutellum of st strongly elevated.

(89). 88. Abdomen elongate, sub-linear .........

(88). 89. Abdomen of $q$ elliptic-oval $\ldots . . . . . . .$.
(8I). 90. Abdomen centrally black or badious.

(92). 91. Hind femora black .......................

(9I). 92. Hind femora red.

(60). 93. Scutellum black or rufo-castaneous.

(95). 94. Abdomen centrally black ..............

(94). 95. Abdomen centrally red.

(97). 96. Head not impressed behind ocelli ; post-petiole scabriculous

(96). 97. Head impressed behind ocelli ; postpetiole sub-aciculate ................

(59). 98. Anus of $q$ immaculate ; scutellum of $\delta$ white at apex only.................
3O. PRIMATORIUS, Forst.

3I. BISIGNATUS, Grav.

32. BELLIPES, Wesm.

33. GRACILICORNIS, Grav.

34. SIllaceus, Grav.

35. emancipatus, Wesm.

36. Formiosus, Grav.

37. QUAESITORIUS, Lim.

38. HaGlund, Holmgr.

39. PICEATORIUS, Wesm.

40. RUFIDENS, Wesm.

4I. Caloscelis, Wesm.

42. INSIDIOSUS, Wesm.

43. SUBCYLINDRICUS, Grav.

44. RAPTORIUS, Grav.

45. Submarginatus, Grav.

46. QUADRIALBATUS, Grav.

47. Cessator, Miill.

48. STIGMATORIUS, Zett.

49. VULNERATORIUS, Zett.

50. haESITATOR, Wesm.

The species of this genus are so extremely closely allied as, in many cases, to defy discrimination by any but a well-practised eye, therefore I 
have thought it expedient to present a second table of species based upon the mainly colour distinctions of Bridgman and Fitch, culled from their synopsis of the super-genus, all distinctions from whose species being here referred to, and including such as have been discovered in Britain since its publication, in 1880.

\section{A Second Table of Species.}

(2). 1. Mesonotum red

(I). 2. Mesonotum black.

(28). 3. Scutellum black or castaneous.

(7). 4. Abdomen black, not red-marked.

(6). 5. Apex of abdomen black

(5). 6. Apex of abdomen white

(4). 7. Abdomen red and black.

(19). 8. Apex of abdomen immaculate.

(14). 9. Face pale or pale-marked.

(II). IO. Face and clypeus yellow

(Io). II. Face and clypeus not yellow throughout.

(13). 12. Frontal orbits pale

(12). 13. Facial orbits pale

(9). I4. Face and thorax without pale marks.

(16). I 5. Segments two to four red

(15). I6. Segments two and three red.

(18). 17. Apex of the first segment pale

(17). 18. Apex of the first segment not pale......

(8). 19. Apex of abdomen pale-marked.

(23). 20. Hind coxae red.

(22). 2I. Areola elongate

(2I). 22. Areola sub-quadrate ........................

(20). 23. Hind coxae black.

(27). 24. Post-petiole aciculate.

(26). 25. Orbits of eyes narrowly red..............

(25). 26. Orbits of eyes flavous $\ldots \ldots \ldots \ldots \ldots \ldots \ldots$

(24). 27. Post-petiole glabrous

(3). 28. Scutellum pale.

(136). 29. Central segments not marked with yellow.

(63). 30. Abdomen black.

(42). 3I. Apex of abdomen immaculate.

(39). 32. Hind tibiae not pale-marked.

(38). 33. Femora black.

(35). 34. Hind tibiae red, apical half black ......

(34). 35. Hind tibiae not red.

(37). 36. Hind tibiae laterally flavescent .........

(36). 37. Hind tibiae black

(33). 38. Femora red

(32). 39. Hind tibiae and tarsi pale-banded.

(4I). 40. Abdomen caerulescent

(40). 4I. Abdomen not caerulescent ..............

(3I). 42. Apex of abdomen pale-marked.

(56). 43. Tibiae not white-marked.

(51). 44. Hind femora dark.

(46). 45. Hind tibiae pale flavous-marked .....

(45). 46. Hind tibiae red and black.

(50). 47. Scutellum sparsely punctate.

(49). 48. Areola quadrate; mesonotum high ...

(48). 49. Areola elongate; mesonotum not high
49. VULNERATORIUS, 오.

47. CESSATOR, o.

47. CESSATOR, + .

9. SUBQUADRATUS, ซึ.

50. HAESITATOR, $q$.

I2. WALKERI, ơ $q$.

8. LATRATOR, ㅇ.

48. STIGMATORIUS, ठै.

49. VULNERATORIUS, के.

8. LATRATOR, ㅇ․

9. SUBQUADRATUS, $q$.

II. ANALIS, $q$.

36. FORMOSUS, ô.

IO. SPURIUS, + .

45. SUbMarginatus, ${ }^{\ddagger}$.

I8. LANGUIDUS,

I. LUGENS, $q$.

46. QUADRIALBATUS, ơ.

2. DELIRATORIUS, 0 .

I. LUGENS, ơ.

18. LANGUIDUS, $q$.

45. SUBMARGINATUS, + 2 I. COMPUTATORIUS, $q$. 
(47). 50. Scutellum closely punctate

22. INQUINATUS, $q$.

(44). 5 I. Hind femora red.

(53). 52. Areola sub-quadrate.

46. QUADRIALbatus, †.

(52). 53. Areola transverse.

(55). 54. Callosity before radix only white

(54). 55. Callosities before and beneath radix white

(43). 56. Tibiae white-marked.

(62). 57. Costulae wanting.

(6I). 58. Hind coxae tufted beneath.

(6o). 59. Hind femora longitudinally canaliculate beneath

(59). 60. Hind femora not canaliculate beneath

(58). 61. Hind coxae not tufted beneath .........

(57). 62. Costulae distinct ..........................

(30). 63. Abdomen red and black.

(75). 64. Apex of abdomen immaculate.

(72). 65. Front coxae black or black and red.

(71). 66. Third abdominal segment transverse.

(70). 67. Space between gastrocaeli not broader than centre of post-petiole.

(69). 68. Second segmient basally striate .........

(68). 69. Second segment basally punctate ......

(67). 70. Space between gastrocaeli broader than centre of post-petiole

(66). 7I. Third abdominal segment sub-quadrate

(65). 72. Front coxae only spotted with white.

(74). 73. Face entirely black

(73). 74. Face entirely stramineous ..............

(64). 75. Apex of abdomen white-marked.

(I05). 76. Meso- only slightly higher than metanotum; antennae filiform.

(90). 77. Hind coxae tufted beneath.

(8I). 78. Femora black; hind tibiae basally rufescent.

(8o). 79. Pronotum white

(79). So. Pronotum not white

(78). 8I. Femora mostly red.

(89). 82. Hind tibiae centrally stramineous.

(86). 83. Coxal tufts distinct.

(85). 84. Third segment broadly yellow ..........

(84). 85. Third segment not broadly yellow......

(83). 86. Coxal tufts sub-obsolete.

(88). 87. Antennae apically sub-attenuate ......

(87). 88. Antennae filiform

(82). 89. Hind tibiae centrally red

(77). 90. Hind coxae not tufted beneath.

(96). 9I. Margins of cheeks buccate below base of mandibles.

(95). 92. Tibiae and tarsi red.

(94). 93. Scutellum clear white ...................

(93). 94. Scutellum dirty yellow

(92). 95. Tibiac pale yellow.

(91). 96. Margins of cheeks not buccate.

(98). 97. Hind tibiae entirely black ..............

(97). 98. Hind tibiae not entirely black.

(102). 99. Hind tibiae centrally stramineous.

(IOI). IOO. Segments two and three red, latter with short black basal band ......

37. QUAESITORIUS, + .

3S. HAGLUNDi, + .

I 3. MOLITORIUS, 우

I4. CRASSIFEMUR, + .

I 5. MELANOTIS, + .

2. DELIRATORIUS, $q$.

33. GRACILICORNIS, ఫే.

42. INSIDIOSUS, $\hat{0}$.

44. RAPTORIUS, ơ.

2I. COMPUTATORIUS, $\delta$.

2 I. COMPUTATORIUS, ఫึ.

39. PICEATORIUS, ơ.

24. ALBICOLLIS. 우

2I. COMPUTATORIUS. + .

5. LAUTATORIUS, $q$.

27. CONFUSORIUS, + .

29. MACROCERUS, $q$.

28. TEMPESTIVUS, $q$.

4. SARCITORIUS, + .

16. BUCCULENTUS, + .

26. GRACILENTUS, + .

17. SUSPICIOSUS, $q$.

23. MILITARIS, + .

I9. TERMINATORIUS, $q$. 
(IOO). IOI. Segments two and three vary from castaneous to black

(99). 102. Hind tibiac basally rufous or flavorufous.

(104). 103. Segments one to three red.

(103). I04. Segments two and three, and sometimes also part of fourth, red.........

(76). I05. Meso- much higher than metanotum; antennae apically attenuate.

(131). I06. Scutellum entirely yellow.

(I 18$)$ I07. Space between gastrocaeli not broader than centre of post-petiole.

(1 I I). I08. Femora black.

(110). 109. Hind tibiae basally flavous; coxae flavous-marked.

(109). IIo. Hind tibiae basally red; coxae black

(IOS). I I I. Femora mostly red.

(I 5). I12. Hind femora apically black.

(II). II3. Front femora red.

(I 3 ). II . Front femora partly black.

(I 12). I I 5. Hind femora apically red.

(I I7). II6. Areola sub-quadrate

(II6). II7. Areola transverse .......................

(107). I18. Space between gastrocaeli broader than centre of post-petiole.

(130). II9. Segments two and three red.

(I2I). I 2O. Tibiae red, centrally yellow ...........

(120). I2I. Tibiae red, apex of hind ones black.

(123). 122. Abdomen parallel-sided...

(122). 123. Abdomen somewhat rounded laterally.

(125). 124. Pronotum pale-marked .................

(124). 125. Pronotum immaculate.

(129). 126. Apex of first segment often red.

(128). I27. Hind tibiae basally red

(127). 128. Hind tibiae basally yellow...............

(126). 129. Apex of first segnient not red .........

(I 19). I30. Segments one to three red...............

(I06). I3I. Scutellum not entirely yellow.

(I33). I32. Scutellum partly flavescent ..........

(132). I33. Scutellum more or less, and segments one to three, red.

(135). I34. Cheeks sparsely punctate ..............

(134). I35. Cheeks very strongly punctate.........

(29). 136. Abdomen with some segments wholly or partly yellow.

(172). I37. Apex of abdomen entirely black.

(1+1). 138. Segment four mostly yellow.

(140). 139. Segments one to four yellow, more or less black basally

(139). 140. Segments two to four yellow, fourth rarely black-marked

(138). 141. Segment four mostly black.

$(165)$. 142. Segments two and three entirely yellow.

(I 44). I 43. Segment three transverse ...............

$(1+3)$. 144. Segment three sub-quadrate.

(I48). I 45. Margins of cheeks sub-buccate below base of mandibles.

(147). 146. Flagellum black

15. melanotis, +

7. MULTipictus,

25. EXTENSORIUS, + .

3O. PRIMATORIUS, $q$.

36. FORMOSUS, + .

33. GRACILICORNIS, $q$.

35. EMIANCIPATUS, $q$.

46. QUADRIALBATUS, + .

32. BELLIPES, $q$.

41. CALOSCELis, $q$.

43. SUBCYLINDRICUS, + .

6. CAEDATOR, $q$.

44. RAPTORIUS, $q$.

34. SILACEUS, + .

42. INSIDIOSUS, $q$.

40. RUFIDENS, + .

33. GRACILICORNIS, ఫै.

49. VULNERATORIUS, $\uparrow$.

48. STIGMIATORIUS, + .

3. XANTHORIUS, ơ.

30. PRIMATORIUS, ơ.

41. CALOSCELIS, ふ̋.

16. BUCCULENTUS, 
(146). I47. Flagellum rufescent beneath.

(I45). I48. Margins of cheeks not buccate.

(158). I 49. Frontal orbits yellow-marked.

(153). I50. Front coxae and trochanters unicolorous.

(152). I5I. Front coxae and trochanters entirely yellow

(I5I). I52. Front coxae and trochanters entirely black

(150). I53. Front coxae and trochanters yellow and black.

(155). I54. Intermediate tibiae black-lined.

(154). I55. Intermediate tibiae apically immaculate.

(157). 156. Central flagellar joints internally carinate

(156). 157. Central flagellar joints not internally carinate

(149). I 58. Frontal orbits not yellow-marked.

(I62). I59. Face entirely yellow.

(I6I). I60. Central flagellar joints internally carinate

(I60). I6I. Central flagellar joints not internally carinate

(I 59). I62. Face, at least centrally, black.

(164). I63. Central flagellar joints internally carinate

(163). 164. Central flagellar joints not internally carinate

(142). 165. Segments two and three not entirely yellow.

(I67). I66. Segment two not black-marked ......

(166). 167. Segments two and three blackmarked.

(169). 168. Segments two and three sub-triangularly black.

(168). 169. Segments two and three basally black.

(I II). 170. Callosity beneath radix pale ............

(170). 171. Callosity beneath radix not pale ......

(137). 172. Apex of abdomen pale.

(178). I73. Antennae pale-banded.

(175). 174. All the segments banded with yellow

(174). 175. Not all the segments pale-banded.

(177). 176. Segments two and three fulvous ......

(176). 177. Segments two and three flavous ......

(173). I78. Antennae not pale-banded.

(182). I79. Coxae entirely black.

(18I). I80. Second segment fulvous.................

(I80). I8I. Second segment not fulvous .............

(I79). I82. Coxae flavous-marked
17. SUSPICIOSUS, すే.

22. INQUINATUS, すో.

20. STRAMENTARIUS, ơ.

28. TEMPESTIVUS, ठే.

29. MACROCERUS, 0 .

26. GRACILENTUS, ơ .

24. ALBICOLlis,

27. CONFUSORIUS, đ.

25. EXTENSORIUS, \$.

35. emancipatus, ơ.

19. TERMINATORIUS, ô.

3I. BISIGNATUS, ‡.

I3. MOLITORIUS, ơ.

I4. CRASSIFEMUR, of.

3. XANTHORIUS, $q$.

19. TERMINATORIUS, $q$.

2O. STRAMENTARIUS, $q$.

5. LAUTATORIUS, Oే.

4. SARCITORIUS, to.

3. XANTHORIUS, ô.

\section{I. lugens, Grav.}

Ichneumon lugens, Gr. I. E. i. 215 ; Ste. Illus. vii. I49, (excl. of); Thoms. O. E. xviii. 1913, $\delta$. Chasmodes lugens, Wesm. Nouv. Mém. Ac. I3rux. I844, p. 16; Mém. couron. Ac. Belg. 1859 , pp. 25 et 26 ; Holmgr. Ichn. Suec. i. 6 ; Berth. Ann. Soc. Fr. I894, p. 519, o \&; S. v. Voll. Pinac. (1875). pl. ii. fig. 2, \&. Ichneumon fuscipes, var. 2, Gr. I. E. i. 226, o. I. napaeus, Holmgr. Ent. Tidskr. 1880, p. 26 ; Berth. Ann. Soc. Fr. 1894, p. 549, ठ. 
A large black species with white markings. Head black, buccate, not narrowed behind the eyes; temples broad; cheeks and mandibles closely punctate, the former tumidous; clypeus sub-bisinuate and depressed in front; mandibles red before their apices; of face and clypeus laterally white. Antennae setaceous in $\delta$, hardly attenuate in $q$, black; whitebanded; of with scape white-marked beneath. Thorax black, callosity beneath radix white; of pronotum and line before radix also white; areola somewhat longer than broad, sub-rectangular. Scutellum white, base narrowly black. Abdomen elongate, entirely black; post-petiole finely centrally aciculate; second segment basally finely punctate, gastrocaeli narrower than intervening space. Legs black; $q$ with front tibiae and tarsi piceous; of with all the tibiae centrally white, front ones laterally pale stramineous at the apex. Wings fumato-hyaline; stigma fulvotestaceous; tegulae black, in. ${ }^{*}$ with a white dot. Length, I 8-20 $\mathrm{mm}$.

The of, described by Gravenhorst (Ich. fuscipes, var. 2), had the antennae entirely black.

Having been transferred in the first instance with some little hesitation to his genus Chasmodes by Wesmael, this species was again included in Ichneumon by Thomson on account of the much lesser degree to which the apex of the clypeus is emarginate than in $C$. motatorius and paludicola, and this position appears more natural, though Berth. again placed it in Chasmodes in I 894 . From all others of the present genus it may, however, be at once distinguished by the more or less sinuousness of the clypeus laterally, as well as by its dilated temples, entirely black abdomen, and deep, narrowly divided gastrocaeli and thyridii.

I. lugens would appear to be somewhat rare in Britain and I do not think it has ever been bred. The females are said to pass the winter in the perfect state. Stephens found it rarely near London, in June, there are specimens in Bridgman's and Chitty's collections and Bignell has taken it at Ivybridge, near Plymouth, also in June. The original of (Ich. fuscipes, var.) was sent to Gravenhorst by Hope, who captured it in the vicinity of Netley.

\section{2. deliratorius, Linn.}

Ichneumon deliratorius, Linn. F. S. I761, ơ; Wesm. Nouv. Mém. Ac. Brux. I844, p. 37 ; Thoms. O. E. xviii. 1914; Berth. Ann. Soc. Fr. 1894, p. 167, o q. I. multiannulatıs, Gr. I. E. i. 223, of; Ste. Ill. M. vii. I5I ; Holmgr. Ichn. Suec. i. 49, of $q$. I. molitorizes, Linn. F. S.; Gr. I. E. i. 258 (part) ?. Cf. Kriechb. Ent. Nachr. I892.

At once known by its caerulescent body from all the other species of the genus. Cheeks and temples normal, diffusely punctate; clypeus truncate, nearly glabrous; $q$ usually with angles of clypeus and frontal orbits red, fo palpi, clypeus and face entirely pale flavous. Antennae distinctly attenuate, of $q$ white-banded, of of black with the scape longitudinally white beneath; first joint of flagellum twice longer than broad, fifth quadrate. Thorax black, of with callosities at radix white; mesopleurae centrally sub-aciculate transversely below; notauli evident anteriorly; metanotum rugosely punctate with complete upper areae; areola rectangular, slightly longer than broad in $q$, semi-lunar in 5 , its apex angulated. Scutellum white. Abdomen blue-black, lanceolate-oval; seventh segment white-marked in $q$; often has incisures of second and third segments reddish; post-petiole aciculate or striate, punctate laterally; 
gastrocaeli large and deep, intervening space distinctly aciculate; terebra slightly exserted. Legs black; all the tibiae and tarsi white, with the apex more or less broadly black, the anterior being somewhat rufescent; $q$ scopulae very narrow. Wings slightly infuscate, less so in of; stigma reddish; to tegulae piceous, sometimes white-marked in front. Length, I $2-16 \mathrm{~mm}$.

This species is very similar to those of Coelichneumon, and forms a connecting link between the two genera, but it may be distinguished from them by the entirely pale face of the $\vec{\delta}$, the apically truncate clypeus, and in having no white mark on the capital vertex.

Stephens found this species about London and records it from Salop and Scotland. Bignell has bred it in Devon, where it is said to be frequent, by the sides of roads, on flowers of Heracleum sphondylinm in June and July, from Noctua brunnea; and Marshall from Dicranura vinula; Essex; Mr. Bradley has found it about Birmingham; Col. Bingham at Ravenscar, in Yorks., in August; Miss Chawner in the New Forest and Col. Yerbury, at Glengariff, in the middle of June ; Mr. F. HI. Peachell has bred it from a "forced" pupa of some Taeniocampa found by him at Weymouth; the parasite emerged on the I 7 th of February, through the end of the chrysalis which was entirely bitten off, leaving within the silken cocoon attached to that of its host, this specimen lived four days in a pill box in my study, and a very handsome insect it is when alive. On the Continent, where it is common, it preys upon Smerinthus populi and Mamestra oleracea.

\section{3. xanthorius, Forst.}

Ichneumon xanthorius, Forst. Nov. Spp. Ins. 83, $q$; Grav. I. E. i. 36 I ; Ste. III. M. vii. 173 ; Wesm. Nouv. Mém. Ac. Brux. 1844, p. 61 ; cf. S. v. Voll. Pinac. pl. xxxvi. fig. 7 ; Berth. Ann. Soc. Fr. I894, p. 623, o \&. Var. I. quadrifasciatus, Gr. I. E. i. 402 ; Ste. Illus. M. vii. I79, ठ。. Var. I. flavoniger, Gr. I. E. i. 403 ; Ste. Ill. M. vii. I 80, o .

A distinct, vespoid species, with no red markings. + . Body stout; head black; internal orbits flavous; cheeks beneath and temples dilated. Antennae stout, much attenuate, piceous; scape flavous beneath and basal half of flagellum bright fulvous, the central joints being paler. 'Thorax black; pronotum, callosity beneath radix, and rarely two apical dots on metathorax, flavous ; latter scabrous, posteriorly nearly perpendicular, with five upper areae, of which the areola is sub-quadrate and posteriorly distinctly arcuate. Scutellum flavous, sub-quadrate, not transverse, obsoletely punctate. Abdomen broad, sub-obtuse, black, with all the segments broadly flavous-margined, five to seven with the colour sometimes abbreviated laterally; post-petiole aciculate throughout; second segment with gastrocaeli large and somewhat deep and the intervening space aciculate, as broad as centre of post-petiole; terebra scarcely exserted, central ventral segments flavescent. Legs black, hind tibiac sinuate at base; anterior femora apically, tibiae and tarsi, flavous; hind legs with tibiae, excepting apex, tarsi and often a coxal mark, flavous; hind coxae without scopulae, setigerous apically beneath. Wings flavescent; stigma pale croceous; radix and tegulae flavous.

o. Head black; mouth, clypeus, face and frontal orbits flavous or mandibles basally and a longitudinal facial line black. Antennae black, 
flagellum sometimes ferrugineous, and scape flavous beneath; basal joints externally carinate. Thorax black; pronotum anteriorly, humeral marks, and sometimes also two lateral ones on metathorax flavous; metanotum rugose, obtusely bidentate, with five upper areae, of which the areola is sub-quadrate and emarginate at apex. Scutellum flavous, slightly convex, obsoletely punctate and pilose. Abdomen lanceolate, black, all the segments flavous-margined, the fifth sometimes entirely black; post-petiole finely aciculate throughout; second segment with gastrocaeli large and deep and the intervening space as broad as the centre of post>petiole. Legs flavous, coxae and trochanters in part, anterior femora slightly above, apices of hind femora and tibiae, black; tarsi flavous. Wings slightly flavescent ; stigma and tegulae pale croceous. Length, I2-18 $\mathrm{mm}$.

Ich. quadrifasciatus, Grav., is a variety of this species with the apical margins of the first four segments flavous, the remainder being entirely black. Ich. flavoniger, Grav., is another of variety with the post-petiole, second and third segments entirely flavous; the gastrocaeli and flagellum piceous ; this is by far the commonest form in Britain and Belgium.

Forster first described the of from England in I771. I expect it is not uncommon except in the north; Stephens only knew of one example of the typical male, though he says the var. flavoniger is common in some parts of the country, and var. quadrifasciatus is very rare.

It is often found flying in the sunshine in the hottest weather; certainly rare in the eastern counties and probably commonest in the south. The female hibernates in tufts of grass, where I have found it on 3 oth November, at Bentley Woods, Suffolk; the male has occurred to me at Ipswich towards the end of July.

About London and in Salop; near Carlisle ; Netley; Devonshire in June (Stephens) ; Lastingham (Marshall); Hollington (Hastings List) ; taken at Shaugh Bridge, May 26th, by Bignell; at Colwyn, in August, by Beaumont; at Tostock, by Tuck; not uncommonly in the New Forest, by Miss Chawner and Mr. Donisthorpe; a female on the sandhills at Hunstanton, early in April, by Pegler; males at Shotover and Oxford, by Hamm; near Carlisle, in early August, by Routledge; both sexes in Cornwall, by Davies; Essex; at Doddington, in Kent, by Chitty; and at Lynmouth, in July, by Charbonnier. Parfitt says it is generally and sparsely distributed in Devon, occurring in July. It is frequent in central and southern Europe, extending to Algeria, but is not found in Sweden and the more northern regions; M. Pic has found it not very common in eastern France. It has been bred on the Continent from Polyphoenis sericata, Esp. ( $=P$. prospicua, Bkh. $)$; in Devon from Dianthacia irregularis, on July I 2 th; and the var. flavoniger, by Mr. Tugwell from Acronycta myricae, Gn.

\section{4. sarcitorius, Linn.}

Ichneumon sarcitorius, Linn. F. S. 397 ; Gr. I. E. i. 302 ; Ste. Ill. M. vii. 165; Zett. I. L. 363 , $q$; Vesm. Nouv. Mém. Ac. Brux. 1844, p. 6o ; Holmgr. Ichn. Suec. i. 56; S. v. Voll. Pinac. pl. xxxvi., ff. I et 3 ; Thoms. O. E. xviii. 1914; Berth. Ann. Soc. Fr. 1894, p. 646, of o. I. vaginatorius, Linn., F. S. 400 ; Gr. I. E. i. 357 ; Ste. Ill. M. vii. I74 ; Zett. I. L. 362 ; Ratz. Ichn. d. Forst. ii. 135, of. I. bipartitus, Vill.

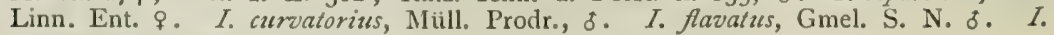
tripunctatus, Gmel. lib. cit. ð.

A very distinct species; the coloration will at once distinguish it from 
all other indigenous insects. Though the sexes are similar in several points, their facies are so divergent that it is perhaps better to describe them separately.

q. Head hardly narrowed behind the eyes, black; mouth and frontal orbits usually reddish. Antennae sub-filiform, sixth joint quadrate; white-banded, basal joints ferrugineous. Thorax black; callosity below the radix, the scutellum always, and sometimes pronotum, white; metanotum scabrous, with only three upper areae ; areola quadrate, emarginate apically, costae not strong. Abdomen elongate-ovate, black; post-petiole aciculate throughout, gastrocaeli normal; segments two and three red, the latter basally black, sixth white-banded, seventh entirely black. Legs stout, red; coxae, trochanters, apices of hind femora and tibiae black; scopulae black, normal. Wings hyaline, stigma fulvous; costa, radix and tegulae reddish.

o. Palpi, clypeus more or less, facial orbits, or sometimes almost the whole face, flavous. Antennae piceous; flagellum ferrugineous, and scape pale flavous, beneath. Thorax black; pronotum, lines at radix and scutellum pale stramineous; areola rectangular, transverse. Abdomen sub-parallel-sided, black; post-petiole aciculate throughout, gastrocaeli normal; first segment usually margined or bimaculate apically, two, three and six margined throughout, four to seven with a narrow interrupted margin stramineous, more rarely flavous; fifth entirely black. Legs flavous, tibiae lighter ; coxae, trochanters and apices of hind femora and tibiae black. Wings flavescent hyaline, stigna and radix fulvous, tegulae flavous. Length, IO-14 mm.

The only species at all resembling the above is $I$. repetitor, Kriechb. Ent. Nachr. I88 I, of o , $(=I$. criticus, Tisch. Stett. Zeit. I88 I, of ) which has the body rather more strongly sculptured, the of with sixth segment maculated, not margined with white, and no pale callosity beneath the radix, the of has segments two to four entirely or mostly flavous, and the two apical segments white throughout. It is unlikely to occur in Britain, however, being, as far as is at present known, a South European species.

I. sarcitorius is among our commonest and handsomest insects. The males are frequently found on flowers of Angelica sylvestris and Daucus carota in the autumn, from August to October; they fly low, among the herbage and are difficult, on account of their coloration, to follow with the eye; the females, which hibernate as imagines, may be shaken from tufts of grass (Aira caespitosa, etc.) during the winter, and I have also found them among marram grass on the coast. St. Ives, in July and August; West Hide, at end of May; Lizard, early in August (Wainwright); Alderney and Guernsey (Luff); Fairlight and Guestling (Bloomfield); Chobham, in July (Saunders); Cadney, Retford, Mablethorpe and South Leverton, in May, July and September (Thornley); Tostock and Bungay (Tuck); Chiddingfold (Donisthorpe); Claydon, Aldeburgh, Lowestoft, Ipswich, Barham, Westleton and Bentley woods, all Suffolk; Oxshott, in July (Morley); Plym Bridge, Devon (Bignell, who has observed it ovipositing in a larva of Arctia menthastri); common in Norfolk (Bridgman); Gareloch Head (Murphy); Shipley (Gurham); King's Cross, Arran, in August (Dalglish); Felden, Herts. (Piffard); Shiere (Butler); Littlehampton (Elliott); Weymouth (Bradley); Kenmare, early in July (Yerbury); Kilmore, Catford, Chobham, Plumstead and Colwyn (Beau- 
mont); a female entering burrows of Andrena trimmerana, at Swanston, in June, and both sexes at Aberdour, St. David's, Ronnytoun, Eyemouth, Coniston and Aberdeen (Evans); Oxford, and Bovey Tracey, in Devon (Hamm) ; Carlisle (Routledge) ; St. Margaret's Bay, Dover, and Colchester (Sladen); St. Ervan, Cornwall (Davies); Fleet coast (Richardson) ; Jersey (Ansted's "Channel Islands").

It is probably parasitic upon several Noctuids, and has been bred from Diloba coeruleocephala and Hydracia leucographa. Stephens says it is abundant about London on umbelliferous flowers, and common in Devonshire, South Wales, Scotland, etc. Berthoumieu remarks that it frequents flowers of Euphorbiae.

\section{5. lautatorius, Desv.}

Ichneumon lautatorizs, Desv. Cat. 18, of 9 ; ff. Morl. E. M. M. I902, p. I22. 'I. sarcitoriuts, var., S. v. Voll. Pinac. pl. xxxvi, f. 2 , o.

․ Head hardly narrowed behind the prominent eyes, black; mouth parts entirely red, with ferrugineous pilosity. Antennae sub-filiform, slightly attenuate towards their apices, sixth joint quadrate ; scape black, flagellum with the twelve basal joints unicolorous bright fulvous throughout, the remainder black above, gradually darker below. Thorax black; callosity beneath the radix and the scutellum flavous, not white; metathorax scabrous, with but three upper areae; areola quadrate, rectangular, not emarginate apically, the costae somewhat strong. Abdomen black, elongate-ovate, somewhat obtuse apically ; post-petiole aciculate throughout ; gastrocaeli normal, deeply impressed; second segment rufo-fulvous ; third and sixth with broad apical margin, the former occupying rather less than half the segment and a little narrowed centrally, latter the whole segment except its extreme base, glaucous-flavous above, not white; remainder black. Legs long and stout; fulvous, all the tibiae indistinctly paler in the centre; coxae, trochanters except their apices, extreme tips of hind femora internally and tibiae, black; scopulae large and black. Wings flavescent-hyaline, ample; stigma and costa fulvous, radix flāvous, tegulae rufo-piceous.

§. Head black, face, clypeus and palpi flavous. Antennae porrect, attenuate, half length of body, black; scape flavous, flagellum orange, beneath. Thorax with a line below and usually before the radix flavous; areola quadrate, costulae indistinct. Scutellum flavous, sometimes slightly rufescent marginally. Abdomen slightly broader than thorax; post-petiole aciculate throughout; gastrocaeli normal and deep ; segment one black, two entirely rufo-fulvous paler apically, three and four with a central sinuate marginal fascia, five rarely with a small apical dot in the centre, seven pale fulvous and triangularly black at the base; ventral segments two to four plicate. Legs fulvo-flavous, tibiae and tarsi paler; coxae, trochanters except their apices, and the tips of hind femora and tibiae, black; apical hind tarsal joints infuscate. Wings with tegulae anteriorly flavous; radix and costa picen-flavous; stigma clear fulvous. Length, I $3-15 \mathrm{~mm}$.

At once known from the last species by its larger size and bicoloured antennae.

The $q$ is abundantly distinct in the unicolorous basal flagellar joints, the remainder being abruptly deep black above; from the last species 
it differs in its paler legs, prominent eyes, sub-obsolete femoral bands, deeper and more coarsely striolate gastrocaeli, flavous markings, and more ample flavescent wings; from Amblyteles pallidicornis, Grav., it differs, besides the generic characters, in its immaculate seventh segment, \&c. The abdominal coloration of the of is quite unlike that of I. sarcitorius, which it closely resembles in structure and contour; the antennae are, however, longer than half the body, the cheeks are not buccate and the pale-marking of the apical segment is extended to its ventral surface.

The types of this species are not in Desvignes' collection in the British Museum, where is but a single o labelled "Whittlesea Mere ; H. Squire," which was mixed with $I$. sarcitorius. "They may, perhaps, be found in the Curtis collection, in the Victorian National Museum, at Melbourne.

I possess a single , captured by Mr. E. C. Bedwell, on September I Ith, I900, at Kessingland in Suffolk, probably on the coast sandhills; it is possible that the original examples are from the same locality, since Curtis collected somewhat extensively about Covehithe, \&c., in 1812-1832. I have found the of by no means uncommonly on the flowers of Angelica sy/restris, near Lyndhurst, in the New Forest, from 6th to 1 th of August ; and I noticed they were sometimes caught in the act of feeding and killed by a white spider, Misumena vatia, Clk., which lurks, almost invisibly with wide-spread legs, upon the flower-tables. The $q$ of this species appears to be unknown upon the Continent and the of to be considered a variety (probably mutabilis, Berth.) of I. sarcitorius, from which Dr. O. Schmiedenecht tells me he does not think it differs. I do not think it possible to be a variety, so constant are the markings and coloration of these two species:; it is, nevertheless, worthy of note that, while it is abundant throughout the country, I. sarcitorius has never been taken, to the best of nyy knowledge, in the New Forest, where alone I have found I. lautatorius of frequent occurrence.

\section{6. caedator, Grav.}

Ichnesmon caedator, Gr. I. E. i. 285 ; Ste. Ill. M. vii. I62; Wesm. Mém. couron. Ac. Belg. 1859 , p. 34 , ; Berth. Ann. Soc. Fr. 1894, p. 656, excl. $\delta$; cf. Thoms., lib. cit. I886, p. 22 ; Thoms. O. E. xviii. 1915, o क. I. decipiens, Holmgr. Ichn. Suec. i. 69 ; Berth. Ann. Soc. Fr. I894, p. 656, of.

This species may at once be known by the extensive anal white marks. Head black, somewhat narrowed behind ; + apex of cheeks, frontal orbits, clypeus and sometimes centre of face, red ; t apex of palpi, clypeus and face entirely or laterally, flavous. Antennae black, of t red below, with the scape flavous, or black beneath ; of $q$ short, somewhat explanate and hardly attenuate apically, white-banded ; sixth joint quadrate ; basal joints, including scape, entirely or beneath reddish. Thorax very little narrower than head, black; pronotum sometimes red; scutellum pale flavous, punctate throughout; areola quadrate, or slightly longer than broad, of of sinuate posteriorly. Abdomen black; post-petiole finely and regularly aciculate, its apex red in of; gastrocaeli small, sub-circular; segments two and three clear red, latter sometimes with an abbreviated black basal fascia ; fourth rarely dotted, fifth always in o narrowly margined, and six and seven in both sexes marked with white. Legs black; tibiae and tarsi basally red or flavidous, latter not dilated; to anterior legs (except coxac 
and trochanters) and the hind tarsi red; hind coxae not scopuliferous. Wings sub-hyaline, stigma and tegulae red. Length, \&-I I mm.

First joint of flagellum nearly twice longer than broad, five and six subquadrate; metanotum punctate-scabriculous, with only three distinct upper areae; post-petiole a little elevated between the spiracles, the central area finely aciculate, narrower than the space between the small and not transverse gastrocaeli, which is strongly and roughly punctate.

This species may be at once distinguished from the rest of the section by its small size, the fifth segment pale-marked in the $q$, the sixth and seventh in both sexes.

From his $I$. decipiens, with which Holmgren confused it, the apically pale-marked abdomen of the $\delta$ at once renders it distinct, as do the narrow and not transverse gastrocaeli from $I$. multipictus.

Apparently very rare; found in July, near London, and in Norfolk (Stephens, whose description of the $q$, taken direct from Gravenhorst, is probably correct) ; Bignell and Bridgman, however, in the very full lists of their respective districts, make no mention of it; nor does the latter refer to Stephens' Norfolk record, which he consequently, probably, considered unreliable.

\section{7. multipictus, Grav.}

Ichneumon multipictus, Gr. Mem. Ac. Sc. Torin, I820, p. 312 ; I. E. i. 347 ; Wesm. Mém. couron. Ac. Belg. 1859, p. 43 ; Thoms. O. E. xviii. 1927 ; Berth. Ann. Soc. Fr. 1894, p. 658, \&.

Very similar to 1 . latrator, from which it differs primarily in the white scutellum and stouter form. Head black, broader than thorax; apex of maxillary palpi and mandibles fulvous, latter apically black; juxtaantennal orbits shortly flavous. Antennae filiform, white-banded above; scape fulvous beneath, first six joints red, apical ones piceous above. Thorax black, pronotum red; areola quadrate, costulae indistinct. Scutellum white. Abdomen black; post-petiole very broad and very finely aciculate centrally, punctate laterally; gastrocaeli shailow, transverse-linear; segments one to three red, a little deplanate ; six and seven white-marked. Legs black; tibiae and tarsi red; hind legs with all the articulations in part red. Wings somewhat clouded; stigma stramineous, tegulae fuscous. Length, 6-7 mm. of unknown.

It differs from the continental $I$. gratus, Wesm., in the somewhat slender mandibles, the quadrate areola, whose costulae are more distinct, the small metathoracic spiracles and in the thyridii, which are nearly broader than the intervening space.

I do not know Marshall's authority for this as a British species, but it is recorded from Essex, and Bignell has taken it at Cann Wood and Bickleigh, in Devon, on March 6th, probably in moss. It appears to be rare on the Continent, being recorded only from Piedmont and Holstein.

\section{8. latrator, $F a b$.}

Ichneumon latrator, Fab. S. I. i. 43I, of ; Gr. I. E. i. 572, excl varr. et $\$$; Ste. Ill. M. vii. 200, $\delta$; Wesm. Nouv. Mém. Ac. Brux. 1844, p. 63, excl. varr. I et 2 ; Bul. Ac. Brux. 1848, p. 162 ; Ruthe, Stett. Zeit. 1859, p. 363 ; Holmgr. Ichn. Suec. i. 87; S. v. Voll. Pinac. pl. xxxvi. ff. 4 et 5 ; Thoms. O. E. xviii. 1928 et xxi. 2395 ; Ann. Soc. Fr. 1887, p. 9 ; Berth. l. c. 1895, p. 576, ơ ․ I. crassipes, Gmel. S. N. i. 2709, \&; Gr. I. E. i. 622 ; Ste. Ill. M. vii. 206, q. Var. I. elegans, Gr. I. E. i. 571 ; Wesm. Mém. 
couron. Ac. Belg. I859, p. 68, . Var. brachypt., Brackyplerns means, Gr. I. E. i. 675 ; Ste. Ill. M. vii. 210 , pl. xl. f. 2 ; Wesm. Mém. couron. Ac. Belg. 1859, p. 84 , fig. (wing) ; of. Marsh. E. M. M. v. I55; S. v. Voll. Schets, i. pl. i. f. 5 ; P'inac. pl, xxxvi. f. 6 ; Pterocormus means, Först. IViegm. Arch. I 850, p. 72 , ?.

This and the three following species are at once known by their small size and entirely black scutellum. Head entirely black; cheeks a little inflated, apically smooth; palpi pale, mandibles reddish. Antennae stout, filiform throughout, black; $q$ white-banded, basally clear red; fflavous beneath. Thorax entirely black; scutellum of t very rarely flavousmarked, of $q$ somewhat rugose apically ; areola always longer than broad, the lateral areae usually confluent. Abdomen elongate-ovate in $q$, sublinear in $\delta$, black; segments one to three and base of four red, six and seven of $q$ white-marked; post-petiole finely aciculate; gastrocaeli sublinear transverse, somewhat shallow, not broader than intervening space; to with third segment quadrate. Legs normal, red; hind femora, tibiae and tarsi apically black; coxae red, anterior sometimes white-marked in t. Wings sub-hyaline; stigma fulvidous; tegulae red; areolet (says Berthoumieu) sometimes sub-deltoid in $q$. Length, 5-7 $\mathrm{mm}$.

This species is distinguished from others in both sexes by the thorax cylindrical, scutellum black, thyridii nearly punctiform, gastrocaeli small, areola longer than broad. The $q$ has the antennae tricoloured, their flagellum not attenuate towards the apex, their post-annellus evidently shorter than the slightly excised sub-cylindrical scape; the spiracles (Thomson tells us) are small, rotund-oval; segments one to four red, seventh, and sometimes also the sixth, with small white marks; the legs are stoutish, red, hind femora and tibiae apically black, the claws stout; the antennae are inserted far below the middle of the prominent face. The ot has the flagellum croceous beneath, and somewhat reddish above near the base ; segments two to four parallel-sided, slightly transverse, red, the fourth sometimes posteriorly, and the petiole usually partly black; legs red; coxae, trochanters and apices of posterior femora and tibiae broadly black, the posterior tarsi fuscous towards the apex

The depth of the post-petiolar aciculation varies considerably in the females.

I. elegrans, Grav., differed from the type only in the pale anal markings of the abdomen, but these may be distinct or quite absent, as is shown in the second table, while all intermediate forms are found; I have, however, seen no indigenous examples with an immaculate anus.

There is a constant brachypterous form of this species, which was first described by Gravenhorst from a specimen taken by Hope, at Netley, as Brachypteris means, and subsequently identified with $I$. latrator, by Wesmael and Marshall, the former figures its little wing; but the neuration is by no means constant, the contour of the apices may differ in a single specimen, being sometimes acuminate, as figured, at others gently rounded, or even truncate.

The wings of $I$. latrator, even when fully developed, vary much in shape, being often narrow with the nervures apically obsolete. All the transitions between this and the form means appear to occur. At first the areolet is still present, though quadrate, the metacarpus extends beyond the apex of the radial nervure and the wings, which are similar to, though narrower than, the macropterous form, to the apex of the second segment. In less 
developed examples the apex becomes more acuminate, the radial nervure is sharply reflexed, meeting the apex of the metacarpus and there forming a minute secondary stigma; in this case the outer margin of the wing is often incised to the apex of the external cubital nervure and the wings extend only to the petiole. It might be thought this form were a case of arrested development, through which to pass the winter months, since the examples are nearly always found in hibernation, but this is not the case, for I found one running swiftly across a dusty rohd in the hot sunshine, at

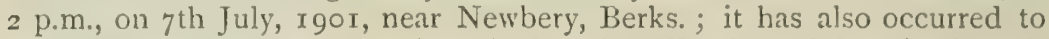
me at Peppering, near Hastings, in Bentley Woods and Barnby Broad, Suffolk; near Guildford, in moss (Capron, Entom. I880, p. 88) ; Bridgenorth (Marshall, E.M.M. I868, p. I54). There are also specimens in Marshall's, from London, and Desvignes' collections; Beaumont has found it at Lewisham, Neach Hill and Norwich.

Ich. latrator is a most abundant species, and the females may be found in multitudes, in tufts of grass, under moss, on stumps and in similar hibernacula; the males are common on Angelica sylvestris, in damp situations, in August and September. The brachypterous form is much rarer, I should say about five or six per cent.

Oulton and Barnby Broads, near Lowestoft, and Montrose, N.B. (Bedwell); Finborough and Tostock, Suffolk (Tuck); South Leverton (Thornley); Tuddenham, Suffolk (Sparke); Ewell, near Epsom (Elliott). Hastings district: Peppering, Brede, Battle, Westfield, etc. New Forest; Henstead, Icklingham, Claydon, Bentley Woods, and Foxhall, in Suffolk (Morley); Plymouth, on banks of the Tavy (Keys); Lastingham (Yorks. List) ; Wicken Fen (Donisthorpe) ; Abinger, Surrey (Butler); near Guildford, abundant (Capron. Entom. I 88c, p. 88) ; Dover and St. Margaret's Bay (Sladen); Cornwall (Davies); Headly Lane (Beaumont); Essex. In Norfolk, Bridgman found it not uncommon at Earlham, Brundall and Cromer; Bignell took it at Bickleigh, Devon, in September; and Stephens says it is not uncommon at the beginning of June, and in August, at Darenth, Charlton, Hampstead and Dover; and that the form means, which he beautifully figures, and of which there are but two examples in his collection, is rare, but has been secured at Coombe IVood, in June, and probably in Salop. Parfitt says he bred this species from pupae of Orthosia stabilis, in March, I857, in Devonshire.

\section{Notes on the Latrator Group.}

I entertain considerable doubt as to the distinction of the above and the following three species, and might extend my scepticism further if the differentiations were indicated by less credible authorities.

The $q$ of both 1 . latrator and of $I$. subquadratus have the density of puncturation on the head variable; in the latter the orbits, in one example only of those examined, are narrowly red; the clypeus is entirely black or apically, or laterally at the apex, red; the mouth parts are always red with the palpi fulvous ; the clypeus is more or less, or not at all, discreted from the face; the scape is sometimes slightly produced externally at the apex; and the lateral upper metathoracic areae are usually not divided, in both species. In one case I. subquadratus has the centre of the pronotum and apex of the scutellum red, approaching the latter of $I$. incomptus, Holmgr.; I. latrator rarely has the petiole brownish throughout or with a central piceous fascia. The extent of the black-marking on the hind legs varies only from the extreme apex to the apical two-thirds of the femora and one-third of the tibiac; sometimes the hind 
coxae are basally black, inclining to those of $I$, analis. The antennae, moreover, usually filiform throughout, occasionally slightly taper in both $I$. latrator and 1 . subquadratus towards their apices, a curious deflection in so vital an organ.

The most reliable points of distinction of the $q$ of $I$. subquadratus from those of $I$. litrutor appear to me to exist in the stronger metathoracic puncturation and darker flagellar joints. The white antennal band is always present on five or six joints, while in I. latrator it is also very often present on five and rarely on six; in both species it is very rarely entirely red. The scape and basal flagellar joints are nearly always infuscated, very rarely clear red, and in one instance the rufous colouring is replaced by stramineous; while in $I$. latrator the scape is rarely infuscated or quite black, and the flagellum unusually darker below the central band. The fourth segment is usually mainly black, in latrator sometimes, in subquadratus very rarely, entirely red; the sixth and seventh are always white-marked, sometimes entirely white in the latter; occasionally the seventh alone or not at all (I. elegans, Grav.) in the former. The areola in both species varies considerably in shape, and is occasionally sub-hexagonal or incomplete apically ; $I$. latrator has it varying from twice longer than broad to distinctly sub-quadrate, but still with the costulae weak and the flagellum basally clear red; in $I$. subquadratus it varies from slightly longer than broad to distinctly transverse. The strength of the areolar costae varies scarcely at all, and is always greater in the last-named species; that of the costulae varies more than the puncturation of the metathorax, which is always deeper and coarser in I. subquadratus, though constant in neither. The metathoracic spiracles are somewhat unstable in size and shape, but are usually elongate-oval in both species, and not larger in I. subquadratus. The cheeks do not appear to be narrower below, nor more coarsely punctate in I. subquadratus. The aciculation of the post-petiole varies in both species from distinct and regular throughout to absolutely wanting, as in $I$. spurius, with the description of which these extreme forms agree, excepting in colour, perfectly; sometimes it is present centrally but quite wanting apically, as in 1. quatriunnellutus, Thoms. ; or it may be mixed with fine, scattered punctures.

The $\delta \sigma^{t}$ of $I$. subquadratus appear to me to differ from those of $I$. latrator in nothing but the colour of the antennae beneath and of the head, if this be a reliable character. If these parts be flavous, the areola is always quadrate or nearly so, as is, however, also the case in I. latrator, which has the head, excepting the mouth parts, black. The size of the spiracles varies in both these species. The flagellum of $I$. subquadratus is sometimes rufous beneath with the basal joints darker. The petiole and part of the hind coxae are occasionally flavous in $I$. latrator.

I. analis, 9 , appears to diverge in no structural detail from large examples of the above species; the antennae taper towards the apex no more than in some otherwise typical individuals of $I$. latrator; the only appreciable distinction seeming to be that the coxae, hind femora entirely, and the anterior femora basally, are black; the inner orbits are red, but this colour would appear to be of an eranescent nature, since a specimen taken three years ago bore at that time distinctly red orbits, no traces of which are now discernible.

My notes on the petiolar aciculation of the preceding species will show the glabrosity of that of $I$. spurius to be an unreliable character, and I do not expect the density of colour on the legs is invariably maintained.

I. memorator, Wesm., seems to differ only in coloration from the above, unless it be in the spinulose anterior tibiae of the $q$ and longer antennae of the c. I. incomptus has the thyridii much broader than the intervening space, and the structure of the head and antennae appear to differ slightly from those of I. latrator. I. quadriannellatus is distinct, beyond its colour, only in the impunctate apical abeminal segments of the $q$ and larger thyridii of the $\$$.

I anticipate that ere long the above, and probably other now-reconnised "species," will be grouped together as local races or varicties of Icluncumon lutrator, Fab. 


\section{9. subquadratus, Thoms.}

Ichneumon latrator, varr. I and 2, Wesm. Mém. Ac. Brux. 1844, p. 63 , ơ. I. subquadratus, Thoms. Ann. Soc. Fr. 1887, p. 9 ; Berth., lib. cit., I895, p. 576 ; Thoms. O. E. xviii. 1928 , o ㅇ.

Black, antennae filiform, thick, tricoloured, basal joints rarely clear red; abdomen red, apex black, with two white marks; legs red, apices of hind femora and tibine black; areola quadrate, costulae distinct.

Very like the last-described species in contour, size and structure of the gastrocaeli and antennae; but is said to differ from it in having the metathoracic spiracles in both sexes larger, the areola shorter, sub-quadrate; $f$ head strongly triangular viewed from in front, cheeks not buccate but coarsely punctate; flagellum with its basal joints not entirely red, and its pale band composed of five or six joints ; petiole finely sub-striate apically ; of face, a pically truncate clypeus and mouth, flavous; antennae croceous, black above.

Doubtless common, though less so than the preceding, with which it has hitherto been mixed, and consequently unrecorded in Britain. It is very often found in direct company with I. latrator, of which it is, perhaps, but a variety. The Mound, Sutherland (Yerbury); Bury St. Edmunds (E. Saunders); Greenings, near Reigate, in $\mathrm{I} 872$ (ex coll. Wilson Saunders); Dover and St. Margaret's Bay (Sladen); Oulton Broad, Suffolk (Bedweli); Hastings District (Bloomfield); New Forest (Chawner). It is common about Hastings, where I have found it at Brede, Battle and Peppering, and about Ipswich, in moss and tufts of Aira caespitosa; Ewell, near Epsom; Oxshott. The males are found in July and August, but I have only found the females in the winter during hibernation. No brachypterous form of this species has hitherto been noticed. On I 7 th August, I90I, I captured a curiously malformed example of the male flying, at Lyndhurst, Hants. ; this had the petiole normal, but the second and third segments were connate, dull and contorted, nearly half as long again on right side, which was much more produced than on the left, and only discreted at the sides; the fourth segment was nearly as long as the two preceding together; the next two extremely short, the fifth being deeply transversely sulcate throughout ; the seventh normal.

\section{Io. spurius, Wesm.}

Ichneumon spurius, Wesm. Bul. Ac. Brux. 1848, p. 162 ; Berth. Ann. Soc. Fr. IS94, p. 580 , ㅇ.

Very like the two preceding species, but at once distinguished from them by its black hind coxae and quite smooth petiole.

Head black, palpi and clypeus laterally reddish, the latter arched above. Antennae short and filiform throughout, black, white-banded. Thorax entirely black; areola sub-rectangular, about twice longer than broad; costulae obsolete. Scutellum black. Abdomen black with segments one to four red, seventh dorsally white; post-petiole centrally smooth throughout, with no trace of aciculation; gastrocaeli normal. Legs black, tibiae and tarsi red, apically black; hind coxae black. Stigma red. Length, 5-6 mm. ơ unknown. 
A female of this doubtful species, which appears of rare occurrence in Britain, taken by Piffard, at Felden, in Herts., is much smaller than the two preceding species, with the flagellar pale band composed of but three joints, the areola only slightly longer than broad, the post-petiole is glabrous, but a microscope reveals central aciculation and a lens lateral punctures, the basal three segments alone are red and all the tarsi are also red, the apices of the hind tibiae only being black. It is said to hibernate among moss.

\section{II. analis, Grav.}

Ichneumon analis, Gr. I. E. i. 62I ; Ste. Ill. M. vii. 205; Wesm. Bul. Ac. Brux. 1848 , p. 163; Berth. Ann. Soc. Fr. 1894, p. 584, \&. ? I. delator, Wesm. Nouv. Mém. Ac. Brux. I844, p. 65 ; Bul. Ac. Brux. 1848, p. 164, o.

․ At once known from the remainder of the group by its red frontal orbits. Head black; palpi, mandibles, margin of clypeus and the frontal orbits red. Antennae sub-filiform, though distinctly attenuate at the extreme apex, white-banded, basal joints red, the apical piceous. Thorax black, pronotum often red; areola sometimes nearly glabrous, often twice longer than broad. Scutellum black. Abdomen sub-obtuse, black; segments one to three red, six and seven dorsally white; post-petiole finely aciculate; gastrocaeli small. Legs red; all the coxae, femora and apex of the hind tibiae black. Stigma red. Length, $8 \mathrm{~mm}$.

Distinguished from the preceding by its aciculate petiole and attenuate antennae.

o. The Rev. T. A. Marshall has assigned I. delator, Wesm., with some hesitation to the present species; although in the index, I find no mention of it in Berthoumieu's "Monographie." It closely resembles $I$. litrator, Fab., but differs therefrom in the entirely black first segment, coxae and antennae; the wings are larger and the clypeus laterally flavous.

The female would appear to be scarce in Britain; Stephens found it so about London, in July. There is a specimen in Marshall's collection (mus. Mason) from Sandown; it is recorded from Essex; and I have taken it in tufts of Aira caespitosa, at Battle, in March.

\section{Walkeri, Wesm.}

Ichnemmon Walkeri, Wesm. Bul. Ac. Brux. 1848, p. I83; Berth. Ann. Soc. Fr. I895, p. 560, .

․ Head narrowed towards mouth and behind eyes, black; palpi rufescent; mandibles in part, clypeus centrally, facial, frontal and vertical orbits, red. Antennae somewhat slender, hardly attenuate, white-banded, basally red. Thorax black; mesonotum red with three piceous vittae; areola sub-quadrate. Scutellum red. Abdomen black with segments one to three and most of fourth red, apex immaculate; post-petiole aciculate; gastrocaeli shallow and transverse. Legs black; tibiae, excepting apices of hind ones, and tarsi red. 'Tegulae and radix red, stigma pale flavous. Length, 9-10 $\mathrm{mm}$.

t has the facies of a large $I$. latrator. Head somewhat coarsely punctate, black; facial orbits partly flavous; mandibles fulvous, extreme apices black; palpi and ligula pale flavous; clypeus not discreted, 
glabrous, with scattered punctures, somewhat rounded apjically; cheeks normal. Antennae setigerous, distinctly attenuate towards apex ; fulvous, centrally darker and scape black above. 'Thorax entirely black and finely punctate; mesosternum more sparsely punctate with sternauli indicated; metathoracic areae distinct and complete; areola rectangular, a little longer than broad; juxta-coxal carinae strong. Scutellum slightly convex, closely punctate; black. Abdomen sub-cylindrical, convex, closely and finely punctate, dull throughout; red, with centre of first segment, and from fifth (except its base) to apex, black; post-petiole indistinctly aciculate, carinae strong; gastrocaeli normal, thyridii not deep; intervening space sub-aciculate, not broader than centre of post-petiole; ventral fold on segments two to four; valvulae retracted, small. Legs red; coxae externally, apices of hind femora, of hind tibiae, and of the tarsal joints, black. Wings flavidous-hyaline; areolet pentagonal; tegulae and stigma flavous. Length, $9 \frac{1}{2} \mathrm{~mm}$.

This little-known species has been ranged by Berthoumieu with those appertaining to Barichneumon, from which it appears to be abundantly distinct, firstly in its aciculate post-petiole and secondly in the normal gastrocaeli of the $\delta$, if not of the $q$. The vertical orbits of the latter are red, as is sometimes the case in Ichnenmon, and not flavous as in Barichneumon; but I have seen no example of the female, and assign the present position to it mainly upon the male characters.

Schmiedeknecht says the $q$ is very like and "vielleicht identisch" Ic/lneumon mustela, Kriech., which, however, has the post-petiole smooth and the gastrocaeli very large and deeply impressed.

The male has not before been described; there is one example in the British Museum, named probably by Wesmael himself, whence the above description is drawn. This is the only indigenous specimen of which I am aware. On the Continent the female is recorded only from Holstein.

\section{3. molitorius, Grav.}

Ichneumon molitorius, Gr. I. E. i. 258, \& (nec Linn.) ; Ste. Ill. M. vii. I59, excl. o ; cf. Wesm. Mém. couron. Ac. Belg. I859, p. 31, et Kriechb. Ent. Nachr. 1892; Holmgr. Ichn. Suec. i. 52 ; Thoms. Ann. Soc. Fr. I886, p. I8; Berth., lib. cit., 1894, p. 638, o $q$; Thoms. O. E. xviii. 1916, excl. o. I. illuminatorius, Gr. I. E. i. 423, ơ ; Ste. Ill. M. vii. I83. I. zonalis, Gr. I. E. i. 323, q; Wesm. Bul. Ac. Brux. I857, p. 378 , 5. 9. I. extensorius, Fonsc. Ann. Soc. Fr. I 847 , p. 50 (nec Grav.), ‥ I. luctatorizs, Wesm. Nouv. Mém. Ac. Brux. I844, p. 57 (nec Linn.); Bul. Ac. Brux. I848, p. 159 (part). I. terminatorius, Holmgr. Ichn. Suec. i. $7 \mathrm{I}, \delta$.

The centrally badious or black abdomen of this and the next species is distinctive. Head black, immaculate, or orbits rarely reddish, in $q$; $\delta$ with palpi and mandibles partly pale, the face and clypeus entirely or laterally, and the frontal orbits flavous; cheeks normal, almost smooth apically. Antennae strongly explanate centrally, gradually attenuate towards apex, fourth joint quadrate; $q$ white-banded, ot scape flavousmarked and flagellum more or less red beneath. Thorax stout, black; immaculate in + , o pronotum and two callosities at radix flavous; metathorax with three upper areae only; areola quadrate or slightly longer than broad, apically emarginate; o pubescence long and whitish. Scutellum flat, somewhat convex in $\delta$; smooth, entirely flavous-white, some- 
what transverse; post-scutellum also white throughout in $0^{*}$. Abdomen, oblong-oval in $q$, elongate-elliptical in $\delta$; black, $q$ with segments two and three dull, sometimes more or less badious or dull red, five or six to seven flavous-marked, of segments two and three flavidous, second more or less black-marked, third basally black and sub-quadrate; postpetiole strongly aciculate, gastrocaeli normal, deeply impressed, the intervening space someivhat rugose. Legs black; q tibiae centrally stramineous-white, femora incrassate, scopulae large and piceous; $\delta$, excepting coxae, trochanters, hind femora, and apices of hind tibine, fulvous; tarsi often more or less fuscous. Wings with stigma fulvous; $q$ somewhat clouded, areolet pentagonal; of flavescent, tegulae flavous, areolet subdeltoid. Length, I3-16 mm.

This species may be known in $q$ by the distinct coxal tufts, the whitish scutellum, anal markings, and posterior tibial band. It varies in having segments two and three dorsally black, castaneous, or entirely red, but the colour of the posterior tibiae and tarsi will easily distinguish it from $I$. confusorius. The of may be known by the long thoracic pubescence, its somewhat short scutellum and white post-scutellum. In I. zonalis, Wesm., both the second and third segments are entirely red, divided by a black band, but this colour is usually dull and rarely clear as in $I$. confusorius, ㅇ․

From $Y$. crassifemur, Thoms., with which it has been confused, it may be distinguished, in the $q$, by the stouter antennae, of which the flagellum is more attenuate apically and the joints are longer, the second flagellar joints being distinctly longer than broad; of $q$ by the shorter scutellum, and the thinner hind femora which are externally closely punctate throughout, and not longitudinally impressed; in the $\delta$, by the callosities beneath the wing, the more strongly and coarsely punctured mesonotum and cheeks, and the slightly broader abdomen.

Stephens thought the $q$ was not common about London, in June, and the of rarer, in July; he also records it from Yorkshire; Bignell took it at Bickleigh, near Plymouth, on September 2 nd; and it is recorded from Norfolk by Paget. It has been bred on the Continent, where it is generally distributed from Noctua brunnea and Trachea piniperda. The o hibernates in moss, and I have taken it beneath the bark of a rotten tree-stump, at Foxhall; beneath a felled pine, at Sproughton, in February; and swept it from herbage as late as November roth, in Bentley Woods, near Ipswich. Mr. Bradley has taken it at Sutton, near Birmingham, in the middle of June, as well as in September; and I believe Mr. Haggart has found it beneath bark, during the winter, at Galashiels ; it is also recorded from Essex, and Mr. Bedwell has taken it, in October, in the New Forest.

\section{4. crassifemur, Thoms.}

Ichnenmon crassifemur; Thoms. Ann. Soc. Fr. 1886, p. 18; O. E. xviii. 1917; Berth. Ann. Soc. Fir. 1894, p. 639, $\delta$ q.

Extremely closely allied to the last-described species, but the shape of the scutellum is very distinctive. Scutellum whitish-flavous, not transverse, flat; second segment evidently broader at apex than at base, the thyridii oblique and gastrocaeli rugose; second and third rarely partly 
croceous. 'The $q$ has the flagellum less attenuate apically than in $I$. molitorius, the joints are shorter, the second flagellar being only slightly longer than broad; hind femora stouter, closely punctate externally, with a distinct almost glabrous longitudinal impression beneath. The of has the face entirely or for the most part flavous; antennal scape flavescent beneath; pronotum sometimes pale; a triangular mark before the radix, tegulac exteriorly, and radix, flavous; thorax and cheeks more fincly and feebly punctate, mesonotum less distinctly pubescent, and abdomen rather narrower, than in 1 . molitorius. Length, $14 \mathrm{~mm}$.

I consider the longitudinal furrow on the hind femora externally beneath in the $q$, and the black callosity beneath the radix, as well as the post-scutellum, in the $\delta$, to constitute the most definite characters.

Mixed with the last species but, occurring in Sweden and Germany, it was likely to be found in Britain. The Rev. A. Thornley, M.A., gave me a specimen, appearing to be a female of this species, which has not hitherto been noted with us; it was taken at Cadney, near Brigg, in Lincolnshire, on $3^{\text {th }}$ March, 1898 , doubtless during hibernation.

\section{I5. melanotis, Holmgr.}

Ichneumon luctatorius, varr. 8 et 9 , Wesm. Nouv. Mém. Ac. Brux, 1844, p. 57, $q$. I melanolis, Holmgr. Ichn. Suec. i. 72, excl. o; Ent. Tidskr. ISSo, p. 76, o; Thoms. O. E. xviii. I9I7 et xxi. 2392 ; Ann. Soc. Fr. 1886, p. 19; Berth. lib. cit, 1894, p. $644, \delta$ ? .

Head a little narrowed posteriorly, frontal orbits often reddish ; $\delta$ also with the mandibles in part red, angles of clypeus and sides of face stramineous. Antennae filiform, slightly attenuate; white-banded in $q$, basal joints cylindrical in of. Thorax black, of with lines at radix flavous; areola a little longer than broad, rectangular, sub-emarginate apically. Scutellum flavidous or white. Abdomen black; $q$ segments two and three sometimes badious-red, five or six and seven flavous-marked : $\widehat{\sigma}$ third segment only flavous and quadrate; post-petiole aciculate-punctate; gastrocaeli normal, intervening space strongly punctate. Legs black, tibiae centrally stramineous-white, with the posterior apically black, tarsi usually partly flavous; $q$ hind coxae not scopuliferous but densely and coarsely punctate and apically pubescent. Wings a little clouded, often flavescent; stigma red, tegulae especially exteriorly rufescent. Length, I 4-I $6 \mathrm{~mm}$.

The 9 much resembles $I$. extensorius, with which it was confused by Wesmael in $I 844$, but the colour of the legs, if not that of the second and third segments, is quite distinct. From I. molitorius, which it more nearly approaches, it is abundantly distinguished by the marks near the radix and the structure of the posterior coxae, as well as by the rather thinner antennae, the flagellum of which has the first six joints black, and the more slender posterior tarsi; the white markings of the scutellum, anus and tibiae are, moreover, less pure.

This species undoubtedly hibernates as an imago, and it is under these circumstances it is usually found, which accounts for our long ignorance of the $\hat{\sigma}$, which, of course, dies off in the autumn. It was taken under the bark of a dead tree by Holmgren, who says it also occurs in meadows and woods. Bignell has taken it at Bickleigh, Devon, in the middle of 
September. Mr. And. Adie Dalglish has kindly given me a $q$ of this species taken on $24^{\text {th }}$ May, I900, at Colintraive, near Edinburgh.

\section{r6. bucculentus, IVesm.}

Iclunetumon luctatorius, var, 9b, Gr. I. E. i. $4 \mathrm{I} 8$, o. Var. I. fulvicomis, Gr. I. E. i. 422 ; Ste. III. M. vii. I82, ठ. I. bucculentus, IVesm. Nouv. Mém. Ac. Brux. 1844, p. 61, 8 क; Bul. Ac. Brux. 1848, p. 162, var. 8; Holmgr. Ichn Suec. i. 60 ; Ent. Tidskr. I880, p. 30 ; Thoms. O. E. xii. I223 et xviii. 1917; Ann. Soc. Fr. I886, p. 19; Berth., lib. cit., I894, p. 645, of क. I. glaucus, Tisch. Stett. Zeit. 1876, $\uparrow$.

This and the following species, which are very closely allied, may be known by the large pale mark on the fifth segment. Head black, broader than thorax; inflated behind eyes; face quadrangular, cheeks strongly buccate; mandibles obliquely truncate; eyes prominent; frontal orbits red in $q$; facial orbits and sometimes clypeus largely flavous in $\delta$. Antennae filiform, white-banded, at least above, in + ; flagellum usually entirely black, scape flavous beneath in of. Thorax black; of of covered with piceous pilosity and with the callosities before and beneath the radix flavous; areola apically emarginate, equilateral, basally somewhat rounded, sub-quadrate, longer in $q$; costulae often wanting. Scutellum flavidouswhite; shining, with large and shallow punctures. Abdomen of $q$ elongateovate, of 0 sub-cylindrical ; black, of with segments two, three, and rarely the fourth basally at the sides, flavous or fulvous, apical ones immaculate, or very rarely marked with yellow; $q$ with segments two, three, and often base of four red, five to seven always with dorsal white marks, of which the first is broader than, or very rarely only as broad as, the following; post-petiole aciculate, carinae not strong; gastrocaeli normal, deeper in $\hat{\jmath}$, intervening space evenly punctate. Legs black; tarsi and tibiae of $\delta$ fulvous, of $q$ red; hind or posterior ones apically black; hind tarsal joints apically fuscous. Wings hardly clouded; areolet pentagonal; tegulae ferrugineous, stigma fulvescent. Length, IO-I $5 \mathrm{~mm}$.

This species agrees with 1. suspiciosus in the following points, which differ from most other species : the $q$ has a large pale dorsal mark on the fifth segment, generally larger than that on the sixth; the posterior coxae, though closely punctate, are not tufted; the antennae slender; scutellum white, not flavous; cheeks buccate; areola oblong-quadrate: the of has the antennal flagellum entirely black; the face and clypeus for the most part flavous; the posterior femora are black, their base, externally hardly, internally with a small red mark; hind tarsi entirely flavous or the joints apically fusco-ferrugineous above. From $I$. susficiosus it is distinguished by the genal costa in both sexes being strongly inflexed, the oral costa in

o laminately elevated, the lower margin of the stout mandibles is sinuate, their apex broad, with the upper obtuse tooth the larger; $f$ with segments two and three dullish and densely punctate; the of has the oral costa hardly clevated, the clypeus apically truncate, sub-marginate; scutellum stramineous-white; segments two and three flavous, and the colour of the posterior legs is also distinctive.

The $q$ hibernates beneath moss, and is found in woods, gardens and meadows. I have seen no British examples of this species, and do not expect it is frequent with us, though common on the Continent. Doubtless mixed with the following. Stephens records the of var. fulitionis, 
which has the antennal flagellum for the most part red, as rare about London, in July.

\section{I7. suspiciosus, Wesm.}

Icluncumon suspiciosus, Wesm. Nour. Mém. Ac. Brux i 844 , p. 62, q; IIolmgr. Ichn. Suec. i. 62, excl. o ; of. Ent. Tidskr. 1880, p. 30 ; Thoms. O. E. xii, 1223 et xviii. 1918; Ann. Suc. Fr. 1886, p. 20 ; Berth lib. cit. I894, p. 642, si + . Var. I. quadripunctatus, Kriechb. Fnt. Nach. I $\$ 90$, o . I. computatorius, Holmgr. Ichn. Suec. i. 53, o (nec Müll.).

Head black; cheeks behind the mandibles and the temples somewhat buccate ; frontal orbits of $q$ red; $\delta$ with palpi, clypeus and face flavous. Antennae of $q$ filiform, sixth joint quadrate, white-banded; of with the scape flavous, flagellum fulvous beneath, without tyloïdes on six basal joints, nor six to ten carinate internally. Thorax black; of with pronotum and lines before and beneath radix flavous; areola rectangular, longer than broad, sub-quadrate in $\delta$; emarginate apically; costulae usually entire. Scutellum of to a little convex, flavous; of $q$ white. Abdomen of $q$ lanceolate-oval, of of sub-linear or elongate-elliptic; post-petiole aciculate, gastrocaeli somewhat small, of of normal ; black, of with segments two and three red, sometimes inclining to yellow, five to seven, and very rarely the fourth (var. 4-punctatus, Kriechb.) also, with large white marks, of which that on the fifth segment is always larger or at least as large as the following; of with segments two and three flavous or ochraceous-red, third subquadrate, anus always immaculate. Legs normal, black; tibiae rufous distinctly stramineous centrally, the front pair rufescent at apex, intermediate at apex and before base usually piceous, hind ones at apex and before base quite black; tarsi red in $q$, flavous with fuscous apices to posterior in $\delta$. IVings flavescent; stigma fulvous or rufescent; tegulae red-brown, of $\delta$ in part flavous. Length, $14-16 \mathrm{~mm}$.

The essential points of the above description are taken direct from that of Berthoumieu, whose specimens were actually captured in "un état de copulation parfaite"; he, however, makes no mention of rufescent coloration in the of tibiae. Very closely allied to I. bucculentus, of which Wesmael thought it possibly only a variety, but pointed out the following o distinctions: the head is narrower, and only as broad as the thorax; the cheeks are less dilated and deflexed; the puncturation of the second and third segments is a little more distinct, and the colour of the tibiae is paler.

It agrees, moreover, therewith in the gradual narrowing of the markings on the apical segments, in the posterior coxae of the of being very closely punctate and dull beneath, as well as in the elongate areola; but differs from it in the genal costa of the $q$ being only slightly inflexed, the oral very slightly elevated, the tibine centrally stramineous, the upper mandibular tooth somewhat acute; $\delta$, the head a little narrowed behind the eyes, the second and third segments more strongly punctate, the scutellum slightly elevated, the disc of the mandibles before the apex is convexly glabrous, and the legs are also distinctive.

In coloration it much resembles $I$. confusorius $q$, from which, however, it may be known at once by the white mark on segment five, which is constant, and the relative size of the following marks, and by the metathoracic spiracles, which are slightly less linear. 
Clarkston and Leigh, near Bristol, in August (Charbonnier) ; New Forest (Chawner); Falkland, in August, and Pettymr, early in May (Evans); Essex (Harwood) ; Tostock, Suffolk, in September (fide Bridgman). On Heraclenm sphondylium flowers, in Henstead Marshes, in July; and in sods of grass, at Bramford, Suffolk, in March. It is known to hibernate in moss, and occurs in woods and meadows on the Continent, where it is common and generally distributed.

\section{r8. languidus, Wesm.}

Ichneumon semiorhitalis, var. I. (abdom, non nigrocaerulen), Gr. I. E. i. 2I3, of. I. luctuosus; Gr. I. E. i. 200, ơ (part.). I languidus, IVesm. Nouv. Mém. Ac. Brux. 1844, p. 52 ; Thoms. O. E. xii. 1232; Berth. Ann. Soc. Fr. I894, p. 597, o \&. $I$. limbatus, Tisch. Stett. Zeit. IS79. J. Var. I. nigrocastaneus, Tisch. Stett. Zeit. I88 I ; Kriech. Ent. Nachr. I 894, .

'The entirely black abdomen renders this species abundantly distinct.

․ Head strongly narrowed behind eyes; frontal orbits sometimes obsoletely reddish. Antennae stout, not compresso-dilated towards apex ; white-banded. Thorax entirely black; areola rectangular, longer than broad, emarginate posteriorly. Scutellum white. Abdomen broad, black, central segments immaculate and not red-margined; the three apical segments white-marked; post-petiole centrally aciculate; second segment basally sub-aciculate, gastrocaeli of normal size and not transverse. Legs black, anterior femora with white apical dot; front tibiae laterally flavous; hind femora for the most part black, their tibiae often also black, but sometimes paler basally; hind coxae without scopulae. IVings a little clouded. Stigma red.

o. Clypeus black, or, like the facial orbits, white more or less laterally. Antennae stout; scape white, flagellum ferrugineous, beneath. Thorax black, humeral marks and occasionally pronotum white; areola striate, quadrate, apically angulate. Scutellum convex, white. Abdomen black, without blue reflection, not rufescent centrally; post-petiole finely aciculate; second segment also aciculate with disc rugose, its gastrocaeli of normal size; third sub-quadrate. Legs black, front coxae rarely whitemarked; tibiae internally flavous, hind ones sometimes entirely black. Tegulae piceous, sometimes white-marked. Length, I6-I $8 \mathrm{~mm}$.

I. migrocastaneus is a variety of this species with the second segment more or less castaneous, the tibiae and tarsi red, apically black.

It differs from $I$. computatorius in the antennae never being compressodilated, and in its distinctly punctate scutellum. The generic characters render it distinct from Melanichneumon, \&c.

Probably a southern species; Bridgman took males at Eaton and Earlham, in Norfolk, in July and August; Parfitt found it on Umbillifirce, in July, in Devon. On the Continent it ranges from Belgium to Spain and Hungary, and is uncommon in France.

\section{9. terminatorius, Grav.}

Ichnoumon terminatorius, Gr. Mem. Ac. Sc. Torin, IS20, p. 302 ; I. F. i. 2Sz, \&; Ste. Ill. NI, vii. I6I ; Wesm. Bul. Ac. Brux. IS48, p. I60; Holmgr. Ichn. Suec. i. 70, excl. $\delta$; Ent. Tidskr. I880, p. 32 ; Tisch. Stett. Zeit xxxiv. p. 423, 8; Thoms. O. E, xviii. 1919; Ann. Soc. Fr. 1886, p. 20 ; Berth. lib. cil., I894, p. 641, o \&. I. lucta. 
torius, var. 14, Wesm. Nouv. Mém. Ac. Brux 1844, p. 57, ‥ I. concinnatorius, Ste. III. M. vii. 166 \%. (?) 1. fulvosculellatus, Ste. loc. cit. I62; ff. Morl. L.M.M. 1902, p. 120.

Again we have the species with three anal pale marks, but that on the fifth segment is now smaller than the following.

Head pilose, black, a little narrowed behind the eyes; of frontal orbits and apices of mandibles and palpi red or flavescent; $\hat{o}$ with palpi, mandibles, clypeus and face flavous. Antennae of $q$ stout, somewhat attenuate apically, white-banded; those of ot are entirely black, with joints six to twenty finely carinate internally. Thorax stout, black; scutellum, sometimes post-scutellum in $\delta$, and pronotum in both sexes flavous; the lines at the rufescent radix being narrowly flavidous in $\delta$; metathorax rather narrowed in $\delta$, with rough puncturation, areola longer than broad, in of gradually narrowed towards the emarginate apex; costulae wanting. Abdomen oblong-oval in o t, elongate-elliptic in 0 ; post-petiole aciculate, gastrocaeli large and somewhat deep; $q$ with segments two and three fulvous or red, the latter with a black basal mark, five to seven with white marks that on fifth being very small; of with segments two and three, often base of four, and apex of first flavous, the third being sub-quadrate with a basal, and rarely a lateral, black margin. Legs stout, black; anterior femora of $\delta$ mostly pale, the tibiae fulvous, hind ones in part black; all the tarsi red or flavous, those of tonly being very rarely slightly marked with black, and its front coxae rarely with flavous; hind coxae of $q$ not scopuliferous. Wings flavescent, stigma fulvous. Length, I 5-I $8 \mathrm{~mm}$.

Both sexes of this species may be known by the flavous posterior tarsi, the posterior femora red before the base only, the more strongly punctate mesonotum, the longer pleurae and temples, thicker fulvo-griseous pubescence, rugosely punctate metathorax whose areola is narrowed behind, and the flavous scutellum and wings; the $q$ has three narrow citrinous anal marks of which the first is the smallest, posterior femora very closely punctate with the inner edge only smooth below, the third segment with a basal black fascia; the ot has the scutellum convex, the flagellum black of which joints six to fifteen bear distinct raised lines, face and frontal orbits flavous, the post-petiole with the central area sparsely but strongly striate, hardly broader than the lateral.

Gravenhorst took the $q$ from Angelica sylvestris, in September; it hibernates in moss. Stephens says it is not uncommon about London, at the end of the summer. He again describes the $q$ under the name $I$. concinnatorius, which differs only from his previous description of $I$. terminatorius, in having the margin of the pronotum yellow and the tarsal joints apically infuscate; he evidently considered it distinct, however, since he says it is a "splendid species, taken near London, but very rare." The pale vertical orbits, never found in the genus Ichneumon (sensu Thoms.), would appear to render it distinct; I suspect, however, that this is a lapsus calami and should read "orbitis frontalibus pallidis." Found commonly in woods and pastures on the Continent. Donisthorpe has found it at Rossbeigh, Co. Kerry, in June (cf. "Irish Naturalist," 1903, p. 68); I have taken it on Angelica flowers, Matley Bog, on August 7 th, and Miss Chawner has also taken it in the New Forest. Bignell tells me he has bred it from Agrotis lucemea. 


\section{0. stramentarius, Grav.}

Ichneumon stramentarius, Gr. I. E. i. $28 \mathrm{I}$; Ste. Ill. M. vii. I6r; Wesm. Bul. Ac. Brux. I848, p. I60 ; Tisch. Stett. Zeit. xxxiv. p. 420, \&; Holmgr. Verh. z.-b. Ges. I878, p. 168, ơ क ; Kriech. Ent. Nachr. 1880, ơ ; Berth. Ann. Soc. Fr. 1894, p. 640. I. Iuctatorius, var. 13, IVesm Nouv. Mém. Ac. Brux. I 844, p. 57, ․

Body stout. Head black, cheeks very slightly inflated, sparsely punctate, clypeus shining; $q$ with internal orbits sometimes pale; of with palpi, mandibles, clypeus and face, flavous. Antennae of $q$ stout, filiform, fourth flagellar joint quadrate, centrally white-banded; of $\$$ with joints six to twenty finely carinate internally, and scape flavous, flagellum sometimes ferrugineous, beneath. Thorax with lines at radix and sometimes the pronotum flavous in $\delta$; pleurae trans-striate beneath, more strongly in $\%$; areola sub-quadrate, its length variable, emarginate apically, often sub-hexagonal in of. Scutellum and usually post-scutellum flavous; of t strongly convex. Abdomen acuminate-oval in $q$, elongate-elliptic in to; post-petiole aciculate; gastrocaeli large and deep, with the intervening space punctate; segments two and three in both sexes entirely, five to seven marked in of with, clear flavous, that on the fifth being the smallest ;

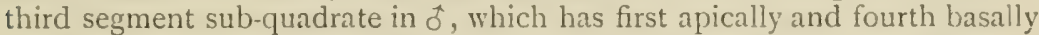
also flavous. Legs black, tibiae clear flavous, posterior apically black; tarsi rufescent, hind ones infuscate; of with front legs, except coxae, flavidous throughout; scopulae normal, reddish. Wings ample, flavescent, stigma rufescent; of tegulae mainly flavous. Length, I $5_{-18 \mathrm{~mm}}$.

The pure flavous central segments of the $q$ are very conspicuous.

This species was for long mixed with its immediate allies, till good distinctions were pointed out by Holmgren in his "Enumeration of the Tyrolean Ichneumons." Marshall thought it synonymous with $I$. suspiciosus, from which it may be known by the coarser puncturation of the whole body, less buccate cheeks and narrower temples, as well as by the $q$ scopulae. It is also very like $I$. confusorius in size and stature, differing in the coloration of the abdomen and legs and the conformation of the antennae.

Stephens found this species rather scarce, in June and.July, on flowers near London and in the north of England. It probably does not extend to Scotland, being rare in northern Europe. Mr. Edward Saunders, F.R.S., has given me a female which he took at Seaton, in Devon, in May, I899; and there is another (probably from Surrey) in Dr. Capron's collection. The female is often found during the winter, among moss, etc., in France.

\section{I. computatorius, Mïll.}

Ichnezmon computalorius, Miill. I'rodr. I52; Gr. I. Is. 256 ; Ste. III. M. vii. 158, \&; Wesm. Nouv. Mém. Ac. Brux. I844, p. 50, ? ? ; Bul. Ac. Brux. I\$48, p I52; IIolmgr. Ichn. Suec. i. 53, excl. o ; ff. Ent. Tidskr. 1880, p. 28 et Tischb. Stett. Zeit. xxxiv. p. 419 ; Thoms. xviii. 1920; of. Ann. Soc. Ir. 1886, p. 19; Berth. lib. cit. IS94, p. 598, ठ ․ I. fuscalus, Gr. I. E., i. I70, of (nec liab.). I. bicolorifes, Tisch. Stett. Zeit. IS68, o. T. malignus, 'Tïsch. lib. cil., IS8I, ó. Var. I. semiorbitalis, var. I, Gr. I. L. i. 212; Wesm. Mém. couron. Ac. Belg. I859, p. 25, ó (part.).

Head black; $q$ with apex of mandibles and usually the frontal orbits red; of with the mandibles sometimes centrally, two marks upon, or the whole centre of, the clypeus white, and the face whitish flavous with a central black mark. Antennac of $f$ strongly compressu-dilated, attcinate, 
white-banded; of of ferrugineous or piceous, the scape white beneath. Thorax stout, of with the pronotum and often a callosity beneath the radix red; ot with callosities before and beneath the radix white; areola rectangular, a little longer than broad, apically emarginate. Scutellum flat, quite glabrous and shining, yellowish white; of 0 punctate, very rarely black. Abdomen black; of $q$ hardly ever red-marked, segments six and seven only white-marked; of s sub-linear, segments two and three often more or less badious, the apical margins always red; post-petiole aciculate; gastrocaeli normal, somewhat deep; ô with intervening space strongly aciculate and third segment quadrate. Legs black; $q$ with tibiae and tarsi for the most part red, scopulae distinct; of with anterior coxae often white-marked, anterior tibiae laterally and hind ones basally stramineous; tarsi reddish or flavidous, fuscous apically. Wings slightly clouded, stigma fulvous or rufescent, tegulae black with a red margin. Length, I0-1 $2 \mathrm{~mm}$.

The antennae strongly compresso-dilated in the middle; coxal tufts distinct ; middle or nearly the whole of the tibiae red, will distinguish the of from that of $I$. molitorius, and the continental I. brevigena, Thom., which latter has no coxal tufts and its cheeks abbreviated.

Holmgren mentions a peculiar variety of the $q$, which has the mesothorax red-lined, and the first two segments entirely red, the third black, with a red mark on either side. The of much resembles $I$. confusorins in colour, but may be known by the darker under-side of the flagellum, whose joints are longer beneath, five to fourteen bearing short raised lines, the apical margin of the clypeus is black above, rotundately truncate, and segments two and three are more coarsely punctate.

Stephens records this species as not very common, in June, at Birch Wood and from the north of England. Parfitt says it is common and generally distributed in Devon, though Bignell did not there meet with it, nor does Bridgman mention it in Norfolk. It has been bred from Orgyia pudibunda on the Continent, where it extends from France to Sweden and Russia, and is found in pastures, woods and meadows; the female is said to hibernate among moss.

\section{2. inquinatus, Wesm.}

Ichneumon luctatorizes, var. I, Gr. I. E. i. 4I3, t. I. salicatorizes, var. 5, Gr. I. E. i. 245, . I. inquinatus, Wesm. Nouv. Mém. Ac. Brux, 1844, p. 53; Bul. Ac. Brux. I848, p. I54; Berth. Ann. Soc. Fr. 1894, p. 660, ơ \&. I. crassorizes, Desv. Cat. IO, 8 \&.

․ Head black; mandibles, clypeus laterally and frontal orbits red; cheeks slightly buccate. Antennae stout, filiform, compressed beneath, apically distinctly attenuate, white-banded. Thorax black, pronotum reddish ; mesonotum strongly and coarsely punctate ; areola sub-quadrate, rectangular. Scutellum flavous, punctate and striate apically. Abdomen black, dull, shining apically, or more uncommonly with segments two and three dark reddish; six and seven dorsally white; post-petiole aciculate, gastrocaeli normal. Legs black, all the tibiae and tarsi red, hind tibiae obscurely red, apically black, never whitish; hind coxae without scopulae. Stigma red.

t. Head black; palpi, mandibles, clypeus, face, frontal orbits and sometimes a genal dot flavous. Antemne black; scape flavous, flagellum 
ferrugineous, beneath; joints six to twenty finely carinate internally. Thorax black, pronotum and humeral lines flavous; mesonotum strongly and coarsely punctate; metathorax scabrous, areola transverse. Scutellum flavous, slightly convex. Abdomen elongate-elliptic, black ; apex of segments two and three flavous, base of third rufescent ; post-petiole centrally aciculate, apical angles often flavous; gastrocaeli large and deeply impressed. Legs black; front femora apically, tibiae and tarsi flavous, the hind ones apically black; anterior, and sometimes hind, coxae and trochanters flavidous. Length, I 2-I $5 \mathrm{~mm}$.

The $\delta$ is very similar to $I$. extensorius, but the head and thorax are more strongly and coarsely punctate, the former is broader, and the anterior coxae and trochanters are entirely flavous. The $q$ hibernates.

Parfitt says this fine insect would seem to be very rare in Devon, where he took but one example. On the Continent it appears to be uncommon, having a somewhat restricted range through France and Central Europe.

[It will be seen by the appended description of $I$. crassorius, Desv., taken by myself, quite independently of any reference to inquinatus, Wesm., from specimens in the British Museum, that these species are identical.

o. Head black, mouth parts flavidous, face entirely yellow. Antennae not paler beneath, excepting the flavous-marked scape. Thorax black, pronotum and lines at radix flavous ; metathorax scabrous, with only three upper areae of which the areola is strongly transverse, its apex sinuate; basal sulcus somerwhat deeply impressed. Scutellum flavous, distinctly convex. Abdomen black, segments two and three either clear flavous with the apical margins very narrowly black, or entirely black; fourth segment laterally with a curved or triangular flavous mark, broadest in centre; petiolar spiracles in both sexes tuberculate; gastrocaeli large, interval aciculate; ventral fold on segments two to four. Legs flavous; anterior with femora in part, trochanters and coxae, except apex of front ones, black; hind legs with femora except extreme base, tibiae narrowly at apex, and coxae black; all tarsi flavous throughout. Wings faintly flavescent; all venation and stigma fulvous ; areolet sub-deltoid.

Var. I : post-petiole bimaculated with flavous apically and front coxae usually strongly flavous.

․ A large, stout insect. Head black; all mouth parts ferrugineous, frontal orbits rufescent. Antennae stout, distinctly attenuate, whitebanded. Thorax black, callosities beneath the radix bright flavous, line preceding it sometimes rufescent. Metathorax with costae and sulcus much less pronounced than in $f$; three areae of which the areola is less transverse, sub-quadrate, its apex sinuate. Scutellum yellowish white, somewhat convex, apically finely striate. Abdomen broad, laterally rounded, black; segments six and seven white-marked; petiole abruptly dilated towards apex, finely aciculate; base of terebra not covered by the apical ventral segment. Legs black; all tibiae and tarsi ferrugineous, posterior apically infuscate; hind coxae coarsely punctate, with piceous pubescence, but no scopulae. Wings as in $\delta$; costa piceous. Length, I5-1 $8 \mathrm{~mm}$.

In the British Museum are twelve examples from the collections of Desvignes and Stephens; four of the males appertain to var. I; unfortunately no localities are attached]. 


\section{3. militaris, Grav. ${ }^{1}$}

Ichnetmon militaris, Gr. Mem. Ac. Soc. Torin, 1820, p. 310; I. E. i. 342, excl. \& Ste. IlI. M. vii. 172 ; Wesm. Mém. couron. Ac. Belg. 1859, p. 40 ; Berth. Ann. Soc. Fr. IS94, p. 654 , o. I. extensorius, var. I, Wesm. Bul. Ac. Brux. 1848, p. 155.

ๆ. Head black, cheeks not buccate. Antennae white-banded, bicoloured, filiform and not attenuate apically, Nesonotum entirely black ; areala sub-quadrate or only slightly longer than broad. Scutcllum white. Abdomen black, secrments two and three red, six and seven dorsally white; post-petiole not gibbous, regularly aciculate; gastrocaeli not transverse. Legs black, tarsi not dilated; anterior tibiae internally flavidous ; hind legs entirely black, their coxae probably not scopuliferous. Stigma piceous; tegulae brown. Length, $9 \mathrm{~mm}$.

This doubtful species was described by Wesmael as a variety of $I$. extensorius, with which it agrees entirely in sculpture, differing only in the colour of the hind legs ; Berthoumieu, however, thinks it "probable " that it bears no scopulae. Till this latter point were decided, it would perhaps be better to consider it as a mere variety of that species.

Not very common; found in the spring, near London, and in Salop (Stephens, October, I835). I know of no other records from Britain, and it would appear to be known on the Continent only from Piedmont, whence it was originally described.

\section{4. albicollis, IVesm.}

Ichneumon albicollis, Wesm. Bul. Ac. Brux. I S57, pp. 371, 372 ; Thoms. Ann. Soc. Fr. I887, p. 5 ; Berth. lib. cit. I894, p. 649; Thoms. O. E. xviii. 1922, ơ o.

Head black; of $q$ with palpi, mandibles and frontal orbits usually red; of $f$ with palpi, mandibles, clypeus and face, stramineous. Antennae black; of $q$ very slightly attenuate at apices, centrally white-banded; of of with scape stranineous, flagellum fulvous, beneath and joints six to twenty internally carinate, the basal four with no tyloïdes. 'Thorax stout, black with pronotum white in both sexes; $f$ with lines before and beneath radix pale; areola quadrate, or in $q$ a little longer than broad; costulae wanting. Scutellum white. Abdomen of $q$ oblong-ovate, black with segments two, three, and basal angles of fourth red, the third being sometimes basally black, sixth and seventh white-marked; of of with segments two,

\section{Ichneumon minutorius, Desv. Cat. 25, o ; cf. Morl. E.M.M. 1902, p. I23.}

This appears to be a good species as far as it is known. For the present, however, I prefer to omit it from our list, pending the discovery of its true position and possible synonymy. It is thus vaguely described by Desvignes :-

Head black; mouth, face and frontal orbits, flavous. Antennae setaceous, half length of body ; black, with scape flavous beneath. Thorax black with callosities before and beneath radix flavous. Scutellum flavous. Abdomen narrower than thorax, black; segments two to four and apex of first flavous; base and apex of fourth sometimes fusco-ferrugineous; fifth to seventh occasionally with a faint dorsal pale spot on each. Legs black; anterior femora flavidous at base and apex, hind ones fulvous at base and extreme apex; tibiae and tarsi pale fulvous, apex of hind tibiae black and hind tarsi excepting their base fuscous. Wings with stigma fulvous; tegulae flavidous; radix and costa ferrugineous; areolet sub-triangular. Length, $8-9 \mathrm{~mm}$.

It would appear to be closely allied in its small size and maculate anus with the of $I$. intricator, Wesm., described by Holmgren in Verh, z.-b. Ges, 1878, p. 174, though undoubtedly distinct therefrom. Desvignes drew his description from twenty examples taken at the same time and place, which are now in the British Museum collection.

Ichuermon niveatus, Desv. loc. cit. 25 , is a $\sigma$ Cryptid, and Desvignes has himself labelled his types in the British Museum "probably Phy adeuon arridens." "They agree perfectly with Gravenhorst's description of that species. 
three, and sides of fourth flavous, more or less intermixed with ferrugineous, the third sub-quadrate and often piceous-marked; post-petiole very finely aciculate; gastrocaeli somewhat small. Legs black; front femora excepting their base, and all the tibiae and tarsi excepting the posterior ones apically, red in $q$, stramineous in $\delta$; $q$ with scopulae normal and tarsi somewhat broad; $\delta$ with front or anterior coxae and apices of the hind trochanters white beneath. WVings slightly clouded; stigma fulvous; tegulae black or castaneous, of of white-dotted. Length, I 2 - I $6 \mathrm{~mm}$.

The broadly pale pronotum, especialiy of the $q$, and the ivory-white, not flavous, markings of the $\tilde{f}$, more especially on the trochanters, should at once render this species distinct.

It extends from central Europe to France and Sweden, and was to be expected in Britain, where it has not been previously noticed. I took two females, which probably hibernate, upon the flowers of Angelia sylvestris at Matley Bog, in the New Forest, on 8th August, I 9or.

\section{5. extensorius, $\operatorname{Linn}^{1}$}

Ichneumon extensorius, Linn. F. S. $176 \mathrm{r}$, no. I58I, $q$; Gr. I. E. i. 266 , $q$ part., excl. $\delta$; Wesm. Nouv. Mém. Ac. Brux. 1844, p. 55 ; Bul. Ac. Brux. 1848, pp. I55, 337, \& ; Thoms. O. E. xii. I 401 et xviii. 1924; Ann. Soc. Fr. 1886, p. 23; Berth. lib. cit. 1894, p. 650 , of 9. I. retractus, Tisch. Stett. Zeit. I. luctatorius, Linn. F. S. I761, no. 1590, of ; Gr. I. E. i. 4Ir, excl. varr. I, 4, 9' I. L. 363 (part.); Wesm. Bul. Ac. Brux. IS36, p. 337 (gynandromorph.); Nouv. Mém. Ac. Brux. 1844, p. 57 , o part. ; Holmgr. Ichn. Suec. i. 76 , o o .

Head not much narrowed behind the eyes, black; $q$ with frontal orbits usually rufescent; of palpi, mandibles, angles only of clypeus, facial orbits and two spots beneath the antennae pale flavous. Antennae black; $q$ filiform, hardly at all attenuate towards apex, consisting of about thirtyeight joints, half the length of the body, white-banded; $\delta$ scape flavous, flagellum often rufescent beneath, joints one to four without tyloïdes, six to twenty carinate internally. Thorax black, with lines at radix and often the pronotum flavous in $\delta$; metanotum with three areae only, of which the areola is rectangular, of $q$ much longer than broad, with its apical margin sharply angulated, of of sub-quadrate, apically emarginate. Scutellurn white; slightly convex and flavous in $\delta$. Abdomen black; of $q$ oblong-ovate and apically obtuse with segments two and three, base of fourth and very rarely apex of first, red; the sixth and seventh whitemarked; of st sub-lanceolate or elongate-elliptic, with segments two and three flavous, citrinous or croceous, fourth sometimes red, at least in the basal angles, third sub-quadrate ; post-petiole aciculate ; gastrocaeli somewhat large, and, in $\delta$, oblique. Legs black; the $q$ with tibiae and tarsi for the most part red, never stramineous-marked; the hind ones apically, very rarely entirely, black; hind coxae pilose and closely punctate throughout with scopulae small and somewhat inconspicuous but always present; the of with the front femora at apex and more or less laterally yellowish; their

1 Since writing the above, I have had the good fortune to capture Iclnnenmon gradarins, WVesm., $\$$, which has not beforc been taken in Britain, upon the flowers of Angelica silvestris in Tuddenham Fen, Sulfolk, at the end of August. It differs from I. extensorius in its very distinctly dilated tarsal joints, of which the intermediate penultimate is much broader, and in its more distinctly and much less contluently punctate frons; the legs, too, are distinctly shorter and nore incrassate. It is said to be parasitic upon Trachea piniperda and Characas graminis. 
tibiae flavidous, often black before the apex; tarsi fulvescent, apically darker ; intermediate tibiae almost invariably with a black streak internally at the apex; hind femora and apex of tibiae black, their tarsi basally stramineous. Wings yellowish-hyaline, stigma fulvous; tegulae reddish, margined in of with flavous. Length, 12-16 mm.

The $q$ of this species is easily distinguished by the small but constant coxal tufts, the hardly attenuate antennal apex, the basally dirty-red posterior femora which are closely punctate without but have a smooth edge below, the sometimes apically fuscous posterior tarsi, as well as by the red anterior knees and tibiae, of which the latter are somewhat spinulose and the posterior pair apically black, by the antennal band, depressed scutellum and only two whitish anal marks. The of much resembles that of $I$. macrocerus, but the head is less narrowed behind the eyes, the intermediate tibiae nearly always have a black internal apical line, the scutellum is less pulvinate and less flavous, and, moreover, the apically rounded clypeus and the face are not entirely flavous, and the flagellum is obscurely ferrugineous below.

From I. bucculentus and I. suspiciosus the apically blackish posterior tarsi, strongly flavous scutellum and the pale under-side of the flagellum render it distinct. While from $I$. gracilentus it may be known by the colour of the posterior legs and by the larger thyridii; ( $c f$. also Kriech. Ent. Nachr. 1 887 , p. 9 ; 1889, p. 286 ; et 1896, pp. 355 et 99).

I. subanmulutus, Grav., Marshall considered a variety of this species ; it appears, however, to be very distinct in having the cribrary organs and face entirely flavous, and less so in joints fourteen to sixteen of the antennae being fulvous with a fuscous spot beneath.

IVesmael's curious gynandromorphous insect had the head and thorax with their organs of the $q$, while the abdomen with its genital appendages were those of the $\delta$; Tischbein describes and figures (Stett. Zeit. xxii. p. 428 , pl. i. f. 3) a polymelian example of the male which has two welldeveloped tarsi, each bearing the normal five joints, but one with only a single claw, on the right hind tibia which is one-sixth shorter than the normal left-hand one.

This is doubtless one of our commonest species; it is abundant throughout Europe. Gravenhorst, who says this species is the Spliex annularis of Poda ( $76 \mathrm{I}$ ), records the female from Netley, and says it hibernates beneath moss and bark of trees, and is found on umbels in summer; Holmgren tells us it is found in woods, gardens and meadows. Stephens, whose 1 . luctatorius probably covers more than one species, records it from Darenth Wood, etc., in June ; it is common in Norfolk and Essex; Bignell took the female, at Bickleigh, in Devon, early in March, and PickardCambridge, in Dorset, among débris (Entom. I 88 I, p. I37). I have found the females commonly at the roots of Aira caespitosa during the winter, from November to the end of April, at Brede, Guestling, Battle and Westfield near Hastings and in the Bentley Woods, as well as hibernating beneath the bark of rotten alder stumps, at Foxhall, near Ipswich; flying among long grass at midday early in July, at Oxshott ; Golspie, in Sutherland, early in August.

It would appear to confine its parasitism to Rhopalocera, since the only records of which I am aware are from Vanessa polychloros, $V$. urticae, Satyrus Janira, and the continental Polyommatus Circe and Lycaena Cyllarus; although Parfitt (Ichn. of Devon) says it is parasitic on Tri- 
flurena promula and other Noctuidae; it is very probable, however, that he confused several species under the present one.

\section{6. gracilentus, IVesm.}

Ichnenmon gracilentus, Wesm. Nouv. Mém. Ac. Brux. I\$44, p. 55 ; Bul. Ac. Brux. ${ }_{1} S_{4}$ S, p. 23 ; Holmgr. Sv. Ak. Handl. I854, p. 31 ; Ichn. Suec. i. 64 ; Thoms. O. E. xviii. 1924; Ann. Soc. Fr. I886, p. 21 ; Berth. lib. cit. 1894, p. 65I, of + I. ascendens, Tisch. Stett. Zeit. 1881, ot. Varr. I. improbus et J. quadrilinealus, Tisch. lib. cit. 188I, s o. Var. I. vicinnes, Holmgr. Ichn. Suec. i. $67, \delta$.

Rather smaller and narrower than the last-described species. Head sub-triangular, black; cheeks of $q$ slightly dilated and smooth beneath; mouth in part and frontal orbits red or flavidous; of with the broadly rounded clypeus, the palpi, mandibles in part, whole face except rarely a central mark, and the frontal orbits, pale flavous. Antennae black; of $q$ filiform, white-banded, with fifth joint quadrate; of scape flavous, and flagellum fulvous or rufescent, beneath. Thorax slightly narrower than head, black, pronotum of $q$ often rufescent, of with usual flavous lines near radix; metathorax with three upper areae of which the areola is sub-quadrate in $\delta$, rectangular and twice longer than broad in $q$, and in both sexes slightly emarginate apically. Scutellum elongate, whitish flavous, punctulate, with the apex strigose; of strongly convex, with postscutellum also often flavous. Abdomen black; of $q$ elongate-oval with segments two and three red, six and seven bearing oblong white marks; of of sub-linear, with segments two and three, and sometimes also base of fourth flavous, third quadrate; post-petiole aciculate, elevated between the spiracles, gastrocaeli normal with intervening space somewhat narrower than centre of post-petiole; legs black; $q$ tibiae and tarsi red, the hind ones apically black; hind femora normal with the inner side strongly punctate, coxae without scopulae; legs of with tibiae and tarsi flavous, the hind ones apically infuscate. Wings sub-hyaline, somewhat fulvescent with tegulae flavous-marked in of; stigma pale fulvous, tegulae reddish. Length, IO-I $2 \mathrm{~mm}$.

This species nay be distinguished by the $q$ head being sub-triangular from in front, the genal costa obsoletely elevated, rufescent frontal orbits, the intermediate coxae closely punctate and slightly shining, the posterior without tufts; of with apex of clypeus broadly rounded, flagellum ferrugineous beneath, posterior tarsi immaculate flavous, frontal orbits and post-scutellum generally flavous, parallel-sided abdomen, and with the posterior femora rufescent before the base only.

From I. extensorins it may be known by its more slender build and smaller size; the petiole elevated between the spiracles; the longer metathoracic areola, in both sexes only slightly emarginate apically; the dilated lower margin of the $f$ cheeks; the colour of the $\delta$ head; the much elongated form of the $\delta q$ scutellum, which is flavous rather than white.

I. improbus is a pale variety of this species, having the legs, including the posterior coxae for the most part, flavous, and the central markings of the abdomen extending from the second to fourth, with a mark on the fifth, segments. I. quadrilineatus is a similar variety with four longitudinal vittae on the mesonotum, the carinae of the scutellum and the post-scutellum flavous. 
I have followed Berthoumieu in considering $I$. vicinus a variety of the present species, from which it differs in its broader gastrocaeli, sub-aciculate base of second segment, shorter and apically more distinctly sinuate areola; the of has the abdomen broader and the of the face and clypeus centrally broadly black. 'Thomson, however, referred it to $I$. albiger, Wesm.

One female, at Earlham, in Norfolk, in August (Bridgrman); Maldon, in Essex (Fitch). Bred from Noctur festiva, in Devon, on I 8th Jume (Bignell); Beaumont has found it at Pitlochry, in Perth, at the end of August and Miss Chawner, in the New Forest; it has been bred from Nonagria sparganii, by Van Vollenhoven, and from Triphaena fimbria once or twice in Britain. It is not uncommon on the Continent, where the female hibernates in moss.

\section{7. confusorius, Grav. ${ }^{1}$}

Ichneumon confusor, Gr. Mem. Ac. Soc. Torin, 1820, p. 300. I. confusorius, Gr. I. F. i. 276 , $q$ excl. varr.; Ste. Ill. MI. vii. 16 ; Holmgr. Ichn. Suec i. 58 ; cf. Ent. Tidskr. 1880, p. 29 ; Thoms. O. E. xviii. I92I et xxi. 2394; Ann. Soc. Fr. 1887, p. 5 ; Berth. lib. cit. I 894, p. 639, o ․ I. luctatorizus, Wesm. Nouv. Mém. Ac. Brux. 1844, p. 57 (part.) ; Bul. Ac. Brux. I848, p. I59, excl. varr. ; (?) Ratz Ichn. d. Forst. i. I36, of क. I. retectus et $I$. crassicornis, Tisch. Stett. Zeit. 1873, $q$ \%

Head black ; $q$ temples and cheeks somewhat inflated, mouth parts and internal orbits often reddish; of strongly narrowed behind the eyes, palpi, clypeus and face pale flavous. Antennae black; of $q$ filiform throughout, hardly half the length of body, white-banded with joints five and six quadrate and apically ferrugineous above; of with scape flavous, and flagellum fulvous or rufescent, beneath, basal half of latter with sub-cylindrical joints, of which the first four bear no tyloïdes. Thorax finely punctate; very rarely with a pale callosity beneath the radix in $q$, always with one both before and beneath it in 0 ; metathorax somewhat shining, with three upper areae, of which the areola is rectangular, in of longer than broad, with its apical margin obsolete in centre, in of sub-quadrate, apically emarginate. Scutellum white in $q$; flavous and somewhat flat in $\delta$. Abdomen of $q$ oblong-ovate, segments two and three red and sometimes darker on disc, six, seven, and often five, with white marks; of of sub-linear, segments two and three entirely flavous, the latter sub-quadrate; post-petiole aciculate; gastrocaeli normal. Legs black; of front tibiae stramineous, posterior tricoloured; scopulae piceous; to tibiae and tarsi flavous, hind ones apically black, intermediate tibiae immaculate at apex. Wings with stigma fulvous, tegulae piceous and flavous; of to a little clouded. Length, $10-15 \mathrm{~mm}$.

The $q$ of this species may be known by the colour of the abdomen and legs, as well as by the structure of the posterior coxae. The 0 differs from that of $T$. computatorius in the truncate apex of its clypeus, which in the latter is slightly emarginate.

The $q$ is very closely allied to that of $I$. extensorius, but its tibiae which bear broad central stramineous bands, the very distinct tufts of the hind

1 I am led, from the material through which I have looked, to believe that this species was very little understood by the older authors; and further to surmise that the name was used in connection with a much smaller species, exceedingly abundant in grass-tufts, etc., during the winter, in Britain, which I expect will prove to be the of of Ichnewmon albrger, Wesm., though I am not yet sufficiently satisfied with my data to bring the latter forward as a British insect. 
coxae, and the close, fine puncturation on the outer side of the posterior femora render it distinct.

From the of $I$. macrocerus this species may be separated by its less closely punctate cheeks, the much finer punctures of the metathorax rendering it shining and not rugose, the costulae wanting, the stronger puncturation of the second and third segments, the large oblique thyridii, posterior tibiae more narrowly black at the apex, the second joint of the trochanters and the base of the femora internally bear more flavous markings, and the size, moreover, is smaller.

Holmgren says he found several females beneath moss and under bark of dead trees, associating with Spilichneumon Gravenhorsti during I 6 th to 24th May, I853, in Ostro-Gothland; and Shuckard says (Ent. Mag. I 838, p. $48 \mathrm{I}$ ) it is common during hibernation in Britain. I have found the females hibernating in March in tufts of Aira caespitosn, at Brede and Battle, near Hastings, and Mr. Dalglish has sent it me from Clarkston, in the middle of January; Essex. Hope sent it to Gravenhorst from Netley; Bignell has taken it at Bickleigh, in August; Bridgman records the male as common, though the female less so, in Norfolk, and there is an example from Wimbledon in his collection; Stephens, whose I. confusorius probably refers to the female of this species, says it is very common about London, in Shropshire and Scotland, as indeed it is throughout Europe. Its parasitism appears to be chiefly confined to the Noctuae, since it has been bred from Dicranura bicuspis, Triphaena pro$m u b a$, as well as from other undetermined Noctuae, and, on the Continent, from Nonagria nexa, and $N$. sparganii, Gortyna flavago several times, Noctua bella, and Cucullia Santonici.

\section{8. tempestivus, Holmgr.}

\section{Ichneamon tempestivus, Holmgr. Ichn. Suec. i. 74 , ơ ․}

q. Head black; palpi fuscous ; mandibles centrally, and frontal orbits sometimes obsoletely, red; cheeks not dilated. Antennae filiform throughout, white-banded, paler apically below. Thorax black; metathorax scabriculous; areola sub-quadrate, apically emarginate. Scutellum white. Abdomen oblong-ovate, black; segments two and three entirely, and four laterally, red, the sixth and seventh dorsally flavous; post-petiole finely aciculate; gastrocaeli normal, somewhat deeply impressed; intervening space slightly broader than centre of post-petiole, strongly punctate; terebra distinctly exserted. Legs black; anterior knees, tarsi and tibiae red, the last centrally flavidous; hind femora and tarsi basally red, tibiae fuscous, centrally flavidous; hind coxae finely punctate, not scopuliferous.

§. Head somewhat narrowed behind eyes, black; palpi, mandibles, clypeus, face and frontal orbits, flavous. Antennae apically attenuate, black above ; red, with scape flavous, beneath. Thorax black, sometimes with a flavous callosity beneath the radix; metathorax as in + , its areola scmi-elliptic. Scutellum flavous. Abdomen parallel-sided, black; sewments two and three entirely flavous; post-petiole strongly aciculate; fastrocauli liarge and decply impressed ; intervening space slightly broader than centre of post-petiole, rugosely punctate. Anterior legs, including coxale, black ; apex of femora and whole of tibiac and tarsi pale; intermediate tibize with 
an apical black line; hind legs with the base of the stout femora and tarsi fulvous, tibiae basally flavous. Length, ro-r $2 \mathrm{~mm}$.

Thomson, in $\mathrm{x} \$ 86$, gave this species as a synonym of $I$. albiger, Wesm. ( 1844$)$, but it appears to differ in the shape of the areola and colour of the tibiae. Berth. in 1894 queried its synonymy with I. macrocenus, Thoms., from which the filiform antennae and natrower cheeks of the $q$, the flavous scape beneath, immaculate front coxae and black-lined intermediate tibiae of the $\delta$, appear to distinguish it.

Bridgman gives no localities, but says it appears to be uncommon in Britain; Bignell took it at Bickleigh, in Devon, on July 28 th ; it is recorded from Essex; and there are females in Marshall's collection, taken at Plympton, in the middle of April, and at Darenth Wood. On the Continent it is mixed with the preceding species.

\section{9. macrocerus, Thoms.}

Ichneumon macrocerus, Thoms. Ann. Soc. Fr. 1886, p. 20; Berth. lib. cit. 1894, p. 639 ; Thoms. O. E. xviii. I921, ơ 9.

Head black; of with face and frontal orbits flavous throughout. Antennae slender; $q$ distinclly sub-attenuate, white-banded; of fulvous or piceous beneath, the joints internally carinate. Lines before and beneath the radix of $\delta$ and the scutellum entirely flavous; areola quadrate. Abdomen of $f$ with segments two and three, as well as basal angles of four, flavous, three being quadrate. Legs black; $q$ with tibiae tricoloured, centrally stramineous, tarsi not or hardly dilated, scopulae entirely wanting; of with anterior coxae often yellow-marked; intermediate tibiae always immaculate at apex. Length, ro- $4 \mathrm{~mm}$.

This species is so closely allied to $I$. confusorius as to need no detailed description. The $q$ may be known therefrom by being a little larger; by the absence of the posterior coxal tuft; the antennae more strongly attenuate apically; joints of flagellum longer beneath; the second longer than broad; the cheeks rather longer; fourth segment without pale apical margin, third sometimes with a black basal fascia. From 1 . extensorius it differs in the absence of the posterior coxal tuft; the femora externally punctate throughout; the longer head; antennae longer and much more strongly attenuate apically, and in the posterior tibiae, which are stramineous somewhat intermingled with red centrally, fuscous before the base and rather broadly black at the apex.

The of also is very like that of $I$. extensorius in having the posterior tarsi black towards the apex, abdomen parallel-sided, the second and the quadrate third segments are stramineous, the oblicpue thyridii and the gastrocaeli are deeply excavated, and the areola sub-quadrate: but it differs in the head being more strongly punctate and narrowed behind the eyes; clypeus apically truncate; face, frontal orbits, and more convex scutellum, flavous; the flagellum ochraceous beneath; anterior coxae with a pale apical spot; intermediate tibiae never black-marked on the inner side of the apex. From I. confusorius it differs only in the pulvinate scutellum, strong costulae and larger size.

Bridgman records one male, identified by Thomson, from Brundall, in Norfolk, in August, ISSo; it has probably been overlooked in Britain. 
On the Continent it is recorded from Sweden, Germany, Italy, France and Spain.

\section{0. primatorius, Forst.}

Ichneumon primatorius, Forst. Nov. Spp. Ins. SI ; Ste. Ill. M. vii. 165, 9 ; Berth. Ann. Soc. Fr. I894, p. 620, of $q$. I. grossorize, Fab. K.. S. ii. I36 ; l'anz. F. G. Ixxviii. 8; Fab. Piez. 57; Gr. I E. i. 298, \&; Wesm. Nouv. Mém. Ac. Brux. I844, p. 38 ; IVilson, Enc. Irit. ed. 8, ix. pl. ccxliv. f. I7 ; Holmgr. Ichn. Suec. i. 92 ; Thoms. O. E. xviii. I930, o $\uparrow$. I. bicinctus, Christ, Hym, 1791, + . I. favolineatus, Gr. I. E. i. 300 ; Ste. Ill. M. vii. 165, ठ́.

A large, robust species. Head black; that of st small, with palpi, mandibles, clypeus and face pale flavous; the apical margin of clypeus slightly depressed and emarginate. Antennae black; $q$ white-banded, with the first joint thrice longer than broad, and the eighth quadrate; of of with scape flavous beneath, the fifth and following joints of flagellum carinate. Thorax broader than head, black; that of 0 with the pronotum, and a callosity before the radix flavous; metathorax bidendate, with five upper areae, of which the areola is coarsely rugose, sub-quadrate, with apex emarginate; that of $\delta$ transverse and broadly rounded at the base. Scutellum obtuse, strongly convex, stramineous. Abdomen black; of $q$ stout and broad, with segments, two three, often also apex of first and part of fourth, red, five to seven broadly, and four rarely narrowly, white-marked; of $\delta$ lanceolate, with segments two to four, apex of first, and sometimes part of five, flavous, or two to four red-yellow, dorsally black-marked, seven with a longitudinal white line, the third transverse and the incisures rufescent; post-petiole aciculate or somewhat rugose, gastrocaeli rather large and deep; the intervening space sub-rugose. Legs flavous, trochanters and coxae in part, $q$ with the femora and apex of hind tibiae, $\delta$ usually with apex of hind femora and tibiae, infuscate or black. WVings slightly clouded; stigma fulvous, tegulae whitish or flavous. Length, $20-22 \mathrm{~mm}$.

One of, which I took upon Angelica sylvestris, at Barnby Broad, in Suffolk, at the end of August, 1898 , has the posterior coxae only narrowly black within, and all the femora, tibiae and tarsi entirely flavous.

Stephens says the females are rather common around London, about Hertford, \&c., but that he had only seen one male, which was taken in a Hertford garden, at the end of May ; Hope found the female at Netley, and Forster says it is rare, in hedges, in England. Bignell has bred it, in June, from Triphanena fimbria; and Thouless has taken the female at Mousehold Heath, in Norfolk (this specimen, labelled September 5 th, $\mathbf{1 8 8}$, is in the Bridgman collection, with another from Chatteris, 1882 ); in the British Museum is an example labelled "Bantham, August"; it is also recorded from Essex.

The forewing is figured in "Knowledge" V. p. 245 ; 'Thomson appears to be in error in ascribing $I$. grossorizs to Linnaeus. It has a wide distrii)ution throughout northern and central Europe, extending to Russia, and is found among undergrowth in woods and gardens.

\section{1. bisignatus, Grav.}

Ichncumon lisignatus, Gr. I. E. i. 410 ; Ste. Ill. M. vii. 1SI ; Wesm. Mém. couron. Ac. Belg. I 859, p. 49 ; Berth. Ann. Soc. Fr. I894, p. 629, ơ. (?) 1. didymus, Gr. I. E. i. 265 ; Thoms. O. E. xviii. I933; Berth. Ann. Soc. Ir. IS94, p. 594, \&. (?) I. balis, 
IJolmgr. Ent. Tidskr. I88o, p. 82, $\delta$ ૬. (?) Trogus wissimulator, Ste. Ill. MI. vii. 272 ; cf. Morl. E.M.M. I902, p. I2I.

o. Head black; palpi, mandibles centrally, clypeus and face for the most part, flavous. Antennae black, scape flavous beneath. Thorax black, pronotum and callosities at radix flavidous; metathorax dorsally dull, laterally obsoletely bidentate; areolarlarge and slightly transverse, sub-rectangular, rounded in front. Scutellum, and sometimes post-scutellum, flavous. Abdomen fusiform, black; segments two to four flavous; their apices triangularly black ; anus immaculate ; post-petiole dull black, finely aciculate; gastrocaeli of normal size, a little broader than the intervening space, which is aciculate. Legs black; marks on anterior coxae, as well as all the tibiae and tarsi, excepting apices of hind ones, flavous. Wings somewhat clouded, stigna and tegulae piceous. Length, $19-21 \mathrm{~mm}$.

[Since Wesmael's query of $\tau 859$ : "Cet Ichneumon ne serait-il pas le mâle de l'I. didymus + ? " has never been satisfactorily answered, I have here quite tentatively considered it to be such.

१. I. didymus, Grav. :- Head black, frontal orbits sometimes red; temples not narrowed behind the eyes. Antennae stout, white-banded, often ferrugineous basally below. Thorax black; pronotum sometimes red and humeral callosities rufescent or flavidous; areola transverse, incomplete apically. Scutellum strongly convex, yellow. Abdomen broadly oblong-oval, black; second segment with two marks and the apical margin red, rarely entirely black; five generally, six and seven always, dorsally white; post-petiole finely aciculate; gastrocaeli normal, not transverse. Legs black, tibiae and tarsi, excepting apices of hind ones, red; hind coxae not scopuliferous. Stigma clear red. Length, I8-20 $\mathrm{mm}$. It is recorded only from northern France, Germany and Finland.]

Hope captured both the original males at Netley; Newman took $T$. dissimulator at Birch Wood; Stephens says they are rare near London, in June, as well as in Salop; and Bignell has bred it early in July, from Vanessa urticae, in South Devon. On the Continent it occurs only in France and Holstein. I know of no indigenous records of $I$. didymus.

\section{2. bellipes, Wesm.}

Ichneumon bellipes, Wesm. Nouv. Mém. Ac. Brux. 1844, p. 38 ; Berth. Ann. Soc. Fr. I894, p. 621, excl. §. .

ๆ. Body stout. Head black; mandibular mark and sometimes the juxta-antennal orbits of eyes red; clypeus apically marginate, centrally depressed and aciculate. Antennae stout, distinctly attenuate; fifth flagellar joint quadrate; white-banded or tricoloured; scape in part red. Thorax black, pronotum obsoletely rufescent, sometimes a line beneath and a dot before radix whitish; notauli and sternauli indicated; areola nearly twice broader than long, apically broadly rounded; apophyses sub-obsolete ; costulae entire ; petiolar area sub-entire. Scutellum white; sub-glabrous, with a few dark setae, centrally depressed. Abdomen elongate-ovate, stout, somewhat apically obtuse, black; segments two and three, or two to four, red, five to seven dorsally white; post-petiole not very finely aciculate, laterally rugose; gastrocaeli somewhat large, deeply impressed, rugose, and about as broad as the intervening space, which is evenly punctate and narrower than centre of post-petiole. Legs clear 
red, coxae and basal joint of trochanters only black; hind coxae shining, centrally sparsely punctate beneath, pilose throughout, with no scopulae. Wings somewhat flavescent; stigma red; tegulae and radix piceous; areolet pentagonal.

o. Dull, somewhat strongly punctate, black; juxta-antennal orbits, line beneath radix, scutellum and part of tegulae stramineous; legs, except coxae and trochanters, fulvous. Head evenly and somewhat strongly punctate; clypeus apically slightly rounded and marginate, centraliy depressed and aciculate ; apex of mandibles and maxillary palpi, except basal joint, red ; cheeks as long as base of mandibles, somewhat narrow; inter-antennal tubercle distinct. Antennae somewhat short, similar to those of $q$, immaculate; flagellar joints cylindrical, the six basal bearing oval tyloildes and the following thirteen distinct external longitudinal raised carinae. 'Thorax strongly punctate, with piceous pilosity; notauli and sternauli distinct; areola, costulae and petiolar area as in ${ }^{\circ}$. Scutellum white, subglabrous with a few dark setae, not centrally depressed, only slightly convex, with its basal margin black. Abdomen dull nearly to its apex, sub-cylindrical, closely punctate; first segment and gastrocaeli as in $q$, with the intervening space sub-aciculate; incisures of second and third segments and the ventral fold on segments two to four obsoletely rufescent. Legs normal; coxae and basal joint of trochanters deeply and evenly punctate, black, with piceous pilosity, apical joint of latter fulvous and glabrous. Wings hyaline; stigma, radix and tegulae piceous, the last anteriorly stramineous; areolet pentagonal. Length, I 7-I $9 \mathrm{~mm}$.

The female of this fine species is similar to 1 . primatorius, Forst., but may be known by its smaller size and immaculate coxae, as well as by the characters above described. The broad body of the $q$ is much like that of an Amblyteles and the of superficially somewhat resembles Ctenichneumon fossorius, Grav.

I am indebted to Mr. J. C. Haggart, of Galashiels, for a knowledge of the true male of this species, which materially differs from that ascribed to it by Wesmael. Two males were bred, along with the female, in July, I900, from pupae of Dastichira fascelina found upon Erica, at Rannoch, in June. The larva constructs but a very slight cocoon of its own, though it possesses the power of closing such rents as may be made in its host's pupa with a substance somewhat rougher than the inner cocoon of Exetastes and containing fine strands. The pale parts of the imago are distinctly visible in the pupa some days before its emergence; the parasite effects its escape through a sub-regularly circular orifice at the

Pupa of

1.bellipes, q. capital extremity of its host's pupa, which it entirely removes. Besides Britain, where I expect it is rare, it is found only in Germany and Belgium.

\section{3. gracilicornis, Grav.}

Ichnemmon gracilicomis, Gr. I. E. i. 290 ; Ste. Ill. M. vii. 163, \&; IVesm. Nouv, Mém. Ac. Brux. I $\$_{44}$, p. 4 I ; Bul. Ac. Brux. I $S_{4} 8$, p. I5I ; Mém. couron. Ac. Belg. IS59, p. 35 ; Holmgr. Ichn. Suec. i. 95 ; Thoms. O. E. xviii. 1924; Ann. Soc. Fir. 1887, p 6 ; Berth. lib. cit. 1894, p. 619, of . I. iocerus, Gr. I. E. i. 326, excl. var. 2 ; Ste. III. M. vii. 170, ó. I. quadrinolalus, Ste. loc. cit. 163 , ․

Head black; of $q$ with very sparse and scattered puncturation on the slightly rounded clypeus, frontal orbits often narrowly rufesecut; of of with 
clypeus and face entirely or in part black or white. Antennae of $q$ long, setaceous, apically attenuate, with first flagellar joint nearly thrice longer than broad, ninth quadrate; tricoloured, joints nine to thirteen pale above only; of of black with the scape white, and usually the flagellum rufescent, beneath, joints seven to sixteen bearing tyloïdes. Thorax black, that of of with white lines before and usually beneath the radix, and the mesosternum laterally fusco-pubescent; metanotum closely punctate, usually with complete upper areae, of which the areola is quadrate or, in $\hat{\sigma}$, transverse, hardly emarginate apically; costulae and petiolar region not or hardly entire. Scutellum convex sub-glabrous, flavidous-white; rarely apically black in $\delta$. Abdomen oblong-ovate in $q$, elongate in $\delta$; black, segments two and three, sometimes also apex of one and base of four, red; five to seven with broad, gradually narrowed white marks in $q$, which are usually obsolete or wanting in $\delta$; fourth rarely also with white apical spot; postpetiole abruptly dilated, densely aciculate throughout; gastrocaeli broad and somewhat deep, inclosing several distinct costae; the intervening space striolate in $\delta$; anus acuminate, terebra distinctly exserted. Legs somewhat slender, red; coxae, trochanters and apices of $q$ hind femora, of their tibiae and tarsi black; tibiae of $f$ sometimes in part flavidous; coxae evenly punctate, shining with short pilosity and no scopulae. Wings slightly clouded, stigma fulvous, tegulae piceous. Length, r $2-16 \mathrm{~mm}$.

'The shape of the areola of the $q$ is variable, and it is sometimes hexagonal.

Berthoumieu has named two varieties of the of nigricaudus and nigroscutellatus, which need no description.

Hope sent Gravenhorst both sexes from Netley. Stephens found the females not uncommonly about London towards the end of summer, and his male (iocerus, Grav.) more rarely, in June and July, in the same district, and in Salop. It is probably common in Britain; I have received it from Guestling near Hastings (Bloomfield); Lyndhurst, early in June (Adams); Rossbeigh, Co. Kerry, in June (Donisthorpe); Bovey Tracey, Devon, middle of August (Hamm); and there are several examples in Dr. Capron's collection. Bignell has taken it at Horrabridge, in Devon, in June; it is recorded from Essex; and Marshall twice found it at Cornworthy, near 'Totnes. On the Continent, where it is quite common, occurring in August, in woods and meadows, it has been bred from Melituea Cynthia, and the female is said to hibernate in moss.

\section{4. silaceus, Grav.}

Ichneumon silacens, Gr. I. E. i. 278 ; Ste. Ill. M. vii. 160, f; cf. Wesm. Mém. couron. Ac. Belg. 1859, p. 33 ; Thoms. O. E. xviii. 1933, of \&; Berth. Ann. Soc. Fr. I894, p. 608, ㅇ.

q. Head entirely black. Antennae somewhat slender, strongly attenuate, flagellar joints one to six obscurely rufescent beneath, seven and eight entirely white. Thorax black throughout; areae as in I. raptorius (no. 44, post). Scutellum white. Abdomen laterally broadly rounded, apically sub-obtuse; black, with segments two and three clear red, latter with apical margin flavous; five to seven broadly, fourth minutely, white-marked; post-petiole aciculate; gastrocacli normal; second segment transverse. Legs red; all the coxae, trochanters and the apical half of hind femora black; tibiae flavescent, the anterior red within and at apex; 
hind pair apically black; tarsi red, the hind ones fuscous towards the extremity. IVings slightly clouded; stigma red, tegulae piceous. Icength, IO- $12 \mathrm{~mm}$.

The of with its abdomen broad, one, two, or three white anal marks, face and clypeus almost entirely flavous-white, the flagellum red beneath, the thyridii broader than the intervening space, will be at once recognized.

Found in June, near London; very rare (Stephens). It is recorded only from the Pyrenees and Germany, where Gravenhorst took it on flowers of Pastinacea sativa.

\section{5. emancipatus, Wesm.}

Ichnerumon emancifatus, IVesm. Nouv. Mém. Ac. Brux. IS44, p. 46 ; Mant. IS48, p. 19, \&; Holmgr. Ichn. Suec. i. 98, of \&; Thoms. O. E. xviii. 1933; Ann. Soc. Fr. I887, p. 7, excl. $\delta$; Berth. lib. cit. I894, p. 618, of क. I. opacus, I. ramiformis, I. hostificus, $I$. migosus, Tisch. Stett. Zeit., $\delta$ o.

Head slightly narrowed behind eyes, cheeks almost smooth bencath ; o black, with frontal orbits narrowly white or more rarely rufescent ; of palpi and mandibles pale, sides of clypeus, of face broadly and sometimes a genal mark, flavous. Antennae of $q$ setaceous, somewhat compressed centrally, and sub-dilated before the apex, black with white band on joints nine to fifteen, or tricoloured; first joint less than thrice longer than broad, ninth quadrate; of black with scape flavous, and flagellum rosy, beneath. Thorax black, without pale callosity at radix; metathorax with complete upper areae, of which the areola is quadrate, rarely transverse. Scutellum hardly convex, more or less white; of $\hat{f}$ flavous. Abdomen black; $ᄋ$ strongly explanate centrally, with segments two and three, and often basal angles of four, red, five to seven broadly, and fourth often minutely, white-marked; of fo lanceolate, with segments two and three only flavous, sometimes marked with red or black, its apex immaculate; post-petiole aciculate; gastrocaeli large, somewhat deep and rugose. Legs red in 우 flavous in of; coxae, all the femora partly, and hind tibiae totally at apex, black; hind tarsi entirely fuscous. Wings somewhat clouded; stigna red, tegulae black. Length, I0-1 2 mm.

The $q$ may be known by the broad white-yellow antennal band; the post-annellus not longer than scape; stoutish mandibles; somewhat coarctate thorax, whose areola is sub-transverse; abdomen and its deep thyridii broad; terebra scarcely reaching beyond the anus; segments five to seven with broad, four sometimes with small, whitish mark; legs somewhat stout; scutellum flavescent-white.

From the $q$ of $l$. gracilicornis, which it resembles in its gastrocaeli and thyridii, it is distinguished by the flagellum being sub-dilated before its apex and the joints shorter bencath; the terebra shorter; the femora thicker, black, anterior and intermediate broadly red apically; the of flagellum is rufescent beneath, the face and clypeus almost entirely whitishyellow. (The of described by Thomson in the "Annales" had the flagellum croceous beneath; the abdomen broad, with the last three or four segments white-marked, and belonged to a different species, probabiy I. siluceus).

Bridgman took the male of this species in the neighbourhood of Norwich, and I have seen a female captured by Colonel Yerbury, at 
Cusop, Hereford, in August (cf. E.M.M. I903, p. I I3). It is widely distributed on the Continent, where the female hibernates among moss.

\section{6. formosus, Grav.}

Ichneumon formosus, Gr. I. İ. i. 613, ơ; Wesm. Mém. couron. Ac. Belg. 1859, p. 76. Var. I. salicatorizes, var. I, Gr. I. E. i. 246 ; Ste. Ill. M. vii. 155, ó. Var. I. Maiklini, Holmgr. Ichn. Suec. i. 127 ; Thoms. O. E. xviii. 1934; Berth. Ann. Soc. Fr. 1894, p. $590, \delta$.

․ Head entirely black, with brown pubescence. Antennae somewhat slender, setaceous, white-banded. Thorax entirely black, with brown pubescence; areola quadrate. Scutellum white. Abdomen dull black, more shining apically; segments two and three castaneous-red, marked with black; fourth sometimes with a dot, five to seven with large dorsal marks, white; post-petiole aciculate; gastrocaeli large, not transverse, about as broad as the strongly aciculate intervening space; incisures of segments three to seven normal. Legs slender, black; tibiae testaceous, hind ones apically black; front femora apically red; hind coxae not scopuliferous. Wings flavescent ; stigna fulvous, areolet narrowed above, sub-deltoid.

o. Head black; palpi pale ; labrum and facial orbits often broadly flavous ; clypeal fascia sometimes ferrugineous. Scape beneath, and joints ten to sixteen for the most part, white. Thorax entirely black; areola transverse. Scutellum black or whitish-flavous. Abdominal sculpture and colour as in + ; the three basal segments dull, the three apical with white or glaucous dorsal marks. Legs black ; tibiae, except apices of hind ones, clear testaceous-red; anterior femora apically pale fulvous ; tarsi basally testaceous. Wings with areolet narrowed above, sub-deltoid. Length, I 5-I $6 \mathrm{~mm}$.

It differs from $I$. obessor, Wesm., in the sub-deltoid areolet, and the whitish of antennal band; the of variety with a pale scutellum and antennal band is I. salicatorius, var. I, Grav. It may be known from I. silaceus, by its darker pilosity, larger size and broader gastrocaeli.

Gravenhorst bred the pale var. from Arctic fuliginosa, and Stephens took it at Coombe Wood, in June. I know of no other British records, though it occurs throughout northern Europe, where the female is said to hibernate in moss.

Wesmael, with the original types before him, says $I$. formosus has "identiquement la même sculpture" as obessor, Wesm., but Berthoumieu has considered obessor a good species, and formosus a variety of Mäklini, Holmgr., saying that the former has the areolet broad above, with the base of the second segment slightly aciculate, and the latter the areolet sub-deltoid, with the second segment basally very rugose. Gravenhorst describes the areolet of formosus as sub-triangular. Berthoumieu himself says the second segment of obessor is strongly aciculate, and Holmgren precisely the same of Mäklini. We may then, I think, take it that obessor is a good species with the areolet sub-pentagonal; formosus a good species with the areolet sub-deltoid and the antennal band white in both sexes; and Mäklini a variety of the latter, with the central abdominal segments and scutellum paler, and the incisures of the basal segments deeper, which, perhaps, is $I$. salicatorius, var. I, Grav. 


\section{7. quaesitorius, $\operatorname{Linn}$.}

Ichnerunon quaesitorius, Linn. F. S. 398 ; Gr. I. E. i. 253 ; Ste. III. M. vii. I57, : Wesm. Mém. couron. Ac. Belg. I859, p. I9; Holmgr. Ichn. Suec. i. I2I ; cf. Ent. Tidskr. I88o, p. 83; Thoms. O. E. xviii. 1934; Berth Ann. Soc. Fr. 1894, p. 589 , of of. I. multicolor, Gmel. S. N. i. 2678 ; Gr. I. E. i. I68; Ste. Ill. M. vii. I4I, excl paludator, Desv. Tr. Ent. Soc. I 854, p. 44 , 8 ? .

Head black, mandibles rufescent; of with internal orbits white and clypeus truncate, the latter being slightly emarginate in $q$. Antennae black, first flagellar joint more than twice longer than broad, cylindrical; o rather slender, setaceous, eighth joint quadrate, white-banded. Thorax stout, black; callosity beneath radix only, in both sexes, pale flavous; metathorax strongly sculptured; areola transverse or sub-quadrate, emarginate apically ; dentiparal areae emitting short teeth and sinuate apically. Scutellum shining, obsoletely punctate; apically, or in $q$ entirely, stramineous. Abdomen black, segment two of t rarely badious; segments five to seven, and sometimes fourth, with a stramineous dorsal mark; post-petiole finely aciculate, slightly convex between the spiracles ; gastrocaeli rather large and deep, obliquely sub-striate laterally, the intervening space aciculate; terebra slightly exserted. Legs somewhat slender, clear red; the coxae and hind tarsi black. Wings slightly clouded; stigma rufescent; tegulae white-marked in $\delta$; areolet receiving recurrent nervure distinctly before centre. Length, I4-16 mm.

The strongly sculptured metathorax and its apophyses will at once distinguish both sexes of this species from its allies. 'The colour of the legs, the decurved and apically nearly right-angled post-petiole with its elevated dorsal carinae, and the space between the deep thyridii being hardly broader than the latter, are very like $I$. cessator; but, in the of, the black flagellum with its six semi-annulated joints, three anal marks and the scutellum whitish, stouter posterior tarsi, whitish callosity beneath the radix, and, in the $\delta$, the white tegulae and radix, flagellum entirely black, scutellum abruptly declived at the apex which is sub-quadrately whitemarked, are distinctive points.

I find this species has been hitherto mixed in Britain with Chasmius paludicola, Wesm., from which, however, it may at once be known by its broader form, longer antennae, which are not tricoloured, by its less buccate head, the white-marked thorax having the costulae entire and the areola not longer than broad, \&c.

Stephens records the male rarely from about London, in July, and the female, from the north of England. Bignell bred it, in Devon, during the first half of September, from Nonagria cannae; and Marshall has taken it at Lastingham, in Yorks. It is recorded from Maldon, in Essex; and has been bred in Britain, from Nonagria typhae, and $N$. geminipuncta. Desvignes tells us it was bred not uncommonly from larvae or pupae of Nonagria paludicola (Hb. = geminipuncta, Htch.) found in the Hammersmith Marshes, by Mr. S. Stevens; one of Desvignes' specimens is in Marshall's collection. On the Continent it has a wide range, from Piedmont to Sweden, and from Hungary to France.

\section{Haglundi, Holngr.}

Ichneamon Hagrlunti, Holmgr. Ichn. Stec. i. 129; Berth. Ann. Soc. Fr. IS9ł, p. 595, ơ \&; Thoms. O. E. xviii. 1935, excl. ơ. 
A stout species. Head a little narrowed behind the eyes, cheeks and temples moderately broad; black, the of with part of the mandibles and of the frontal orbits red; the 0 with palpi, mandibles and labrum stramineous, face entirely or for the most part white. Antennae with first flagellar joint longer than broad ; o rather stout, attenuate towards apex, black and rather paler beneath, with white band on joints seven to fourteen; of black with the scape white, flagellum rufescent beneath, and joints eleven to nineteen forming a white band. Thorax black, callosities before and beneath the radix in both sexes white; metathorax rugosely punctate, with three upper areae, of which the areola is a little broader than long. Scutellum white, shining, and very obsoletely punctate. Abdomen black, segments five to seven, and in $q$ the fourth, white-marked; post-petiole aciculate, gastrocaeli somewhat deep, with the intervening space rugoseaciculate. Legs black, somewhat stout ; anterior tibiae laterally flavidous; of with the anterior coxae white-marked; of with hind coxae closely punctate, without scopulae. Wings a little clouded, stigma fulvous, tegulae of toften flavous-marked; areolet receiving recurrent nervure slightly beyond centre, sub-triangular, with the lateral nervures almost coalescing above. Length, 1 3-16 $\mathrm{mm}$.

I have followed Berthoumieu in restoring Holmgren's original of to the present species; that described by Thomson is a very different insect :Antennae without pale band; all tibiae with a complete white band before the base; hind metatarsi with the basal half white; sometimes the apical margin of third abdominal segment, or also the sides of the fourth, stramineous ; anus immaculate.

The $q$ is very like I. Mäklini, Holm., but the joints of the pale antennal band are transverse and shorter below, the femora and tarsi are shorter, there are pale callosities before and below the radix, and the abdomen is a pically strongly obtuse.

Mr. T. R. Billups bred the male of this species, in 1886, from Arctia fuliginosa; it is now in the Bridgman collection in the Norwich Museum. It has also been bred in Britain by MM. Adkin and Barker from the same host ( $c$. Meeting Ent. Soc. 2nd April, I 89o); an example in Beaumont's collection was taken at Lewisham, in April. Holmgren says it is very rare, in woods, in Sweden; and it is also found in Holstein.

\section{9. piceatorius, Wesm.}

Ichnenmon piceatorius, Gr. Nem. Ac. Sc. Torin, 1820, p. 335 ; I. E. i. 473 (?); Wesm. Bul. Ac. Brux. 1855, p. 386 ; Berth. Ann. Soc. Fr. I894, p. 592, ó.

f. Head black; mouth, face and frontal orbits flavous-white. Antennae black, scape beneath white, third and following joints beneath ferrugineous. Thorax black, callosities before and beneath radix white; metathorax coarsely rugose; areola sub-quadrate. Scutellum flavouswhite. Abdomen, including anus, black, very finely punctate, shining; second segment apically ferrugineous, the third with two large red marks; post-petiole very broad, aciculate; gastrocaeli normal, intervening space aciculate. Legs black; front femora pale beneath; all the tibiae pale flavous, the hind ones apically black or piceous; tarsi flavous, hind ones piceous; front coxae flavous-marked. Areolet sub-deltoid; stigma ye.lowish-brown, tegulae and radix white-marked. Length, $16 \mathrm{~mm}$. 
It is difficult to correctly place a $\sigma^{t}$ whose $q$ is unknown, and this would appear as natural a situation as can at present be found for it. From 1. extensorius, it appears to differ primarily in the entirely fuscous hind tarsi, as well as in its rather more shining and coarsely rugose metathorax, distinctly broader post-petiole, the coloration of the abdomen and head, that of the latter being paler, and of the former darker.

It appears related to $I$. Haglundi in the coloration, the coarsely sculptured thorax and sub-deltoid areolet; the immaculate anus and antennal band will, however, instantly distinguish it therefrom.

Marshall introduced this species as British, in his I 870 Catalogus, under the genus Amblyteles, but, in 1872 , he restored it to Ichneumon. It appears to be little known on the Continent, occurring only in Germany and Piedmont; I know of no indigenous examples.

\section{0. rufidens, Wesm.}

Ichneumon mufulens, Wesm. Nouv. Mém. Ac. Brux. I844, p. 49 ; Berth. Ann. Soc. Fr. 1894, p. 607,, .

ๆ. Head black, facial orbits generally pale; mandibles narrow, red, edentate; clypeus large, flat, smooth and usually laterally rufescent. Antennae somewhat slender, setaceous, white-banded; second joint much longer than broad. Thorax black; areola transverse, irregularly hexagonal. Scutellum flavous-white; post-scutellum sometimes castaneous. Abdomen black; post-petiole, segments two and three entirely, and fourth laterally, red; six and seven with large, and fifth sometimes with small; dorsal flavous marks; post-petiole bicarinate, more or less distinctly aciculate; gastrocaeli small and superficial, as broad as the intervening space. Legs black; femora more or less apically, tibiae and tarsi, red; hind legs with apices of tibiae black, tarsi entirely fuscous; coxae not scopuliferous. Stigma flavous; tegulae piceous; radix rufescent. Length, $10 \mathrm{~mm}$. of unknown.

The peculiar structure of the mandibles and clypeus is very distinctive.

This species was introduced as British, by Marshall, in I 870 , but I know of no indigenous records; it would appear to be rare on the Continent, being only found in Belgium and Holstein.

\section{I. caloscelis, Wesm.}

I. ammonius, Gr. Mem. Ac. Sc. Torin, I 820 , p. 30 I ; I. E. i. 279 , excl. false \& ; Ste. III. M. vii. I60; $c$. Wesm. Mém. couron Ac. Ielg. I 859 , p. 33. I. caloscelis, Wesm. Nouv. Mém. Ac. Brux. IS44, p. 59, o; Bul. Ac. Brux. IS49, p 37, ó; Holmgr. Ichn. Suec. i. 102 ; Thoms. O. E. xviii. 1937; Berth. Ann. Soc. Fr. I894, p. 608, o o. Var. I. zonalis, Kriech. Ent. Nachr. o.

Head a very little narrowed behind the eyes; cheeks only slightly buccate; clypeus obsoletely punctate, almost glabrous, rounded and a little produced apically in the centre; $q$ generally with the mouth parts, frontal and vertical orbits rufescent; of with palpi, mandibles, clypeus, face, frontal orbits, and sometimes a genal mark, flavous. Antennae of $q$ slightly attenuate apically, fifth joint quadrate, black with a white band or tricoloured; of black, with the first five joints cylindrical, the scape flavous and flagellum rufescent beneath. Whorax black; of with pronotum and callosities before and bencath the radix flavous; metathorax distinctly 
less elevated than mesonotum, with three upper areae, of which the areola is a little broader than long and only slightly sinuate apically; of with spiracles elongate-oval. Scutellum stramineous; flavous in of. Abdomen black with segments two and three, often apex of first and base of fourth, red or flavidous; that of $q$ with five to seven white-marked, the fifth minutely; of of lanceolate, apically immaculate; post-petiole strongly aciculate, carinae distinct; gastrocaeli normal, the intervening space obliquely aciculate ; incisures somewhat deep. Legs black ; $q$ with tibiae and tarsi red or flavous, hind tibiae tricoloured, puncturation of hind femora coarse; hind coxae closely punctate, without scopulae; of front femora apically, tarsi and tibiae except apex of hind ones, flavous. Wings flavescent; stigma fulvous; tegulae rufescent, flavous in $\delta$. Length, IO-I $4 \mathrm{~mm}$.

The var. zonalis has the third abdominal segment black with the anterior angles only red.

This species is at once distinguished by both sexes having all the tarsi pale, the mesonotum more strongly punctate and the head a little narrowed behind the eyes; by the $q$ having the clypeus shining, sparsely punctate and its apical margin sub-rotund and centrally produced; and by the 0 having the face and clypeus flavous, the former sometimes with the apical margin nigrescent in the centre.

Taken occasionally in the vicinity of London, in June (Stephens); Essex (Harwood) ; captured at Bickleigh, in Devon, at the end of August (Bignell); I have taken the female, which hibernates among moss, in the middle of August, at Matley Bog, in the New. Forest, on flowers of Angelica Sylvestris, in the morning; and there are examples in Marshall's collection, from Bishop Teignton, Cornworthy and Lustleigh Cleave ; it is distributed throughout Europe.

\section{2. insidiosus, Wesm.}

Ichneumon extensorius, varr. 2 et 3, Gr. I. E. i. 269 (?). I. insidiosus, Wesm. Nouv. Mém. Ac. Brux. 1844, p. 46 ; S. v. Voll. Pinac. pl. xx. f. 8 , $\$$; Holmgr. Ichn. Suec. i. IOS ; Berth. Ann. Soc. Fr. I894, p. 6I I, excl. of Thoms. O. E. xviii. 1937 et xxi. 2398, of q. Var. I. affectator, Tisch. Stett. Zeit. I879; of. Kriech. Ent. Nachr. I 894, .

q. Head with temples a little narrowed; cheeks apically smooth and glabrous; black, frontal and facial orbits usually rufescent. Antennae somewhat thickened centrally, very little attenuate towards apex; white centrally above only, with joints three and eight occasionally reddish, seven and eight quadrate. Thorax stout, immaculate; areola sub-quadrate, sometimes rather broader than long, apically emarginate. Scutellum flat, white. Abdomen broad, black, with segments two, three, and often the sides of the fourth, red, six, seven, and sometimes five obsoletely, white-marked; post-petiole aciculate, gastrocaeli rather small, the intervening space subrugosely punctate, never striate. Legs black; anterior femora except at base, tibiae and tarsi, red; hind tibiae and tarsi basally red. IVings a little clouded, stigma fulvous.

of. Head broad, slightly narrowed behind the eyes; mouth, clypeus and face entirely or in part flavous. Antennae black, scape flavous beneath. Thorax with pronotum and callosity at radix always flavous. Scutellum flavous. Abdomen black; apex of first, whole of second and third, 
and margin of fourth, segments lighter or darker yellow, the following with the apical margin rufescent. Legs black; anterior femora apically and tibiae flavidous; hind tibiae apically black; anterior tarsi almost entirely, hind pair at the base only, fulvo-stramineous. Wings slightly clouded; stigma fulvous, tegulae black. Length, 10-I $4 \mathrm{~mm}$.

The of may be known from that of I. emancipatus, with which Holmgren (followed by Berthoumieu) confused it, because the latter has segments two and three only, red; no flavous callosities near the radix, and the legs are of a different colour.

This species much resembles $I$. captorius, Thoms., but it is rendered distinct by the larger size of the $q$, which has thicker antennae, black post-petiole, and less closely punctured hind coxae; the $c^{t}$ by the broader head, which is slightly narrowed behind the eyes, and the pubescence of the meso- and meta-sterna is longer. It differs from $I$. raptorins, to which it also is closely allied, in the paler villosity and coarser puncturation of the body, which is especially apparent beneath the posterior coxae, these in I. mplorius are finely and very closely punctured, in I. insidiosus strongly and less closely; the size is always larger, the antennae are less attenuate apically; the scutellum is a little less elevated and flatter vertically. 'The $q$ also closely resembles $I$. extensorizus in its coloration and flat scutellum, but the antennae are stouter and less filiform, while in the latter the areola is always longer than broad.

The variety affectator has the antennae somewhat shorter, the gastrocaeli broader, and the post-petiole apically red.

Bridgman took a female of this species at Brundall, in Norfolk, in August, 1878 . It has probably been overlooked, since it appears to be common on the Continent, where the female hibernates among moss.

\section{3. subcylindricus, Grav.}

Ichneumon subylindricus, Gr. I. L.. i. 32 I et Ste. Ill. M. vii. I69, excl. ठ ; Wesm. Mém. couron. Ac. Belg. 1859, p. 37 ; Berth. Ann. Soc. Fr. I894, p. 614, ․

q. Head broader than thorax, not narrowed behind eyes, black ; clypeus with a small median fossa; centre and sides of face protuberant, glabrous, very shining. Antennae somewhat slender, strongly attenuate, setaceous, white-banded; second joint distinctly longer than broad. Thorax sub-cylindrical, black, callosity beneath radix white; areola very slightly longer than broad, sub-rectangular. Scutellum white. Abdomen elongate, parallel-sided, sub-linear; segments two to five somewhat longer than broad, sub-equal; seventh laterally compressed; segments two and three entirely red, six and seven with large, slightly longer than broad, white dorsal marks; post-petiole aciculate; gastrocaeli as broad as the intervening space ; terebra somewhat exserted. Legs stout, black ; femora, tibiae and tarsi red; hind tibiae and tarsi apically nigrescent ; hind coxae not scopuliferous. Wings a little clouded; stigma red, tegulae rufescent. Length, I4 mm. of unknown.

The facies of this species are similar to those of Spilichneumon occisorius, but the head is posteriorly broader and thicker, the median facial protuberance larger and shorter, and the petiole is broader.

In its facial prominences and incrassate legs it somewhat approaches Alomyia debellator. 
As far as I am aware, its inclusion in our list rests solely upon Stephens' record (including Gravenhorst's of, which is Sfilichneumon limnophilus, 'Thoms, and has nothing in common with the present species), from near London, taken very rarely. On the Continent, it would appear to be of extreme rarity ; (Gravenhorst's original specimen was from 'Turin, in Piedmont; Berthoumieu omits this, but says "Russie méridionale"; Grav. calls Turin, "Tauria," and possibly Berth. mistook this to refer to 'Taurida, in southern Russia. I know of no other localities.

\section{4. raptorius, Grav.}

Ichneumon raplorius, Gr. I. E. i. 286 , excl. o (nec Linn.) ; Ste. Ill. M. vii. 162 (part); Wesm. Nouv. Mém. Ac. Brux. I844, p. 43, of + , excl. varr. 4, 5, 6; Ratz. Ichn. d. Forst. i. 138; Wesm. Mém. couron. Ac. Belg. 1859, p. 35 ; Holmgr. Ichn. Suec. i. 104; Berth. Ann. Soc. Fr. I894, p. 615. of \&. 1. culpatorizes, varr. 3, 4, 5. Gr. I. E. i. 516, o. I. Nereni, Thoms. Ann. Soc. Fr. I887, p. 8 ; O. E. xviii. I939. Var. 1. rufolineatus, Holmgr. Ichn. Suec. i. 112, o.

Head distinctly narrowed behind eyes, black; $q$ with internal orbits and often centre of face rufescent ; f face and clypeus entirely or laterally white. Antennae of $q$ slender, setaceous, not thickened centrally, somewhat attenuate at apex, the eighth joint quadrate, white-banded or tricoloured; of with scape flavous, and flagellum piceous, beneath. Thorax black, that of of with white lines beneath the radix; areola sub-quadrate, somewhat transverse in $\delta$, apically emarginate. Scutellum white, somewhat strongly convex. Abdomen of $t$ sub-cylindrical, of $q$ elliptic-oval ; black, segments two and three, often apex of first and base of fourth, red, fourth and sometimes part of third in of black; sixth, seventh, and often fifth minutely, white-marked, these anal marks often wanting in $\delta$; postpetiole aciculate; gastrocaeli small, thyridii elongate and very distinct, the intervening space sub-striate in $\delta$, coarsely punctate in $q$; terebra slightly exserted. Legs black; $q$ with anterior femora, tibiae and tarsi, and hind ones basally, red; of with anterior tibiae and tarsi fulvous, hind ones black towards the apex; hind coxae with fine puncturation. Wings a little clouded; stigma fulvous, tegulae dark. Length, 7-10 mm.

The $q$ has the flagellum slender, setaceous, basally entirely or beneath red; anterior femora entirely red; the of is very like that of $I$. gracilicomis, but the thorax is shorter and more strongly convex, the second flagellar joint longer than broad, the thyridii are a little smaller than the intervening space, and the apex of the anterior metatarsi has an acute tubercle on its inner side.

The $q$ is also very like that of $I$. gracilicornis, which, however, has the femora more slender and much attenuate apically; the gastrocaeli large and the mark on fifth segment is larger than the following, but always smaller in $I$. raptorius.

From I. extensorius, and other allied species with red tibiae, it may be told by its sub-quadrate areola, more convex scutellum and apically attenuate antennae. It is like $I$. insidiosus, but always smaller, with the scutellum in both sexes more elevated and convex, the petiole bicarinate, the areola of $\delta$ shorter, the posterior coxae of $q$ much more finely punctured beneath, apex of antennae more tapering.

From I. captorius, Thom., which it most resembles, it differs in the rather more slender legs and antennae, the anterior femora are entirely 
flavous or with only a basal black mark, the intermediate broadly red apically; the $q$ has the vertex of the head narrower; scutellum white, somewhat strongly elevated; abdomen broader, the gastrocaeli and thyridii rather larger, the latter hardly narrower than the rugosely punctate intervening space, fifth segment with a small transverse and the sixth and seventh with larger white marks; of flagellum is piceous beneath the scape, clypeus and sides of the face broadly pale yellow, segments two and three red, sometimes seven or also six, white-marked.

It should be remembered that Ichneumon raptorius, of Linnaeus, is said to be Spilichnemmon Gravenhorsti, of IVesmael, and quite distinct from the present insect, which was renamed $I$. Nereni by Thomson, because Gravenhorst had mistaken Linnaeus' species. Berthoumieu believes the Linnean species to be neither of these; undoubtedly the present is that described by Gravenhorst, as proved by Wesmael, and if the Linnean $I$. raptorius prove to be an Amblyteles, I see no reason why it also, being included under a different genus, should not stand.

Stephens, who certainly does not refer to the species as we now understand it, says it is abundant about London, at the end of summer, and common at the roots of trees in the winter, but neither Bridgman nor Bignell seem to have taken it. On the Continent, where it appears to be very common, it has been bred from Satyrus Janira and Liparis monacha.

\section{5. submarginatus, Grav.}

Ichneumon submarginatus, Gr. I. E. i. 244; Ste. Ill. M. vii. 155, \&; Wesm. Mém. couron. Ac. Belg. I859, p. 28 ; Thoms. O. E. xviii. I937; Berth. Ann. Soc. Fr. I894, p. 596, s ㅇ. I. subreptorius, Wesm. Bul. Ac. Brux. I855, p. 374, + ; Holmgr. Ichn. suec. i. 125, of क.

Head a little narrowed behind the eyes; $q$ apex of palpi, mandibles centrally and the frontal orbits, sometimes red; of palpi piceous and facial orbits narrowly flavous. Antennae stout, setaceous, dilated towards apex, basal joint of flagellum twice longer than broad, black; of $q$ white-banded, of $\delta$ with flagellum ferrugineous beneath. Thorax of of with white lines beneath the radix; metanotum with complete upper areae, of which the areola is sub-quadrate, apically scalloped. Scutellum convex, sparsely punctate; entirely, or in of apically, white. Abdomen lanceolate-oval in of, sub-ovate in $q$; black, second segment badious, with its base centrally and the lateral margins sometimes rufescent, two to four with apical margin red, paler in $q$, which sex alone has the fifth with a minute and six and seven with larger stramineous marks; post-petiole aciculate, gastrocaeli normal, sub-circular, the intervening space rugosely punctate in $q$, coarsely aciculate in of; terebra very slightly exserted. Legs black; front femora apically, tibiae except generally apices of the intermediate and always apical half of hind ones, and tarsi except apex of hind ones, red. IVings slightly clouded; stigma reddish, tegulae darker. Length, Io-I4 mm.

Wesmael thought the coloration of the $q$ nearly identical with that of $I$. computatorius, from which, he says, it may be known by its more slender antennae, more convex scutellum, its shorter and quite quadrate areola, and by the shorter, more ovate abdomen.

Holmgren points out that the $\sigma$ is also very like that of $I$. computaforius, but the thorax is obviously higher in front, and adds the of may be 
known by its stout and apically attenuate antemnae and by the abdominal markings.

'Thomson is doubtful of the identity of Holmgren's of with Gravenhorst's O ; he observes that it is much like that of I. caloscelis, Wesm., that it has the arvical joints of the posterior tarsi ryfo-fuscous, the flagellum ferrugineous beneath, the mesonotum very finely and densely punctate; but, from the mesonotal sculpture, he concluded it must be correctly here placed.

Stephens, who follows Gravenhorst in describing incorrectly the sixth and serenth seuments of the of as dorsally white, records it as uncommon, taken at Hertford, in July; Bignell took it, at Bickleigh, in Devon, at the end of June. It extends throughout northern and central Europe, and has been recorded from Algeria, by M. Pic.

\section{6. quadrialbatus, Grav.}

Ichneumon quadriallatus, Gr. Mem. Ac. Sc. Torin, 1820 , p. 298 ; I. E. i. 252 , excl. 8̈; Ste. III. MI. vii. I56 (part.) ; IVesm. Nouv. Mém. Ac. Brux. I 844 , p. 42 ; Bul. Ac. Brux. I848, p. I51, o ; Mém. couron. Ac. Belg. 1859, p. 30 ; Berth. Ann. Soc. Fr. I894, p. 589 , o \&; $c f$. Thoms. O. E. xviii. 1940. (?) I. fossorius, var. 2, Gr. I. E. i. 165, excl. of Fennico. (?) Var. Amblyteles camelinus, Wesm. Bul. Ac. Brux. I848, p. 299, ó.

FIead of $q$ entirely black; of of with facial orbits rarely white. Antennae slender; of $q$ setaceous, white-banded with the flagellum generally basally red; of contirely, or beneath, ferrugineous, with scape usually immaculate. Thorax black, of of sometimes with an obscure red dot before the radix; areola sub-quadrate, apically hardly emarginate. Scutellum distinctly convex; usually entirely, of to sometimes only apically, white. Abdomen black, segments two and three sometimes laterally castaneous or more or less badious, and $q$ with six and seven whitemarked; post-petiole aciculate; gastrocaeli rather large and deeply impressed, not transverse, and hardly broader than the intervening space. Legs slender, red; all the coxae as well as apices of hind tibiae and their tarsi black; femora clear red; hind coxae not scopuliferous. Wings a little clouded; stigma red, tegulae and radix piceous. Length, $12 \mathrm{~mm}$.

This species is very like $I$. cessator, from which, however, its pale scutellum will at once distinguish it. It is also extremely like Holmgren's I. inops, in which the antennae and hind tarsi are stouter, the size larger and the scutellum and anal spots less distinctly white; the antennal band, moreover, is wanting.

Stephens, who incorrectly includes Gravenhorst's ơ, says it is not common, but found in June, near London and at Darenth. Neither Bridgman nor Bignell met with it, and I know of but few recent records; Col. Partridge has bred both sexes from Geometra smaragdaria, in October, and there is an old male in Marshall's collection. It has been bred by Mocsary, from Leucania evidens, and has a wide distribution throughout central Europe, where the female is known to hibernate, extending to Italy and France.

\section{7. cessator, Müll.}

Ichnemmon cessator, Muill. Prodr. I58; Gr. I. E. i. I55; Ste. Ill. M. vii. I38, \&; Wesm. Nouv. Mém. Ac. Brux. I\$44, p. 40; Holmgr. Ichn. Suec. i. I23; ff. Ent. 


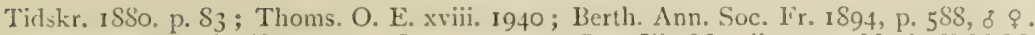
I. custodialor, Fab. E. S.. I. compunctor, Ste. Ill. M. vii. I3I ; Morl. E.M.M. 1902, p. I19, ठ.

Head, thorax and abdomen nearly entirely black. Head with mouth partly piceo-rufescent; clypeus of $q$ somewhat closely punctate ; t with facial orbits more often flavidous. Antennae of o slender, setaceous, ninth joint quadrate, usually entirely black, though sometimes broadly red-banded; of to black, more or less rufescent, the scape never flavous beneath. Thorax entirely black in both sexes; metanotum with complete areae, of which the areola is sub-quadrate, broader in of, apically scalloped; dentiparal areae with a short apical tooth. Scutellum strongly punctate, convex, entirely black. Abdomen of to entirely black, of $q$ black, with segments six and seven, or one of them, with a linear glaucouswhite mark; post-petiole aciculate; gastrocaeli rugose, somewhat large and deep, with the intervening space rugosely aciculate in $\delta$; apical segments nitidulous; terebra somerwhat exserted. Legs rather slender, clear red, with all the coxae, hind tarsi and (?) apices of hind tibiae, black. Wings a little clouded, stigma rufescent. Length, I 4-I $7 \mathrm{~mm}$.

This species may be known by the fulvous femora and tibiae, the posterior pair of tibiae and their tarsi black, scutellum convex and entirely black ; the $q$ anus is rather acute, with two yellowish-white vittae, sometimes with one or the other wanting; the cheeks and the apically truncate clypeus rather closely punctate, antennae slender, setaceous, with no distinct band: the of has the flagellum obscurely ferrugineous beneath, the face sometimes with the orbits shortly pale.

Compared with $I$. guacsitorius, which it most resembles, this species has the thorax robust, rather elevated anteriorly; scutellum punctate, entirely black ; metathorax rugulose, its areola transverse, or in the of occasionally sub-quadrate with two distinct upper areae on either side, of which the dentiparal are apically straight, not sinuate, somewhat produced into a very short tooth at their apices. The abdomen is very like that of $I$. quaesitorius, but in $q$ the anus is more strongly acuminate, and the terebra is shortly produced beyond the apex.

The of at first sight is very similar to Ctenichneumon castigator, but may be told therefrom by the head being obliquely narrowed behind the eyes, the face and clypeus longer, the scutellum more elevated, the metathoracic spiracles a little longer, the post-petiole less dilated and convex, the second segment distinctly narrowed towards its base, while in castigator it is parallel-sided; and the gastrocaeli are less deep.

The ${ }^{+}$is also not unlikely to be confounded with that of $C$. camelinus, IV esm., from which it may be known by the hypopygium being more acute and the hind tibiae not internally flavous. Thomson, nevertheless, says (O. E. xi.. 2082) that they are hardly distinguishable. Berthoumieu mentions a variety, presumably of the $q$, which he calls imfollutus, having the anal markings entirely wanting.

Stephens says the $q$ is very rare, but had occurred near London, in June, as well as in Norfolk; Bridgman, however, did not there meet with it ; Bignell took it, at Bickleigh, in Devon, early in June, and there are males in Marshall's collection, from Lydford and Cornworthy. On the Continent, where it is widely distributed, it has been bred from linnessir polychloros and Acronycta psi. 


\section{8. stigmatorius, Zett.}

Ichneumon deceptor, var. 4 , Gr. I. E. i. 336, ९. I. eremitalorius, Zett. I. L. 364 , 8. I. stigmalorius, Zett. I. L. 364 , \&; Holmgr. Ichn. Suec. i. 116 ; Berth. Ann. Soc. Fr. I 894, p. 58I, o o ; of. Thoms. O. E. xviii. 1942. (?) I. perhiematus, Tisch. Stett. Zeit. I879, \&. Var. I. ignolizlis, IVesm. Bul. Ac. Brux, 1855, p. 375, ‥ Var. I. dolosuls, Wesm. lib. cit. p. 404, $\$$.

Head a little narrowed behind the eyes, coarsely punctate; clypeus somewhat depressed centrally and slightly emarginate apically; entirely black, with cribrary organs only in part pale. Antennae normally attenuate, rather stout ; first flagellar joint twice longer than broad, eighth subquadrate; rufescent basally, white-banded; of of entirely black. Thorax coarsely punctate, immaculate; areola a little broader than long. Scutellum convex, black or more often apically or even entirely rosy. Abdomen only partly black, with apex of segment one, whole of two and three, and in $\delta$ rarely of four, red; $q$ with six and seven white-marked and somewhat retracted; post-petiole aciculately scabriculous, laterally sub-rugose with the angles obtuse; gastrocaeli transverse, somewhat deep, sub-linear, intervening space slightly narrower than centre of post-petiole. Legs somewhat slender, black; with tibiae, tarsi and apices of femora red, hind ones usually apically black. Wings very slightly clouded; tegulae rufescent or piceous, stigma fuscous in $\delta$, fulvous in $q$; areolet wide above. Length, 7-I $2 \mathrm{~mm}$.

Thomson gives the following observations, which may or may not apply to the present species:- $q$ vertex of head narrow; the apically truncate clypeus and cheeks very closely punctate; antennae thin; sides of pronotum not striolate; meso-pleurae very densely punctate; metathoracic spiracles not small; post-petiole closely striolate centrally; thyridii rather deep and nearly transverse: $f(=$ varr. 3 et 4 , Holmgr.) with joints six to fourteen of flagellum with elevated carinae; face and clypeus rarely cntirely, generally partly, flavous; segments two and three flavidous-red; front femora sometimes entirely, intermediate broadly at apex, red; hind tarsi pale red, apically fuscous. Berthoumieu's var. pallidus is an extreme form of the of with palpi, mandibles, clypeus, face and scape beneath, flavous.

The variety of this species with the scutellum wholly, and third segment apically, black is TVesmael's $I$. ignobilis; and that with scutellum and tibiae wholly red is his $I$. dolosus. Bridgman records it from Britain, taken at Kingussie, in coll. Cameron ( $c f$. Trans. Ent. Soc. I88 I, p. I 44). In Sweden it is not rare, in August and September, in grassy places and among undergrowth in woods, where the female hibernates in moss. Undoubtedly a northern species, extending from Lapland to Hungary and Germany.

\section{9. vulneratorius, Zett.}

Ichnenmon vulneratorius, Zett. I. L. 364 ; Thoms. O. E. xviii. I943, \&; Holmgr. Ichn. Suec. i. II9; Berth. Ann. Soc. Fr. I894, p. 581 , o 9 . I. rubedinis, Desv. Cat. 29, \&; cf. Morl. E. M. M. 1902, p. 123. I. Dahlbomi, Wesm. Bul. Ac. Brux. 1857, p. 3 So, ?.

Head narrowed posteriorly, impressed behind the ocelli, cheeks apically smooth, clypeus distinctly discreted by a transverse fossa; black, with the cribrary organs partly, and in $q$ very often the frontal orbits and a badious facial mark beneath the antennae, red. Antennae black; in $q$ sub-filiform, white-banded, only slightly attenuate apically and centrally thickened, 
first flagellar joint twice longer than broad, the sixth quadrate; in of rather slender and strongly attenuate 'Thorax black, mesonotum of $q$ entirely, or with two longitudinal vittae, red; metathorax not bidentate, somewhat scabrous, with three upper areae, of which the areola is quadratc or slightly longer than broad in $q$, transverse in $\sigma^{\star}$. Scutellum and post-scutellum usually dull red; the former convex. Abdomen black, segments two and three red; apex of one also red, and six and seven white-marked in $q$; post-petiole funely and distinctly aciculate ; gastrocaeli transverse, intervening space slightly narrower than centre of post-petiole. Legs red; femora often in part, hind ones except extreme base, as well as hind tibiae and tarsi apically and all the coxae, black. Wings sub-hyaline, darker in 9 ; stigma flavo-stramineous, of of black; areolet broad above. Length, $7-8 \mathrm{~mm}$.

Differs from $I$. stigmatorius in the stouter and sub-filiform antennae of the $q$; the head more distinctly impressed behind the ocelli; the $q$ areola quadrate, or sometimes slightly longer than broad and the post-petiole much more finely and distinctly sculptured. The colour of the $q$ abdomen is similar to that of I stigmatorius, but the head narrowed behind the eyes, less narrowed towards the mouth, the more sparsely punctate cheeks, larger scutellum and much smaller spiracles render it distinct. The colour of the legs varies considerably.

I. rubedinis, Desv., which Berthoumieu incorrectly refers to $I$. ochropis, is nothing but a rather profusely red-marked form of this species, having the face and frontal orbits rufescent; the first seven flagellar joints, two longitudinal mesonotal vittae, and a callosity before the radix, always red. The fourth abdominal segment is clear red, and the two following somewhat infuscate. The are five $q$ o in the British Museum from Desvignes' collection, three of which are labelled "September, Ireland."

Hardy first recorded this species from Britain on the strength of several specimens found by Bold, one of which is in Marshall's collection, in the Cheviot Hills, \&c., in May and June (cf. Proc. Berwick. Nat. Club, vii. p. I 54 et Ent. Ann. I 874, p. I42). It has also been taken by Cameron, in Scotland, and by Champion, in Ireland, which is probably the southern limit of its range (Trans. Ent. Soc. 1889, p. 410). Mr. Malloch has given me this species, which he found at Bonhill ; and Mr. Evans has taken it, in March, beneath a stone, probably hibernating, on the summit of Carnethy, in the Yentlands, at an altitude of I880 feet. It is evidently quite a northern species, since Holmgren says it occurs in grassy places and forest undergrowth in northern Sweden, and it is only elsewhere found in Lapland and Russia.

[I. haematonotus, Wesm., which Marshall, in Ent. Ann. 1874, gives as a doubtful synonym, is a distinct species ( $f$. Holmgr. Ent. 'Tidsk. ISSo, p. 78), differing in its stouter structure and antennae, which are also obviously filiform, thicker legs and different coloration.]

\section{0. haesitator, Wesm.}

Ichneumon latralor, Gr. I. E. i. 572, excl. o. I. haesitator, Wesm. Nouv. MIém.

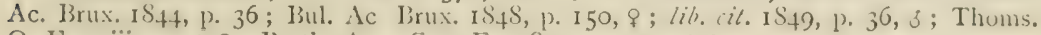
O. E. xviii. 1945, \&; Berth. Ann. Soc. Fr. I894, p. 573, of \&.

Head of $q$ triangular, obliquely narrowed behind eyes, clypeus closely punctate, with its foveace small, mandibles not stout; black, or with frontal 
orbits narrowly white; of of with palpi, frontal orbits, mark on temples, clypeus and face stramineous, the last centrally black-marked. Antennae sub-filiform, moderately attenuate, white-banded in $q$, scape flavous beneath in o. Thorax of o black, with pronotum rarely obscurely pale; of $\delta^{*}$ with pronotum and lines before and beneath the radix white; areola rectangular, oblong-(puadrate, broader in tै, apically angulated. Scutellum convex, black; apically glabrous, nitidulous and sometimes, in of, white. Abdomen black; $q$ with segment one at apex and two to four red; 0 two and three only margined with red; anus immaculate; post-petiole strongly dilated, finely aciculate; gastrocaeli transverse, of of sulciform. Legs red; posterior coxae and apex of hind tibiae black; hind tarsi slender, infuscate. IVings a little clouded; stigma and tegulae piceous; o with radius not apically inflexed. Length, ro $\mathrm{mm}$.

It is a rare species, apparently confined to France, Belgium and Holstein. I know of no indigenous records, though it was introduced as British, by Marshall, in I 870.

\section{EXEPHANES, Wesmael.}

\section{Wesm. Nouv. Mém. Ac. Brux. I844, p. I3.}

Head sub-triangular, not buccate, narrowed behind eyes; clypeus depressed, apically truncate and immarginate; labrum exserted. Antennae setaceous, apically attenuate. Thorax stout, punctate; metanotal areae often incomplete, spiracles linear. Scutellum not elevated. Abdomen of st sub-linear, of $q$ elongate-fusiform; petiole not twice longer than apically broad; post-petiole bicarinate, its central area aciculate and twice broader than the lateral ones; gastrocaeli and thyridii small or subobsolete; $q$ with eighth segment and the terebra shortly exserted, the valvulae of the latter broad; apical ventral segment twice longer than the penultimate, which is longer than the fifth. Legs normal and somewhat slender. Wings with areolet pentagonal.

The of of of this genus are very distinct and allied to those of Chasmias, but the $q$ o so closely resemble those of the genus Ichneumon as to often defy discrimination by any but the practised eye; the eighth segment is often exserted in the latter genus, and the most trustworthy points appear to be the incrassated valvulae and broader central post-petiolar area ; the inconspicuous gastrocaeli have also been indicated as a reliable distinctive feature.

Only the two species originally ascribed by Wesmael to this genus have hitherto been recorded from Britain, although nine others ( $f$. Kriech. Ent. Nachr. I903, p. 325) are known on the Continent.

\section{Table of Species.}

(2). I. Hind femora entirely black; $q$ anus laterally compressed; of face white ..................

(1). 2. Hind femora apically black; $q$ anus not compressed; of face centrally black ..............

I. HILARIS, Grav.

2. OCCUPATOR, Grav.

\section{I. hilaris, Grav.}

Ichneumon hilaris, Gr. I. E. i. 329; Ste. Iil. M. I70, ․ Exephanes hiluris, Wesm. Nouv. Mém. Ac. Brux. I844, p. I7; Thoms. O. L. xviii. I\$97; Berth. Ann. Soc. Fr. 
I\$95, p. 573, o क. Ichncumon cxulans, Gr. I. E. i. 522, o . I. ischioxrnthus, Gr. lib. cit. 330 ; Wesm. Mém. couron. Ac. Belg. 1859, p. 39, ठ. Exephanes subnudus, Tisch. Stett. Zeit, I88I, ㅇ. .

Contour slender in both sexes. Head narrowed behind eyes, black; face slightly prominent longitudinally in the centre, terminating in an obtuse tooth between the scapes; clypeus hardly discreted, truncate, of o glabrous with deep isolated punctures and a small apical fovea in the centre, of of closely sculptured; + with frontal orbits red, of with mandibles except their apices, palpi, clypeus and face, white. Antennae slender, setaceous, of $q$ white-banded, of $\delta$ with scape white, and flagellum more or less rufescent, beneath. Thorax finely punctate, somewhat shining, black; of with tegulae, adjacent linear callosities, and pronotum, white; metanotum with but three areae of which the areola is longer than broad in $q$, or sub-quadrate in $\delta$, finely scabrous with the costae fine. Scutellum flat in $q$, sub-convex in of; punctate, white. Abdomen closely punctate, black; of $q$ apically compressed laterally, of $\delta$ linear, equilateral ; segments two, three and often base of fourth, red, in of rarely dorsally black-marked and always quadrate; sixth, seventh, and rarely also fifth, apically white in $q$ only; post-petiole finely and densely aciculate, of ơ narrow ; gastrocaeli very small, hardly discernible; f with two to four ventral segments plicate; of valvulae laterally sinuate. Legs slender pale red ; coxae, trochanters, hind femora, tarsi and apices of their tibiae, black; coxae closely punctate, simple. IVings hyaline, stigma flavous. Length, IO-I $2 \mathrm{~mm}$.

The female is probably not uncommon in tufts of grass, in the winter, though I have seen but one English male ; Luff has, however, sent them to me from Guernsey and Alderney. Stephens tells us it is not uncommon near London, in June; Bignell took it at IVhitsand Bay and Egloskerry, in Cornwall, in July, at Bickleigh, on 6th May, and Hope found it at Netley; Beaumont has taken it at Boxhill, in the middle of March, as well as at Plymouth and Headley Lane; Rev. F. D. Morice, at Effingham, in Surrey, early in June, and in Kent ; Davies, in Cornwall; Richardson, at Bloxworth, in July; and Sladen a male at Kingsdown, also in July. It has been bred from Miana arcuosa and Tapinostola ely'mi; and is widely distributed on the Continent.

\section{2. occupator, Grav.}

Ichneumon occupator, Gr. I. F. i. 425 ; Ste. III. M. vii. I83, ơ. Exephanes occupator, Wesm. Nouv. Mém. Ac. Brax. I844, p. I7; Bul. Ac. Brux. I848, p. I4I ; Mém. couron. Ac. Belg. I 859 , p. 47 ; IJolmgr. Ichn. Suec. i. 8; Ent. Tidskr. I88o, p. 23 ; Ijerth. Ann. Soc. Fr. I895, p. 575; Thoms. O. E. xviii. IS97. o \&. Iclunezmon extensorius, var. 5, Gr. I. E. i. 270, $\%$. 1. venuslus, Tisch. Stett. Zeit. I88I, ó. Var. I. contaminatus, Gr. I. E. i. 39I, o.

Head black, punctate, narrowed behind eyes; vertex obliquely depressed, broadly but not deeply emarginate; clypeus apically truncate; of with frontal orbits usually rufescent, of with palpi piceous, mandibles and labrum often, as well as the facial orbits flavous. Antennae slender, setaceous, black; of $q$ white-banded, of of ferrugineous throughout beneath. Thorax coarsely punctate, entirely black; metanotal areae complete, areola quadrate; spiracles linear. Scutellum flavous; of $q$ flat, of of slightly convex and often basally black. Abdomen of $q$ fusiform 
and not compressed apically, of of sub-linear; black with segments two and three, and in $q$ base of fourth, red or fulvidous, of $\delta$ sometimes flavous with infuscate disc, third of of quadrate; six to eight and sometimes fifth, as well as terebra, white-marked in $q$, of usually with a flavous mark on seventh; post-petiole fincly aciculate, bicarinate, angles obtuse ; gastrocaeli very small, of of circular; terebra very stout and distinctly exserted; o with second and third ventral segments plicate, of valvulae not sinuate. Legs normal, onychium of intermediate tarsi thrice longer than penultimate joint; fulvous or red with coxae, trochanters, and apices of hind femora, tibiae and tarsi, black. Wings slightly clouded; stigma fulvous, tegulae piceous. Length, I $2-15 \mathrm{~mm}$.

Besides its colour, this species may be at once known from the last by the extent of the ventral fold and the absence of sinuation in the valvulae. The type form is that of the of with immaculate anus. I. contaminatus is a variety with the last three or four segments white-marked; the scape beneath, tibiae and central segments, flavous; it is I $5 \mathrm{~mm}$. in length.

This would appear to be of more frequent occurrence than the preceding and has a wider continental distribution. Stephens says the male is rather uncommon near London, and at Netley, in June; it has been captured, at Bickleigh, in Devon, by Bignell, early in June; and upon several occasions it has been bred from Nonzgria typluae and $N$. sparganii, in August. Schm. adds Amblyptila acanthodactyla as an occasional host.

\section{PROBOLOIDES, Morley.}

n. $n$.

Head somewhat tumidulous, rounded and hardly narrowed behind the eyes; cheeks sub-buccate; mandibles stout, apically obtusely bidentate with the upper but little longer than the lower tooth; clypeus distinctly discreted, apically sinuate or broadly rounded, often marginately reflexed; face short and convex; frons concave; vertex emarginate next exterior ocelli. Antennae filiform, of of somewhat attenuate apically ; scapes subcontiguous; flagellar joints of $q$ moniliform, of $f$ cylindrical. Thorax elongate, obsoletely punctate and nitidulous ; meso- very little higher than meta-notum, which latter is completely areated; spiracles linear, apophyses wanting, sternauli rarely strong. Abdomen obsoletely punctate and strongly nitidulous; basal segment with spiracles beyond the middle, and a central dorsal intumescence, but without sculpture; gastrocaeli nearly wanting, extremely superficial; ventral segments two and three of $\delta$ plicate, the ultimate of $q$ not reaching base of the slightly exserted terebra. Legs normal; coxae sub-glabrous with a few large scattered punctures, but no scopulae; onyches simple. Wings normal, silaceo-hyaline; areolet pentagonal, broad or coalesced above; radial nervure externally arcuate.

The lack of sculpture in the basal abdominal segments of this genus somewhat resembles that of Alomyia, some forms of which the male of $P$. glabratus superficially approaches; the petiolar intumescence allies it strongly with Probolus, near which indeed must be its most natural position; this, however, is at present precluded by the retraction of the female's hypopygium, which unmistakably places this genus among the Oxypyini. Here the irregular clypeus points to an affinity with Chasmias, and the superficial gastrocaeli with Exephanes. 


\section{Table of Species.}

(2). I. Areola small, sub-circular; meso- and metanotum immaculate

(1). 2. Areola normal, sub-quadrate; meso- and metanotum flavous-marked

I. GLABRATUS, Morl.

2. Maculatus, Morl.

\section{I. glabratus, $s p . n$.}

Head buccate, black; cheeks sparsely punctate; clypeus apically broadly rounded, of of transversely produced and piceous centrally; palpi, labrum, mandibles, and usually the external and vertical orbits, pale; $q$ with apex of clypeus also red; to with face and clypeus also flavous. Antennae black; scapes contiguous in both sexes, of $\delta$ pale beneath; $q$ with fourth flagellar joint quadrate. Thorax obsoletely punctate, shining, black; mesonotum of $q$ somewhat deplanate, of tormal ; mesopleurae and sterna sub-glabrous and strongly nitidulous; metathorax of normal length, its costae weak; areola very small, sub-circular, apically emarginate. Scutellum glabrous, shining, flavous, apically sub-truncate; of $q$ very flat, of $\delta$ normally convex and carinate nearly to its centre; post-scutellum flavous. Abdomen strongly nitidulous, sub-glabrous, black; of $q$ with the two basal segments, except the petiole, flavous; terebra black, shortly exserted and rising far from apex; of of with the three basal segments entirely flavous, and the second and third ventral plicate, the ultimate being obtusely a little produced with the valvulae black. Legs normal, glabrous, flavous with the coxae and hind trochanters black; anterior trochanters of $q$ piceous; anterior femora internally canaliculate. Wings flavescent, normal; areolet pentagonal; nervures, stigma, tegulae and radix fulvous, darker in $\delta$. Length, I $2-13 \mathrm{~mm}$.

The of has the external or vertical orbits, or both, pale; its areolet is sometimes broad and at others nearly coalesced above.

I am indebted to the Rev. H. S. Gorham, F.Z.S., \&c., for a female and three males of this very distinct species; but beyond certifying to their British origin, he could tell me nothing regarding their history.

\section{2. maculatus, $s p . n$.}

Head sub-buccate, of of transverse; black; cheeks glabrous ; clypeus apically broadly rounded and centrally marginate; mandibles strongly obtuse with the teeth sub-obsolete; face, clypeus, mandibles except their apices, palpi, lower half of exterior orbits nearly to base of mandibles, the frontal, and in $q$ vertical, orbits broadly flavous. Antennae black; scapes pale beneath, of $\delta$ inserted nearer the eyes than each other, of $q$ contiguous with the seventh flagellar joint quadrate. Thorax obsoletely punctate, shining, black; mesonotum somewhat flat, with a central flavous patch; pronotum, a long pre-radical line, two large patches on the mesopleurae, another on the metapleurae, and the areola, flavous; mesostema indistinctly rufescent; of also with small pale callosities beneath both pairs of wings; mesopleurae and sterna obsoletely punctate and nitidulous; metathorax elongate, convex; costae distinct, though fine; areola somewhat large, sub-quadrate, apically truncate. Scutellum glabrous, shining, flavous, apically sub-truncate, carinate beyond its base; of $q$ very flat, of of strongly convex. Abdomen strongly nitidulous, glabrous; of $q$ entirely 
red, of of flavous with segments five and six discally infuscate. Legs normal, glabrous, flavous or fulvous; coxae black, with the anterior of of red, of flavous, beneath; hind coxae broadly flavous above. Wings normal, of $q$ flavescent, of of sub-hyaline; areolet pentagonal, narrowed though not quite coalesced above; nervures and stigma fuscous or piceous ; radix and tegulae fulvous. Length, i $4 \mathrm{~mm}$.

Mr. Gorham gave me also a male and female of this species, which were mixed with the preceding; and it is curious that two such obviously closely allied kinds should yet so materially differ in markings and sculpture, both having been probably bred, and previously unnoticed.

\section{CHASMIAS, Ashmead.}

Ashm. Proc. U. S. Nat. Mus. 1900, p. I7; Chasmodes, Wesm. Nouv. Mém. Ac. Brux. 1844, p. I3 (nec Cuvier).

Sub-equilateral, with clypeus apically sinuate. Head stout, not narrowed behind eyes; cheeks of $q$ slightly buccate; clypeus immarginate and, especially in $q$, emarginate; mandibles stout; labrum exserted. Antennae somewhat short, hardly attenuate towards apex. Thorax sub-linear, punctate, narrower than head; metanotum with distinct areae; areola elongate, rectangular ; spiracles linear. Abdomen elongate, sub-linear, narrow with anus acuminate; central area of post-petiole twice broader than lateral ones; second segment a little longer than broad, third quadrate; terebra slightly exserted. Legs not stout; tarsi not dilated.

This genus is certainly better placed at the end than at the beginning, as has been the usual practice of the authors, of the Oxypygini, on account of its affinity with the first of the Amblypygini, as pointed out by Thomson (Annales Soc. Fr. I888, p. I I I). The two species-excluding Ichnemmon luoens, Grav., tentatively herein placed by Wesmael-known on the Continent, both occur in Britain; one is very common with us, but the second, which is now for the first time recorded hence, would appear to be rare or to have been previously overlooked.

\section{Table of Species.}

(2). I. Post-petiole finely aciculate; body slender...

I. MotatoriUs, Fab.

(I). 2. Post-petiole strongly aciculate; body stout...

2. PALUdiCOLA, Wesm.

\section{I. motatorius, Fiab.}

Ichneumon motatorius, Fab. S. E. 329 ; Gr. I. E. i. 353 ; Ste. Ill. M. vii. I72 ; Boie, Kröy. Tids. 1840, p. 319, + . Chasmodes motatorius, Wesm. Nouv. MIém. Ac. Brux. 1844. p. I5 ; Bul. Ac. Brux. I848, p. I41, excl. varr. 5 et 6 ; Holmgr. Ichn. Suec. i. 4 ; 'Thoms. O. E. xviii. I 896 ; Berth. Ann. Soc. Fr. I894, p. 518, o \&.

Head closely punctate, not narrowed behind eyes, black; mandibles and labrum usually rufescent; cheeks and clypeus glabrous with isolated punctures, latter hardly discreted and apically distinctly emarginate, slightly produced centrally; face rather flat, confluently punctured; of with juxtaantennal always, and occasionally the facial, but never the frontal, orbits white. Antennae black, of $q$ filiform, slightly attenuate towards base, tricoloured; of $\$$ setaceous, distinctly setiferous, joints beyond middle somewhat nodulose, apex attenuate, piceous beneath and very rarely (var. 
muptus, Berth.) with a white band. Thorax dull, closely and evenly punctate, black; notauli small but distinct; metathorax very closely and finely scabrous, with three upper areae only (in the costulae are sometimes traceable however), of which the areola is equilateral, much longer than broad, with very flat costae, the basal and apical ones being obsolete, that of $\hat{\sigma}$ shorter, with stronger and more complete costae; juxta-coxal areae wanting. Scutellum flat, shining, with scattered punctures; white. Abdomen lanceolate, sub-linear, black; of $f$ with segments one to three and sometimes a mark on disc of fourth clear red and the seventh white; of of more rarely with the second segment or post-petiole wholly or partly red; its anus immaculate; post-petiole smooth or obsoletely aciculate; gastrocaeli, especially in o deep, oblique and striate, extending to base of segment, intervening space narrower than centre of post-petiole of $\delta$, sub-striate with the thyridii lunate and red; anus acuminate with terebra distinctly exserted, of of sub-obtuse with apical ventral segment normal. Legs red with coxae black and hind tarsi infuscate; the whole legs, especially of $\delta$, sometimes mainly black; anterior femora canaliculate beneath; coxae closely punctate, simple. Wings hyaline; stigma fulvous or often in of nigrescent ; tegulae and radix piceous, former in of anteriorly white; areolet pentagonal, broad below and, in of, narrowed above. Length, $8 \frac{1}{2}-\mathrm{I} 2 \mathrm{~mm}$.

Both sexes sometimes have the abdomen entirely, and rarely the legs also, black. In all the $q$ examples $I$ have seen the femora and tibiae are red, excepting two in which the former are almost entirely black; the of nearly always has the scutellum white; the coloration of the species appears to be fairly constant.

Moderately common, taken near London, about the end of May, and in June (Stephens) ; very common in Norfolk (Bridgman); taken at Bickleigh, in Devon, in September (Bignell); Sutton, near Birmingham, of ô, in August and September (Bradley); Shotover, Oxford (Hamm); $q$, near Carlisle, in January (Routledge); Newport, in Midlothian, and in Aira caespitosa, in winter, at Kirknewton (Evans); Hastings (Esam); Barr, Ayrshire and Lemeytown (Dalglish) ; Essex (Harwood); Foxhall, in Suffolk, several $q$ o already in winter quarters, beneath bark of prostrate fir trees, on September 23 rd (Tomlin); Lyndhurst, in Hants. (Adams); Kidbrook, Oxshott and Pitlochry (Beaumont). 'I'he $q q$ are extremely abundant from September to April, beneath bark, moss on stumps, but especially at the roots of various kinds of grasses, and appear to be much less particular in their selection of an hibernaculum than are the Ichnenmones; that they do not retreat to hibernate simultaneously is certain, since I have found them upon the flowers of Angelica sylzestris and in winter quarters at the same time in the autumn; the hibernating o $q$ have occurred to me at Brede and Beaufort Park, near Hastings, and commonly at Foxhall, Orwell, Bentley Woods, \&c., about Ipswich. They would appear to be somewhat gregarious, since on one occasion twelve specimens had formed a coterie as far in some rotten wood as they could push, and carefully avoiding all damp or mouldy spots. 'The of of do not, apparently, hibernate, are generally found upon flowers and are less frequently met with; I have only found them at Aldeburgh, Henstead, Foxhall and Bealings, in Suffolk. C. motatorius preys upon reed-and

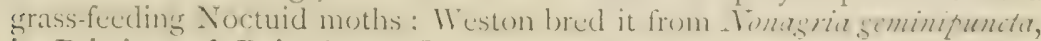
in Britain, and Boie, from Nocha airae (Frr. =1liana arcuosct, Hw.), on 
the Continent, where it is common. One would suspect, however, that such a ubiquitous species has much commoner hosts than the above, and I have not noticed it to be especially attached to marshy localities.

\section{2. paludicolà, IVesm.}

Chasmodes motatorius, varr. 5 et 6, Wesm. Bul. Ac. Brux. 1848, p. r41. C. paludicola, IVesm. lib. cit. 1857, p. 356; Holmgr. Ichn. Suec. i. 5; Thoms. O. F. xviii. 1897; Berth. Ann. Soc. Fr. I894, p. 518, ơ $९$.

Head black with the palpi fuscous; labrum and sometimes mandibles ferrugineous; facial orbits of the of stramineous. Antennae black, more or less ferrugineous beneath and, at least in $q$, centrally white-banded. Thorax black, of rarely with a white dot beneath the radix. Scutellum entirely or apically, and sometimes in $q$ the post-scutellum also, white. Abdomen black with the incisures or sides of the second and third segments often ferrugineous; of 0 ventrally plicate, of $q$ with segments six and seven dorsally white-marked. Legs red; coxae, trochanters, hind tarsi and sometimes the apices of their tibiae, black. Wings sub-hyaline, stigma fulvous; tegulae nigrescent, with pale marks in 0 ; areolet somewhat narrowed above. Length, I4-I $5 \mathrm{~mm}$.

The structure of this species varies so little from that of the preceding as to necessitate no mention above ; it differs, however, in having the post-petiole centrally sub-distinctly aciculate, the fourth to sixth segments are more elongate, the genital valvulae stouter and more prominent; the abdomen of the $q$ is not broadly red, and the $\delta$ antennae are usually white-banded; it may superficially be at once distinguished by its robuster form and much larger size.

This species has several times been bred from Nonagria typhae, on the Continent, where it is mixed with, though much rarer than, the preceding. It appears to have been unaccountably mixed with Ichneumon quaesitorius, in Britain, where it has hitherto been overlooked and unrecorded. Rev. E. N. Bloomfield has taken both sexes in the Hastings district and Bignell has several times bred it, in the middle of September, from Nonagria cannae, in Devonshire; the $q$ is said, like that of the last, to hibernate in the perfect state.

SUB-TRIBE.

\section{AMBLYPYGINI.}

\section{Table of Genera.}

(4). I. Abdomen equilateral, linear; of $q$ apically compressed.

(3). 2. Spiracles elongate; scutellum subtriangular; tarsi not white .........

(2). 3. Spiracles oval ; scutellum quadrate; tarsi centrally white ................. 2. Hyponecus, Wesm.

(I). 4. Abdomen laterally slightly rounded or sub-ovate.

(16). 5. First segment not dorsally intumescent in the centre.

(15). 6. Pronotal furrow entire.

(14). 7. Clypeus apically truncate.

(13). 8. Tarsi pilose and setiferous beneath. 
(เо). 9. Gastrocaeli deep, broader than rugose intervening space; fourth ventral segment not plicate

(9). Io. Gastrocaeli small; fourth ventral segment usually plicate.

(I2). II. Mesosternal epicnemia entire; terebra concealed

3. Ctenichneumon, Thoms.

(II). I2. Mesosternal epicnemia not entire; terebra not entirely concealed ......

(8). I3. Tarsi pilose, but with no setae beneath

(7). I4. Clypeus apically rotund and centrally mucronate..........................

(6). I 5. Pronotal furrow centrally tuberculate or carinate

(5). I6. First segment dorsally intumescent in centre

4. Spilichneumion, Thoms.

5. Amblyteles, Wesm.

6. Hepiopelius, Wesm.

7. Acolobus Wesm.

8. Anisobas, Wesm.

9. P'ROBOLUS, Wesm.

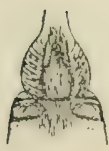

Gastrocaeli, \&c., of Ctenichnewmon.

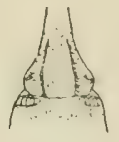

Gastrocaeli, \&c., of Amblyteles.

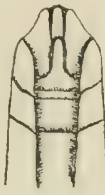

Hypopygium of Spilichneumon, ठี.

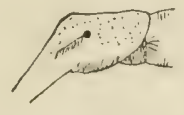

Basal segment of Probolus.

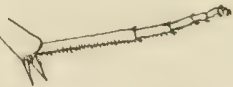

Setiferous tarsus of Amblyteles.

\section{LIMERODES, Wesmael.}

Wesm. Nouv. Mém. Ac. Brux. I844, p. ir r.

Head normal, temples sub-buccate; clypeus distinctly bisinuate at the apex, especially in $q$; mandibular teeth unequal. Antennae slender, filiform. Thorax somewhat slender and convex; metanotum of normal length, distinctly areated; spiracles sub-linear. Abdomen elongate, narrow; of $q$ strongly compressed towards the truncate apex, with terebra slightly exserted; of $\delta$ depressed, linear ; segments two to four longer than broad, the second sub-impressed laterally towards its apex; post-petiole smooth and shining; gastrocaeli sub-obsolete. Legs slender, tarsal claws simple. Wings somewhat narrow.

The affinity of this genus with Chasmias is well marked in the elongate body and sinuate clypeus, as well as in the structure of the thorax and antennae.

\section{I. arctiventris, Boie. a}

Ichnezmon arctiventris, Boie. Kröy. Tids. 1840, p. 319; Stett. Zeit. 1855, ?. Limerodes arctiventris, Wesm. 13ul. Ac. Brux. 1848, p. 294 ; cf. lib. cit. 1854. p. 77 ; IIolmgr. Ichn. Suec. ii. 297 ; lierth. Ann. Soc. Fr. I895, p. 578, o \&. L. ophioniventris, W'esm. Nouv. Mém. Ac. Brux. 1844, p. 112, o.

A shining, brightly coloured, linear species. Head sub-buccate and only slightly narrowed posteriorly, black; of with palpi and mandibles white, face and clypeus flavous or with a central piceous mark. Antennae piceous, more or less ferrugineous beneath; of $q$ white-banded, of $\delta$ with scape white beneath. Thorax black; of with pronotum and callosities before and beneath radix usually white; areola glabrous, sub-semioral, incomplete 
apically; costulac entire. Scutellum white. Abdomen black and shining with segments one to three or four, except apex of latter, red or in $\delta$ flavous; first segment of taterally smooth and shining, rarely black; gastrocaeli sub-obsolete, being indicated by a slight longitudinal depression; hypopygium of $q$ not reachingapex, terebra exserted; of with two to four ventral segments plicate. Legs somewhat slender, black; tibiae and tarsi, except apices of hind ones, and the front femora, red. Wings hyaline; stigma fulvous; tegulae of $q$ piceous, of t white. Length, IO-I $2 \mathrm{~mm}$.

This strongly shining and extremely linear species can hardly be mistaken for anything else among the Ichneumoninae; it is well figured with details by Wesmael in his "Amblyp. Europ."

On the Continent, it is said to be rather widely distributed throughout the central and northern regions, and is recorded from the dunes, near Ostend, in September. Bridgman and Fitch say it is not common generally, and I know of no specified records of it, except that from Essex. Mr. E. A. Elliott has captured the male at Birnam, in Perth, early in August, and in a sandy place, near the coast at Hayburn Wyke, near Scarborough, in the middle of August ; indeed, it would appear to be a coast insect with us, since I have also taken the male, by sweeping Malricaria flowers, near the beach, at Southwold, in Suffolk, early in August, and two females by searching at the roots of marram grass, on the north dunes, at Lowestoft, towards the end of the same month. It is said to prey upon Hydrilla (Miana) arcuosa, Eubolia mensuraria, Tapinostola elymi, and Miana literosa (=Apamea suffuruncula, Tr.) ; and to be very rare in Germany.

\section{HYPOMECUS, Wesmael.}

Wesm. Nouv. Mém. Ac. Brux 1844, p. III.

Body slender. Head not buccate, narrowed behind the eyes and towards the mouth ; clypeus sub-convex, separated from face, apically subtruncate and mutic, lateral foveae deeply impressed; mandibles slender, the teeth unequal. Antennae setaceous, nearly length of body, those of to with tenth to fourteenth flagellar joints externally sub-dilated; white-banded 'Thorax slender, sub-convex; pronotum with no central tubercle; metanotum areated; spiracles oval. Scutellum short, sub-quadrate, slightly convex, laterally margined at the base only. Abdomen elongate, narrow; petiole slender; thyridii somewhat large, remote from base of second segment; apical segments of $q$ sub-compressed, the apical ventral nearly vomeriform and reaching slightly beyond the eighth dorsal, which is subexserted. Legs slender; hind tibiae a little arcuate basally; onyches simple; hind tarsi white-banded. Wings normal ; areolet narrowed above.

Thomson places this genus anong the Platy'urini, but he has not been followed by subsequent authors, and the present appears to be its most natural position, although it is not closely allied to the genera in either sub-tribe. The petiole, though sub-linear, is not broader than vertically thick; and the present appears allied to the preceding genus in its elongate form, slender legs, absent petiolar carinae and in the long, apically subcompressed abdomen, filiform $q$ antennate, the joints of which are, however, much longer, and in its clypeus being sub-quadrate and much further produced. 


\section{I. quadriannulatus, Grav.}

Ichneumon quadriannulatus, Gr. I. E. i. 556, + . Hypomecus albitarsis, Wesm. Nouv. Mfém. Ac. Brux. 1S+4, p. I47; Bul. Ac. Brux. Annexe, IS53-54, pl. ff. It-17; lib. cit. IS55, p. 410 ; Holmgr. Ichn. Suec. ii. 295; Thoms. O. L. xix. 2114 ; Berth. Ann. Soc. Fr. 1896, p. 298, ơ $q$.

A slender, dark species, finely punctate with white pubescence. Head black; clypeus with deep lateral foveae; frons impressed above the scrobes; facial, frontal, exturior and dots at the vertical orbits stramineous; of with mouth and face entirely white. Antennae white-banded in both sexes, with scape rufescent beneath. Thorax black, with pronotum, a line before, and in of beneath, the radix, stramineous, and sometimes with two rufescent patches on the metanotum; areola usually longer than broad; costulae weak; apophy'ses small. Scutellum and post-scutellum with two stramineous dots; of usually has the former entirely pale. Abdomen very slender, black; apical margin of second, and sometimes of the first segment also, red; petiole long and slender; post-petiole convex and shagreened, with no carinae; second segment strongly narrowed basally, with gastrocaeli sub-obsolete and thyridii long, oblique and some distance from the base; third and fourth segments quadrate; o with hypopygium apically white and reaching apex of anus ; terebra not exserted. Legs red; apices of hind tibiae, and sometimes all the coxae and trochanters, black; hind tarsi black, usually with central joints white; of with the coxae and trochanters, as well as the sides of the front tibiae and tarsi, white. Wings with stigma piceous and areolet strongly narrowed, sub-coalesced above. Length, I O-I $2 \mathrm{~mm}$.

The white-banded tarsi and antennae, which latter are also a little centrally incrassate, together with the slender abdomen, linear petiole, and the produced valvulae of the $q$, will at once distinguish this species, which is somewhat variable in colour.

It is found uncommonly in central and northern Europe, and has been bred in Germany from Acidalia trilineatu, Melanifpe luctuata and Anticlia berberata. I do not anticipate that it is uncommon in Britain when properly sought; Cameron has taken it, at Cadder, near Glasgow, and Bignell, early in July, at Bickleigh, in Devon. Here, too, it seems to confine its parasitism to the smaller Geometers having been bred by WV. H. B. Fletcher, of Worthing, from Ephyra punctaria ; and Mr. A. M. Montgomery has given me a live female, together with the chrysalis of Eplyyra trilinearia (Zonosoma linearia) from which it emerged, on April 28th, I90I ; the host in this case had been collected in woods, near Chalpont Road, Bucks. The parasite emerges directly through a somewhat regular orifice, made by entirely removing the extremity of the pupa, in which is no distinct cocoon nor silken lining whatever. Schmiedeknecht takes it annually in damp, shady places among alder bushes; there are several from the New Forest in coll. Bridg. ; and Mr. E. R. Bankes has bred it from a doubtful geometer (possibly Melanippe galiata) at Dartmouth, in August and the end of May.

\section{C'TENICHNEUMON, Thomson.}

Thoms. O. E. xix. (1S94), $20 \$_{3}$.

Head with the vertex broad, not or hardly narrowed posteriorly, black; facial orbits rarely white; mandibles bidentate. Antcmnal flagellum 
generally basally incrassate, of of sub-serrate or with the joints not elongate-cylindrical. Thorax not convex; pronotum not pale, pro-pleurae inferiorly striolate; metathorax sub-mutic, costulae generally wanting; mesosternal epicnemia interrupted above. Scutellum not gibbose. Abdomen with gastrocaeli and thyridii large and deeply impressed, as broad as the strongly sculptured, usually convex, but never simply punctate, intervening space; serenth segment not white; fourth ventral not plicate; ot valvulae apically broadly rounded; terebra of $q$ almost entirely concealed. Wings with costa and tegulae usually nigrescent.

The features of this genus, as indicated by its author, are six in number, viz. : The serrate antennae of the $f$, the strongly developed gastrocaeli, invariably immaculate anus, not plicate fourth ventral segment, the elongate valvulae which are longer than the hypopygium and the membraneous apex. Thomson (loc. cit.) points out that some of the species of this genus, e.g. C. sputator and C. homocerus, might be transposed to Stenicknetumon.

IVesmael, in 1844, drew the genus Amblyteles from Ichneumon, Grav., and divided it ("Amblypygi Europaei," I854) into two main groups; those species with the gastrocaeli small and the intervening space flat, he called Microsticti; those with the gastrocaeli large and deeply impressed with the interval convex and longitudinally sculptured, constituted his Macrosticti. The former he sub-divided into four colour-groups and the latter into three, of which the Crioceri differed from the Leptoceri in having the basal flagellar joints sub-moniliform and the Coryphaei from both in their narrow, elongate areola, etc. Thomson ("Notes Hymén.") held the presence or absence of a fold on the fourth ventral segment to be of primary importance and the size of the gastrocaeli as secondary to it ; but in "Opusc. Ent." he raises the Macrosticti to the genus Ctenichnenmon, and divides the Microsticti into two others based upon the ventral folds, development of the epicnemia and the position of the hypopygium in relation to the terebra, relegating the Coryphaei in part to his genus Proticlnueunon and erecting a new one, Tricholabus, for the reception of Amblyteles strigatorius, among the Platyurini. Ashmead has again divided the latter's genus Amblyteles into two, in one of which the metathoracic apophyses are distinct and in the other but tuberculiform; but unfortunately he gives $A$. palliatorins, which has distinct though small spines, as the type of his mutic genus, Pseudamblyteles. The value of the mandibular dentation, so difficult to follow in the Diadromus group, is here discounted by such species as $A$. equitatorius and $A$. castanopygus, in which the lower tooth, though almost wanting, is discernible; and it is certainly difficult to seize good characters by which to distinguish these insects in both sexes.

The genus Amblyteles of Wesmael was at best artificial and divided from his genus Ichneumon at first solely by the fact that the hypopygium of the females covered the base of the terebra and that the female anus was obtuse. To this Holmgren ("Ichn. Suecica," I864) added that the males, after death, possessed through the fermentation of the bile a longitudinal fold on at most the second and third ventral segments, whereas in Ichnenmon the fourth was also plicate, but this is incorrect, for about a third of the species of Amblyteles (sensu Wesm.) have the fourth segment folded in the males. They are consequently extremely difficult to distinguish therefrom. Nevertheless the males have the head less narrowed behind 
the eyes, the vertex somewhat emarginate, the cheeks longer, and the temples more strongly pilose than in the Oxypyini; their genital valvulac, moreover, are usually larger, more strongly exserted, and, in such as possess it, the mucronation of the hypopygium at once proclaims their adhesion to smblyteles (sensu Wesm.), of which the following diagnosis embraces the three subsequent genera :-

Head not very large; clypeus apically truncate, generally obsoletely punctate; labrum very often shortly exserted; mandibles with unequal teeth, of which the lower is occasionally sub-obsolete and, in a few instances, entirely wanting. Antennae strongly attenuate in both sexes; not centrally dilated. 'Thorax usually stout ; metathorax of normal length, often more or less strongly bidentate; pronotum with no central tubercle; spiracles linear or oval. Scutellum not strongly convex, sub-triangular. Abdomen convex, not compressed, elongate-fusiform, rarely sub-linear, and always more or less apically obtuse ; post-petiole usually abruptly constricted at its apical third; second segnent narrower at base than apex; the last ventral segment somewhat longer than the penultimate and reaching the apex of the seventh dorsal in the typical form, or only attaining the apex of the sixth dorsal in the transitional form, i.e., that most closely allied to Ichneumon, Wesm. ; the third, fourth, or fifth and sometimes all the rentral segments of the of not plicate, the hypopygium occasionally acuminately produced in the centre ; terebra not exserted. Legs normal; coxae never scopuliferous; hind tarsi setiferous beneath, onyches simple. Wings with the areolet rarely coalesced above. fauna.

About 126 species are included in this super-genus in the European

Table of Species.

(2). I. Body blue-black.......................

I. CAERUleator, Zett.

(1). 2. Body not blue-black.

(6). 3. Metathoracic apophyses distinct.

(5). 4. Antennae white-banded, not redmarked ...............................

(4). 5. Antennae not white-banded, redmarked ..............................

(3). 6. Metathoracic apophyses wanting or tuberculiform.

(12). 7. Antennae not white-banded; basal flagellar joints of $\delta$ cylindrical.

(II). 8. Ventral segments two and three plicate.

(Io). 9. Thorax strongly sculptured; head entirely black .........................

(9). Io. Thorax finely sculptured; head partly pale ..........................

(8). I I. No ventral segment plicate ..............

(7). 12. Antennae of $\$$ white-banded; basal joints of st sub-serrate.

(16). 13. No ventral segment plicate.

(15). 14. Abdomen centrally red.................

(14). I5. Abdomen centrally black ...............

(13). I6. Ventral segments two and three plicate.

4. CASTIGATOR, Fab.

5. PlicatUS, Morl.

6. PANZERI, Wesm., + .

2. SPUTATOR, Fab.

3. HOMOCERUS, WeSm.

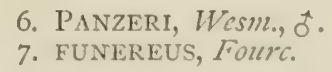

(22). 17. Front legs not flavous-marked.

(2I). I8. Scutellum white. 
(20). 19. Antennae with fourth flagellar joint

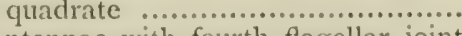

(19). 20. Antennae with fourth flagellar joint elongate ............................

(18). 21. Scutellum black ......................

(17). 22. Front legs flavous-marked.

(24). 23. Abdomen apically castaneous ........

(23). 24. Abdomen not apically castaneous.

(26). 25. Metathoracic spiracles sub-oval; pubescence white

(25). 26. Metathoracic spiracles linear ; pubescence piceous.

(30). 27. Abdomen centrally red.

(29). 28. Third flagellar joint elongate ; hind tibiae reddish

(28). 29. Third flagellar joint quadrate ; hind tibiae not rufescent, often broadly white

(27). 30. Abdomen not red.

(32). 31. Areola sub-quadrate; abdomen entirely black

(3I). 32. Areola transverse; abdomen not entirely black

\author{
8. FOSSORIUS, Grav. \\ 9. INSPECTOR, WeSM. \\ IO. MFLANOCASTANUS, Grav. \\ II. REPENTINUS, Grav. \\ 12. MESOCASTANUS, Grav.
}

13. MESSORIUS, Grav.

I4. DIVISORIUS, Grav.

I5. HAERETICUS, WeSm.

16. Flavocinctus, Desv.

\section{I. caeruleator, Zeti.}

Ichneumon caeruleator, Zett. I. L. 359, ठ. Amblyteles coenuleator, Holmgr. Ichn. Suec. ii. $278, \delta$ \&. A. caemuleator, Berth. Ann. Soc. Fr. 1895, p. 597, $\delta$ q. I. maculiventris, Desv. Cat. 5 , $q$; $c f$. Morl. E M.M. 1902, p. 122.

A stout species, blue-black throughout. Head slightly buccate, narrowed behind the eyes; clypeus apically truncate; rarely with frontal orbits, lateral circular dots on clypeus, and the palpi, flavidous. Antennae slender, setaceous, attenuate towards the apices, the sixteenth flagellar joints quadrate; of $q$ white-banded, of $f$ with the basal flagellar joints sub-cylindrical. Thorax blue-black, somewhat dull ; areola transverse or sub-quadrate; costulae complete in t; apophyses tuberculiform. Scutellum not pale, scabrosely-punctate, somewhat flat. Abdomen dull, blueblack with segments two to five narrowly ferrugineous apically, sometimes the second and third segments dorsally ferrugineous; fourth and fifth strongly nitidulous; post-petiole aciculate, bicarinate; gastrocaeli transverse, striate, very large and deeply impressed; intervening space narrow, not broader than centre of post-petiole; ventral surface flavidous with large fuscous patches. Legs normal, black or partly blue-black; front or anterior legs more or less fulvous or stramineous internally. Wings slightly clouded, flavescent ; stigma rufescent ; tegulae blue-black. Length, I $4 \mathrm{~mm}$.

The only British example of this species, recorded elsewhere only from Sweden where the males occur in August and from Holstein, that I have seen is the one described by Desvignes, which is from Stephens' collection; no locality is quoted, but since it bears a label "fasciatus" in the latter's handwriting, it is possibly the type of his Ichneumon fasciatus (III. M. vii. I 29), which is said to have been found, in July, in the New Forest, but he makes no reference in his description to the distinctly cyanescent coloration of this handsome insect. Desvignes' type is in the British Museum. 


\section{2. sputator, Fab.}

Ichneumon sputator, Fab. E. S. ii. I53; Gr. I. E. i. 542 ; Ste. Ill. M. vii. 195. Amblytcles spulator, Wesm. Nouv. Mém. Ac. Brux. 1844, p. 128; Bul. Ac. Brux. I848, p. 298 ; Voll. Pinac. pl. vii. f. 7 ; Berth. Ann. Soc. Fr. IS95, p. 593, o $q$.

Head black. Antennae setaceous, white-banded in both sexes; of $q$ slender, of of with basal flagellar joints sub-cylindrical. Thorax black; areola quadrate; metathoracic apophyses small but distinct. Scutellum black and somewhat flat. Abdomen black with second and third segments red or badious; post-petiole aciculate; gastrocaeli deep and transverse, the intervening space narrow and aciculately punctate; second and third ventral segments plicate, fourth of of often carinate but not folded. Legs slender, black; tibiae, except apices of posterior, and the front femora in part, red. Wings somewhat clouded, with stigma fulvous and tegulae black. Length, $15 \mathrm{~mm}$.

The of rarely has the abdomen or antennae entirely black or all the femora and tibiae red.

This species is very similar to Stenichnemmon culpator, Schr., from which the $q$ differs, besides the generic points, in the absence of the coxal scopulae and in the obtuse anus; and the $f$ in having the head as broad as the thorax, the body more slender; the post-petiole centrally canaliculate and the metathorax bispined.

It is said to frequent umbelliferous flowers, in August and September, in central Europe and France, where it has been bred from Plusia gamma, and the female hibernates. I know of no British record since Stephens said he found it, in Darenth Wood, at the beginning of June.

\section{3. homocerus, Wesm.}

Ichneumon castigator, Gr. I. E. i. 124, var, metathorace bispino, 8. Amblyteles homocerus, IVesm. Bul. Ac. Brux. I854, p. I2I; Mém. couron. Ac. Belg. I859, p. 91 ; Berth. Ann. Soc. Fr. 1895, p. 595, 8 \%.

A black species with red legs. Head and antennae black; latter slender, setaceous, of $q$ rarely red-banded, of $\delta$ with apical joints sub-nodulose. Thorax entirely black; areola sub-quadrate, sometimes a little broader than long, apically truncate; apophyses short and distinct. Scutellum black, only slightly convex, dull and strongly punctate. Abdomen black; post-petiole finely aciculate, often rugulose in 0 , bicarinate; gastrocaeli large, deep and transverse, with the intervening space narrow; of with fourth ventral segment not plicate. Legs red; coxae except sometimes the posterior of the $\delta$, trochanters, and the apices of the hind tibiae and tarsi, black. Wings more or less clouded, stigma fulvous; areolet pentagonal ; tegulae and radix black. Length, 14-16 mm.

This species is closely allied to the next, with which Gravenhorst mixed it, but it may be at once known by the distinct metathoracic spines and by its longer clypeus.

It was first detected in Britain, in June, I S $\mathrm{I}$, when examples were brecl by Bignell, in South Devon, from Arsynnis Papluia ; it is not uncommon on the Continent, in the central and southern regions, extending to northern Africa, but is still much confused with the following species. 


\section{4. castigator, Fab.}

Ichneumon castigator, Fab. E. S. ii. I66; Piez. 68 ; Gr. I. E. i. 125, excl. var. I ; Ste. Ill. M. vii. I3I. Amblytelés castigralor, Wesm. Nous. Mlém. Ac. Brux. 1S44, p. I29; Bul. Ac. Brux. 1854, p. 123; Holmgr. Ichn. Suec. ii. 272 ; Berth. Ann. Soc. Fr. I895, p. 595, of . Ctenichnentmon castigator, Thoms. O. E. xix. 2087.

A black species with red legs. Head black, cheeks hardly dilated. Antenmae slender, setaceous ; black, very rarely dotted centrally with white, basal half of flagellum more or less red beneath; of 0 with basal joints sub-cylindrical, apical ones sub-nodulose. Thorax entirely black; areola usually transwerse, costulae incomplete; apophyses wanting or tuberculiform. Scutellum black, only slightly convex, sparsely punctate. Abdomen dull black, apically nitidulous; post-petiole aciculate, rougher in ot, bicarinate, with apical angles rounded; gastrocaeli sub-circular, large and deeply impressed, intervening space rugose-aciculate; of with genital valvulae normal and the fourth ventral segment not plicate. Legs clear red; coxae and trochanters black, hind tibiae except usually towards their apices, and tarsi, nigrescent. Wings sub-hyaline, stigma fulvous, or testaceous, rarely piceous. Length, I $5^{-1} 7 \mathrm{~mm}$.

This species may at once be known, though it bears a certain resemblance to Ichneumon quaesitorius and I. cessator, by its black scutellum, slender flagellum, the fulvous stigma and legs, as well as by the nodulose and not serrate antennal joints of the 0 . Bridgman noticed the variation in colour of the stigma and in outline of the areola. It is also very similar to Amblyteles camelinus, Wesm., in which, however, the scutellum is strongly elevated.

Undoubtedly quite a common species in Britain; it occurs on shrubs and umbelliferous flowers and has been bred from Vanessa Atalanta, $V$. Io, V. cardui, Argynnis Paphia, Gortyna flavago, Dianthaecia carpophaga, and Hadena oleracea; as well as, on the Continent where it is common extending to northern Africa, from Cucullia absintlai, Nonagria sparganii and Cleorc viduaric. It occurs, commonly, in Norfolk; Essex; about Hastings ; at Plym Bridge, Devon, at the end of June ; and Stephens says it was not uncommon, about London, towards the end of June and beginning of July, and had been also taken in Shropshire and South Wales. I have seen examples, taken by Miss Ethel Chawner in the New Forest; Mr. Hamm, at Shotover, in June; Mr. Beaumont, at Appledore, in September; Mr. F. H. Day, near Carlisle; and Mr. IV. A. Luff, in Alderney. Mr. E. G. J. Sparke has bred it from Ampluydasis betularia, in June, and I reared the female, at Ipswich, from a pupa of Taeniocampa instabilis, in 1893. It gnaws round and entirely removes the capital extremity of its host's chrysalis in a somewhat irregular circle, having spun within and upon it a loose cocoon of coarse grey strands. Mr. F. H. Peachell has also bred the male from the last-named host, in the middle of March, at Weymouth; this example was "forced," which process apparently had a deleterious effect upon it, since the left intermediate tibia is strongly foreshortened, internally emarginate, with the inferior calcar recurved. I have seen an example from St. Albans.

\section{5. plicatus, $s p . n$.}

Black; head anteriorly, mouth parts, callosities at radix, scutellum, margins of four apical segments, ventral fold, tibiae, tarsi and stigma, 
flavous; flagellar joints cylindrical; hypopygium spinate. Length, I4 mm. ot.

This species so exactly bears the facies of C. flavocinctus, Desv., as to require no detailed description. Therefrom it may be known by the following characters:-Duller and slightly narrower. Head not rounded, with longer pilosity behind the eyes; mandibles red or flavous; clypeus flavous; face entirely, or only its orbits, flavous. Flagellar joints short cylindrical, not sub-dentate. Areola not broader than long, apically strongly emarginate; costae weaker. Petiolar carinae normal; thyridii exactly transverse; second and third ventral segments with a strong, bright flavous fold; the ultimate strongly spinate apically, with very large valvulae; second and third dorsal segments immaculate, apical half of seventh flavous. Legs rather shorter ; flavous or fulvous, not stramineousmarked; base of hind tibiae entirely pale, their apices black. Stigma and tegulae fulvous; areolet broader.

Mr. F. W. Sladen has taken two males of this species, one at St. Margaret's Bay, on 3 oth August, I898, and one, with which he has very kindly presented me, at Ripple Court, near Dover, on the preceding day ; I have also seen an example taken, by sweeping, on 25th August, 1901, at Church Stretton, in Shropshire, by Mr. Alfred Beaumont.

\section{Panzeri, Wesn.}

Icluneunon laboratorius, Gr. I. E. i. 3 I7 (nec Fab.), o . (?) I. fumigator, Gr. I. E. i. 537, excll. of et $\&$ stigmate rufo. Amblyteles Panzeri, Wesm. Nouv. Mém. Ac. Brux. 1844, p. I36; Bul. Ac. Brux. 1848, p. 303 ; lib. cit. 1854, p. 132; Berth. Ann. Soc. Fr. 1895, p. 590, ơ \&. Var. Iclmezmon vexillarizes, Tisch. Stett. Zeit. I874, ó.

A very handsome, strongly nitidulous species, with white pubescence. Head black; of of with clypeus transversely, and more or less of face, flavous. Antennae black, with no pale band; of to with flagellum more or less red and scape often flavous beneath, its flagellar joints sub-dentate. Thorax shining, black; of to with pronotum, a callosity before, and often another beneath, the radix, stramineous ; metathoracic spiracles somewhat short; areola sub-quadrate; spines wanting. Scutellum slightly convex; of $f$ stramineous, of $q$ very rarely marked with white. Abdomen brilliant black, with the second and third segments red; the of nearly always has the third to sixth stramineous-margined; seventh immaculate; post-petiole aciculate, broader in $\delta$; gastrocaeli rather large, deeply impressed; no ventral segment plicate. Legs black, with the hind femora rarely castaneous ; ot has front coxae marked with, and tibiae and tarsi except apices of the posterior, white. Wings a little clouded, stigma piceous ; tegulae of of white-dotted. Length, IO-I $4 \mathrm{~mm}$.

Both sexes occasionally have the femora red, or the abdomen entirely black; the varicty vexillarius has the second and third segments black, apically flavous-margined.

In France and central Europe, this is a frequent and most beneficial insect, preying upon the turnip-moth, Agrotis sevetum: its range extends to Algeria. 'There are, however, but few records from Britain ; Marquand mentions it from the Land's End district; Buckler and Bignell have bred it from Agrotis exclamationis, the latter in South Devon, on I Gth July; and Dale records it from Parley Heath, in Dorset. 


\section{7. funereus, Fourc.}

Ichnenmon funerens, Fourc. E. P. ii. 406 ; Gir. I. E. i. 205 ; Ste. Ill. M. vii. I48 ; excl. 8. I. perilencus, Gr. I. E. i. 227 ; Ste. III. M. vii. 152, excl. \&. Amblyteles funereus, IVesm. Nouv. Mém. Ac. I3rux. 1844, p. 136; Bul. Ac. Brux. 1854, p. 131 ; Holmgr. Ichn. Suec. ii. 270 ; Berth. Ann. Soc. Fr. I895, P.591, o \&. Cratichneumon funereus, Thoms. O. E. xix. 2087, of .

A black species with white markings. Head pilose, cheeks and temples a little dilated ; ot with facial orbits and sometines two dots on the clypeus white, rarely entirely black. Antennae somewhat slender, setaceous, black; of $q$ white-banded, of $\delta$ with flagellar joints sub-dentate. Thorax black, of with lines before and beneath radix white; areola quadrate or slightly transverse, hardly emarginate posteriorly; costulae sub-obsolete; apophyses tuberculiform. Scutellum white. Abdomen alutaceous, black; the central segments rarely obscurely castaneous or badious; post-petiole aciculate, bicarinate, apical angles rounded; gastrocacli large and deep, intervening space about as broad as centre of post-petiole, coarsely striolate; no ventral segment plicate. Legs normal, black; anterior legs of $q$ with tibiae and tarsi partly ferrugineous, of of with femora internally and tibiae and tarsi white; hind tibiae of $q$ variable, but usually with a white mark towards the base, of of broadly basally white-banded; coxae immaculate. Wings somewhat clouded; stigma fulvous or piceous; tegulae of to white, sometimes black-margined. Length, I I-I $5 \mathrm{~mm}$.

This species occurs on bushes, in June, and on the flowers of garden carrot, in September; it appears to be widely distributed but not very common on the Continent; the female hibernates among moss. Stephens says it was taken rarely, at Darenth Wood, in July; it is also recorded from Alphington and Bickleigh, in Devon, early in July; Essex; and a single male from Eaton, near Norwich. Mr. Beaumont has a specimen in his collection from Bury St. Edmunds; but it has not yet been bred, though Mr. Bignell possesses a male, received from Ireland, which was "captured hawking over Sesia apiformis."

\section{8. fossorius, Grav.}

Ichneumon fossorius, Gr. Mem. Ac. Sc. Torin, 1820, p. 2 Io, excll. synon. et $\delta$; I. E. i. 164, excll. $\delta$ et var. 3, o ; Ste. Ill. M. vii. I39 (part.). Amblyteles fossorius, Wesm. Bul. Ac. Brux. 1848, p. 301 , $q$; lib. cit. 1854, p. 125, excll. varr. part. ; Holmgr. Ichn. Suec. ii. 262, excl. synon. ; Thoms. Ann. Soc. Fr. 1888, p. I20; Berth. lib. cit. I 895 , p. 587, excl. var. I, o $q$. Var. $I$. pallipes, Gr. I. L. i. 233 , excl. $\$$; I. perileucus, var. I, Gr. lib. cit. 228, q. Var. A. favator, Tisch. Stett. Zeit. IS8I, ó.

Head black, cheeks and temples moderately dilated; facial orbits sometimes white. Antennae somewhat stout, setaceous, black; of $q$ attenuate towards apex, white-banded with the third and fourth flagellar joints subquadrate; of sometimes rufescent beneath, joints sub-dentate. Thorax black, often with a white line below radix; areola transverse or sub-quadrate, rectangular; apophyses wanting; spiracles short. Scutellum white, somewhat convex. Abdomen entirely black; post-petiole aciculate; gastrocaeli and thyridii large, deep and rugose, with the intervening space aciculate; of with the fourth ventral segment not plicate and the hypopygium apically rounded. I.egs black ; femora red, more rarely black, the hind pair somewhat long; posterior tibiae basally stramineous. Wings a little clouded with the stigma red or piceous. Length, $12-17 \mathrm{~mm}$. 
The variety pallipes appears to differ only in having an elongate white patch at the base of the hind femora; var. flavator has the central segments flavous, with their bases ferrugineous.

[Ichneumon amputatorius, Panz. et Grav, has been considered a variety of the present species by authors following Wesmael, and of $A$. uniguthatus, by Tischbein ( $c f$. Stett. Zeit. 1875, p. 274), but it was reinstated as a good species by Thomson. From $C$. fossorius it differs in having the abdomen more or less clear red, and from $C$. divisorius and $C$. messorius in its entirely flavidous hind tibiae, \&c. ; the of, moreover, has the hypopygium apically acute, though not acuminate. I know of no authentic British records of this species.]

$C$. fossorius is a widely distributed and apparently common species on the Continent, where the female is known to hibernate. Stephens says it is abundant about London, in June and July, on flowers, but he probably mixes more than one species under this name. The only at all reliable record I can find is that of Parfitt, who tells us it is common in Devon, where it has occurred in July; I have seen two old males in Bignell's collection and it is recorded also from Essex. It has been bred from Vanessa Antiopa, Leucania lithargyria, Hadena baltica and H. adusta.

\section{9. inspector, Wesm.}

Amblyteles inspector, Wesm. Nouv. Mém. Ac. Brux. 1844, p. I30; Bul. Ac. Brux. I848, p. 300 ; lib. cit. 1849 , p. 40 ; lib. cit. 1854 , p. 123 , $q$; Holmgr. Ichn. Suec. ii. 264 ; Berth. Ann. Soc. Fr. 1895, p. 588, o \&. Ctenichneumon inspector, Thoms. O. E. xix, 2085 , of 오.

Closely allied to $C$. fossorius, from which it primarily differs in the elongate fourth flagellar joint and the usually rufescent central abdominal segments, and, compared with which, the temples of the $q$ are more finely punctate. All the basal flagellar joints are longer, more slender, and sometimes red; in the of the antennae are longer. The apophyses are wanting, the spiracles oval, and the petiolar area of the $q$ is tri-divided; the $\delta$ has the mesonotum more coarsely punctate and less shining; the white scutellum is more sparsely punctate. Abdominal segments two and three more or less red, with a concolorous ventral fold; the $\delta$ has the ventral fold on these segments fulvous with their apical margins fuscous. The shorter and more slender femora, as well as the anterior tibiae and tarsi, are fulvous; the of coxae are more sparsely punctate and shining. Length, II-I4 mm.

The male varies in having the thorax and scutellum rarely black, or the antennae white-dotted above ; its abdomen, too, is sometimes black.

Marshall considered this to be a variety of the preceding insect, and it probably has no right to an individual position in our fauna at present, though somewhat widely distributed on the Continent and not unlikely to occur with us; the female is said to hibernate among moss, but I do not think it has been yet bred.

\section{1o. melanocastanus, Grav.}

Ichnemmon melanocastanus, Gr. Mem. Ac. Sc. Torin, IS20, P. 35I ; I. E. i. 553 ; Ste. Ill. M. vii. 197. Amblyteles melanocastanus, Wesm. Nouv. Mém. Ac. Brux. ISłt, p. I35, excll. varr. I et 2 ; Bul. Ac. Brux. I849, D. 40 ; lib. cit. IS57, p. I31 ; IIolmgr. Ichn. Suec. ii. 267 , excl. synon.; Berth. Ann. Soc. Fr. 1895, p. 58 , o \& . 
A black species, with the abdomen mainly red. Head immaculate, cheeks and temples hardly dilated. Antennae black; of of setaceous, slender, white-banded with the tenth flagellar joint sub-quadrate; of $\delta^{t}$ with the basal flagellar joints sub-dentate. Thorax black, rarely with a white callosity at radix of $\delta$; metathorax punctate; areola sub-quadrate; costulae wanting; apophyses obsolete. Scutellum black. Abdomen elliptical, badious or castaneous with first and base of second segment black, sometimes with first five or six segments infuscate or black-marked, rarely entirely black in \$ ; post-petiole aciculate; gastrocacli somewhat large and oblique, with the intervening space roughly striolate; of with fourth ventral segment not plicate. Legs normal, black; anterior femora, tibiae and tarsi, and sometimes all the femora in part, red or castaneous. IVings sub-hyaline, stigma testaceous or piceous; tegulae nigrescent. Length, II-I $4 \mathrm{~mm}$.

This is a widely distributed species on the Continent, and is probably not uncommon in Britain. Gravenhorst tells us Hope took it, about Netley, and that it is to be found, upon shrubs, in July. It used to be taken, in June, at Coombe and I)arenth Woods, and Stephens also records it from the New Forest, where it has recently been captured by Miss Chawner. The species is said to have been bred from Taeniocampa cruda, Cucullia chamomillae and Dianthaecia cucubali; its female passes the winter in the perfect state.

\section{II. repentinus, Grav.}

Ichneumon repentinus, Gr. Mem. Ac. Sc. Torin, I 820 , p. 334 ; I. E. i. 467 , o o; Ste. III. M. vii. 189. Amblyteles repentinus, Wesm. Bul. Ac. Brux. 1857, p. 403; Voll. Pinac. pl. vii. fo 8 ; Berth. Ann. Soc. Fr. 1895, p. 584, o o. A. melanocastanis, var. 2, Wesm. Nouv. Mém. Ac. Brux. I 844 , p. 135 ; Holmgr. Ichn. Suec. ii. 267, synon. $\delta$ ? Ctenichneumon repentimus, Thoms. O. E. xix. 2086, ơ o. Var. Ichneumon menstrualis, Gr. I. F. i. 532 , o.

Very like C. melanocastamus, from which it may be known by the antennae of the $q$ having all the flagellar joints longer than broad; of the $t$ not distmctly serrate and somewhat slender. Thorax black, with usually two pale callosities at radix ; mesonotum strongly punctate and somewhat dull. Scutellum, at least towards its apex, white. Abdomen castaneous, basally black; post-petiole not or hardly transverse. Legs black, front femora and tibiae apically or internally stramineous; hind tibiae more or less rufescent basally or throughout. Length, IO-14 $\mathrm{mm}$.

The variety menstrualis has the three basal segments, as well as the dorsum of the fourth and fifth, black.

This species is common on the Continent, where the female hibernates; Stephens records it from Norfolk, but is not quoted by Bridgman in his county list.

\section{2. mesocastanus, Grav.}

Ichneumon mesocastanus, Gr. Mem. Ac. Sc. Torin, 1820, p. 334 ; I. E. i. 469 , 8. Amblyteles mesocastanus, IVesm. Nouv. Mém. Ac. Brux. 1844, p. 135; Bul. Ac. Brux. I 855 , p. 409 ; Holmgr. Ichn. Suec. ii. 266 ; Berth. Ann. Soc. Fr. 1895, p. 589, $\delta$ $\$$ Ctenichneumon mesocastames, Thoms. O. E. xix. 2087, ơ ‥ Var. Ichneemnon vespertimus, Christ, Hym. 342, pl. xxxiv., f. 5 ; Gr. I. I. i. 234 ; Ste. Ill. M. vii. 154, o ; Wesm. Mém. couron. Ac. Belg. 1859, p. 27. I. nitens, Gr. I. E. i. 476, 9 .

A red and black species, clothed with whitish pubescence. Head narrowed behind the eyes, black; of with facial orbits often pale. An- 
tennae setaceous, black; of $q$ stoutish, white-banded, flagellar joints four and five quadrate; of $\delta$ with flagellar joints sub-dentate. Thorax black, sometimes with a white line beneath, and in of another before, the radix; pronotum hardly striolate; metathorax roughly punctate; areola quadrate or transverse ; costulae sub-obsolete ; apophyses entirely wanting ; spiracles sub-oval, not elliptic. Scutellum, at least in part, white. Abdomen black with segments two to four or five red; both sexes rarely have the abdomen, except the basal segment, entirely red; basal four segments of $q$ strongly punctate; post-petiole aciculate, with its spiracles rotund; gastrocaeli rather large and deep, the intervening space aciculate-punctate; fourth ventral segment of $o$ not plicate. Legs black; tibiae of $q$ internally flavous; of with front femora, tibiae and tarsi, mainly stramineous and the hind tibiae externally marked with white at the base. Stigma nigrescent. Length, Io-I $4 \mathrm{~mm}$.

The variety vespertinus has the abdomen black, with the second and third segments only narrowly red-margined, and the tegulae with a white dot.

This species is not uncommon on the Continent, where it is found in August, on umbelliferae, and has been bred from Caradrina cubicularis and Trichiura crataegi; the female hibernates. I am not, however, aware that it has been found in Britain since the very doubtfully authentic record of Stephens, who says he obtained it from Donovan's collection, but knew nothing regarding its history.

\section{3. messorius, Grav.}

Ichneumon messorius, Gr. Mem. Ac. Sc. Torin, I820, p. 345 ; I. E. i. 529, excl. $\delta$. Anzlyteles messorizus. WVesm. Nouv. Mém. Ac. Brux. I844, p. I34; Bul. Ac. Brux. 1854, p. I30, ơ \&; $f$. Mém. couron. Ac. Belg. I859, p. 64; IIolmgr. Ichn. Suec. ii. I6I ; Berth. Ann. Soc. Fr. I895, p. 586, of क. Ctenichneumon messorius, Thoms. O. E. xix. $2085, \delta$; .

A little smaller and narrower than the following species, the body clothed with brownish pubescence. Head black, somewhat narrowed behind the eyes. Antennae rather slender, rufescent beneath; of of white-banded, with the third flagellar joint longer than broad; of of black, with the joints sub-dentate. Thorax black, with a white callosity beneath the radix; areola sub-quadrate, apophyses wanting. Scutellum white. Abdomen black, second and third segments immaculate red, except only the latter rarely in the ${ }^{*}$; first and fourth segments also occasionally for the most part red; anus immaculate; post-petiole aciculate; gastrocaeli and thyridii somewhat large and deeply impressed, with the intermediate space aciculate; ventral segments two and three with a dark longitudinal apical fold; hypopygium of the of not apically acuminate. Legs normal, black; tibiae red or piceous, front ones internally flavous and the posterion apically or entirely black. Wings somewhat flavescent-hyaline, stigma fulvous or ferrugineous. Length, $12-15 \mathrm{~mm}$.

This species may be known from $C$. divisorius by the more slender antennae and immaculate central segments of the $q$, and the $\sigma^{*}$ by its less strongly serrate flagellum, of which the second joint is not produced as in ampututorius. The $q$ usually has a callosity beneath the radix, and the angles of the pronotum, white; the of occasionally a mark before the radix also pale. 
This species occurs on flowers of Anrelica sylerestris, in August and September; Bridgman found it, at Earlham, near Norwich, and Marquand records it from the Iand's End district; Benumont took it at Plumstead; in the British Museum is an example named by Desvignes, taken in "Suffolk," by Fred Smith; Essex. It does not appear to be uncommon on the Continent, but has not been yet bred.

\section{I4. divisorius, Grav.}

Ichnezmon divisorius, Gr. Mem. Ac. Sc. Torin, I820, p. 335 ; I. E. i. 470 ; Ste. Ill. M. vii. 189, o. Amblyteles divisorius, Wesm. Nouv. Mém. Ac. Brux. 1844, p. 133; Bul. Ac. Brux, I854, p. 127 ; Holmgr. Ichn. Suec. ii. 258 ; Berth. Ann. Soc. Fr. 1895, p. $585, \delta$ o. Ctenichneumon divisorius, Thoms. O. E. xix. 2084, $\delta$ q. Var. Ichneunon edtictorizus, Gr. I. E. i. 228 ; Ste. Ill. M. vii. I52 ; Wesm. Nouv. Mém. Ac. Brux. I844, p. $218, \delta$.

Head black, a little narrowed behind the eyes and towards the mouth; frons with two slight depressions; of with facial orbits white. Antennae rather stout, black; of $q$ strongly attenuate, white-banded with third flagellar joint sub-quadrate; of $\delta$ with the basal flagellar joints subdentate. Thorax stout, black; callosity beneath, and in of before, the radix generally white; mesonotum punctate and shining; metathorax rugulose-punctate ; areola, especially of $t$, transverse, apically entire ; costulae wanting; petiolar area tri-divided ; apophyses sub-obsolete; spiracles sub-linear. Scutellum white. Abdomen elongate-elliptic, black; segments two and three pale red, with their apical margins nearly always black; anus immaculate; post-petiole aciculate, laterally rounded, carinae distinct, apical angles obtuse ; gastrocaeli and thyridii large, deep and rugose, with the intervening space about as broad as centre of post-petiole, aciculately rugose ; ventral segments two and three with, but fourth without, a fold; hypopygium of ot not apically acuminate. Legs normal, black; femora somewhat stout, those of $\delta$ more or less white internally; front tibiae of $q$ within, and the posterior, more especially of 5 , broadly banded in the centre with, white; of with tarsi pale, the posterior becoming apically piceous. Wings a little clouded and flavescent; stigma fulvous, ferrugineous, or rarely darker. Length, $15^{-1} 7 \mathrm{~mm}$.

The colour of the legs is somewhat variable, since the of occasionally has the external base of the hind femora white-marked; and the hind tibiae of the $q$, sometimes immaculate, are rarely as broadly white-banded as are those of the $\delta$. Both sexes may have the central segments fuscocastaneous.

The variety edictorius is abundantly distinct in colour, having the abdomen entirely black, or sometimes the central segments narrowly margined with red; the tibiae also are broadly white-banded. It is said to occur in May, but Stephens calls it very rare about London,

From C. amputatorius, Panz., this species differs in its elongate metathoracic spiracles and its smaller antennal scrobes, as well as in the colour of its legs; and from C. lissonotus, Holmgr., in the aciculate base of the second segment, white-marked hind legs, and simply punctate mesonotum.

This is undoubtedly quite a common species in Britain, though I can find no records since Stephens said it was uncommon, in June, near London. Miss Chawner has taken several examples in the New Forest; Rev. A. Thornley several at Mablethorpe and Tiddlethorpe, in Lincs., and 
Torksey on Trent, all in June; Walker records it from the Isle of Man ; Tuck has found it late in September, in Finborough Park, in Suffolk; Iuff in Alderney; Hamm at Wellington College, in Berks., in August, and Shotover, near Oxford; Sladen at St. Margaret's Bay, in July ; Essex ; and the males have occurred to me upon several occasions, always early in August, at Foxhall and Bramford, near Ipswich, on flowers. On the Continent, where it is common upon umbelliferae and Euphorbiae, in June, and upon shrubs, in August, it is widely distributed and extends to Algeria. It is said to have been bred from Nonagria sparganii and Hadena adusta.

\section{I5. haereticus, IVesm.}

Ichneumon melanogaster, var. I, Gr. I. E. i. 210 ,. . Amblyteles haereticus, Wesm. Bul. Ac. Brux. 1854, p. I20; lih. cit. I857, p. 40I, q ; Kriech. Ann. K. K. nat. Ilofmus, I888, of; Berth. Ann. Soc. Fr. I895, p. 596, of $q$.

Head slightly narrower than thorax; $q$ with cheeks broad, face and clypeus coarsely punctate, the former produced dentately between the scapes, internal orbits sometimes pale; of with facial orbits white. Antennae somewhat slender, setaceous, apically attenuate; of $q$ white-banded with the ninth flagellar joint quadrate. Thorax somewhat shining, black with a callosity beneath, and in of a line before, the radix usually white or flavidous; areola rectangular, slightly broader than long, apically truncate; costulae and apophyses wanting; coxal area entire ; spiracles linear. Scutellum stramineous, hardly convex, sparsely punctate. Abdomen subobtuse, of ot broad-elliptical, dull black; segments two and three very finely and closely punctate, sometimes badious; remainder immaculate, smooth and nitidulous; post-petiole aciculate; gastrocaeli deep, rugose, somewhat large, and as broad as the aciculate intervening space; fourth ventral segment not plicate. Legs normal, black; of $q$ with anterior femora and tibiae internally stramineous, of of with the anterior and often the base of the posterior tibiae ferrugineous. Wings somewhat flavescent, stigma fulvous; radix and tegulae black, of of flavous-marked. Length, I4-I $6 \mathrm{~mm}$.

The female very strongly resembles that of Amblyteles indocilis in general cutline and colour, but the anus is immaculate and, in the example in my collection, the sculpture of the thorax and base of the abdomen is much stronger.

This species is found in central Europe and has not before been recorded from Britain; it preys upon V anessa urticae and Agrotis comes. Miss Chawner has kindly given me a female which she captured recently in the New Forest.

\section{I6. flavocinctus, Desv.}

Ichneumon favocinctus, Desv. Cat. 22. 8. Amblyteles favocinctus, Bridg. Trans. Int Soc. 1881, p. 144; Berth. Ann. Soc. Fr. 1895, p. 653, o. (?) A. albomarginatus, Kriech. Ent. Nachr. I878; Besth. Ann. Soc. V'r. 1895, p.622, $\delta$.

A finely punctate, yellow and black species. Head black, rounded behind the eyes; internal orbits and a broad, sinuate, often incomplete line on the sub-truncate clypeus, the palpi and labrum, flavous; mandibles bidentate. Antennae somewhat stout, apically attenuate, internally somewhat strongly scrrate especially towards the base, about half length of the 
body; black, fulvous with scape usually flavous beneath. Thorax black with lines before and beneath radix, and usually the post-scutellum flavous; areola usually twice broader than long, basilly narrowed, apically truncate, laterally curved; costae strong ; petiolar area tri-divided ; apophyses tuberculiform, spiracles linear. Scutellum slightly convex, entirely flavous. Abdomen somewhat slender, black ; segments three to six with apical margins pale flavous, the second often with an apical longitudinal flavous line; seventh immaculate; post-petiole centrally aciculate, carinae strong, somewhat elevated ; gastrocaeli large and deeply impressed ; thyridii distinctly oblique; intervening space aciculate, about as broad as centre of postpetiole ; second segment elongate, remainder transverse ; second segment only bearing a concolorous fold, the ultimate apically rounded and depressed; genital valvulae black. Legs normal, black; anterior coxae sometimes pale, their femora internally ferrugineous, apically stramineous; tibiae and tarsi stramineous, hind tibiae at base and apex black. Wings hyaline; tegulae white; stigma black or piceous; areolet pentagonal, narrowed above. Length, I3-14 mm. q unknown.

The clypeal line is sometimes replaced by two pale dots and the hind tarsi are occasionally nigrescent.

From C. plicatus, Morl., it may at once be known by its sub-dentate flagellar joints and simply rounded hypopygium.

There is little doubt, from the description of Berthoumieu, that $A$. albomarginatus, which is only recorded from Hungary, is a synonym of the present species; it appears to differ only in its pale-marked posterior coxae, the basal, and sides of the two following segments.

Var. rufescens. I have found, in Dr. Capron's collection, a very distinct form of this species, which I propose to distinguish by the above name. From the entirely black and pale flavous type form it differs materially in colour. The whole of the second segment and the third except centrally at the base are brightly rufescent, all the femora are red above and the posterior tibiae slightly tinged towards their apices with the same colour. No locality is indicated, but it is certainly British and probably from Shiere, in Surrey.

Desvignes mentions no locality for his species, but it is recorded from Glanvilles IVooton, Essex, the Hastings district, and Mr. W. F. Sladen has taken it, at Ripple, near Dover, towards the end of July.

\section{SPILICHNEUMON, Thomson.}

Thoms. O. E. xix. (1894), 2087.

Mandibles bidentate. Pronotum hardly striolate laterally; mesosternal epicnemia entire. Scutellum white. Abdomen centrally red; apical segments black with white markings; thyridii and gastrocaeli small ; ventral segments two and three, rarely also four, plicate; hypopygium large, nearly concealing terebra, of ot spinately produced or laterally obviously sinuate. Hind femora black; tibiae spinulose; tarsi and their claws stout. Wings with stigma and nervures usually pale; areolet pentagonal.

This genus is further rendered distinct by the elongate body resembling at least in the that of the Ichneumon extensorius group, finely striate post-petiole of the $q$, weak metathoracic costae, elongate or sub-quadrate areola; the face of the male is entirely or partly flavous. The only species 
of the next genus which can be confused with it are $A$. vadatorius, whose areola is much shorter, and $A$. negatorius, whose areola is also short, with head black.

\section{Table of Species.}

(2). I. Head obliquely narrowed behind; fifth segment not white

(I). 2. Head not obliquely narrowed behind; fifth segment white-marked.

(4). 3. Mandibles stout; apical segment margined with white.......................

(3). 4. Mandibles slender; apical segment marked with white.

(6). 5. No white line beneath radix; six and seven segments apically white.........

(5). 6. Line beneath radix white; six and seven

segments dorsally white ............. 4. SEPTEMGUTtatus, Grav.

I. FABricil, Grav.

2. OCCISORIUS, Fab.

3. Gravenhorsti, Wesm.

\section{Fabricii, Grav.}

Ichnennon Fabricii, Gr. I. E. i. 616, o; cf. Wesm. Mém. couron. Ac. Belg. I859, p. 77. I. melanocerus, Wesm. Bul. Ac. Brux. 1855, p. 377, o. Amblyteles Fabricii, Tasch. Zeits. Ges. Nat. I870; Berth. Ann. Soc. Fr. I895, p. 640, o. Ichneumon iuticularis, Desv. Cat. I5; Morl. E. M.M. 1902, p. I22, ơ 9.

․ A bright, red and black species. Head obliquely rounded behind the eyes and narrowed towards the mouth; mandibles bidentate; clypeus somewhat convex, finely punctate and apically truncate ; frontal orbits red or white. Antennae slender, setaceous, black. Thorax entirely black; areola rectangular, longer than broad, apically emarginate. Scutellum flat, shining, black. Abdomen sub-cylindrical, not strongly obtuse apically, nitidulous, black; segments two and three, the base of fourth and usually apex of first, castaneous-red ; sixth and seventh white-marked; post-petiole aciculate; gastrocaeli small, triangular; second segment strongly and somewhat closely punctate, the following becoming smoother apically. Legs normal, black; tibiae, except front ones externally and the posterior at their apices, and the tarsi, red; femora sometimes in part also red. Wings a little clouded; stigma piceous or ferrugineous, tegulae black; areolet pentagonal. Length, $8 \mathrm{~mm}$.

o. Head obliquely narrowed behind the eyes and towards the mouth, transverse with the vertex narrow; frons evenly, face closely, and clypeus sparsely punctate; clypeus not separated, apically truncate; black, internal orbits, angles of clypeus, and the mandibles except their apices, flavous; palpi fulvous. Antennae setaceous, hardly thickened centrally, black throughout. Thorax finely punctate, shining, black; callosity before the radix and the pronotum flavous; areola sub-quadrate; costulae entire; apophyses wanting. Scutellum flat, sparsely punctate and, except extreme base, flavous. Abdomen cylindrical, dull, somewhat flattened dorsally, not very fincly punctate, incisures deeply impressed; black with segments two to four, and sides of the fifth at the base, red; seventh nearly entirely, sixth with a minute apical central dot, white; post-petiole coarsely aciculatepunctite, carinae strong ; gastrocacli normal, deep), striate, with intervening space punctate and slightly marrower than centre of post-petiole; ventral segments two to four plicate; valvulae small, retracted; ultimate segment neither sinuate nor produced. Legs piceous, front femora at apex and 
their tibiae internally flavous. IVings hyaline; tegulac and stigma piceous, the former with an anterior flavous dot; areolet pentagonal. Length, $9 \mathrm{~mm}$.

The broad gastrocaeli and simplé apical ventral segment appear to ally this of strongly with species of the preceding genus, but its large apical, and plicate fourth ventral segment, basally smoothly punctate second segrment, \&c., justify the position here assigned to it. It is closely related to Amblyteles truncicola, Thoms. (cf. O. E. xxi. 2404), but the gastrocaeli are larger, the metanotal areae complete, scape immaculate, \&c.

$I$ have described the sexes of this species separately, because the male has previously been but insufficiently noticed by Desvignes, and even now some doubt must be entertained concerning their relationship.

Desvignes, upon whose authority alone this species finds a place in our fauna, indicates no locality for the examples in the British Museum, which would not appear to be from Curtis' collection.

\section{2. occisorius, $F a b$.}

Ichnezmon occisorizs, Fab. F. S. ii. I42; 1'iez. 6r ; Gr. I. E. i. 389 , o. Amblyteles occisorius, Wesm. Nouv. Mém. Ac. Brux. I844. p. I22 ; Bul. Ac. Brux. I848, p. 296 ; lib. cit. I849, p. 40 ; lib. cit. IS54, p. I00 ; Ilolmgr. Ichn. Suec. ii. 233 ; Voll. Pinac. 43, pl. xxvii., ff. I, 2 ; Thoms. Ann. Soc Fr. 1888, p. II8; Berth. lil. cit. I895, p. $645, \delta$ \&. Iihneumon sangumatorius, (ir. I. L. i. 295, \& (sic o) ; Ste. Ill. M. vii. 164. I. maryinatorius, Panz. F. G. Lxviii. I4, o. Spilichneumon occisorizes, Thoms. O. E. xix. 2089, ơ + .

Head black, cheeks and temples a little dilated; oral costa strongly elevated; mandibles stout, obtuse, pale, bidentate with the lower tooth the longer ; palpi pale; frons with a small dentation between the scapes; of with clypeus apically angulated and with face entirely or partially flavous; $q$ with frontal orbits usually rufescent. Antennae black; of $q$ incrassate, apically attenuate, white banded with the flagellar joints moniliform, of which the second is quadrate; ot with the flagellum sub-cylindrical, and the scape usually flavous beneath. Thorax black with a line beneath and sometimes before the radix, and rarely the pronotum, flavidous; areola sub-quadrate, longer in $q$, rectangular; costulae obsolete ; apophyses wanting. Scutellum stramineous. Abdomen sub-cylindrical, black; segments two and three red in o , generally flavous with or without black markings in $\delta^{\text {* }}$; fourth to sixth with apical margins, and the seventh distinctly marked with, white in $q$, and flavous in $\delta$; post-petiole aciculate apically closely punctate, of $q$ sub-coriaceous; gastrocaeli normal but superficial ; fourth ventral segment of of plicate, and the ultimate strongly spinate; genital valvulae black. Legs somewhat stout, black; tibiae and tarsi spinulose and, except apices of the posterior, red; front femora often apically red. Wings a little clouded; stigma fulvous, tegulae sometimes flavous; areolet narrowed above. Length, I I-I $6 \mathrm{~mm}$.

The of rarely has the central segments entirely or dorsally black, or the face and scutellum and abdomen black, with only the two apical segments flavous-marked; Holmgren enumerates twelve distinct varieties of the 0 , running from face and second and third segments entirely flavous to entirely black.

Ichneumon ammonius of Gravenhorst, recorded as British, by Stephens, is considered a variety of this species by Marshall, of S. limnophilus, Thoms., 
by that author, and as a good species by Kriechbaumer; the cheeks are more strongly dilated, the antennae basally ferrugineous, and the fourth and fifth segments are not margined with white.

This is a common species in Britain; Gravenhorst tells us it occurs in August and September, and that Hope took both sexes about Netley; Stephens records it not uncommonly about London and in Salop, in July. It is common in Norfolk and Essex; Professor J. IV. Carr has sent me specimens to name, from Arnold, near Nottingham, and Mr. Beaumont has found it at Stretton, both in the middle of August; Mr. Wainwright, in Wyre Forest, in the middle of September; Mr. Hamm, at Streathy; Mr. Chitty, both sexes at Huntingfield, in August; Mr. Sladen, at Ripple, near Dover, also in September, and Mr. Piffard, at Felden, in Herts. I have only met with the female during hibernation, in tufts of Aira caespitosa, at the Bentley Woods, near Ipswich, in April. It is common on the Continent, where it has been bred from Gortyna flavago; Mr. Adkin has also bred the female in Britain, from Odonestis polatoria, Linn.

\section{Gravenhorsti, Wesm.}

Ichneumon extensorius, Gr. I. E. i. 266, excl. \& (nec Linn.). I. Gravenhorsti, Wesm. Bul. Ac. Brux. I836, pp. 337-34I (gynandromorph.). Amblyteles Gravenhorsti, Wesm. Nouv. Mém. Ac. Brux. I844, p. 127 ; Bul. Ac. Brux. 1848, p. 297 ; lib. cit. I854, p. 100, o o. A. Gravenhorsti, Holmgr. Ichn. Suec, ii. 230 ; Berth. Ann. Soc. Fr. 1895, p. 643, of \&. A. raptorius (? Linn. S. N. ed. x. 1758, 561), Thoms. Ann. Soc. Fr. I888, p. II8. Spilichnetunon raplorius, Thoms O. E. xix. 2088, o

A handsome, elongate species. Head black, temples somewhat buccate; oral costa not elevated; mandibles bidentate, short and slender, those of of as well as the apically truncate clypeus in its centre, and usually too the middle or sides of its face, flavous. Antennae somewhat slender, setaceous, black; of $q$ white-banded with the basal flagellar joints filiform, of which the sixth is quadrate; of of with scape white beneath. Thorax black with a white line before the radix; areola semi-elliptic, a little longer than broad; costulae and apophyses obsolete. Scutellum white. Abdomen black, of of sub-cylindrical; the second and usually the third segments entirely red, the remainder apically white-marked; post-petiole aciculate; gastrocaeli obsolete; third segment of of quadrate; fourth ventral not plicate; hypopygium of of always short, laterally sinuate but not apically acuminate. Legs normal, black; tibiae and tarsi, except apices of the posterior, and whole of $q$ front femora, red. Wings flavescent with stigma fulvous ; t with tegulae usually white-marked. Length, I $2-16 \mathrm{~mm}$.

I have, in spite of Thomson's protestation, provisionally retained Wesmael's name for this species as being that in general use, but it would appear probable that that of Limnaeus, whose description I have not seen, will eventually have to be adopted.

This is not an uncommon species on the Continent, where it is widely distributed; Holmgren found the female beneath the bark on a dead tree, and the males referred to, collecting socially in autumn beneath oak bark, by Gravenhorst were almost certainly females too. It has been lored from Lencania vilellina, Gorlyna flavaryo, and Cucullia Santonici. In liritain, as far as I am aware, it is recorded only from Devonshire, where this 
pretty insect is widely distributed but not common, and from Guestling near Hastings.

\section{4. septemguttatus, Grav.}

Ichnemmon septemgruttatus, Gr. I. E. i. 320 ; Ste. III. M. vii. 169; Wesm. Nouv. Mém. Ac. Brux. 1844, p. 47, o. Amblyteles seplengultatus, Thoms. O. E. xii. I 234 (nec Kriech.) ; Berth. Ann. Soc. Fr. 1895, p. 644, o \&. A. Wesmaeli, Tisch. Stett. Zeit. 1868, $\%$.

Closely allied to the last-described species. Head somewhat narrowed behind the eyes, black; mandibles bidentate, slender; of with palpi, sides of face, and sometimes the angles of the truncate clypeus, white. Antennae setaceous, black; of $q$ white-banded with the eighth flagellar joint quadrate; scape of $f$ white beneath, Thorax black with white lines before and beneath the radix; areola semi-elliptic, a little longer than broad; costulae obsolete. Scutellum white. Abdomen closely and finely punctate, of $q$ elliptic, of of sub-linear, black; segments two and three clear red or, of $\delta$, flavescent; five to seven and sometimes the fourth broadly white-margined; the third of of transverse, black-marked; postpetiole aciculate; gastrocaeli small; fourth ventral segment of $\delta$ plicate. Legs normal, black; tibiae and tarsi, except apices of the posterior, and part of the front femora, red; hind tibiae of of sometimes flavous. IVings flavescent, stigma fulvous. Length, I 2- I $5 \mathrm{~mm}$.

Extremely similar to the preceding; Thomson says the sculpture, size, colour, etc., are nearly identical, but that the front femora beneath, and the intermediate at the base, are more broadly black, the fifth segment has an apical line, the sixth a dorsal mark, and the seventh is a little more broadly, white.

This species occurs in France and Germany, in June. Stephens says it is very rare, near London, and no subsequent observers appear to have noted it.

\section{AMBLYTELES, Wesmael.}

IVesm. Nouv. Mém. Ac. Brux. 1844, pp. I I I, I I 2 ; Thoms, O. E. xix. (I894), 2090.

Head usually somewhat small ; mandibles bi- or uni-dentate; clypeus apically truncate. Antennal flagellum of of not crenulate. Pronotum often anteriorly pale, generally inferiorly striolate; mesosternal epicnemia interrupted above. Gastrocaeli and thyridii usually small, not broader than the never strongly sculptured but usually smoothly punctate intervening space; second, third and often the fourth ventral segments plicate. Tarsi setose beneath.

\section{Table of Species.}

(34). I. Apophyses small or tuberculiform; mandibles bidentate (PSEUDAMBLYTELES, As/lmm.).

(3). 2. Central segments strongly punctate, entirely castaneous .................

(2). 3. Central segments finely punctate, not castaneous though often red.

(I7). 4. Apophyses small, acute; ventral segments two to four plicate.

(14). 5. Apical segments not white-margined; ô hypopygium not acuminate. 
(I I). 6. Post-petiole black ; hypopygium of of not laterally sinuate.

(10). 7. Abdomen not centrally red.

(9). S. Gastrocaeli small ; cheeks black ...

(S). 9. Gastrocaeli normal ; cheeks pale...

(7). Io. Abdomen centrally red

(6). II. Post-petiole pale; hypopygium of of laterally sinuate.

(13). 12. Mandibles bidentate; femora black

(12). 13. Mandibles sub-unidentate; femora fulvous

(5). If. Apical segments white-margined; $\hat{\sigma}$ hypopygium acuminate apically.

(I6). 15. Head posteriorly truncate; hind femora fulvous

(I 5). I6. Head posteriorly not truncate; hind femora black..........................

(4). 17. Apophyses tuberculiform, sub-obtuse; ventral segments two and three at most plicate.

(27). I8. Basal half of flagellum pale, at least beneath.

(20). 19. Areolet sub-deltoid; fourth ventral segment of of plicate ...............

(19). 20. Areolet pentagonal; fourth ventral segment not plicate.

(26). 21. Hind femora pale; hypopygium of $\delta$ acuminate, of $q$ not concealing terebra.

(23). 22. Second segment immaculate.........

(22). 23. Second segment pale-marked.

(25). 24. Flagellum basally entirely flavous, of $q$ not banded

(24). 25. Flagellum basally black above, of o white-banded

(21). 26. Hind femora black; hypopygium of $\delta$ shortly acuminate, of $q$ concealing terebra ......................

(1S). 27. Basal half of flagellum not entirely pale, rarely rufescent beneath.

(29). 2S. Frontal orbits and all the tarsi clear red .................................

(28). 29. Frontal orbits and the tarsi not entirely red.

(3I). 30. Areola transverse ; central segments mainly red.

(30). 31. Areola quadrate; central segments not red.

(33). 32. Abdomen oval or elliptic ; legs not red

(32). 33. Abdomen sub-linear; legs clear red

(1). 34. Apophyses stout and often large ; mandibles sometimes unidentate (AMIDLYTELES, auctt.).

(45). 35. Mandibles bidentate; hypopygium of not acuminate.

(45). 36. Scutellum pale; abdomen finely punctate, not entirely red apically.
2. PALliatorius, Grav.
3. TRIFASCIATUS, Grav.
4. Litigiosus, Wesin.

5. CRISPATORIUS, Limn.

6. equitatorius, Panz.

7. ATRATORIUS, Fab.

8. QUADRIPUNCTORIUS, Mïll.

9. MONITORIUS, Panz.

Io. GLAUCATORiUs, Fab.

II. PALLIDICORNIS, Grav.

12. VADATORIUS, Illig.

I3. Amatorius, Müll.

I4. CERINTHIUS, Grav.

15. NEGATORIUS, Fab.

16. INDOCILIS, Wesm.

I7. SUBSERICANS, Grav. 
(40). 37. Central segments broadly flavous; antennae not banded.

(39). 38. Apophyses large; fourth ventral segment of ơ plicate

(38). 39. Apophyses normal; fourth ventral segment of to not plicate .........

(37). 40. Central segments not broadly flavous; antennae usually whitebanded.

(44). 4I. Tibiae broadly pale-banded.

(43). 42. Coxal area indistinctly discreted ; tibiae white

(42). 43. Coxal area distinctly discreted; tibiae flavidous ......................

(4I). 44. Tibiae not pale-banded ................

(36). 45. Scutellum black; abdomen strongly punctate, apically red ..............

(35). 46. Mandibles unidentate; hypopygium of $\sigma^{*}$ acuminate.

(48). 47. Metathorax not emarginate at base of apophyses ........................

(47). 48. Metathorax emarginate at base of apophyses ..........................
I8. ARMATORIUS, Forst.

19. INFRACTORIUS, Panz.

20. ORATORIUS, Fab.

2I. MARGINEGUTtATUS, Grav.

22. MICROCEPHALUS, Steph.

23. Castanopygus, Steph.

24. Uniguttatus, Grav.

25. CONSPURCATUS, Grav,

\section{r. punctus, Grav.}

Ichneamon punctus, Gr. I. E. i. 323 , ơ ; Ste. Ill. M. vii. I69; Wesm. Nouv. Mém. Ac. Brux. I844, p. 49, of क ; $c$. Thoms. Ann. Soc. Fr. I886, p. 23. I. deceplor, Gr. I. E. i. 332, + , excll. varr. et $\delta$; Ste. III. M. vii. I7o (part.). Amblyteles punctus, Thoms. O. E. xix. 2091 ; Berth. Ann. Soc. Fr. I895, p. 648, o \&. Var. I. leucomelas, Gr. I. L. i. 255 , excl. $q$; of. Wesm. Mém. couron. Ac. Belg. 1859, p. 29.

A distinctly slender species. Head narrowed behind the eyes, black with the internal orbits of the $\delta$, and sometimes the frontal of the $q$, white; mandibles bidentate, those of 0 and the angles of the clypeus sometimes white. Antennae somewhat slender, setaceous; of $q$ whitebanded; of of with scape white beneath. Thorax black with usually the pronotum and, in $\hat{\sigma}$, dots before and beneath the radix white; areola transverse or sub-quadrate, costulae obsolete. Scutellum white. Abdomen elliptic, strongly punctate; black with the first three, and base of fourth, segments dark red; five to seven white-marked, post-petiole strongly aciculate; gastrocaeli somewhat small and deeply impressed; fourth ventral segment of $o$ plicate, fifth of $q$ shorter than the apical. Legs somewhat slender, black; tibiae, except apices of posterior, and sometimes all the femora, red; front tibiae of of flavous. Stigma piceous or ferrugineous. Length, I $2-15 \mathrm{~mm}$.

This species is included in Marshall's catalogues in the genus Ichneumon, from which the $q$ may be known by the relative length of its apical ventral segment and by its obtuse anus. Thomson in "Annales" says it is related to Ctenichneumon melanocastanus in the form and sculpture of the abdomen and not spirally contorted antennae, but in "Opusc. Ent." he retains it in his genus Amblyteles.

It occurs in central and northern Europe, where it has been bred from Caradrina Kadenii, on flowers in July; but it would appear to be very rare in Britain, having once been found near London and once taken at 
Horrabridge, in Devon, by Bignell, at the end of June ; Gravenhorst says Hope took the female, at Netley.

\section{2. palliatorius, Grav.}

Ichneumon palliatorizes, Gr. I. E. i. 385 ; Ste. Ill. M. vii. 177, \& $q$. Amblyleles palliatorius, Wesm. Nouv. Mém. Ac. Brux. I844, p. II ; Bul. Ac. Brux. I854, p. 82 ; Holmgr. Ichn. Suec. ii. 214 ; Voll. I'inac. pl. vii., ff. 4, 5 ; Thoms. Ann. Soc. Fr. I888, p. I12 ; Berth. lib. cit. I895, p. 618 ; Thoms. O. E. xix. 2092, o \&. A. aequivocus, 'Tisch. Stett. Zeit. 1879, o. Ichnetumon gemmatus, Tisch. lit. cil. 1881, ठ. Var. I. erythropygus, Gr. I. E. i. 381 ; Ste. Ill. M. vii. I77, o. Var. I. defensorius, Gr. I. E. i. 408 ; Ste. Ill. M. vii. I8I; Wesm. Mém. couron. Ac. Belg. 1859, p. 49; \&c. ; ठ. Var. I. ochraceus, Tisch. Stett. Zeit. 1873; I. laelus, Tisch. lib. cit. 1881, J. Var. $A$. spoliator, Wesm. Nouv. Mém. Ac. Brux. 1844, p. I17; Bul. Ac. Brux. 1854, p. 83, \&; Holmgr. Ichn. Suec. ii. $216, \delta$ \%

Head black, a little narrowed behind the eyes, of of with piceous pubescence; cheeks immaculate; mouth parts ferrugineous, frontal orbits flavous or red; f with palpi, mandibular mark, clypeus, face except rarely its centre, and sometimes a line at the external orbits, flavous; mandibles bidentate and somewhat slender. Antennae slender, setaceous, black ; of o white-banded, of $\delta$ with scape flavous beneath. Thorax black with lines before and beneath radix flavous; areola sub-quadrate, costulae obsolete; apophyses small but distinct. Scutellum flavous, rarely black in ${ }^{*}$. Abdomen elongate-oval, black; segments two and three flavous or fulvous and generally apically black, or with only the basal margin flavidous or red; six and seven fulvous-margined; second to fourth ventral segments of of plicate, ultimate not spinate; post-petiole aciculate; gastrocaeli and thyridii small, sub-obsolete. Legs somewhat slender, black; tibiae, except apices of posterior, flavous; tarsi usually fulvous ; anterior and often the hind legs of of flavidous. Wings a little clouded, stigma fulvous. Length, I2-I $7 \mathrm{~mm}$.

The $q$ may be known by its sub-triangular head and slender antennae, of which the second flagellar joint is longer than broad; the of has the genital valvulae dorsally pale; and in both sexes the metathoracic spines are small but distinct, the coxal areae obviously discreted and the metapleurae sub-rugosely striate.

This is one of our most variable species, especially in the colour of its scutellum, legs, and abdomen, which last varies from entirely black to fulvous or flavidous with the basal segment only black. Four of these varieties have been described as distinct species: that with the second and third segments red, more or less apically black, the fourth to sixth black with the seventh fulvous, was named $A$. spoliator, by Wesmael, followed by Marshall ; that with the basal segment only entirely black, two flavous patches on the prothorax, metanotum, and occasionally also on the mesonotum, constituted I. ochracues and I. laetus of Tischbein; that with the central segments flavous, apically black, is I. erythropygus, Grav.; and the male with these segments red-yellow, margined with brown, and having the hind femora for the most part flavous and the anus rosy, is his $I$. defensorius.

$\Lambda$ very abundant species throughout Europe, it has rarely been bred and is only known to prey upon Simerinthus ocellatus, Aiterontia Alropos and Cucullia verbasci in Britain, where Beaumont has recently raised it 
from Asrolis lucernea, and upon Gnopliria rubricollis and Mamestra (Aplecta) tincta, on the Continent. It occurs from the middle of June to September, and I have found it in the greatest profusion upon flowers of Anselica sylvestris, near Lyndhurst, in the New Forest, in August; the females are certainly rarer than the males and fly more freely in the morning than in the afternoon, when they may occasionally be found resting beneath the flowers. It probably occurs freely everywhere and is recorded from Devonport; Mousehold and Brundall, near Norwich; Ivybridge, Longbridge and Seaton; and as one of the most abundant of the whole group in Devonshire. I possess examples from Land's End, Cheddar in Somerset, Hastings, Boxhill, Felden in Herts, Nottingham, South Leverton, Retford, Birmingham, Carlisle; Bonhill, Dundonald in Ayrshire; Parknasilla and Glengariff, in Cork and from Kilmore. Oxford, Queensferry, Dunbar, Essex, Isle of Arran, Ely, Kent.

\section{3. trifasciatus, Grav.}

Ichnenmon trifasciatus, Gr. I. E. i. 380 ; Ste. III. M. vii. 176, of. Amblyteles trifasciatıs, Wesm. Nouv. Mém. Ac. Brux. 1844, p. I19; Bul. Ac. Brux. 1854, p. 82 ; Berth. Ann. Soc. Fr. 1895, p. 620, of o. Ichneumon fascialorizs, Gr. I. E. i. 376, excl. o. I. triangulator, Ste. Ill. M. vii. 177, o. (?) I. dubitatus, Desv. Cat. 20, $\delta$; cf. Morl. E.M.M. 1902, p. I22.

Closely allied to the last-described species. Head black; of $q$ with the internal orbits flavous and cheeks castaneous, of of with the mouth, face, frontal orbits, and the cheeks, flavous; mandibles bidentate. Antennae elongate, black with the scape of the $q$ castaneous, of the $t$ flavous, beneath ; flagellum of former centrally pale-banded. Thorax black, of of with lines before and beneath the radix, laterally on the prothorax and sometimes on the mesothorax, flavous; apophyses small but distinct; areola sub-quadrate, costulae obsolete. Scutellum, and in of usually two dots on post-scutellum, flavous. Abdomen black, of $q$ apically truncate; second and third segments of $q$ with a broad basal flavous band, which is angulated and sometimes divided centrally, of of with two large flavous apical patches; the following, at least laterally, flavous-margined; post-petiole aciculate; gastrocaeli quite distinct though small; last segment of ${ }^{+}$ entirely fulvous. Legs black; tibiae and tarsi, except the posterior towards their apices, and the of anterior femora, flavous. Length, I $6-18 \mathrm{~mm}$.

This species differs from $A$. palliatorius, which it very closely resembles, in having the antennae a little longer, the cheeks somewhat more buccate and always pale, the post-petiole broader with stronger carinae, the gastrocaeli larger and a little deeper, and the femora slightly longer.

I have seen no British specimens which I could with certainty refer to this species, though Rev. A. Thornley has given me a male, from the New Forest, in August, and I took another, at Broomfield, near Taunton, in July, $\mathrm{x} 887$, which look very like it ; elsewhere we have only old records of captures, by Hope, at Netley, and by Stephens, in Darenth Wood, in June; "Ichnenmon fasciatorius" is recorded from Jersey, in Ansted's "Channel Islands," I862, and appears to have been identified by Walker or Desvignes. It occurs in August, in France and Germany, but has not, I think, been bred. 


\section{4. litigiosus, Wesm.}

Ichneumon culpatorizs, Gr. I. E. i. 513, excll. ot et varr. (nec Fab.). Amblyteles culpatorizs, Thoms. Ann. Soc. Fr. 1888, p. 112 ; Berth. Ann. Soc. Fr. I895, p. 605, $\delta q$. A. litigiosus, Wesm. Bul. Ac. Brux. I854, p. 92 ; Thoms. O. E. xix. 2093, o \&. I. gradarins, Holmgr. Ichn. Suec. i. 80 , excl. + . Var, I. oblongatus, Tisch. Stett. Zeit. 1873 , d.

Head short, black, cheeks somewhat buccate; palpi, the bidentate mandibles, sides of truncate clypeus, and the internal orbits, ferrugineous or flavous; of with temples grey-haired, and its broadly rounded clypeus and face for the most part or entirely flavous. Antennae somewhat slender, setaceous, black; of $q$ flavous-banded and basally red with the fourth flagellar joint quadrate; scape of $q$ ferrugineous, of of flavous, beneath. Thorax black, pronotum sometimes red in $q$ or with two flavous dots in t, usually also with concolorous lines before and beneath the radix; areola sub-quadrate, broader in of; costae weak, costulae sub-obsolete; metathorax sub-mutic. Scutellum, and in of often post-scutellum, flavous. Abdomen black with second and third segments red, often piceous apically and fulvous basally; the remainder not pale-margined; postpetiole closely and finely aciculate, laterally punctate; gastrocaeli subcircular, of normal size and somewhat superficial ; extreme base of second segment striate; the $\delta$ has the angles of first, base or sides of fourth and the sub-truncate, depressed and nitidulous genital valvulae also flavous; second to fourth of ventral segments plicate, the ultimate not spinate; terebra slightly exserted, rufescent. Legs black; $q$ with tibiae, except the posterior towards their apices, and the anterior femora, fulvous or rufescent; of with tibiae, apices of front femora and often marks on the anterior coxae, flavous. Wings flavescent-hyaline; stigma, tegulae and radix fulvous or flavous-marked. Length, I I-I $5 \mathrm{~mm}$.

The seventh segment of the $q$ is often entirely rosy. The of resembles those of the Iclneumon extensorius group, but the head is less narrowed behind the eyes, the temples pilose, apex of clypeus broadly rounded, flagellum immaculate, gastrocaeli much smaller, thyridii oblique, and the structure of the genital valvulae is distinct.

The var. oblongatus has the areola elongate, not transverse as in the type, third segment sub-quadrate, and the apical margin of the first to fourth flavous, the third and fourth being black-marked and margined.

Gravenhorst noticed this species in July, on plants infested with Afhide's and Syrphid larvae, in August, on umbelliferous flowers, and records it from Netley. It has been bred from Melitea maturna and Setina ramosa on the Continent, where it occurs in France, Sweden, Germany, etc., and in Britain from Mania typiar. Sladen has very kindly given me a female, taken at St. Margaret's Bay, early in August ; and Bradley has found it, in May, at Barmouth, which dates indicate its possible hibernation.

\section{5. crispatorius, Linn.}

Iclmetmon crispatorius, Linn. F. S. 399, \&. Amblyteles crispatorius, Wesm. Bul. Ac. Brux. 1854, p. 91 ; Ilolmgr. Ichn. Suec. ii. 240 ; Thoms. Ann. Soc. Fr. ISS8, p. II3; Berth. lib. cit 1895, p. 625 ; Thoms. O. E. xix. 2095, $\delta$ o. Var. I. xanthius, Gr. I. E. i. 392, ơ; Ste. Ill. M. vii. 178. Amblyteles xanthius, IVesm. Nouv. Mém. Ac. Brux, 1844, p. 120; Bul. Ac. Brux, IS48, p. 296, of . Var. I. rufiatorius, Gir. I. E. i. 388, \&. Var. I. iricoloreus, Christ, Hym. 1791, \&. Var. I. Lichtensleini, 'Tisch. Stett. Zeit. $1876, \delta$. 
Head black, chceks somewhat buccate; palpi, the bidentate mandibles, and in $q$ the frontal orbits rufescent; $f$ with clypeus and face, except sometimes centrally, and often the external orbits, flavous. Antennae setaceous, somewhat stout, apically attenuate; of $q$ piceous with basal half ferrugineous, flavous centrally above, and the sixth flagellar joint quadrate ; of $\delta$ black with the scape flavous beneath. Thorax black with lines at radix and, in $\delta$, the pronotum, flavous or rufescent; areola quadrate or sub-transverse, costulae obsolete or distinct ; apophyses generally very small. Scutellum, and in of sometimes the post-scutellum, flavous. Ab. domen elliptic-oval, black with the first three or four segments flavous and often basally piceous and apically rufescent; the of genital valvulae and often its seventh segment dorsally rosy; post-petiole sub-rugose; gastrocaeli small and deeply impressed; of with fourth ventral segment plicate, the ultimate long, laterally sinuate and centrally rounded at the apex. Legs normal, black ; front femora within, and the posterior apically, ferrugineous or flavous; tibiae and tarsi fulvo-flavous, paler in $\delta$; hind femora of $q$ externally sparsely punctate. Wings flavescent, stigma and tegulae flavous in 0 ; areolet somewhat narrowed above. Length, $12-16 \mathrm{~mm}$.

The apophyses of this species vary somewhat in length, often being so short as to be obsolete. It should be noted that the post-petiole is entirely pale and sub-rugose.

The $q$ variety rufatorius has the antennae tricoloured, the four apical segments, all the orbits and often the whole face, red; tricoloreus is another $q$ var. with the meso- and meta-notum red; Lichtensteini is a 0 with three marks on the mesonotum, the four basal segments at their apices, and the posterior femora, flavous; the var. xanthius has red markings on the metanotum only.

On the Continent this species is very widely distributed and extends to Lapland; Holmgren says vaguely that it occurs in woods, meadows and pastures; Rondani has bred it from Macaria liturata and the female hibernates among moss. It would, however, appear to be rare in Britain ; Bignell has taken it, at Bickleigh, in Devon, at the beginning of August and in the middle of June; Stephens believed the var. xanthius had been taken near London; it is recorded by Bairstow, from Bradley Wood, near Huddersfield, in I879; and from Essex.

\section{6. equitatorius, Panz.}

Ichneamon equitatorius, Panz. Schaef. Ic. 56, pl. ii. f. 19; Gr. Mem. Ac. Sc. Torin, I820, p. 32 I ; I. E. i. 405 ; Ste. Ill. M. vii. I80, o. Amblyteles equitatorius, Wesm. Bul. Ac. Brux. 1848, p. 300 ; Holmgr. Ichn. Suec. ii. 243; Thoms. Ann. Soc. Fr. I888, p. I13 ; Berth. lib. cit. I895, p. 603; Thoms. O. E. xix. 2095, ơ ․ I. antenna. torius, Gr. I. E. i. $5 \mathrm{II}$, . A. antennatorius, Wesm. Nouv. Mém. Ac. Brux. I844, p. 130, \&; Bul. Ac. Brux. 1854, p. 92, of क. Var. I. flaviceps, Tisch. Stett. Zeit. I879; Kriech. Ent. Nachr. 1894, ơ.

Head black; mandibles strongly obtuse apically, with the lower tooth small and indistinct, sometimes obsolete in the of ; frontal orbits usually red; of with clypeus, face and part of the mandibles flavous. Antennae setaceous, somewhat stout, apically attenuate, black; of $q$ white-banded and usually red towards the base, fourth flagellar joint sub-quadrate; of 0 piceous, with the scape flavous, beneath. Thorax black; pronotum and callosities at radix of ${ }^{t}$ flavous, of $q$ sometimes ferrugineous; areola sub- 
quadrate, broader in of and occasionally incomplete apically; costulae entire ; apophyses small or sub obsolete. Scutellum, and in toften post-scutellum, flavous. Abdomen fulvous, rarely flavidous with the intermediate segments ferrugineous or black; the last three sometimes, or the abdomen rarely entirely, black; post-petiole finely aciculate; gastrocaeli small and superficial; of with second to fourth ventral segments plicate, and the ultimate elongate, laterally sinuate. Legs normal, red or flavidous; coxae, trochanters partly or wholly, and the apices of the $q$ posterior tibiae, black; femora externally closely punctate. Wings a little clouded, stigma and tegulae fulvous or ferrugineous, latter often flavous in $\delta^{t}$. Length, I $2-16 \mathrm{~mm}$.

The apophyses of this species, like those of the last, are often very small or sub-obsolete; the post-petiole also is pale, but not sub-rugose ; all the femora are fulvous and the conformation of the mandibles is distinctive.

The $q$ variety commutatus, Berth. (A. antennatorius, var. I, Wesm. I 854 ), has the frontal orbits, central flagellar joints, pronotum, lines at radix, scutellum, post-scutellum, marks on coxae and tegulae, as well as the second to fourth segments for the most part, flavous; the sixth, seventh and apex of the fifth segments are fulvous. The of var. flaviceps has the coxae and trochanters entirely flavous and is larger than the typical form.

This species does not appear to have been recorded from Britain since Stephens found it, rarely, near Hertford, and at Ripley, in June, and bred it from Trachea finiferda; it seems to be attached to pine woods, since it has been bred from the above host on the Continent, where it is very widely distributed and the female hibernates; Gravenhorst found it beneath bark of decaying Pinus sylvestris, in the middle of October, and also "in Pino abiete" ; Panzer, too, took it in woods.

\section{7. atratorius, Fab.}

Ichnemmon atratorius, Fab. E. S. ii. I34; Piez. 56 ; Trentep. Isis, 1826, p. 76 ; Gr. I. E. iii. 89i,. Amblyteles atratorius, Wesm. Bul. Ac. Brux. I 854, p. 89, §; Mém. couron. Ac. Belg. 1859, p. 53 ; Thoms. O. E. xix. 2096 ; Berth. Ann. Soc. Fr. IS95, p. 624, ơ ․ I. viridatorizs, Gr. Mem. Ac. Sc. Torin, 1820, p. 324 ; I. E. i. $428, \delta$ क; Ste. Ill. M. vii. I84. A. viridatorius, Wesm. Bul. Ac. Brux. I848, p. 295, $\delta . A$. mediatorius, Thoms. Ann. Soc. Fr. 1888, p. II4, o \& (nec Panz.). A. natatorius, Holmgr. Ichn. Suec, ii. 245 (part.).

Head truncate posteriorly and somewhat narrowed behind the eyes, black; of $q$ sometimes with the internal orbits pale; of with palpi, mandibles, clypeus, face and frontal orbits, flavous. Antennae slender, black ; of $q$ white-banded with the twelfth flagellar joint quadrate, of $\delta$ with scape flavous beneath. Thorax black, of of with pronotum, lines before and beneath the radix, flavous; areola quadrate, costulae entire; apophyses small, acute, larger in $\delta$. Scutellum of $q$ white, of to flavous. Abdomen elongate, black with the third segment pale-banded or bimaculated at the base in both sexes; the fourth to serenth of $q$ usually margined with glaucous-white; post-petiole aciculate: gastrocaeli small, of $f$ sub-ebsolete; ventral segments two to four of of plicate, the ultimate apically acuminate. Legs slender, fulvous ; coxiae, truchanters and posterior tarsi black; of with anterior coxae and sometimes the base of the hind tibiae flavous. Wings sub-hyaline, stigma red; tegulae of o* flavous. Length, I6-I $8 \mathrm{~mm}$. 
The body is smaller and less stout than that of the next species, from which it may be known by the form of the head, slightly stouter antennae, more oblong abdomen, immaculate femora and less distinctly spinulose tibiae.

This is the species known to the older British authors as I. viridatorius, which is said to have been scarce, in the New Forest and about London, towards the end of June. I know of no recent captures, nor does it appear to have been bred. It occurs throughout central Europe, extending to Italy.

\section{8. quadripunctorius, Miill.}

Ichneumon quadripunctorius, Müll. Prodr. n. 1773, $\$$. Amblyteles quadripunctorius, Berth. Ann. Soc. Fr. I895, p. 623, ơ . A. quadrinolorius (sic), Thoms. O. E. xix. 2096. I. notatorius, Trentep. Isis, 1826, p. 74. I. natatorizes (sic), Fab. E. S. Suppl. 219 ; Piez. 57 ;.Gr. I. E. i. 429 ; Ste. Ill. M. vii. 184, ㅇ. A. nataiorizs, Wesm. Nouv. Mém. Ac. Brux. 1844, p. II4 ; Bul. Ac. Brux. 1848, pp. 294, 338; lib. cit. 1854, p. 90 ; Holmgr. Ichn. Stiec. ii. 245 (part.) ; Voll. Pinac. pl. vii. f. 3 ; Thoms. O. E. xii. I234, o q. T. bidentorius, Gr. I. E. i. 426 ; Ste. Ill. M. vii. 183, 8. I. xanthozosmus, Gr. I. E. i. 383, ơ A. xanthozosmus, Thoms. Ann. Soc, Fr. 1888, p. 113, o ․ I. mediatorizes, Panz. F. G., pl. vii. (nec Fab. et Thoms.).

Head not truncate posteriorly, somewhat narrowed behind the eyes, cheeks long; of with frontal orbits flavous; of with palpi, mandibles, clypeus and face, flavous. Antennae slender, setaceous, black; of $q$ white-banded, with eighth flagellar joint quadrate; of $\delta$ with scape flavous beneath. Thorax black; of of with pronotum, lines before and beneath the radix, flavous; areola sub-quadrate, costulae entire; apophyses small, acute. Scutellum flavous. Abdomen of $q$ broad, of $f$ lanceolate, black; $q$ with segments two and three flavous, or the latter with only two large and sometimes confluent patches flavous, and the fourth to seventh margined with glaucous-white; of of immaculate or with the central segments more or less marked and apically margined with flavous; post-petiole aciculate ; gastrocaeli small and superficial ; $\hat{o}$ with ventral segments two to four plicate and the ultimate apically acuminate. Legs somewhat slender, fulvous-red ; coxae, trochanters, and apices of posterior femora and tibiae, black; of with anterior coxae in part and all the tibiae and tarsi, except apices of the posterior, flavous; tibiae somewhat strongly spinulose. Wings a little clouded, stigma fulvous, areolet narrowed above; tegulae of of flavous. Length, $16-20 \mathrm{~mm}$.

The fourth to seventh segments of the $f$ are often immaculate; and the of occasionally has the abdomen entirely black. The of variety Ichneumon infestorius, Fonsc., has only the third segment bimaculate and the fourth pale-dotted.

This is the A. notutorius of Marshall's catalogues, and is certainly a not uncommon species in Britain, where it is to be found in gardens, etc. It is recorded from Essex, London and Hastings, as well as from Bickleigh, Lydford and other places in Devon, where Bignell has bred it from Triphaena comes and, at the end of June, from T. fimbria. Fitch has also bred it from the former; and Montgomery has sent me a live female ( $c f$. E.M.M. I 899, p. 273) from the latter host, whose larva was found in May, at Galashiels, in the middle of July ; in emerging, this last had entirely removed the capital extremity of the pupa in an irregular jagged circle. It is a common species on the Continent, extending to Algeria; and has 
also been bred from Polia polymita, Agrotis comes, Triphatna interjecha and T. promuba.

\section{9. monitorius, Panz.}

Ichneumon monitorius, Panz. F. G. Ixx. I3 ; Gr. I. E. i. 373 ; Ste. Ill. M. vii. 175, 8 9 . Amblyteles monitorius, Wesm. Nouv. Mém. Ac. Brux. I844, p. 114 ; Berth. Ann. Soc. Fr. IS95, p. 622, $\delta$ \%. I. mercatorius, Fab. Piez, 62, $q$ (nec F. S.). I. interruptorius, Trentep. Isis, I 826, p. 80, $\&$.

Head strongly narrowed behind the eyes, black with internal orbits flavous; ${ }^{t}$ also with palpi, the bidentate mandibles, sides of labrum, clypeus and face, flavous. Antennae setaceous, black; of $q$ not whitebanded, but with the third to the thirteenth flageliar joints usually rufescent, and the scape of the of flavous, beneath; the of rarely has the flagellum mainly fulvescent. Thorax black with a flavous dot at the radix; apophyses wanting. Scutellum flarous. Abdomen black with segments two and three at the sides broadly, and the fourth to seventh with apical margin, flavous ; apical segment of of sometimes immaculate ; post-petiole aciculate ; gastrocaeli sub-obsolete ; ventral segments two to four plicate, flavous; genital valvulae black. Legs flavous; coxae, base and apex of hind femora, hind tibiae towards their apices and their tarsi, black. Wings a little flavescent, stigma fulvo-flavous; areolet of $q$ sub-deltoid, of ot deltoid. Length, I4-I $7 \mathrm{~mm}$.

As far as I am aware, the inclusion of this species in our fauna is based entirely upon Stephens' record: "Very rare, taken near London, in June." In central Europe it occurs, in July, and extends to Russia ; it has been bred from Smerinthus populi and Perigrapha J-cincta.

\section{ro. glaucatorius, Fab.}

Ichneumon glancatorius, Fab. E. S. ii. I36; Gr. I. 433 ; Ste. Ill. M. vii. I85. Amblyteles glaucatorius, Wesm. Nouv. Mém. Ac. Brux. 1844, p. 122; Bul. Ac. Brux. 1854, p. 99 ; lib. cit. 1855, p. 407 ; Holmgr. Icln. Suec. ii. 227 ; Thoms. Ann. Soc. Fr. I888, p. II7; Berth. lik. cil. 1895, p. 631; Thoms. O. E. xix. 2096, o \%. I. albiventris, Gmel. S. N. i. 2708.

Head very slightly narrowed behind the eyes, black; mandibles bidentate, rarely white-marked; to has the angles of clypeus and facial orbits usually pale. Antennae setaceous, black with the flagellar joints towards the base ferrugineous, at least beneath, with the tenth sub-quadrate ; scape of ${ }^{t}$ sometimes pale beneath, its flagellar joints sub-cylindrical. Thorax black, callosity beneath the radix stramineous; areola sub-quadrate or transverse, the lateral areae short with the costulae sub-obsolete; apophyses tuberculiform; spiracles elongate or sub-oval. Scutellum somewhat flat, stramineous; rarely entirely black or with an apical dot. Abdomen oblongovate, black with the third segment sometimes laterally dotted, fourth to seventh apically margined laterally, more rarely throughout, with glaucouswhite, the apical sometimes immaculate; the of rarely has the second segment also laterally, or only the last or last two, glaucous-margined; post-petiole aciculate; gastrocaeli somewhat small and striate; ventral segments two and three only plicate, the ultimate in of elongately acuminate with genital valvulae black; terebra ferrugineous. Legs normal, clear red; cosae, trochanters, and apices of hind tibiac and their tarsi, black. Wings very little clouded, stigma fulvous or piceous; areolet 
pentagonal, narrowed above; tegulae and radix of ${ }^{*}$ often pale. Length, I I-I $5 \mathrm{~mm}$.

This is probably a somewhat common species in Britain, though I have not personally met with it; it occurs on umbelliferous flowers, in August and September; Gravenhorst also found it in Nay, probably after hibernation, on the Continent, where it is widely distributed and has been bred from Cuculizic verbasci, $C$. argentea and C. artemisiae, and from Anarta iliyrtillii. It is recorded from I)arenth Wood, the New Forest and Horrabridge, in Devon, from June to August, as well as from Essex; I have seen females taken by Bradley, at Barmouth and Wyre Forest, early in September; and Wainwright has kindly given me an example captured in the middle of September, at the latter locality; Dale records it from the Isle of Purbeck, in 1836 .

\section{rr. pallidicornis, Grav.}

Ichncumon pallidicomis, Gr. I. E. i. 294 ; Ste. Ill. M. vii. I64. Amblyteles pallidicornis, Wesm. Nouv. Mém. Ac. Brux. 1844, p. I2I ; Bul. Ac. Brux. 1854, p. 100 ; Holmgr. Ichn. Suec. ii. 226 ; Thoms. O. E. xix. 2097 ; Berth. Ann. Soc. Fr. 1895, p. $628, \delta$. 1. dimidiatus, Ste. I1l. M. vii. 173, excl. $\$$.

Head narrowed towards the mouth and behind the eyes, black; clypeus finely rugose; mandibles bidentate, piceous or ferrugineous; the of has the frontal orbits and part of mandibles and palpi flavous. Antennae setaceous, flavous; black towards their apices and sometimes fulvous beneath; of $q$ not white-banded. Thorax black, of $\delta$ with lines before and beneath radix flavous; areola transverse, costulae and apophyses wanting. Scutellum flavous. Abdomen black with the second and third segments more or less red centrally or laterally, the fifth to seventh white-margined; the second of $d$ with two lateral flavous patches; post-petiole aciculate; gastrocaeli small and not very deep; second and third ventral segments only plicate; the ultimate in of elongately acuminate. Legs normal, fulvo-flavous, with the coxae, trochanters and apices of hind tibiae, tarsi, and sometimes of femora, black. Wings a little clouded, stigma red; areolet pentagonal, somewhat narrowed above. Length, $\mathrm{x} 2 \mathrm{~mm}$.

An abundantly distinct and handsome species, at once known by the bright basal ten flagellar joints and abdominal markings.

This species ranges, on the Continent, from France, through Germany and Belgium, to Sweden, and is probably rare in Britain; Stephens took it, at Coombe Wood and Richmond Park, in June; he figures his I. dimidiatus (I.c. pl. xxxix. fir. inf. dext.), which was captured in the north of England; the males are found upon umbels and the females are abroad till the end of September; Wesmael $\left(\mathrm{r}_{544}\right)$ bred it from a Noctuid pupa in May.

\section{I2. vadatorius, Illig.}

Ichneumon sarcitorius, var., Linn. F. S. 397, 9. I. ambulatorius, Panz. F. G. Ixxviii. Io (nec Fab.), o. I. vadatorius, Rossi, F. E., ed. Illig. (ISo7) ii. 59, nota, o. Gr. I. F. i. 304 ; Ste. Ill. M. vii. 166. Amblyteles vadatorius, Wesm. Nouv. Mém. Ac. J3rux. I844, p. I22 ; Holmgr. Ichn. Suec. ii 225 ; Voll. Pinac., pl. vii. f. 6 ; Thoms. Ann. Soc. Fr. I888, p. 117 ; Berth. lib. cit. 1\$95, p. 627; Thoms. O. E. xix. 2096, of $q$.

Head slightly narrowed behind the eyes, black, cheeks and temples dilated; ocelli large; mandibles stout, bidentate, centrally red; clypeus 
truncate; $q$ with internal orbits ferrugineous; to with palpi, sides of clypeus and of face, flavous. Antennae setaceous, black; flavous or fulvous towards the base, at least beneath; of $q$ white-banded with the sixth flagellar joint quadrate. Thorax black with a flavous line beneath the radix; of also has the pronotum and sometimes a line before the radix, flavous ; areola sub-quadrate, of $\sigma^{*}$ transverse; costulae obsolete; apophyses very minute. Scutellum stramineous. Abdomen acuminateoval, at least in $\delta$; black, with the second and third segments, except their incisures, red; fourth to serenth apically white-margined; post-petiole aciculate; gastrocaeli small; ventral segments two and three alone plicate, the ultimate of $\sigma^{*}$ elongately acuminate; genital valvulae black. Legs normal, red or fulvous; coxae, trochanters and apices of hind femora, tibiae and tarsi, black. Wings a little clouded; of fot flavescent with pale tegulae; stigma red; areolet pentagonal, strongly narrowed above. Length, I 2-I $6 \mathrm{~mm}$.

At once known from the last five species by its centrally red abdomen.

This is a very widely distributed species throughout Europe, and it has been bred from Agrotis segetum and Triphaena promuba. Parfitt found it upon umbelliferous flowers, on the borders of woods, during July, in Devonshire; it is also recorded by Bridgman, from Norfolk, by Bairstow, from Goole, in 1879 , and by Stephens as scarce, near London, in June, and in the British Museum is an example under this name labelled "Suffolk." I have seen a fine male, captured by Luff, at St. Ouen Bay, in Jersey, early in August ; the female hibernates and is to be met with in September and late in August, when I have found it upon flowers of cultivated carrot, at Tuddenham St. Mary, in Suffolk.

\section{I3. amatorius, Miill.}

Ichnewmon anatorius, Muill. Prodr. I5I ; Gr. I. E. i. 3 I5 ; Curt. B. E. pl, dccxxviii. (details) : Ste. Ill. M. vii. I68, pl. xl. f. i. o. Amblyleles anatorius, IVesm. Nouv. Mém. Ac. Brux. 1844 , p. I23; Holmgr. Sv Ak. Handl. 1854, p. 39 ; Ichn. Suec. ii. 219 ; Thoms. Ann. Soc. Fr. 1888, p. II7; Berth. lib. cit. I\$95, p. 626; Thoms. O. E. xix. 2097, o ․ . I. laboratorius, Fab. E. S ii. 142, o. I. ambulatorius, Fab. E. S. ii. 139, ९. I. luctatorius, var. 4 , Gr. I. L. i. 4 I $4, \delta$.

Head narrowed behind the eyes and towards the mouth, black with the internal orbits flavous; $\tilde{\sigma}$ has the truncate clypeus, face, and sometimes the bidentate mandibles, flavous. Antennae setaceous, stout; of $q$ whitebanded and usually red towards the base with the third flagellar joint quadrate, of with flagellum piceous beneath. Thorax stout, black, callosities at radix and, in of, the pronotum flavous; areola sub-quadrate, apically usually truncate; costulae often obsolete; apophyses wanting. Scutellum somewhat flat, sparsely punctate and shining, flavous. Abdomen black with second and third segments fulvo-flavous, the former entirely red in $q$; the apical margins of first, fourth and fifth of of usually, and of third to seventh of $q$, flavous; post-petiole aciculate; gastrocaeli superficial, of normal size though smaller in $q$; ventral segments two and three alone plicate; genital valvulae black; ultimate segment of $q$ concealing terebra, of of shortly acuminate. Legs black, tibiae and tarsi flavous, of $q$ fulvidous; of with anterior femora flavous, and the apices of hind tibiae and tarsi black. Wings a little clouded, of of flavescent; stigma and tegulae flavous, areolet narrowed above. Length, $13^{-1} 7 \mathrm{~mm}$. 
The $f$ differs from that of $I$. sarcilorius in having the fourth flagellar joint hardly longer than broad, the temples pilose, the cheeks a little longer, hind tibiae not broadly black, and above all in the fourth ventral segment nearly entirely black, not plicate and the hypopygium in the centre apically sub-spinate.

Stephens seems to have known the female of this species well, but says he had only seen four examples; it was recorded from England by Fabricius and is capitally figured by both Curtis and Stephens. It is recorded from the Lonclon district, and Marshall, in whose collection is a specimen from Aberdeen, took it at Lastingham, in Yorks.; a female has also been bred in the Huddersfield district, and Mr. Bignell has an example captured, at Dulwich, on 6th September. It is rather widely distributed on the Continent, where it is found in woods, gardens and meadows, and has been bred from Polyphoenis sericata and Agrotis linogrisea.

\section{4. cerinthius, Grav.}

Ichneumon cerinthizs, Gr. Mem. Ac. Sc. Torin, I820, p. 303; I. E. i. 284 ; Ste. Ill. M. vii. 161, ․ Anblyteles cerinthizus, Marsh. E.M.M. 1878, p. 278; Bridg.-Fitch, Entom. I881, p. 78, of o ; Berth. Ann. Soc. Fr. 1895, p. 638, 9.

q. Head somewhat small and hardly narrowed behind the eyes, black; cheeks somewhat broad; mouth parts ferrugineous ; clypeus hardly discreted from, and a little more sparsely punctate than, the face, apically truncate with the lateral angles rufescent; frons and occiput somewhat coarsely punctate; frontal orbits clear red. Antennae filiform, apically attenuate, black; seventh to twelfth flagellar joints clear stramineous throughout, fifth to seventh infuscate. Thorax black, somewhat closely punctate and dull; a line beneath the radix indistinctly flavous; metanotum scabriculously punctate, costae sub-obsolete; areola longer than broad, apically emarginate; apophyses strongly obtuse. Scutellum finely punctate, nitidulous; apically truncate and, except at its base, stramineous; post-scutellum also apically flavous. Abdomen broader than thorax, subovate, apically obtuse, black ; basal half of second, and dots at basal lateral angles and another in centre of third, segment bright flavous; seventh obsoletely rufescent; post-petiole only basally bicarinate, distinctly aciculate with the apex centrally glabrous; second and third segments finely and closely punctate, former with gastrocaeli of normal size and depth, thyridii transverse ; the intervening space flat, finely aciculate and slightly broader than centre of post-petiole; fourth and following segments nitidu lous and sub-glabrous; ventral segments two, three and the obsolete fold on fourth rufescent, the hypopygium setigerous and apically rounded; terebra ferrugineous, not exserted. Legs normal, black; all the tarsi, their onyches, and the apices of the anterior femora, clear red ; tibiae rufescent, centrally flavidous, the hind pair apically piceous. Wings distinctly narrow, somewhat flavescent; tegulae and radix piceous; stigma clear red; areolet pentagonal, broad above. Length, I $2 \frac{1}{2} \mathrm{~mm}$.

The above description of the $q$, which has not previously been adequately diagnosed, is drawn from a single example, captured by Mr. Bignell, at Bickleigh, near Plymouth, and differs from that of Gravenhorst in the entire flagellar band, the not altogether wanting apophyses, the scutellum not entirely white, and the gastrocaeli not unusually small; the 
second and third segments are, moreover, said to be flavous with darker incisures and the sixth and seventh flavous-marked.

Rev. T. A. Marshall (l.c.) describes a deformed $q$ with one eye almost obliterated, and adds that the $f$, which had not before been noticed, differs from the $q$ slightly in having the antennae black with the two basal joints flavous beneath and in the absence of the dark suffused stain at the base of the segments; its length is seven lines or one-and-a-half lines longer than that of the $q$.

This species would appear to be of very rare occurrence both here and abroad; Stephens says it was found near London, in August, and J. Scott has bred it from Acherontia Atropos. On the Continent it is only known from Piedmont and Provence; Gravenhorst's female was described from the former locality.

\section{I5. negatorius, Fab.}

Ichneumon negatorius, Fab. E. S. ii. I4I ; Piez. 60, $\delta$. Anblyteles negatorius, WVesm. Nouv. Mém. Ac. Brux. IS44, p. I33; Bul. Ac. Brux. IS4S, p. 303 ; Holngr. Sv. Ak. Handl. 1854 , p. 41 ; Ichn. Suec. ii. 25I ; Thoms. Ann. Soc. Fr. IS88, p. I17 ; Berth. lib. cit. I\$95, p. 6.40; Thoms. O. E. xix. 2097, 8 \&. I. omatorius, Gr. I. E i. 311 ; Ste. Ill. M. vii. I67; Zett. I. L. 363 , o. I. sartorine, Gr. I. E. i. 308 ; Ste. Ill. M. vii. $166, \%$.

A stout species. Head black, not narrowed behind the eyes; cheeks and temples dilated; of sometimes with the internal orbits and the slender, bidentate mandibles pale. Antennae setaceous, black; of $q$ nearly always white-banded, with the fourth flagellar joint quadrate; of of somewhat rufescent beneath. Thorax black, with white lines at radix; areola transverse, rounded in front and sub-truncate apically; apophyses wanting; costulae entire. Scutellum white. Abdomen black; second and third segments red with incisures more or less black; fifth and sometimes the fourth margined, sixth and seventh dorsally marked, with white; postpetiole aciculate; gastrocaeli normal ; ventral segments two and three only plicate, ultimate of + nearly hiding terebra; genital valvulae generally pale-marked. Legs somewhat stout, black; front tibiae and tarsi of 0 laterally pale towards their apices; of with all the tibiae and tarsi, except the hind ones in part, flavous or fulvescent. Wings sub-hyaline; stigma fulvous. Length, I 2-I $7 \mathrm{~mm}$.

The of variety nubilus, Berth., has the antennae, scutellum and four apical segments entirely black; the last, however, sometimes bearing a white dot.

This species occurs throughout Europe, and is found from July to September, in woods, gardens and fields, upon shrubs and umbelliferous flowers; its only known host is Noctur brunnea; the female is said to hibernate. In Britain it is probably common and widely distributed; Fabricius says, "Habitat in Anglia, Mus. I) om. Banks" (1 So 4). In spring, near Hertford, in Norfolk, Essex and Salop; in June and July, about London; Bickleigh, in Devon, at the end of July; South Leverton, in Notts.; Plymouth and Netley. I have taken the female upon flowers of Anseliar sylvestris, at Claydon bridge, in Suffolk, in the middle of September ; there is also an example from "Suffolk," in the British Museum. Sladen has found it at Kingsdown and I over, in August, and 1)avies tel!s me he has several times taken the male hovering along hedges, at St. 
Ervan, in Cornwall, early in October. Boar's Hill, Oxford (Hamm); Isle of $\Lambda$ rran (Waterston); on Heracleum flowers, Southwold cliffs, in July.

\section{x6. indocilis, Wesm.}

Ichneumon salicatorius, Gr. I E. i, 245 ; Ste. Ill. M. vii. 155, ९ (part.); cf. Wesm. Ném. couron. Ac. Belg. 1859, p. 28. Amblyteles indocilis, Wesm. Nouv. Mém. Ac. Brux. 1844, p. 126, of क; Bul. Ac. Brux. 1848, p. 297, excl. of ; cf. lib. cit. 1854, p. 85 ; Holmgr. Ichn. Suec. ii. 248 , excl. $\delta$; Voll. Pinac. pl. xxvii. f. 4 ; Thoms. Ann. Soc. Fr. I888, p. II7; Berth. lit. cit. I895, p. 652; Thoms. O. E. xix. 2097, of \&. I. relucens, Desv. Cat. II, $q$.

9. Black, somewhat stout. Head with the cheeks and temples not narrowed; clypeus sparsely punctate, apically truncate; mandibles basally closely punctate, bidentate; frontal orbits white. Antennae setaceous, apically attenuate, centrally white-banded, basal flagellar joints short, the third quadrate. The pronotum and a callosity beneath the radix usually white; metathorax scabriculous, areola as long as broad, its apical costa wanting; costulae fine but entire; coxal areae obsolete; apophyses tuberculiform. Scutellum flat, finely and obsoletely punctate, shining, stramineous. Abdomen black, the seventh segment dorsally, and the sixth often with a minute apical dot, stramineous; post-petiole finely aciculate throughout, carinae distinct; gastrocaeli distinct and narrower than the flat, finely aciculate intervening space; second segment coriaceous, remainder nitidulous and sub-glabrous; second ventral segment alone plicate, the sixth glabrous with long, dense, pale pilosity, the ultimate reaching to apex of dorsum and nearly concealing terebra, which is occasionally slightly exserted. Legs normal; anterior femora apically red; tibiae dull flavous or ferrugineous, the intermediate apically piceous and the hind ones apically black; tarsi rufescent, front ones paler. Wings sub-hyaline; tegulae and radix black; stigma fulvous.

t. Black. Palpi fulvous; mandibles, two dots on clypeus and the face, except its centre longitudinally, stramineous; mandibles bidentate; clypeus apically broadly rounded. Antennae with scape white-dotted beneath. Lines before and beneath radix white; metathorax mutic. Scutellum somewhat flat, white. Abdomen black with apex of first segment fulvous, second, third and base of fourth flavidous, remainder immaculate; thyridii not oblique; second and third ventral segments fulvo-flavous; fourth nearly entirely black, not plicate; hypopygium strongly sinuate laterally, genital valvulae black. Legs and wings as in $q$; hind femora stout; radix and tegulae stramineous. Length, $15^{-1} 7 \mathrm{~mm}$.

I describe the sexes separately, because I only know the of, which has never before been adequately delineated, and because Wesmael had some doubt as to the propriety of the conjunction of his first-ascribed $t$, since accepted by authors, with his , which appears in all but its immaculate central segments to coincide accurately with the type of Gravenhorst's I. salicatorius.

The of strongly resembles that of Ichneumon sarcitorius, but the second flagellar joint is said by Thomson to be shorter, the hind femora more sparsely punctate and stouter, the thyridii not oblique and, above all, the fourth ventral segment is not plicate and nearly entirely black. Thomson tells us (O. E. 192 I) that Holmgren did not think Wesmael had ascribed the correct of to $A$. indocilis, and that the former had many males of this 
species mixed in his collection with Iitneumon confusorius and many of A. palliatorius mixed with those of $A$. indocilis.

This is the species described from Britain by Desvignes under the name Ichneumon relucens; he cites no locality and it does not appear to have been here again noticed until Mr. Erans recently sent me Scotch examples to determine. He has recorded these (Ann. Scot. Nat. Hist. I 902, p. 57) from the Pentlands above Balemo, early in October; from Coniston, in July; and from Macbiehill. On the Continent, where the female is known to hibernate, it appears to be restricted to Belgium, Prussia and the north of France; Holmgren says it is rare in central and southern Sweden.

\section{I7. subsericans, Grav.}

Ichneumon subsericans, Gr. Mem. Ac. Sc. Torin, I820, p. 285 ; I. E. i. I6I. Ambly. teies subsericans, Wesm. Nouv. Mém. Ac. Brux. I844, p. 128 ; Holmgr. Ichn. Suec. ii. 249 ; Sv. Ak. Handl. I854, p. 40; Thoms. Ann. Soc. Fr. IS88, p. I17; Berth. lib. cit. IS95, p. 65I ; Thoms. O. E. xix. 2097, of 9. I. cognatus, Ste. III. M. vii. I39; $f f$. Morl. E.MI.M. I902, p. II9.

Head somewhat buccate, narrowed behind the eyes; clypeus apically truncate, sparsely punctate; of with palpi, the bidentate mandibles, labrum, clypeus, and face flavescent, the last sometimes bimaculated with black; temples punctate and pilose. Antennae setaceous, elongate and slender, black; of $q$ white-banded, and ferrugineous beneath towards the apices, with basal flagellar joint cylindrical and the twelfth sub-quadrate; of with scape flavidous beneath. 'Thorax black with sometimes white dots before and beneath the radix; areola sub-quadrate, apically emarginate; costulae generally entire; apophyses usually present, tuberculiform. Scutellum somewhat flat; entirely or apically white, rarely entirely black. Abdomen elongate, sub-linear, finely sculptured; black, with seventh segment of $q$ nearly always with a more or less distinct longitudinal glaucous mark ; third of of sometimes rufescent at the margins ; post-petiole aciculate; gastrocaeli small and superficial, but distinct; second segment dull and strongly alutaceous; the remainder becoming smoother apically; the fourth rentral not plicate, hypopygium of $f$ nearly concealing the terebra, of $\delta$ a little produced centrally; genital valvulae very large; anus of $q$ usually acuminately compressed. Legs normal, clear red ; coxae, except the flavous front ones of the $\hat{\sigma}$, and trochanters, sometimes the apices of hind tibiae and their tarsi, nigrescent. Wings fulvescent, stigma fulvous ; tegulae piceous, sometimes white-marked; areolet a little narrowed above. Length, r $2-18 \mathrm{~mm}$.

Berthoumieu points out that the greater or less dilatation of the $q$ abdomen, which renders the apical segment quadrate or transverse, is regulated by the fecundity or sterility of the insect.

'This species may be known by the elongate antennae being much longer than half the body, which is narrow, sub-linear and by no means stout; the of has the last dorsal segment a little longer than the penultimate and its valvulae very large and strongly convex; the apex of the $q$ abdomen is nearly always laterally compressect.

It is not uncommon on the Continent, but has only once been bred, from Odonestis fotatoria (Billups). In Britain, Stephens says his $I$. cognatus was "common near London, during the summer, frequenting umbelliferous flowers, etc., by woodsides and heclges"; l'iffard has found 
A. subsericans not uncommonly about Felden ; Parfitt, at Ide, in Devon, in August; Bignell, at Ivybridge, in the middle of August; Chitty, at Woking and Forres; Hamm, at O.ford; Harwood, in Essex ; Beaumont, at Whitby and Harting, in August, as well as at Byfleet and Bury St. Fdmunds; 1)r. Cassal has scut it to me from Ashby, near Doncaster, where he took it at the end of June; and Waterston, from the Isle of Arran, in September. ${ }^{1}$

\section{I8. armatorius, Forst.}

Ichneumon armatorius, Forst. Nov. Spp. Ins. 82, o. Amblyteles armatorius, Berth. Ann. Soc. Fr. IS95, p. 6I8, o ․ I. fasciatorius, Fab. S. E. 330; Piez. 6I ; Panz. F. G. Ixxx. I2; Gr. I. E. i. 376, excl. क; Ste. Ill. M. vii. 175, 古; Wesm. Bul. Ac. Brux. I 839 , pt. ii., p. 448 (gynandromorph.). A. fasciatorizs, Wesm. Nouv. Mém. Ac. Brux. I844, p. II 3 ; Bul. Ac. Brux. 1854, p. 84; IJolmgr. Ichn. Suec. ii. 2 I 8 ; Voll. Pinac., pl. vii., ff. I, 2 ; Thoms. Ann. Soc. Fr. 1888, p. I16 ; O. E. xix. 2094, o 9 . I. quadrimaculatus, Gr. I. E. i. 370 ; Ste. III. M. vii. 176, + . I. diversorius, Ste. lib. cit. I75, ․ A. regius, Tisch. Stett. Zeit. I878, $\delta$ \%.

A dull, black and yellow species. Head narrowed behind the eyes, vertex somewhat emarginate, black; palpi and the slender bidentate mandibles partly pale, internal orbits flavous; of with clypeus and face also flavous. Antennae slender, setaceous; ferrugineous, more or less piceous above and towards the apices; scape and sometimes flagellum of of flavous beneath. Thorax black, with pronotum and callosities before and beneath the radix flavous; areola sub-quadrate, costulae obsolete; coxal areae not discreted; apophyses very large and stout. Scutellum obtuse, somewhat convex, flavous. Abdomen dull black, of $q$ fusiform, of $f$ elongate; second and third segments broadly banded at the base, the following posteriorly margined, with flavous; of with fourth and fifth usually immaculate and the seventh entirely flavous; post-petiole aciculate; gastrocaeli small, superficial ; first ventral segment of $q$ not plicate, fourth of of plicate with hypopygium apically truncate. Legs somewhat slender, flavous; coxae, except usually anterior of $\hat{\delta}$, and part of hind femora and tibiae, black. IVings somewhat clouded, of $\delta$ flavescent; stigma fulvous, tegulae sometimes flavous. Length, r 2-16 $\mathrm{mm}$.

The coloration of this species, which may at once be known by its large and acute apophyses, is unusually stable; that of the of showing no variation and that of the varying only in the extent of black upon the third, and to a small extent also upon the second, segment; the hind tibiae of the former are apically ferrugineous.

This is one of our commonest ichneumons, though I have chanced to meet with it but once, while flying over heather, near Lyndhurst, in Hants., in the middle of August; Forster says it is frequent in gardens, and Gravenhorst found it upon Chaerophyllum; it is abundant on the Continent, where it has been bred from Phlogopliora meticulosa, Xyloplarsia nurea, Mamestra brassicae and Agrotis finbria; its distribution is wide, extending to northern Africa. In Britain it occurs from the middle of June to September, and is extremely abundant on flowers and among potatoes throughout the metropolitan district; it is recorded from Darenth Wood, Norfolk, Essex and Salop; the Land's End district; Holgate, near Hastings, among young oaks; Huddersfield, Bishop's Wood and Ilkley, in Iorks. ; and Parfitt says it is a widely distributed and common species

1 The example of this species recorded in the Hastings list is referable to Chasmias paludicola. 
in Devonshire, where it is found at Bickleigh and Horrabridge, adding that the males are frequently to be met with on flowers by woodsides, in June and July. I have seen examples from Blackheath, Lewisham, Plymouth, Bodiam, Lynmouth, Dover, Portland, Birmingham, Worksop, Reading, Shotover ; Hayton NIoss, in Cumberland ; Edinbugh, Orniston, Aberlady and Gullane, in Haddington; and possess others from Eusby and Strathblane, in Stirling ; King's Cross, in Arran; Bonhill ; Glengariff, in Cork ; Barnsley, Lastingham and Ravenscar, in Yorks.; Treswell and South Leverton, in Notts. ; Ashby, in Lincs.; Westhide; Felden; and from Tostock, in Suffolk. In Britain it has been bred from Vanesssa Atalanta, Saturnia carpini, Lasiocampa mi (Buckler), Notodonta camelina carly in June; Asrotis segetum and -1. Ashatorthii, Noitua wanthographa, Triphaten orbonu in July, and T. pronoba. Curiously enough, it never appears to have been found in the early spring, and there appears to be no record of this species passing the winter in the perfect state, though that it does so is, I think, proved by the discovery by Mr. O. E. Janson of a female among dead leaves in his garden, at Highgate, in November, I90I ; Mr. C. J. Watkins has also found it, at Painswick, Glos., towards the end of October.

\section{I9. infractorius, Panz.}

Ichneumon infractorizs, Panz. F. G. lxxviii. 9, o ; Gr. I. E. i. 363 ; Ste. Ill. M. vii. 172, of $q$. Amblyteles infractorius, WVesm. Nouv. Mém. Ac. Brux. I844, p. I2I ; Berth. Ann. Soc. Fr. I895, p. 621, o o. I. volutatorizes, Trentep. Isis. I\$26, o. Var. $I$. mercatorizes, Fab. E. S. ii. I43; Gr. I. E. i. 369 ; Ste. Ill. M. vii. 173, ठ.

Somewhat resembling the last-described species. Head black; mandibles bidentate; internal orbits and, in $\delta$, the face except its centre, flavous. Antennae setaceous, flavo-fulvous; towards the apex, and sometimes above, piceous. Thorax black, callosities before and beneath the radix flavous; apophyses not large and stout. Scutellum flavous. Abdomen black with second and third segments basally, latter also apically, and remainder usually margined with, flavous; post-petiole aciculate; gastrocaeli small, indistinct; of with fourth ventral segment not plicate, the ultimate apically emarginate. Legs flavous or fulvous; coxae, trochanters, and hind femora, black, IVings flavescent; stigma fulvous, tegulae flavous. Length, I $4-17 \mathrm{~mm}$.

The coloration appears to be similar to that of $A$. armatorius, but the metathoracic spines are much shorter, the fourth ventral segment of the $\delta$ is not plicate, and its apical segment is dorsally not entirely pale.

The of variety mercatorius has a dot beneath the scape, two on the clypeus and others beneath the coxae flavous.

This species is found in France and central Europe, extending to Caucasia, in August and September, on flowers of Angelica syliestris, and other umbels. It has been bred from Agrotis tritici (aquilina, Hüb.) and $A$. corticae. Stephens says it was scarce near London, in June, and P'arfitt adds that he found it widely distributed in Devonshire, on flowers by woodsides, in July.

20. oratorius, $F_{i l b}$.

Ichneumon oratorius, Fab. E. S. ii. I38; Panz. F. G. Ixxx. 10; Gr. I. E. i. 394, 8 et var. 1, \& ; Ste. III. MI. vii. 179. Amblyteles oralorius, Wesm. Nouv. Mém. Ac. Brux. 1844, p. I I6 ; Bul. Ac. I3rux. I854, p. 87 ; Holmgr. Ichn. Suec. ii. 223 ; Thoms. Ann. Soc. Fr. 1888, p. 116 ; Berth. lib. cit. 1895, p. 649; Thoms. O. L. xix. 2094, \& 
Var. I. atramentarius, Gr. I. E. i. 397 ; Ste. III. M. vii. 179 ; cf. Wesm. Mém. couron. Ac. Belg. IS59, p. 48, $\delta$. Var. I. cingulipes, Ste. Ill. M. vii. I57, of ; of. Morl. E.M!.M. I902, p. I20.

A shining species, with slender body and elongate legs. Head strongly narrowed behind the eyes, vertex somewhat emarginate, black; mandibles slender, bidentate; frontal orbits broadly white, the external sometimes red-lined; of also has the palpi, mandibles, clypeus, face, and usually a genal patch, white or white-marked. Antennae slender, setaceous, whitebanded in both sexes, with tenth flagellar joint of $q$ quadrate; $\delta$ rarely has scape pale-dotted below. Thorax black; of $q$ rarely with a dot before the radix white; of $\delta$ with lines before and beneath the radix, and rarely a patch on the metanotum, white; areola quadrate or slightly elongate, apically often incomplete; costulae obsolete; coxal areae sub-obsoletely discreted; apophyses distinct. Scutellum, and in of sometimes the postscutellum, white. Abdomen nitidulous, somewhat elongate, slightly bluishblack, sericeous-haired; the first or rarely the first three segments usually margined, the sixth and seventh dorsally marked, with white; post-petiole finely aciculate or sub-rugose, apically glabrous; gastrocaeli small and superficial ; apical segments of $q$ nitidulous ; ventral segments two to four of of with a white central fold. Legs slender, black; tibiae broadly whitebanded; anterior tarsi piceo-flavous, of of whitish with anterior coxae and trochanters white. Wings with stigma fulvous and areolet narrowed above. Length, I 2-I $5 \mathrm{~mm}$.

The nitidulous black body and clear white markings of this species can only be confused with those of the next-described.

The variety $I$. cingulipes, Ste. (bipunctus, Berth.) has the anterior segments entirely immaculate; it is recorded from Darenth Wood, in June. The var, atramentarius has the antennae entirely black and the sixth, as well as sometimes the second, segment immaculate; this variety was originally taken by Hope, at Netley, and was considered by Stephens, who found it occasionally about London but "more abundantly" in Salop, in June, as rather uncommon.

This handome insect is probably somewhat common with us; it has occurred in the vicinity of the metropolis, at the end of June; near Huddersfield and Leeds, in June; in Essex; at Plym Bridge and Bickleigh, in Devon, where Parfitt says it is not common, occurring near woods and thick hedges in July, towards the end of September; in South Wales, in September; at Mousehold Heath, Norwich; in the district of Land's End; and at Peppering, near Hastings; I possess an example captured by Piffard, at Felden, in Herts. It has been bred from Gonepterj' $x$ rhammi, Salurnia pavonia and Aplecta nebulosa; and on the Continent, where it is somewhat widely distributed and frequents humid situations, from Noctua brumnea and $N$. festiva; the female is said to hibernate among moss.

\section{I. margineguttatus, Grav.}

Ichnenumon marginesuttatus, Gr. I. E. i. 393, ठ. Amblyteles marginesuttatus, Wesm. Nouv. MÍm. Ac. Brux. I844, p. I2I, excl. $\$$; Mém. couron. Ac. Belg. 1859, p. 48 ; Holmgr. Ichn. Suec, ii. 22 ; Thoms. Ann. Soc. Fr. 1888, p. I16; Berth. lit. cit. I895, p. 650 ; Thoms. O. E. xix. 2094, ơ o. Var. A. novilizus, Wesm. Bul. Ac. Brux, 1854, p. $86, \delta$ \&.

Very like the last species. Head narrowed behind the eyes; vertex somewhat cmarginate; cheeks and temples strongly punctate; clypeus 
apically sub-truncate or slightly emarginate; mandibles slender, bidentate ; internal orbits and, in $q$, sometimes a central facial mark, fulvescent; 0 t has clypeus and face white or white-marked. Antennae somewhat slender, setaceous, black; of $q$ only white-banded with the sixth flagellar joint quadrate; scape of $\hat{f}$ sometimes white-dotted beneath. Thorax black with pronotum and lines before and beneath the radix flavous; areola quadrate; costulae obsolete; coxal areae distinctly discreted; apophyses distinct. Scutellum flavous, sometimes basally black. Abdomen somewhat broad, black with a very faint blue reflection; segments one to three with two apical flavous marks; sixth usually, and seventh flavous-marked; post-petiole aciculate; gastrocaeli small and superficial, intervening space often finely aciculate; apical segments of $q$ nitidulous. Legs normal, black; tibiae broadly flavo-white-banded; anterior tarsi piceo-red, of oै stramineous with anterior coxae white-marked. IVings a little clouded, stigma fulvous ; areolet narrowed or coalesced above. Length, I $3^{--1} 7 \mathrm{~mm}$.

The variety novitius differs from the type only in having the flavous marks on the basal segments coalesced into an apical band, the third segment occasionally being immaculate.

This species is much rarer than the preceding, being found only in Germany, Siveden and Belgium, upon bushes, in August. The only British examples I am able to instance are that bred by Bignell, in South Devon, at the end of May, I882, from Noctua brunnea, and that captured in the neighbourhood of Guildford, by Dr. Capron, in $1879^{1}$; it was, however, known to be a British species in 1872 .

\section{2. microcephalus, Steph.}

Ichneamon microcephalus, Ste. IIl. M. vii. 158; Bridg.-Fitch, Entom. ISSO, p. I05, o ?. Amblyteles microcephalus, Morl. E.M.M. I902, p. I20, ơ.

t. Head small, transverse, narrowed behind the prominent eyes, evenly punctate, dull, black; clypeus truncate, not discreted; mandibles bidentate, piceous ; palpi ferrugineous ; facial orbits narrowly flavous. Antennae black, flavous-banded. Thorax normal, black; metathorax rugose, costae strong; areola slightly transverse, apically emarginate; costulae wanting; petiolar area tri-divided; spiracles elongate. Scutellum flat, punctate, shining, dull flavous. Abdomen broad, sub-ovate, black, apically obtuse; post-petiole and base of second segment centrally striolate; first segment abruptly explanate, with very prominent spiracles; gastrocaeli small, striate; incisures narrowly aciculate; segments five, six and seven with dorsal flavous marks, that on sixth being the largest and longitudinal; ventral segments two to four plicate, hypopygium not produced. Legs normal, piceous; femora and coxae darker; apices of front femora dull flavous. WVings infumato-hyaline; tegulae black; nervures and stigma fulvous ; areolet small, narrowed above. Length, I4 $\mathrm{mm}$.

The above description is taken from the only example remaining in Stephens' collection; he says the o, which very probably appertained to a different species and was, perhaps, removed by him before presenting his types to the nation, differed from the $\delta$ in having the scutellum only pale at its apex, and the abdomen broader and duller.

1 In Dr. Capron's collection (which I have recently acquired) are three specimens, of of of under this name; these certainly do not belong to A. margineguttatus; his recoro must, consequently, be regarded with suspicion. 
This species appears to be unknown on the Continent, but its systematic position, in the absence of the true $q$, is largely a matter of conjecture, and that now assigned to it must be but tentative.

"Found near London and in Scotland, in June" (Stephens). Fred. Smith named a specimen in I.conard Jenyns' collection, now in the Cambridge Museum, as appertaining to this species; it was taken "by the riverside, Wisbeach, I 831.

\section{3. castanopygus, Steph.}

Ichnemmon castanopyga, Ste. Ill. M. vii. 197, o $q$. Amblyteles castanopygus, Bridg.Fitch, Entom. I88I, p. 8I ; Rerth. Ann. Soc. Fr. I895, p. 607 ; Morl. L.M.M. I902, p. I2I, of o. A. rubriventris, Wesm. Bul. Ac. Brux. I854, p. II6; Holmgr. Ichn. Suec. ii. 254 ; Thoms. Ann. Soc. Fr. I888, p. I13; O. E. xix. 2094, $\delta$.

Head posteriorly sub-truncate, and narrowed towards the mouth and behind the eyes; clypeus separated from, and more sparsely punctate than, the face; cheeks aciculately punctate; mandibles slender, apically obtuse, bidentate, lower tooth very small and sub-obsolete; black, of with mouth parts fuscous, $\delta$ with palpi, mandibles except their apices, sides of labrum, of clypeus, and the facial orbits, white. Antennae somewhat slender, setaceous, black; of $q$ white-banded. Thorax black; of with dots or lines before and beneath the radix white; mesosternum internally distinctly bifoveolate at the apex, at least in $q$; metathorax strongly and closely punctate ; areola of $q$ sub-rectangular and longer than broad, of 0 horse-shoe shaped ; costulae entire ; apophyses stronger in to. Scutellum black, strongly punctate. Abdomen black, with the second segment closely punctate, of $q$ somewhat shining and dark red; third or fourth to apex sanguineous- or castaneous-red, hardly nitidulous; post-petiole of $q$ finely aciculate, of $\hat{f}$ sub-rugose throughout, its apex centrally elevated and glabrous; gastrocaeli small, somewhat deeply impressed and striate with the intervening space evenly punctate; ventral surface castaneous, segments two to four plicate. Legs somewhat long and slender, black; anterior femora apically and tibiae laterally, and their tarsi, stramineous; hind tibiae basally arcuate. Wings hyaline with stigma and nervures black; areolet pentagonal ; tegulae white-dotted. Length, I I-I4 $4 \mathrm{~mm}$.

The $q$ differs, besides its smaller gastrocaeli, etc., from that of $C$. melanocastanus in the form of its head, the longer and more slender legs and antennae, the bidentate thorax, elongate areola and evenly punctate second segment.

In describing this species, Stephens says, "Very rare; the female I possess I took at Hertford, in June ; the male I obtained from Scotland." Newman (Brit. Moths, 279) says it preys upon Dasypolia templi, remarking that, although the larvae live entirely in darkness and totally concealed, an overwhelming majority are destroyed by the present species and by a small species of Micrograster. Bignell, who has kindly given me an example from North Wales, also bred it in South Devon, from Xanthia cerago and has captured a female, at Ivybridge, near Plymouth, on Ist June, I $\$ 93$. Further, I have seen a male, taken at Pitlochry, in Perth, by Beaumont, on 9th September, I892; and another, by Mr. S. Image, at Morthoe, Devon, in August; the male has once occurred to me, by sweeping reeds, at the edge of Tuddenham Fen, in Suffolk, at the end of August; it also occurs in Essex. Holmgren records a single example of both sexes 
from Sweden; and Wesmael also mentions it from Germany, France and Switzerland.

\section{4. uniguttatus, Grav.}

Ichnermon uniguttatus, Gr. I. E. i. 310 ; Ste. Ill. M. vii. 167. Ambiytcles uniguttatus, Wesm. Nouv. Mém. Ac. Brux. 1844, p. 124; Bul. Ac. Brux. I848, p. 297 ; lit. cit. I 854 , p. I02; Tisch. Stett. Zeit. I875, p. 274; Berth. Ann. Soc. Fr. I895, pp. 600, 64I, 8.+ Var. I. interjectus et $I$. subfascialus, Tisch. Stett. Zeit. I 879, o 9. Var. I. atripes, Gr. I. E. i. 309 ; Ste. Ill. M. vii. 167, ㅇ. Var. J. intemptus, Gr. I. E. i. 319, of; of. Wesm. Mlém. couron. Ac. Belg. IS59, p. 37 ; et Tisch. Stett. Zeit. 1875, p. 274. Var. I. flavolimbatus, Gr. I. E. i. 316, o ; cf. Wesm. Bul. Ac. Brux. IS54, p. I15. Var. I. quadricingulatus, Gr. I. E. i. 297 ; Wesm. Bul. Ac. Brux. 1854, p. 104, o. Var. I. praedutor, Fonsc. Ann. Soc. Fr. I847, p. 61, o. Var. I. pratensis, Gr. I. L. i. 212 ; Ste. III. M. vii. I49, of ; cf. WVesm. Bul. Ac. Brux. I 854 , p. I03. Var. I. Goedarti, Gr. I. E. i. 474 ; Ste. Ill. M. vii. I89; Amblyteles Goedarti, Wesm. Nouv. Mém. Ac. Brux. I844, p. 125; Bul. Ac. Brux. I854, p. 107, o o. Var. I. fumigalor, Gr. I. E. i. 537, excll. varr. I, 3 (nec Fonsc.), \&; Ste. Ill. M. vii. 195; Amblyteles allernator, Tisch. Stett. Zeit. I879,

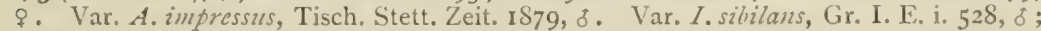
cf. Wesm. Nouv. Mém. Ac. Brux. 1844, p. 125. Var. I. fossorizus, var. 3, Gr. I. E. i. 165; cf. Wesm. Mém. couron. Ac. Belg. I859, p. 17. Var. I. favifemur, Tisch. Stett. Zeit. IS73, of. Var. I. ignotus, Fonsc. Ann. Soc. Fr. I847, p.6r ; Amblyteles ignolus, Wesm. Bul. Ac. Brux. 1854 , p. I06, ơ.

Head obliquely narrowed behind the eyes; mandibles uni-dentate, the lower tooth being entirely wanting; of with facial orbits rarely white. Antennae somewhat stout, setaceous, strongly attenuate, black; of $q$ sometimes centrally fulvous above, with sixth flagellar joint quadrate; of o with the joints of basal two-thirds of flagellum cylindrical. Thorax black; often has pronotum, and lines before and beneath radix, white; metathorax not emarginate at the base of the distinct apophyses; areola subquadrate or, in $\delta$, transverse ; costulae wanting; apophyses stout, obtuse. Scutellum entirely or partly white (in type form). Abdomen black, nitidulous towards its apex; of $\sigma^{*}$ elliptic, of $q$ sub-ovate; second segment red; third of $\delta$ black with base and sides red, of $q$ red, sometimes blackmargined; the seventh with a small dorsal white dot (in type form) ; postpetiole aciculate; gastrocaeli, especially of $q$, small ; fourth ventral segment of $f$ not plicate, the ultimate with a long apical process. Legs somewhat stout, black; coxae (of type form) black; tibiae laterally red or, in $\delta^{*}$, sometimes dull flavous. Wings somewhat clouded, stigma red or piceous; radix and tegulae of to (type form) white-dotted. Length, I 4-1 $7 \mathrm{~mm}$.

Two reliable points will at once distinguish this species from our others of the genus, viz., the mandibles are uni-dentate and the metathorax is not emarginate at the base of the spines. From the Continental species of the uni-dentate group, the present may be known by its stout antennae, of which the flagellar joints of the $q$ become quadrate at the sixth, its distinctly bispinate metathorax, and shining abdomen.

The varieties which have been described as distinct species are very numerous; the following eight have the anus white-marked. Filmammn interjectus has segments six and seven white-marked-this occurs in (ireece and Austria; atripes is a $q$ with antennae semi-white-banded and segments five to seven white-margined-Stephens records this as rare, near London, the female is said to hibernate; intermptus, Grav., has femora, tibiae and tarsi red, with segments four to sis laterally maruined at apex, and seventh marked, with white; the var. rufinus, Berth., differs from this 
last in having the hind coxae marked, and segments one to six narrowly margined, with flavous; flarnlimbatus has the femora apically, tibiae laterally and the margin of segments two and three flavous, with the fourth glaucous-white margined; quadricingulutus has the anterior femora and tibiae, and the hind tibiae basally and intemally, red, with the third segment at its apical angles, and the fourth to seventh margined with, white; fradutor has segments three to five red-margined, and the seventh only white-marked; pratensis the tibiae and tarsi fulvous, the hind ones being apically black, with the coxae sometimes partly white, and segments two to four narrowly margined apically throughout or laterally with flavous this, Stephens says, is rare about London, in July. The remaining seven specifically described varieties have the anus immaculate. Iihnemmon Gocdarti ${ }^{1}$ has the scutellum white and the apical segments immaculate-taken near London and in Norfolk, says Stephens; in fumigator the body is stout, the scutellum black and the wings often strongly clouded - this has been taken at Darenth Wood, Stephens says, and in the New Forest; the var. stygius, Berth., differs from fumisator in having the central segments unicolorous black; impressus has scutellum white, fourth segment, as well as second, third and tibiae, fulvous, with the hind coxae often whitemarked-this occurs in Hungary; sibilans has scutellum white, femora and tibiae mainly red, and the abdomen black with the second segment piceo-flavous-a German form; from sibilans, fossorius differs in its whitemarked coxae and basal segment; fuvifemur has the scutellum and two dots on the clypeus white, with segments two, three, base of four, femora and tibiae, flavous-recorded from France and Austria; ignotus has the scutellum entirely or apically white, with the anterior legs entirely red-it is found in Provence. As to the acknowledged varieties, not described as good species, their name is legion: Tischbein, at Stett. Zeit. 1875, p. 274 , alone, tabulates forty forms of the male-verb. sap. : cf. loc. cit.!

This species occurs in June, August and September, on Angelica sylvestris and other Umbelliferae; it has been bred from Abrostola urticae and A. triplasia, and the female hibernates. Its continental range is throughout central and southern Europe to northern Africa. In Britain, it is probably a southern species, hardly likely to occur in Scotland, since it is unknown in Sweden; Stephens says it has been taken near London, and Beaumont has an example from Bury St. Edmunds; it is also recorded from Essex. Many of the above enumerated varieties, moreover, are unlikely to occur with us at all, probably being due to influences which do not here obtain.

\section{5. conspurcatus, Grav.}

Ichnemmon conspurcatus, Gr. I. E. i. 409; Ste. IIl. M. vii. ISI. Amblyteles conspurcatus, Wesm. Bul. Ac. Brux. 1854, p. I07, o ; Berth. Ann. Soc. Fr. I895, p. 601, 8 o.

I Whether Ichneunon cinctorius, Desv. Cat. 25, merits specific rank, or whether it be, as would appear more probable, a mere variety of $A$. uniguttatus, allied to Goedarti, is at present an unanswerable question, and I prefer to tentatively treat it in the latter fashion (cf. E.M.MI. I902, p. I23).

Head black; mouth parts, whole of clypeus, sides of face, and frontal orbits narrowly, whitish; exterior orbits immaculate. Antennae setaceous, black throughout, half length of body. Thorax black; metanotum with complete areae, of which the areola is ill-defined and lunate. Scutellum flavous. Abdomen narrow, equilateral, deplanate; dull, more shining towards the anus; entirely, black or with apex of second segment laterally and apical half, as well as whole latcral margin, of third, castaneous; post-petiole aciculate, gastrocaeli small; ventral fold on segments two and three sometimes indistinctly extending to fifth. Legs black; base of femora narrowly, of tibiae broadly, and of the tarsal joints, fulvous. Wings hyaline, base not darker; nervures piceous; stigma stramineous. Length, $15 \mathrm{~mm}$.

There are two examples in the British Museum; one from Desvignes', and one from Stephens', collection, which latter is said to have been taken in Hants., before I835. 
A. hipustulatus, Wesm. lit. cit. p. 113 , 9. Var. I. nigripes, Gr. I. E. i. 476 ; Vonsc. Ann. Soc. Fr. 1847, p. 402 ; cf. Wesm. Bul. Ac. Brux. I 854, p. 107, ठ́.

This species, rendered distinct by reason of the emargination of the metathorax at the bases of the apophyses, so closely resembles the lastdescribed as to need no separate description. It is most closely allied to the var. Goedarli, always having the anus immaculate and the scutellum flavous, or in the $q$, the latter bimaculated with white. The of has the coxae, femora and tibiae partly flavous and the abdomen elongateovate with second, third and part of fourth segments, flavous or fulvous. Length, I $6 \mathrm{~mm}$.

The var. nigripes has the legs black and the fourth segment immaculate.

This species has been hopelessly mixed with intricacies of the lastdescribed; the only British record I can find is Stephens', which is hardly likely to be reliable. He says, "Rather scarce; taken in June near London." On the Continent it extends from France to Italy.

\section{HEPIOPELMUS, Wesmael.}

Wesm. Nouv. Mém. Ac. Brux. I844, p. I I I.

Head a little buccate; clypeus apically truncate; mandibles bidentate with lower tooth the shorter. Antennae setaceous, strongly attenuate towards the apex; basal flagellar joint cylindrical. Thorax stout, somewhat elevated anteriorly, longer than high; metathorax sub-entire basally, with the upper areae complete and spiracles linear. Abdomen of of linear or ovate-lanceolate, of $q$ elongate-fusiform with the anus obtuse and terebra very shortly exserted; post-petiole not aciculate, gastrocaeli normal ; hypopygium obtuse, not retracted, hardly covering base of terebra. Legs normal; tarsi of the $q$ with no setae beneath, of the of with shorter setae than in the preceding genus. Wings normal; areolet pentagonal, somewhat narrowed above.

The position of this genus has long been a moot point; Wesmael, from its first erection, was doubtful of its right to a separate existence, and noted its analogy with the Oxypygini, especially in the slender bodies of its males ; he, however, retained it among the Amblypygini, in 1854 . Holmgren described it, as above, in $187 \mathrm{I}$, as certainly distinct, though Marshall, in 1872 , sank it in the genus Iclmeumon; and Thomson and Ashmead both recognise it, though Berthoumieu, in $\mathbf{r} 895$, merges it in his genus Amblyteles.

\section{Table of Species.}

(2). I. Markings flavous; second segment palemarked

(1). 2. Markings white; second segment immaculate.......................................

I. VARIEgatorius, P'tnz.

2. LeUCOSTIgniUs, Griv.

\section{I. variegatorius, Panz.}

Tchneumon varicsatorius, Panz. F. G. Ixxiii. II ; Gr. I. F. iii. $S S S$, o (nec Ilolmgr. Ichn. Suec. i. 120, \%; Thoms O. L. xxi. 2401; Kriech. Ent. Nachr. IS89, p. 201 ; etc.). Hepiopelmus variegatorius, Wesm. Nouv. Mém. Ac. Brux. 1844, p. 14r, $\delta$ \&; Voll. l'inac. pl. xxvii, f, 6, o. Amblyteles variegutorius, Berth. Ann. Soc. lir. IS95, p. 632, 8 . . I. notatorius, Panz. F. G. lxx. 9, q (nec Trentep.). I. flavogullalus, Gr. I. L. i. 442 ; Ste. III. M. vii. 185,8 ㅇ. 
Head black; o with palpi, mandibles, frontal, vertical and external orbits as well as the sides of the face and of the clypens, broadly flavous, frons coriaceous, clypeus discreted, scrobes large; of with cribrary organs, face, cheeks and frontal orbits, flavous. Antemnae black, with scape flavidous beneath; of $q$ somewhat slender, broadly flavous-banded, of to sub-dentate, usually with joints eleven to nineteen flarous above. 'Thorax stout, black with pronotum and lines before and bencath radix, and sometimes two dentiparal patches on the metanotum fulvous or flavous; all the pleurae sometimes broadly flavous in $\&$; areola sub-quadrate or transverse, apically slightly emarginate; petiolar area equilateral, its costae strong and apically sub-dentate, costulae obsolete. Scutellum convex, fulvous or flavous. Abdomen sub-elongate, black; first two or three segments broadly flavous at their apical angles; second to fourth ventral segments at least centrally flavous and plicate; post-petiole glabrous, with a few scattered punctures, often centrally foveate; gastrocaeli normal, somewhat deeply impressed and striate. Legs normal, elongate, black, with posterior tibiae and tarsi sub-tomentose; anterior coxae and, in $\delta$ front legs entirely, flavous; posterior femora partly, tibiae except at base, coxae and trochanters occasionally, flavous-marked; tarsi flavous with apices of the joints fulvous. Wings a little clouded; radix flavous, tegulae piceous ; stigma fulvous. Length, $15-17 \mathrm{~mm}$.

The extent and distribution of the flavous markings are most distinctive.

This lovely species, Stephens says, has been taken about London, in June; and MIarquand records it, in I $\$ S_{4}$, from the district of Land's End; Essex; there are three ancient males with no data in Marshall's collection; I have recently received a female, captured in Cornwall, by $\mathrm{Mr}$. E. C. H. Davies, in I902. On the Continent it extends from Belgium, through central Europe, to Russia ; but has not, I think, been bred. Mr. Davies adds :- "The example I took was resting on a road, upon high ground, in the parish of St. Ervan ; it appeared to be perpetually shivering all over in a very venomous way, which, with its colour, was most repellent; it, however, allowed me to capture it with my fingers without any attempt at flight."

\section{2. leucostigmus, Grav.}

Ichneumon leucostigmus, Gr. Mem. Ac. Sc. Torin, 1820, p. 327 ; I. E. i. 446, o. Hepiopelmus lezucostigmus, Wesm. Nouv. Mém. Ac. Brux. I844, p. I4I ; Bul. Ac. Brux. I 849, p. 4 I ; Holmgr. Ichn. Suec. ii. 280 ; Voll. Pinac. pl. xxvii. f. 5 , o \& ; cf. Thoms. O. E. xix, 2098. Amblyteles leucostismus, Berth. Ann. Soc. Fr. I895, p. 633, o 9. A. incorruplus, Holmgr. Ichn. Suec. ii. 239, . A. pallidizientris, Rud. Ent. Nachr. I888, \&. Var. I. melanogaster, Gr. I. E. i. 209, ․

Body finely punctate. Head black; cheeks scarcely dilated ; mandibles and clypeus partly flavidous ; frontal orbits white; of with palpi and mandibles in part, clypeus, face and sometimes the external orbits, also white. Antennae black, white-banded in both seixes; of $q$ slender, of of subdentate towards the base, with the scape white beneath; its central band occasionally obsolete. Thorax stout, black, of of with pronotum and a line before the radix white; areola sub-quadrate or transverse; costulae entire; apophyses tuberculiform. Scutellum distinctly convex; white, except sometimes basally in $q$. Abdomen black, with the incisures often rufescent; basal segments with the angles usually white; post-petiole glabrous or shagreened, obsoletely punctate and often centrally foveate, 
with the apical angles somewhat prominent and strongly obtuse ; gastrocaeli normal, deeply impressed, with intervening space broader than centre of post-petiole; ventral fold on segments two to four flavous; of with genitalia ferrugineous and the ultimate ventral segment obtuse. Legs normal, black; tarsi pubescent, though not setiferous beneath; anterior tibiae in part red; 0 with anterior femora, tibiae and often coxae whitish. Vings a little clouded, stigma rufescent or testaceous; tegulae piceous. Length, I 3-16 $\mathrm{mm}$.

The var. melanogaster has the post-petiole and usually the scutellum entirely black, its of often has the central flagellar band, which occupies most of the basal third in the type, entirely wanting.

This species, which is widely distributed on the Continent, is probably not uncommon in Britain, though the only record I know is that of a female, bred in $\mathbf{1} 880$, by Bignell, from the cocoon of Odonestis potatoria, for which no locality is indicated, though he tells me he has captured this species at Bickleigh. I swept a fine female from Myrica gale, at Matley $\mathrm{Bog}$, in the New Forest, on $\mathrm{I} 3^{\text {th }}$ August; Piffard has given me both sexes, which he took at Felden, in Herts.; and Bridgman was of opinion that Tuck had found it at Tostock, in Suffolk, October, $\mathbf{1} 892$. It is said to have been bred from Simyra albovenosa by Schm.

\section{ACOLOBUS, Wesmael.}

Wesm. Nouv. Mém. Ac. Brux, i 844 , p. i I I.

Head thick, hardly buccate, slightly rounded and a little narrowed behind the eyes; clypeus punctate, obsoletely discreted, strongly rounded, with a little tooth in the centre, apically; labrum nearly hidden; mandibular teeth sub-equal in length; frons with a vertical tubercle. Antennae slender, setaceous. Thorax stout, longer than high, a little elevated anteriorly; pronotum with no transverse depression; upper metathoracic areae complete; spiracles linear. Scutellum basally carinate. Abdomen elliptic, apically obtuse; post-petiole not depressed, sub-glabrous, with carinae feeble; gastrocaeli obsolete; terebra short. Legs normal, posterior elongate ; tarsi not pectinate. Wings narrow, sides of areolet strongly converging above.

$A$. sericeus, WVesm., the only other species of this genus, closely resembles our species, and is, perhaps, no more than a variety of it. The cephalic and thoracic puncturation is finer, and the abdomen more nitidulous. Its male (cf. Brisch. Schr. Nat. Ges. Danz, 1878 ) is described in Zeits. Syst. Hym. I 903, p. I 88.

\section{I. albimanus, Grav.}

Ichncumon albimanus, Gr. I. E. i. 132 ; Ste. Ill. M. vii. ז33, ô. Acolobus albimanus, Wesm. Nouv. Mém. Ac. Brux, 1844, p. I40; Bul. Ac. Brux. I854, p. I36; Mém. couron. Ac. Belg. 1859, p. 13; Berth. Ann. Soc. Fr. 1896, p. 292, of \&.

Head somewhat finely punctate; mandibles ferrugineous; palpi white; t with cribrary organs, face and external orbits, white; $q$ with marks on clypeus, facial, frontal and vertical orbits, stramineous. Antennae black with the scape pale beneath; of $q$ white-banded. 'Thorax finely punctate, black; lines beneath, and sometimes before, the radix white; areola subhexagonal or sub-triangular. Scutellum black, rarely apically white in of. 
Abdomen smooth, very finely punctate and distinctly shining, of of sublinear with white pubescence; black with all the segments narrowly ferrugineous-margined. Legs black, with all the tibiae of the $q$ dull red and its hind tarsi usually rufescent apically; 0 with front legs, except femora externally, whitish, and the hind tarsi rufescent apically. Wings with piceous stigma. Length, 9--10 $\mathrm{mm}$.

This species is said to superficially resemble Amblyteles oratorius; ( $f$. Kriech. Ent. Nachr. 1896, p. 357). It was first described by Gravenhorst, from an example sent to him by Hope from Netley, and the type is probably still in the latter's collection, at Oxford; Stephens says he found it uncommonly, near London and in Shropshire, in June and July; I know of no recent captures in Britain and the species has not been bred. It is of great rarity on the Continent, being recorded only from Prussia and near Brussels, in July.

\section{ANISOBAS, Wesmael.}

IVesm. Nouv. MIém. Ac. Brux, I844, p. II ; Bul. Ac. Brux. I854, p. 137.

Head of variable size ; mandibles somewhat stout, with the teeth usually sub-equal in length; clypeus deplanate, not discreted from the face; genal costa continuous; epistoma with no inter-antennal tubercle; eyes sub-ovate, with the internal orbits parallel. Antennae somewhat slender, inserted high on frons. Thorax stout, strongly convex ; basal transverse sulcus of the pronotum centrally intercepted by a tubercle or carina; metanotal areae complete; coxal areae entire; epicnemia centrally elevated, not reaching beyond the callus. Abdomen lanceolate- or oblong-ovate, centrally red, apically fasciated with white; gastrocaeli and thyridii deep. Posterior legs stout, the front ones relatively somewhat short; tibiae submutic. Areolet large, broadly pentagonal; radius short, not or hardly apically curved.

Eight palaearctic species are known, of which but one has been recorded from Britain.

\section{I. hostilis, Grav.}

Ichnenmon hostilis, Gr. Nem. Ac. Sc. Torin, I\$20, p. 309 ; I. E. i. 339 ; Ste. Ill. MT. vii. 171, \&. Anisobas hostilis, Thoms. O. E. xix, 2099; Berth. Ann. Soc. Fr. IS96, p. 301, ó + Var, A. relellis, Wesm. Nouv. Mém. Ac. Brux. 1844, p. 145; Bul. Ac. Brux. 1848, p. 68 ; lib. cit. I 854 , p. 138, o; Thoms. O. E. xix. 2099; A. hostilis, Thoms. Ann. Soc. Fr. 1888, p. I2I, $\delta$.

Head black; cheeks somewhat dilated; clypeus sub-truncate; of with external and often the frontal orbits white-marked; ot with internal orbits white. Antennae setaceous, white-banded. Thorax black; to with callosities before and beneath radix white; areola sub-quadrate or transverse. Scutellum gibbous, abruptly declived posterionly, laterally carinate only to its centre, nearly always white; post-scutellum dull and finely striate. Abdomen somewhat broad, black, with first three or second and third segments red, the latter sometimes black-marked; fourth to seventh, and rarely third, broadly white-margined; post-petiole aciculate, more strongly towards its apex; gastrocaeli somewhat large and deeply impressed; second and third segments not very strongly punctate, basally aciculate; of with whitish genital valvulae and the fourth ventral segment plicate. Legs red; coxae, trochanters, apices of hind tibiae and sometimes the sides of 
femora, black; oै with front tibiae internally white. Wings hyaline, stigma piceous; areolet not narrowed above. Length, Io $\mathrm{mm}$.

The variety rebellis, considered distinct by Thomson, is larger, with the abdomen broader, its sculpture coarser, and the incisure of the third segment deep; the declivity of the of scutellum, moreover, is laterally carinate throughout.

This species may be known from its congeners by its strongly gibbous scutellum, stout and normal mandibles, and in having the four or five apical segments white-margined. From the common $A$. cingulatorius, with which Holmgren confounded it, and which should certainly occur upon umbelliferous flowers in Britain, it differs in its dull and finely striate post-scutellum and in its broader and somewhat more coarsely punctate abdomen, which also is more plentifully white-marked.

Stephens says he found this species, which is widely distributed on the Continent, near Hornsey, in April ; the only three indigenous examples I have seen are males of the above variety and were taken in the New Forest, one by Mr. R. C. Bradley, in I 894 , and the other by myself, on the Sth August, running in the bright morning sunshine, about the leaves of a buckthorn bush, at Matley Bog; this circumstance suggested to me that it might be parasitic upon Gonoptery'x rhammi and in the act of searching for the full-fed larvae of that species. 'The last was also captured by Mr. Bradley, in August, at Barmouth. Mr. Bignell has an example bred in France from Lyeaena Iolas.

\section{PROBOLUS, IVesmael.}

Wesm. Nouv. Mém. Ac. Brux. 1844, p. 150.

Head somewhat tumidous, a little dilated behind the eyes and towards the mouth; upper mandibular tooth the longer; clypeus apically subtruncate, laterally rounded. Antennae setaceous, apically attenuate. 'Thorax stout; metathorax short, sub-truncate, rugulose, with the areae sub-obsolete and spiracles short, ovate. Scutellum somewhat flat, laterally immarginate. Abdomen lanceolate-ovate, apically obtuse; basal segment rugosely punctate, with a central dorsal cariniform prominence obliterating the carinae; gastrocaeli sub-obsolete; ventral fold wanting, or present on the second segment only. Legs normal; scopulae wanting; tarsi setulose beneath, claws simple. Wings normal; areolet narrowed above; fenestrae confluent.

All previous authors have followed Tresmacl in placing the present genus among the Platyurini, but the petiole is not at all, or so little as to be quite inconspicuously, broader than high. Personally, I should place it next before Ctenichneumon, but assign the present position, at the end of the Amblypygini, to it in deference to their opinion. Wesmael himself says, in 1854 , that the abdomen is sculptured, excepting the first segment, as in his Amblyteles, adding, however, that the petiole is broader, the metathoracic spiracles shorter and the areolet sub-triangular. Thomson, in I888, remarks the analogy of the structure of the whole body, antennae and legs with that of Amblyteles, excepting only the basal segment; and, in his "Opuscula," he says, "This genus agrees with Ctenichnewmon in the most important characters, especially in the formation of the ventral valvulac of the $f$, but differs in the tuberculiform prominence (tuberliel- 
formiga uppdrifningen) on the disc of the petiole, together with the confluent fenestrae and superficial gastrocacli. But it cannot be united with the Platylabi, since the hind tibiae are not curved and are, like the front ones, spinulose."

Table of Species.

(2). I. Apex of petiole and base of second segment dull, sub-rugose

(1). 2. Apex of petiole and base of second segment shining, glabrous

I. ALtiCOLA, Grav.

2. CONCINNUS, Wesm.

\section{r. alticola, Grav.}

Ichnemmon alticola, Gr. Mem. Ac. Sc. Torin, I820, p. 336 ; var. I, I. E. i. 478 ; Ste. Ill. M. vii. I9o (part.), f. Probolus alticola, Wesm. Bul. Ac. Brux. 1848, p. 306; lib. cit. I853, p. 302 ; Holmgr. Ichn. Suec. ii. 300; Berth. Ann. Soc. Fr. I896, p. 305, $\delta$ q . I. femorator, Ste. III. M. vii. I42, o. P. fossorizs, Wesm. Nouv. Mém. Ac. Brux. 1844, p. I50, 8 q. Var. I. fossorizes, Gr. I. E. i. I64, excl. $q$ (part.). Var. I. truccidator, Gr. I. E. i. I72; Ste. Ill. M. vii. I40, of; cf. Wesm. Mém. couron. Ac. Belg. I859, p. I9.

Head dull black; face a little prominent, short, and roughly punctate ; two vertical dots, and sometimes others at the external orbits, white. Antennae black, somewhat compresso-dilated; scape strongly pilose; of $q$ white-banded with the tenth flagellar joint quadrate. Thorax somewhat shining, black, of $q$ rarely with a line beneath the radix white; metathoracic areae sub-obsolete; apophyses distinct but short. Scutellum, at least apically, flavous; post-scutellum of of also sometimes pale. Abdomen black; of $q$ somewhat nitidulous with segments two, three, sides of four, and sometimes apex of the first, red; of entirely black with the three basal segments finely rugose and dull; post-petiole finely rugose and dull throughout. Legs black, with the front tibiae in part and tarsi of $q$, all the femora, tibiae and, except the hind ones, tarsi of $\hat{\sigma}$, red. Wings with stigma piceous ; areolet deltoid, the sides strongly converging or coalesced above; tegulae piceous, of oै sometimes flavous-marked. Length, I $3-\mathrm{I} 5 \mathrm{~mm}$.

This species, which is common on the Continent, where the female is known to hibernate, is undoubtedly widely distributed in Britain, and nearly all the local lists include it. It has been bred from Hadena adusta, Abrostola triplasia, and, in south Devon, from Taeniocampa stabilis, in the middle of August; there are records of its occurrence in south WVales; near London, in June and July; Bickleigh, in Devon, in September; Land's End; not uncommonly in Norfolk; Essex; and at Hastings, where it has been several times captured by Mr. IV. W. Esam. Adams has taken it in his fly-trap, at Lyndhurst, Hants., in the middle of August ; Thornley, at South Leverton and Cadney, in September; and 'Tuck, both sexes, near Bury St. Edmunds.

\section{2. concinnus, Wesm.}

Ichneumon alticola, Gir. I. E. i. 478 , o (part.). Probolus concinnus, Wesm. Bul. Ac. Brux. 1853, p. 303; Thoms. Ann. Soc. Fr. I888, p. 121 ; Berth. lib. cit. 1896, p. 306, o \& ; Morl. E.M.M. 1902, p. 54, क. (?) I. crassicomis, Ste. Ill. M. vii. I40, of ; $c f$. Morl. E. M.M. 1902, p. 119.

Extremely closely allied to the last-described species, from which it may be known by the body being more strongly nitidulous and slightly larger; the head has the vertex broader and is not narrowed posteriorly, of of rarely 
with a minute vertical dot and sometimes another at the external orbits; the antennae of the $q$ are a little shorter, with the second flagellar joint not longer than broad and the pale central band broader, of $\hat{\sigma}$ rarely semiannulated with white or red; metathorax a little shorter and less rugose; the scutellum, and of post-scutellum, usually white, not flavous; the basal segments shining, punctate or hardly rugose; post-petiole slightly broader, finely sculptured and centrally glabrous at its apex; the legs are a little shorter and the of tegulae and radix are mainly white.

I recently brought forward this species, whose female is known to hibernate, as new to Britain on the strength of an example of that sex, taken by Col. Yerbury, at Parknasilla, in S.W. Ireland, in the middle of July, and I subsequently stated the probability of Ichnemmon crassicomis, Steph., being its male. I have not yet verified nor controverted this latter analogy; Stephens says his insect was taken near London, in June, and probably also at Hertford. Wesmael's species is probably mixed in our, as in the Continental, collections with the preceding ( $f$. Kriech. Ent. Nachr. I 893 , p. 264 et Schm. Opusc. Ichn. iii. 2 r 2).

Sub-TRIEE

\title{
PLATYURINI.
}

Table of Genera.

(6). I. Scutellum not margined beyond its centre.

(5). 2. Hind tibiae straight.

(4). 3. Clypeus apically incrassate; front tarsi

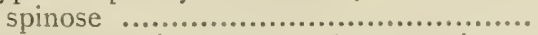

(3). 4. Clypeus not incrassate; front tarsi not spinose ....................................

(2). 5. Hind tibiae slightly arcuate; clypeus and tarsi normal ..............................

(1). 6. Scutellum margined to beyond its centre.

(8). 7. Scutellum always margined to its apex ; $\delta$ antennae distinctly serrate.................

(7). 8. Scutellum rarely margined to its apex; antennae not distinctly serrate ...........

\author{
I. ERISTICUS, Wesm. \\ 2. Tricholabus, Thoms. \\ 3. Eurylabus, Wesm. \\ 4. Pristiceros, Grav. \\ 5. Platylabus, Wesm.
}

\section{ERISTICUS, Wesmael.}

Wesm. Nouv. Mém. Ac. Brux. I844, p. I3.

This genus differs from all others of the Ichneumoninae, except, perhaps, my genus Proboloides, in having the clypeus apically incrassate, narrowly reflexed in the form of a hem; the scutellum is of normal height and gradually declived posteriorly, laterally carinate only at the base; the front tarsal joints are furnished for the most part with fine spines.

Wesmael, in 1844 , erected it on account of the singular clypeal formation for the reception of Ichneumon clericus, Grav., but placed it among the Oxypygini; he subsequently entertained doubts concerning its individuality, finally remarking "chacun est libre d'en juger comme bon lui semblera," and Marshall, followed by Berthoumieu, re-merged it in Ichneumon, but Ashmead, in I900, has transposed it to the Platyurini. Schmiedeknecht considers neither the present genus nor I'risticeros to be valid. 


\section{I. clericus, Grav.}

Iihneumon clericus, Gr. I. F. i. I 40 ; Ste. Ill. M. vii. I35, ơ ; $c$. Wesm. Mém. couron. Ac. Belg. 1859, p. 15; Berth. Ann. Soc. Fr. 1895, p. 225, 8 9. Eristicus clericus, IVesm. Nouv. IIém. Ac. Brux. 1844, p. I3; Bul. Ac. Brux. 1848, p. 139, 8 \&, excl. var. I. Ichneumon eucephahus, Wesm. Bul. Ac. Brux. 18.48, p. 333, o $q$.

Head black, laterally buccate, broader than thorax, of $q$ nearly cubical; clypeus apically incrassate; mandibles centrally red; of with face, clypeus and sometimes the external orbits, white. Antennae black, filiform, a little attenuate apically; of $q$ centrally white-banded, of $f$ with scape often white-dotted beneath. Thorax black, humeral callosities of $\delta$ sometimes white; areola sub-rectangular, of o longer than broad, of st subquadrate. Scutellum black. Abdomen black, elongate, of of sub-linear; apical segment of $q$ white-marked; post-petiole narrow, shagreened or sub-aciculate, of of shortly deeply canaliculate in the centre; gastrocaeli obsolete, with the intervening space aciculate; terebra shortly exserted, as long as the two apical segments. Legs normal, red with coxae and apices of hind femora and tibiae black; front coxae of of occasionally whitemarked. WVings hyaline, stigma and tegulae black; areolet pentagonal, narrowed above. Length, $12 \mathrm{~mm}$.

In conformation the of resembles that of Cratichneumon fabricator.

This species occurs among undergrowth in June, in Germany, France, Hungary and Belgium; but its inclusion in our fauna rests, as far as I am aware, entirely upon Stephens, who says it is rare, but has been taken near London, in July.

\section{TRICHOLABUS, Thomson.}

Thoms. O. E. xix. (1894), 2102.

Head shortly pilose; vertex broad; clypeus apically truncate; mandibles somewhat stout. Antennae of of serrate. Thorax shortly and coarsely pilose, strongly punctate; areola elongate-pentagonal; costulae obsolete, emitted from before the middle. Abdomen sub-equilateral, red, with anus black, fasciated with white; thyridii and gastrocaeli deeply impressed; hypopygium of st short, convex, sub-auriculate and apically sinuate on either side, with the valvulae large and broadly gaping. Hind tibiae straight. Areolet pentagonal.

\section{I. strigatorius, Grav.}

Ichneumon strigatorius, Gr. I. E. i. 352, o ๆ. Amblyteles strigatorius, Wesm. Nouv. TIém. Ac. Brux. 1844, p. I38; Bul. Ac. Brux. I849. p. 4 I ; lib. cit. I854, p. 134 ; Holmgr. Ichn. Suec. ii. 275 ; Thoms. Ann. Soc. Fr. IS8S, p. I20; Berth. lib. cit. 1895, p. 629. Tricholabus strigatorius, Thoms. O. E. xix. 2113 , of 9

Head posteriorly narrowed; mandibles bidentate; frontal orbits stramineous-marked; 0 with all the orbits, and sometimes the mandibles, clypeus and face partly white. Antennae inserted high on frons, black, white-banded in both sexes; of $q$ slender, setaceous, with the fourteenth flagellar joint quadrate; of $\hat{\sigma}$ denticulate. Thorax narrower than head, black; of with humeral callosities more or less distinctly white, and metathorax rarely white-marked; areola a little longer than broad; costulae entire; coxal areae not discreted; apophyses obsolete. Scutellum and 
sometimes a dot on the post-scutellum, white. Abdomen black; three basal segments, except occasionally the petiole, and base of fourth, red; the three apical apically margined, and the fourth often dotted, with white; post-petiole glabrous, with a few scattered punctures and sometimes a central foveola ; gastrocaeli deep, transverse, with the intervening space very narrow; fourth ventral segment of of plicate, its valvulae entirely exserted and very large, black, often white at the apex; terebra of $q$ short, obtuse. Legs somewhat slender, black; tibiae and tarsi, except apices of posterior, and also rarely the apically attenuate femora, red. Wings a little clouded; stigma flavous; areolet narrowed, though not coalesced, above. Length, IO-I $2 \mathrm{~mm}$.

Wesmael, in i 849 , described a variety, called concolor by Berthoumieu, which has the basal segments black, the second and third with a narrow red margin, and the hind tibiae only centrally red.

The Scandinavian T. femoralis, Thoms., which is not unlikely to occur in northern Britain, resembles the present species in size and stature and colour, but may be known by its red legs, its duller, more closely and finely punctate central segments and by the hypopygium of the o not concealing the terebra. It is the only other known species of the genus.

T. strigatorius, which is found somewhat extensively among herbage on the Continent, has been bred, as well as its variety, from Heliothis dipsacea. It was recorded from Britain, by Marshall, in I870, and I possess examples from Hamm, taken probably about Oxford, and in Capron's collection, taken probably about Guildford; it is certainly uncommon with us.

\section{EURYLABUS, Wesmael.}

Uesm. Nouv. Mém. Ac. Brux. I844, p. I50.

Head with cheeks and temples more or less strongly dilated; vertex somewhat broad; frons excavate; clypeus sometimes elevated, apically truncate, not incrassate; mandibles bidentate. Antennae setaceous, not obtusely dentate; basal flagellar joints cylindrical. Thorax stout; notauli distinct; metanotum with areae usually entire and apophyses nearly always strong and large; spiracles elongate. Scutellum flat, with the lateral carinae not extending beyond its centre. Abdomen black, sub-linear, elongate-fusiform or sub-ovate; not apically truncate; ventral segments of I nearly reaching apex of abdomen; basal segment curved, with postpetiole elongate, flat, neither rugose nor transverse; thyridii situated near basal margin of second segment. Front tarsi with no spines; hind tibiae slightly arcuate, sometimes sub-incrassate. Wings normal ; arcolet laterally narrowed, and often coalesced above.

\section{Table of Species.}

(2). I. Abdomen broad; hind legs incrassate; clypeus porrect ...............................

(1). 2. Abdomen narrow ; hind legs normal; clypeus deplanate.

(4). 3. Hind tibiae and tarsi entirely red ; head and scutellum pale-marked ..........................

(3). 4. Hind tibiac and tarsi mainly black; head and

I. DIRUS, WeSm. scutellum immaculate.

(8). 5. Apophyses distinct; antennae not red above.

2. LARVATUS, Christ. 
(7). 6. Clypeus closely and strongly punctate; gastrocaeli normal

(6). 7. Clypeus sparsely and obsoletely punctate; gastrocaeli small

(5). 8. Apophyses wanting; antennae mainly red, at least basally

\author{
3. TORVUS, Wesm. \\ 4. TRISTIS, Grav. \\ 5. RUFIPES, Steph.
}

\title{
I. dirus, Wesm.
}

Ichneumon tristis, Gr. I. E. i. I37, excl. "s." Eurylabus dirnes, Wesm. Bul. Ac. Brux. 1853 , p. 307 , o ; lib. cit. 1857, p. 406 ; Holmgr. Ichn. Suec. ii. 302 ; Thoms. O. E. xix. 2102 ; Berth. Ann. Soc. Fr. 1896, p. 310, $\delta$ q.

A very broad, closely punctate and somewhat dull species. Head black, temples very strongly buccate and broader than the eyes; clypeus strongly porrect, forming an angle with the centrally prominent face, coarsely punctate and apically broadly rounded; occiput depressed and centrally canaliculate; of with maxillary palpi apically ferrugineous. Antennae black; apically attenuate. Thorax black, stout; metanotum scabriculous, dull, posteriorly obliquely truncate; areola transverse, costae strong; costulae wanting; apophyses short, obtuse; spiracles linear. Scutellum black, strongly convex, carinae extending to its centre; postscutellum also strongly convex. Abdomen of $q$ ovate, of tolliptic, black; segments two and three dull, of of narrowly red-margined; postpetiole bicarinate, more or less roughly shagreened, broad, deplanate, submarginate, its spiracles large and oval ; gastrocaeli normal, deep and nearly as broad as the rugose intervening space; ventral segments one to four plicate. Legs stout, hind tibiae and tarsi distinctly incrassate; red, with coxae, trochanters, hind tibiae except basally, and their tarsi, black; hind coxae, at least of $q$, not contiguous with the intermediate, and minutely dentate above. Wings hyaline, stigma red or piceous; areolet deltoid, externally produced, coalesced above; tegulae and radix black. Length, I5-16 mm.

The broad abdomen, stout legs and reflexed clypeus will at once indicate this distinct species, which probably merits generic rank.

Hope first took this insect, at Netley, and it was subsequently, as recorded by Wesmael, taken near London, by Desvignes. It is in all probability commoner with us than is at present supposed. Bignell has taken it, at Bickleigh, in Devon, early in June; Carr, at Treswell, in Notts., in the middle of July ; Fitch, at Maldon, in Essex; and Thornley has given me two fine females, captured at South Leverton, in Notts., during August. On the Continent it is of very wide distribution, extending to Algeria. It has been bred from Trichiura crataegi, and several times in Britain from Eriogaster lanestris. Mr. T. Vilson (Yorks. Nat. I88I, p. I53) bred this species, at Holgate, near York.

\section{2. larvatus, Christ.}

Ichnenmon Vimulator, Geer, Mém. i. 58o. E. Vimulator, Thoms. O. E. xix. 2102. I. larvatus, Christ, Hym. 348, pl. xxxv. f. 5 ; Gr. I. F. i. 160. Eurylahus larvatus, Wesm. Bul. Ac. Brux. 1857 , p. 406 ; Holmgr. Ichn. Suec. ii. 303, 9 ; Berth. Ann Soc. Fr. I896, p. 307, of $q$. Mischophorus favosignatus, Kriech. Ichn. nov. Mus. Hung. 1894, o. Var. E. intrepidus, Wesm. Bul. Ac. Brux. 1855, p. 410, o.

Head sub-cubical, black, quadrate anteriorly and not narrowed behind the eyes; of of with cheeks and temples strongly dilated and the vertex 
transverse; frons strongly concave, transversely striate; mandibles, palpi, cheeks, frontal orbits, sides of clypeus and of face, more or less broadly flavous. Antennae setaceous, black; white-banded in both sexes; of $f$ elongate with the joints cylindrical and the scape flavidous beneath. Thorax black; pronotum, lines before and beneath radix, propleurae and usually the meso- and meta-pleurae, flavidous; metathorax bidentate, short and much lower than the mesonotum, which is centrally canaliculate in $\sigma^{*}$; its basal area distinct; areola transverse or sub-hexagonal; costulae wanting, spiracles lincar. Scutellum flavous, oblong-quadrate, of of with post-scutellum also flavous. Abdomen black, lanceolate-ovate; segments three to five sub-quadrate; six and seven short, the latter apically truncate; post-petiole somewhat narrow, flat, shagreened or fincly aciculate, apically glabrous; gastrocaeli small, transverse-linear; second and third segments rugosely punctate, former sub-aciculate in of. Legs elongate, pale red, tibiae and tarsi stout; anterior coxae, and hind ones marked with, flavous. Wings slightly clouded and flavescent; stigma piceous; areolet deltoid, sometimes coalesced above; radial nervure apically curved. Length, I4-I $8 \mathrm{~mm}$.

E. intrepidus is a $q$ variety of this species with the antennae sub-dilated, often entirely black; the thorax also usually entirely, and the coxae and trochanters always, black. It, moreover, rarely has two parallel vittae on the mesonotum and the post-scutellum flavous.

Holmgren points out that the size and extent of the pale markings are very variable in the $q$, which, he says, ranges from I 5 to $22 \mathrm{~mm}$.; he indicates two varieties, of which the first differs from the type only in having the scape beneath, sides of the breast, and the trochanters in part, pale, the second has the antennae entirely, the thorax entirely, the scutellum entirely excepting sometimes its extreme apex, and all the coxae and trochanters, black. From its congeners it may be known by the sub-cubical, anteriorly quadrate head and entirely pale tibiae and tarsi.

I have not investigated the subject of De Geer's name, but am doubtful of its ralidity since, eren though the identity be established, it appears to be pre-Linnean. ${ }^{\mathrm{I}}$

This species occurs throughout the whole of Europe, and has been found in northern Africa, but it appears to be rare in Britain and was for long considered doubtfully indigenous; it has been bred both here and abroad from Dicranura wimula and Stauropus fagi, the larvae of the latter in one instance having been collected in the New Forest.

\section{3. torvus, Wesm.}

Ictuncumon tristis, Gr. I. E. i. I36, ó (part.). Eurylabus torvus, IVesm. Nouv. Mrém. Ac. Brux. 1844, p. I5I : Bul. Ac. Brux. IS53, p. 304 ; Holmgr. Ichn. Suec. ii. 305 ; Thoms. O. E. xix. 2102 ; Berth. Ann. Soc. Fr. 1896, p. 309, o o .

Head sub-quadrate anteriorly, not narrowed behind the eyes; frons strongly concave, transversely rugose and centrally canaliculate; clypeus strongly punctate, slightly depressed laterally, foreace normal, in the centre of the apex are two small gramulae; of with facial orbits stramineous.

1 It may be of interest, in this connection, to call attention to some capital and very perfect observations "On the strange Generation of a Species of Ichneumon fly," in some hawk-moth caterpillar feeding upon willow, which were published by John Hill, M.D., in his "Essays in Natural History and Philosophy"; London, 1752, pp. 72-90. 
Antennae long and very slender, flavous or ferrugineous beneath towards the base; of $q$ semi-annulated with white. Thorax black; areola subpentagonal, costae strong; costulae entire; coxal areae not discreted; apophyses somewhat short, distinct; spiracles clliptic. Scutellum black; of of convex. Abdomen sub-linear or fusiform, black; basal segment centrally arcuate, gradually dilated from base to apex, rugosely punctate and narrowly margined; second and third segments dull, the remainder nitidulous; gastrocaeli small, transverse, not deeply impressed with the intervening space narrower than centre of post-petiole; third segment transverse ; fourth ventral segment of ot plicate. Legs normal, red; coxae, trochanters and apices of hind tibiae and tarsi, black. Wings slightly clouded; stigma piccous, radix and tegulace black; arcolet strongly narrowed, sometimes coalesced, above. Length, I I-I $3 \mathrm{~mm}$.

Closely allied to the next species, from which it differs in the characters enumerated under the latter.

This species is not uncommon on the Continent, and Bridg.-Fitch say it is the commonest of the genus with us. It has, I think, been but once bred-by Marshall, from British Gnophria rubricollis; and is recorded from Essex.

\section{4. tristis, Grav.}

Ichneumon tristis, Gr. I. E. i. I37, "ס" ; Ste. Ill. M. vii. 134. Eurylahus tristis, Wesm. Bul. Ac. Brux. 1853 , p. 307 ; lib. cit. 1857, p. 405 ; Holmgr. Ichn. Suec. ii. 306 ; Thoms. O. E. xix. 2102 ; Berth. Ann. Soc. Fr. 1896, p. 310 , \& \&. E. corvinus, IVesm. Nouv. Mém. Ac. Brux. 1844, p. I52; Bul. Ac. Brux. 1853, p. 305, $q$.

Black, shining; clypeus convex; to with facial orbits, and flagellum beneath, pale; metathorax sub-bidentate; scutellum of often apically white-dotted; legs red, with coxae, trochanters, hind tibiae towards their apices, and their tarsi, black. Length, II-I $3 \mathrm{~mm}$.

So closely related to the last-described species as to need no repetition. It is, however, abundantly distinct in being rather broader, in its more convex clypeus, which is sparsely punctate, not depressed laterally nor apically bigranulate; the antennae of the $q$ are shorter and centrally immaculate; the costae of the areola are sub-obsolete; the metathoracic spiracles shorter; the third segment quadrate; gastrocaeli smaller and the legs stouter; moreover the fourth ventral segment is not plicate.

This species is much mixed with E. torvus; it has been bred from Trachea piniperda, Dianthacia carpophaga and, in Britain, from D. capsincola. Stephens tells us it is somewhat rare, but has been taken about London, in June; Marquand records it from the distict of Land's End; Harwood from Essex ; and Bradley has met with it at Barmouth. Bignell has taken it in the act of piercing the last-named host, at the end of April, bred it therefrom early in July, and has also found the species, at Starcross, early in August; Davies has found it at St. Ervan, in Cornwall.

\section{5. rufipes, Steph.}

Ichneumon mifpes, Ste. Ill. M. vii. I3I, of \&. Eurylabus mifpes, Morl. E.M.M. 1902, p. I19, ơ o. E. nificornis, Berth. Rev. Sc. Bourb. IS94, p. I8I ; Amn. Soc. Fr. I896, p. 309, ठे.

A slender, shining, finely punctate, black species. Head transverse, black, with cribrary organs and clypeal foveae usually rufescent; clypeus 
only slightly convex centrally; mandibles bidendate, with the teeth subequal and basally punctate; cheeks and temples somewhat narrowed. Antennae setaceous, joints cylindrical, the central ones slightly compressodilated in $\delta$; the basal sixteen to eighteen flagellar joints and often the post-annellus bright fulvous, or the central joints fulvous with the basal more or less infuscate; the apical generally abruptly black above. 'Thorax feebly scabriculous, black; notauli distinct; often with a pale dot before radix ; areola transverse, apically truncate, narrowed in front, costae often obsolete; basal area distinct, coxal not discreted ; costulae usually entire ; apophyses obsolete, tuberculiform ; spiracles elongate-oval, sub-ecpuilateral. Scutellum black, somewhat deplanate, shining, funcly punctate and pilose ; basal carinae not extending to its centre. Abdomen sub-linear, smooth and shining, black, with incisures of first and second segments often rufescent; post-petiole gradually explanate from base to apex, smooth and nitidulous ; gastrocaeli circular, small, sub-obsolete; the four basal ventral segments plicate and more or less piceous. Legs slender, clear red; coxae, trochanters, onychii, apices of hind tibiae and their tarsi black. Wings often somewhat clouded; stigma testaceous, radix and tegulae piceous ; areolet sub-pentagonal, not strongly narrowed above. Length, IO- $14 \mathrm{~mm}$.

No doubt can remain, I think, that this is the species recently described by Berthoumieu under the above name, since Stephens distinctly says the metathorax is unarmed and his description throughout is unusually lucid; there are, however, in his types in the British Museum no red dots before the radix, the stigma is not piceous, and the tegulae are not, as stated by Berthoumieu, red. Very probably these markings fade after death through desiccation.

In describing this species, Stephens says, "Not very uncommon within the metropolitan district, occurring, in July, at Coombe IVood and Hertford and in Salop." I took two males, upon flowers of Angelica sylvestris, at Matley Bog, in the New Forest, on August rgth, Igor. The only circumstance that renders the synonymy of $E$. muficomis doubtful is that it is only recorded from Oran, in western Algeria.

\section{PRISTICEROS, Gravenhorst.}

Gr. I. E. i. (1829) 635.

Head narrower than thorax, constricted posteriorly; maxillary palpi long, slender and setaceous. Antennae attenuate apically, slender and elongate; of $\hat{\sigma}$ internally strongly serrate and villose. Scutellum triangular, sub-convex, laterally carinate from base to apex. Abdomen elongate-oblong; post-petiole sub-quadrate; petiole slender. Legs subelongate. Areolet triangular.

'This genus was erected by Gravenhorst for the reception of the following species, on account of the extraordinarily serrate antenmate of the s, which sex he alone knew. Those of the $\%$ are sub-normal and consequently it is very probable this genus should be merged in the next, or vice virsit, as indeed has already been done by Berthoumieu. Being, however, of opinion that grood characters will yet be discovered by which the present genus may be distinguished, I provisionally here retain it. 


\section{I. serrarius, Grav.}

Pristiceros serrarius; Gr. I. E. i. 637; Wesm. Bul. Ac. Brux. I853, p. 309; cf. lib. cit. Annexe, p. 297 , f. 7,8 , ơ ; Brisch. Schr. Nat. Ges. Danz. 1878, n. 6, p. 50 ; Bridg.Fitch, Entom. 18Si, p. 207, of. Platylabus serrarius, Berth. Ann. Soc. Fr. 1896, p. 317 .

Head black, with the internal and part of the external orbits white; $\delta$ sometimes has mandibles and two dots on the clypeus also white. Antennae white-banded, setaceous; of $\delta$ serrate, of $q$ a little dilated beyond the centre. Thorax gibbulous, black; an elongate line before the radix, two patches on the metanotum and sometimes on the pronotum, white; areola semi-elliptic; costulae entire; apophyses short, distinct. Scutellum black or with an apical white dot. Abdomen black, with the fifth to seventh segments sometimes narrowly white-margined; post-petiole somewhat arcuate, and finely bicarinate; gastrocaeli large; genital valvulae large; terebra shortly exserted. Legs black; anterior tibiae internally, their femora apically, and the basal joint of their tarsi, flavo-ferrugineous. Things more or less clouded; stigma, radix and tegulae nigrescent; areolet sub-triangular. Length, I $5 \mathrm{~mm}$.

This would appear to be an extremely rare species and Gravenhorst was uncertain if it were even European, but Wesmael settled the question by taking a male, near Diest, in I 850 ; they did not, however, know the female or, as I have stated, the genus would probably never have been erected. Brischke bred a male from the pupa of Boarmia consortaria and captured a female, in Prussia, on 2oth August, 1876 . Wesmael, in 1854 , tells us Desvignes found this species near London, and the latter, in 1856 , says it is contained in his collection; whether it was actually taken by himself is doubtful, as there is an example from his collection in the British Museum, which was captured by Fred. Smith, in Coombe IVood, in 1839.

\section{PLATYLABUS, Wesmael. $^{1}$}

Wesm. Nouv. Mém. Ac. Brux. 1844, p. I 50.

Head generally sub-triangular anteriorly, and narrowed behind the eyes ; cheeks and temples normal; frontal depression not strong, sometimes lunate; genal costa inflexed; mandibles never stout, apically attenuate; clypeal foveae somewhat deeply impressed. Antennae slender, setaceous, elongate, often slightly dilated beyond the centre, apically attenuate; inserted somewhat high on frons. Thorax often slender; petiolar area nearly always discreted and basally dilated ; spiracles elliptic, oval or rarely sub-circular. Scutellum laterally carinate to beyond its centre. Abdomen elongate-fusiform or sub-oval, apex of $q$ usually strongly obtuse ; apical dorsal segments retracted; thyridii often broad; petiole more or less explanate, not incrassate; post-petiole transverse and deplanate. Legs normal, often elongate; hind tibiae a little stout and always slightly arcuate, nearly mutic. Areolet rarely broad above, its sides generally distinctly convergent.

1 I have to-day made the astonishing discovery, while glancing through the collection in the British Museum, that Mesostenus maurus, Marsh. (E.M.M. ix. p. 2.4) is a Platylabus. The areolet in no way resembles that of Mesostenus; it is a large black insect of five lines length, with pale scutellum and flagellar band, and may possibly be the female of $P$. dacmon, Wesm.-C.M., Ioth Nov., 1903. 


\section{Table of Species.}

(26). I. Notauli obsolete; spiracles elongate or oval.

(3). 2. Abdomen metallic blue-black...........

I. NiGRocyaneUS, Grav.

(2). 3. Abdomen not blue-black.

(5). 4. Head and thorax mainly red

2. RUFUS, Wesm.

(4). 5. Head and thorax not red.

(17). 6. No abdominal segment entirely red.

(12). 7. Cheeks not buccate; apophyses usually wanting.

(II). S. Mesopleurae and all the orbits not white-marked.

(10). 9. Second segment basally sub-rugose; antennae filiform ......................

(9). I0. Second segment basally sub-glabrous ; antennae centrally stout

(S). I I. Mesopleurae and all the orbits whitemarked

(7). 12. Cheeks sub-buccate; apophyses distinct

(I t). Ij. Apophyses large and stout; apical segment entirely white ................

(13). I4. Apophyses small; apical segment at most white apically.

(16). 15. Costulae and coxal areae entire; legs mainly red ............................

(I 5). I6. Costulae and coxal areae obsolete; legs mainly black

(6). 17. Central segments entirely red.

(2I). I8. Gastrocaeli obsolete; scrobes large; frons sub-glabrous.

(20). 19. Post-petiole glabrous; petiolar area tri-divided ............................

(19). 20. Post-petiole scabrous; petiolar area entire ................................

(IS). 21. Gastrocaeli distinct; scrobes small; frons punctate.

(23). 22. Spiracles elliptic; anus white-marked

(22!. 23. Spiracles broad oval; anus black.

(25). 24. Lateral scutellar carinae entire; face broadly white .............................

(24). 25. Lateral scutellar carinae wanting; face narrowly white .......................

(1). 26. Notauli distinct; spiracles nearly circular.

(34). 27. Metathorax black; scutellar carinae not entire.

(3i). 28. Scutellum black.

(30). 29. Apophyses obsolete; anus immaculate

(29). 30. Apophyses distinct; anus whitemarked

(28). 31. Scutellum white.

(33). 32. Antennae centrally white-marked ......

(32). 33. Antennae of of centrally immaculate...

(27). 34. Metathorax usually red; scutellar carinae entire.

\section{PEDATORIUS, Fab. \\ 4. PUMilio, Holmgr. \\ 5. Phaleratus, Hal.}

6. VARIEGatus, Wesm.

\section{DOLOROSUS, Grav. \\ S. TENUICORNIS, Grav.}

Io. Semirufus, Desv.

I I. ORBITALIS, Grav.

12. TRICINGULATUS, Grav.

13. DECIPIENS, Wesm.
I4. RUBEllus, Grav.

15. NigRiCOLLIS, IVesm.

I6. Volubilis, Grav.

17. PACTOR, Wesm.

IS. Dimidiatus, Grav.

\section{I. nigrocyaneus, Grav.}

Ichnemmon nigrocyanens, Gr. I. E. i. I17; Ste. III. M. vii. 129, \&. Plabylabus nigrocyaneus, Wesm. Mém. couron. Ac. Belg. 1859, p. 12, ठ ; Thoms. O. E. xix. 2105 ; 
Berth. Ann. Soc. Fr. 1896, p. 313 , $\$$. P. armatus, Wesm. Nouv. Mém. Ac. Brux. I 844 , p. I 55, ; ; $f$. Bul. Ac. Brux. I $\$ 53$, p. 309.

A very beautiful, strongly metallic blue insect. Head with clypeus laterally rounded; of $q$ with lateral clypeal dots, the frontal orbits and external orbits, white; of of with palpi, labrum, base of mandibles, and the facial orbits also white. Antennae slender, slightly compressed before their apices, white-banded in both sexes. 'T'horax and scutellum blueblack; areola quadrate, anteriorly rounded ; coxal areae obsolete; apophyses stout and obtuse; spiracles oblong-linear. Abdomen elongate, apically acuminate; post-petiole finely rugose; gastrocaeli deep and transverse; $q$ with second segment narrowly red-margined and the apices of sixth and seventh narrowly pale, its terebra slightly exserted and the apical ventral extending beyond the dorsal segment. Legs blue-black; front femora and tibiae laterally flavidous, latter of white; basal joint of hind tarsi longer than all the remainder. Wings hyaline; stigma piceous; areolet sub-deltoid. Length, ro $\mathrm{mm}$.

On the Continent, this lovely insect, whose brilliancy at once renders it unmistakable, is found in Germany, France and Belgium, where it has been bred from Fidonia piniaria and Trachea piniperda. It is probably of uncommon occurrence in Britain. Stephens bred it from a larva of Plusia festucae, found in the Plaistow Marshes; and Bignell has also twice bred it, in South Devon, from a Noctuid pupa, early in June.

\section{2. rufus, Wesm.}

Hoplismenus pictus, Gr. I. E. ii. 418, excl. ค. Platylabus rufus, IVesm. Nouv. Mém. Ac. Brux. 1844, p. 154, \& ; Bul. Ac. Brux. 1878, p. 307 ; lib. cit. 1853, p. 309 ; lib. cit. I855, p. 4I3 ; Holmgr. Ichn. Suec. ii. 3I4 ; Sv. Ak. Handl, I854, p. 43 ; Thoms. Ann. Soc. Fr. I8S8, p. 125; Berth. lib. cit. 1896, p. 314 ; Thoms. O. E. xix. 2107 , of $q$.

A somewhat large, flattish, red species. Head laterally rounded; cheeks sub-buccate ; clypeus convex, closely and distinctly punctate, apically truncate and not laterally rounded; all the orbits stramineous or white; of with palpi, mandibles, apices of cheeks and most of the clypeus, and of the face, white. Antennae slender; of $q$ nearly always white-banded with scape rufescent, or of to white, beneath. Thorax with pronotum, lines before and beneath radix, stramineous; meso- and meta-notum more or less black, especially in $\hat{\sigma}$, which generally bears two red vittae; notauli obsolete; areola transverse; costulae and coxal areae wanting; apophyses small, distinct; spiracles oblong. Scutellum apically stramineous; of ơ centrally black. Abdomen very rarely black throughout; the two basal segments mainly black, the remainder basally piceous; post-petiole finely rugose; gastrocaeli obliquely sulciform with the intervening space narrow. Legs somewhat stout; the slightly explanate hind tibiae apically, their tarsi, and all the coxae and trochanters more or less, black. IVings flavescent with stigma nigrescent and arcolet narrowed, or coalesced, above. Length, io $\mathrm{mm}$.

This species may be at once known by its entirely or mainly red coloration ; the abdomen of $q$, except basally, is smooth and shining, of of finely punctate; the frons is sub-glabrous and nitidulous with large scrobes.

By no means uncommon on the Continent, where it extends as far north as Lapland, among bushes, in August. I expect it occurs freely also with 
us, since it has been found at Cann Quarry, in South Devon, early in September; in Essex; at Church Stretton, in September, and York, in October; about Lynn, and bred from Cabera pusaria, in Norfolk; Ely; Raynor has bred it from Ypsipetes impluviata; Nr. A. Adie Dalglish has given me females, from Irvine, in Ayrshire, early in September, and Bishopton, in Renfrew, in early July. I have swept the male, from swamps, at Horning, in Norfolk, as early as June 15 th, and taken the female, upon Myriar gale, at Matley Bog, in the New Forest, in August.

\section{3. pedatorius, $F_{a} b$.}

Ichneumon pedatorizs, Fab. E. S. ii. I33, ó; Gr. I. E. i. I8o; Ste. Ill. M. vii. 142, of . Platylabus pedatorizs, Wesm. Nouv. Mém. Ac. Brux. I844, p. I58; Bul. Ac. I3rux. I848, p 309; cf. lib. cit. 1853, p. 312; Holmgr. Sv. Ak. Handl. I 854, p. 43; Ichn. Suec. ii. 317 ; Thoms. Ann. Soc. Fr. I888, p. I23; Berth. lib. cit. I896, p. 32 I,

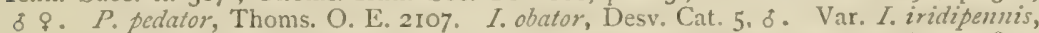
Gr. I. E. i. I94; Ste. Ill. M. vii. I45, ơ. P. iridipennis, Wesm. Bul. Ac. Brux. I853, p. 313 (nec ante); Thoms. Ann. Soc. Fr. 1888, p. 124; O. E. 2108, o q.

Head black, narrowed behind the eyes; frons very finely punctate, shortly canaliculate or foveate centrally; clypeus sub-truncate; cheeks not buccate, sinuate near mandibles; internal orbits stramineous ; of also with apices of the cheeks, sometimes the external orbits or the whole face and clypeus, pale. Antennae long, slender, setaceous, not dilated nor centrally incrassate; of $q$ centrally white-banded, with the sixteenth flagellar joint sub-quadrate; scape of of flavous beneath. Thorax black, of $q$ and sometimes of with pale callosities at the radix; areola usually transverse ; costulae and apophyses wanting; coxal area entire; spiracles elongate. Scutellum laterally carinate nearly to its apex, black; sometimes centrally or apically, and also occasionally the post-scutellum, whitish. Abdomen sub-elliptic, black ; petiole somewhat short, of normal breadth ; post-petiole obsoletely carinate, more or less finely rugose or sub-glabrous ; gastrocaeli of normal breadth and depth, the intervening space rugosely punctate. Legs normal, red; coxae, trochanters and tarsi black; hind tibiae sometimes apically infuscate. Wings hyaline; stigma dark; areolet convergent, or coalesced, above. Length, 8-10 mm.

The variety iridifennis, which Thomson considered a good species, and which, indeed, seems to have as good a claim to distinction as the following, differs in its smaller size, and in always having the lines before and underneath the radix, the scutellum and post-scutellum flavidous; but especially in its convex frons, larger eyes, short lateral scutellar carinae, which hardly reach the centre, smaller spiracles and longer terebra; the t, moreover, has the anterior coxae flavidous.

It should be noted that the present species has the head narrowed behind the eyes, the genal costa anteriorly sinuate and the frons but finely punctate; the mesonotum is nitidulous; the stigma is pale, or, in the of, nigrescent; the abdomen is black, with the incisure of the second segment usually rufescent, its thyridii are obligue and somewhat decply impressed, and the third is transverse; the hind tarsi are not incrassate, and the apices of their tibiae, and sometimes also of their femora, are infuscate; the face of the $\delta$ is variable in colour, but often has the internal orbits, sides of the clypeus and two dots beneath the scapes, flavidous.

Several continental species are extremely closely allied. P. piderturius 
differs from $P$. opaculus, Thoms, in its smaller size, finely punctate frons, basally red tibiae and shining mesonotum, shorter spiracles and more slender legs; from $P$. pumilio, Holmgr., in its larger size, the linear antennae of the $q$, which are longer and have the twelfth joint elongate, as well as in its larger thyridii, the space between which is rugose; from $P$. punctifrons, Thoms., in its fincly and closely punctate frons, somewhat longer petiole and sub-rugrose, not alutaceous, post-petiole; from $P$. slemolewius, Wesm., in its distinct gastrocaeli, which in the latter are sub-obsolete with the white markings more profuse; $P$. pullus, IVesm., is another allied species, but may at once be known by its smaller size, broad and subbuccate head, centrally incrassate antennae, more slender petiole and finely, closely punctate post-petiole, which is a little broader and shorter than in $P$. pedatorius. Several others of the group have been described, but the foregoing are those most likely to be found in Britain.

'This species is common everywhere, on oaks and umbelliferous flowers, from June to September. It has been bred from Pelurgia comitata early in March, Hibemia defoliaria, Eupithecia sobrinata, E. innotata, E. scopariata, E. nanata, E. exiguata, E. pimpinellata; and in Britain from $E$. subnotata, Thera firmata, Limacodes testudo and Hyponomeuta egregiella. It has been recorded from Bickleigh and Hartley, in Devon, where it was bred towards the end of September, from Lobophora lobulata; from Land's End; about London ; Essex ; Hertford ; York ; Goole ; and commonly from Norfolk. The type form would appear to be of much less frequent occurrence than the variety; indeed, besides those mentioned without locality, in Ent. Rec. I899, p. 332, I have only seen one example, which was from Mr. Piffard's collection, taken at Felden, in Herts., and one at Ripley, early in June, by Mr. Morice. The var. iridipennis I possess, from London, in July (IV. Saunders) ; New Forest (Miss Chawner); Whitby, in August, and bred at York, from Eupithecia albipunctata, in April (Beaumont); Chippenham Fen, in Cambs., in July (Tuck); Bramford Marshes, near Ipswich, flying about oak leaves, in the middle of July, and Tuddenham Fen, in Suffolk, late in August, by myself. Dr. Cassal has given me a male, bred from the pupa of Penthina dimidiana, on Myrica gale, together with the chrysalis, which it had evacuated through a sub-circular hole in the ventral surface of the thorax, having composed no cocoon and spun no silken threads therein. It is common throughout Europe.

\section{4. pumilio, Holngr.}

Platylabus pumilio, Holmgr. Ichn. Suec. ii. 422, $\$$; Thoms. Ann. Soc. Fr. 1888, p. I24; Berth. lib. cit. I896, p. 322 ; Thoms. O. E. xix. $2108, \delta$ q. P. iransversus, Bridg. Trans. Ent. Soc. I889, p. 412 ; Berth. Ann. Soc. Fr. 1896, p. 323, o ; ff. Morl. Ent. Rec. I899, p. 332, add. note.

This species very closely resembles the last-described in size and structure, but the clypeus is apically glabrous; the genal costa anteriorly subsinuate and the oral hardly elevated; the antemnae of the $q$ are shorter, with the twelfth flagellar joint quadrate, the following ones being thicker, sub-dilated, and the pale band is narrower; the scutellum always has an apical white dot and the post-scutellum is also sometimes pale in the $\delta$; the second segment is sub-glabrous and never rugose at its base, with the thyridii smaller and the gastrocaeli broader. The of sometimes has the anterior coxae basally, and the face entirely, white. Length, 7-8 $\mathrm{mm}$. 
The hind tibiae appear to be almost constantly black throughout.

It varies sometimes in having pale lines before and beneath the radix, and may be known from $P$. pullus, IVesm., by the equally broad head and thorax.

I have no doubt that Bridgman's of was that of Holmgren's species, though Berthoumieu has separated them on the basis that in the latter the frons is finely punctate and in the former entirely glabrous, though described as "almost free from punctures" by Bridgman; the sub-glabrous base of the second segment appears identical in both and at once distinguishes this species from the preceding, of which I am by no means sure that it is more than a variety.

Bridgman introduced the female as British, in I 884 , on the strength of an example, taken by Rev. E. N. Bloomfield, near Guestling, in Sussex. Five years later he described $P$. transversus, with no reference to its similarity with $P$. pumilio, from two males, bred by Cross, of Ely, from the larvae of Cidaria sagittata, in July. Piffard has taken $P$. transversus, at Felden, in Herts.; Rev. C. D. Ash has bred it at the end of June, from Dianthaecia carpophaga, from Shoreham, in Sussex; and Thornhill has given me both sexes, bred together from osier twigs, doubtless containing larvae, at Cambridge, in the middle of July. $P$. pumilio occurs in Sweden, Lapland and Germany.

\section{5. phaleratus, Hal.}

Ichneumon phaleratue, Hal. Ann. Nat. Hist. I839, p. II2; Bridg.-Fitch, Entom. I880, p. 216 , of of. Platylabues phaleratus, Berth. Ann. Soc. Fr. I896, p. 332 ; $f$. Morl, E. MI M. I902, p. I2I. P. leucogrammus, Wesm. Bul. Ac. Brux, I853, p. 316 ; Holmgr. Ichn. Suec. ii. 315 ; Thoms. Ann. Soc. Fr. IS88, p. I25; Berth. lib. cit. 1896, p. 327 ; Thoms. O. E. xix. 2107 , of $q$

Head black, narrowed behind the eyes ; cheeks sinuate ; clypeus apically sub-truncate or slightly rounded ; frons somewhat glabrous, sparsely punctate, centrally sub-canaliculate; face and cheeks sometimes rufescent; all the orbits white; to also has palpi, mandibles, angles of clypeus, and the facial orbits broadly, or the whole face, white. Antennae slender, apically attenuate; scape white beneath; of with the flagellar joints a little explanate beyond the centre, and the central ones in both sexes with a white band, often obsolete or wanting in $\delta$, which latter has the fifth and sixth flagellar joints carinate. Thorax shining, black, with lines before and beneath the radix, dots on the mesopleurae, in the pleural areae and two in the petiolar area, white; of usually with two white vittae on the mesonotum; areola short; costulae and coxal areae entire; apophyses distinct, though very small; spiracles elongate. Scutellum and post-scutellum white, former carinate to beyond its centre. Abdomen nitidulous, black, with all the segments broadly white-margined; first segment feebly arcuate; post-petiole smooth or shagreened, carinae sub-obsolete, apical angles obtuse ; gastrocacli sub-obsolete, thyridii distinct, intervening space scibriculous; following segments smoother ; ventrul fold white or flividous, extending to fourth segment; terebra slightly exserted. Legs normal, pale red; coxae and apices of hind femora, tibiae and their tarsi, black; anterior coxae of $q$ sometimes rufescent, of $\delta$ white; tarsi of $\delta$ sub-spinulose beneath. IVings sub-hyaline; stigma fuscous, radix white, tegulae nigrescent; areolet coalesced above. Length, $8-9 \mathrm{~mm}$.

At once distinguished from $P$. variegratus by its smaller apophyses and 
gastrocaeli, the more broadly-margined segments, the croceous legrs, and more profusely pale-marked head and thorax.

Here again we meet with the marvellous powers of concise description possessed by Haliday. In a very few words he describes at an early date a species which, I think, can be nothing but that here conjoined with it. 'Though the types are probably still extant in the Dublin Museum of Science and Art, the Director informs me he cannot indicate them, since no labels are affixed, and it reflects the more credit on the author that types are not necessary to the synonymy of his species. I am indebted to Rev. T. A. Marshall for calling my attention to the similarity between Haliday's and Wesmael's descriptions.

Observers have naturally hesitated to record their captures on the authority of Haliday's short description, and we consequently find only the original meintion of this species in Britain, "Ireland, on a willow, in September"; I took several of both sexes upon Salix repens, var. fusca, in Tuddenham Fen, at the end of August, and there is, I believe, a specimen in the British Museum labelled "F. Bond; I. of Wight." On the Continent, $P$. leucogrammus has been found in Sweden, Holstein, Hungary and Russia, but has not yet been bred.

\section{6. variegatus, Wesm.}

Platylabus variegatus, Wesm. Nouv. Mém. Ac. Brux. I 844, p. I56, ơ ; cf. Bul. Ac. Brux, 1853, p. 322; Holmgr. Ichn. Suec. ii. 310; Thoms. O. E. xix. 2107 ; Berth. Ann. Soc. Fr. 1896, p. 314, $\delta$.

Head black, strongly narrowed behind the eyes; cheeks sub-buccate; frons alutaceously punctulate, centrally obsoletely canaliculate; angles of the convex, closely and distinctly punctate clypeus somewhat obtuse ; $\hat{\sigma}$ with facial and frontal orbits flavous. Antennae slender, white-banded in both sexes; scape of of occasionally rufescent beneath. Thorax dull, black; pronotum, callosities before and beneath radix, and two dots in the petiolar area, stramineous ; areola transverse; costulae sub-entire ; coxal areae distinctly discreted; apophyses somewhat long and acute; spiracles elongate. Scutellum and post-scutellum flavidous. Abdomen black, with all the segments apically white-margined and the seventh entirely white; post-petiole rugose, apically rectangular ; gastrocaeli large and deep, with the intervening space narrower than the centre of post-petiole and often striate; remaining segments smoother; terebra hardly exserted; of genitalia stout. Legs red; coxae, trochanters, hind tarsi, apices of their somewhat arcuate tibiae, and sometimes of their femora, black. Wings hyaline, stigma testaceo-piceous; areolet deltoid, sub-coalesced above. Length, 9-10 $\mathrm{mm}$.

On the Continent this species appears to be of somewhat rare occurrence, being found only in Belgium and Sweden. It was first recorded from Britain in Marshall's 1870 catalogue, but I know of no records.

\section{7. dolorosus, Grav.}

Ichneumon dolorosus, Gr. I. E. i. 204 ; Ste. Ill. M. vii. I48, ․ Platylabus dolorosus, Wesm. Bul. Ac. Brux. 1848, p. 308 ; Holmgr. Ichn. Suec. ii. 312 ; Thoms. Ann. Soc. Fr. 1888 , p. 125 ; Berth. lib. cit. 1896, p. 315 ; Thoms. O. E. xix. $2106, \delta$ o. $P$. sol licitus, Wesm. Nouv. Mém. Ac. Brux. 1844, p. 156, \&. 
Head black; cheeks and temples slightly dilated; clypeus closely and distinctly punctate; frons finely punctate, centrally canaliculate ; rertical dots rarely white; $q$ with lateral clypeal dots, internal and external orbits, stramineous; of with cribrary organs, clypeus, face and apices of the cheeks, also pale. Antennae slender, elongate; scape pale beneath; of $q$ white-banded. Thorax black; pronotum, lines before and beneath the radix, stramineous or flavous; apex of metathorax rarely white; areola transverse; costulae and coxal areae entire; apophyses small and feeble, often surmounted in $q$ by a flarous dot ; spiracles elongate-oval. Scutellum centrally flavous; post-scutellum often red. Abdomen black; all the segments, except sometimes the fourth, more or less apically margined with white, the apical often obsoletely so in of; post-petiole more or less rugose, apically rounded and occasionally bimaculate; gastrocaeli and thyridii large and deeply impressed; ventral segments two and three, but not the fourth, plicate; ultimate of $q$ nearly concealing the not exserted terebra. Legs black; anterior coxae sometimes marked with, and a patch above the hind ones, pale; anterior femora and tibiae red or fulvous, the latter flavous laterally; hind tibiae piceous, laterally whitish and their coxae often white-marked. Wings hyaline, stigma nigrescent, radix pale; tegulae fuscous, white-dotted; areolet deltoid, coalesced above. Length, 9-10 $\mathrm{mm}$.

This species is closely related to the last, but may be at once known by the second and third ventral segments alone plicate, and by the large and deep gastrocaeli ; from $P$. variegatus it differs in the much smaller apophyses and in having the apex only of the sixth and seventh segments white.

Bridgman bred this species, which is uncommon on the Continent, occurring in Prussia and Sweden, from Cidaria silaceata (taken at Worthing by Fletcher), in the middle of May; and Brischke from an unidentified Geometrid; the only indigenous record of which I am aware is Stephens', who says he took it rarely, near London, in June.

\section{8. tenuicornis, Grav.}

Ichneumon tenuicornis, Gr. I. E. i. I15, $\delta$ o, excl. var. I ; Ste. Ill. M. vii. I28. Platylabus tenuicomis, IVesm. Mém. couron. Ac. Belg. 1859, p. Io ; Holmgr. Ichn. Suec. ii. 309; Thoms. Ann. Soc. Fr. I8SS, p. 123; Berth. lib. cit. 1896, p. 320; Thoms. O. E. xix. $2106, \delta$ \&. P. niger, Wesm. Nouv. Mém. Ac. Brux. I 444 , p. I 55 , १; Bul. Ac. Brux. I853, p. 310, o $q$.

Head black, hardly constricted behind the eyes; temples sub-buccate and, with the cheeks, clothed in piceous pubescence; clypeus convex, apically sub-truncate and laterally rounded ; frons strongly nitidulous, scrobes large ; apices of the cheeks and the internal orbits, more broadly in of, white; the vertex immaculate. Antennae slender, slightly compressed centrally and white-banded. Thorax entirely black; areola transverse; costulae and coxal arcae obsolete; apophyses short and distinct ; spiracles oblong. Scutellum sometimes apically white. Abdomen elongate, black, with the apical segments occasionally with pale membrane; petiole somewhat short, deplanate; post-petiole (quadrate, basally bicarinate and rugose, but sub-glabrous towards its apxx, with prominent spiracles; gastrocacli strongly transwerse, somewhat deeply impressed, intervening space rugulose and much narrower than centre of post-petiole; terebra slightly exserted. 
Legs somewhat stout, black ; anterior femora apically, and tibiae internally, rufescent or flavidous. Wings sub-hyaline; stigma and tegulae fuscous; areolet deltoid, coalesced above. Length, ro $\mathrm{mm}$.

This species is easily recognised in both sexes by its white-banded antennae, black abdomen, large and oblicuely transwerse gastrocacli, mainly black legs, and stout apophyses.

It occurs in Belgium, Sweden and Germany, where it has been bred from Platypteryx curvatula; but the only British record I can find is from Norfolk, where Stephens tells us it has been rarely found, but Bridgman does not quote this in his county list, and he probably entertained misgivings regarding its authenticity.

\section{9. albinus, Grav.}

Hoplismenus albinus, Gr. I. E. ii. 424, ; Wesm. Mém. couron. Ac. Belg. I859, p. S7. Platylatues allinus, Thoms. O. E. xix. $2110, \delta$ \%. H. cratimudus, G. I. E. ii. 425, $\delta$ (nec 7 dorso albis). P. errahundus, Wesm. Nouv. Mém. Ac. Brux. I844, p. 162, ; ; Bul. Ac. Brux. IS48, p. 312 , 9 ; Holmgr. Ichn. Suec. ii. 328 (part.); Thoms. Ann. Soc. Fr. I888, p. 125 ; Berth. lib. cit. 1896 , p. 326 , oै $q$.

Head narrowed behind the eyes, somewhat shining, black ; frons obsoletely punctulate, sub-glabrous, more or less centrally canaliculate, scrobes small ; apices of cheeks sinuate ; clypeus apically rounded ; frontal orbits stramineous; of also with centre of mandibles and the internal orbits usually white. Antennae slender, centrally slightly dilated and whitebanded; basal flagellar joints of $q$ sometimes rufescent, scape of to white beneath. Thorax black, with lines beneath radix stramineous; metathorax declived from near its base; areola obcordiform, not transverse ; costulae incomplete or wanting; petiolar area distinctly discreted; spiracles elongate. Scutellum and sometimes the post-scutellum stramineous; the latter being sometimes red. Abdomen black; second and third and part of fourth segments red; the apical two or three narrowly white-margined; petiole slightly convex; post-petiole narrow, glabrous, with no carinae and its apical angles rounded; gastrocaeli wanting or very superficial, the intervening space sub-rugose. Legs normal, red or fulvous, with hind femora stout; coxae, trochanters, hind tarsi and apices of their tibiae, black. Wings slightly clouded; stigma usually dark, tegulae white-dotted; areolet convergent, though not coalesced, above; nervellus oblique. Length, 8-9 $\mathrm{mm}$.

Even though Thomson had not pointed out that Gravenhorst's description of errabundus, which obviously differed from the type examined by Wesmael, could not stand for this species, since he writes of the apical segments "dorso albis" ("stor fläck"), the latter's albinus should have taken precedence and is here adopted.

Brischke bred this species on the Continent, where it is somewhat widely distributed, from Anticlea simnata and A. mubidata. It is said to occur upon shrubs, in August, and is probably common in Britain; Bignell has taken it, at lickkigh, in Devon, early in September; Piffard has found it, at Felden, in Herts. ; Routledge, at Geltwoud, near Carlisle ; and it has occurred to me, in the middle of June, among the swamps, in Tuddenham Fen, in Suffolk; and towards the end of August, on flowers of Angelica syluestris, at Matley Bog, in the New Forest. 
I0. semirufus, Desv.

Hoplismenus semimfus, Desv. Cat. 50, \&. Platylabus semimufus, Bridg.-Fitch, Entom. I8SI, p. 208; Berth. Ann. Soc. Fr. 1896, p. 33I, o; if. Morl. E. M. 11. 1902, p. 123 .

Head black, narrowed behind the eyes; clypeus somewhat broadly rounded in front, not discreted from face : frons not canaliculate ; cribrary organs fuscous ; frontal and vertical orbits narrowly flavous. Antennae black, slender throughout, centrally white-banded. 'Thorax and the somewhat deplanate scutellum closely punctate, dull and entirely black; sternauli wanting; areola sub-circular, slightly longer than broad, apically emarginate; costulae and apophyses wanting; petiolar area entire, not discreted; spiracles elongate, equilateral. Abdomen closely punctate, dull, elongate-orate; first three segments and base of fourth red, remainder black ; post-petiole scabrous ; gastrocaeli sub-obsolete ; (the production of the fifth ventral segment is accidental); terebra slightly exserted. Legs piceous ; front femora apically and their tibiae internally white ; posterior tibiae somewhat ferrugineous basally. Wings hyaline; tegulae piceous, radix and stigma fulvous ; areolet pentagonal, its sides convergent, though not coalesced, above. Length, $8 \mathrm{~mm}$.

This species, of which the male is at present unknown, is closely related to $P$. Stallii, Holmgr., in its elongate, equilateral spiracles, black and red abdomen, immaculate thorax and anus, sub-obsolete gastrocaeli, and entire frons, but differs in the conformation of the petiolar area, scabrous postpetiole, posteriorly narrowed head, as well as in the colour of the scutellum and post-scutellum, stigma and hind femora.

No one has recorded this species since Desvignes' time, and there is but a single example from his collection, without locality; in the British Museum. It is quite possibly known on the Continent under a different name, with which, it is hoped, the above description, drawn directly from what appears to be the type specimen, will aid to associate it.

\section{II. orbitalis, Grav.}

Ichnemmon orbitalis, Gr. I. E. i. 490 ; Ste. Ill. M. vii. 19I, o. Platylabus orbitalis, Wesm. Nouv. Mém. Ac. Brux. I844, p. I58; Holmgr. Ichn. Suec. ii. 322 ; Thoms. O. E. xix. 2110 ; Berth. Ann. Soc. Fr. IS96, p. 324, ơ Q Var. I. subalhellus, Gr. I. E. i. 338 ; Ste. III. M. vii. I7I, o ; ff. Wesm. Mém. couron. Ac. Belg. I859, p. 39. Var. I. persecutor, Gr. I. F. i. 491 ; Ste. Ill. M. vii. I9I ; Wesm. Mém. couron. Ac. Belg. 1859, p. $62, \delta$.

Head black, somewhat narrowed behind the eyes; frons deplanate, closely alutaceo-punctate, scrobes small and lunate; clypeus laterally rounded; + with facial, external and rarely a dot at the vertical orbits, narrowly white; of with all the orbits white. Antennae slender, apically attenuate; white-banded in both sexes; of $q$ slightly incrassate beyond the centre. Thorax black, often with two white dots on the pronotum; mesonotum dull, coarsely punctate; areola transverse; costulae more or less complete; apophyses obsolete; spiracles elliptic. Scutellum white, its lateral carinae extending beyond the centre. Abdomen sub-cylindrical, black; the four basal segments red or castaneous; the last two narrowly pale-marsined ; petiole short ; post-petiole nearly glabrous and nitidulous, carinae fine and distinct; gastrocaeli somewhat large and sub-circular, intervening space oftun scabriculous, as broad as centre of post-petiole; 
terebra shortly exserted. Legs normal, black; anterior femora apically, and their tibiae more or less, rufescent, the hind ones basally red. Wings sub-hyaline; stigma and tegulae fuscous; areolet coalesced above. Length, 7-io mm.

The var. subalbellus has the head nearly entirely black, and the apices of the hind trochanters white; the var. persecutor has the base of the mandibles and a dot on the tegulae white, the areolet not coalesced, the basal segments sometimes black and the apical immaculate or with only the seventh narrowly pale-margined. Both these varieties were originally described by Gravenhorst from specimens sent to him by Hope from the neighbourhood of Netley.

No further hosts of this species have been noticed since Bridg.-Fitch compiled Fidonia piniaria, Lobophora sexalata, Thera juniperata and Melanippe fluctuata. All these were bred on the Continent, where it is somewhat widely distributed. In Britain, it is recorded from Essex; Perkins has bred it from Phibalaptery'x tersata; and on 20 th August, 1900, Rev. C. D. Ash found a male had emerged from Cidaria testata, at Selby, in Yorks.; a female also emerged a few days later from the same host. Stephens says neither the type nor varieties were common, about London, in June and July; Marquand records it from the district of Land's End; and Parfitt bred what he states is a variety of this species, with the inner orbits alone flavous, from a larva feeding on citron leaves, in a greenhouse, at Coaver, near Exeter, in March.

\section{I2. tricingulatus, Grav.}

Ichneumon tricingulatus, Gr. Mem. Ac. Sc. Torin, I820, p. 34I ; I. E. i. 505 ; Ste. III. M. vii. 193, ơ. Platylabus tricingulatus, Wesm. Nouv. Mém. Ac. Brux. IS44, p. 160 ; Thoms. Ann. Soc. Fr. 1888, p. 125 ; Berth. lib. cit. I896, p. 328 ; Thoms. O. E. xix. $2112, \delta$.

Head black, narrowed behind the eyes; frons closely punctate, scrobes small and lunate; genal costa a little elevated; mouth, face and clypeus, white, with a central black line. Antennae black; scape white beneath. Thorax black, pronotum and callus beneath radix, white; mesonotum shining, evenly punctate; notauli obsolete; areola transverse ; coxal areae entire; spiracles broad-oval. Scutellum entirely or apically white, its lateral carinae entire. Abdomen black, with second segment for the most part, and apical margin of first and third, red; remainder immaculate ; post-petiole broad, strongly bicarinate; gastrocaeli and thyridii large and somewhat deeply impressed. Legs normal, black; anterior coxae and trochanters white-marked; femora and tibiae, except apices of posterior, red. Wings sub-hyaline; stigma fuscous, tegulae white-marked; areolet sub-deltoid. Length, $8 \mathrm{~mm}$. of.

[Platylabus pallidens, Wesm. Bul. Ac. Brux. I853, p. 320 ; Holmgr. Ichn. Suec. ii. 323 ; Berth. Ann. Soc. Fr. 1896, p. 325, \& ; Thoms. O. E. xix. $2111, \delta$ \% .

Head black, somewhat narrowed behind the eyes; frons closely punctate, scrobes small and lunate; mandibles for the most part, facial, frontal and external orbits, and sometimes dots at the apices of the cheeks and on the vertex, white. Antennae slender, centrally white-banded and slightly dilated. Thorax black; pronotum and usually lines before and beneath the radix white; mesonotum not very dull, notauli obsolete; costulae wanting; petiolar area entire. Scutellum white. Abdomen 
somewhat narrowed apically, black, with the four basal segments more or less red; the last two narrowly white-margined; gastrocaeli and thyridii large, the former sub-circular. Legs normal, red; femora stout; coxac, trochanters, hind tarsi and apices of their tibiae, black. Wings subhyaline; stigma nigrescent, tegulae white-marked, radix pale; areolet coalesced above. Length, 7-S $\mathrm{mm}$. q

This $q$ differs from $P$. orbitulis in its finer puncturation, stouter legs, obsolete costulae, smaller and more superficial gastrocaeli and entire petiolar area.

I give the above description of the $P$. pallidens, since Thomson says, "Forsitan P. pallidentis mas," and again, "Kanske honan till denna art är varietetan I af P. pallidens." He, however, describes a of of $P$. pallidens, which was overlooked or not accepted by Berthoumieu, as differing from $P$. tricingulatus in having the external orbits centrally, nearly the whole of the internal, and a dot at the vertex, as well as the flagellum centrally above, and an elongated line before the radix, white, with the hind tarsi basally fuscous; but he makes no mention of its structure, which is, presumably, identical with that of the $q$.

$P$. tricingulatus is recorded from Piedmont, Germany, Russia and Sweden; $P$. pallidens only from Sweden and Holstein. The former is recorded by Stephens, from about London, in June, and Bignell has bred it, on Ioth June, from Eupithecia pulchellata, in south Devonshire ; Essex.

\section{I3. decipiens, IVesm.}

Platylabus decipiens, Wesm. Bul. Ac. Brux. I848, p. 310, ; lib. cit. I853, p. 319 ; Ilolmgr. Ichn. Suec. ii. 325; Thoms. O. E. xix. 2 III ; Berth. Ann. Soc. Fr. ISg6, p. $324, \delta$ ? . Ischnus Minai, Stephani, Nat. Sicil. I886, of $q$.

Head triangular anteriorly, strongly narrowed behind the eyes; frons closely punctate, scrobes smail and lunate; apices of cheeks, frontal and a trace at the external orbits, white; facial orbits of 5 also narrowly white. Antennae slender, slightly dilated beyond the centre; white-banded in both sexes, though often obsoletely so in male. Thorax immaculate, somewhat shining, black; areola transverse, apically emarginate ; costulac obsolete; apophy'ses small and distinct; spiracles oval. Scutellum and sometimes post-scutellum white; former laterally carinate at the base only. Abdomen with the four basal segments somewhat strongly punctate, red; the apical three or four black, the last only narrowly red- or whitemargined; petiole broad; post-petiole bicarinate, very finely scabriculous, apically glabrous; gastrocacli narrow, transverse and deeply impressed, the sub-rugose intervening space being narrower than the centre of postpetiole; terebra shortly exserted. Legs normal, black; the anterior, and bases of hind, femora and tibiae red. Wings sub-hyaline; stigma and tegulae nigrescent, latter often pale-marked; areolet coalesced above. Length, Io $\mathrm{mm}$.

Bignell captured examples of this species, which was not previously known as British, at Plym Bridge, at the end of May; and at Bickleigh, towards the end of July; and Bradley has given me a specimen which he took at Birmingham. Bankes has given me several examples, bred in South Devon, in July, from Anticlea sinuata, Hb. It has also been bred from Siona dealbata, and occurs in central Europe, France and Sweden. 


\section{I4. rubellus, Gmel.}

Ichneumon mbellus, Gmel. N. S. i. 2704 ; Gr. I. E. i. I38, excl. + ; Ste. Ill. M. vii. 134. Ectopizus rubellus, Wesm. Mém. couron. Ac. Belg. I859, p. I4, ठ。. Platylabus rubellus, Berth. Ann. Soc. Fr. 1896, p. 328, of क. P. Thedenii, Holmgr. Ichn. Suec. ii. 329, of 9 ; of. iii. 388 .

A somewhat shining species. Head short, black, hardly broader than thorax, rounded behind the eyes; frons smooth, centrally canaliculate; face transverse, convex; clypeus transverse, rather strongly convex, apically truncate and finely margined; apices of cheeks somewhat reflexed and alone flavous. Antennae black, sub-filiform, slender though slightly incrassate centrally. Thorax gibbulous, black; mesonotum shining and finely punctate; metathorax short, abruptly truncate apically, rugosely punctate with complete areae; areola very short and broad, transversely linear ; petiolar area discreted, large and flat; spiracles very small and rotund-oval. Scutellum black, strongly protuberant, laterally margined to near its apex. Abdomen oblong; black, with second segment apically castaneous ; petiole elongate, deplanate ; post-petiole quadrate, equilateral, smooth and shining, disc sub-convex, carinae obsolete, spiracles prominent; second segment elongate, narrowed basally, finely and closely punctate, with linear and sub-parallel thyridii ; third transverse ; terebra hardly exserted. Legs normal, red; tibiae sub-arcuate; coxae, trochanters, hind tarsi and apices of their tibiae, nigrescent ; hind tibiae of $q$ sometimes entirely red. IVings sub-hyaline; stigma large and infuscate; areolet deltoid; tegulae and radix piceous or stramineous. Length, $6-7 \mathrm{~mm}$.

The $q$ rarely has the three basal segments more or less red, and the flagellum centrally white above.

I do not consider that Holmgren's name for this species can stand, as indicated by Schm. in Opusc. Ichn. p. 227 , since its identity with that of Gravenhorst is established, if not by IVesmael, certainly by Thomson in O. E. xix. 2104 .

Stephens took this species uncommonly, about London, in June; it occurs on umbelliferous flowers, in August. It has been bred in Britain, from Emmelesia unifasciaria, by Mr. Elisha. On the Continent it is recorded from Germany, Sweden and Austria.

\section{I5. nigricollis, Wesm.}

Platylabus nigricollis, Wesm. Nouv. Mém. Ac. Brux. I844, p. I6I ; Bul. Ac. Brux. 1848, p. 31 ; Thoms. Ann. Soc. Fr. I881, p. I25; Berth. lib. cit. I896, p. 330; Thoms. O. E. xix. $2113, \delta$.

Head triangular anteriorly, and narrowed behind the eyes, black; vertex short; clypeus apically rounded; frons coriaceous, scrobes small and lunate; fo with bases of mandibles, angles of clypeus, facial and sometimes a dot at the vertical orbits, white. Antennae setaceous, centrally slightly compressed and white-banded; of of with scape white beneath and the central band often sub-obsolete. Thorax black, of of with a pale callosity beneath the radix; notauli distinct, short; areola transverse, often sub-incomplete apically; costulae entire; apophyses short and distinct; spiracles small, sub-circular. Scutellum black; its lateral carinae posteriorly indistinct. Abdomen somewhat short, black; two or three basal segments red, the first being sometimes black in 0 ; the apical three 
white-margined ; post-petiole bicarinate, glabrous ; gastrocacli large, somewhat superficial and slightly oblique; ultimate ventral segment not hiding the shortly exserted terebra. Legs red; coxae, trochanters, hind tarsi and apices of their tibiae, black ; front tibiae laterally flavous ; tarsi slender, of $q$ sub-spinulose. Stigma and nervures black; areolet pentagonal, more or less broad above ; nervellus vertical. Length, $6--8 \mathrm{~mm}$.

This species occurs in central and northern Europe, and is probably common in Britain, where Bridgman is said to have bred it from Hyponomeuta padella; Essex; Col. Perbury took it, at Caragh Lake, in S. IV. Ireland, about the middle of Iugust; and I have found it, at Ipswich, by sweeping nettles, in Bentley Woods, at the end of May.

\section{I6. volubilis, Grav.}

Cryptus volubilis, Gr. I. E. ii. 507, ô. Platylabus volubilis, Bridg.-Fitch. Entom. I88r, p. 208; Berth. Ann. Soc. Fr. IS96, p. 330, o.

Head generally with the internal, and a trace at the external, orbits narrowly white. Antennae centrally white-marked. Thorax black, with white callosity beneath the radix; spiracles circular. Scutellum white. Abdomen sub-fusiform, red; petiole and segments six, seven, and sometimes the margins of the fourth and fifth, black; sixth and seventh generally white-margined; post-petiole gradually dilated; gastrocaeli distinct. Legs slender, elongate, red; coxae, trochanters, anterior legs laterally, and hind ones at the apex, black. Wings sub-hyaline; stigma and tegulae piceous, latter sometimes white-dotted; areolet sub-triangular. Length, $9 \mathrm{~mm}$.

The legs appear to vary somewhat in colour. This species has never been adequately described, and the female is still unknown.

Gravenhorst records its occurrence on umbelliferae and sallows, in Germany, in August. It was introduced as British, by Desvignes, in $1 \$_{5} 6$, and transposed to the present genus, by Marshall, in I 870 . I know of no distinctly indigenous records, however, and it has not been bred.

\section{I7. pactor, Wesm.}

Platylabus pactor, Wesm. Nouv. Mém. Ac. Brux. 1844, p. I64; Bul. Ac. Brux. I848, p. 313 ; lib. cit. 1849 , p. 42 ; lib. cit. IS55, p. 413 ; Holmgr. Ichn. Suec. ii. 331 ; Thoms. Ann. Soc. Fr. ISSS, p. I26; Berth. lib. cit. 1896, p. 330 ; Thoms. O. E. xix. 2112, $\delta$ q.

Head triangular anteriorly, narrowed behind the eyes; vertex short; clypeus apically depressed and laterally rounded; frons coriaceous, scrobes small and lunate; frontal orbits and vertical dots white; of with face also white. Antennae somewhat slender, black; of $q$ centrally sub-dilated and white-banded; of $f$ ferrugineous beneath. 'Thorax black, with pronotum and lines before and beneath radix white; notauli distinct, short; areola transverse, arcuate; costulae entire; apophyses wanting; spiracles small, sub-circular. Scutellum and often post-scutellum white; sides of former shortly carinate at the base only. Abdomen black, with first four or five segments red; fifth or sixth to seventh, of which the apical two are retracted, white-nargined; post-petiole somewhat narrow, glabrous, apical 
angles quadrate ; gastrocaeli somewhat superficial, transverse; anus of $q$ densely ciliate, its hypopygium not concealing the shortly exserted terebra. Legs normal, red; coxae, trochanters, hind tarsi and apices of their tibiae, black; anterior coxae of $\delta$ white; tarsi slender, of $q$ spinulose. Stigma red or fuscous ; tegulae of $\delta$ white; areolet pentagonal, narrowed above ; nervellus vertical. Length, 5-8 $\mathrm{mm}$.

This pretty little species is probably not common in Britain. I possess an example found in the London district; Bridgman took it, at Earlham, near Norwich, and is said to have bred it from Eupithecia minutata. On the Continent, it has emerged from $E$. absynthiata, and is frequent on bushes, in France, Belgium, Sweden and Germany.

\section{I8. dimidiatus, Grav.}

Hoplismenus dimidiatus, Gr. I. E. ii. 421, ᄋ. Platylabus dimidiatus, Wesm. Nouv. Mém. Ac. Brux. 1844, p. I60; Bul. Ac. Brux. I848, p. 3 II ; Holmgr. Ichn. Suec. ii. 332 ; Thoms. Ann. Soc. Fr, I888, p. I26 ; Berth. lit. cit. I896, p. 329 ; Thoms, O. E. xix. 2113, o \&. Phygadenon discedens, Gr. I. E. ii. 673, ó.

Head triangular anteriorly, strongly narrowed behind the eyes, black; vertex short; clypeus centrally flat, laterally rounded; frons coriaceous, scrobes small and lunate. Antermae slender, black, centrally white-banded in both sexes; of $q$ usually red towards the base. 'Thorax red; mesonotum, especially of $f$ entirely or partly black, the latter more often has the metathorax also black; notauli distinct, short; areola transverse; costulae entire; apophyses obsolete or wanting; spiracles small, subcircular. Scutellum black, very often red or red-margined, its lateral carinae entire. Abdomen somewhat short, black, with the two basal segments red and the apical three broadly white-margined; petiole deplanate; post-petiole bicarinate, glabrous ; gastrocaeli superficial, narrow, obliquely longitudinal; hypopygium not hicling the shortly exserted terebra. Legs somewhat slender, red; hind tarsi and apices of their tibiae, occasionally the coxae and trochanters, black; tarsi slender, of $q$ spinulose. Stigma dark; tegulae nigrescent; areolet pentagonal, narrowed or coalesced above; nervellus vertical. Length, $6-8 \mathrm{~mm}$.

The coloration of this species is somewhat variable, especially in regard to the extent of the thoracic and, in $q$, antennal red ; the latter occasionally has the legs black, with the posterior coxae in part red; the of rarely has the two basal segments black with the second red-marked.

This handsome little insect is by no means uncommon, in August and September, on shrubs, in Britain, and is somewhat widely distributed on the Continent, where the female is known to hibernate among moss, etc. It has been bred from Depressaria heracleana and $D$. depressella; and in England, from Melunippe fluctuata, and in the middle of May from the equally common $M$. montanata. It is recorded from Land's End, South Devon, Essex, Mousehold Heath near Norwich, Hastings, and Kenmare in S.W. Ireland early in July. I have examples taken at Felden in Herts., Lewisham in the middle of June, and in the New Forest; Beaumont has found it at Catford, Chobham, Malvern, Colwyn and Kilmore; Luff, in Guernsey; and Chitty, at Parley, Surrey, in May. 
TRIBE.

\section{PHAEOGENIDES.}

The species of this tribe were grouped together by Wesmael, in his "Tentamen" (1844) under the name of Iclneumones-pneustici, which was retained by Holmgren, in I889, and Thomson, in I89I; but in 1896 Terthoumieu applied that of Cyclopncustici to it, in contradistinction from the Stenopneustici, which latter term enbraced all those genera already described. Ashmead more recently split off the sub-tribe Heresiarchini from, and raised it to equal dignity with, the Pluatogenides, reinstating the Alomyides nearly in the position here assigned to it.

\section{Table of Sub-tribes.}

(2). I. Mandibles apically acute, lower tooth wanting: head broad

(I). 2. Mandibles apically obtuse, bidentate; head normal

HERESIARCHINI. PHAEOGENINI.

\section{SUB-TRIBE.}

\section{HERESIARCHINI.}

The apically acute and edentate mandibles, very broad head, and usually strongly concave occiput will at once distinguish the present subtribe from the next, with which alone it can be confused by reason of the circular metathoracic spiracles and general conformation. Only four genera are enumerated as known to science, of which but one has, somewhat recently, been found to occur in Britain. This genus differs from the more typical ones in having the vertex of the head entire.

As to the validity of this sub-tribe, no inconsiderable doubt may be entertained, since, as will be found in the Pluceogenini, the mandibular dentation is prone to wide and varied modification, becoming, in the genus Ischuius, very nearly unidentate by reason of the pusillity of the lower tooth; in the latter genus, however, the scutellum is sub-conical. There can, I think, be no doubt that this sub-tribe is too nearly related with the remainder of the Phaeggenides to merit equal rank therewith.

\section{STENODONTUS, Berthoumieu.}

Berth. Ann. Soc. Fr. I896, p. 346 ; Gnathoxys, Wesm. Nouv. Mém. Ac. Brux. I844, pp. I65, 168 (nec IVestw.).

Head buccate, broader than thorax, very finely punctate; mandibles apically acute, with the lower tooth entirely wanting; clypeus broader than long, somewhat convex, hardly discreted from the centrally protuberant face, its apex simple and mutic; genal costa sub-continuous and not elevated. Intemae filiform, pulsescent, somewhat incrassale; scape hardy emarginate and longer than post-annellus; second flagellar joint quallate? the following transverse. Thorax deplanate; pronotum nitidulous ; metanotum finely areated, not produced posteriorly. Scutellum not strongly elevated. Abdomen shining, elongate; post-petiole quite smooth, somewhat narrow, and laterally immarginate; thyridii distinct and fir from base of second segment; terebra stout. 


\section{I. marginellus, Grav.}

Ichnenmon marginellus, Gr. I. E. i. 192, 8. Gnathoxys marginellus, Wesm. Nouv. Mém. Ac. Brux. 1844, p. 168, o ; Bul. Ac. Brux. 1855, p. 416 ; Holmgr. Ichn. Suec. iii. 382 ; Thoms. O. E. xv. $1615, \delta$; ; Brisch. Schr. Nat. Ges. Danz. 1878, n. 6, p. 52, \%. Sienodontus marginellus, Berth. Ann. Soc. Fr. 1896, p. 346, of q.

A small black species, with red legs and partly white scutellum. Head buccate; occiput only slightly emarginate; temples broad, shining, sparsely punctate; face closely punctate ; clypeus large, anteriorly broadly rounded and depressed; black, of with internal orbits and cheeks, mouth and usually two dots on the clypeus, stramineous, $f$ with palpi pale, mandiules fulvous, clypeus basally rufescent and frontal orbits whitish. Antennae sub-filiform; of of rather more than half length of body, black with scape white, and flagellum ferrugineous, beneath; of $q$ less than half length of body, sometimes rufescent in centre beneath. Thorax narrower than head, sub-cylindrical ; mesonotum shining, finely punctate ; metanotum rugulose, areola rounded in front and longer than broad, especially in $q$; costulae sometimes complete; black, with pronotum and callosities at radix white. Scutellum laterally white or flavidous. Abdomen somewhat smooth, obsoletely punctate, with fine grey hairs; black, with segments two to six often apically pale; seventh usually narrowly white-marked. Legs red, stouter in $q$; of coxae red or black, the anterior white-marked. Wings hyaline; stigma fusco-testaceous, radix and tegulae stramineous; areolet somewhat narrowed above. Length, 5-7 $\mathrm{mm}$.

The only other European species of this genus, $S$. nasutus, Wesm., is also likely to occur in Britain, since it is found in France, Germany, etc. From the above, it may be known by the white flagellar band of the o, and the entirely white face of the $\delta$, which also has the antennae flavous beneath.

S. Marginellus was first taken with us by Bignell, at Plym Bridge, towards the end of September, I88I; Dr. Capron records it from Shiere, in 1885 (E. M.M. 1886, p. 264); Piffard has given me an example from Felden, in Herts.; and I have swept it from Vicia sativa, in Bentley Woods, near Ipswich, towards the end of June, and taken it at Gosfield, in Essex. It is probably overlooked and not uncommon in Britain, since, on the Continent, where the female hibernates, it is somewhat widely distributed, though I am not aware that it has yet been bred.

SUb-TRIBE.

\section{PHAEOGENINI.}

\section{Table of Genera.}

(26). I. Mandibular teeth of more or less unequal length; frons rarely glabrous.

(3). 2. Clypeus quadrate; metathorax biden-

(2). 3. Clypeus transverse; apophyses wantI. Apaeleticus, Wesm.

(23). 4. Scutellum simply convex.

(22). 5. Metathorax not apically produced above hind coxae.

(17). 6. Second segment with distinct transverse basal impression. 
(I4). 7. Clypeus, with no central depression before its apex.

(13). 8. Areolet entire.

(12). 9. Epistoma not elongate ; clypeus distinctly discreted.

(II). 10. Lower mandibular tooth very small; nervellus antefurcal

(10). II. Lower tooth normal ; nervellus postfurcal or opposite .....................

(9). I2. Epistoma not transverse; clypeus not or hardly discreted

(8). I3. Areolet apically interstitial ..............

(7). I4. Clypeus with a distinct central depression before its apex.

(16). I 5. Epistoma not transverse; clypeus broadly excavate apically ...............

(15). I6. Epistoma not elongate; clypeus, with at most an apical fovea.................

(6). I7. Second segment with no basal impression.

(19). I8. Head normal ; nervellus antefurcal or opposite ...............................

(I8). I9. Head buccate; nervellus post-furcal.

(2I). 20. Mandibles of $q$ sinuate below; fflagellum not basally attenuate .........

(20). 2I. Mandibles of $q$ not sinuate; flagellum basally attenuate ................. Io. Centeterus, Wesm.

(5). 22. Metathorax apically produced above coxae, sub-caudate......................

(4). 23. Scutellum distinctly elevated, gibbous.

(25). 24. Anus acute ; terebra straight ........... 12. Ischnus, Grav.

(24). 25. Anus obtuse; terebra reflexed ......... I3. HETERISCHnUs, Wesm.

(I). 26. Mandibular teeth of equal length, or frons nitidulous and nearly glabrous.

(28). 27. Abdomen scabrous; intermediate coxae sub-globose ..................... I 4. TRACHYARUS, Thoms.

(27). 28. Abdomen punctulate; coxae normal or elongate.

(30). 29. Metanotum areated ; frons punctate... i 5. Hemichneumon, Wesm.

(29). 30. Metanotum not areated; frons glabrous.

(32). 3I. Areolet complete; metanotum gradually declived

(3I). 32. Areolet incomplete; metanotum abruptly declived .................... I7. MELANomicrus, Morl.

\section{APAELETICUS, Wesmael.}

Wesm. Nouv. Mém. Ac. Brux. 1844. p. 165.

Head somewhat tumidous, narrowed towards the mouth and behind the eyes; epistoma convex; clypeus sub-quadrate, sub-discreted, convex, smooth or sparsely punctate; mandibular teeth unequal. Antennac subfiliform, sometimes incrassate; basal flagellar joint cylindrical. Thorax somewhat strongly punctate; notauli distinct; metanotum rugose, distinctly areated and bidentate, with the costulae entire; mesopleurae shortly sulcate; spiracles circular. Scutellum convex, usually margined to its middle. Abdomen ovate-lanceolate, in $q$ apically sub-truncate and 
retracted; petiole with no dursal carinae ; gastrocacli very distinct ; terebra scarcely visible. Legs normal, hind ones somewhat long and stout; tarsi slender. WVings with areolet narrowed above, pentagonal.

Wesmael at first placed this genus in his Pneustici, on account of its circular spiracles, but in 1853 he was of opinion that its more natural position was next after Platylabus, in the Platyuri, considering the deplanate, sub-truncate and apically retracted abdomen of the $q$, in spite of the more slender and more suddenly explanate post-petiole. 'This opjinion he maintained in 1855 , and in it he has been followed by Thomson (who makes no mention of the genus in his "Opuscula "), Brischke and Holmgren. Authors of the present day, however, have reinstated it in its original position, which, if not the most natural, is at least the most convenient under our arbitrary and, I hope, ephemeral classification.

No species of this genus appears to have yet been bred in captivity. A. mesostictus, Grav., which is generally distributed in Europe, and A. flammeolus, WVesm., which is found in Belgium, France, Sweden, etc., out of the eight continental species, are very likely to inhabit Britain.

\section{Table of Species.}

(2). I. Apophyses long and acute ; anus not entirely

(1). 2. Apophyses small, though distinct; ; anus entirely red.

I. BELLICOSUS, Wesm.

2. INCLYTUS, Wesm.

\section{I. bellicosus, IVesm.}

Apaeleticus bellicoszıs, Wesm. Nouv. Mém. Ac. Brux. 1844. p. 166; Bul. Ac. Brux. Annexe, I853-54, pl. i. f. II, $\$$; lib. cit. 1855, p. 4I3, var. ó ; lib. cit. 1853, p. 324 ; Holmgr. Ichn. Suec. ii. 336 ; Thoms. Ann. Soc. Fr. I888, p. 126; Berth. lib. cit. 1896, p. $335, \delta$..

Head short, black; frons roughly punctate, centrally sub-canaliculate; face protuberant; cheeks externally sinuate and slightly reflexed; clypeus somewhat convex, sparsely punctate and apically truncate; frontal orbits pale; o with facial orbits red; of with mouth, clypeus, face and apices of cheeks, flavous. Antennae attenuate towards apex, slightly thickened beyond the middle; seventh flagellar joint quadrate; of of with flagellum ferrugineous, and scape flavous, beneath; of $q$ centrally white-banded, with scape red beneath. Thorax black; metanotum rugose, with complete and determinate areae, of which the petiolar is discreted and transversely striate; apophyses large, stout and acuminate; pronotum, humeral callosities, and sometimes a mark near the spines, pale. Scutellum white or, in of, flavous. Abdomen red; post-petiole strongly and closely punctate; second segment transversely impressed at base, with large and deep gastrocaeli; the apical segments usually infuscate, with a narrow, pale margin; petiole of $f$ black. Legs red; $q$ with trochanters, hind femora apically, base and apex of hind tibiae and the hind tarsi, black; of with anterior coxae and trochanters sulphureous. IVings with piceous stigma. Length, 6-7 $\mathrm{mm}$.

In his "Miscellanea," mention is made by Wesmael of a foriety, with the clypeus, second and third segments infuscate, and the last four entirely black; Kriechbaumer (Ann. Soc. Esp. Hist. Nat. I 854 ) describes $A$. balearicus, $q$, which Berthoumieu considers a variety of the present species, 
with the head and thorax red, the metanotum, abdomen and legs for the most part, black. Thomson says the colour of the capital and thoracic markings is not flavous in the typical of, but white or lacteous.

This species, which is somewhat widely distributed on the Continent, appears to be represented in Britain by a single specimen, which Fitch says is in the National Collection, from that of Desvignes; and it must, consequently, though very likely to occur with us, be at present regarded with due reserve as indigenous.

\section{2. inclytus, IVesm.}

Apaeleticus inclytus, Wesm. Bul. Ac. Brux. I853, p. 328; Brisch. Schr. Nat. Ges. Danz. I878, n. 6, p. 52 ; Berth. Ann. Soc. Fr. I896, p. 336, o.

Similar to the preceding. Head black, with the cheeks sub-sinuate and sub-reflexed; palpi, mandibles, the apically mutic clypeus, face, frontal and apex of external orbits, white. Antennae with flagellum flavous, and scape white, beneath. Pronotum and lines before and beneath the radix white; metathoracic apophyses small. Scutellum white. Abdomen red, with the petiole black; post-petiole punctate throughout. Legs black, the anterior coxie and trochanters white beneath; anterior femora and tibiae, and base of hind femora, red. Stigma black; radix and tegulae white. Length, $6 \mathrm{~mm}$.

Thomson, in the "Annales," considered this species to be the of A. flammeolus, IVesm., but, since M. Pic has more recently discovered the true of of that species in Switzerland, $A$. inclytus is still accounted a good species, of which the $q$ is at present unknown.

It was first recorded from Britain, by Bridgman (Trans. Ent. Soc. I 886, p. $33^{6}$ ), on the strength of a specimen, taken by Thouless, at Lakenham, near Norwich ; and he himself subsequently captured it at Earlham, in the same neighbourhood, in July. On the Continent it appears to have only been found in Prussia and the northern districts of France.

\section{HERPESTOMUS, IVesmael.}

Wesm. Nouv. Mém. Ac. Brux. I844, pp. I65, I69.

Head hardly narrowed behind the eyes; vertex rather broad; clypeus sub-discreted and densely punctate, apically rounded or sub-truncate; mandibular teeth unequal, the upper being large and somewhat acuminate, the lower very small; face moderately convex. Antennae filiform and distinctly short; scape sub-cylindrical, hardly emarginate apically. Pronotum densely punctate; metanotal areae distinct and complete; areola sul-pentagonal. Abdomen elongate-sub-fusiform ; petiole somewhat short and deplanate; post-potiole strongly dilated and usually punctate; gastrocaeli of variable depth; thyridii distinct and transverse. Legs somewhat stout; calcaria long; coxae mutic. Areolet narrowed above; discoidal cell with its lower angle hardly acute; nerrellus oblique, antefurcal.

\section{Table of Species.}

(4). I. Gastrocacli large and somewhat deep.

(3). 2. lost-petiole quadrate, punctate-aciculate ... I. BRUNNICORnis, Grue.

(2). 3. Post-petiole transverse, punctate throughout 2. NASUTUS, IVesm.

(I). 4. Gastrocaeli sub-obsolete or wanting. 
(6). 5. Petiolar area broad and deeply excavate ... 3. Furunculus, Wesm.

(5). 6. Petiolar area only slightly impressed.

(8). 7. Face not black; post-petiole centrally glabrous

(7). 8. Face black; post-petiole centrally aciculate

4. $\Lambda$ RRIDENS, Grav.

5. DISTINCTUS, Bridg.

\section{I. brunnicornis, Grav.}

Ichnesmon brannicomis, Gr. I. E. i. I45; Ste. Ill. M. vii. I36; Ratz. Ichn. d. Forst. i. 134. Herpestomus brannicomis, Wesm. Nouv. Mém. Ac. Brux. 1844, p. I7o; Holmg. Sv. Ak. Handl. I854, p. 44 ; Ichn. Suec. iii. 377 ; Thoms. O. E. xv. 1617; Berth. Ann. Soc. Fr. 1 \$96, p. 347, of ; $f$. Voll. Schets. I. pl. iii. f. I2.

Head black, with the vertex somewhat deeply emarginate; palpi and mandibles pale; facial orbits narrowly flavous; of with clypeus and face stramineous. Antennae filiform, about half length of body ; usually ferrugineous throughout, sometimes darker above and, in of, stramineous towards the base beneath. Thorax stout, black; notauli distinct; lateral sternal sulci deep and very determinate ; areola obcordiform; petiolar area slightly excavate, discreted and transversely striate; ot usually with pronotum fulvescent and a white dot before the radix. Abdomen punctate, black; post-petiole roughly punctate, sul-aciculate, its apical angles obtuse; gastrocaeli large and deep; third segment transverse; terebra stout and slightly exserted; of with incisures of central segments testaceous. Legs normal, rufescent, with paler trochanters; apices of hind tibiae, tarsal joints and often the coxae, infuscate; of with anterior coxae and trochanters flavous and hind femora apically nigrescent. Stigma clear brown; tegulae pale. Length, 5-7 mm.

Found, not rarely, near London, in June and July (Stephens). It has also been taken in Essex and Devon, but is not recorded from Norfolk. Tuck has captured it, at Tostock, in Suffolk, in September; Piffard, at Felden, in Herts. ; and I have beaten it, from Pinus sylvestris, in Bentley Woods, near Ipswich, early in April, probably after hibernation. It is, I expect, a common species with us, and is widely distributed on the Continent, where it has been bred from Hyponomeuta padella, H. malinella, $H$. evony'mella and $H$. cognatella; the late Rev. J. Hellins bred two females, which I have examined, towards the end of July, I896, from the first-named host, the larva having been taken at Chichester.

\section{2. nasutus, Wesm.}

Herpestomus nasutus, Wesm. Nouv. Mém. Ac. Brux. 1844, p. I70 ; Bul. Ac. Brux. I 848 , p. 314 ; Thoms. O. E. xv. 1617 ; Berth. Ann. Soc. Fr. 1896, p. 348, o \&. Var. H. intermedius, WVesm. loc. cit., + .

Head black; face protuberant ; cheeks not buccate ; mandibles red in o; in $\delta^{t}$, as well as the palpi, a facial fascia and sometimes a part of the apically truncate clypeus, flavous. Antennae sub-filiform, apically attenuate, dark ferrugineous becoming paler, and in of flavous, towards the base beneath. Thorax somewhat short and gibbous; pronotum and callosities at radix white; notauli short; areae distinct and, in $\delta$, with elevated costae. Scutellum black. Abdomen black; of of with sides and apex of the very broad, dull and closely punctate post-petiole, and segments two to four red; ô with segments two to seven laterally and 
apically rufescent; gastrocaeli minute but distinct. Legs red; anterior trochanters, and in of coxae, flavous; of with hind coxae black and hind femora and tibiae fuscous towards their apices. Stigma red; tegulae white. Length, 5-7 $\mathrm{mm}$.

H. internnedius, Wesm., is now considered a $q$ variety of this species, which has the body very finely and closely punctate throughout, and differs from it in its puncturation being much less close, rendering it more strongly nitidulous, the thorax is entirely black and more cylindrical with the mesonotum less convex, the impression on the mesopleurae beneath the hind wings is deeper and the central segments are more or less infuscate.

Bridgman took the type form, at Earlham, near Norwich, in August, I88I, and the var., at Eaton, in the same neighbourhood; the latter is recorded by Bignell, from Bickleigh, in August, and Lxeter, early in September. It is a local species on the Continent, and has not been bred.

\section{3. furunculus, IVesm.}

Herpestomus furzunculus, Wesm. Nouv. Mém. Ac. Brux. IS44, p. I7I ; Berth. Ann. Soc. Fr. 1896, p. $348, q$.

This species will probably prove to be no more than a variety of the preceding, from which it differs in the broadly and deeply canaliculate petiolar area ; the slightly longer and more slender petiole, and somewhat more incrassate legs, of which all the coxae are red.

Bridgman says (Trans. Ent. Soc. I $88_{3}$, p. I 40 ) he took a specimen, appearing to appertain to this species, in which the legs were decidedly thinner than those of $H$. intermedius. He expressed some doubt, however, and, until this be cleared up, $H$. furunculus, which is only recorded elsewhere from the vicinity of Brussels, has but a poor claim to incorporation in our fauna, in spite of his record of its occurrence at Earlhan, Eaton and Mousehold, in August and September (Trans. Norf. Nat. Soc. 1893, 1. 6 Io).

\section{4. arridens, Grav.}

Ichnenmon arridens, Gr. I. E. i. 50I, ठ̊; Ste. Ill. M. vii. I93; Wesm. Mlém. couron. Ac. Belg. I859, p. 62. I. xanthops, Gr. I. E. i. 502, 8. Herpestomus xanthofs, Holmgr. Ichn. Suec. iii. 378 ; Berth. Ann. Soc. Fr. I896, p. 349, o o. I. facialis, Cir. I. E. i. 590, \&. H. facialis, IVesm. Nouv. Mém. Ac. Brux, I844, p. 173, + ; Bul. Ac. Brux. I 848 , p. 31 5, of B Brisch. Schr. Nat. Ges. Danz. 1878, n. 6, p. 53 ; Thoms. O. L. xv. 1618, o 9. I. pusillator, Gr. I. F. i. 605, excl. क; Ratz. Ichn. d. Forst. i. I35, excl. o; cf. WVesm. Mém. couron. Ac. Belg. I859, p. 75. Var. Diadromus erubescens, Berth. Bul. Soc. Fr. 1899, p. 137, o ; ff. lib. cit. 1900, p. 252.

Head sub-rotund; cheeks buccate, frons finely and closely punctate; f with mandibles, the discreted and apically truncate clypeus, and the face, rufescent; of with palpi, mandibles, apex of cheeks, the clypeus and the face, stramineous. Antennae short and stout, not attenuate, dark ferrugineous; of $q$ paler beneath and semi-anmulated with white; scape of $\delta$ whitish beneath. Thorax cylindrical; pronotum, a conspicuous line from the somewhat indistinct notauli to the tegulae, and a little line below the radix, white; metanotum rugulose, areae complete; areola sub-pentagonal, apically truncate. Scutellum black and deplanate, its apex usually white in $\delta$. Abdomen red, with the petiole and more or less of the dorsum 
infuscate; post-petiole red, aciculate, a little dilated and centrally glabrous; gastrocaeli wanting, but thyridii distinct. Legs red; coxae nigrescent, those of $\delta$ mainly white. Stigma and tegulae piceous; radix whitish. Length, 5-6 $\mathrm{mm}$.

The typical of has the scutellum flavous, with the basal segment black, the second black with a red margin, the third red witli a nigrescent dorsal mark, and the following red, the ultimate being infuscate; I. xanthops has two apical confluent white dots on the scutellum, and the abdomen black with the post-petiole, second, third and fourth segments marked with castaneous; I. facialis has the scutellum black, with the three basal segments, except the petiole, red, the fourth being entirely black or in part red; I. pusillator also has the scutellum black, but with all the segments redmargined.

Scarce, taken near London, in July (Stephens); Mr. F. C. Adams has been good enough to send me two females of this distinct species, taken at Lyndhurst, in the New Forest, in May and June; it is probably local, having a restricted continental range, from Belgium to Sweden, and has not been bred.

\section{5. distinctus, Bridg.}

Herpestomus distinctus, Bridg. Trans. Ent. Soc. I887, p. 362 ; Berth. Ann. Soc. Fr. I 896, p. 349, o.

This species would appear to be very closely allied to the last-described, from which it differs in the following particulars:- Head transverse, scarcely narrowed behind the eyes, impunctate, entirely black; apex of clypeus broadly rounded. Antennae somewhat clavate. Thorax immaculate; notauli distinct; costulae sub-complete. Basal abdominal segment somewhat irregularly and coarsely aciculate, with its apex nitidulous. Apical half of hind femora, apex and extreme base of hind tibiae, infuscate. Length, $5 \mathrm{~mm}$.

Bridgman described this species from a single female, taken by Mr. G. C. Champion, at Caterham. 'The type is probably in the former's collection, in the Norwich Castle Museum; it is unknown on the Continent.

\section{PHAEOGENES, Wesmael. ${ }^{1}$}

Wesm. Nouv. Mém. Ac. Brux. 1844, p. 166.

Head often transverse, and broader than thorax; clypeus sub-glabrous, not abruptly depressed apically ; epistoma short, distinctly discreted from clypeus by a transverse impression; mandibles of nearly equal breadth from base to apex, their teeth of nearly equal length, the lower being slightly the shorter. Antennae filiform or a little attenuate apically ; scape rarely inflated or deeply excised at apex. Metathorax not posteriorly produced. Scutellum almost invariably black. Gastrocaeli transverse-linear, sub-confluent centrally; thyridii always distinct, those of $q$ somewhat remote from base of second segment. Legs somewhat stout; hind coxae

I Ichnemon rufator, Ste. III. M. vii. $20 \pi, \sigma^{3}$, is a Phaengenes, as his type in the British Museum indicates, but I do not know to which of the recognised specics it belongs. Stephens took it about London, in June, and Parfitt boldly records it from Hatherleigh, in Devon. 
of $q$ often dentate or carinate beneath. Areolet complete; nervellus post-furcal or opposite.

The peculiar appendages of the hind coxae exist almost exclusively in the $q 9$, and are, consequently, of but little value in compiling a tabular view of the species in both sexes. Bridg.-Fitch, relying upon colour as of primary distinction, and Berthoumieu, upon the coxal conformation, give none at all, or most unsatisfactory ot distinctions. 'Thomson's thirteen divisions of the genus-excluding Mevesia and Bacosemus-are of equal value inter se and not always adapted to clear linear arrangement. 'The following, however, appears to be a comparatively comprehensible conspectus of our often extremely closely allied species of this pretty genus.

The insects of this genus, with one or two unauthentic exceptions, are parasitic upon quite small Lefidoptera, and they have more especially been bred from Psychids, notably Psyche viciella and P. nitidella.

The extremely close relationship between the genera Phaeogenes and Diadromus led IVesmael himself to, subsequently, consider them identical, and in this he has been followed by British authors; but Thomson (O. E. $\mathrm{xv}, \mathrm{I} 6_{3}$ ) has placed them upon a fairly satisfactory footing by pointing out that as a rule, beyond the discretion of the clypeus (which is wanting in $P$. plinifrons), the anterior angles of the clypeus are impressed, the antennae shorter and less attenuate apically, with the post-annellus less elongate, and that the $q q$ have the hind coxae (excepting in Holmgren's sub-genera) mucronate, in the present genus. Both genera are now well established upon the Continent.

\section{Table of Species.}

(4). I. Transverse anal nervure of hind wing not intercepted ; coxae mutic (MEVESIA, Holmgr.).

(3). 2. Legs pale fulvous or basally whitish...

(2). 3. Legs piceous-red, not basally paler ...

I. ARGUTUS, Wesm.

2. SIMILIS, Bridg.

(I). 4. Transverse anal nervure of hind wing intercepted.

(Io). 5. Head tumidulous, strongly dilated posteriorly; coxae mutic (PROScus, Holmgr.).

(9). 6. Pronotum black.

(8). 7. Head strongly punctate; of face black; of flagellum white-banded ............

(7). 8. Head finely punctate; ô face flavous; of flagellum not white ..................

(6). 9. Pronotum white-marked ..................

(5). 10. Head normal, not strongly dilated posteriorly.

(12). II. Post-petiole coarsely and regularly punctate ; coxae mutic (BAEOSENIUS, Först.)

(I1). 12. Post-petiole not coarsely punctate; coxae of o usually dentate (PH.AEOGENES, auctt.).

(22). 13. Face strongly, somewhat coarsely and confluently punctate.

(15). 14. Clypeus apically sub-sinuate and centrally slightly produced.................

(14). 15. Clypeus apically truncate or broadly rounded.

(21). 16. Post-petiole not aciculate.

3. cephalotes, Wesm.

4. SUSPICAX, Wesm.

5. ACUTUS, Grav.

6. mitigosus, Grav.

7. STIPATOR, Hism 
(20). 17. All the coxae black.

(19). IS. Head as broad as thorax; cheeks apically dilated ........................

(I8). 19. Head broader than thorax; checks apically not dilated

(I7). 20. All the coxae mainly red....

(16). 21. Post-petiole distinctly aciculate .........

(13) 22. Face not strongly, more or less closely and distinctly punctate.

(24). 23. Cheeks apically sinuate and produced bencath mandibles.....................

(23). 24. Cheeks not sinuate and not or hardly produced.

(50). 25. Frons closely, sometimes sub-obsoletely, punctate.

(35). 26. Frons deeply punctate; clypeus neither margined nor sinuate; tegulae nigrescent.

(34). 27. Clypeus laterally entire.

(29). 28. Notauli elongate; segments two to four finely alutaceous

(28). 29. Notauli obsolete or punctiform ; segments two to four punctate.

(33). 3o. Post-petiole not aciculate; coxae black.

(32). 3I. Cheeks sub-buccate; vertex normal ...

(3I). 32. Cheeks not buccate; vertex rounded

(30). 33. Post-petiole usually aciculate; front covae piceous or red

(27). 34. Clypeus laterally sub-sinuate ...........

(20). 35. Frons superficially and finely punctate.

(39). 36. Clypeus laterally sub-sinuate, apically immarginate ; tegulae pale.

(38). 37. Flagellum of $q$ tricoloured, its coxae mucronate ...........................

(37). 38. Flagellum bicoloured, coxae mutic ...

(36). 39. Clypeus laterally entire.

(43). 40. Clypeus apically margined by an impressed line.

(42). 4I. Frons of $\delta$ not smooth; flagellum of o tricoloured

(4I). 42. Frons of of sub-glabrous; flagellum of $q$ bicoloured ............................

(40). 43. Clypeus apically immarginate.

$(45)$. 44. Coxal tooth of $q$ vertical; face of $f$ white.

(44). 45. Coxal tooth of $q$ not vertical; face of ô mainly black.

(47). 46. Antennae mainly black; length, $5 \mathrm{~mm}$.

(45). 47. Antennae mainly red; length, $8 \mathrm{~mm}$.

(49). 48. Flagellum not entirely red $\ldots . . . \ldots . .$.

(48). 49. Flagellum entirely red ....................

(25). 50. Frons sparsely punctate, especially in the centre.

(52). 51. Aludomen in both sexes black; hind tibiae and tarsi white-banded .........

(51). 52. Abdomen of $q$ centrally red; hind legs not or indistinctly white-marked.

(54). 53. Pronotum and humeral callosities white (53). 5t. Pronotum and humeral callosities black.
8. SEMIVUlpinus, Griv.

9. PLANIFRONS, Wesm.

10. Melanogonus, Gmel.

II. HETEROGONUS, Holmgr.

12. OPHTHALMiCUS, Wesm.

13. MODESTUS, Wesm.

14. FUSCICORNIS, Wesm.

I 5 . TREPIDUS, WeSM.

I6. INFIMUS, Wesm.

17. EQUES, Wesm.

I8. ISCHIOMELINUS, Grav. I9. IMPIGER, Wesm.

20. BELLICORNIS, Wesm.

2I. NANUS, Wesm.

22. MIACUliCoRnis, Steph.

23. Mysticus, Wesm.

24. STIMULATOR, Grav.

25. HOMOCHLORUS, Wesm.

26. CALIopUS, Wesm.

27. FUlvitarsis, Wesm. 
(56). 55. Segments two and three red; legs of

(55). 56. Segments two to four red; legs of $f$ 28. CORYPHAEUS, IVesm. not basally white.

(58). 57. Anterior covae of of flavous 29. RUSTICATUS, IV CSM.

(57). 58. Anterior coxae black 30. NITIDUs, Bridg.

For the further elucidation of the females, included in the restricted genus, the following table of the very distinctive hind coxal structure may be found of use.

Corae of female Phacogenes, showing armature.

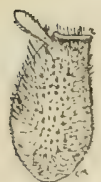

semilvulpinus.

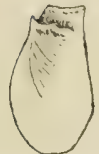

ophthalmicus.

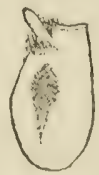

maculicornis.

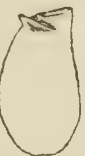

fulvitarsis and vusticatus.

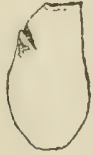

stipator.

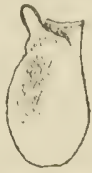

stimulator and liomochloris.

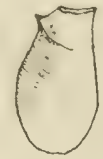

bellicormis.

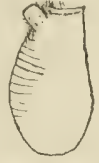

melanogonts and (less striate) planifrons.

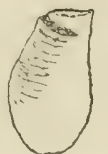

ischiomelinus.

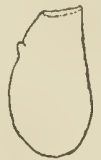

nanus.

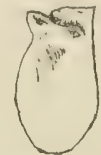

mysticus.

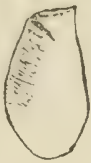

eques.

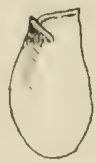

callopus.

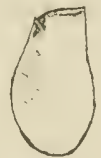

infimus and modestus.

(26). I. Coxae carinate or clentate beneath.

(5). 2. Carinae wanting ; tooth large and vertical.

(4). 3. Tooth elongate, cylindrical, apically sub- 8 . SEMIVULPINUS. acuminate

II. HETEROGONUS.

22. MACULICORNIS

(3). 4. Tooth somewhat short, apically truncate ..... $\left\{\begin{array}{l}\text { 9. PLANIFRONS. } \\ \text { 10. MLLANOGONUS. }\end{array}\right.$

(2). 5. Carinae present.

(19). 6. Carinae produced into an oblique apical tooth.

(10). 7. Carinae inflexed.

(0). S. Carinae sub-bidentate, transverse

12. OPHTHAI.MICUS.

(8). 9. Carinae strongly unidentate, oblique...

$\int$ 24. STIMULATOR.

(7). Io. Carinae straight.

(12). I1. Carinae elevated at base and apex

25. HOMOCHLORUS.

(11). 12. Carinae elevated at apex only.

(14). I3. Tooth somewhat elongate

23. MYSTICUS.

(13). 3. Tooth short.

(18). 15. Coxae sub-trans-strigose before the carinae.

(17). I6. Coxae and tooth red

28. CORYPILAES.

(16). 17. Coxae black before, red beyond the carinae

26. CALLOPUS.

20. LELLICORNIS 
(15). 18. Coxae simple before carinae, recl, with tooth

(6). I9. Carinae not produced apically.

$\int 27$. FULVITARSIS.

(29. RUSTICATUS.

(25). 20. Carinae distinct.

(24). 2I. Carinae acute, reaching apex of coxac.

(23). 22. Coxae red, distinctly aciculate before carinac $\{$ 17. EQUES.

(22). 23. Coxae black or piceous, indistinctly aciculate $\left\{\begin{array}{l}\text { 13. MODEST tis. } \\ \text { 3. }\end{array}\right.$

(21). 24. Caringersus.

(21). 24. Carinae scopuliform, not reaching apex; 7. STIPATOR. coxae not aciculate ......................... It. FLSCICORNIS.

2I. NANUS.

(20). 25. Carinae sub-obsolete $\ldots \ldots \ldots \ldots \ldots \ldots \ldots \ldots \ldots \ldots \ldots \ldots \ldots \ldots \ldots$ I5. TREPIDUS.

(1). 26. Coxae mutic .............................. I9. IMPIGER.

\section{I. argutus, Wesm.}

Phaeogenes argutus, Wesm. Nouv. Mém. Ac. Brux. 1844, p. 20 ; Brisch. Schr. Nat. Ges. Danz. 1878 , n. 6, p. 57 ; Berth. Ann. Soc. Fr. 1896, p. 383, o o. Mlevesia arguta, Holmgr. Ichn. Suec. iii. 4I9; Thoms. O. L. xv. 1629, $\delta$ q.

Head sub-buccate, frons convex, deeply impressed ; face strongly protuberant ; epistoma longer than broad; mandibles narrow, teeth of nearly equal length, the upper acute; clypeus completely discreted, its apical margin entire; $q$ with mouth, clypeus and sometimes the facial orbits, red; of with mouth, clypeus, apices of cheeks, and the face, white. Antennae with scape apically deeply excised without; of $q$ apically incrassate: of 0 as long as body, dark above, pale, with scape white, below. Thorax black, with lines at radix and often pronotum, especially in 0 , pale; notaûli distinct; areola short, sub-lunate, costulae emitted before its centre ; petiolar area longitudinally excavate. Abdomen elongate-fusiform, sub-glabrous, shining; segments two to five apically, or nearly entirely, pale; six and seven of $q$ pale fulvous; post-petiole finely aciculate; thyridii transverse, pale and very distinct. Legs of $\hat{\sigma}$ whitish, hind femora, base and apex of hind tibiae, and their tarsi, infuscate; of $q$ pale fulvous, with hind ones partly fuscous. Stigma stramineous; radix and tegulae whitish; nervellus oblique and the lower margin of the hind wings densely and evenly ciliate. Length, 4-6 $\mathrm{mm}$.

This and the next species may be known from the remainder of the genus by having the transverse anal nervure of the hind wing not intercepted; but Thomson retained Holmgren's genus Mevesia primarily on account of its longer clypeus and epistoma, its semi-glolose head and the female's smooth and sub glabrous abdomen.

Undoubtedly a common British species. Eaton and Earlham, near Norwich, where Bridgman first found it in Britain; Wilson Saunders took it at Reigate, and Greenings, in I873 ; Piffard has found it not uncommonly, at Felden, in Herts.; Beaumont, at Harting, in Sussex, at the end of August, and Kilmore ; and Dalglish has sent it to me, from Orookotom, in Scotland; I have several times turned it up, at roots of grass, during the winter, in Bentley Woods. On the ist September, IS9r, Mr. Richardson bred a female, which I have examined, from Stephensia brunnichella, at Paignton, near Torquay. It has not before been bred, though recorded from Sweden, Belgium, Germany, etc. 


\section{2. similis, Bridg.}

Phacogenes similis, Bridg. Trans. Ent. Soc. I881, p. 148, pl. viii. f. 4, \%.

Head tumidous, hardly narrowed behind eyes ; clypeus smooth, shining and not depressed; frons finely and somewhat closely punctate ; mandibles piceous. Antennae slender, sub-incrassate apically, pale ferrugineous; scape black and four basal flagellar joints piceous above. Thorax black ; notauli indistinct; pronotum ferrugineous; areola longer than broad, semi-oval ; petiolar area slightly excavate. Abdomen cylindrical ; second segment apically ferrugineous; post-petiole sub-aciculate; thyridii very distinct; terebra distinctly exserted. Legs slender : coxae mutic; the anterior piceous-red with femora, apices of tarsi and of intermediate tibiae, infuscate ; hind legs fusco-piceous, with trochanters, base of femora, tibiae and tarsi, rufescent. 'Tegulae pale, stigma dark. Length, 5-6 mm.

This insect seems to be closely related to the preceding, and, although the salient features of Mevesia were unknown to Bridgman, it would appear to fall most naturally therein.

One female alone is known, which was taken, by Billups, in Britain, in I 880 .

\section{3. cephalotes, Wesm.}

Phaeogenes cephalotes, Wesm. Nouv. Mém. Ac. Brux. I844, p. 197, ơ ๆ; Bul. Ac. Brux. I 855, p. 427, var. + ; Holmgr. Sv. Ak. Handl. I854, p. 47 , $\$$; Thoms. O. E. xv. 165I ; Berth. Ann. Soc. Fr. I896, p. $38 \mathrm{r}$, of $q$. Proscus cephalotes, Holmgr. Ichn. Suec. iii. 421 , o o.

Head large, strongly punctate, dilated behind eyes; vertex deeply emarginate; cheeks short and buccate; genal costa inflexed, but not elevated ; clypeus very short, sub-triangular, laterally sub-sinuate, dorsally impressed and distinctly discreted; mandibles elongate, stout, apically a little narrowed, teeth nearly equal; of with second joint of palpi white. Antennal flagellum stout, basally attenuate; of $q$ broadly white-banded, of $f$ ferrugineous apically beneath. Thorax narrower than head; notauli small ; metathorax of of rugose ; areae complete; areola not longer than broad; petiolar area discreted. Abdomen elongate, narrow, of of subacuminate apically ; centrally more or less rufescent ; post-petiole convex, of $\delta$ coarsely rugose and bicarinate, of $q$ centrally smooth; second segment of to basally rugose, of $q$ aciculate ; terebra shortly exserted. Legs black, with anterior tibiae and apices of front femora usually rufescent. IVings a little clouded; stigma and tegulae black; nervellus nearly antefurcal. Length, 9-I I $\mathrm{mm}$.

The large head and stout form of this and the next two species, which also seem to belong to Holmgren's genus Proscus, superficially resemble those of the aculeate genus Pempliredon, and will serve to separate them from those which follow.

In Marshall's collection (Mus. Mason) is an example of this species bred "From pupa of Aeg. (Sesia) culiciformis, Tilgate Forest, Sussex." I do not think that it has before been bred; Bignell has taken it, at Horrabridge, in the middle of September, and Piffard has given me a specimen, from Felden, in Herts. ; there is another in Desvignes' collection. It has a wide range throughout central Lurope. 


\section{4. suspicax, Wesm.}

Phacogenes suspicax, Wesm. Nouv. Ném. Ac. Brux. 1844, p. 200, ơ $q$; Brisch. Schr. Nat. Ges. Danz. 1878 , n. 6, p. 57, + ; Iridg. Trans. Ent. Soc. 1881, p. 147, $\delta$; Thoms. O. E. xv. 1651 ; Berth. Ann. Soc. Fx. IS96, p. 382, of o. Proscus suspicax, Holmgr. Ichn. Suec. iii. 422, 8 \% .

Black; antennae brown, sub-annulated with red; areola longer than broad; second and third abdominal segments often mostly red; legs variegated with red and fuscous ; tegulae often white; of with mouth, clypeus and face sulphureous, and the anterior coxae and trochanters apically white. Length, $4-5 \mathrm{~mm}$.

This species so closely resembles the last-described in structure as to need no detailed description; it may instantly be known therefrom by its finely punctate, convex and shining frons, by its excavate and very indistinctly discreted petiolar area, transverse areola and small size.

Scotland (Bridgman); captured at Bickleigh, in Devon, I ith August (Bignell). Probably mixed with $P$. cephalotes, in Britain; elsewhere it is only noted from Sweden, Germany and Brussels. Ratzeburg (Ichn. d. Forst. iii. I67) was almost certainly in error in supposing Brischke, who makes no reference to the fact in his "Ichneumoniden der Provinzen West- und Ost- Preussen," bred this species, from burrows of Saperda populnea, which lives in the twigs of Populus tremula (cf. Diadromus subtilicornis, post).

\section{5. acutus, Grav.}

Ichnenmon acutus, Gr. I. E. i. 598 ; cf. Wesm. Mém. couron. Ac. Belg. I859, p. 74.

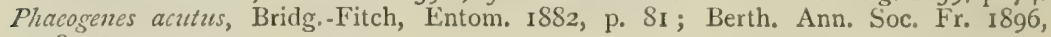
p. 385, , .

Black. Antennae half length of body ; flagellum fuscous, with base and two central joints ferrugineous. Thorax black with pronotum white. Abdomen gradually narrowed from second to fifth segnients; the basal hardly sub-foveolate; second and third castaneous. Legs stout, black; anterior tarsi and most of their tibiae, base of all the femora, and inner side of hind tibiae, ferrugineous. Wings a little clouded; stigma fuscous, radix and tegulae flavous. Length, $6-8 \mathrm{~mm}$.

This $q$ has never been adequately described, and its present position rests upon Wesmael's remark that it is allied to, but constitutes a very different species from, his $P$. cephralotes.

Gravenhorst took this little-known species, in June, in Germany ; it was introduced as British, by Marshall, in his I $\$ 70$ catalogue, but I failed to notice it in his collection, nor am I aware of any indigenous records.

\section{6. mitigosus, Grav.}

Ichneumon mitigosus, Gr. I. E. i. 604, excl. var. I ; Ste. Ill. M. vii. 204. o ; of. Wesm. Mém. couron. Ac. Belg. 1859, p. 74. Baeosemus mitigosus, Holmgr. Ichn. Suec. iii. 424 ; Thoms. O. E. xv. 1614, of $q$. Phaeogenes mitigosus, Berth. Ann. Soc. Fr. I896, p. 385, o 9 .

Head sub-triangular, not buccate, slightly narrowed behind the eyes; mandibles moderately broad, with nearly equal teeth; clypeus very closely and finely punctate, apically broadly rounded, somewhat indistinctly discreted; cheeks not short. Antęnnae slightly attenuate apically; scape a 
little excised; of flagellum ferrugineous beneath, scape black; q with scape and the eight basal flagellar joints red. Thorax entirely black; notauli punctiform; epomiae wanting : metanotum distinctly areated; areola not longer than broad, pentagonal; petiolar area slightly excavate. Ahdomen grey-haired, elongate-ovate; black, with the second, third, and usually apices of the following segments, red ; the first geniculate, with the petiole stout; post-petiole broad, coarsely and strongly punctate throughout; thyridii ill-defined, transverse-linear ; terebra slightly exserted. Legs black, with all the tibiae, anterior tarsi, and more or less of their femora, red; coxae mutic. Wings hyaline ; areolet not broad; lower angle of discoidal cell sub-acute; nervellus sub-opposite. Length, $7 \mathrm{~mm}$.

The structure of the basal segment will at once distinguish this species.

Stephens says, "Taken at Hertford and Coombe Wood, in June" ; and no one seems to have found it in Britain since 1835 , though it is included in all the catalogues but Desvignes'. Its right to inclusion in our fauna is certainly nebulous ; on the continent it occurs in Sweden and Germany.

\section{7. stipator, Wesm.}

Phacogenes stipator, Wesm. Bul. Ac. Brux. I855, p. 422, + ; Holmgr. Ichn. Suec. iii. 442 ; Thoms. O. E. xv. 1645; Berth. Ann. Soc. Fr. 1896, p. 378, o \&. P. cicutella, Siebold, ? Preuss. Provinzialbl. I850, p. 212 ; Brisch. Schr. Nat. Gies. Danz. I878, n. 6, p. 56, ó ㅇ. P. jucundus, Wesm. Bul. Ac. Brux. 1855, p. 423, ơ. Ichneumon cambrensis, Desv. E.M.M. I867, p. I30. Limeroiles cambrensis, Bridg.-Fitch. Entom. ISSI, p. 60, \&; cf. Morl. F..M.MI. I902, p. I23.

Head sub-buccate; frons nearly flat, a little impressed, strongly and sub-rugosely punctate; clypeus distinctly discreted, punctate, apically sub-sinuate and centrally slightly produced; palpi and mandibles reddish. Antennae stout, short, basally attenuate; of $q$ sub-filiform, with four basal flagellar joints red, the sixth quadrate, and centrally white-banded. Thorax sub-deplanate, entirely black; notauli obsolete; metanotal areae complete; areola a little longer than broad; petiolar area discreted and centrally hardly concave. Abdomen elongate, black, with four basal segments red; post-petiole sub-aciculate, shining; gastrocaeli distinct, the intervening space in of aciculate ; terebra distinctly exserted. Legs red ; hind ones with apex of femora, and base and apex of tibiae, black ; coxae of $q$ with a short, simple, dentiform tubercle beneath. Stigma fuscous; tegulae dark ; radix white. Length, 8-9 $\mathrm{mm}$.

At first sight this species somewhat closely resembles those of the genus Colpognathus; it may, however, be distinguished from $C$. jucundus by its sub-buccate head, completely discreted petiolar area, more deeply cxcised and black scape, and sub-cylindrical body; from $C$. celerator the of differs in the basal impression of the second segment, the colour of the coxac, etc.

Marshall first found this species, in Britain, in the autumn of 1866 , in a marsh near the sea, at Gellyswick, in Pembroke; these specimens were sent to WVesmael, who pronounced them to be new to science, and were subsequently described by Desvignes as such; nevertheless it will be seen by comparing the following description, which I have taken direct from Desvignes' types in the British Museum, with that of $P$. jucundus in the "Miscellanea," that they are nothing but males of $I$ '. stififor, as promted out by Berthoumieu. It has also been bred, in Britain, from Orthotelic spargenella in the New liorest (Trans. Lint. Soc. ISS.f, 1) +223); and I have 
found it hibernating in tufts of Aira cacsfitesa, at Brede, near Hastings, in March : and upon umbelliferous flowers, at Ipswich, early in September. On the Continent it occurs in Prussia and Sweden.

[Ichneamon cambrensis, Desv., of. Head sub-cubical; face centrally produced and evenly punctate; cheeks and temples broad; frons evenly and confluently punctate ; clypeus distinctly discreted, sparsely punctate, anterior margin slightly reflexed and broadly rounded throughout ; mandibles except their apices clear red, the upper tonth longer but not stouter than the lower; palpi flavous. Antennae setaceous, joints elongate throughout. Mesonotum shining; metanotum scabriculous, with complete areae; areola elongate, sub-hexagonal; petiolar areae transversely wrinkled; spiracles quite circular. Scutellum flat, pilose, evenly punctate. Abdomen cylindrical, finely punctate and shining; black, with segments one except sometimes its base, to four except its apex, red; post-petiole narrow, shining, extremely obsoletely aciculate, with carinae obsolete ; gastrocaeli long; thyridii transverse and somewhat deep, with the intervening space a little depressed and aciculate. Legs red; all the onychii, and extreme apices of hind femora and tibiae, black; coxae simple. Wings very slightly clouded; areolet somewhat broad pentagonal ; stigma and tegulae piceous; radix flavous. Length, $9 \mathrm{~mm}$.]

\section{8. semivulpinus, Grav.}

Ichneumon semivulpinus, Gr. I. E. i. 565 ; Ste, Ill. M. vii. 199, 9. I. mutabilis, Gr. I. E. i. 599 (part.), б. Phacogenes primarius, Wesm. Nouv. Mém. Ac. Brux. I844, p. I8I, ơ ㅇ. P. semivulpinus, Wesm. Bul. Ac. Brux. I848, p. 317 ; Holmgr. Sv. Ak. Ilandl. I854, p. 45 ; Ichn. Suec. iii. 427 ; Brisch. Schr. Nat. Ges. Danz. 1878, n. 6, p. 53 ; Thoms. O. E. xv. I643; Berth. Ann. Soc. Fr. I896, p. 370, ठ $q$.

Head strongly punctate, not narrowed behind the eyes, triangular from in front ; cheeks strongly punctate, somewhat buccate, reflexed and dilated below the base of the often rufescent mandibles; clypeus sparsely punctate, not or hardly discreted, and apically broadly rounded; palpi apically testaceous. Antennae black, with first and second flagellar joints equal ; of $q$ filiform, with joints three to six red, ninth quadrate, ten to fifteen white; of of ferrugineous beneath. Thorax entirely black, strongly punctate; epomiae distinct; notauli wanting; metanotal areae complete; areola hexagonal, apically sub-truncate. Abdomen black, with segments two to five and apex of first entirely red ; post-petiole smooth and shining, laterally sparsely punctate; second segment with basal impression entire; terebra stout and a little exserted. Legs normal, black ; anterior femora and tibiae, base of hind femora and middle of hind tibiae, red; hind coxae of $q$ with a long, stout spine. Stigma and tegulae nigrescent; radix white. length, 7-9 $\mathrm{mm}$.

The anterior femora in both sexes are occasionally infuscate.

This species, which is amongst the largest of the genus, may be known by its apically dilated ear-like cheeks and the large $q$ coxal spine; the ot differs from that of $P$. ophthalmicus in the breadth of its head behind the eyes.

Found in June, near London and in Norfolk, not common (Stephens); Lastingham, in Yorks. (Marshall); common about Brundall and Norwich (Bridgman); Bickleigh, in middle of May, and Egloskerry, in Cornwall, 
towards end of July (Bignell); Guestling, near Hastings (Bloomfield); Greenings, near Reigate, in May.(W. Saunders). Certainly a common species in Britain. Piffard has captured it, at Felden, in Herts., and Tuck several times, at Tostock, in Suffolk. It is very widely distributed on the Continent, where it has been bred from Tortrix rosana and Euchromia rufana.

\section{9. planifrons, Wesm.}

Ichnentmon mutabilis, Gr. I. E. i. 599 (part.), ot. Phacogenes planifrons, Wesm. Nouvv. Mém. Ac. Brux, IS44, p. I82; Bul. Ac. Brux. I848, p. 317 ; Holmgr. Sv. Ak. Handl. I854, p. 45; Ichn. Suec. iii. 433; Brisch. Schr. Nat. Ges. Danz. I878, n. 6, p. 54 ; Thoms. O. E. xw. I644; Berth. Ann. Soc. Fr. I896, p. 37 I, of o.

This species so closely resembles the last, that a detailed description were entirely superfluous; it differs therefrom in having the head broader than the thorax, that of the of being distinctly dilated behind the eyes; cheeks not buccate and scarcely at all dilated below the mandibles; the fifth abdominal segment is black; the legs are paler, with the coxal tooth of the $q$ much smaller. Length, $6-8 \mathrm{~mm}$.

The mesopectoral acetabulae.are a little emarginate, and its medial sulcus is entire.

Lastingham, in Yorks. (Marshall); Brundall, in August (Bridgman); Guestling, near Hastings (Bloomfield). Probably much mixed with the last species in Britain, and not uncommon with us, as upon the Continent.

\section{Io. melanogonus, Gmel.}

Tihnoumon melanojonus, Gmel. S. N. i. 2709 ; Gr. Beit. Ent. Schl. IS29, p. 3, excl. varr. ; I. E. i. 581, excl. varr. ; Ste. Ill. M. vii. 202, o . I. mulabilis, varr. 2-3, Gr.

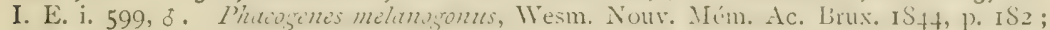
Bul. Ac. Brux. 1848 , p. 317 ; Holmgr. Sv. Ak. Handl. I854, p. 46 ; Ichn. Suec. iii. 434 ; Brisch. Schr. Nat. Ges. Danz. I878, n. 6, p. 54; Thoms. O. E. xv. I645; Berth. Ann. Soc. Fr. I\$96, p. 37 I, of o. Var. P. protervus, IVesm. Bul. Ac. Brux. I $\$ 55$, p. 428 ; Brisch. Schr. Nat. Ges. Danz. 1878, n. 6, p. 55, ช. .

Very like the two preceding species. Apical margin of clypeus usually with a fine elevated carina; $q$ with seventh flagellar joint quadrate, and scape and four basal flagellar joints red, with eight to eleven white; $0 *$ with first flagellar joint shorter than second; segments two to four and whole or apex of the first red, incisures of following often rufescent ; postpetiole slightly convex, shining and alutaceous; all the coxae and trochanters red, excepting the nearly vertical and apically truncate coxal tooth of the $q$, and sometimes the upper side in the $f$, which are black; tegulae usually red. Length, $7 \mathrm{~mm}$.

From $P$. semivulfinus it may be known by the head being broader than the thorax, with its cheeks not buccate and hardly dilated below the mandibles, and from $P$. flanifrons by its acetabulae not being emarginate and the medial sulcus evanescent or wanting.

Taken at Coombe and Darenth Wood, in June and July (Steplens); Isle of Man (Walker); Plym I3ridge, early in August (IBignell); Malulon, in Essex (Fitch). Another common species, taken by sweeping, in meadows, near woods; Mr. E. A. Butler has taken it, near Dorking, in August ; Mr. B. Tomlin at Carlisle also in August; I have beaten it from oak, at the end of May; and swept it, at dusk, early in October, in 13untley 
Woods, near Ipswich. It is common on the Continent, where it has been bred from Oenectra pilleriana and Depressaria nervosa.

\section{II. heterogonus, Holmgr.}

Phaeogenes hetcrogonus, Holmgr. Ichn. Suec. iii. 431; Berth. Ann. Soc. Fr. I896, p. $372, \delta$.

Head black; clypeus usually indistinctly discreted; palpi piceous. Antennae black; of $q$ with the four basal flagellar joints red, the seventh quadrate and, together with the four following, white; of of with flagellum apically ferrugineous beneath. Thorax black; areola slightly longer than broad. Abdomen black, with segments two to four, apex of first and a mark on the fifth, red; post-petiole finely and distinctly aciculate; basal impression of second segment gastrocaeliform, centrally wanting ; terebra incrassate, shortly exserted. Legs normal, black, with anterior femora and tibiae red; $q$ with hind tibiae centrally and femora basally red; $q$ coxae with stout, triangular, sub-acuminate teeth. Wings slightly clouded; stigma fuscous, radix whitish, tegulae black. Length, 7-9 $\mathrm{mm}$.

The conformation of the head and thorax is very similar to that of $P$. semivulpinus, from which the sculpture of the post-petiole will at once distinguish it ; the form of the clypeus is most nearly like that of $P$. planifrons, but the cheeks are distinctly dilated and auriculate apically, which feature will also separate it from $P$. melanogonus.

I know of but one indigenous example of this species, which was taken at Castle Island, Loch Leven, early in June, I 898 , by Mr. W. Evans, who sent it to me for determination; on the Continent it occurs in Sweden and, it is said, in northern Spain.

\section{I2. ophthalmicus, Wesm.}

Phacogenes ophthalmicus, Wesm. Nouv. Mém. Ac. Brux. IS44, p. I88; Bul. Ac. Brux. r848, p. 320 ; Brisch. Schr. Nat. Ges. Danz. 1878, n. 6, p. 56 ; Thoms. O. E. xv. I648; Berth. Ann. Soc. Fr. I896, p. 373; Holmgr. Ichn. Suec. iii. 439, of क; Sv. Ak. Handl. 1854, p. 46, + . P. hybridus, Wesm. Bul. Ac. Brux, 1855, p. 428, oे.

Head punctate, obviously narrowed behind the eyes, black; mouth partly pale; cheeks as long as base of mandibles, strongly punctate, their external margin sinuate a little before the apex, which is auriculately produced below the mandibles; clypeus sub-convex, punctate, distinctly discreted and apically broadly rounded. Antennae slightly attenuate apically; of $q$ tricoloured, with the eighth flagellar joint quadrate. Thorax entirely black; notauli indicated; mesopectoral sulcus and the juxta-coxal areae entire; metanotal areae complete; areola hardly longer than broad. Abdomen finely but distinctly punctate, black; segments two to four and more or less of the first and fifth, red; post-petiole alutaceo-punctate; third segment transverse; terebra slightly exserted. Legs normal, black; anterior femora more or less and the tibiae rufescent; hind tibiae often centrally piceous; $q$ with hind femora, except apices, and their tibiae, centrally, red; hind coxae of of strongly punctate, apically transversely sub-strigose, of $q$ rugulose, apically depressed, with the carinae obliquely curved in the centre and thence emitting a-small tooth. Stigma piceous; radix pale, tegulae nigrescent. Length, 7-9 $\mathrm{mm}$. 
Holmgren mentions a variety with the internal orbits and most of the scape red. I have followed him in referring $P$. hybridus to the present species, since he had examined typical examples, although Wesmael's description, "post-petiolus aciculatus . . . . stigmate sordide rufo," etc., with no mention of the produced cheeks, does not accord well therewith.

This species superficially strongly resembles $P$. semivulpimus and $P$. planifrons, but may at once be distinguished therefrom by the posteriorly narrowed head, the post-petiolar sculpture and the peculiar armature of the of coxae.

Doubtless one of the commonest British species of the genus, occurring upon flowers of Angelica sylzestris and upon herbage in marshy situations. Mr. W. W. Esam has taken it, at Ewhurst, in Sussex; Mr. Piffard, at Felden, in Herts.; Mr. Bignell, at Bickleigh, in the middle of May; Mr. Donisthorpe, at Rossbeigh, Co. Kerry, in June; Rev. T. A. Marshall, at Cornworthy, near Totnes; and I have found it commonly, in Barnby Broad, in Suffolk, in July and August, as well as at Henstead, in the same neighbourhood. It is, however, recorded from neither Norfolk nor Essex, but is widely distributed on the Continent.

\section{I3. modestus, Wesm.}

Phaeogenes modestus, Wesm. Nouv. Mém. Ac. Brux. I844, p. I93; Bul. Ac. Brux. 1848, p. 323, o ; Bridg. Trans. Ent. Soc. I886, p. 336 ; Berth. Ann. Soc. Fr. I896, p. 379 , o + ; Thoms. O. E. xv. 1652, excl. $\delta$.

Head black, a little buccate posteriorly; cheeks short and somewhat broad; palpi pale; mandibles red or black; frons very finely punctate. Antennae piceous; $q$, with basal flagellar joints red and the central ones more or less distinctly white. Thorax black; notauli elongate; metanotum sub-rugose with complete areae; areola about as broad as long, hexagonal or nearly pentagonal ; petiolar area not elongate, a little dilated basally. Abdomen with sparse scattered punctures ; post-petiole irregularly aciculate; second segment longer than broad, the remainder transverse; $q$ with the four basal segments red, those of of varying from piceous with the incisures rufescent to the second and third mainly red. Legs red; coxae and trochanters mainly black; $q$ hind coxae with a short, oblique cristula, resembling an acute tooth; of with hind tarsi, apices of their femora, and of their tibiae, infuscate. Tegulae black; radix white, stigma piceous; nervellus post-furcal. Length, $7 \mathrm{~mm}$.

I have followed Bridgman in describing the of as differing in colour from the $q$ only in respect to its legs and abdomen, since he bred both sexes at the same time. Thomson attributes to it a male with white clypeus and basally infuscate hind tibiae.

It differs from the three following species in its elongate notauli, and alutaceous or, as Bridgman terms it, finely granular abdomen.

This species was introduced as British by Bridgman (loc. cit.) on the strength of specimens bred by Mr. IV. H. B. Fletcher, from Euchromia flammeana, from Ramnoch, in June; and there is an example of both sexes, probably from the same source, in Dr. Capron's collection. On the Continent, it has a restricted range through France and belgium, but has not been there bred. 


\section{I4. fuscicornis, IVesm.}

Placogenes fuscicomis, Wesm. Nouv. Mém. Ac. Brux. I 844, p. 189, \&; Holmgr. Iclın. Suec. iii. 457 ; Thoms. O. E. xv. 1652 ; Berth. Ann. Soc. Fr. 1896, p. 376, $\delta$

Head very slightly narrowed behind the eyes, black; palpi pale; frons sub-convex and closely punctate; temples and cheeks shining and remotely punctate, latter short and sub-obsoletely dilated below the red mandibles; clypeus smooth and nitidulous. Antennae of of apically slightly attenuate and often ferrugineous beneath; of $q$ filiform, with the fifth flagcllar joint sub-quadrate, basal flagellar joints rufescent but central pale band wanting. Thorax black; mesonotum punctate, notauli hardly indicated; metanotum completely areated, areola slightly broader than long; petiolar area discreted and centrally concave. Abdomen black, with second to third or fourth segments red, more or less infuscate in $\delta$; the following ones immaculate; post-petiole nitidulous and glabrous, laterally punctate; remainder of abdomen finely punctate; third segment transverse; terebra slightly exserted. Legs normal, rufo-testaceous, with coxae and base of trochanters and the hind tarsi black; of with centre of anterior and whole of hind femora, with base and apex of hind tibiae, black; $q$ with apex of hind tibiae, and usually, also, of hind femora, sometimes to their centre, black; hind coxae of $f$ with a short, oblique, dentiform crest beneath, but no tooth. Stigma and tegulae fuscous, radix white. Length, $6 \mathrm{~mm}$.

The $f$ is somewhat like that of $P$. melanogonus; the cheeks and temples, however, are more nitidulous and sparsely punctate, the mesopectoral sulcus is deeper, etc. ; the coxal armature, and the colour of the antennae and of the legs, render the $q$ distinct.

The only British record of this species is that of Mr. Bignell, who captured it at Bickleigh, in south Devonshire, on 28th July; Mr. Albert Piffard has given me a female taken at Felden, in Herts. ; and Mr. Charbonnier another, which I believe is referable to this species, bred from a bramble stem, possibly bored by some microlepidopterous larva, on April 25th, I900. Mr. E. A. Newbery has taken it at Shirley, in Surrey.

\section{I5. trepidus, Wesm.}

Phaeogenes trepidus, Wesm. Nouv. Mém. Ac. Brux. I844, p. 190; Berth. Ann. Soc. Fr. 1896, p. 377 , $q$; Thoms. O. E. xv. 1653,8 \&.

Head sub-triangular viewed from in front, somewhat rounded and narrowed behind the eyes; frons closely punctate; palpi apically pale. Antennae of $q$ basally dull red. Thorax sub-ovate, black. Abdomen with segments two, three and most of fourth, red. Trochanters and anterior femora apically red; tibiae red, the hind ones being apically black; coxal cristulae of $q$ very small, hardly discernible. Tegulae black; radix white; stigma fuscous. Length, $5 \mathrm{~mm}$.

This species is very like the last-described, but is a little smaller, the vertex circularly narrowed, the cheeks a little longer and not buccate, and the antennae of the $\delta$ are longer.

It is not rare in Britain, according to Bridgman, who took it at Hethersett and Wroxham, in May; Billups discovered it at Burford Bridge during 
hibernation, in November; and Bignell found it early in August, at Widewell and Plym Bridge, in Devon. Berthoumieu records it only from Belgium, where Wesmael first took it near Brussels.

\section{I6. infimus, Wesm.}

Phaeosenes infinus, Wesm. Nouv, Mém. Ac. Brux, i844, p. I9r ; Thoms. O. E. xv. I653; Berth. Ann. Soc. Fr. IS96, p. 377, o.

Head stout ; frons strongly punctate ; mandibles piceous ; palpi fulvous. Antennal flagellum basally red. Thorax sub-ovate, black; areola subquadrate ; costulae fine; petiolar area not strongly impressed. Abdomen with second segment except its centre, the third, and base of fourth, red; post-petiole sub-aciculate; the remaining segments somewhat strongly punctate and shining. Legs red; hind femora apically sub-fuscous; hind coxae black, with an elevated, oblique, sub-obsolete line. Tegulae and stigma black; radix white. Length, $5 \mathrm{~mm}$.

The red anterior coxae will serve to differentiate this species; the aciculation of the post-petiole is not always present in my examples, and would appear to be an inconstant character.

This species, which has not before been noticed in Britain, is probably one of our commonest kinds, since I have beaten it freely from the branches of large Pinus sylvestris in Bentley Woods, near Ipswich, throughout April during several years; it was probably just emerging from hibernation.

\section{I7. eques, Wesm.}

Phaeogenes eques, Wesm. Nouv. Mém. Ac. Brux. 1844, p. 194; Thoms. O. E. xv. 1654 ; Berth. Ann. Soc. Fr. 1896, p. 379, \&.

Black. Mandibles and pronotum sometimes rufescent. Antennae tricoloured; scape in part black. Abdomen nitidulous, distinctly punctate ; segments two to four, and often apex of first, red; post-petiole aciculate before its glabrous apex. Legs red; apex of hind femora and tibiae, with often the base of the latter, infuscate; coxae with carinae sub-dentately elevated obtusely towards their apex. Tegulae, radix and stigma testaceous. Length, $6 \frac{1}{2} \mathrm{~mm}$.

This may be known from the last four species by its laterally sub-sinuate clypeus and the distinct aciculations before the sub-elevated coxal carinac. It is more likely to be confused with $P$. ischiomelinus, with which it has the somewhat broad vertex, laterally sub-sinuate clypeus, pale tegulae, partly infuscate hind cosae and tricoloured flagellum in common; but it differs therefrom in its more coarctate body, shorter and stouter flagellum, dull and irregularly punctate frons, absent notauli and more shortly produced coxal carinae.

I was so fortunate as to beat an example of this species, which has not hitherto been noticed in Britain, from young birch trees in Assington 'Thicks, in Suffolk, upon r6th May, r9o2. It is found in France, Germany and Siveden, but has not been bred. 


\section{I8. ischiomelinus, Grav.}

Ichneumon ischiomelinus, Gr. I. E. i. 608, $\delta$, excll. varr. Phaeogrenes ischiomelinus, Wesm. Nouv. Mém. Ac. Brux, I844, p. 192; Holmgr. Sv. Ak. Handl. I854, p. 47 ; Ichn. Suec. iii. 456; Thoms. O. L. xv. 1653 ; Berth. Ann. Soc. Fr. 1896, p. 379, o $q$.

Head not or hardly narrowed behind the eyes, black; palpi pale; frons closely and evenly punctate, shining; temples and cheeks somewhat broad, latter very distinctly a little produced below the red mandibles; clypeus shining, sparsely punctate. Antennae of of slightly attenuate apically and more or less ferrugineous beneath; of $q$ stout, filiform, with fifth flagellar joint sub-quadrate, centrally white-banded with base of flagellum and most of scape rufescent. Thorax black; mesonotum punctate, notauli distinct; metanotum sub-rugosely punctate; areola not or hardly longer than broad, slightly emarginate apically; petiolar area discreted and centrally concave. Abdomen black with segments two to four or five red, the following ones apically rufescent; post-petiole aciculate, in of gradually narrowed basally; second segment entirely impressed and sometimes black basally, in of rugulose; third transverse, punctate and shining; terebra slightly exserted. Legs normal; anterior testaceous, with coxae and trochanters paler; hind ones of of black with apices of coxae and trochanters stramineous, base of femora and centre of tibiae rufescent, of $q$ red, with apex of femora sometimes broadly infuscate; hind coxae of o basally fuscous, obliquely crested and sub-strigose beneath, but not dentate. Stigma fuscous; radix and tegulae stramineous. Length, 6-7 $\mathrm{mm}$.

The of may be known by the colour of its legs and the distinctly produced cheeks; the $q$ is similar to that of $P$. rusticatus, but the coxal structure is very different.

Lastingham in Yorks. (Marshall); common at Shere (Capron); common in Norfolk (Bridgman); Bickleigh, in Devon, late in July (Bignell); near Guildford early in August (Butler); Felden, in Herts. (Piffard); Tostock, in Suffolk, early in September (Tuck); Mayford, in June (Morice) ; Carlisle, in September (Tomlin) ; Essex. Doubtless common with us, as it is upon the Continent, but not yet bred.

\section{I9. impiger, Wesm.}

Phaeogenes impiger, Wesm. Nouv. Mém. Ac. Brux. 1844, p. 198; Thoms. O. E. xv. 1654 ; Berth. Ann. Soc. Fr. I896, p. 384 , of $\$$; Brisch. Schr. Nat. Ges. Danz. I878, n. 6, p. 57, o.

Head black; mandibles often piceous or red; palpi dull testaceous; frons very closely punctate. Antennae of $q$ stout, centrally towards the base or the whole basal half red; of of entirely black. Thorax sub-ovate; metanotal areae very finely delineated; areola hexagonal, apically sinuate; petiolar area centrally impressed. Abdomen black, with segments two, three, apex of first and most of fourth red; post-petiole smooth and shining. Legs red; o with hind femora and coxae at least partly, and apex of hind tibiae, fuscous; of with coxae, trochanters, hind femora and, except centrally, their tibiae, black; coxae mutic. Tegulae red or piceous, radix pale; stigma fuscous. Length, $6 \mathrm{~mm}$.

The mutic coxae and bicoloured antennae will differentiate the $q$; the o may be known from that of $P$. fuscicornis, which it closely resembles in size and coloration, by its pale tegulae and apically sub-rotund clypeus. 
Bridgman took this species at Norwich and Earlham, in August and September; the only example I have seen was kindly given to me by Mr. Bignell, who took it at Bickleigh, in Devon, in the middle of June. M. Pic tells us it occurs in France, from June to August; it is also found in Belgium.

\section{0. bellicornis, Wesm.}

Phaeogenes bellicornis, Wesm. Nouv. Mém. Ac. Brux. I844, p. r86; Thoms. O. E. xv. 1655; Berth. Ann. Soc. Fr. 1896, p. 374, of ; $f$. Brisch. Schr. Nat. Ges. Danz. I 878, n. 6, p. $56, \%$.

Head black, somewhat obliquely narrowed posteriorly ; frons shining, very finely and sub-obsoletely punctulate; $q$ with palpi and apices of mandibles and clypeus red. Antennae black; of $q$ filiform with the central joints white, and the six basal ones clear red. Thorax black. Abdomen in both sexes, with segments two to four, and apices of the remaining three, red, though sometimes discally infuscate in 0 ; postpetiole sparingly punctate. Legs red; $q$ with hind femora internally infuscate, hind coxae mainly black and bearing a short dentiform cristula ; of with anterior coxae stramineous-marked, the hind tibiae apically and sometimes the base of the anterior femora fuscous; the of also bears an elevated, though hardly discernible, tubercle before the apex of its hind coxae. Radix and usually tegulae white, the latter sometimes, like the stigna, fulvous. Length, 5-6 $\mathrm{mm}$.

Thomson says the of has the facial orbits or also the clypeus pale flavous, though Wesmael expressly states, "caput . . . . nigra."

The $q$ is rendered distinct by the clear red basal half and central white band of the flagellum, the hind coxal sub-elevated apical cristula, and subtilely punctate frons; the of by its frons, which is not quite smooth as in the Continental P. amoenus, Wesm., short flagellum, which is fuscous above and testaceous beneath, as well as by its sub-transverse central segments.

P'iffard has given me a female from Felden, in Herts. ; Marquand records it from the Land's End district; and Bridgman took a pale-legged form at Brundall and Earlham near Norwich, in May and September. The species ranges on the Continent from France to Russia, whence it is recorded by Woldstedt.

\section{I. nanus, Wesm.}

Pluacogenes nanus, Wesm. Nouv. Mém. Ac. Brux. I844, p. I90; Berth. Ann. Soc. Fr. 1896, p. 377, ; ; Thoms. O. E. xv. 1655, ơ \&.

Head black; palpi pale; $q$ with clypeus and mandibles red; fo with clypeus and sometimes a facial dot or line flavidous; frons extremely finely and obsoletely punctate. Antennae black; of $q$ ferrugineous towards the base, at least beneath ; of ol elongate. Thorax sub-cylindrical ; callosity before the radix sub-rufous; petiolar area broad, but not deeply impressed. Abdomen obsoletely punctate, black with the second and third segments, except centrally, and the apical margin of the fourth, red ; post-petiole convex, glabrous. Legs black; anterior coxae, the apices of their trochanters and femora, and all the tibiae and tarsi, red; hind coxae of $q$ with a small, oblique, elevated line beneath. Tegulae and radix pale ; stigma piceous. Length, $5 \mathrm{~mm}$. 
From $P$. bellicomis, it may at once be known by the colour of the flagellum and femora, the almost glabrous frons, and the male's longer antennae. The $q$ is similar to $P$. infimus in size and shape, but may be distinguished by its much smaller carinate and much more nitidulous frons.

Bridgman took two females with dark mouth and front coxae, at Norwich, perhaps Eaton, in July and August; I possess a single female found at Felden, in Herts., by Mr. Piffard:

\section{2. maculicornis, Steph.}

Ichnesmon maculicomis, Ste. Ill. M. vii. I36, $q$; f. Morl. E.M.M. I902, p. II9. Phaeogenes scutcllaris, Wesm. Nouv. Mém. Ac. Brux. I844, p. 183. \&; Bul. Ac. Brux. 1855 , p. 419 ; lib. cit. 1857, p. 417, ơ ; Brisch. Schr. Nat. Ges. Danz. IS78, n. 6, p. 54 ; Thoms. O. E. xv. 1649; Berth. Ann. Soc. Fr. 1896, p. 372, o ․

Head black; palpi, mandibles and facial orbits white; to has nearly the whole face and the apices of the cheeks also white ; clypeus of tontirely, of $q$ often centrally, white, with its apical margin sub-impressed; frons finely and closely punctate. Antennae filiform and somewhat slender ; scape of $\mathrm{A}$ white ; basal flagellar joints apically or entirely rufescent ; of $q$ usually centrally white-banded. Thorax black, with pronotum and callosities before and beneath radix white; metanotum evenly punctate, with complete upper areae, of which the areola is elongate, gradually narrowed basally and sinuate apically. Scutellum white; of $q$ basally, or rarely entirely, black. Abdomen red or badious with first and base of second segment black; sometimes nearly entirely black; incisures often paler; post-petiole smooth, of t quadrate and nitidulous. Legs of $q$ red, with anterior coxae and trochanters white, basally infuscate; hind coxae black with apex and the long, acute tooth red; apices of hind femora and tibiae and sometimes more or less of their tarsi, fuscous; legs of to stramineous with coxae and trochanters white, the hind ones being basally black; hind femora red, their tarsi and apices of their tibiae fuscous. Radix and usually tegulae white; stigma piceous. Length, $8 \mathrm{~mm}$.

This very distinct species, which has hitherto been known by its Wesmaelian name, is sufficiently well-described by Stephens; any doubt which might remain is removed by an examination of the type specimen in the British Museum collection, as I have (loc. cit.) pointed out.

Taken near London, in July, but rarely; also, I believe, near Andover

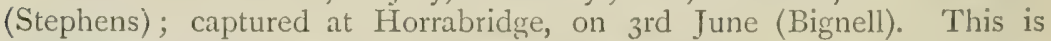
certainly a common species in Britain; Essex; Mr. Piffard has found it at Felden, in Herts., and I have both beaten it from Coniferae, in the Bentley Woods, in April, and found it hibernating beneath the rotten bark of a fallen fir log, at Foxhall, in Suffolk, in March. On the Continent, it is found in Germany, Belgium and France, but does not appear to have been bred, though probably parasitic upon Tortrices.

\section{3. mysticus, IVesm.}

Phacogenes mysticus, IVesm. Bul. Ac. Brux. I855, p. 42I ; Berth. Ann. Soc. Fr. IS96, p. 386, ơ ; Holmgr. Ichn. Suec. iii. 453, excl. o. P. tetricus, Wesm. Bul. Ac. Brux. I 555 , p. 422 ; Berth. Ann. Soc. Fr. I896, p. 376, \&; Thoms. O. L. xv. 1650, o \&.

9. Head with mandibles and palpi red. Antennae black, sub-ferrugineous towards their apices beneath. Thorax with pale callosity before 
radix. Abdomen black with second segment apically red. Legs red; hind tarsi with joints two to four infuscate; hind coxae unidentate. Tegulae and stigma fuscous ; radix white. Length, $6 \mathrm{~mm}$.

o. Head with mandibles centrally, and a dot towards the base of the clypeus, white. Antemnae and thorax entirely black. Abdomen black with apical margin of second segment rufescent. Legs red; coxae black or apically rufescent; hind trochanters basally, base and apex of hind tibiae, and sometimes the apex of their femora, black; hind tarsi infuscate. Stigma and tegulae black; radix white. Length, $5 \mathrm{~mm}$.

Wesmael, who shortly describes both sexes as above, tells us the $q$ is allied to those of $P$. stimulator and $P$.homochlomis, but differs in the colour of its antennae, the joints of which are shorter and stouter; and adds that the $\delta$ is also similar to that of $P$. stimulator, though quite possibly constituting a variety of $P$. callopus.

I have followed Thomson in uniting these two species, though it is to be regretted that he gives us no clue to the identity of Holmgren's $q$ mysticus, which he probably examined. To the above description the former adds that the present species differs from $P$. stimulator and $P$. maculicornis in its less dilated petiole and finely alutaceo-punctate abdomen ; that the legs of the $q$ are stouter, with the coxal crista elevated at both base and apex.

A female taken at York by Mr. Beaumont towards the end of September has the above coxal characters and abdominal alutaceousiness well marked, but its antennae are pale-banded, and second to fourth abdominal segments ferrugineous, with the pale radical callosity wanting. Mr. G. C. Bignell records $P$. tetricus, in his "Ichneumonidae of South Devon," as having been captured at Exeter on I 7 th August. Much confusion exists regarding this species or these species, whose continental distribution is at present uncertain.

\section{4. stimulator, Grav.}

Ichneumon stimulator, Gr. Beit. Ent. Schl. I\$29, p. 1, excl. var. ; I. E. i. 143, excl. varr. ; Ste. Ill. M. vii. I35; Katz. Ichn. d. Forst. i. I34, ơ \&. Phaeogenes stimulalor, IVesm. Nouv. Mém. Ac. Brux. 1844, p. IS4; Bul. Ac. Brux, 1848, p. 318 ; Holmgr. Ichn. Suec. iii. 447; Thoms. O. E. xv, 1649; Berth. Ann. Soc. Fr. ISg6, p. 376, 8 \%.

Head not buccate, hardly narrowed behind the eyes, black; frons finely and densely punctate, somewhat shining; apices of cheeks broadly subdilated below the mandibles; clypeus shining, apically depressed, basal incisure arcuate; palpi and mandibles of $q$ red, of $t$, as well as sometimes a dot at the facial orbits and another on pronotum, flavous. Antennae filiform, rather longer than half the body; of forrugineous beneath, of $q$ rufescent with scape black and central joints pale, the eighth being sub-quadrate. Thorax shining, black with pale callosities at radix; notauli indicated; metanotal areae strong and complete; areola sub-hexagonal, slightly longer than broad; petiolar area concave, discreted and centrally transversely sub-strigose. Abdomen black, with segments two to four apically sub-castaneous; post-petiole centrally glabrous and nitidulous; second segment shorter than apically broad, finely but very distinctly punctate, with the gastrocaeli very deep and occupying nearly the whole base; terebra slightly exserted. Legs red, coxae and hind tarsi usually black; base and apex of hind tibiae infuscate; of with anterior coxae and trochanters flavous, and often the apices of hind femora black 
legs of $q$ stout, the hind coxae with a curved longitudinal crest, which terminates in a stout red tooth. Stigma fuscous, radix flavous, tegulae often testaceous. Length, 8-10 mm.

The large size, dark coloration, deep gastrocaeli, short second segment and the conformation of the $q$ coxae will serve to distinguish this species.

Mr. A. A. Dalglish has sent me an undoubted $q$ of this species, taken early in March, at Johnstone, in Scotland, which, though bearing the normal coxal tooth, has the mandibles sculptured as in Herpestomus brunnicomis, thus forming a distinct link between these two closely allied genera.

Not very uncommon in gardens and woods, in June, in the metropolitan district; found also in Salop and in Norfolk (Stephens); Lastingham, in Yorks. (Marshall) ; common, at Shere (Capron); Bickleigh, in Devon, in September (Bignell) ; near Guildford (Butler) ; Felden, in Herts. (l'iffard); Treswell and Retford, Lincs. (Thornley). I have beaten it from the undergrowth in Assington 'Thicks and Bentley Woods, in Suffolk, in May, and it almost certainly hibernates in the imago state. On the Continent it is a widely distributed species, and has been bred from Tortrix viridana pupae frequently; in Britain, Butler has bred it from Hyponomenta padellar and H. W. Barker from Ellopia fasciaria.

\section{5. homochlorus, Wesm.}

Phacogenes homochlonis, Wesm. Nouv. Mém. Ac. Brux. I844, p. I84; Berth. Ann. Soc. Fr. 1896, p. 376, $q$.

Head black; palpi and mandibles pale red; frons not very closely punctate, shining. Antennae sub-filiform ; flagellum entirely red. Thorax black, with a white callosity before the radix; metanotum rugulose; areola elongate, basally rounded and apically sub-truncate; costulae sub-obsolete. Scutellum black. Abdomen black, with apical margin of second and third segments fulvous; post-petiole glabrous. Legs red with most of the coxae and part of the femora, as well as the apices of the hind tibiae and of their tarsal joints, fuscous ; hind coxae with a long and stout tooth, their femora centrally impressed externally. Tegulae piceous; radix white; stigma red. Length, $8 \mathrm{~mm}$.

This species, to which no $t$ has been assigned, appears to differ from $P$. stimulator in no pertinent particular, but the colour of the flagellum. Thomson makes no mention of it, and it were, I think, better considered a mere variety of the latter species, although Bridgman thought it "very distinct."

Billups first took it in Britain, at Chobham in 1882 , and Piffard has given me an example from Felden, in Herts., so named by Dr. Capron. Berthoumieu records it from France and Belgium.

\section{6. callopus, IVesm.}

Ichenemon stimulator, var. I, Gr. Beit. Ent. Schl. I829, p. 3, ๆ ; varr. I-2, I. E. i. I44. Phaeogenes callopus, Wesm. Nouv. Mém. Ac. Brux. I844, p. I85; Bul. Ac. Brux. I848, p. 318 ; lit. cit. I855, p. 420 , excl. var, b ; Holmgr. Ichn. Suec. iii. 449 ; Thoms. O. E. xv. 1647; Berth. Ann. Soc. Fr. 1896, p. 375 ; $f$. Brisch. Schr. Nat. Ges. Danz. I 878, n. 6, p. $55, \delta$ 웅.

Black; ot with mouth, clypeus, face and underside of scape, white; flagellum of $q$ nigrescent, red towards the base and centrally white-banded. 
Legs red; hind femora apically black; hind tibiae black, with a central white band, their tarsi also white-banded; anterior coxae of ot white; radix, tegulae, the adjacent callosities and centre of pronotum, white. Length, 5-8 mm.

This species so closely resembles the last two described, with which Gravenhorst confused it, as to need no detailed description. 'Therefrom it is, however, abundantly distinct in its sparsely punctate frons, white markings, more slender body and in the sculpture of the second segment, which is not shorter than its apical breadth, alutaceo-punctate and more nitidulous; the petiolar area, too, is less concave, and the coxal tooth of the $q$ is distinctly smaller.

Wesmael, in 1855 , set forth seven varieties of the 8 , which go to show that its hind tibiae may be either centrally white with the flagellum entirely black, or centrally red with the flagellum concolorous beneath; the mouth and clypeus are always white, but the face is often partly or wholly black; and in one example, he says, the scutellum bore two apical pale dots.

Common in Norfolk (Bridgman); Maldon in Essex (Fitch); bred from Eriogaster lanestris in the middle of July, and captured at Bickleigh early in August (Bignell); common at Shere (Capron); Felden in Herts. (Piffard); Bungay in Suffolk in June, and several at Tostock in September (Tuck); near Guildford in August (Butler). I have taken it in Bentley Woods in September, at Chipperfield in Herts., on juniper, in August, and at Gosfield in Essex in July. It is common on the Continent, but has not there been bred.

\section{7. fulvitarsis, Wesm.}

Ichnezmon melanogonuts, var. I, Gr. I. E. i. $5 \$_{2}$, + . Phaeogenes fulvitarsis, WVesm. Nouv. Mém. Ac. Brux. I844, p. 185, ; ; Brisch. Schr. Nat. Ges. Danz. I878, n. 6, p. 55 ; Berth. Ann. Soc. Fr. 1896, p. 375, excl. $\delta$; Thoms. O. E. xv. $1647, \delta$ \&. $P$. callopus, var. b., Wesm. Bul. Ac. Brux. 1855, p. 420, of.

Head sub-obliquely narrowed posteriorly, black; palpi, mandibles and usually the clypeus, pale; of with face also entirely or partially white; frons shining and obsoletely punctate. Antennae of $q$ basally red and centrally white-banded. Thorax black, with pronotum and callosity before radix white; metanotum finely rugose with complete upper areae; areola somewhat elongate; petiolar area centrally impressed. Abdomen black, with apex of first segment more or less, the three or four following entirely, and occasionally the incisures of the remainder, red; post-petiole very finely aciculate. Legs red ; apices of hind femora and tibiae, and base of latter, black; all the coxae, trochanters and tarsi pale fulvous, the of however has the anterior coxae and trochanters white and the base of the hind coxae sometimes infuscate; hind coxae of o with a somewhat long, black tooth. Tegulae and radix pale; stigma ferrugineous. Length, 5-7 mm.

Brischke's of, adopted by Berthoumieu, cannot belong to this species, on account of its closely punctate and dull frons ; in other respects it differs from $P$. callopus, var. b., in its immaculate face, red mandibles, the anterior trochanters being alone "gelb," and in the infuscescence of the hind tarsal joints.

This is certainly quite a common species in Britain, as it also is in central Europe, though nothing is yet ascertained regarding its economy. 
Plym Bridge in May; Plymouth in July; Exeter, Horrabridge and Bickleigh, in Devon, early in September (Bignell); common in Norfolk (Bridgman); Maldon in Essex (litch); found at Hastings (lisam); Felden in Herts. (Piffard); caught on carrot flowers at T'ostock; and two or three in Finborough Park in Suffolk, probably on flowers of Angelia sylvestris, late in September ('Tuck). I have taken it among the undergrowth in Bentley Woods, in June; in a market garden at Aldeburgh towards the end of July ; and in the marshes at Bramford in Suffolk in early October.

\section{8. coryphaeus, IVesm.}

Phaeogenes coryphaeus, Wesm. Nouv. Mém. Ac. Brux, 1844, p. 183, 8 . P. versutus, Wesm. lib. cit. p. I86, excl. $\delta$; Brisch. Schr. Nat. Ges. Danz. 1878, n. 6, p. 55, \&; Thoms. O. E. xv. 1847 ; Berth. Ann. Soc. Fr. 1896, p. 375, of o.

Head black; frons strongly nitidulous, very finely and sparsely punctate; palpi and mandibles of $q$ fulvous, of $\overrightarrow{0}$, as well as the clypeus, white. Antennae fuscous; red, with scape of to white, beneath ; central band of of white. Thorax and scutellum black; ot with white callosity before radix. Abdomen black; of of with apical margin of second segment pale, of third to fifth rufescent ; of $q$ with apex of first, whole of second, third, and sometimes base of fourth, red; sixth and seventh segments of $q$ apically pale and post-petiole smooth. Anterior legs fulvous, with of coxae and trochanters white; hind ones black, of to with apex of coxae, trochanters, centre of tibiae and base and apex of the tarsal joints, stramineous, of $q$ with coxae in part, base of femora and centre of tibiae red, therr coxal tooth elongate. Tegulae and radix white or red; stigma piceous. Length, 7-8 $\mathrm{mm}$.

This species differs from the last-described in the head of both sexes being shorter, with conformation of the vertex similar to that of $P$. planifrons, and the antennal scrobes large ; the $q$ has the hind coxal cristulae terminating in a stout and acute tooth, no thoracic pale markings, the fourth segment black or basally red ; the immaculate face and colour of its hind legs will distinguish the male.

There can be no doubt that this species must be known by its male name.

A female, which Bridgman (Tr. Ent. Soc. 1887, p. 363 ) believed to be this species, was taken by Mr. G. C. Champion at Mickleham. It also occurs in Belgium and Germany.

\section{9. rusticatus, Wesm.}

Phacogenes rusticatus, Wesm. Nouv. Mém. Ac. Prux. 1844, p. I88; Bul. Ac. Brux. r848, p. 320 ; Holmgr. Ichn. Suec. iii. 450 ; Thoms. O. E. xv. I648 ; Berth. Ann. Suc. Fr. 1896, p. $374, \delta$ o

Head black; palpi, mandibles and, in ot, clypeus with often the whole or part of the face, stramineous; clypeus of $q$ sometimes apically or entirely rufescent. Antennae black, of $q$ centrally white-banded and basally rufescent, of $f$ reddish with the scape flavous beneath. Thorax black with callosities more or less distinctly white, especially in the of, which has the pronotum concolorous. Abdomen punctate-alutaceous; of of with central incisures obscurely rufescent, of of with segments two to four or five clear red. Legs red; apices of hind femora and tibiae, as well 
as base of latter, black; anterior coxae and trochanters of of stramineous; coxal carina of $q$ terminating in a small tooth. Stigma pale fuscous; radix and tegulae white, latter fulvous in $q$. Length, 5-9 $\mathrm{mm}$.

The size and sculpture are nearly identical with those of $P$. callopus, from which the constant colour of the abdomen of the $q$, and of the hind legs in both sexes, will distinguish it. Holmgren especially points out that the apical nigrescence of the hind tibiac of the of never extends to their centre nor beyond it, as is the case in $P$. callopus, which occasionally has them centrally pale red and not white as in typical examples.

I had the good fortune to take an example of this species, which has not before been recorded with certainty from Britain, though very probably not uncommon here, at Tuddenham Fen in Suffolk, in the niddle of June; Mr. E. C. Bedwell took another at Montrose during hibernation in December; and, at Scarborough towards the end of August, Mr. E. A. Elliott took a female, which appears intermediate between the present species and $P$. nitidiventris, Holmgr. On the Continent it occurs in Switzerland, Lelgrium and Sweden, but has not yet been bred.

\section{0. nitidus, Brids.}

Phaeogenes nitidues, Bridg. Trans. Ent. Soc. ISS6, p. 337 ; Berth. Ann. Soc. Fr. I 896, p. 387 , o.

Head transverse, sub-buccate posteriorly; black, with mouth, clypeus, centre of mandibles and more or less of the facial orbits, flavous; frons nitidulous, finely and sparsely punctate; clypeus apically truncate. Antennae nearly as long as the body; red beneath, with the scape flavousdotted. Thorax and scutellum entirely black; metanotum nearly glabrous ; upper areae complete; areola transverse, reniform, basally rounded and apically sinuate. Abdomen black, with incisures of first and second segments rufescent; post-petiole centrally depressed and obsoletely punctate, shining. Legs red; coxae and base of trochanters black; hind femora more or less apically, apex of their tibiae and their tarsi, infuscate. Stigma and tegulae nigrescent. Length, $6 \mathrm{~mm}$.

This of may at once be known from the remainder of those with sparsely punctate foreheads by its black coxae and trochanters. It appears to bear a close superficial resemblance to $P$. fuscicornis, from which the subglabrous frons and pale capital markings will distinguish it.

Two males were bred in Britain, perhaps at WVorthing, from an unidentified lepidopterous host, by Mr. W. H. B. Fletcher, in 1885 ; it is unknown upon the Continent. ${ }^{1}$

\section{DIADROMUS, Wesmael.?}

Wesm. Nouv. Mém. Ac. Brux. i $8_{44}$, p. 207.

Head somewhat tumidulous, not broader than thorax, scarcely narrowed behind the eyes; vertex broad; clypeus slightly convex; broader

1 Since writing the above I have seen this species in Bridgman's collection, though I had no time to examine it. He evidently subsequently sent it to Lund, and has labelled it, "Thomson says Phygadewon, spiracles circular." I shall hope to clear up the synonymy at some future time.

2 Ichnermon abdominator, Ste. III. M. vii. $202, \delta$, and $I$. picipes, Ste lib. cit. $204, q$, are probably cognate species of this genus; but, since the types appear to be lost and the descriptions inadequate, it is impossible to attcmpt their synonymy. 
than long, its apical margin straight or a little rounded, immarginate, and abruptly depressed throughout; mandibles bidentate, lower tooth short; face somewhat convex centrally, and not or hardly discreted from the clypeus. Antennae filiform, or a little attenuate apically; scape often inflated, deeply and obliquely excised at the apex. Metathorax not posteriorly produced, its areae complete. Abdomen elongate-fusiform or, in ot, linear; central segments very finely alutaceous; second not striolate, with thyridii somewhat remote from base; terebra a little exserted. Legs normal; hind coxae of $q$ usually simple. Areolet complete; nervellus always intercepted obviously below the middle.

This genus has hitherto been merged in Britain in Phaeogenes, since WVesmael subsequently considered its characters insufficient to warrant generic rank, and in this he was followed by Marshall, and, later, by Bridgman and Fitch. On the Continent, however, it has been universally accepted, and is now well established by the additional characters indicated above.

\section{Table of Species.}

(2). I. Thyridii remote from base of second segment; thorax red-narked (THYRAEELLA, Holmgr.) ......................

(1). 2. Thyridii approximating base of second segment; thorax not red-marked discally (DIADROMUS, auctt.).

(4). 3. Head normally buccate ; scutellum apically white

7. COLLARIS, Grav.

I. Troglodytes, Grav.

2. SUBTILICORNIS, Grav.

3. VARICOLOR, WeSm.

4. guttulatus, Grav.

6. CONCILIATOR, Wesm.

5. CANDidAtUS, Grav.

\section{I. troglodytes, Grav.}

Ichneumon troglodytes, Gr. I. E. i. 587 ; Ste. III. M. vii. 202, \&. Diadromus troglodytes, Wesm. Nouv. Mém. Ac. Brux. I844, p. 207 ; Bul. Ac. Brux, I848, p. 329, $q$; lib. cit. I855, p. 431, of ; Holmgr. Ichn. Suec. iii. 385 ; Thoms. O. E. xv. 1631; Berth. Ann. Soc. Fr. I 896, p. 358 , $\delta$ 웅.

Head hardly narrowed posteriorly, black; vertex not dilated; frons dull and closely punctate; palpi and mandibles pale; of with sides of face and usually the clypeus stramineous. Antennae apically sub-attenuate, red, more or less black above; of $f$ with scape beneath, of $q$ with central band, white; those of $q$ hardly reach beyond thorax. Thorax shining, black; t with callosities at radix white; areola hardly longer than broad, apically truncate; petiolar area slightly impressed. Scutellum with usually a white sub-apical fascia. Abdomen narrow, red with first segment black, 
or black with incisures rufescent; post-petiole transverse, shining, smooth in 9 , sparsely sub-punctate in $\delta$, which has the second segment basally narrowed and dull with broad thyridii. Legs red; of with all the coxae and trochanters mainly white, those of of sometimes infuscate; hind legs of variable colour, normally blackish, with femora basally and often tibiae red; coxae mutic. Stigma fuscous; radix and usually tegulae white. Length, 6-8 $\mathrm{mm}$.

Found near Hertford and in Darenth Wood; not common (Stephens); captured at Bickleigh, 3rd August, and at Plym Bridge, 24th September (Bignell). This is a common species in Britain; Mr. Piffard has several times taken it at Felden, in Herts., and Mr. J. H. Keys has given me a specimen taken at Ivybridge, near Plymouth, in moss during hibernation, in February, IS94. I have beaten it out of fir trees in Bentley Woods in the middle of April. On the Continent it is somewhat widely distributed, and has been bred from Cerostoma $s p$. by Van Vollenhoven.

\section{2. subtilicornis, Grav.}

Ichneumon subtilicomis, Gr. I. E. i. 592, excl. o. Diadromus subtilicomis, Wesm. MÍm. couron. Ac. Belg. I859, p. 72, ơ ; Brisch. Schr. Nat. Ges. Danz. I878, n. 6, p. 58, \& ; Holmgr. Ichn. Suec. iii. 396 ; Thoms. O. E. xv. I633; Berth. Ann. Soc. Fr. IS96, p. 355, of $q$. D. imbellis, IVesm. Nouv. Mém. Ac. Brux. I844, p. 209 ; Holmgr. Sv. Ak. Handl. 1854, p. 47, $\%$.

Head triangular from in front, hardly narrowed behind the eyes, black; vertex not broad; frons finely punctate and somewhat shining; palpi and the weak mandibles often rufescent. Antennae fuscous; flagellum ferrugineous at least beneath, with no pale band. Thorax entirely black; areola quadrate; petiolar area elongate, sub-impressed. Abdomen narrow, black ; segments two to four generally red, in of with more or less prevalent black discal marks ; the following in $q$ with incisures rufescent; postpetiole distinctly and irregularly aciculate; second and third segments alutaceous, former in $q$ with confluent thyridii; anus not compressed; terebra distinctly exserted. Legs slender, red; anterior sometimes with tarsi and base of coxae infuscate; hind ones with coxae, apex of femora and tibiae, base of latter and the tarsi, infuscate; coxae of $q$ with a punctiform tooth or small cistula beneath. Stigma fuscous; radix and tegulae whitish, latter sometimes fulvous. Length, 5-8 mm.

The legs of the female are occasionally entirely red, and the male sometimes has all the femora or the whole of the hind ones infuscate; the male rarely has the third segment clear red.

This is another probably common, though overlooked, species in Britain. I have taken it in the marshes, at Brandon, in Suffolk, in June. Billups, who considers this a "very rare" species, records the emergence of three females from Agrotis Ashworthii, in Britain. It is somewhat widely distributed on the Continent, and occurs in France in August; Brischke bred it from a Tortrix (? Semasia corollana, Hüb.) pupa in a tumid twig from Populus tremula, in Prussia.

\section{3. varicolor, TVesm.}

Diadromus varicolor, IVesm. Nouv. Mém. Ac. Brux. 1844, p. 211 ; Bul. Ac. Brux. I848, p. 33I ; Holmgr. Ichn. Suec. iii. 392 ; Thoms. O. E. Xv. 1632; Berth. Ann. Soc. Fr. 1896, p. $361,8 \%$; if. Bridg. Trans. Ent. Soc. 1889, p. 413 , $\delta$. Var. D. inter- 
medius, Wesm. Nouv. Mém. Ac. Brux. 1844, p. 21 I, ơ ; Holmgr. Ichn. Suec. iii. 393, 8 ㅇ.

Head tumidous, not narrowed posteriorly, black; vertex broad; frons hardly shining; apex of clypeus sub-sinuate centrally; mouth partly rufescent. Antennae black, flagellum ferrugineous beneath in $\sigma^{\star}$, basally in $q$, which latter has a central white flagellar band. 'Thorax black; pronotum of o dull red; notauli hardly indicated; areola pentagonal, a little longer than broad, basally rounded and apically truncate; petiolar area hardly impressed, transversely rugulose. Scutellum black. Abdomen narrow, black; of with central incisures usually rufescent, $q$ with apex of first segment, whole of two to four red, and apices of the following pale; post-petiole partly aciculate; base of second segment normally impressed. Legs red; hind ones with base of coxae, apex of femora, base and apex of tibiae, and the tarsi, infuscate; hind femora linearly impressed beneath; coxae mutic. Stigma and tegulae piceous; radix white. Length, 6--8 mm.

The variety intermedius differs only in colour from the type form; the thorax is entirely black, the anterior legs have the coxae, trochanters and tarsi infuscate, and the hind pair are darker; the $q$ antennae are not, or very indistinctly, white-banded; the of pronotum is black, and its central segments are entirely red.

Bridgman's record (loc. cit.) of "four males from Gunton by Cromer" is possibly a slip for Runton, though it is perpetuated at Tr. Norf. Nat. Soc. v. p. 6ro; he took them all on August ist, 1887 , one being referable to the var. intermedius; Rev. T. A. Marshall is said to have also captured the species. On the Continent it occurs in Belgium and Sweden.

\section{4. guttulatus, Grav.}

Ichneamon guttulatus, Gr. I. E. i. 580, excll. varr.; Ste. Ill. M. vii. 201, ๆ. Diadromus guttulatus, Berth. Ann. Soc. Fr. 1896, p. 361 ; $f$. Wesm. Mém. couron. Ac. Belg. I859, p. 70 , 9 .

Head finely and closely punctate, black; apex of clypeus sub-sinuate centrally; mandibles and palpi ferrugineous; facial orbits in part white. Antennae slender, filiform, black; apically, and towards the base beneath, ferrugineous; centrally white-banded. Thorax black; pronotum and callosities before and beneath the radix white. Abdomen black, with the post-petiole, whole of segments two to four, part of five, and incisures of remainder, red. Legs slender, red; base of coxae and the hind tarsi infuscate; hind femora linearly impressed beneath. Stigma fuscous; radix and tegulae flavescent. Length, $7 \mathrm{~mm}$.

The propriety of including this species in the present genus must be regarded with some doubt, since nothing appears to be known of it beyond the type specimen examined by Wesmael, who, comparing it with $D$. varicolor, says, "la limite entre le chaperon et la face plus nettement indiquée par une linéole transversale enfoncée."

Found at Coombe WVood, in June (Stephens); Gravenhorst records it from Germany, in June, but I know of no authentic British example, and its right to inclusion in our fauna is doubtful.

\section{5. candidatus, Grav.}

Ichneumon candidatus, Gr. I. E. i. 193; Ste. Ill. M. vii. 145, б. Diadromus canditatus, IVesm. Bul. Ac. Brux, 1848, p. 330 ; Brisch. Schr. Nat. Ges. Danz. I878, n. 6, 
p. 59, ơ ; Berth. Ann. Soc. Fr. 1896, p. 359, of o. D. decolor, Holmgr. Ichn. Suec. iii. $400, \delta$ \&.

Head somewhat tumidous, black ; cheeks sub-buccate and laterally subsinuate; face protuberant; $q$ with palpi pale, and mandibles weak and rufescent; of with mouth and most of the face stramineous. Antennae of $q$ apically sub-attenuate, tri-coloured; of $\sigma^{t}$ with flagellum black, more or less ferrugineous with the scape white, beneath. 'Thorax black; 0 with pronotum and lines at radix white; metanotal areae complete; areola elongate; petiolar area discreted. Scutellum of 0 apically stramineous. Abdomen narrow and black, with segments two to four or five nigrescent or badious; post-petiole punctate. Legs red; hind femora, tibiae and tarsi apically infuscate; of with anterior, and sometimes base of hind, coxae and trochanters stramineous, and the anterior tarsi infuscate. Stigma sub-testaceous; radix and tegulae whitish, latter sometimes piceous. Length, 6-8 $\mathrm{mm}$.

Taken at Hertford, in June, rare (Stephens); a doubtful example taken in Acomb Wood, near York, in I88I (Wilson). Gravenhorst bred it from the pupa of a moth, in June, and Bignell, from Tortrix viridana, early in August, in Devon.

\section{6. conciliator, Wesm.}

Ichneumon opprimator, Gr. Mem. Ac. Sc. Torin, I820, p. 355 ; I. E. i. 595, excl. \& ; Ste. Ill. M. vii. 203, part. Phaeogenes conciliator, Wesm. Mlém. couron. Ac. Belg. I859, p. 73 ; Berth. Ann. Soc. Fr. 1896, p. 386, ơ.

Head finely and closely punctate; clypeus smooth; epistoma subelongate and not protuberant; palpi white; mandibles fulvous. Antennae fuscous with scape entirely, and flagellum beneath, fulvous. Thorax black; areola elongate and narrow; petiolar area not at all concave. Abdomen black, with apex of first, whole of segments two to four and part of five, red; petiole long and slender; post-petiole convex and a little dilated; second segment sub-quadrate, narrowed and deeply impressed basally; the following segments transverse. Legs slender, red; anterior coxae and trochanters paler; hind coxae, apices of their femora and tibiae, base of latter and the tarsi, black. Stigma fuscous; tegulae and radix white. Length, $5 \mathrm{~mm}$.

This is a very little-known species, of which we have nothing but IVesmael's description to rely upon; I have provisionally included it in the present genus on the strength of Thomson's remark (O. E. xv. I630), "Troligen är äfven Wesmaels $P \%$. conciliator en hanne till någon Diadromid att döma efter det långa epistomat."

'laken, but not commonly, about London in June (Stephens); this record only in part refers to the present species, which, nevertheless, appears to have been conceded a place in our fauna solely upon the strength of it, for I know of no other reference to this species in Britain; and on the Continent Berthoumieu records it only from Piedmont.

\section{7. collaris, Grav.}

Ischnus collaris, Gr. I. E. i. 653, ․ Diadromus callaris, Wesm. Nouv. Mém. Ac. Jrux. 1844, p. 209; Holmgr. Sv. Ak. Ifandl. I 854, p. 48, \&; Brisch. Schr. Nat. Ges. Danz. 1878, n. 6, p. 58 ; Thoms. O. E. xv. 1633; Berth. Ann. Soc. Fr. 1896, p. 355, $\delta$ \&. Thyraeella collaris, Ilolmgr. Ichn. Suec. iii. $403, \delta$. 
Head sub-tumidous, black; clypeus imperfectly discreted; palpi and the weak mandibles pale. Antennae very slender, filiform; basal flagellar joints elongate ; fulvous, somewhat darker above; scape of $q$ sub-infuscate. Thorax mainly red; pronotum of of flavidous; metathorax black; areola not longer than broad, basally rounded and apically truncate; costulae sub-obsolete; petiolar area not impressed; mesosternal sulci short and deep. Scutellum sub-elevated, convex, red. Abdomen elongate, narrow, red; with the first segment, except usually its apex, basal half of fifth and of sixth and most of seventh, black; three or four apical segments of $q$ black; post-petiole convex, glabrous and shining ; impression deep, entire and situated in the basal third of second segment ; terebra exserted. Legs slender, red; coxae and trochanters fulvous or stramineous; + + with apex of hind femora and tibiae, and often base of latter, infuscate ; coxae mutic. Stigma fuscous; radix and tegulae white. Length, $5-8 \mathrm{~mm}$.

The mesonotum is sometimes more or less infuscate, and Brischke refers to examples with the thorax and scutellum entirely black (var. Brischkei, Berth.).

Besides the points already indicated, this species is very distinct from the rest of the genus in the conformation of its body, its gibbulous scutellum and very slightly produced meso- and meta-sterna, which characters ally it with Ischmis.

This is undoubtedly quite a common species in Britain. Mr. A. Beaumont has taken it at Appledore, in August; Mr. Tuck, at Tostock and Finborough Park, in Suffolk, in September; Bridgman, at Eaton, in July ; and I have found it on Mousehold Heath, near Norwich, early in June, at Bramford early in November, and beaten it from spruce and Scotch fir, at Foxhall and Bentley Woods, near Ipswich, and at Gosfield, in Essex, in April. It is common on the Continent, where Brischke bred it from a Tortrix pupa, on oak. As Holmgren remarks, the male is of much rarer occurrence ; I have seen but one specimen of it, taken probably at Shere, in Dr. Capron's collection.

\section{EPITOMUS, Förster.}

Först. Verh. Pr. Rheinl. I868, p. 192; Thoms. O. E. xv. (I891) I625.

Head with genal sulcus impressed; frons sub-coriaceous; vertex not very broad, convexly narrowed behind eyes; cheeks hardly buccate, not elongate; mandibular teeth unequal; epistoma oblong and convex, discreted from clypeus. Antennae sub-filiform, post-annellus elongate. Thoracic notauli inconspicuous; mesosternum nearly transverse; metanotum finely punctate, petiolar area reaching beyond its middle and dilated above; areola quadrate. Abdomen with post-petiole transverse and a little dilated; thyridii distinct; terebra short and slender. Legs not stout. Wings with areolet incomplete externally, the anterior with discoidal cell rectangular apically below ; nervellus sub-opposite.

\section{r. parvus, Thoms.}

Epitomus parvus, Thoms. O. E. xv. 1626, ठ \&.

Black; fo with mouth, face and under side of scape, flavous-white. Abdomen with central segments pale-margined. Legs red; anterior coxac 
and trochanters sulphureous; hind coxac black and hind femora infuscate. Length, $3 \mathrm{~mm}$.

Thomson says, "Ej sällsynt i norra och medlersta Europa"; in Britain the only record is that of Bridgman (Tr. Norf. Nat. Soc. v. p. 6II), "Taken occasionally in the neighbourhood of Norwich." I took what I believe to be a male of this species in the New Forest, near Hurst Hill, on

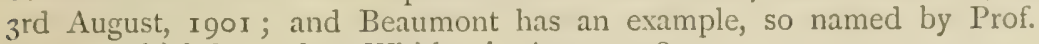
Brauns, which he took at Whitby, in August, 1897.

\section{OIORHINUS, Wesmael.}

Wesm. Nouv. Mrém. Ac. Brux. IS44, pp. I66 et 202.

Head not narrowed behind the eyes; vertex broad but not deeply emarginate; clypeus broader than long, strongly convex, deeply discreted from face, at apex broadly and abruptly excavate sub-circularly in the centre; apices of mandibles strongly narrowed, upper tooth long and acute, the lower short and a little inflexed. Antennae somewhat slender; scape sub-dilated and gaping at apex; flagellum filiform, elerenth joint of o sub-quadrate. Thorax not elongate; notauli sub-obsolete; metathorax not produced apically; areola short, transverse, sub-reniform; petiolar area sub-excavate longitudinally. Abdomen narrow, elongate-fusiform, a little shining; petiole slender, elongate, smooth; thyridii distinct, transverse, remote from base; terebra short. Legs slender, coxae simple. Areolet complete; nervellus oblique and hardly intercepted.

The following is the only known species.

\section{I. pallidipalpis, Wesm.}

Oiorhinus pallipalpis, Wesm. Nouv. Mém. Ac. Brux. I844, p. 202 ; Bul. Ac. Brux. I848, p. 326 ; Holmgr. Ichn. Suec. iii. 408; Thoms. O. E. xv. 1628, $\delta$ o. O. pallidipalpis, Berth. Ann. Soc. Fr. I 896, p. 345, $\delta$ \%. (?) Herpestomus striatus, Bridg. Trans. Ent. Soc. I881, p. 145, \& $\$$.

Head slightly buccate, finely punctured, black; cheeks more strongly punctate, margined and shining; palpi and sometimes the mandibles pale. Antennae slender, filiform; flagellum ferrugineous, at least beneath; of $\delta$ elongate, with central joints externally sub-dilated. Thorax shining, black; mesonotum finely punctate with obsolete notauli; metathorax scabriculous; areola short, reniform, apically emarginate; petiolar area subimpressed. Abdomen black with the thyridii and incisures fulvous; segments two to four of $q$ red; first segment straight, narrow and smooth; second finely alutaceous and somewhat dull, its basal impression distinct. Legs slender, red, with anterior coxae and all the trochanters stramineous; hind coxae black, more or less pale at apex, their femora and tibiae towards their apices, base of the latter, and the tarsi, black. Stigma piceous ; radix white; tegulae fulvescent. Length, 5-6 $\mathrm{mm}$.

This species closcly resembles Phatosenes arsutus supurficially; but may at once be known from allied genera by the peculiar structure of its clypeus.

$H$. striatus appears to differ from the present species in its aciculate post-petiole and fulvous of coxae and trochanters; moreover, Lridgman 
describes it within a few pages of recording $O$. pallitipalpis, which he, consequently, evidently knew at the time, from Britain. It is quite possible, however, that he sent his types for examination to Professor 'Thomson, who (ioc. cit.) united the species in r89r. Bridgman maintained their distinctness in I 893 ('Trans. Norf. Nat. Soc.).

O. pallidipalpis was first taken in Britain, near Norwich, in July and September, by Bridgman, who subsequently says it is not uncommon at Eaton, Earlham and Mousehold, in the autumn; Bignell has found it at Egloskerry in Cornwall towards the end of July. On the Continent it occurs in Germany, Belgium and Sweden, but does not appear to have been bred. $H$. striatus is not noted in Berthoumieu's "Monographie"; Bridgman took both sexes about Norwich-at Eaton, Earlham and Brundall, in July and September; and Bignell informs me he has captured it at Bickleigh in Devon.

\section{AETHECERUS, Wesmael.}

IVesm. Nouv. Mém. Ac. Brux. I844, pp. I66 et 203.

Head hardly or moderately buccate ; vertex not broad ; frons impressed ; face short, centrally protuberant; clypeus broader than long, shining, sparsely punctate, deeply discreted from face, its apex with a fovea in the centre, laterally reflexed or denticulate; mandibles broad, lower tooth the shorter. Flagellum filiform; scape elongate, sub-compressed, at base generally broadly oblique, and, in ó, more or less dilated. Thorax stout; metathorax not produced posteriorly, completely and very distinctly areated. Abdomen elongate-fusiform, or in of parallel-sided; second segment distinctly impressed; terebra stout and but shortly exserted. Legs normal; hind coxae of $q$ usually with small scopulae. Areolet narrowed above.

The following species are very closely allied; I have found them difficult to distinguish, and have considerable doubt as to their specific value. Six other kinds are known on the Continent.

\section{Table of Species.}

(2). I. Metathorax slightly produced apically

(1). 2. Metathorax not produced apically beyond insertion of hind cosae.

(4). 3. Head narrowed posteriorly; o coxal cristulae acute .................

(3) 4. Head not narrowed posteriorly; o coxal cristulae obtuse or wanting.

(8). 5. Pronotum usually pale ; scape hardly (ô) or not $(q)$ dilated.

(7). 6. Areola of o elongate; clypeus of of black

(6). 7. Areola of of sub-quadrate; clypeus of to white

(5). 8. Pronotum black; scape strongly (ô) or slightly ( $q$ ) dilated

I. LONGULUS, Wesm. 2. P'L.ICIIT's, Il ism.

3. NITIDUS, IVesm.

4. DISCOLOR, Wesm.

5. DISPAR, Wesm.

\section{I. longulus, IVesm.}

Acthecentes longulus, Wesm. Nouv. Mém. Ac. Brux. I844, p. 206 ; Brisch. Schr. Nat. Ges. Danz. I878, n. 6, p. 59 ; Berth. Ann. Soc. Fr. 1896, p. 365, $\$$; Thoms. O. E. xv. I642, of + ; of. 13ridg. Trans. Ent. Soc. IS8I, p. I50. Phacogenes formosus, Bridg. loc. cit. p. 149, 9 . 
․ Head stout, broader than thorax, transversely rectangular; frons closely punctate; mandibles and palpi pale. Antennae elongate, fuscous ; centrally white-banded; flagellum towards the base somewhat attenuate, with the joints there elongate and red. Thorax black; metanotum rugosely punctate with the areae distinct; areola long and narrow, parallelsided ; incomplete apically and, at least sometimes, carinate longitudinally in the centre. Abdomen oblong-linear with segments two to four entirely or mainly fulvous; post-petiole glabrous and shining; second segment elongate, sub-aciculate, strongly contracted basally, with the thyridii at its basal third. Legs slender, fulvous ; hind tibiae at base and apex, apex of tarsi, and sometimes their coxae and apices of femora, black. T'egulae fulvous, radix white, stigma piceous. The of is black with thyridii, incisures and legs, except apex of hind femora and the apex of their tibiae, red. Length, 5-6 mm.

The caudate production of the thorax beyond the coxal insertion in both sexes, the linear post-annellus of the $q$, and the short petiole, shining and hardly punctate frons, black mouth and antennae, with the slightly dilated scape of the 0 , will distinguish this species, which bears the facies of a Diadromus. Bridgman referred his $P$. formosus to this genus, but he has placed his type specimen under the present species in his collection.

Bridgman took the female of his $P$. formosus, at Earlham, near Norwich, in September. He does not, in his Norfolk Ichneumon list, reiterate the record of $A$. longulus, taken at Norwich, in June, recorded by him loc. cit. supra. Marquand records $P$. formosus from the Land's End district; and Rev. 'T. A. Marshall has named an example, subsequently damaged, which I took at Ipsivich, early in September, as A. longulus. It is widely distributed on the Continent, but has not been bred.

\section{2. placidus, Wesm.}

Aethecerus placidus, Wesm. Nouv. Mém. Ac. Brux. IS44, p. 206 ; Brisch. Schr. Nat. Ges. Danz. I878, n. 6, p. 59 ; Berth. Ann. Soc. Fr. I896, p. 365, ; Thoms. O. E. xv. $164 \mathrm{I}, \delta$ ㅇ.

․ Head black, somewhat narrowed behind the eyes; frons a little nitidulous, finely and sparsely punctate; apex of clypeus with a central sub-obsolete foveola; mandibles and palpi pale. Thorax black. Abdomen black, with the second and third segments, most of fourth, and apices of the following and of the first, red. Legs red, with apices of hind femora and tibiae, often the hind coxae and base of their tibiae, infuscate; hind coxae with a minute, acute, oblique granule. 'Tegulae red, radix white, stigma infuscate. The of appears to differ only in having the coxae, the hind trochanters and most of the quadrate central segments, black; the genal costa inflexed, and the cheeks apically excavate, but with the genal costa not strongly reflexed. Length, 5-6 $\mathrm{mm}$.

It may be known from $A$. nitidus by the posteriorly sub-constricted head, shorter vertex, and more sparsely punctate frons; the acute granule of the hind coxae will further distinguish the female.

This species has not before been noted in Britain, and is doubtless much mixed with the following. I was so fortunate as to capture a male at Burgh Castle, near Lowestoft, on 9th August, 1898 . Its continental range appears to be somewhat restricted. 


\section{3. nitidus, Wesm.}

Aethecenus nitidus, Wesm. Nouv. Mém. Ac. Brux. I844, p. 204 ; Thoms. O. E. xv. 1640 ; Berth. Ann. Soc. Fr. 1896, p. 363, of ; cf. Bridg. Trans. Ent. Soc. I88I, p. 149, $?$.

Head black; frons shining, sparsely and somewhat strongly punctate; palpi and mandibles of $q$ red. Antennac of $q$ with hasal half of flagellum, or at least its centre, red; of of with the scape basally compresso-dilated. Thorax black; of $q$ with pronotum red and the areola twice longer than broad, the latter of of sub-quadrate. Abdomen black, with segments two to four more or less red, as is also the basal segment of 9 ; post-petiole finely aciculate. Legs red; apices of hind femora and tibiac, and in of the base or whole of latter, black; of with all the coxae and hind trochanters black; hind coxae of $q$ with dentiform cristulae. Tegulae ferrugineous; radix pale ; stigma piceous. Length, $7--8 \mathrm{~mm}$.

Bridgman (loc. cit.) says the hind coxae and basal segment are sometimes mainly infuscate, and the pronotum occasionally immaculate.

From $A$. dispar, the $q$ of this species differs in its more closely and strongly punctate frons, entirely or mainly red hind coxae, and rather longer post-annellus; the male has the scape less distinctly dilated and the central segments red.

Bridgman took this species, in July and September, at Earlham, Lakenham, Heigham and Gunton, in Norfolk, and adds that Mr. Atmore bred it at Lynn from Cosmia diffinis; Bignell took it at Plym Bridge, in Devon, early in May; Mr. Brunetti has given me an example from Rye House, early in July; and it has occurred to me at Ryde, in the Isle of Wight, and at Barton Mills, in Suffolk, in June. On the Continent it is found in Germany, Belgium, and in June, in France.

\section{4. discolor, Wesm.}

Aethecerus discolor, IVesm. Nouv. Mém. Ac. Brux. 1844, p. 204; Brisch. Schr. Nat. Ges. Danz. I878, n. 6, p. 59; Holmgr. Ichn. Suec. iii. 4I3; Berth. Ann. Soc. Fr. I896, p. 364 , ơ 9 ; Thoms. O. E. xv. I640, excl. $\&$.

Head not narrowed behind the eyes, black; temples and cheeks subbuccate, the latter broad and, especially in to, auriculately produced beneath the mandibles; face shining, sparsely punctate; mandibles and palpi pale, those of $\delta$, as well as the clypeus, white. Antennae filiform; scape not dilated, of $\delta$ white beneath; flagellum ferrugineous, at least beneath; of $q$ sometimes with the central joints obsoletely white. Thorax black; pronotum and callosities at radix red in $q$, white in $\delta$; notauli indicated; metanotal areae complete; areola hardly longer than broad, basally rounded and apically sub-truncate. Abdomen black, with at least the incisures red; o with segments two to four entirely red and six and seven sometimes narrowly white; post-petiole sub-rugulose or irregularly aciculate; thyridii transverse and distinct, basal impression not deep; terebra shortly exserted. Legs normal, red; anterior with coxae and trochanters of $\delta$ white; hind ones stouter, with base of coxae and usually apex of femora, infuscate; $\delta$ with apex of hind coxae white, and most of their tibiae with the tarsi infuscate; $q$ with a sub-obsolete coxal cristula. Stigma red or fuscous; radix and tegulae white, the latter sometimes fulvous. Length, $6-8 \mathrm{~mm}$. 
This species may be known from $A$. dispar by its capital and thoracic markings, the more strongly punctate frons and the conformation of the antennae.

Bridgman took the female, at Earlham, near Norwich, in September, I 877 , but did not subsequently meet with it; I swept two females, at dusk, in Bentley Woods, on 2oth September, I897. It has a wide continental distribution, and the female is said to hibernate.

\section{5. dispar, Wesm.}

Tchnermon ischiomelinus, var. I, Gr. I. E. i. 6oS, of Acthecerus dispar, Wesm. Nouv. Mém. Ac. Brux. I 844 , p. 203 ; Bul. Ac. Brux. I848, p. 327 ; Holmgr. Ichn. Suec. iii. 414 ; Thoms. O. E. xv. 1639; Berth. Ann. Soc. Fr. 1896, p. 364, $\delta$ q. Var. A. frontatzs, Wesm. Nouv. Mém. Ac. Brux. 1844, p. 205, \&.

This species so closely resembles the preceding as to require no detailed description. From the remainder of the genus both sexes may be at once known by the shining, sub-obsoletely and sparsely punctate frons, the excavated apices of the cheeks, which are dilated below the mandibles with the oral costa reflexed, the short notauli, discreted and sub-parallel petiolar area, costulae emitted from before the centre of the areola, the centrally smooth and shining post-petiole, and by the nervellus being intercepted nearly in its centre. The of has the scape impressed and broadly dilated basally, a deeper impression at the base of the second segment, and its hind legs are darker, having only the femora basally and tibiae sometimes entirely rufescent. The $q$ bears a conspicuous semi-rotund dentiform cristula beneath the hind coxae, its antennae are tricoloured, the basal segment entirely black, the post-annellus longer than broad, hind legs stout, with the base of the coxae and apices of femora and tibiae black.

From $A$. discolor, the black clypeus and scape of the $\sigma^{\star}$, entirely black thorax, rarely stramineous coxae, which are often basally infuscate, mandibles black in 9 and centrally red in $\sigma^{*}$, will distinguish it.

The var. frontatus differs in the absence of a pale flagellar band. Wesmael also mentions a variety of the 0 with two apical scutellar dots and the mandibles white, which Berthoumieu has named albipictus.

This species is common in Norfolk, and Bignell took it at Egloskerry, near Launceston, towards the end of July. I found the female hibernating in a tuft of Aira caespitosa, in Guestling Wood, near Hastings, in April, and the male at Dunwich, in Suffolk, early in August. It is widely distributed on the Continent.

\section{DICAELOTUS, Wesmael.}

Wesm. Nouv. Mém. Ac. Brux. I844, pp. 165 et I75.

Head not tumidous; vertex and cheeks broad but not buccate; frons convex, transversely impressed; epistoma broader than long; clypeus very broad and very short, distinctly discreted, shining and sparsely punctate, its apical margin entire, not foveate, smooth, mutic, straight or very broadly rounded; mandibles somewhat narrow, with the lower margins entire and teeth of nearly equal length. Flagellum stout, filiform; scape sub-cylindrical, hardly excised apically. Thorax stout; notauli distinct, of variable length; mesosternum transverse, with its lateral sulci 
broad and deeply impressed; metathorax not produced posteriorly; areae complete, with strong carinae; areola short, sub-reniform or sub-caudiform; petiolar area elongate, deeply excavate; apophyses more or less strong. Post-scutellum with two sub-confluent foveae. Abdomen elongate fusiform; post-petiole a little dilated; second segment with no basal impressions, or the gastrocaeli barely traceable; terebra shortly exserted, hypopygium strongly retracted. Legs somewhat stout; coxae mutic; calcaria long. Areolet complete ; nervellus antefurcal or opposite.

Thirteen kinds are recorded as occurring in the palaearctic region.

\section{Table of Species.}

(10). I. Anus of $q$ sub-obtuse.

(9). 2. Head anteriorly rounded; mandibular teeth sub-equal (DICAELOTUS, auctt.).

(6). 3. Frons distinctly and sparsely punctate.

(5). 4. Hind femora and tibiae mainly black...

(4). 5. Hind femora and tibiae fulvous .........

(3). 6. Frons closely and sub-confluently punctate.

(8). 7. Petiolar area trans-striolate and discreted.

(7). 8. Petiolar area not trans-striolate nor discreted

I. PUNillus, Grav.

2. CAMERONi, Bridg.

3. RUfiliaibatus, Grav.

4. RUFicoXatus, Grav.

(2). 9. Head anteriorly triangular; mandibular teeth unequal (CINXAELOTUS, Holmgr.)

5. PARVUlus, Grav。

6. PUSIllator, Grav.

(1). 10. Anus acute

\section{I. pumilus, Grav.}

Ichneumon pumilus, Gr. I. E. i. I52 ; Ste. III. M. vii. 138,. . Dicalotus pumilus, Wesm. Nouv. Mém. Ac. Brux. 1844, p. 175, 9; Bul. Ac. Brux. 1848, p. 315 ; lib. cit. I 849 , p. 43, ơ ; S. v. Voll. Schets. I. pl. iii. f. I4 ; Holmgr. Ichn. Suec. iii. 361 ; Thoms. O. L. xv. I6I9; Berth. Ann. Soc. Fr. 1896, p. 34r, of $q$.

Head sub-rotund, viewed from in front; frons shining, distinctly, but finely and sparsely punctate; vertex short but not narrow; genal costa not inflexed; mandibles hardly narrowed apically; mouth and palpi partly pale, of with clypeus entirely or laterally stramineous. Antennae dark, with flagellum not attenuate, and mainly, at least beneath, ferrugineous; scape of of stramineous below; post-annellus of $q$ sub-quadrate. Thorax black, or with a pale callosity below or before radix; metanotal areae complete ; areola sub-triangular, apically indentate ; petiolar area discreted, centrally deeply concave and trans-striate. Abdomen black, incisures and most of second segment, in $\hat{\delta}$ also of three to five with whole of anus, ferrugineous; post-petiole roughly aciculate, sometimes strongly punctate or apically glabrous; second segment strongly punctate, with gastrocaeli obsolete but traceable; terebra very shortly exserted. Legs variable in colour ; anterior coxae of $q$ and femora red or black, their tibiae and tarsi red or stramineous; anterior coxae and trochanters of $\hat{\sigma}$ stramineous; hind legs black, with base of femora and of tibiae red or fulvous, their tarsi infuscate. Stigma somewhat large and piceous, radix and tegulae white, the latter often rufescent. Length, 4-6 mm.

Wesmael's var. 2 (rufoniger, Berth.) has the antennae entirely black, the abdomen except its basal segment, and most of the legs, red. 
Common throughout the metropolitan district, in June and July, at Darenth, Hertford, etc., and in Salop (Stephens); Lastingham, Yorks. (Marshall) ; Essex. This is an abundant species in Britain. It has been taken in the Pentland Hills, in Narch, by Evans; at Rame Head and Malvern, by Bignell, and at Mousehold, by Bridgman, in June ; at Reigate, in July and August, by Wilson Saunders; at Felden, by Piffard; at 'T'ostock, Finborough Park and Wicken Fen, in September and October, by 'Tuck ; near Guildford, by Butler ; at Colwyn and York, in October, by Beaumont; and at Darlay Dale, near Matlock, by Tomlin. I have found it at Brandon, in Suffolk, in June ; but usually during or just after hibernation, in Bentley Woods and at Ipswich, where the female is not uncommon in tufts of Aira caespitosa and in moss, and subsequently in April lurking beneath bits of wood and in the branches of Coniferce. When this species is frightened it presses its legs to its sides, protrudes its antennae close together and straight forward, and in this position will often roll over and over without moving a muscle. When at rest, the antennae are held straight forward, close together at the basal two-thirds, then abruptly curved outwards laterally in a semi-circle. On the Continent it is very widely distributed and extends to Algeria; it has been bred from Depressaric nervosa, and in Britain I have examined a female bred by Mr. Richardson on I Ith September, I89i, from Gelechia plantaginella, at the Chesil Beach. I have only seen one male example of this species.

\section{Cameroni, Bridg.}

Dicaelotus pumilus, Wesm. (partim). D. Cameroni, Bridg. Trans. Ent. Soc. I8 88 , p. I46, pl. viii. f. 3 ; Holmgr. Ichn. Suec. iii. 363 ; Berth. Ann. Soc. Fr. IS96, p. 342, o ; Thoms. O. E. xv. 1619 , o \%.

Head strongly nitidulous, with a few minute scattered punctures, black ; frons finely and sparsely punctate; palpi pale; mandibles and clypeus of fulvidous, of $\delta$ stramineous. Antennae fuscous, half length of the body; basal flagellar joints moniliform, ferrugineous; to with scape stramineous beneath. Thorax shining, black; pronotum often rufescent; mesonotum and scutellum finely and sparsely punctate; metanotum finely rugose, with complete areae; areola sub-triangular, apically obtuse; petiolar area discreted, centrally slightly concave. Abdomen nitidulous, black; dull stramineous beneath; margins of second and third segments red; post-petiole punctate, hardly aciculate laterally; second segment finely punctate throughout. Legs fulvous; hind coxae, and sometimes their trochanters, black; anterior coxae and trochanters of to stramineous. Stigma dull stramineous; radix white; tegulae fulvidous. Length, 5-6 $\mathrm{mm}$.

This species is closely allied to the preceding, especially in its size and in the nearly continuous genal costa, but it is much more shining and finely punctate, the antennae are longer and more slender, the thorax a little longer, the metathoracic sculpture finer, and the colour of the legs is also distinctive.

D. Cameroni was described from examples taken in Scotland by Cameron and at Heigham and Earlham, by Bridgman, in August. I possess two females, sent me by Mr. Donisthorpe, from Rossbeigh, in Co. Kerry, in June, 1902; they both have the abdomen mainly red. 'Two specimens were bred by Mr. Bankes from Swanage Butalis senescens, Stn., on June 8th and 20 th, 1895. 


\section{3. rufilimbatus, Grav.}

Ichneumon muflimbatus, Gr. Mem. Ac. Sc. Torin. IS20, p. 355; I. E. i. 603 ; Ste. Ill. M. vii. 204; Wesm. Mém. couron. Ac. Belg. IS59, p. 74, o. Dicaelotus ruefilim. batus, Wesm. Bul. Ac. Brux. 1855, p. 417, ơ ; Brisch. Schr. Nat. Ges. Danz. 1878, n. 6, p. 53 ; Berth. Ann. Soc. Fr. I896, p. 342, o \&. D. crythrostoma, IVesm. Nouv. Mém. Ac. Brux. I844, p. 176 ; ? Bul. Ac. Brux. 1855, p. 417, q var. ; Thoms. O. E. xv. I620, $\delta$ \&.

Head black, with mouth, clypeus, and sometimes more or less of the internal orbits of $\delta$ stramineous; mouth and usually clypeus of $q$ red. Antennae infuscate; scape of $t$ beneath flavous, of $q$ often entirely red; flagellum, at least basally beneath, ferrugineous. Thorax black; metanotal areae well defined; areola cordiform; petiolar area discreted, centrally trans-striate and concave. Abdomen black, with segments two to four, except discally, and the apex of fifth, red; post-petiole and following segments punctulate, the former sub-aciculate in $q$; gastrocaeli wanting. Legs of $q$ entirely red or with the femora and hind coxae in part black; of $f$ black, with anterior tarsi, and most of the tibiae and femora flavidous, the hind ones with base of femora and of tibiae rufescent. Stigma piceous ; radix and tegulae stramineous, latter often fulvidous Length, $6 \mathrm{~mm}$.

From the two already described, the present species may be known by its more closely and deeply punctate frons, more strongly sculptured metathorax which bears small lateral apophyses, as well as by its colour and larger size.

Thomson thinks (loc. cit.) it to be quite possible that the true $I$. mufimmbatus of Gravenhorst $(\hat{\delta})$ and the female varieties of $D$. erythrostoma, described by Wesmael in 1855 , are referable to a species distinct from $D$. erythrostoma, Wesm. (I844), namely, to his own D. inflexus. If this prove to be the case, the insect occurring in Britain, if, indeed, it occur at all, will be known as $D$. erythrostoma, Wesm., since little reliance is to be placed upon Stephens' old record.

Scarce, found near London, in June (Stephens). I know of no more recent records. On the Continent it is taken in France, Belgium, etc., so its occurrence with us is far from improbable. Since writing the above, I am told by Mr. Bignell that he has captured this species at Egloskerry, in Cornwall, late in July.

\section{4. ruficoxatus, Grav.}

Ichneumon ruficoxatus, Gr. I. E. i. 597 : Ste. Ill. M. vii. 203,.+ Dicaelotus ruficoxatus, Wesm. Bul. Ac. Brux. 1857, p. 415; Mém. couron. Ac. Belg. 1859, p. 73 ; Thoms. O. F. xv. 1622; Berth. Ann. Soc. Fr. 1896, p. 340, $\delta$ \&. D. unipunctalus, Wesm. Nouv. Mém. Ac. Brux. I844, p. I76; Bul. Ac. Brux. 1848, p. 316, q.

Head black ; cheeks hardly buccate ; frons closely punctate; palpi and apices of mandibles rufescent; of with facial orbits sulphureous. Antennae infuscate; flagellum often rufescent or sub-stramineous beneath basally, of $q$ filiform; scape of $\hat{o}$ flavous beneath. Thorax black; pronotum of $q$ red, of of with callosities before radix flavous; metanotum dull, shortly bispined; petiolar area finely shagreened throughout, not trans-strigose nor discreted. Abdomen closely and strongly punctate, black with segments one to three, base of fourth, and incisures of the following, sanguineous-red; apex black; post-petiole not broad, closely punctateaciculate, shorter than terebra. Legs red; anterior femora and hind coxae 
in part, apices of hind femora, of their tibiae and the tarsi, infuscate; 0 with coxae and trochanters flavous, anterior legs pale and the base of the hind tibiae infuscate. Stigma ferrugineous, of 0 basally white; radix pale; tegulae piceous or white. Length, $6 \mathrm{~mm}$.

Found at Hertford, in June (Stephens). Mr. Bignell has taken this species at Bickleigh, in Devon, towards the end of June; it also occurs in France and Belgium.

\section{5. parvulus, Grav.}

Ichneumon parvulus, Gr. I. E. i. 59I ; Ste. Ill. M. vii. 203, \&; cf. Wesm. Mém. couron. Ac. Belg. 1859, p. 72. Dicaelotus parvulus, Holmgr. Ichn. Suec. iii. 365 ; Berth. Ann. Soc. Fr. 1896, p. 342, $\uparrow$; Thoms. O. E. xv. 1621, of $q$.

Head triangular from in front; cheeks longer than base of the piceous mandibles, not buccate; face centrally prominent, of of sometimes with a basal clypeal flavous fascia; palpi pale; frons remotely punctate. Antennae infuscate; flagellum basally ferrugineous and, in $q$, apically attenuate; scape of $\hat{\sigma}$ quadrately flavidous beneath. Thorax black; mesopleurae trans-strigose. Abdomen black with pale pubescence, beneath subflavidous; segments two and three punctate throughout with at least their margins red; post-petiole parallel-sided; second segment broader than long, gradually narrowed basally, with the gastrocaeli and thyridii wanting; terebra slender and not very shortly exserted. Legs red; coxae, base of trochanters, and sometimes apices of hind femora and tibiae black; anterior trochanters of $t$ sometimes flavidous. Radial cell somewhat short; stigma and tegulae piceous; radix white. Length, $4 \mathrm{~mm}$.

It may be known by its small and compact form, its somewhat strongly dilated and punctate post-petiole, which is half as long as the terebra, the head strongly declived and narrowed posteriorly, and entirely black thorax; the female has the second segment transverse, somewhat dull and red, the third with a large posterior mark; the male has the mandibles and often the whole clypeus black, the palpi and tegulae white, and the hind femora and tibiae towards their apices somewhat broadly infuscate.

This species is similar to D. pumilus in size, conformation, and in the structure of the metanotum, but differs in colour and in having the second and third segments transverse and strongly punctate throughout.

Not common, found in June, near London (Stephens); captured at Plym Bridge, late in May, and at Bickleigh, in Devon, early in June (Bignell). Mr. Piffard has given me an example of this species, taken at Felden, in Herts., and correctly named by Dr. Capron. On the Continent it ranges from Austria to Sweden.

\section{6. pusillator, Grav.}

Ichneumon pusillator, Gr. I. E. i. 605, excl. o ; Ratz. Ichn. d. Forst. i. 135, excl. 8 . Dicaelotus pusillator, Wesm. Mém. couron. Ac. Belg. 1859, p. 75 ; Berth. Ann. Soc. Fr. I896, p. 344, ㅇ. .

Head black; mouth parts fulvous. Antemnae half length of body; infuscate, with scape beneath and flagellum towards its base red. 'Thorax black; petiolar area obliquely declived and centrally strongly excavate. Abdomen with basal segment smooth and black, the following redmargined; anus acute; terebra shortly exserted. Legs red, hind coxae 
entirely or partly black. Stigma piceous, radix stramineous, tegulae fuscous. Length, $5 \mathrm{~mm}$.

The above appears to be all that is known of this $q$, to which the present position was assigned by Wesmael, together with the description of the metathorax ; I am certainly inclined to doubt its individuality.

Lastingham in Yorks. (Marshall). Bignell records it from Bickleigh, in Devon, in the middle of September. On the Continent, where it has a restricted distribution, it is said to have been bred from Cossus ligniperda and from a species of Notodonta.

\section{COLPOGNATHUS, Wesmael.}

Wesm. Nouv. Mém. Ac. Brux, 1844, pp. I65 et I74.

Head buccate, not narrowed posteriorly; cheeks and temples broad; clypeus transverse, entire and not convex; apically truncate and very broadly rounded, distinctly discreted from the face; of with lower margin of the stout mandibles sinuate, their teeth sub-equal. Flagellum filiform, of to not basally attenuate; scape sub-cylindrical. Post-scutellum not impressed. Abdomen with second segment not basally impressed, though sometimes striolate in $\delta$; of $q$ apically obtuse, with terebra retracted and concealed. Coxae in the British species mutic.

\section{Table of Species.}

(4). I. Gastrocaeli wanting; anterior coxae black.

(3). 2. Antennae of $q$ tricoloured; second segment of ot entire ........................................

(2). 3. Antennae of $q$ bicoloured; second segment of $\hat{o}$ basally striate ...........................

(1). 4. Gastrocaeli indicated; anterior coxae fulvidous

I. CELERATOR, Grav.

2. DIVISUS, Thoms.

3. JUCUNDUS, Wesm.

\section{I. celerator, Grav.}

Ichneztnon celerator, Gr. Mem. Ac. Sc. Torin. I820, p. 353 ; I. E.. i. 566 ; Ste. Ill. M. vii. 2c0, q. Colpognathas celerator, Wesm. Nouv. Mém. Ac. Brux. 1844, p. 174; S. v. Voll. Schets. I pl. iii. f. I3; Holmgr. Sv. Ak. Handil. I854, p. 44; Ichn. Suec. iii. 370; Thoms. O. E. xv. 1636; Berth. Ann. Soc. Fr. 1896, p. 337, o q. Phygadeuon procerus, Gr. I. E. ii. 722 ; Ste. Ill. M. vii. 302, o (part.). Ichnemmon femorator, Ste. III. NI. vii. 200 , q.

Head black, strongly punctate, transversely sub-quadrate viewed from in front ; cheeks half shorter than bases of mandibles ; epistoma protuberant ; clypeus shining, sparsely punctate; mandibles strongly sinuate below; palpi apically pale. Antennae of to slender, black; of $q$ short, stout and tricoloured. 'Thorax punctate and shining, black; notauli obsolete; metanotal areae complete; areola hardly longer than broad, sub-hexagonal, apically sub-truncate; petiolar area a little concave, not or hardly discreted, broad above. Abdomen of to elongate and sub-cylindrical, of $q$ sub-fusiform; black with apex of first, whole of second to fourth segments and usually part of fifth, clear red; post-petiole glabrous, or in of subaciculate, second segment of latter not basally striolate. Legs red, with coxae, trochanters, apices narrowly of hind femora and tibiae, and tarsi, black. Stigma fuscous, radix white, tegulae black. Length, 7-10 $\mathrm{mm}$. 
Not unfrequent in woods, near London, in Jume (Stephens) ; Lynn, in Norfolk (Bridgman); Bolt Head, in June, and Horrabridge, in September (Bignell); Land's End district (Marquand) ; Harting and Oxted (Beaumont); it is also recorded from Essex. In France, M. Pic found it commonly about Digoin, in meadows near woods. I expect most of the foregoing records really refer to the next species, which is not noted in Berthoumieu's work. I have found C. celeritor, Grav, to be uncommon in Britain. Miss Chawner has given me a specimen from the New Forest, and Mr. R. C. Bradley another, captured about Birmingham in Igor. It is said to be common throughout Europe, where Grasenhorst records it copiously on umbelliferae, and to have been bred from the pupa of Sesica hylaeiformis and from Botys mubilalis (lupulinalis).

\section{2. divisus, Thoms.}

Colpognathus divisus, Thoms. O. E. xv. 1636, o $q$.

Closely allied to the preceding, from which it may at once be known by its smaller size, more elongate thorax, more deeply punctate mesonotum, longer areola, and by the strongly discreted petiolar area, which is more strongly contracted basally; the of has the second segment distinctly striolate basally, all the coxae and trochanters red, with the hind femora more narrowly black at their apices; the $q$ has the antennae bicoloured and the mandibles much less deeply sinuate below. Length, 6-8 $\mathrm{mm}$.

This species has hitherto been mixed with the preceding, and is unrecorded from Britain, where it is undoubtedly abundant during hibernation in tufts of Aira caespitosa and other grasses. The male, which is found in September, is of much rarer occurrence, and I have only seen two examples of it taken at Tostock by Mr. Tuck, and at Oulton Broad, in Suffolk, by Mr. Bedwell. Dalglish has taken fentales at Bowling in May; Col. Yerbury at Golspie in August; Piffard, at Felden ; and I have found it freely, at Bentley IToods, near Ipswich, at Sedlescombe, Brede and Battle, near Hastings. Heads Nook, near Carlisle (Routledge); Plymouth (Bignell); and both sexes at Harting (Bcaumont); Darenth and South IVales (Chitty).

\section{3. jucundus, Wesm.}

Phaeogenies jucundus, Wesm. Nouv. Mém. Ac. Brux, I844, p. I94; Bul. Ac. Brux. 1848, p. 324, o; Holmgr. Ichn. Suec. iii. 444; Berth. Ann. Soc. Fr. IS96, p. 383, of $\$$. Colpognathus jucundus, Thoms. O. E. xv. I636.

Head strongly nitidulous, black; palpi and mandibles sometimes pale. Antennae black; of $\delta$ with flagellum basally rufescent beneath; of $q$ with scape and basal flagellar joints red, the central three white. Thorax black; notauli obsolete ; areola hardly lonerer than broad; petiolar area slightly concave. Abdomen of of sub-cylinclrical, of $f$ clongate-fusiform; blick, with segments two and three or four and part of first and fifth, red; post-petiole nearly quadrate, indistinctly aciculate: second secment basally densely striolate, with somewhat distinct gastrocaeli; terebra hardly ex'serted. Legs red; anterior coxae and trochanters fulvidous; hind coxae in part, apices of hind femora and tibiae, and all the tarsi, infuscate. Tegulae piceous; radix white, stigma infuscate. Length, $8 \mathrm{~mm}$. 
From the preceding this species differs in having the thorax longer, with the sculpture of the mesonotum deeper, the hind femora are more broadly black, the post-petiole nearly guadrate and the second segment densely striolate at the base.

Bignell has found this species at the end of August and beginning of September, at Bickleigh, in Devon; and Piffard has given me the female from Felden, in Herts. ; Bradley, I believe, has also taken it, near Birmingham, in June. On the Continent it occurs in Belgium and Sweden, but has not been bred.

\section{CENTETERUS, Wesmael.}

Wesm. Nouv. Mém. Ac. Brux. 1844, pp. 166 et I76.

Head buccate, nearly cubical ; cheeks and temples broad; frons somewhat excavate centrally in front; lower margin of the somewhat narrow and red mandibles not sinuate, their teeth sub-equal ; clypeus transverse, convex, entire, laterally sub-reflexed and distinctly discreted from the face. Flagellum of to basally attenuate; scape deeply excised apically. Postscutellum smooth, with no foveae. Abdomen sub-cylindrical; segments two to four strongly punctate; the second narrowed and not impressed basally ; terebra slightly exserted. Coxae mutic.

Bridgman and Fitch tell us the species of this genus are not uncommon in Britain.

\section{Table of Species.}

(4). I. Thyridii of to wanting; scape of $q$ mainly black.

(3). 2. Frons slightly excavate; front coxae black... I. MAJOR, Wesm.

(2). 3. Frons distinctly excavate; front coxae red … 3. OPPRIMATOR, Grav.

(I). 4. Thyridii of of indicated; scape of $q$ entirely red

2. CONFECTOR, Grav.

\section{r. major, Wesm.}

Centeterus major, Wesm. Nouv. Mém. Ac. Brux. I844, p. I77 ; Holmgr. Ichn. Suec. iii. 372 ; Thoms. O. E. xv. I638; Berth. Ann. Soc. Fr. I 896, p. 338, ơ $q$.

Head black; palpi and centre of mandibles rufescent. Antennae with scape black; flagellum of $q$ tricoloured, of to basally ferrugineous. Thorax strongly punctate, black; of to with pronotum centrally white; notauli obsolete ; sternum sub-quadrate ; metanotal areae complete; areola elongate-subpentagonal. Abdomen of to elongate, of $q$ elongate-fusiform, closely punctate, red with first segment of $\delta$, whole of sixth and seventh, and in $q$ apex of fifth, black; post-petiole glabrous; second segment twice broader at apex than at base; thyridii wanting. Legs red, with coxae, trochanters, apices of hind femora and tibiae, and base of latter, black. Tegulae and stigma black; radix white. Length, 8-9 $\mathrm{mm}$.

From the following ones this species may be known by the black scape and tricoloured flagellum of the $q$, and by having in the ${ }^{t}$ segments two to four entirely red, with no indication of thyridii at the base of the former.

I know of no definite records of this species with us, though there is no doubt that it occurs here, and I fancy Mr. E. A. Butler took a male near Guildford in August, I goo. It occurs in Belgium, Sweden and Germany, where it has been bred from the pupa of Sesia hylaciformis. 


\section{2. confector, Grav.}

Ichnenmon confector, Gr. I. E. i. 579 ; Ste. Ill. M. vii. 201, + ; cf. IVesm. Mém. couron. Ac. Belg. 1859, p. 70. Cenleterus confector, Brisch. Schr. Nat. Ges. Danz. I878, n. 6, p. 53 ; Holmgr. Ichn. Suec. iii. 373; Thoms. O. E. xv. 1638; Berth. Ann. Soc. Fr. 1896, p. 338, excl. var.; $\delta$ o. C. picticollis, Wesm. Nouv. Mlém. Ac. Brux. I 844 , p. I77, excl. $\delta$.

This species very closely resembles the preceding, from which it may be known by its colour, more distinctly excavate frons and the thyridii of the $\delta$, which are distinctly traceable, translucent and somewhat remote from the base of the second segment. In colour both sexes differ in the anterior coxae and trochanters being entirely or partly red; the $q$ has the clypeus often apically or entirely red, the scape red, the pronotum and sometimes elongate lateral callosities red; the of has the pronotum immaculate, segments two to four discally black, the third alone being sometimes entirely, like the hind femora, red. Length, 6-7 $\mathrm{mm}$.

The red scape of the $q$ and the conformation of the thyridii should be especially noticed.

Taken in August, $18_{34}$, in the gardens of the Hermitage (Stephens). Mr. Beaumont took this species at Kilmore towards the end of August and Mr. Piffard, at Felden, in Herts. ; I have found it in a garden at Lyndhurst, in the New Forest, in August. It is common on the Continent, where Brischke bred it, in Prussia, from the pupa of Nonagria geminipuncta; in France it is found with $C$. celerator in July, but is said to be of rarer occurrence.

\section{3. opprimator, Grav.}

Ichneumon opprimator, Gr. Mem. Ac. Sc. Torin. I820, p. 355 ; I. E. i. 595 ; Ste. IIl. M. vii. 203, excl. 8. Centeterus opprimator, WVesm. Nouv. Mém. Ac. Brux. IS44, p. I78, of o; Holmgr. Sv. Ak. Handl, I854, p. 45, ᄋ; Ichn. Suec. iii. 374 ; S. v. Voll. Schets. I. pl. iii. f. I5 ; Thoms. O. E. xv. 1638 , of $q$.

From the last-described species, this may be known by its more strongly punctate and less deeply excavate frons; the $q$ has the scape sometimes more or less red and the flagellum bicoloured, the pronotum red, the basal segment entirely black and the hind legs more broadly black-marked; the thyridii of the $\hat{\delta}$ are entirely wanting and its central segments are more broadly black discally; the anterior legs in both sexes are red and the hind coxae generally red with their base black. Length, $6 \mathrm{~mm}$.

The bicoloured scape and black basal segment of the $q$, the infuscate central segments and the absence of thyridii in the $\hat{\sigma}$, will render this species, which Berthoumieu has considered a variety of $C$. confector, at once distinct.

This is probably our most widely distributed species of the genus. Bridgman found it commonly at Brundall, in Norfolk; Bignell took it at Bickleigh, in Devon, in August, and at Yelverton, in April ; Luff has captured the male in Alderney; Mr. W. H. Bumett has griven me a female taken in Pett Level, near Hastings; and I have found it at the roots of grass, during hibernation, in the Bramford Marshes, near Ipswich. It would appear to be attached to humid situations, but it has not yet been bred. 


\section{ORONOTUS, Wesmael.}

Wesm. Nouv. Mém. Ac. Brux. 1844, pp. I66 et 213.

Head strongly punctate, narrowed behind the eyes ; checks not buccate ; vertex somewhat broad ; clypeus a little convex, glabrous, apically entire; lower mandibular tooth short and strongly inflexed. Antennae slender, apically sub-attenuate; post-anncillus linear. Thorax strongly punctate and anteriorly elevated; metathorax declived throughout, apically subcaudately produced beyond the insertion of the hind coxac. Abdomen narrow; basal third of second segment sub-obsoletely impressed and densely striolate throughout, the thyridii placed a little before its centre. Legs slender; hind coxae of $q$ with a minute and often obsolete subapical tooth beneath.

Wesmael says the form of the thorax resembles that of the Ophionid genus Anomalon; Holmgren failed to discover any excrescence of the $q$ hind coxae; and Thomson tells us the sculpture of the second segment, etc., most closely allies it with Diadromus.

\section{r. binotatus, Grav.}

Phygadenon binotatus, Gr. I. E. ii. 721 ; Tasch. Zeits. Ges. Nat. I865, p. 5 I, o . Oronotus binotatus, Holmgr. Ichn. Suec. iii. 356 ; Thoms. O. E. xv. 1626 ; Berth. Ann. Soc. Fr. I896, p. 387, of ㅇ. O. coarctalus, Wesm. Nouv. Miém. Ac. Brux. I844, p. 214 ; S. v. Voll. Pinac. pl. xxxvi. ff. 8 et 9 , of $q$.

Head broad, transwerse, black; face and frons confluently punctate; palpi and mandibles pale. Antennae of $q$ tricoloured, of $t$ fulvous with the apices infuscate. Thorax black; areola elongate and very narrow, apically entire; petiolar area short, not concave. Abdomen black with griseous pubescence, of $q$ elongate-subfusiform; segments one to four fulvous; the second basally constricted and, in f, with two black dots before its apex; petiole four times longer than the post-petiole; anus acute, terebra slightly exserted. Legs fulvous; anterior coxae and trochanters stramineous ; apices of hind femora and tibiae, and base of latter, black. Tegulae and stigma red or piceous; radix white. Length, 8-9 mm.

Van Vollenhoren (loc. cit.) remarks upon the resemblance of this slender species to the genera Limerodes and Anomalon.

This species is said to be not uncommon on the Continent, where it is found on heaths and supposed to be parasitic upon some Leucanid larva, feeding on down grasses and sheltering by day at their roots; Gravenhorst took it in a grassy field in early August. It appears to be extremely rare in Britain, whence I know of no indigenous records, though it has stood in our catalogues since $\mathbf{1} 870$.

\section{ISCHNUS, Gravenhorst.}

Gr. I. E. i. 638 (I829); Wesm. Nouv. Mém. Ac. Brux. 1844, p. 2 I 5.

Head stout, broader than thorax, strongly punctate; vertex broad; checks sub-buccate, genal costa sub-dentate; mandibles strongly attenuate and arcuate apically, their lower tooth sub-obsolete; clypeus large, smooth, convex, apically sub-truncate. Antennae long and slender, apically attenuate; scape short and apically deeply excised; post-annellus linear. Thorax 
conver; pronotum with a basal transverse impression and central tubercle, its epomiae distinct; mesosternum centrally sub-produced in front, its sulci short; metathorax somewhat produced beyond the coxal insertion. Scutellum strongly convex and protuberant, margined to beyond its centre. Abdomen elongate and narrow, closely punctate ; first segment short, convex, post-petiole quadrate; second transversely impressed towards the base, with thyridii at its basal third; anus acute; terebra straight, slender, longer than post-petiole. Legs slender; tarsal claws setosely pectinate. Nervellus post-furcal, intercepted below the middle.

\section{Table of Species.}

(2). I. Scutellum and thoracic markings not flavous ; hind tibiae not basally white.................

(I). 2. Scutellum and thoracic markings flavous; hind tibiae basally white

I. NIGRICOLLIS, WeSm.

2. THORACICUS, Grav.

\section{I. nigricollis, Wesm.}

Ischnus nigricollis, Wesm. Nouv. Mém. Ac. Brux. 1844, p. 216, q; Bul. Ac. Brux. 1849, p. 43 , ठ ; lib. cit. 1855, p. 432, var. ; Brisch. Schr. Nat. Ges. Danz. 1878, n. 6, p. 60 ; Holmgr. Ichn. Suec. iii. 352 ; Thoms. O. E. xv. 1623; Berth. Ann. Soc. Fr. I 896 , p. 390 , \& 9 .

Head black, usually with palpi and mandibles pale. Antennae of $\delta$ ferrugineous towards the base, of $q$ tricoloured with the apex sometimes fulvidous or the central band wanting. Thorax black with the pronotum, mesopleurae and sides of the metathorax at apex, castaneous; notauli distinct; metanotum rugosely punctate with complete upper areae; areola elongate, sub-hexagonal; petiolar area trans-strigose, slightly concave. Scutellum entirely red or black, or more or less black basally; postscutellum usually red. Abdomen black with post-petiole, second segment, more or less of third to fifth, red, or with the anterior incisures alone ferrugineous; anus immaculate; incisures of second and of the transverse third segment deeply impressed. Legs pale red with the hind tarsi and often their tibiae infuscate towards their apices; to with more or less of the coxae and trochanters also often infuscate. Tegulae and stigma fulrous, latter occasionally fuscous ; radix white. Length, 6-7 $\mathrm{mm}$.

It will be noted from the above description how variable is the colour of this species, the $f$ of which, moreover, sometimes has a frontal line and the apex of the scutellum whitish; nevertheless, the mesonotum is invariably black and the hind tibiae are not white-marked.

This is probably not an uncommon species in Britain, though I have not personally met with it. Bridgman took it at Norwich, and it has several times been bred from Pterophorus galactodactylus by Barrett, Porritt, etc. It occurs on the Continent in France, Germany, Belgium, and Sweden.

\section{2. thoracicus, Grav.}

Ischuns thoracicus, Gr. I. E. i. 647 ; Wesm. Nouv. MÍm. Ac. Brux. 1844, p. 215 ; Mém. couron. Ac. Belg. 1859 , p. 82 ; Holmgr. Ichn. Suec. iii. 354 ; Thoms. O. E. xv. 1624 ; Berth. Ann. Soc. Fr. 1896, p. 389, o $\$$.

Head black, with mouth and frontal orbits stramineous; fo also with face and usually the cheeks white. Antennae ferrugineous bencath of $q$, 
centrally white-banded. 'Thorax red, with black and flavous markings; pronotum dorsally and metathorax at base and apex black, callosities at radix and the sides of the pronotum flavous ; notauli distinct; metanotum rugosely punctate, with complete upper areae; areola elongate, subhexagonal; petiolar area trans-strigose, slightly concave. Scutellum and post-scutellum flavous or fulvous. Abdomen black; post-petiole rugose ; terebra exserted. Legs red, basally stramineous; apices of hind femora and tibiae, and the latter before their bases, together with base of hind trochanters, infuscate; hind tibiae, and sometimes their tarsi, basally white. Tegulae and radix flavous; stigma sub-testaceous. Length, 7-10 $\mathrm{mm}$.

This species also varies very considerably in colour, the head, scutellum and abdomen being sometimes mainly red; from the preceding, the red mesonotum, flavous scutellum and thoracic markings, as well as the basally white hind tibiae, will distinguish it.

I am unable to instance any definite locality for this handsome insect, which has appeared in our catalogues since I870. Gravenhorst took it among undergrowth in July, September and October, and it has been bred on the Continent, where it occurs in Germany and France, from Pterophoms phaeodactylus, P. pentadactylus and a convolvulus-feeding larva.

\section{HETERISCHNUS, Wesmael.}

Wesm. Mém. couron. Ac. Belg. 1859, p. 83.

Antennae filiform. Abdomen apically obtuse, with the anal segment very short and truncate; terebra vertically arcuate; post-petiole abruptly explanate, sub-aciculate. Legs with the tarsal claws pectinate, not subsetose.

Whether the species falling herein have right to generic rank is doubtful, since they differ from those of the genus Ischmus only in the characters enumerated above and in the shorter antennae; the simple pectination of the claws would, however, appear a good and constant distinction.

I see no probably constant character of distinction between the two following species, and, to judge from the meagre descriptions which for comparison I have given in extenso, it might be supposed that they are identical, were it not nearly certain that, in that case, Wesmael would have noted the fact when examining Gravenhorst's types, in 1859.

Table of Species.

(2). I. Abdomen and hind coxae black ; pronotum and callosities fulvous ..............................

(1). 2. Abdomen centrally and hind coxae rufescent; thorax immaculate

I. PULEX, Mïll.

2. RUFIPES, Wesm.

\section{r. pulex, Miill.}

Ichneumon pulex, Muill. Prodr,, n. I807, \&. Ischnus pulex, Gr. I. E. i. 652, . Heterischnus pulex, Wesm. Mém. couron. Ac. Belg. I 559 , p. 83; Berth. Ann. Soc. Fr. 1896, p. 388, + . Ichneumon brevicornis, Gr. I. E. i. 146; Ste. IIl. M. vii. 136 ; $f$. Wesm. Mém. couron. Ac. Belg, I859, p. 17, $\$$.

Head black, with the palpi infuscate. Antennae slender, filiform, half length of body; central flagellar joints white above, ferrugineous beneath. 
Thorax black, with centre of pronotum and callosity at radix fulvous. Abdomen black, central segments cylindrical; terebra shortly exserted. Legs slender, red; hind coxae and apices of their tibiae sometimes infuscate. Stigma, radix and tegulae stramineous, the last sometimes piceous. Length, $8 \mathrm{~mm}$.

Scarce, found in June near London (Stephens). This appears to be the only British record of this species, which occurs elsewhere only in Germany and has not been bred; its inclusion in our list must consequently be regarded with due reserve.

\section{2. rufipes, Wesm.}

Ischmus rufipes, IVesm. Bul. Ac. Brux. I 848 , p. 332, ơ; Holmgr. Ichn. Suec. iii. 353 ; Thoms. O. E. xv. I625; Berth. Ann. Soc. Fr. I896, p. 390, 8 \%

Head black ; palpi and mandibles pale. Antennal flagtllum furrugineous or fuscous beneath, of + centrally semi-annulated with white or pale red. Thorax and abdomen strongly punctate, black; the latter with central segments laterally castaneous; the incisures of second and third deeply impressed, the latter sub-quadrate; terebra slightly reflexed. Legs red; hind tibiae towards their apices, and the posterior tarsi, infuscate. Stigma stramineous; radix and tegulae white. Length, 6-7 $\mathrm{mm}$.

From Ischmus, this species may be known, besides the generic characters, by its shorter thorax, distinct petiolar area, smaller eyes and more elongate cheeks. The of is very similar to $I$. thoracicus, but its head is more strongly punctate, the legs slightly shorter and the petiole a little more slender; it has the scutellum black and the stigma stramineous.

Marshall first introduced this species as British in his 1872 catalogue, but I know of no definite records, and it has not been bred. Germany appears to be its headquarters, though it is also found in Belgium and France, where M. Pic has taken it during hibernation in December.

\section{TRACHYARUS, Thomson.}

Thoms. O. E. xv. (I89I), I607 et I6I2.

Head sub-triangular; frons nitidulous, sub-glabrous; mandibles weak, with the teeth of equal length. Flagellum slender. Thorax sub-nitidulous; metanotum gradually declived from base to apex; petiolar area reaching nearly to the base. Abdomen a little longer than the thorax, scabrous; basal segment sub-deplanate, second with distinct and transwersely oval thyridii. Intermediate coxae sub-globose. Wings with the areolet sometimes incomplete and the discoidal cell acutely produced at its lower angle.

This genus, its author tells us, closely approaches Hemichnemmon in the structure of the wing-nervures and its somewhat deplanate basal segment, but differs both in its elongate petiolar area and in its triangular head.

\section{I. corvinus, Thoms.}

Trachyarus corvinus, Thoms. O. E. xv. $1612, \delta \%$.

Black. Head broader than thorax, narrowed behind the eyes; vertex not broad; clypeus not discreted, apically rotund, of ot whitc. Antemnac 
sub-filiform, nigrescent, of $q$ slender; first flagellar joint longer than second. Thorax not coarctate; mesonotum shining, with distinct notauli ; metathorax finely scabrous, areae not well determinate; areola transverse; dentiparal areac elongate. Abdomen convex, ovate-fusiform, black, dull and very finely scabrous; second segment not longer than broad, apically red; third transverse; terebra short. Legs slender, black, with the knees, trochanters and tibiae partly dull red, front ones paler in of; hind tarsi slender. WVings pure hyaline ; nervellus sub-opposite, intercepted far below the middle. Length, $4 \mathrm{~mm}$.

This species is very like Diadromus subtilicomis in size and conformation, but differs in colour as well as in the metathoracic structure and glabrous frons.

Thomson simply say's of it, "Funnen $i$ båda könen vid Pålsjö nära Helsingborg; en hanne har Bridgman sändt till pâseende frân England." The latter took a single male at Earlhham, near Norwich, in July.

\section{HEMICHNEUMON, Wesmael.}

Wesm. Bul. Ac. Brux. 1857 , p. 410.

Head short, transverse, from in front sub-rotund; clypeus convex, apically mutic, basally discreted; cheeks buccate; vertex hardly narrow; frons nitidulous, sparsely punctate; mandibular teeth weak, of equal length. Antennae slender. Thorax not coarctate; notauli elongate; metathorax gradually declived from base to the slightly produced apex; areola elongate, apically incomplete. Abdomen sub-cylindrical, elongate, sub-convex; thyridii distinct; terebra retracted. Legs not stout; coxae elongate, the intermediate sub-ovate, the hind ones of $q$ compresso-subdentate apically. Areolet incomplete externally, rarely entire in of ; nervulus opposite; nervellus a little antefurcal, intercepted far below the middle.

\section{I. elongatus, Ratz.}

Hemiteles elongatus, Ratz. Ichn. d. Forst. iii. I54, + . Hemichneumon elongatus, Holmgr. Ichn. Suec, iii. 358 ; Thoms. O. E. xv. 1611 ; Berth. Ann. Soc. Fr. 1896, p. 392, 8 \%. H. subdolus, Wesm. Bul. Ac. Brux. 1857, p. 4 II ; Brisch. Schr. Nat. Ges. Danz. 1878, n. 6, p. 59, $\delta$. .

Head black; face somewhat protuberant, transversely sculptured ; clypeus smooth; palpi pale; mandibles and clypeus of of generally white or red. Antennae red, scape sometimes black; flagellum filiform, apically infuscate and slightly attenuate. Thorax black; epomiae wanting; sternal sulci deeply impressed; petiolar area concave, apically slightly emarginate. Abdomen black, with central segments more or less distinctly red; postpetiole narrow, centrally aciculate; second segment elongate, finely coriaceous, with gastrocaeli small, the thyridii transverse and somewhat remote from the base; third sub-quadrate; terebra very short, somewhat stout. Legs red; coxae, trochanters, tarsi and, in $\hat{o}$, apices of hind tibiae with more or less of all the femora, black. Stigma infuscate; radix white, tegulae usually black. Length, 5-7 $\mathrm{mm}$.

Probably not uncommon in Britain, whence it has not been hitherto recorded. I was so fortunate as to breed a female from the cocoon of a 
Coleophora, at Ipswich, in 1895 , and to take another on the wing, among undergrowth, in Bentley Woods, in the middle of June, I902; and Mr. A. H. Hamm has also taken it, probably about Oxford. On the Continent it is not a rare species, and has there been bred from the case of Psyche viciella and from a species of Coleofhora. Professor Ratzeburg remarks upon the resemblance of its elongate form, and especially that of the metathorax, with the long and slender case of its host.

\section{NEMATOMICRUS, Wesmael.}

\section{Wesm. Nouv. Mém. Ac. Brux. 1844, p. 166.}

Body linear, smooth and nitidulous. Cheeks and face short, the latter strongly protuberant and, viewed laterally, forming a right angle with the very flat frons. Antennae inserted low on frons. Thorax dorsally deplanate; mesosternum sub-longitudinally excavate; metathorax gradually declived from base to the slightly produced apex, its areae obsolete and indeterminate, with central longitudinal costae fine. Scutellum very flat, sub-obsolete. Abdomen with petiole not laterally marginate; second segment with two central foveae at the base. Hind femora of $q$ short and stout. Areolet entire; nervellus antefurcal, intercepted below the middle.

Wesmael tells us that the only species of this genus, excepting the acute anus of the $q$, has much the form of Alomyia.

\section{I. tenellus, Wesm.}

Nematomicrus tenellus, Wesm. Nouv. Mém. Ac. Brux. I844, p. 179; Thoms. O. E. xv. 1613; Berth. Ann. Soc. Fr. 1896, p. $387, \delta$.

Head black; palpi white, frontal orbits flavous; mandibles and clypeus of $q$ fulvous, of $\delta$ as well as the face and sometimes apices of the cheeks, flavous. Antennae dull red, basally piceous; of of incrassate and somewhat short. Thorax black, with an elongate callosity before, and a subobsolete one beneath, the radix flavous. Abdomen black, with apical margins of the six apical segments centrally red and laterally, at least in ô, flavescent ; ventral surface mainly flavidous ; terebra very shortly exserted, its valvulae broad and apically sub-acute. Legs pale red; hind coxae and trochanters basally, their femora and tibiae in part, and the tarsi, black; anterior coxae and trochanters of ot white; calcaria short and red. Tegulae and radix flavous ; stigma rufescent. Length, $6 \mathrm{~mm}$.

This distinct species was brought forward as British by Marshall, in his I870 catalogue, but I know of no indigenous records, though there is one female in Mr. Alfred Beaumont's collection, which he took at Colwyn on the 2 nd of August, ISgI. On the Continent it occurs in Denmark, Belgium, etc., but has not yet been bred.

\section{MELANOMICRUS, Morley.}

n. $n$.

Head hardly narrowed behind the eyes; frons totally glabrous; vertex broad and laterally a little protuberant ; epistoma tuberculiform ; clypeus not discreted, apically mutic and broadly rounded; cheeks normal; 
mandibles not stout, distinctly bidentate with the upper much longer than the lower tooth. Antennae filiform, inserted low on frons. Thorax elongate, dorsally deplanate; nitidulous and sub-glabrous throughout; mesosterna not excavate, their sulci very fine; metathorax exareated; spiracles minute, circular, impressed. Scutellum somewhat large and very flat. Abdomen cylindrical; petiole short and broad; post-petiole transverse and laterally margined; second segment with basal impression entire; thyridii small and transverse; terebra apically truncate. Legs somewhat broad; intermediate coxae elongate, the hind ones simple. Areolet incomplete; nervellus as in Mevesia; radial cell short and complete.

This genus is closely allied to Nematomicms in its protuberant epistoma, deplanate notum, exareated metathorax and glabrous frons, but differs in its unequal mandibular teeth, abruptly declived metanotum, incomplete areolet, laterally margined petiole and the conformation of the second abdominal segment.

\section{Elliotti, sp. n.}

Head black; palpi flavous; mandibles red; face and clypeus glabrous, with sparse puncturation; frons a little coriaceous above the antennae. Antennae piceous, with flagellar joints somewhat short, the eighth quadrate; post-annellus large. Thorax entirely black; meta- as long as the meso-notum and of equal height; metathorax with no costae nor areae, its posterior face very short and abruptly declived. Abdomen not strongly nitidulous, with large isolated punctures, black with incisures narrowly sub-rufescent ; post-petiole glabrous with a few large punctures ; gastrocaeli sub-obsolete; terebra distinctly exserted. Legs piceous, with tarsi, trochanters and anterior coxae, ferrugineous; hind coxae with large, sparse, superficial punctures. Radix, tegulae and stigma, testaceous. q. Length, circa $3 \mathrm{~mm}$.

An example of this very distinct species was beaten from Pinus sylvestris, in which it was doubtless hibernating, in the Belstead Woods near Ipswich, on I6th February, I899; and there is another, probably from Surrey, in Dr. Capron's collection. Its small size, perhaps, partly accounts for our previous ignorance of it.

To ERnest A. Elliott, F.E.S., etc., I dedicate this species in Inadequate Token of all $I$ oreve to his Guidance and Fellowship in Entomological Research; and more especially of the Valuable Assistance without which the present volume could not have been compiled.

TRIBE.

\section{ALOMYIDES.}

The position of this tribe has always been a moot point. Gravenhorst, treating it of primary rank, places it immediately after his genus Troyrus, to which indeed the often basally tuberculate metanotum with its somewhat deep sulcus of the $t$ allies it, though the scutellum is remarkably deplanate, pointing out the while that the globose head resembles that of the Xorides, as also do the elongate prothorax and deeply impressed notauli ; nevertheless, the conformation of the wings and petiole differ widely therefrom. Wesmael, in $\mathbf{1} 844$, placed it, as an aberrant group, 
among his Ichneumones, and expressed the opinion, followed practically by Woldstedt, that its position was intermediate between the Ichneumoninae and the Tryphoninae, to which latter the structure of the metathorax and basal segment bears affinity. Förster excluded it from the Ichneumones proper; and no mention is made of this tribe in Berthoumieu's work on the present sub-family, since he considered that it belonged to the Tryphoninae. Holmgren, in 1864 , thought it allied to the Xorides, but in 1878 he gives it under a family of equal rank with all the remaining Iclineumoninae. Brischke, again, goes even so far, perhaps casually, as to insert it at the end of the Cryptinae, after Pezomachus. Thomson (Opusc. Ent. xii. I 235) has entered somewhat at length into this vexed question, and points out the relationship of the tribe with his genus Spilichneumon in its strongly developed hypopygium, large head, stout mandibles, and short legs, of which the anterior tibiae are strongly spinose; he is decidedly of opinion that that here assigned to it is the best position that can be found. Finally Ashmead, in 1900 , places it in a tribe, ranking with my Placooginini, though standing in the midst of the Cyclopnenstici, after the end of which is probably its most natural position in our present classification. Only one genus and species is known.

\section{ALOMYIA, Panzer.}

Panz, Krit. Revis, ii. $S_{4}$ (ISo6).

Head sub-cubical; frons excavate below the ocelli; cheeks short and strongly buccate; face centrally protuberant ; clypeus depressed, coarsely punctate, transverse, apically truncate; mandibles stout, obtusely bidentate. Antennae of $q$ shorter than head and thorax, filiform; flagellar joints short, transverse, the basal ones sub-moniliform. Prothorax elongate; metanotum of of basally sulcate, of $q$ sub-contiguous with the postscutellum, its areae obsolete or wanting; notauli distinct and deeply impressed; spiracles ovate. Scutellum deplanate. Abdomen with basal segment gradually explanate from base to apex, laterally marginate, its spiracles placed in the centre; second segment with no trace of gastrocaeli nor thyridii, sub-obsoletely impressed in of longitudinally on either side. Legs of $\delta$ normal, of $q$ short and stout. Areolet broad, pentagonal; radial nervure sinuate and apically reflexed.

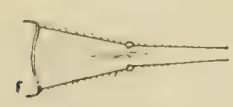

Basal segment.

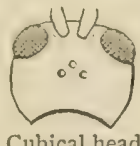

Cubical head

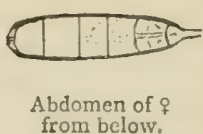

from below.

\section{I. debellator, Fab.}

Ichnenunon debellator, Fab. S. E. 333; Panz. F. G. Ixxviii. I3, \&. I. ovator, Fab. E. S. ii. 163, o. Alomy avator, Gr. I. E. ii. 398 , cf. i. Suppl. 697; Latr. Cuv. R. A. ed. Masson, pl. cxi. f. 7 ; Ste. Ill. MI. vii. 273; Wesm. Nouv. Mém. Ac. Brux. IS 44 , p. 217 ; Holmgr. Sv. Ak. Handl. I854, p. 48 , $\delta$ \%; Voll. Schets. I. pl. i. f. I5. Var. A. nigra, Gr. I. E. ii. 405, if. i. Suppl. 698; Ste. III. M. vii. 274, 8. Var. A. semiflava, Ste. Ill. M. vii. 274 , \& \&. Var. I. victor, Curt. B. E. pl. cxx. $\&$ (details); if. Gr. I. E. i. Suppl. 697 ; Morl. F. M. M. 1902, p. 118. 
Head transverse-cubical, sparscly punctate, black; frons shining, subglabrous; mandibles towards their apices glabrous and often piceous. Antennae of ot black, elongate, gradually sub-attenuate apically; of $q$ black, with basal half of flagellum testaceous. Thorax black; pro- and meta-notum scabriculous; mesothorax and scutellum somewhat strongly and sparsely punctate and nitidulous; mesosternal sulci sub-obsolete; arcola of of traceable, sub-triangular, basally sub-elevated, often tuberculate; petiolar area entire, strongly transverse, not apically produced, its basal costa strong and in of emarginate. Abdomen finely punctate sub-glabrous and nitidulous, elongate, sub-cylindrical, broader in $q$; red, with first segment, except usually its apex, more or less of fifth, and often of fourth and third, with whole anus, black; post-petiole sub-aciculate between the spiracles, apically finely and more or less sparsely punctate, often sub-glabrous, the apical margin sub-sinuate with a small transverse impression in its centre ; eighth dorsal segment shortly exserted, of $q$ subtruncate; ventral segments two and three plicate, the sixth of $q$ large, apically rounded and covering the base of the retracted terebra; of valvulae incrassate. Legs not elongate; coxae, trochanters, most of the femora, with, in $q$, the extreme base and apex of hind tibiae, usually black ; the remainder more or less flavidous. Wings of $q$ somewhat small, of $\delta$ normal ; stigma testaceous, basally whitish; radix and tegulae piceous. Length, I I-I $9 \mathrm{~mm}$.

The metathorax and abdomen of the $q$ are much smoother, with the puncturation more indistinct than of the $\delta$, and the upper metanotal areae of the former are entirely wanting; the average size of the $\delta$ is much larger than that of the .

The type form, as already stated, has the abdomen centrally more or less red, the petiole black and the thorax immaculate. Three well-marked varieties have been named:-Var. nigra is a form of the of with the whole of the abdomen, thorax, head, and often also the legs excepting only the anterior tibiae, black; sometimes, however, the legs are no darker than those of typical examples. Var. semiflava has the thorax with flavidous callosities near the radix and the rufescent coloration of the abdomen replaced by bright, clear flavous, and the anterior legs are also pale. Var. victor appears to differ from typical $q q$ in nothing but the entirely red basal segment. A detailed, if somewhat involved, account of these varieties, there regarded tentatively as species, is given by Stephens (loc. cit.).

Stephens records this species as common about London in June and July, from the New Forest, Devonshire, Salop, Dover, Bristol, about Edinburgh; and Curtis adds Norfolk and Dunkeld. Holgate, near York, in I88I (Wilson); the male is very common, but the female is rarely seen in Norfolk (Bridgman, whose collection at Norwich contains but one female $^{1}$ ); Ivybridge, in the middle of May (Bignell); Epping Forest (Butler); Eastbourne and Hastings (Esam); Birmingham, in June (Bradley); Croydon, in June (Brunetti); Bonhill (Malloch); Shotover, Oxford and Streathy in May, July, August and September (Hamm); Carlisle, in July (Routledge); Essex (Harwood); Thornton, Heriot and

1 The much greater rarity of the $q$ is everywhere noticeable, and is probably due to the fact that they "do not appear to fly much; they are generally found running among moss and grass, for w hich purpose their short and strong legs are well adapted," as Curtis says (loc. cit.). I have, however, secn it flying vigorously about shrubs in the sunshine upon one or two occasions. 
Ardpeaton (Evans); Whitby and Chobham (Beaumont); Kingsdown, Dover and St. Mrargaret's Bay, in Kent (Sladen) ; Tostock (Tuck); South leverton and Torksey, in Lincs. (Thornley); Felden (Piffard); Baldock (Donisthorpe) ; New Forest (Miss Chawner, etc.) ; Worksop (Miss Alderson); Woking (E. Saunders); Cadder, in Lanark (Dalglish); Bottisham and Thornley in May and September, I 843 (Cambs. List). I have never seen this species in July, and little doubt can remain that it hibernates in the perfect state, since it is commonest in September, on the flowers of Angelica sylvestris and of both wild and cultivated Dancus carota, after which it may still be taken freely in early October; it is uncommon in the early summer upon flowers of Chaerophyllum and Heracleum; it flies slowly, low down, just above the roadside grasses, etc. I have found it at the following localities in Suffolk:-Farnham, Westleton, Benacre Park, Dodnash Woods, Tuddenham Fen, Wortham, Eye, Claydon Bridge, Foxhall, Henstead and Barnby Broad. The melanic form of the male appears to be influenced more by the humidity of the situation than bleakness of climate, thus the majority of the examples from Barnby Broad are referable to the var. nigra, while those from Cadder, Bonhill and Heriot have the abdomen at least partly pale; Mr. E. A. Elliott has, however, taken the black form in the very heart of London. It is a most remarkable fact that this abundant species has never been bred, and we have no knowledge of its hosts, ${ }^{1}$ which one is led consequently to believe must be other than lepidopterous. The discovery of coleopterous or hymenopterous hosts would be a great excuse for excluding this insect, which is common throughout Europe, from the Ichneumoninae.

OBS.-Microleptes splendidulus, Gr. (I. E. i. 679 ; Ste. Ill. M. vii. 2 I I, pl. xl. f. 3 ; Voll. Schets. I. pl. i. f. 6, f), for the reception of which Marshall, in his 1872 catalogue, raised the section Microlepti, ranking along with Wesmael's Heterogastri, etc., of the Ichneumoninae, is not placed by Ashmead, and by Berthoumieu is considered to appertain to the Tryphoninae.

1 There is one slight, though I fear unreliable, clue to the economy of this species, which appears to have hitherto been overlooked. Rev. William Kirby, F.R.S., tells us (Introd. to Ent. ed. vii. I54) that a species of ichneumon, allied to A. debellator, "which I have named A. stercorator" (? MS.), oviposits in stercorareous larvae; and Stephens says that the Alomy'a stercorator of his Catalogue, No. +456 , is nothing but a variety of A. ovator, Fab. I think, however, the insect here referred to more likely to be one resembling Exolytus laevigalus, Grav., which I myself have found ovipositing in dipterous larvae in a dead cow's head. Mr. C. W. Dale thought (E.MI.M. I903, p. 100) it was a well-known fact that this species was parasitic on the larvae of Geotrupes, and adds that he has taken the var. nigra, the $f$ of which 1 have never seen and is not described, ovipositing in slercore vaccino: Geotrupes larvae, however, do not feed in the dung, but several inches below the surface of the ground underneath it, and I am not aware that the spicula of even the + nigra is telescopic! 


\section{ADDENDA.}

\section{NOTES ON DOUBTFULLY BRITISH SPECIES, ETC.}

From the New Forest I have received a of Crutichneumon with whitebanded antennae, which I am strongly of opinion is referable to Ichneumon palli[di] tarsis, Thoms. Ann. Soc. Fr. I887, p. I ; O. E. xviii. 1949. From C. nigritarius it is said to differ in the smaller and sometimes wanting tibial band, pale hind tarsi, finer mesonotal sculpture and shorter areola; the of has but a narrow antennal band, the thyridii and gastrocaeli smaller, and all the femora and tibiae fulvous, with apices of the hind ones hardly darker; the $q$ has the coxal scopulae smaller, all the tarsi and tibiae pale, terebra longer, and the seventh segment with a small, broad, dull testaceous mark. It is recorded from Swedish pine woods, and subsequently from Lapland.

Barichneumon ridibundus. - I note that Herr Reissig is said to have bred Ichneumon hussicus from Cryptorhy'uchus lapathi at Darmstadt, but a great deal more proof is needed before any reliance can be placed upon the records of any Ichmeumoninae preying upon Coleoptera; and I certainly incline to the belief that the host mentioned at p. 248 was more probably lepidopterous. Both sexes of Barichnemmon derogator have been bred from Depressaria heracleana by Dr. R. T. Cassal.

The Rev. T. A. Marshall, in the interleaved copy he used of his 1872 Catalogue, has inserted Ichneumon memorator, Wesm. (referred to at p. I 2 I) as having occurred in Britain; this was probable, since it is found in Belgium, Holstein, Sweden and Lapland. Thomson (Ann. Soc. Fr. I 887, p. Io) says it is very closely allied to I. latrator and I. subquadratus, but that the $q$ differs in its immaculate hind tibiae, sub-attenuate flagellum, buccate cheeks, discreted clypeus, shining metathorax, and that the of has the head black with the facial orbits rarely pale-marked, the antennae longer and infuscate beneath, tegulae and hind femora black with base of latter red and the areola well defined.

In his Catalogus Hym. Europae (I867), Kirchner gives Ichneumon Panzerii as having been described from England by Stephens. I have heard of no such species, though Amblyteles Panzeri, Wesm., which is correctly inserted in the latter genus from Brussels, was recorded hence by Desvignes in 1856 .

Eurylabus intrepidus is noted as being a good species in Marshall's MS. ; distinct from E. larvatus and not yet found in Britain.

Mr. Piffard at Felden and I at Foxhall have taken a Phaeogenes which is very like $P$. socins, Holmgr. Mr. Dalglish has sent me from Scotland another species not included in our list ; this appears to be $P$. macilentus, Wesm., one of the kinds with mutic coxae, and it has occurred to me at Rushford in Suffolk, and in moss during the winter at Ipswich ; I cannot, 
however, satisfy myself that the above are the correct names of these pretty little creatures.

In Dr. Capron's collection are both sexes of an insect named Diadromus tenax, Wesm. (Nouv. Mém. Ac. Brux. I 844, p. 2 10); but there are no data to indicate their British origin. 'They agree very well with the descriptions of that species - the of of which Thomson says does not possess tricoloured antennae-excepting that the coxae are entirely red and the of pedicellus is not unusually dilated.

From the same source I possess a of and o named Misetus oculatus, Wesm., which species should certainly occur in Britain, since it is recorded from all the adjacent countries. The. \& referred to may be correctly named, and appears to belong to Wesmael's var. i. (Tentamen, p. 213), but the clypeus is not in a condition to admit of close examination of its apical central tooth, which feature at once distinguishes this genus with its single species from the remainder of the Phaeogenides. The $q$ is a Phaeogenes with no relation to Misetus; it is probably referable to $P$. muricifer, Holmgr. Ichn. Suec, iii. 440, closely allied in coxal structure to $P$. ophthalmicus, but with the basal segment black. No data are affixed and the specimens' origin unknown.

Ichneumon erythrocerus, Gr. (Mem. Ac. Sc. Torin. 1820 , no. I02; I. E. i. 6 I 0 , excl. var.) is indicated in Marshall's MS. notes, without query, as taking precedence to Oiorhinus pullifalpis, and the description appears to leave but little doubt as to the correctness of the synonymy, in spite of Wesmael's remarque critique (Mém. couron. Ac. Belg. I859, p. 76).

"Ischnidium (formerly Ischnogaster) albibucca [sic], Kriechb." Ent. Nachr. 1890 , p. 153, is also indicated (loc. cit.) as having been ascertained to be British, though apparently only previously known from Bavaria. The genus (which should be called Notosemus, Först. Verh. pr. Rheinl. I 868, p. I94, according to Ashmead's synonymy) contains but this species, and may be distinguished from the remainder of the Pharegenides, among which it is allied to Ischnnes, in its hardly convex scutellum, linear and sub-acute abdomen, complete areolet and metathoracic areae.

Among the Irish Iclnemmonidae recorded by me in E.M.M. I902, p. 54, Col. Yerbury sent what I am of opinion is Colpognathus armatus, Thoms.; it was omitted from the list, however, because I was not satisfied as to the presence of the coxal tubercles, in which it differs from the remainder of the genus. It was unfortunately damaged in re-examination, and the abdomen lost ; one hind coxa, however, remains, and this certainly appears to bear a globose apical tubercle, but the antennae are distinctly bicoloured and not tricoloured as described in the great Opusc. Ent. xv. 1636. 


\section{Catalogue.}

A CLASSIFIED LIST OF THE BRITISH ICHNEUMONINAE AS ENUMERATED IN THIS VOLUME.

Order. HYMENOPTERA.

Section. ICHNEUMONIDEA.

Family. ICHNEUMONIDAE.

Sub-family. ICHNEUMONINAE.

Tribe. LISTRODROMIDES.

LISTRODROMUS, Wesm.

I. nycthemerus, Grav.

NEOTYPUS, Först.

r. lapidator, Fab.

Tribe. JOPPIDES.

HOPLISMENUS, Grav.

I. perniciosus, Grav.

2. albifrons, Grav.

3. uniguttatus, Grav.

HYBOPHORUS, Tisch.

I. aulicus, Grav.

DINOTOMUS, Först.

r. lapidator, Fab.

2. pictus, Kriech.

3. spinosus, Morl.

AUTOMALUS, Wesm.

I. alboguttatus, Grav.

TROGUS, Panz.

I. lutorius, $F a b$.

2. exaltatorius, Panz.
PROTICHNEUMON, Thoms.

I. fusorius, Linn.

2. pisorius, Linn.

3. erythrogaster, Steph.

4. fuscipennis, Wesm.

5. disparis, Poda.

6. laminatorius, Fab.

COELICHNEUMON, Thoms.

I. Bohemani, Holmgr.

2. sugillatorius, Limn.

3. cyaniventris, Wesm.

4. fuscipes, Gmel.

5. periscelis, Wesm.

6. sinister, IVesin.

7. leucocerus, Grav.

8. comitator, Linn.

9. derasus, Wesm.

Iо. bilineatus, Grav.

Ir. consimilis, Wesm.

I2. lineator, Fab.

I3. ruficauda, Wesm.

I4. microstictus, Grav.

I5. liocnemis, Thoms.

I6. albicillus, Grav.

I 7. moestus, Grav.

I8. impressor, Zett.

19. castaneiventris, Grav. 
Tribe. ICHNEUMONIDES.

Sub-tribe. Oxypygini.

STENICHNEUMON, Thoms.

I. culpator, Schr.

2. pistorius, Grav.

3. trilineatus, Gmel.

4. scutellator, Grav.

5. rufinus, Grav.

6. multicinctus, Grav.

7. ochropis, Gmel.

8. pictus, Grav.

9. castaneus, Grav.

I0. defraudator, IVesm.

I I. apricus, Grav.

CRATICHNEUMON, Thoms.

I. luteiventris, Grav.

2. sicarius, Grav.

3. rubricosus, Holmgr.

4. ruficeps, Grav.

5. rufifrons, Graz.

6. nigritarius, Grav.

7. liostylus, Thoms.

8. dissimilis, Grav.

9. fabricator, Fab.

I0. annulator, Firb.

II. pallidifrons, Grav.

I 2. fugitivus, Grav.

I3. coruscator, Linn.

I4. Gravenhorsti, Fonse.

I5. albilarvatus, Grav.

I6. lanius, Grav.

I 7. varipes, Grav.

18. magus, IVesm.

EUPALAMUS, Wesm.

I. oscillator, HVesm.

2. Wesmaeli, Thoms.

MELANICHNEUMON, Thomls.

r. leucomelas, Gmel.

2. dumeticola, Grav.

3. nudicoxa, Thoms.

4. bimaculatorius, Panz.

5. saturatorius, $\operatorname{Linn}$.

6. monostagon, Grav.

7. perscrutator, IVesm.

8. liaunus, Grav.

9. erythraeus, Grav.

Io. sanguinator, Rossi.
BARICHNEUMON, Thoms.

I. anator, Fab.

2. geniellus, Grav.

3. ridibundus, Grav.

4. sexalbatus, IVesm.

5. tergenus, Grav.

6. incubitor, Linn.

7. basiglyptus, $K$ riech.

8. rufidorsatus, Bridg.

9. vacillatorius, Grav.

ı. heracleanae, Brids.

I r. semirufus, Grav.

12. pulchellatus, Brids.

I3. eupitheciae, Brisch.

I 4. albicinctus, Grav.

I 5. plagiarius, IVesm.

I6. derogator, IVesm.

I 7. bilunulatus, Grav.

I $S$. vestigator, IVesm.

I 9. lepidus, Grav.

20. angustatus, WVesm.

$2 \mathrm{r}$. chionomus, IVesm.

22. callicerus, Grav.

ICHNEUMON, Linn.

1. lugens, Grav.

2. deliratorius, Linn.

3. xanthorius, Forst.

4. sarcitorius, Linn.

5. lautatorius, Desv.

6. caedator, Grav.

7. multipictus, Grav.

S. latrator, Fab.

9. subquadratus, Thoms.

10. spurius, TVesm.

II. analis, Grav.

I 2. Walkeri, IVesm.

13. molitorius, Grav.

I4. crassifemur, Thoms.

15. melanotis, Holgmr.

16. bucculentus, W Vesm.

I 7. suspiciosus, IVesm.

I S. languidus, $I V$ esm.

19. terminatorius, Grav.

20. stramentarius, Grav.

$2 \mathrm{I}$. computatorius, Mïll.

22. inquinatus, IV esm.

23. militaris; Grav.

24. albicollis, IVesm.

25. extensorius, Linn. 


\section{ICHNEUMON-continued.}

$25 \%$.gradarius, Wesm.

26. gracilentus, IVesm.

27. confusorius, Grav.

28. tempestivus, Holmgr.

29. macrocerus, Thoms.

30. primatorius, Forst.

3. bisignatus, Grav.

32. bellipes, $I$ esm.

33. gracilicornis, Grav.

34. silaceus, Grav.

35. emancipatus, IVesm.

36. formosus, Grav.

37. quaesitorius, Linn.

38. Haglundi, Holmgr.

39. piceatorius, IVesm.

40. rufidens, WVesm.

4I. caloscelis, IVesm.

42. insidiosus, IVesm.

43. subcylindricus, Grav.

44. raptorius, Grav.

45. submarginatus, Grav.

46. quadrialbatus, Grav.

47. cessator, Miull.

48. stigmatorius, Zett. .

49. vulneratorius, Zett.

50. haesitator, Wesm.

EXEPHANES, IVesm.

I. hilaris, Grav.

2. occupator, Grav.

PROBOLOIDES, Morl.

I. glabratus, Morl.

2. maculatus, Morl.

CHASMIAS, Ashm.

I. motatorius, Fab.

2. paludicola, IVesm.

Sub-tribe. Amblypygini.

LIMERODES, IVesm.

I. arctiventris, Boie.

HYPOMECUS, IVesm.

I. quadriannulatus, Grav.
CTENICHNEUMON, Thoms.

I. caeruleator, Zett.

2. sputator, Fulb.

3. homocerus, IVesm.

4. castigator, Fab.

5. plicatus, Morl.

6. Panzeri, IVesm.

7. funcreus, Fourc.

8. fossorius, Grav.

9. inspector, IVesm.

Iо. melanocastanus, Grav.

I I. repentinus, Grav.

I 2. mesocastanus, Grav.

I3. messorius, Grav.

I4. divisorius, Grav.

15. haereticus, WVesm.

I6. flavocinctus, Desv.

SPILICHNEUMON, Thoms.

I. Fabricii, Grav.

2. occisorius, $F a b$.

3. Gravenhorsti, IVesm.

4. septemguttatus, Grav.

AMBLYTELES, IVeSm.

I. punctus, Grav.

2. palliatorius, Grav.

3. trifasciatus, Grav.

4. litigiosus, JVesm.

5. crispatorius, Linn.

6. equitatorius, Panz.

7. atratorius, $F a b$.

8. quadripunctorius, Mïlll.

9. monitorius, Pinz.

Io. glaucatorius, Fab.

II. pallidicornis, Grav.

12. vadatorius, Illig.

13. amatorius, Miïl.

I 4. cerinthius, Grav.

15. negatorius, Fab.

16. indocilis, Hesm.

I 7. subsericans, Grav.

i8. armatorius, Forst.

19. infractorius, Panz.

20. oratorius, Fab.

2 I. margineguttatus, Grav.

22. microcephalus, Steph.

23. castanopygus, Steph.

2+. uniguttatus, Grav.

25. conspurcatus, Grav. 
HEPIOPELMIUS, Wesm.

I. variegatorius, $P$ anz.

2. leucostigmus, Grav.

ACOLOBUS, Wesm.

r. albimanus, Grav.

ANISOBAS, IVesm.

I. hostilis, Grav.

PROBOLUS, W'esm.

I. alticola, Grav.

2. concinnus, IVesm.

\section{Sub-tribe. Platyurini.}

ERISTICUS, Wesm.

I. clericus, Grav.

TRICHOLABUS, Thoms.

I. strigatorius, Grav.

EURYLABUS, TVesm.

I. dirus, IVesm.

2. larvatus, Christ.

3. torvus, IVesm.

4. tristis, Grav.

5. rufipes, Sleph.

PRISTICEROS, Grav.

I. serrarius, Grav.

PLATYLABUS, Wesm.

1. nigrocyaneus, Grav.

2. rufus, IVesm.

3. pedatorius, Fal.

4. pumilio, Holmgr.

5. phaleratus, IFal.

6. variegatus, IVesm.

7. dolorosus, G»av.

8. tenuicornis, Grav.

9. albinus, Grav.

Io. semirufus, Desv.

I I. orbitalis, Grav.

I2. tricingulatus, Grav.

I3. decipiens, IVesm.

14. rubellus, Gmel.

I 5. nigricollis, IVesm.
PLATYLABUS-continued.

I6. volubilis, Grav.

I 7. pactor, Hesm.

I8. dimidiatus, Grav.

Tribe. PHAEOGENIDES.

Sub-lribe. Heresiarchini.

S'l'ENODON'TUS, Berth.

I. marginellus, Grav.

\section{Suli-tritie. Phacogenini.}

APAELETICUS, $/ V^{\prime} S m$.

I. bellicosus, IVesm.

2. inclytus, Wesm.

HERPESTOMIUS, Wesm.

I. brunnicornis, Grav.

2. nasutus, IVesm.

3. furunculus, IVesm.

4. arridens, Grav.

5. distinctus, Bridg.

PHAEOGENES, IVesm.

r. argutus, Wesm.

2. similis, Brids.

3. cephalotes, IVesm.

4. suspicax, IVesm.

5. acutus, Grav.

6. mitigosus, Grav.

7. stipator, IVesm.

8. semivulpinus, Grav.

9. planifrons, /Vesm.

Iо. melanogonus, Gmel.

I I. heterogonus, Holmgr:

I2. ophthalmicus, Tiesm.

I3. modestus, /Vesm.

I4. fuscicornis, Hesm.

I5. trepidus, IVesm.

I6. infimus, Vism.

I 7. eques, llesm.

I8. ischiomelinus, Grav.

19. impiger, IVesm.

20. bellicornis, lfesm.

21. nanus, // esm.

22. maculicornis, Sleph. 
PHAEOGENES-continued.

23. mysticus, TVesm.

24. stimulator, Grav.

25. homochlorus, IVesm.

26. callopus, IVesm.

27. fulvitarsis, IVesm.

28. coryphaeus, IVesm.

29. rusticatus, Whesm.

3०. nitidus, Bridg.

DIADROMUS, Wesm.

I. troglodytes, Grav.

2. subtilicornis, Grav.

3. varicolor, IVesm.

4. guttulatus, Grav.

5. candidatus, Grav.

6. conciliator, IVesm.

7. collaris, Grav.

EPITOMUS, Först.

r. parvus, Thoms.

OIORHINUS, IVESm.

I. pallidipalpis, IVesm.

AETHECERUS, Wesm.

I. longulus, WTesm.

2. placidus, Wesm.

3. nitidus, IVesm.

4. discolor, Wesm.

5. dispar, IVesm.

DICAELOTUS, IVesm.

I. pumilus, Grav.

2. Cameroni, Bridg.

3. rufilimbatus, Grav.

4. ruficoxatus, Grav.

5. parvulus, Grav.

6. pusillator, Grav.
COLPOGNATHUS, IVesm.

I. celerator, Grav.

2. divisus, Thoms.

3. jucundus, Wesm.

CENTETERUS, Wesm.

I. major, IVesm.

2. confector, Grav.

3. opprimator, Grav.

ORONOTUS, IVesm.

r. binotatus, Grav.

ISCHNUS, Grav.

I. nigricollis, IVesm.

2. thoracicus, Grav.

HETERISCHNUS, IVesm.

I. pulex, Mïll.

2. rufipes, IVesm.

TRACHYARUS, Thoms.

I. corvinus, Thoms.

NEMATOMICRUS, IVesm

I. tenellus, IVesm.

MELANOMICRUS, Morl.

I. Elliotti, Morl.

Tribe. ALOMYIDES.

ALOMYIA, Panz.

I. debellator, Fab. 


\section{INDEX OF SYNONYMS, ETC.}

\section{AETIIECERUS.}

frontatus, Wesm.

ALOMYIA.

nimra, Gir.

water, (ir.

semifliva, site.

stercorator, Kirby

2.30

$2 \mathrm{Sis}$

291

\section{A.MBLYTELES.}

aequivocus, Tisch. ................. I 87

albomarginatus, Kriech. ........... I79

alternator, Tisch. ................... 205

antennatorius, IVesm. ............. 190

lipus!ulatus, $\| \mathrm{i}^{\mathrm{e}} \mathrm{em} . \quad \ldots \ldots \ldots \ldots \ldots . .207$

caeruleator, Holmgr. ............... 170

camelinus, Wesm. W............... I5t

castigator, Wesm。 .................. 172

culpatorius, Thoms. ............... 189

dimidiativentris, Rud. ............. I2

divisorius, Wesm. ................... I7 8

Faluricii, Tasch. ...................... IS I

fasciatorius, Wesm. ............... 200

flavator, Tisch. ..................... I74

flavocinctus, Bridg. .............. 179

fossoritus, IVesm. ….............. I74

funcrens, Wesm. ...................... I7t

fuscipennis, Wesm................. I9

fusorits, Hoslmgr. ................. If

Gnedarti, Wesm. ................... 205

Gravenhorstii, Wesm. ............ I 83

haereticus, Wesm. ................... I 79

homocerus, Wesm. ................... I7I

ignotus, Wesm. ..................... 205

impressus, Tisch. .................... 205

incorruptus, Hoimer................. 205

in-pector, Wism, …............. I 75

intersertor, IVesm. .................... 50

laminatorius, Wesm. ................ 20

leucostigmus, Berth. .................. 208

mexlintmius, Them-............... I0)

melanocastanus, IVesm........175, 176

mesocastanus, WVesm. .............. 176

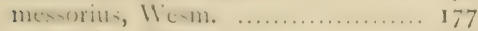

inataturius, IJolugr. ................ If I

natatorius, Wesm. ................. 192

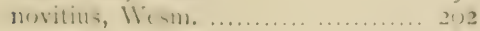

occisorius, Wesm. .................... is 2

pallidiventris, Rud. ................ 208

Panzeri, Wesm....... (et Addenda) 173

l'motalus, We-111. .................. 2)

quadrinotorius, Thoms, ............. 192
AMBLTTELES-continued. PAGE.

r:ptorils, Thoms. ................... is is

regius, Tisch. ...................... 200

repentinus, Wesm................... 176

rubriventris, IVesm. ................. 20.4

septemguttatus, Thoms. ........... IS 4

speciosus, Wesm. ................. 50

spoliator, Wesm. .................. I I 7

sputator, Ilesm. .................. 17 I

strigatorius, Wesm. ................ $2 I_{4}$

varicestorius, lierth. .............. 207

viridaturius, Ilesm. ................. I'I

Wesmaeli, Tisch. ................... Ist.

xanthius, Wesm..................... 189

xanthozosmus, Thoms. ............ 192

ANISOBAS.

hostilis, Thoms. .................... 210

rebellis, Wesm. ...................... 210

APAELETICUS.

balearicus, Kriech. ............ $76,23 \mathrm{~S}$

BAEOSEMUS.

mitigrosus, $H 10 \operatorname{lmg} r \ldots \ldots \ldots \ldots \ldots \ldots . \ldots \ldots$

BANCHUS.

venator, Illig.

10

BARICINEUMON.

derivator, Thoms. ................ $9 \mathrm{~S}$

BRACHYPTERUS.

means, Gir.

CENTETERUS.

picticollis, Wesm. ................ 2SI

CHASMODES.

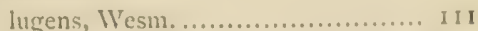

motatorius, Wesm.............162, 164

paludicola, Wesm. ..................... 164

CRATICHNEUMON.

grandiceps, Thoms.

\section{CRYPTUS.}

anator, Fal). …..................... \$ \$5

Ratzelurgi, IIart. ................... is

sangruinator, Desv. ..................... S2

volubilis, Gir. .................... 233 
COLPOGNATIIUS.

armatus, Thoms.

P'AGE.

Addenda

\section{DIADROMUS.}

decolor, IIolmgr.

267

crubescens, Berth.

2.11

imbellis, Wesm.

265

intemerlius, Wesm. ................ 265

tenax, Wesm.

Acklenda

\section{DICAELOTUS.}

erythrostoma, Wesm. 276

pumilus, IVesm.

unipunctatus, Wesm.

\section{ECTOPIUS.}

rubellus, Wesm.

\section{EUPALAMUS.}

oscillator, Wesm.

\section{EUIRYLABUS.}

corvinus, W'esm.

intrepidus, Wesm.... (et Addenda) 216

ruficornis, Berth. .................. 218

Vinulator, Thoms. .................. 216

\section{EXEPHANES.}

rufoniger, Tisch.

subnudus, Tisch.

\section{GNATIIOXYS.}

marginellus, IVesm.

\section{IIENICINEUMON.}

subdolus, Wesm.

\section{HEMITELES.}

elongatus, Ratz. 286

\section{IIERIESTOMUS.}

facialis, Wesm. ...................... 24

intermedius, Wesm. ................ 240

striatus, Bridg. ..................... 269

xanthops, Holmgr. .................. 241

\section{HOPLISMENUS.}

albinus, Gr. ....................... 228 aulicus, Wesm. ..................... 8 8

bidentatus, Gr, ..................... 6

dimidiatus, Gir. .................. 234

errabundus, Gr, ....................... 228

moestus, Gr. ....................... 6

pictus, Gr. .................. 48, 222

semirufus, Desv.................... 229

\section{HYPOMECUS.}

albitarsis, Wesm.
ICHNEUMON. PAGE.

abdominator, Ste. .................... 263

acutus, Gr. ........................... 248

adulator, Tisch. ..................... 44

aethiops, Gr. .................... 57

affectatur, Tisch. .................. 150

alacer, Gr. ........................ 65

albicaulatus, Fon:c ............... 102

albicillus, Gr. ...................... 36

allicinctus, (ir. ................... 95

allifrons, Ste. .................................... 60

albilarvatus, Gr. ..................... 67

albinotatus, Gr. ................... 97

albimanus, Gr. .................... 209

albiventris, Gmel. ................ 193

allogguttatus, Cir. ................... 40

albolineatus, Gr..................... 74

albosignatus, Ste. …............. 76

albostriatus, Tisch. .................... 46

alticola, Gr. ................. 212, 212

amatorius, Miill.................... 195

ambulatorius, Fab.................. I95

ambulatorius, Panz. ............... $19+$

ammonius, Gr. ............... I49, I 82

amputatorius, Panz. ................. 175

anator, Fab. ..................... $\mathrm{S}_{5}$

ancipterus, Desv. ................... 38

angustatus, IVesm. .................... I02

annulator, Fab. ..................... 62

annulator, Gr. ................. 57, 63

annulator, 11 esm. ................... 57

anospilus, Thoms. ................. 37

antennatorius, Gr. ................ I90

apricus, Gr. ........................ 50

arctiventris, Loie. ................. 165

armatorius, Forst. $\ldots \ldots \ldots \ldots \ldots \ldots \ldots . . .200$

armatorins, l'anz. .................. 6

arridens, Gir. ................... 24r

ascendens, Tisch. .................... 137

atramentarius, Gr. ................ 202

atratorius, Fab. .................... I9 I

atripes, Gr. ........................ 205

atrocaeruleus, Tisch. ................ 43

atropos, Curt......................... 15

aulicus, Gr.......................... \&े

aulixifer, Tisch. ...................... \&

auspex, Miill, ......................... 28

balticus, Ratz. ....................... 12

basiglyptus, Kriech. ............... 9 I

batis, Holmgr. .................... I4I

bellicosus, Stephi. .................... 6

biannulatus, Gr. ..................... 28

bicinctus, Christ ...................... I4I

bicoloripes, Tisch. ................... I3 I

bicuspis, Kriech. ................... 38

bidentatus, Gmel. .................... 6

bidentorius, Gr. .................... 192

biguttatus, Thunb.................. 32

bilineator, Don. ....................... 74

bilineatus, Gmel. .................. 30

bilunulatus, Gr. ...................... 98

bimaculatorius, Panz................. 77

binotatus, Desv. .................... 65 


\section{ICINEUMON-contimed.}

PAGE.

linotatus, Ste. $2 S$

lifuntitus, Vill. 114

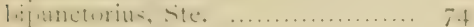

Bohemani, Holmgr. ................ 23

bresicornis, Gir. ..................... $2 S_{4}$

Brischkii, liatz. .................... 44

brunnicornis, Gr. ................. 240

colucatur, Tisch. .................. it

cacrulentor, l'anz. .................. 9

caeruleator, Zett. ................... I70

caerulescens, Tisch. ............... 32

callicerus, Gir................. 102, 103

cambrensis, Dess. ................... 249

candidlatus, Gr. .................... 266

carlmatur, Tisch. ................. 20

carnifex, Miill. .................... $7 \mathrm{~S}$

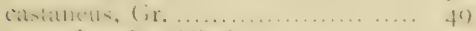

castanicaudus, Tisch. ............... 37

castaniventris, Gr. ................. 37

ch-tampysa, sic. ................. 204

canticatur, Fab. .................. 172

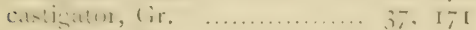

celerator, Gr. ..................... 278

cerinthim, (ir. ................... I $(x)$

chionomus, Wesm. ................. IO2

cincurias, 1)e-1. ...................... 20,5

cingulipes, Ste. ................... 202

cirmelater, schr. ................ It

clasiper, (ime! ..................... 012

clericus, Gr....................... $2 \mathbf{I}_{4}$

coerulator, Fal. .................... 9

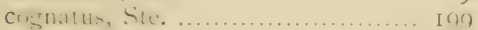

comitatur, ir ....................... 20

comitalor, Linn. ......................... 28

comitatur, list: ..................... 57

comitator, Sulz. .................... 30

comitator, Wesm. ................... 29

conituncter, ste. …................ 155

computatorins, flolmgr. ........... I2

concinnatorius, Ste. .............. 130

confector, Gir. ....................... $2 S^{\mathrm{I}}$

confusor, Gr. ..................... 138

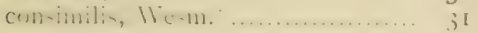

conspurcatus, Gr. .................. 206

contaminatus, Gr. ................ 159

(impatelti, llism. ................... is

corlu-citur, Lihis. ................... 015

crassicornis, Desv. .................... I7

crassicornis, Ste. …............. 212

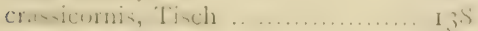

cranip..., fincl. .................... Iis

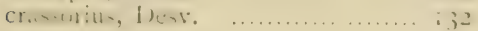

crispatorius, Linn. ................. is9

crocatus, Fourc. ...................... I4

culsicularis, Desv. .................. IS I

culex, Miiil. ........................ 62

culpator, Schr. .................... 42

culpatorius, Gir. .............. 152, ISo

culpatorius, Schr. .................... 20

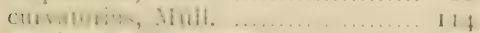

curvinervis, Holmgr. ................ 62

custodiator, Fal. ................. 155
ICINEUMON-contimed. PAGE.

cyaniventris, Wesm. .............. 24

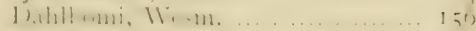

debellator, Hab. ..................... 289

deceptor, Cir. ............. 99, 156, 186

decimator, Gr. .................... 69

decipiem, llwhir. ............... 117

delensorius, Gr. ................... 157

defraudator, Wesm. ................. $5^{\circ}$

delator, $\mathbb{W}$ esm. ................... 123

deliratorius, Gr. ................... 43

derasus, W'esm. ....................... 29

derivator, IVesm. ................... $9 \mathrm{~S}$

derogator, lVesm. ..................... 97

designatorius, Gr. .................. 23

designaturius, Linn. ................ 24

didymu, fir. ...................... I I

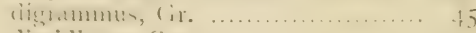

dimidiatus, Ste. ..................... 194

discrepator, Wesm. ................. \$2

disparis, l'oda ........................ 20

dissimilis, Gr. .................. 59, 60

diversorius, Ste. ..................... 200

divisorius, Gir.................... $17 \mathrm{~S}$

delomesils Gir........................ z

dulusits, Wistm. .................... 150

dulutatus, Desv. ...................... Is

dubius, Tisch........................ 20

dumeticola, Gr. ................... 75

edictorius, Gr........................ $17 \$$

clegans, (ir....................... It

equitatorius, l'anz. .................. 190

eremitatorius, Zett. ................ 156

erythracus, (ir ................... s?

erythrocerus, Gr. .............. Adklenda

erythrogaster, Ste. .................... IS

erythropyysus, Gr. ................. Is 7

eucephalus, Wesm. ................ 214

eupitheciac, bisch. .................

exallatoum, l'at..................... is

eximith, sie. .................... 21

exormatus, IIisu. .................. ty

expectatorius, Fab. .............. 17

explurutur, Tish. ................... it

cxichorius, funce............... 12t

extensorius, Gir. ........ 150, 159, $\mathrm{IS}_{3}$

extensorius, Wesm. ................. I I 34

evinctus, kinte. ..................... क

exulans, Gr. .................... 159

faluicalur, lah. ...................... it

fabricator, Wesm. ................ 64, 67

Filricii, lir. ..................... 191

facialis, Gr ......................... 241

falcatus, 'Tisch. ..................... 20

fallax, Gir. ............................. 10

fasciatorius, $\mathrm{Fab}$.................. 200

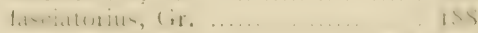

fasciatus, Gr. ................ $2 S, \quad 170$

1. math, lit. ........ st

femorator, Kirlyy ................... $2 S$

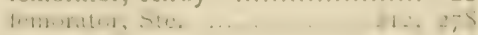

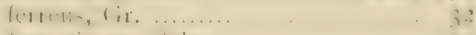

knurimens, sthr. .. ... 2) 
ICHNEU MON-continted. PAGR.

flavatorius, Fab. ...................... 20

flavatus, cimel. ..................... It

flaviceps, Gimel. .................... 20

flaviceps, Tisch. ..................... 190

flavifemur, Tisch. ................ 205

flavipetiolatus, Tisch................ \&

flavocinctus, Desv. ................. I79

flavosuttatus, (ir. .................. 2r) 7

flavolimbatus, Gr. ................ 205

flavolineatus, Gr. ............... $1+1$

flavoniger, Gr. .................. I 13

fossorius, Gr. ..... 15 t, 17t 205,212

fucatus, WVesm. ................... 55

fugatorius, l'anz. …........... I7

fugitivus, Gir. ..................... $\sigma_{4}$

fulvicornis, Gir .................. I 27

fulvipes, Site. ..................... 60

fulvoscutellatus, Ste. ............... I30

fumigator, (ir. …....... 42, I 73, 205

funebris, Holngr. ................. 29

funereus, Fourc. .................. $\mathbf{I}_{74}$

fuscalus, Gr. ................. I $_{3} \mathrm{I}$

fuscipes, Gmel. ................... 25

fuscipes, Gr. .................... I I I

fuscipes, Wesm. ................... 26

fuscucastaneus, Gr. $\ldots \ldots \ldots \ldots \ldots \ldots . \quad 78$

fusorius, Cor. ........................ IS

fusorius, Gr. ................. 17, 19

fusorius, Linn. ................... I7

gasterator, Ste. .................... 65

gemellus, Gr. ..................... 86

gemellus, Wesm. ................... 27

geminatus, Tisch. .................. I $\mathrm{S}_{7}$

glaucatorius, Fab. ................ 193

grtancus, Tisch. ................... I 127

Goedarti, Gr. ...................... 205

gracilicornis, Gr. . ............... $1 \mathrm{OO}_{3}$

gradarius, Holmgr. .................. ISg

grandiceps, Thoms. ................ 67

Gravenhorsti, Fourc ................ 67

Gravenhorstii, Wesm. ............. $18_{3}$

grossorius, Fab. ................... If I

guttiger, Wesm. .................... 24

guttulatus, Gr. .................... 266

haematonotus, Wesm. ............. I57

haemorrhoidalis, (ir. .............. 37

I Iartigii, Ratz. .................. 60

hassicus, Ratz. ...... (et Addenda) \$7

Helleri, Holmgr. .................. 46

heracliana, Bridg. .................. 93

hilaris, Gr. ........................ 158

hostificus, Tisch..................... 145

hostilis, Gr. ....................... 210

ictericus, Christ ..................... 20

ignobilis, Wesm .................... $15^{\circ}$

ignotus, Fonsc. ..................... 205

illuminatorius, Gr. .................. 124

imperatorius, Panz. ................ It

impressor, Zett. .................... 37

improlsus, 'Tisch.................... 137

impugnator, Wesm. ................ 60

inculbitor, Gr. ............... 97, 102
ICINEUMON-continned. PAGE.

incubitor, Linn. .. .................. 90

inclagator, Wesm. .................. 79

indictus, Ti-ch. ................... 53

infenturius, limsc. ................ 192

intiklus, lierth. .................... $5 \mathrm{~s}$

infractorius, l'anz. ................. 201

ingratorius, Gr. .................. 54

inquilimus, $\mathrm{H}$ tolmgr. $\quad . . . \ldots \ldots \ldots \ldots . . . \quad 37$

interjectus, Tisch. .................. 205

interruptorius, Trentep. ............ I93

interruptus, Gr. .................. 205

incertis, (ir........................ 143

irilipennis, (ir. ................... 223

ischiomelinus, Gr. .. ...........256, 27.3

ischioxanthus, Gr. ................ I 59

jucularis, Wesm. ..................... 59

jus,ulus, Gr..................... 54

laboratorius, Fab. .................. I9 95

laboratorits, Cir.................. 173

lachrymator, Fonsc. ................ 3t

laetus, Tisch. .................... I 187

laevis, Ratz. ..................... 69

laminatorius, Fab. .................. 20

limius, Gr. ................... 68

larvatus, Christ $\quad . . . \ldots \ldots \ldots \ldots \ldots \ldots . . . .216$

lapidator, Fab. .................. 4 , 9

latrator, Gr. ................... I 57

littrator, Wesm. .................. I 22

lautus, Tisch. ...................... 95

lentorius, I'anz. .................. 17

lepidus, Gr................... 88 , Iо I

lencocerus, (ir. ................. 27, 27

leucomelas, Gmel. ................. it

lencomelas, Gir. .................. I IS6

leucopygus, Gr. ................... SI

lencostigmus, (ir. ................. $20 \mathrm{~S}$

letrosituma, (imel. ................... 60

Lichtensteini, Tisch. ................. I S 9

limbatus, Tisch. ... . ............. 129

lineatur, Fal. ...................... 32

lineator, llolmgr. .................. 34

liocnemis, berth. ................ 35

liustylus, Thums. .................. 58

luctatorius, Gir. ........ I27, I32, 195

luctatorius, Linn. ................. I 35

luctatorius, IV., 124, 126, I29, I3I, I S

luctuosus, Gr. ................ 79, I 29

luriclus, (ir. ....................... $66_{5}$

luteirentuis, Gir. ............... 53

lutorius, Fal). .. .................... It

maculicomis, Ste. ................. $25 \mathrm{~s}$

maculifrons, Ste. ................... bo

maculiventris, Desv. ............. 1 ;

magus, Viesm...................... 70

Malklini, Holmgr. .................... I. 6

malignus, Tisch...................... I I 1

marginatorius, Panz. ................ IS'z

margineguttatus, Gr. ............... 202

marsincllus, (ir. .................. 236

mediatorius, l'anz. ................... 192

melanocastanus, Gr. .............. 175

melanuccrus, Wesm. ............... ISI 


\section{ICHNEUMION-continued.}

melanogaster, Gr. melanogonus, Gmel. melanogonus, Gr. melanopyrrhus, Sic. memorator, IVesm. (170 mercatorius, Fab. .......... 193, 201 mesocastanus, Gr. ................. I76 mesorius, (ir. ...................... 177 microcephalus, Sie. ............... 203 microcerus, Gir. ..................... \$5 microstictus, Gr..................... 34 militaris, Gr. ...................... 102 minutorius, Desv. ................... 134 mitigosus, Gr...................... 248 muxstus, Wism. ................... j( molitorius, Linn. .................. 112 muliturins, schr................... 43 monitorius, l'anz. ................ 193 monostagon, (ir..................... if moratorius, lab,.................... 24 motatorius, Fiab)...................... 162 multiannulatus, Gr. ............... 112 multicinctus, Gr. ................. 46 n:ulticolor, Gmel. ................. I 147 mutabilis, Gr. .......... 250, 251, 25 I napaeus, Ifolmgr. ................... If I natatorius, Fab. .................... 192 nesatorius, Fab. ................... 197 Aireni, Thoms. .................... I 152 nigerrimus, Sle. ...................... 32 nigratorius, I'anz. .................. 54 nigriounis, Wesm................... 37 nigripes, Gr. ..................... 207 nigritarius, Gir. ................... 57 nigritarius, Holmgr. ............... 62 nigrocastaneus, Tisch. ............. 129 nigrocyaneus Gr. .................. 22 I nitens, (ir. ....................... 176 niventus, Desv. .................... I 34 noblilitator, (ir. ..................... notaturius, J'anz. ................. 207 notatorius, 'Trentep. ............... 192 nothus, Holmgr...................... 28 nudicnsa, Thoms. .................. 76 nycthemerus, Gr. ................. 2 olnator, Desv. ........................ 223 oblongatus, Tisch. .................. 189 occisorius, Fab. ...................... 182 occupatser, (ir. ......................... 1 is ochraceus, Tisch. ................. IS reliropin, (imel. ...................... 47 octerultatus, (ir. .................. in (1) opprimator, Gir. ...............267, 28 I gitiruti, (ir. ....................... is

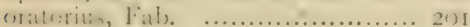

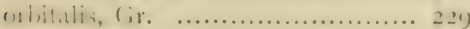
ornatorius, Gr. .................. 197 oscillator, Holmgr. .............. 72, 72 ovator, Fab. ........................ 289 pallialorius, Gr.
ICHNEUMON--continued.

I'AGE.

pallidatorius, Gr. ............... 56 pallidicornis, Gir. .................. In palliditarsis, Thoms. ............ Addenda pallifrons, Gr. ..................26, $\sigma_{3}$ pallipes, Gr. ................. 72, 174 paludator, I ess.................... It l'anzerii, Steph. ................. Addenda parvulus, Gr. .................... 277 perlaturius, liah. .................... $2 \geq 3$ percussor, Tisch $\quad$................29, 79 perhiematus, Tisch. ............... 156 perileucus, Gr. ..............174, 174 periscelis, IVesm. ................... 26 perscrutator, Wesm. .................. So persecutor, Gr. .................... 229 personatus, (ir. .................... 5 . phaleratus, IIal. .................... 225 picipes, ste. ...................... 20 i 3 pictus, IVesm. ....................... \& pisorius, (ir. $\quad \ldots \ldots \ldots \ldots \ldots \ldots \ldots \ldots \ldots \ldots \ldots$ pisorius, Linn. .................. 17 pisorius, Panz. ................... 14 pistoritus, Gr. .................... +3 plagiarius, Wesm. .................. 97 plurialbatus, Wesm. ................ I03 praedator, Fonsc. .................. 205 pratensis, (ir. ..................... 205 procerus, Gir. ....................... is

I'roteus, Christ .................... 20 pulchellatus, Bridg. ................. 94 pulchricomis, (ir. ................ 49) pulex. Mïll. ...................... $2 S_{4}$ pumilus, Gir. $\ldots \ldots \ldots \ldots \ldots \ldots \ldots \ldots . \ldots \ldots \ldots \ldots+27 t$ punctifrons, Holmgr. ............... 59 punctus, Gr. ..................... I 186 pusillator, Gr.................24I, 277 pyrenaeus, Tisch. ................... 65 pyrrhopus, Ste. ..................... 64 quadriannulatus, Gir. ............... I6 67 quadricingulatus, Gr............... 205 quadricolor, Gmel. .. ................ ou quandrifasciatu, (ir. ............... II quadrilineatus, 'lisch. ............... I 37 quadrimaculatus, Gr. ................ 200 quadrinotatus, Ste ................. 143 quadripunctatus, Kriech. ........... 12S quadripunctorits, Mitll. ............. 192 quinqueguttatus, Gr. .............. 2 ramiformis, Tisch. .................... I 45 raptorius, Linn. ..................... I\$ raptorius, Trentep. ................. 102 rulinitus, Tisch. .................. reluecns, Desv. .................... 19. repentinus, (ir. $\ldots \ldots \ldots \ldots \ldots \ldots \ldots . .170$ restaurator, Gr. .................... 32 retectls, I isch. .................... 1,j retractus, Ti.dh.................... 1 is ridilitundus, (ir. ..................... is rubedinis, Desv. .................... 156 rubellus, Gmel. .................... 232 rubricosus, Holmgr. ................ 5.4 rufator, Ste....................... $2 .{ }^{2}$ 


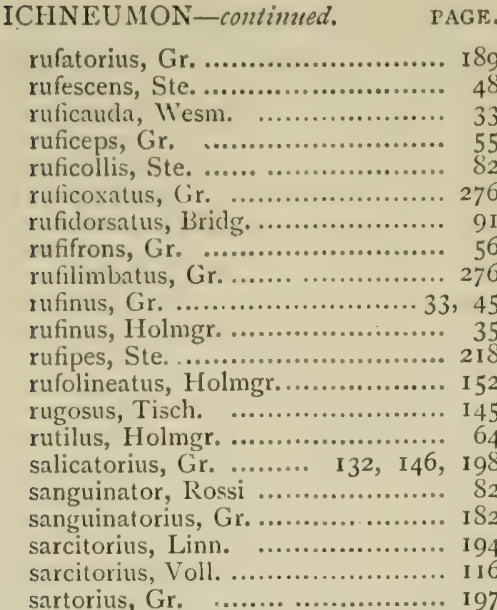

saturatorius, (ir.................. 76, 77 saturatorius, Linn. ................. 78

Schaefferi, Panz..................... 20

scutellator, Gr. .................... 45

sedulus, Gr.................. 50, 88, 90

semiorbitalis, Gr. ........ 27, 129, I31

semirufus, Gr. .................... 94

semivulpinus, Gr. ................. 250

septemguttatus, Gr. ............... I84

serenus, Gr....................... 34

sexalbatus, Wesm.................... \&8

sexlineatus, Gr. .................... 98

sibilans, Gr. ...................... 205

sicarius, Gr. ...................... 54

similatorius, Holmgr................. I7

similatorius, Wesm. ............... 90

sinister, Wesm. .................... 27

sociatorius, Yanz. ................. 20

specularis, Tisch. ................... 28

spiracularis, Tisch. .................... 60

sputator, Fab. ..................... I I I

stimulator, Gr. ...............259, 260

strigatorius, Gr. .................... 2 I 4

suavis, Gr. ................... 99, IOI

subalbellus, Gr. ..................... 229

subfasciatus, Tisch................... 205

subguttatus, Gr. ..................... 25

subreptorius, Wesm. ................ I53

subsericans, Gr. ..................... I99

subtilicornis, Gr.................... 265

sugillatorius, Gr..................... 24

sugillatorius, Linn. ................. 24

tenebrosus, Wesm. ................... 54

tenuicornis, Gr. ..................... 227

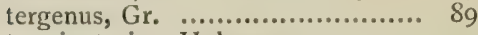

terminatorius, Holmgr.............. 124

tibialis, Fourc....................... 62

tibiator, Gr. ......................... 5I

triangulator, Ste....................... I 88

tricingulatus, Gr. ................. 230

tricoloreus, Christ .................. I89
ICHNEUMON-continued. PAGE.

trifasciatus, Gr. ................... I 88

trilineatus, Gmel. .................. 44

tripunctatus, Gmel. ................. I I4

tristis, Gr. ............ 216, 217, 218

troglodytes, Gir. ..................... 264

Troscheli, Ratz. ....................... 98

trucidator, Gr...................... 2 I 2

umbraculosus, Gr. ................. 44

uniguttatus, Gr. ..................... 205

vacillatorius, Gr................ 92, 93

vadatorius, Illig. .................... 194

vaginatorius, $\mathrm{Linn} . . . . . . \ldots \ldots \ldots \ldots \ldots$ II 4

variegatorius, Panz. ............... 207

varipes, Gr. ......................... 69

venustus, Tisch. .................... I 59

versicolor, Gmel. . .................. 60

vespertinus, Christ ................. 176

vestigator, Wesm. ................. 99

vexillarius, Tisch. ................ I 73

viator, Curt........................ 289

vicinus, IIolmgr.................. 137

victor, Schr. ................... 62

Vinulator, Geer ...................... 216

viridatorius, Gr. .................. I9 $\mathrm{r}$

volutatorius, Trentep. .............. 201

xanthius, Gr. ....................... I 89

xanthops, Gr. ..................... 2 I I

xanthozosmus, Gr. ................. 192

zephyrus, Wesm. ................. 59

zonalis, Gr. ....................... I 124

zonalis, Kriech. ................... I 49

\section{ISCHNIDIUM.}

albibucca, Kriech. .............. Addenda

\section{ISCHNUS,}

collaris, Gr. ....................... 267

Minai, Stephi. ................... 23I

moestus, Gr. ..................... 36

pulex, Gr. ....................... $2 \$_{4}$

rufipes, Wesm. ..................... 285

\section{LIMERODES.}

cambrensis, Bridg.-Fitch ........... 249

ophioniventris, Wesm. ............. 165

LISTRODROMUS.

lapidator, Wesm. .................. 4

nobilitator, Wesm. .................. 4

quinqueguttatus, Bridg - Fitch ..... 2

\section{MESOSTENUS.}

maurus, Marsh.

\section{MEVESIA.}

arguta, Holmgr.

\section{MICROLEPTES.}

splendidulus, Gr. 
MISCIIOPHORUS.

I'ACE.

flavosignatus, Kriech.

216

MISETUS.

oculatus, IVesm.

Adclenda

NEOTYPUS.

nobilitator, Thoms.

NOTOSEMIUS.

albibucca, Kriech.

- Addenda

\section{OIORHINUS.}

erythrocerus, Gr.

Addenda

pallipalpis, Wesm. 269

\section{ORONOTUS.}

coarctatus, Wesm. $2 S_{2}$

\section{PHAEOGENES.}

callopus, Wesm. .................... 26 I

cicutella, Sieb. ..................... 249

conciliator, Wesm................... 267

eupitheciae, Berth. ................... 95

formosus, Bridg. ...................... 270

hybridus, llesm. ............... 252

jucundus, Wesm. ............. 249, 279

macilentus, IVesm. ...............Addenda

muricifer, Holmgr. ............... Addenda

primarius, IVesm. .................. 250

protervus, IVesm. ................. 25I

scutellaris, Wesm. ................... 258

socius, Holmgr. ................. Addenda

tetricus, IVesm. ..................... 258

versutus, Wesm. .................... 262

\section{PHYGADEUON.}

arridens, (ir.

binotatus, Gr.

$2 \mathrm{~S}_{2}$

discedens, Gir. .................... $23 t$

piniperdae, Ratz. ................ 75

procerus, Gr. ....................... 278

terminatorius, Gr. ................ 68

\section{PLATYLABUS.}

armatus, Wesm. .................... 222

crrabundus, Wesm................... 22S

iriclipennis, Wesm................. 223

leucogrammus, Wesm. .............. 225

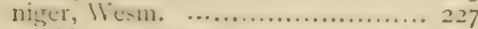

pallidens, WVesm.
I'LATYLABUS-contimuel. PACE.

pedator, Thoms. .................... 223

serrarius, Berth.................... 220

sollicitus, WVesm.................... 226

Thedenii, IIolmgr. ..................... 232

transversus, liridgr................. 22.4

\section{PROBOLUS.}

fossorius, Wesm.

212

\section{PROSCUS.}

cephalotes, Holmgr.

suspicax, Holmgr.

\section{PROTICHNEUMON.}

Jesperi, Thoms.

\section{PSILOMASTIX.}

lapidator, Tisch.................. IO, II

pictus, Kriech. .................... II

y)ramidalis, Tisch. ................. I I

\section{PTEROCORMUS.}

means, Fürst.

SPHEX.

annularis, Poda ..................... I 36

crassicornis, Scop. .................. 20

disparis, Poda ....................... 20

\section{SPILICHNEUMON.}

raptorius, Thoms.

THYRAEELLA.

collaris, Holmgr. 267

TROCHUS.

coeruleator, Trentep.

\section{TROGUS.}

alboguttatus, Gr. atrocaudatus, Ste,

atropos, Ste. ........................... 15

caeruleator, Panz. .................. 10

dissimulator, Ste. .................. I 42

excellens, Tisch...................... I4

flavatorius, Gr. ................... 20

fuscipennis, Gr. ................... 10

lapidator, Gr. ....................... I0

luteiventris, Gr. ................. 53 


\title{
I I Iist of the Einumetrated 'Ibosts.'
}

\author{
[CORRECTED BY C. G. BARRETT, F.E.S.]
}

\section{LEPIDOPTERA.}

PAGE.

Papilio Machaon, L.

Lithosia quadra, L.

PAGE.

Gonepteryx rhamni, L..........202, 211

Argynnis l'aphia, L. ............ I7 I, 172

, Tandora, Schiff, ${ }^{*}$........... 10

Melitaea Athalia, E. .................... 43

", Cynthia, Hb. *............. I 44

, maturma, L. * ............. ISg

Vanessa urticae, L. ...... Ij6, I42, I79

", polychloros, L......... I 36 , I 55

, Antiopa, L. .................. I75

,$\quad$ Io, L. ......................... I 72

, Atalanta, L............172, 201

,, carclui, I. ................. I72

Apatura Iris, L. ..................... I I

Satyrus Janira, L. .............. 36,153

," Maera, L. * ................ 7

Chrysophanus Circe, Schiff. * ........... 136

Lycaena Cyllarus, Rott. * ............. 136 , Iolas, Ochs. ${ }^{*} \ldots \ldots \ldots \ldots 102,211$

,$\quad$ argiolus, L................... 3

Smerinthus ocellatus, L., I4, I 5. 17, I $\$ 7$

, populi, L., I 4, 17, 21, 113, 19.3

" tiliae, L. ................ 20

Acherontia Atropos, L., I4, I 5, 20, I87, 197

Splinx convolvuli, L. ............... 20

, ligustri, L. ... I3, I4, I 5, I 7, 20

, pinastri, L. ........... I7, I8, 2 I

Deílephila euphorbiae, L. ............ 36

," galii, Schiff. .............. I4, 2 I

Chaerocampa porcellus, L. ........... 19

, $\quad$ elpenor, L. ...........20, 2 I

Macroglossa stellatarum, L........... 20

," fuciformis, L. .......... 20

Sesia hylaeiformis, Lasp. * ........279, 2 SO

" culiciformis, L.................. 247

,, apiformis, L.................... 174

Cossus ligniperda, F. ................ 278

Limacodes testudo, Schiff.............. 224

Setina aurita, Esp. * ................ 43

, $\quad$ ramosa, $\mathrm{F}_{0}$ * ................... I89

, rubricollis, L., 54, 57, I 88,2 I 8

Euchelia jacolaeae, L. .............. 79

Callimorpha dominula, L. ........ 19, 20

Chelonia caja, I. ................... 45

Arctia fuliginosa, L. ........ 27, I46, 148

," menthastri, Esp................ I I 5

Liparis chrysorrhaea, L. ............. 45

, auriflua, F.................. I3

, salicis, L. .................... 20

", dispar, L. .......................20, 49

, monacha, L. .......13, 20, 24, 153

Orgyia pudibunda, L., 13, 44, 61, 99, $\mathbf{1}_{32}^{2}$ ,fascelina, L ................. 143

Trichiura crataegi, L. $43,72,177,216$

Eriogaster lanestris, L...... 58, 2 І 6, 26 I

liombyx rubi, L....................... 201

Odnnestis potatoria, L. ... 183, 199, 209

Saturnia carpini, Schiff. ........201, 202

Angerona prunaria, I. ................ $5 \mathrm{~S}$

Ellopia fasciaria, L. ................. 260

Selenia lunaria, Schiff. ............... 56

Odontopera bidentata, L............. 25

Amphydasis betularia, L. ....... 75, I72

Cleora viduaria, Bkh............. 29, 172

Boarmia consortaria, F............... 220

Tephrosia extersaria, H. ............ 54

Geometra smaragdaria, F. ......... I 54

Hemithea thymiaria, L. ............. 46

Ephyra punctaria, L................... 167

,, trilinearia, Bk. ............. 167

Acidalia trilineata, Scop. * .......... 167

Cabera pusaria, L. ................... 223

Macaria liturata, L., 49, 58, 6r, 63, 96, 98,190

," signaria, Hb. * .............. 58

Fidonia piniaria, L., $29,54,58,63,96,99$, 222,230

Eurranthis plumistaria, Vill. * $\ldots . . . .633$

Scoria dealbata, L. …............. 23 I

1 The various pages quoted will indicate the number of parasitic species attacking each kind of lost. Extra-British species are indicated by an asterisk ("); their indigenous allies may be supposed subject to the same parasite. I make no apology for following Doubleday's classification, since it is, if not the most strictly scientific, at least the most widely known among British Lepidopterists of all sorts.-C.M. 
PAGE.

Aspilates strigillaria, II.

7

Abraxas grossulariata, L., 29, 31, 45, 45, $48,5 S$

IIybernia defoliaria, L. ............... 224

I.mmelesia unifasciata, H. .......... 232

Fupithecia pulchellata, Ss. ..... 95, 231 helvelicati2, 13. ... 65, 90, 95

, pinpinellata, H. .......... 224

", innotala, H. .............. 224

," nanata, H. ................ 224

, subnotata, II. ............. 224

", absynthiata, L. ........... 234

, minutata, G. ............. 234

," exiguata, II. ............. 224

", sobrinata, H. ............. 224

, rectangulata, L. .......... 96

, digitaliata, Dietze. * ..... 95

", scopariata, Rhr. * ....... 224

Lobophora sexalata, II. ............. 230

, lobulata, H. ............. 224

Thera juniperata, L. ........... 49, 230

, firmata, H. .................... 224

Ypsipetes ruberata, Frr................ 96

, impluviata, IIb............ 223

," elutata, 11.................. 33

Melanippe luctuata, H.............. 167

, montanata, Schiff. ........ 234

", fluctuata. L., 19, 96, 230, 234

"galiata, Schiff. .............. 167

Anticlea sinuata, Hb. ...........228, 231

,. rubilata, $\mathrm{F}, \ldots \ldots \ldots \ldots \ldots \ldots . . \ldots \ldots$

, berberata, Schiff.............. 167

Phibalapteryx tersata, Hb. ........... 230

Cidaria corylata, Thunb. ............ 57

,, sagittata, li. ................. 225

, silaceata, Hb. ................ 227

", testata, I. .................. 230

, fulvata, Forst. ............... 49

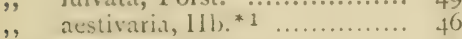

Pelurga comitata, L. ${ }^{2} \ldots \ldots \ldots \ldots \ldots \ldots . .224$

Eubolia menstiraria, Schiff. ........... I66

Platypteryx curvatula, Bkh. * ........ 228

Dicranura bicuspis, Bk............... 139 vinula, L. ........79, 113,217

Sitauropus fici, I. .................... 217

Clostera reclusa, Fal,. ................ $5^{8}$

P'tilodontis palpina, L. ................ I7

Notodonta camelina, L. .............. 20 I

,$\quad$ dromedarius, L. .......... 61

", dodonea, Hb. ............. 31

Diloba cacruleocephala, L. .......... I 16

Thyatira batis, L. .................... 13

Cymatophora or, Fab.................6 6 i

Bryophila glandifera, 116., 33, 31, 33, 45

1 This is probably Hemithea thymiaria.-C.G.13.

IIt appears advisable to draw attention to the fact that TYPICA. $P$. pedatorius have never emerged from l'clurga comitala - as given by Schmied. as recently as this year; it is nothing but a synonym of Gcometra chenopodiati rccorded by Grav. as host of the var. irilipenuis.C.M.
Acronycta psi, L. ................... 155

," megacephala, liab........ $2 S$

". myricae, G. .......... 26, I14

Simyra venosa, 13k. .................. 20

Leucania vitellina, $11 . \ldots \ldots \ldots \ldots \ldots \ldots, 18_{3}$

, lithargyria, $\mathrm{E} . \quad \ldots \ldots \ldots \ldots . . .175$

" phragmitidis, H. ........... 79

," evilens, liti. ............... 15.4

Tapinostola Elymi, Tr. .......... 159, 166

Meliana flammea, Curt................ 79

Nonagria geminipuncta, l[ıch., 33, So, $147,16_{3}, 2 \mathrm{SI}_{\mathrm{I}}$

, cannae, $0 . \quad \ldots .79,147,164$

" typhae, E. ...79, 147, 160, 164

", sparganii, Esp.," So, 138, 139, $160,172,179$

, nexa, $11 \mathrm{l} .{ }^{*} \quad$............... 139

Gortyną flavago, Esp., 33, 37, 139, 172, $18_{3}, 18_{3}$

Hydraecia leucographa, Bkh. *.. 32, I 16

Axylia putris, I......................... 6 I

Xylophnsia rurea, F. .................. 200

Cliaraeas graminis, L. .............. 135

Mamestra brassicae, L. ................ 200

Miana literosa, IIw. .................. 166 arcuosa, Hw. ......... I59, 163, 166

Caradrina cubicularis, 13kh. ........... 177 Kedenii, Frr. * ............ 186

Agrotis segetum, Esp. ... 173, 195, 201

, exclamationis, L.............. 173

, corticea, Hb. ............... $20 \mathrm{I}$

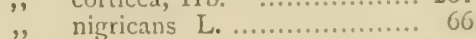

"tritici, L. ..................... 201

, lucernea, T................ 130, ISS

", Ashworthii, Db. .........201, 265

". linogrisea, Schiff." ${ }^{*}$........... 196

Triphaena fimbria, L., $138,141,192,200$

, interjecta, 11. ............ 193

, orbona, Hf, I79, I92, 193, 20I

, pronuba, L., 17, 136, 139, I93, I95, 201

Noctua brunnea, Fab., 75, II 3, 125, 197, 202, 203

," festiv, IIb. ............ I3 3 , 202

, rubi, لiew................... 1 i9

, xanthographa, Fab. ........... 201

Trachaea piniperda, P., 29, 45, 45, 5S, $61,63,63,76,9 S, 99,125,135$, $191,218,222$

Taeniocampa gothica, L. ...........30, 65 instabilis, lisp.......... 65, 173

", instabilis, $1 . s p . \ldots .65,173$

stabilis, View. .............. 120,212

", $\quad$ stabilis, 1 miniosa, F............. 5 S, 66

," cruda, Tr. ............... 170

Orthosia upsilon, Bkh. ................. $3^{6}$

Xanthia cerago, F. .................. 204

Cosmia trapezina, L. .................... 34

, diflinis, L..................... 272

abluta, 11b. ${ }^{*}$.................. 34

Dianthaceia irregularis, IIf. ........... 114

, carpophaga, 13k., 172, 21S, 225 


\section{LEPIDOPTERA-continued.}

Dianthrecia capsincola, Hb............ 218

," cucubali, Fuessl. ........... 176

Polia polymita, L. *.................... 193

Dasypolia templi, Thnb. .............. 204

Epunda viminalis, F.................. 96

Miselia oxyacanthae, L. ............. 20

Agriopis aprilina, L. .................. 66

Phlogophora meticulosa, L. ........... 200

Polyphoenis sericata, Esp。* ..... I14, I 96

Aplecta nebulosa, Hf. ................. 202

,, tincta, Brahm. ............. 188

Hadena adusta, E. 99, 103. 104, 175, 179, 212

," protea, Bkh.

," oleracea, L. ............... II 3, 172

", pisi, L. .................. 17, IS

", baltica, Hering. * ....... 99, 175

Cucullia verbasci, L. ............. I87, 194

," absynthii, L. ................. 172

", chamomillae, Schiff. ........... 176

", Santonici, Hb. ${ }^{*}$........ 139, 183

", argentea, Hufn * ........... I94

, artemisiae, Hufn. * ........... I94

Ifliothis dipsacea, L. ............... 215

Anarta myrtilli, L ..................... 194

Abrostola urticae, H. ................ 206 triplasia, L. ..........2 26,2 I 2

Plusia festucae, L. .................. 43, 58, 222

," gamma, L. ........ 29, 58, 79, I7 I

Perigrapha J-cincta, F. * …......... 193

Mania typica, L. ........... 79, IO2, I89

Toxocampa craccae, F................ 39

PAGE

Ophiodes illunaris, Hb. ${ }^{*}$............ 46

Botys lapulinalis, Clk. ............... 279

Tortrix crataegana, H. ............... 33

"r rosana, L. ................... 251

," viridana, L. ...............260, 267

Oenectra pilleriana, Schiff. ........... 252

Penthina dimidiana, So. ............. 224

Euchromia rufana, S. ............... 25I

, flammeana, $\mathrm{Hb}^{*}{ }^{*}$........ 253

Paedisca solandriana, L. ............. $7 \mathrm{r}$

Semasia corollana, $\mathrm{Hb}$. ${ }^{*}$............... 265

Retinia pinicolana, Db................. 65

Psyche nitidella, St. ................... 243

,, viciella, Schiff. ............243, 287

Yponomeuta padella, L.... 233, 240, 260

, cognatella, II. ............ 240

"evonymella, L............. 240

", malinella, Zett. * ......... 240

,, egregiella, Dup * ........ 224

Orthotaclia sparganiella, Thunl....... 249

Depressaria umbellella, Ss. ........... 83

$\begin{array}{ll}\text { depressella, H. ............. } 234 \\ , " & \text { nervosella, Hw......252, } 275 \\ , " & \text { heracleella, Deg. (et Addenda), }\end{array}$
$66,93,102,234$

Gelechia plantaginella, Stn. ........... 275

Butalis senescentella, Stn. $\quad \ldots \ldots \ldots \ldots .275$

Stephensia brunnichella, L. ............ 246

Pterophorus acanthodactylus, II $\quad \ldots \quad 160$ ," phaeodactylus, H. ...... 284

," galactodactylus, $\mathrm{H}, \ldots \ldots .283$

", pentadactylus, L. ......... 284

\section{HYMENOPTERA.}

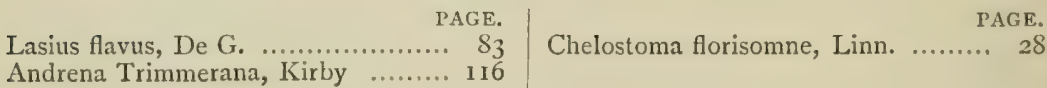

\section{DIPTERA.}

PAGE. PAGE.

Syrphid larvae

86,189 Stercorareous larvae

291

\section{COLEOPTERA.}

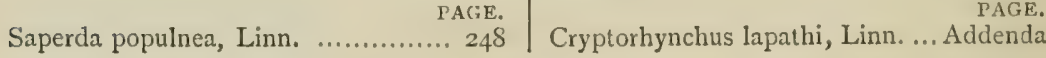

PAC:E. 


\section{INDEX.}

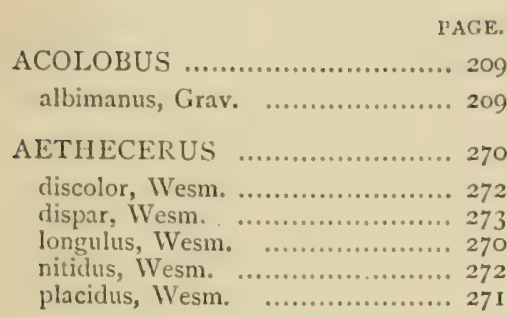

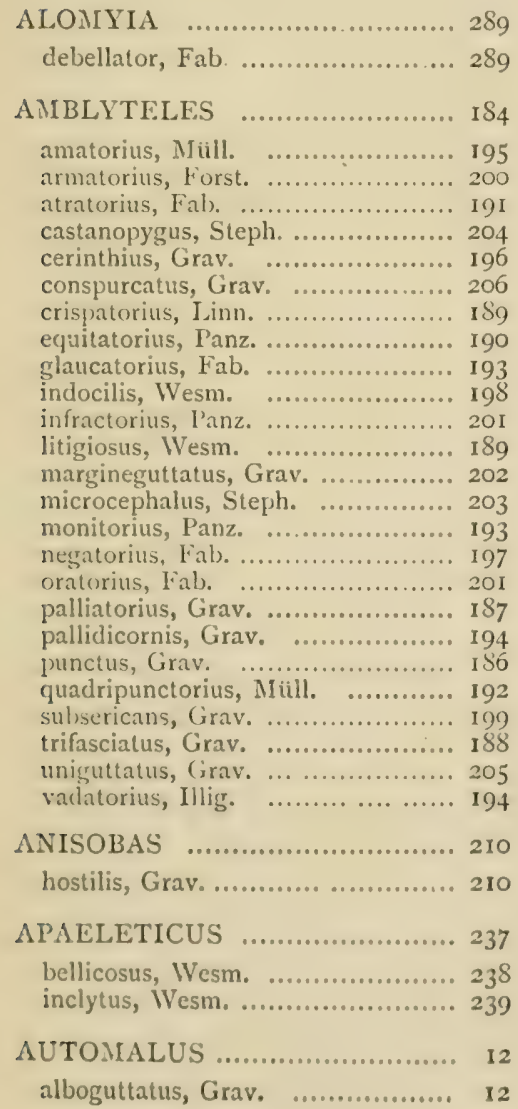

PAGE.

BARICHNEUMON .................. $\delta_{3}$

albicinctus, Grav. ................... 95

anator, liab. ...................... \& $\$_{5}$

angustatus, Wesm.................. 102

basiglyptus, Kriech. ............... gr

bilunulatus, Grav. ................... 98

callicerus, Grav. ...................... I0

chionomus, Wesm.................... I02

derogator, Wesm. ................. 97

eupitheciae, Brisch. ................ 95

gemellus, Grav. .................... 86

heracleanae, l3ridg. $\quad . . . \ldots \ldots \ldots \ldots \ldots . . .63$

incubitor, Linn. .................... 90

lepidus, Grav. ...................... Ior

plagiarius, Wesm. .................. 97

pulchellatus, Bridg. .............. 94

ridibundus, Grav. .................. \$7

ruficlorsatus, Bridg..................... 9I

semirufus, Grav...................... 94

sexalbatus, Wesm. .................. 88

tergenus, Grav. ...................... 89

vacillatorius, Grav. ................ 92

vestigator, Wesm. .................. 99

COFLICHNEUMON ............. 2 I

albicillus, Grav. ...................... 36

bilineatus, Grav..................... 30

Bohemani, Holmgr. ............... 23

castaneiventris, Grav. ........... 37

comitator, Linn. ................... $2 S$

consimilis, WVesm. .................. $3 \mathrm{I}$

cyaniventris, Wesm. ............... 24

derasus, WVesm. .................... 29

fuscipes, Gmel. ................... 25

impressor, Zett. ..................... 37

leucocerus, Grav. ................ 27

lineator, Fab. ...................... $3^{2}$

liocnemis, Thoms. ................ 35

microstictus, Grav. .................. it

moestus, Grav. .................. 30

periscelis, Wesm. .................. 26

ruficauda, Wesm. ................. 33

sinister, Wesm. .................... 27

sugillatorius, Linn.................. 24

CENTETERUS ...................... aSo

confector, Grav. ..................... 2SI

major, IVesm. .......................... 2So

opprimator, Grav. ................. $2 \mathrm{~S} \mathrm{~s}$ 


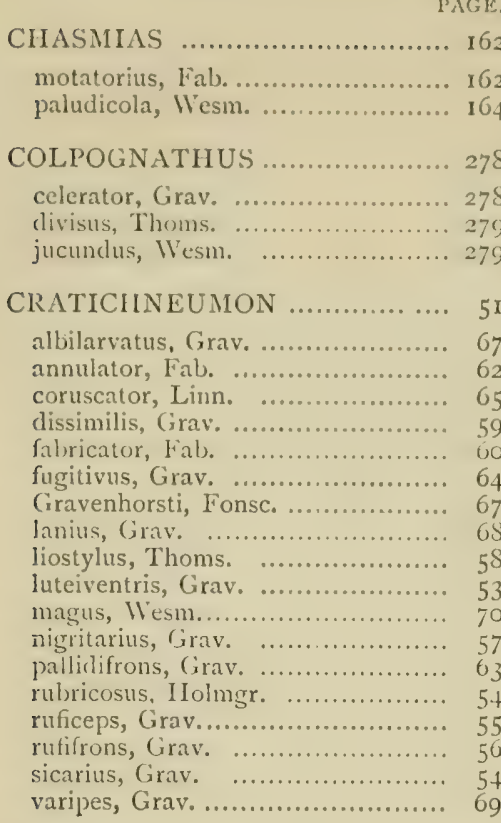

CTENICHNEUMON ................ 167

caeruleator, Zett. .................... I70

castigator, Fab. ................... 172

divisorius, Grav. .................... I7 8

flavocinctus, Desv. ................. 179

fossorius, (irav. ................... 174

funereus, Fourc. .................... 174

haereticus, Wesm. ................. 179

homocerus, Wesm................... I 71

inspector, Wesm. ................. 175

melanocastanus, Grav. ............. 175

mesocastanus, Grav. ............... 176

messorius, Grav................... 177

l'anzeri, Wesm. .................. I 73

plicatus, Morl. .................. 172

repentinus, Grav. ................. 176

sputator, Fab..................... I7 I

DIADROMUS ...................... 263

candidatus, Grav. ................... 266

collaris, Grav. ..................... 267

conciliator, Wesm................... 267

guttulatus, Grav. ................. 266

subtilicornis, Grav..................... 265

troglodytes, Grav. .................. 264

varicolor, Wesm. ................... 265

DICAELOTUS ....................... 273

Camernni, Bridg. ................... 275

parvulus, Grav. .................... 277

pumilus, Grav. ................... 274
DICAELOTUS-continued. PACR.

pusillator, Grav. ................... 277

ruficosatus, Grav. ..................... 276

rufilimbatus, Grav. .................. 276

DINOTOMUS ..................... 9

lapidator, Fab. ...................... 9

pictus, Kriech. ...................... II

spinosus, Morl. ..................... If

EPITOMUS ....................... 268

parvus, Thoms. .................... 268

ERISTICUS ........................ $2 \mathrm{I}_{3}$

clericus, Grav...................... 214

EUPALAMUS ...................... $7 \mathrm{r}$

oscillator, IVesm. ................. 72

Wesmaeli, Thoms. .................... 72

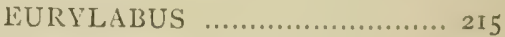

dirus, Wesm. ....................... 216

larvatus, Christ ...................... 216

rufipes, Steph........................ 218

torvus, Wesm........................ 217

tristis, Grave. ....................... 2I 8

EXEPHANES ...................... I 58

hilaris, Grav. ....................... I 58

(iccupator, Grav....................... I 59

IIEMICHNEUMON $\ldots \ldots \ldots \ldots \ldots . \ldots 286$

elongatus, Ratz. .................... $2 S 6$

HEPIOPELAIUS .................... 207

leucostigmus, Grav. ................. 208

variegatorius, Panz. .............. 207

IIERPESTOMLS.................. 239

arridens, Grav. ..................... $24 \mathrm{I}$

brunnicornis, Grav. ................ 240

distinctus, Bridg. .................. 242

furunculus, Wesm. ................ 24I

nasutus, Wesm. ..................... 240

HETERISCHNUS $\ldots \ldots \ldots \ldots \ldots \ldots . \ldots 284$

pulex, Müill. ........................ 284

rufipes, IVesm. .................... 285

IIOPLISMENUS .................... 6

allifions, Grav. ................... 7

perniciosus, Grav. ..................... 6

uniguttatus, Grav. ................... \&

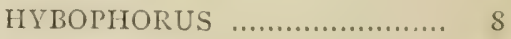

aulicus, Grav. ....................... . 8 
PAGE.

IIY POMECUS 166

quadriannulatus, Grav. 167

\section{ICHNEUMON}

albicollis, Wesm. ................. 134

analis, Grav. ....................... 123

bellipes, Wesm. .................... I I 42

bisignatus, Grav. ............... I I I

bucculentus, Wesm. ............... I 27

caedator, Grav. ..................... 117

caloscelis, Wesm. .................. I49

cessator, Miill. .................... I 54

computatorius, Miill. ................ I3

confusorius, Grav. ................... I $38^{8}$

crassifemur, Thoms. .............. 125

deliratorius, Linn. ................. I1 2

emancipatus, Wesm. ................ I45

extensorius, Linn. ................. I 135

formosus, Grav. .................... 146

gracilentus, Wesm. ............... I 37

gracilicornis, Grav. ............. 143

gradarius, Wesm. ................. 135

haesitator, Wesm. .................. 157

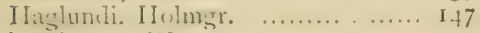

inquinatus, Wesm. ............... I I 32

insidiosus, $\mathbf{W e s m}$. .................. I50

languidus, Wesm. .................. I 29

latrator, lab. ....................... I1

lautatorius, Desv. .................. 116

lugens, Grav. ... . ................... II I

macrocerus, Thoms. ............... 140

melanotis, Holmgr. ............... I2 6

militaris, Grav. .................... I.34

molitorius, Grav. .................. I 24

multipictus, Grav. ................... I I 8

piceatorius, IVesm. ................. I 48

primatorius, Forst.................. I I I

quadrialbatus, Grav. .............. 154

quaesitorius, Linn. ................ I 47

raptorius, Girav. .................... 152

rufidens, Wesm. ...................... 149

sarcitorius, Linn, ... ............. I1 4

silaceus, Grav. ................... 144

sturitu, Wesm. .................... I 22

stramentarius, Grav, ................. I3I

stigmatorius, Zett. .................. I56

sulicylindricus, Grav................ I 15

sulmarginatus, Grav. ............ 153

subquadratus, Thoms $\ldots . . . \ldots \ldots . . .122$

suspiciosus, Wesm.................. 128

tempestivus, Holmgr. ................ I39

terminatorius, Grav. ................. 129

vulneratorius, Zett. ................. ${ }_{15} 6$

Walkeri, Wesm. ...................... 123

santhorius, Forst. .................. II 3

ISCIINUS ........................ 282

nigricollis, Wesm. ................ $2 S_{3}$

thoracicus, Grav. ................. 283

PAGR.

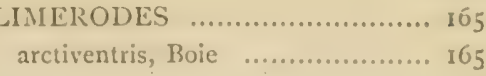

LISTRODROMUS ................. 2

nycthemerus, Grav. ............... 2

MELANICIXI:UMON ........... 73

bimaculatorius, Panz. ........... 77

dumeticola, Grav. .................... 75

erythraeus, Grav. ................. $\mathbf{S}_{2}$

Faunus, Grav........................ $S_{1}$

leucomelas, Gmel. ................... 74

monostagon, Grav. .................. 79

nudicoxa, Thoms. ..................... 76

perscrutator, Wesm.............. So

sanguinator, Rossi .................. $\delta_{3}$

saturatorius, I.inn. ................... 78

MELANOOMICRUS ............... $2 S_{7}$

Elliotti, Morl.................... $28 S$

NEMATOMICRUS . ................. 287

tenellus, Wesm. .................. $2 S_{7}$

NEOTYPUS ....................... 4

lapidator, Fab. ..... ........... 4

OIORHINUS $\ldots \ldots \ldots \ldots \ldots \ldots \ldots \ldots . \ldots . \ldots . \ldots 269$

pallidipalpis, Wesm. ............... 260

ORONOTUS $\ldots \ldots \ldots \ldots \ldots \ldots \ldots \ldots . . . . . \ldots S_{2}$

binotatus, Grav. ................... $2 \Omega_{2}$

I'HAEOGENES $\quad . . \ldots \ldots \ldots \ldots \ldots \ldots .242$

acutus, Grav. ......................... 248

argutus, Wesm. .................... 246

bellicornis, Wesm. .................. 257

callopus, Wesm....................... 260

cephalotes, IVesm. ................... 247

coryphaeus, Wesm. ................ 262

eques, Wesm. ....................... 255

futvitarsis, IVesm. .................. 2 (i)

fuscicornis, Wesm. .................... 254

heterogonus, Holmgr. …....... 252

homochlorus, Wesm.................. 260

impiger, Wesm. ....................... 256

infimus, Wesm. .................... 255

ischiomelinus, Grav. ............. . 256

maculicornis, Steph. …........... $25 \mathrm{~S}$

melanogonus, Gimel. ................. 251

mitigosus, Grav. ....................... $24 \mathrm{~S}$

modestus, Wesm. ................... 253

mysticus, W'esm. .................. 258

nanti., Wirm. ................. 25

nitichus, Bricig. .................... $2 v_{j}$

oplithalmicus, Wesm. .............. 252

planifrons, Wesm. .................. 251

rusticatus, Wesm. ................. 262 


\begin{tabular}{|c|c|}
\hline ES-continued. PAGE. & PROTICHNEUMON-continued. PAGE. \\
\hline 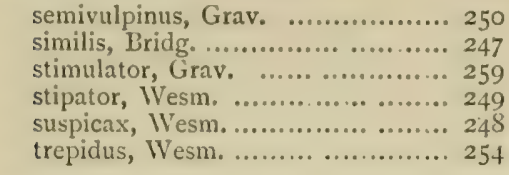 & 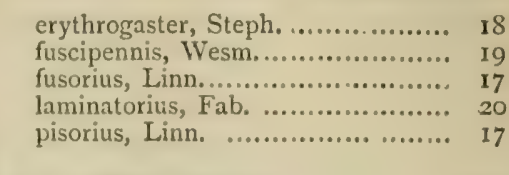 \\
\hline PLATYLABUS & SPILICHNEUMON \\
\hline 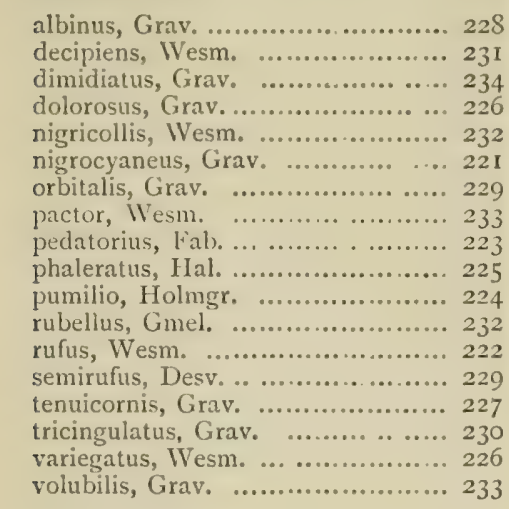 & 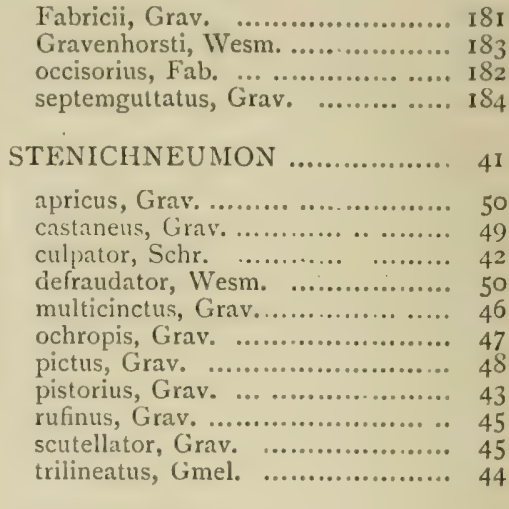 \\
\hline 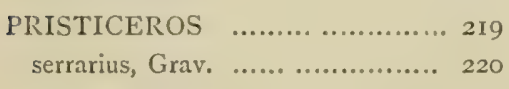 & $\begin{array}{r}\text { STENODONTUS..................... } 235 \\
\text { marginellus, Grav. ................. } 236\end{array}$ \\
\hline 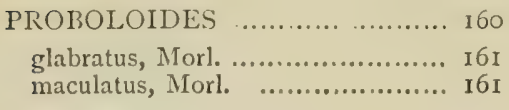 & $\begin{array}{l}\text { TRACHYARUS } . . . \ldots \ldots \ldots \ldots \ldots \\
\text { corvinus, Thoms. } \quad \ldots \ldots \ldots \ldots \ldots \ldots\end{array}$ \\
\hline 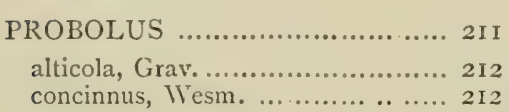 & $\begin{array}{c}\text { TRICHOLABUS ... } \\
\text { strigatorius, Grav. }\end{array}$ \\
\hline 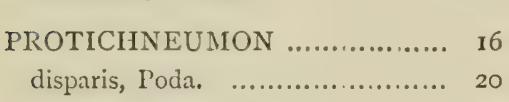 & 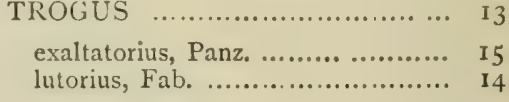 \\
\hline
\end{tabular}




\section{LIST OF SUBSCRIBERS.}

ADAMS, FREDk. C., F.Z.S., F.E.S. 50, Ashley Gardens, Westminster, London, S.W. [2 copies

ADKIN, ROBT., F.E.S.

4, Lingard's Rd., Lewisham, S.E.

ALDliRson, Miss E. MAUDE . . Park House, Worksop.

Ash, The Rev. C. D., M.A. . . Skipwith Vicarage, Selby.

BANkES, EUSTACE R., M.A., F.E.S. Norden, Corfe Castle, Wareham.

Bardify Naturalists' Soc, The, Barnsley.

Bayford, E. G. . 2, Rockingham Street, Barnsley.

BEARE, P'of. T. HUDSON, B.SC., F.R.S.K, F.K...

- The University, Edinburgh.

Benumont, Alfred, F.E.S. . . The Cottage, Gosfield, Halstead.

BEdWELL, E. C., F.E.S. 29, Flect Street, London, E.C.

MniNet, ( i. C., F.E.S. . . . The Ferns, Home Park Road, Saltash.

Binghim, Col. C. T., F.Z.S., F.E.S. 6, Gwendwr Road, West Kensington, London, W.

BL.ı F.l....

Eagle House, Batheaston, Bath.

BLOOMFIELD, The Rev. E. N., M.A., F.E.S.

Guestling Rectory, Hastings.

BOND, J. Kinton, B.A., B.Sc. . The Crescent, Plymouth.

BUCKELl, EdWARD . . . Wykeham House, Romsey, Hants.

Butler, E. A., E.A.. B.Sc., F.E.S. . 53, Tollington Park, London, N.

CARr, Prof. J. IV., M.A., F.L.S., F.G.S. . University College, Notts. [2 copies

CASSAL, R. T., M.R.C.S., F.E.S. - . Auckland Terrace, Ramsey, I. of M.

Chapian, 'I. Algernon, M.D., F.Z.S., l.k.S.

Betula, Reigate.

Chawner, Miss, F.E.S. . . . Forest Bank, Lyndhurst, Hants.

Chitty, A. J., M.A., F.E.S. 27, Hereford Square, S.W. [2 copies

ClARK, I'rof. JAMES, M.A., D.Sc., A.R.C.S., Central Technical Schools for Cornwall, 'Truro.

Dalglish, AND. Adif, F.E.S. 2 I, Prince's Street, Pollokshields, Glasgow.

DAY, F. H.

7, Thirlmere Strect, Carlislc.

DONisthorI'E, HoRACE ST. J. K., F.Z.S., F.E.S., 58, Kensington Mansions, South Kensington, S.IV.

Dublin Science and Art Museum, Dublin.

DUlaU \& Co. . . . 37, Soho Siquare, London, W. [ a copics 
Edelsten, H. McD., F.E.S. Forty Hill, Enfield.

EDINBURgh MUSEUII OF SCIENCE AND ART.

Enivards, JaMes, F.F.S. . . Colesborne, Cheltenhani.

Edvakds, Stanley, F.I..S., F.Z.S., F.E.S., I5, St. German's Place, Blackheath, London. S.E.

Entomological Socinty of London, The, in, Chandos Street, Cavendish Square, London, W.

EVANS, WILLIAM, F.R.S.E. 38, Morningside Park, Edinburgh.

Fitch, EdvaRd A., F.L.S., F.E.S. Brick House, Maldon, Essex.

FURNIVAL, T. F.

. Honduras Cottage, Bushey Heath, Watford.

Gaulle, J. de . . . . 4I, Rue de Vaugirard, Paris.

Girbs, A. E., F.L.s. . . . Kitchener's Meads, St. Albans.

Gorham, The Rev. Henry S., F.Z.S.,

F.E.S.

Shirley Warren, Southampton.

Guilie-Alles Library, The . Guernsey.

Hami, A. H. . . . . 22, Southfield Road, Oxford.

HARrison, Albert, F.L.S., F.C.S., F.E.S., Delamere Grove Road, South Woodford, Essex.

HaRwood, W. H. . . . Station Road, Colchester.

Hermani, A. . . . . $6 \&$ iz, Rue de la Sorbonne, Paris.

JACkson, Dr. W. Hatchett Pen Wartha, Weston-super-Mare.

Janson, O. E., \& Son • 44, Great Russell St., London, W.C.

Jenkinson, Frdncis, M.A. Io, Brookside, Cambridge.

Johnson, The Rev. F. W., M.A., F.E.S., Acton Glebe, Yoyntzpass, Co. Armagh, Ireland.

Leighton, Gerald, M.D., F.R.S.E. I7, Hartington Place, Edinburgh.

LEMANN, FREDK. C., F.E.S. . Black Friars House, Plymouth.

London COUnTy COUnCIL Records

COMMITTEE

Spring Gardens, Charing Cross, S.W.

LufF, W. A. . La Chaumière, Brock Rd., Guernsey.

LYLE, G. T. . . . . Bank House, Brockenhurst, Hants.

MACDOUg.ALL, R. STEWART, M.A.,

D.SC., F.R.S.E.

13, Archibald Place, Edinburgh.

McGowan, Bertram . . . Ellangowan, Dumfries.

MCLachlaN, R., F.R.S., F.L.S., F.Z.S., F.E.S., West View, 23, Clarendon Road, Lewisham, S.E.

Malloch, J. Russell • . . Bonhill, Dumbartonshire.

Manchester Museum . . . Owen's College, Manchester.

Marlborough College Natural

History SOCIETY . . . The College, Marlborough, Wilts.

MASON, P. B., M.R.C.S., F.L.S., F.E.S. Trent House, Burton-on-Trent.

Mitchell Library, The . . F. T. Barrett, Librarian, 21, Miller Strect, Glasgow.

MORICE, The Rev. F. D., M.A., F.E.S., Brunswick, Mount Hermon, Woking. Morley, Jas. Hy. - o . The Elms, Appley, Ryde, I. of W. 
Morton, KrNneth J., F.E.S. . . 13, Blackford Road, Edinburgh.

Mushair, John F. • • . Blenheim House, South Park, Lincoln.

Nevinson, BASIL GEORGE, M.A., F.Z.S., F.E.S.

3, Tedworth Square, Chelsen, S.W.

NEWBERY, E. A. 12, Churchill Road, Dartmoutli, Park, N.IV.

OXFord SCIENCE MUSEUM

P'ERKINS, VINCENT R., F.E.S.

PFANKUCH, K. .

Oxford.

PICKARD-CAMIBRIDGE, The Rev. O. M.A., F.R.S., etc.

Wotton-under-Edge, Gloucestershire.

Warturmer-Chaussee 9I, Bremen, Germany.

Bloxworth Rectory, Wareham.

Piffard, Alibrt, F.E.S. . . . Felden, Boxmoor, Herts. [2 cofie's

Plyalouth Institution and D. \& C. Natural History Society, The

Plimouth Museum (E. Ernest Lowe, F.L.S., Curator).

RADCLIFFE LIBRARY . . . Museum, Oxford.

RothsCHILD, The Honble. L. WV,

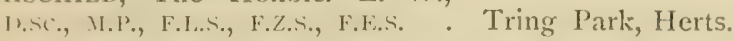

Routledge, GEORge Beli, F.E.S. . Tarn Lodge, Heads Nook, Carlisle.

Rowland-Brown, H., M.A., F.E.S. Oxhey Grove, Harrow Weald.

SAUNDERS, EDWARD, F.R.S., F.L.S.,

SHEPHEARD-IVALWVN, H. IV., M.A.,

SHEPHEARD-IVALIVYN, H. IV., M.A.,
F.F.S.

St. Ann's, Mount Hermon, WVoking.

SPARKE, E. G. J., B.A., F.E.S. . I, Christchurch Villas, Tooting Bec Road, S.W.

STECK, Dr. THEODOR

- Conservator, Museum of Natural History, Bern, Switzerland.

THHN, JaMES

Thomas, Mrs. Rose HAIG

Bookseller, 55, South 13ridge, Edinburgh.

Thornley, Rev. Alfred, M.A., F.L.S., F.E.S.

Warmwell House, Dorchester.

South Leverton Vicarage, Lincoln.

TRAIL, JAMES W. H., A.M., M.D., F.R.S., Professor of Botany .

University of Aberdeen.

WAGNER'SCHE UNIVERSITÄTS-BUCHHANDLUNG, Innsbruck.

WAINIRIGIT, COLbRAN J., F.E.S. 57, Handsworth Wood Road, Handsworth, Staffordshire.

Watkins \& DONCASTER - . Naturalists, 36, Strand, IV.C. [5 copic's

Watkins, C. J., F.E.S. . . . King's Mill House, Painswick,

Waterston, James, M.A. 9, Woodburn Terrace, Edinburgh.

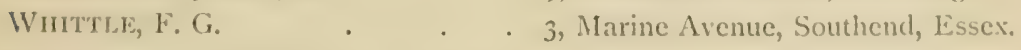

YERIUURY, Colonel J. W. (late R.A.), F.L.S., F.E.S.

8, Duke Street, St. James, London. 
PLINTER 
WORKS BY CLAUDE MORLEY, F.E.S.

\section{ICHNEUMONOLOGIA BRITANNICA :}

THE ICHNEUMONS OF GREAT BRITAIN.

\section{ICHNEUMONINAE.}

Frontispiece and numerous structural illustrations. 366 pp. Extra demy 8vo, cloth. 26s.

\section{THE COLEOPTERA OF SUFFOLK:}

A fully annotated Catalogue of 1763 spp., with sketch of Geology, Flora, etc. Price, 3s. 6d.

\section{THE HYMENOPTERA OF SUFFOLK.}

\section{ACULEATA.}

A fully annotated Catalogue of 282 spp. (out of 374 in Britain). Price, 2s. 6d.

CATALOGUE OF BRITISH ICHNEUMONINAE.

Printed on one side of the paper only, for LABELLING. Price, nd.

Plymouth: J. H. KEYS, 7, Whimple Street. 




UNIVERSITY OF ILLINOIS-URBANA

595.79M821 C001 V001

ICHNEUMONOLGIA BRITTANNICASPL YMOUTH

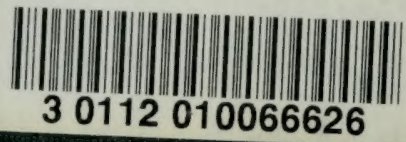

